\title{
HYDROGEOLOGY AND GROUND-WATER \\ CHEMISTRY OF THE SAN ANDRES-GLORIETA \\ AQUIFER IN THE ACOMA EMBAYMENT AND \\ EASTERN ZUNI UPLIFT, \\ WEST-CENTRAL NEW MEXICO
}

By Joe A. Baldwin and Scott K. Anderholm

U.S. GEOLOGICAL SURVEY

Water-Resources Investigations Report 91-4033

Prepared in cooperation with the

NEW MEXICO STATE ENGINEER OFFICE,

PUEBLO OF ACOMA,

PUEBLO OF LAGUNA,

and the

U.S. BUREAU OF INDIAN AFFAIRS

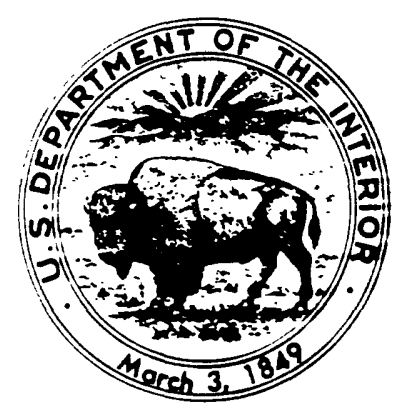

Albuquerque, New Mexico 
U.S. DEPARTMENT OF THE INTERIOR

MANUEL LUJAN, JR., Secretary

U.S. GEOLOGICAL SURVEY

Dallas L. Peck, Director

For additional information

write to:

District Chief

U.S. Geological Survey

Water Resources Division

Pinetree Corporate, Centre

4501 Indian School Rd. NE, Suite 200

Albuquerque, New Mexico 87110
Copies of this report can be purchased from:

U.S. Geological Survey

Books and Open-File Reports

Federal Center

Box 25425

Denver, Colorado 80225 


\section{CONTENTS}

Page

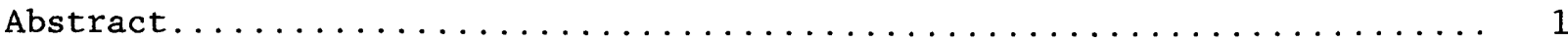

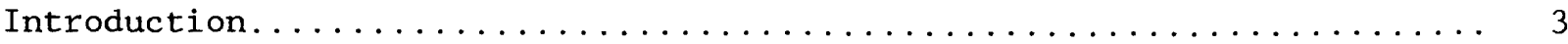

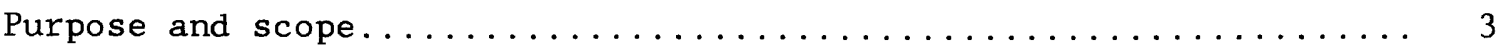

Location and climate.......................... 4

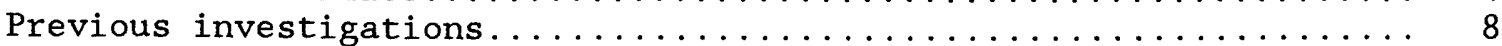

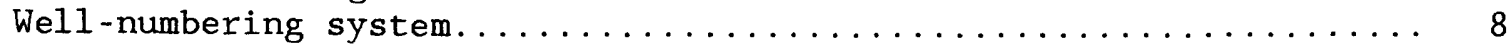

Acknowledgments . . . . . . . . . . . . . . . . . . . . . . . . 9

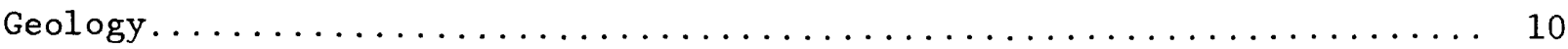

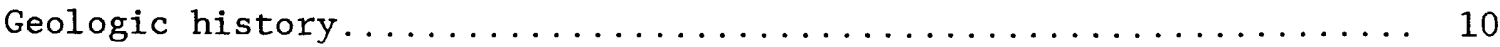

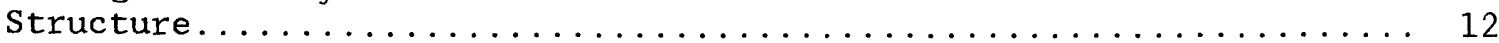

Stratigraphy............................ 14

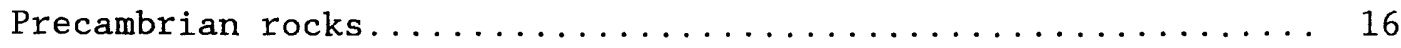

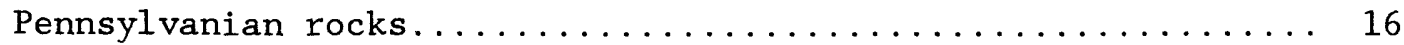

Permian rocks............................ 16

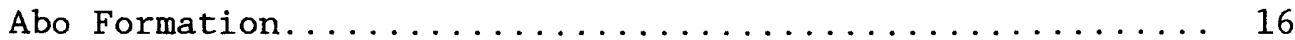

Yeso Formation.......................... 18

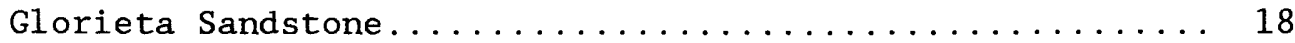

San Andres Limestone...................... 18

Triassic rocks........................... 22

Rocks younger than Triassic and older than the Quaternary

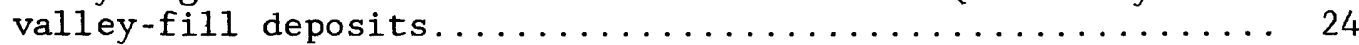

Quaternary valley-fill deposits.................. 24

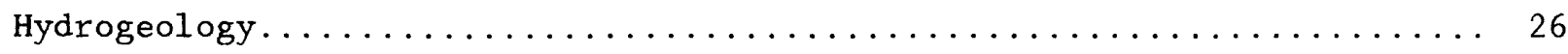

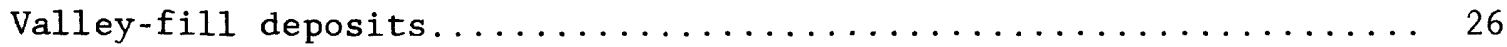

Hydraulic properties....................... 26

Ground-water movement........................ 26

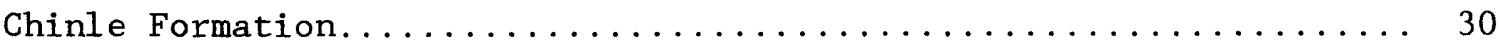

Hydraulic properties........................ 30

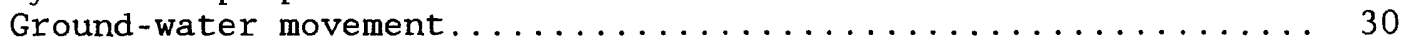

San Andres-Glorieta aquifer....................... 30

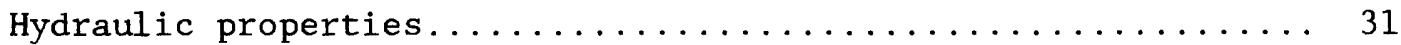

Ground-water movement..................... 37

Water-level changes due to changes in precipitation and ground-water withdrawals...................... 44 
Hydrogeology - Concluded

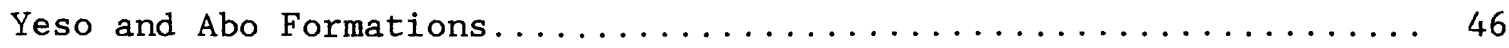

Hydraulic properties........................ 46

Ground-water movement........................ 48

Pennsylvanian rocks........................... 49

Hydraulic properties........................ 49

Ground-water movement........................ 49

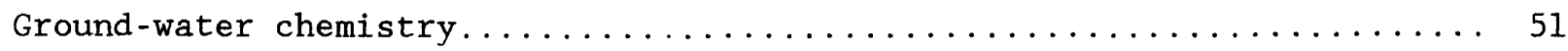

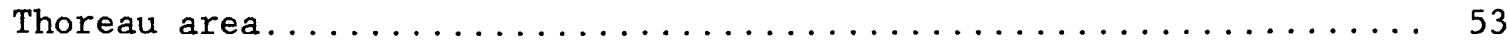

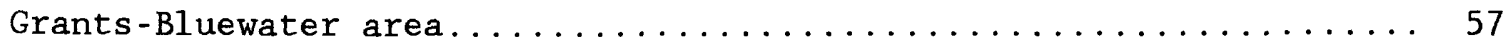

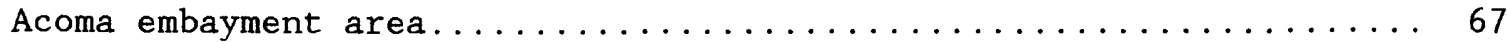

Horace Springs............................ 78

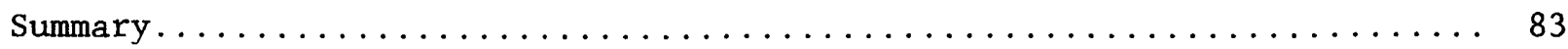

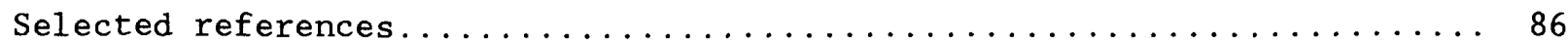

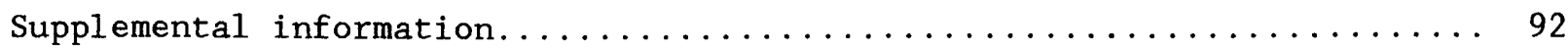

\section{PLATES}

[ In back pocket]

Plate 1. Geologic sections of the Acoma embayment and Zuni uplift, west-central New Mexico

2. Map showing surficial geology and concentrations of selected dissolved constituents and properties of water from wells in the Grants-Bluewater area 


\section{FIGURES}

Page

Figure 1. Map showing location of the study area and precipitation stations................... 5

2. Graphs showing annual precipitation for selected stations within and adjacent to the study area.......6 6

3. Diagram showing system of numbering wells and springs in New Mexico ........................ 9

4-14. Maps showing:

4. General geology of the study area............ 11

5. Regional structural features of northwestern New Mexico........................... 13

6. Location of major faults in the study area....... 15

7. Thickness of undivided Pennsylvanian rocks in the study area....................... 17

8. Thickness of undivided San Andres Limestone and Glorieta Sandstone in the study area......... 20

9. Generalized structure contours on the top of the San Andres Limestone surface.............. 21

10. Thickness of the Chinle Formation in the study area.......................... 23

11. Water-level contours for Quaternary valley-fill deposits in the Grants-Bluewater area......... 27

12. Generalized transmissivity zones for the San Andres-Glorieta aquifer............... 32

13. Potentiometric-surface contours for the San Andres-Glorieta aquifer, drawn on the basis of the highest hydraulic-head values on record...... 33

14. Potentiometric-surface contours for the San Andres-Glorieta aquifer in the Grants-

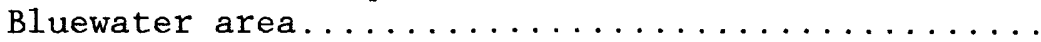




\section{FIGURES--Continued}

Figure 15. Graphs showing cumulative departure from mean precipitation for the period of record at stations

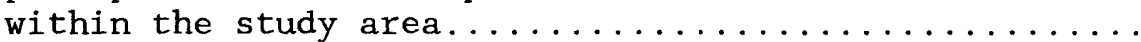

16. Water-level hydrographs for wells in the Grants-

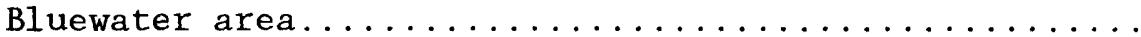

17. Graphs showing comparison of water levels, groundwater withdrawals, and cumulative departure from mean precipitation for the Grants-Bluewater area......

18. Map showing ground-water-chemistry discussion areas, potentiometric surface, and specific conductance of water from the San Andres-Glorieta aquifer...........

19. Map showing selected chemical analyses of water from wells completed in the San Andres-Glorieta aquifer

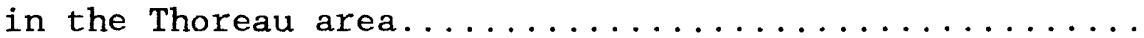

20. Piper diagram of selected chemical analyses of water from wells completed in the San Andres-Glorieta

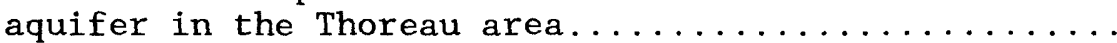

21. Map showing molar ratio of bicarbonate concentration to sulfate concentration in water from selected wells completed in the San Andres-Glorieta aquifer

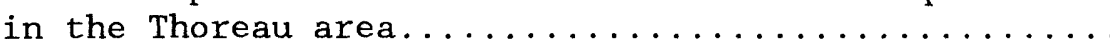

22. Piper diagram of selected chemical analyses of water from wells completed in the San Andres-Glorieta aquifer in the Grants-Bluewater area..............

23. Map showing dissolved-nitrate, chloride, and sulfate concentrations in water from wells completed in the San Andres-Glorieta aquifer in the Grants-Bluewater

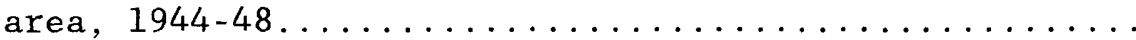

24. Map showing dissolved-nitrate, chloride, and sulfate concentrations in water from wells completed in the San Andres-Glorieta aquifer in the Grants-Bluewater

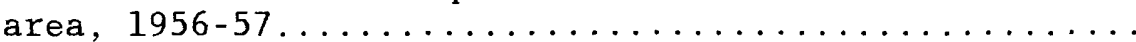




\section{FIGURES--Continued}

Figure 25. Map showing dissolved-nitrate, chloride, and sulfate

Page concentrations in water from wells completed in the San Andres-Glorieta aquifer in the Grants-Bluewater

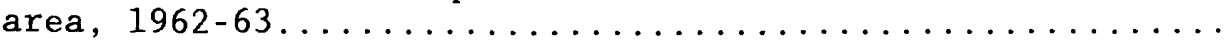

26. Map showing dissolved-nitrate, chloride, and sulfate concentrations in water from wells completed in the San Andres-Glorieta aquifer in the Grants-Bluewater

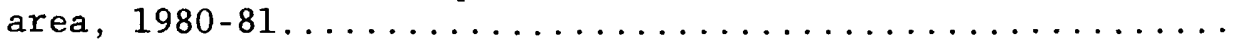

27. Graph showing chloride concentration in water from ojo de Gallo and San Rafael municipal wells, 1947-86......

28. Map showing selected chemical analyses of water from wells completed in the San Andres-Glorieta aquifer in the

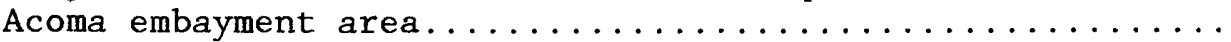

29. Piper diagram of selected chemical analyses of water from wells completed in the San Andres-Glorieta aquifer in the

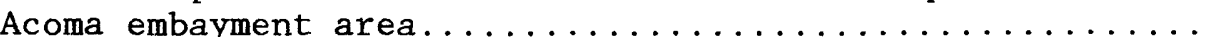

30. Hydrogeologic section through the Acoma embayment area......

31. Generalized geologic map and dissolved-chloride concentration in water from selected wells and springs in the eastern part of the Acoma embayment area..........

32. Piper diagram of selected chemical analyses of water from wells and springs in the eastern part of the Acoma

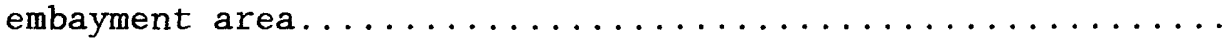

33. Map showing selected water-chemistry values in water from wells in the vicinity of Horace springs..............

34-36. Graphs showing:

34. Concentration of chloride in water from Horace Springs and the Rio San Jose near Grants, 1961-86..........

35. Results of Jacob straight-line method of analysis used to calculate transmissivity of Laguna Casa

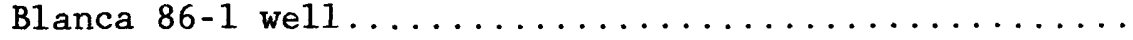

36. Results of recovery method of analysis used to calculate transmissivity of Laguna Casa Blanca

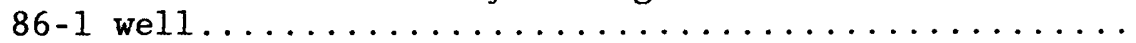




\section{FIGURES--Concluded}

Page

Figures 37-40. Graphs showing:

37. Results of Jacob straight-1ine method of analysis used to calculate transmissivity of Laguna Sand

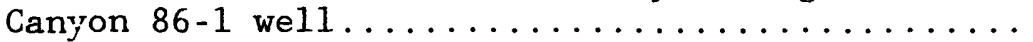

38. Results of recovery method of analysis used to calculate transmissivity of Laguna Sand Canyon

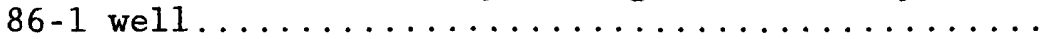

39. Recovery at Acoma 1 observation well (9.9.28.1344) from flow test at Anzac 86-1 (10.9.25.3241)..... 103

40. Water-level trends at Acoma 1 observation wel1 $(9.9 .28 .1344)$

\section{TABLES}

Table 1. Records of wells and springs in the Acoma embayment and

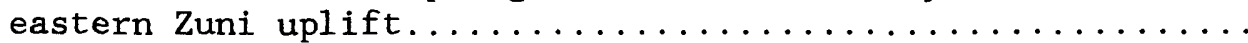

2. Temperature, geothermal gradient, and specific conductance for hydrologic-test wells in the Acoma embayment.......... 249

3. Transmissivity values of the San Andres-Glorieta aquifer in the study area........................... 250

4. Storage coefficients calculated from four aquifer tests...... 252

5. Ground-water withdrawals for 1945-57 and 1979-82 in the Grants-Bluewater area..................... 253

6. Lithology percentages for Pennsylvanian rocks and the Yeso and $\mathrm{Abo}$ Formations in the study area................ 253

7. Selected water analyses from wells in the Thoreau area...... 254

8. Selected water analyses from wells and springs in the

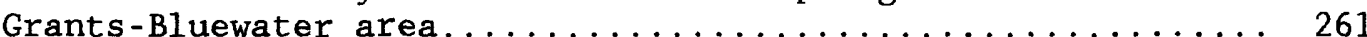

9. Selected water analyses from wells and springs in the Acoma

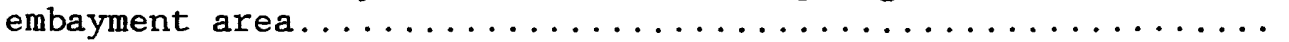




\section{CONVERSION FACTORS AND VERTICAL DATUM}

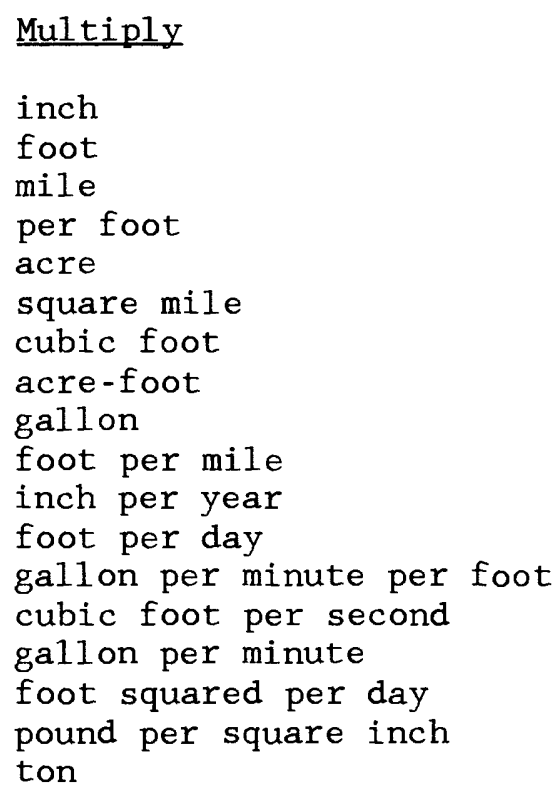

$\quad$ By
25.40
0.3048
1.609
3.281
0.4047
2.590
0.02832
0.001233
0.003785
0.1894
25.40
0.3048
0.2070
0.02832
0.06309
0.09290
6.895
0.9072

To obtain

millimeter

meter

kilometer

per meter

hectare

square kilometer

cubic meter

cubic hectometer

cubic meter

meter per kilometer

millimeter per year

meter per day

liter per second per meter

cubic meter per second

liter per second

meter squared per day

kilopascal

megagram

Temperature in degrees Celsius $\left({ }^{\circ} \mathrm{C}\right)$ can be converted to degrees Fahrenheit $\left({ }^{\circ} \mathrm{F}\right)$ by the equation:

$$
{ }^{\circ} \mathrm{F}=9 / 5\left({ }^{\circ} \mathrm{C}\right)+32
$$

Sea leve1: In this report "sea level" refers to the National Geodetic Vertical Datum of 1929--a geodetic datum derived from a general adjustment of the first-order level nets of the United States and Canada, formerly called Sea Level Datum of 1929. 


\title{
HYDROGEOLOGY AND GROUND-WATER CHEMISTRY OF THE
}

\section{SAN ANDRES-GLORIETA AQUIFER IN THE ACOMA EMBAYMENT}

AND EASTERN ZUNI UPLIFT, WEST-CENTRAL NEW MEXICO

By Joe A. Baldwin and Scott K. Anderholm

\begin{abstract}
The San Andres Limestone and the underlying Glorieta Sandstone of Permian age comprise the San Andres-Glorieta aquifer in west-central New Mexico. The San Andres Limestone is composed mainly of limestone and some sandstone and is unconformably overlain by the Chinle Formation. The Glorieta Sandstone conformably overlies the Yeso Formation and is composed of well-sorted, wellcemented, fine- to medium-grained sandstone.

Most of the water in the San Andres-Glorieta aquifer is transmitted in solution channels, cavernous zones, and fractures in the San Andres Limestone. Seven transmissivity zones were identified in the study area on the basis of aquifer-test results and the lithology of the aquifer. Values of transmissivity of the zones range from 10 to 50,000 feet squared per day. Zones with values of transmissivity of 50,000 feet squared per day are located in the Grants area and in an area east and south of the Zuni uplift. The zone with the smallest transmissivity, 10 feet squared per day, is located at the eastern margin of the study area.

Recharge to the San Andres-Glorieta aquifer occurs on outcrops along the Zuni uplift and Lucero uplift by infiltration of precipitation and surface water. The quantity of recharge is related to the areal extent of outcrops of the aquifer. Recharge to the San Andres-Glorieta aquifer also occurs south of the Zuni uplift where the aquifer subcrops beneath The Malpais. Recharge to the aquifer also is the result of leakage from Bluewater Lake and Bluewater Creek. Surface water and ground water used for irrigation also may infiltrate and recharge the aquifer in the Grants-Bluewater area.

Ground-water movement in the San Andres-Glorieta aquifer generally is outward from the Zuni uplift (recharge area). In the northwestern part of the study area, ground water moves toward the northeast. The direction of movement changes to the east at distance from the Zuni uplift. Ground water moves east away from the Zuni uplift and toward the Rio Grande rift in the eastern part of the study area.
\end{abstract}


Discharge of ground water from the San Andres-Glorieta aquifer is by spring discharge, withdrawal from wells, underflow out of the study area, and leakage to adjacent rocks. Prior to development of the ground-water resources in the Grants area, 0 jo del Gallo probably was a major discharge point in the part of the aquifer northwest of Grants. Discharge did not take place at 0 jo del Gallo during 1953 to 1982. This cessation in discharge at 0jo del Gallo probably was due to the large volume of ground-water withdrawal in the GrantsBluewater area and to changes in the quantity of precipitation, which affects recharge.

Discharge from the San Andres-Glorieta aquifer at Horace Springs also has been postulated. Evaluation of hydrologic, geologic, and water-chemistry data, however, indicates that water discharging from Horace Springs is derived from the alluvial aquifer.

Discharge from the San Andres-Glorieta aquifer in the Grants-Bluewater area increased substantially in the mid-1940's when wells were first used as a source of irrigation water. Withdrawals peaked in 1956, when 14,210 acre-feet of water was pumped from the aquifer. The large volume and changes in location of pumpage with time probably resulted in changes in the direction of ground-water movement in the aquifer. Water-chemistry data indicate changes in ground-water chemistry in the area during this time.

The mechanism for discharge of water from the San Andres-Glorieta aquifer east of the Zuni uplift is not known, but several possibilities exist. Underflow of ground water into the Rio Grande rift sediments is one possibility; however, in the area north of the Lucero uplift where this underflow could possibly occur, the San Andres-Glorieta aquifer is in fault contact with fine-grained sediments and leakage into these sediments probably is very small. Discharge from Pennsylvanian rocks east of the San AndresGlorieta aquifer does occur in the Lucero uplift area. The source of this water may be downward leakage from the San Andres-Glorieta aquifer (discharge) through the Yeso and Abo Formations.

The specific conductance of ground water derived from the San AndresGlorieta aquifer in the Thoreau area ranges from 470 to 1,390 microsiemens per centimeter at 25 degrees Celsius. Calcium and magnesium are the dominant cations and bicarbonate and sulfate are the dominant anions in ground water in this area. In the Grants-Bluewater area, calcium generally is the dominant cation and bicarbonate and sulfate generally are the dominant anions in ground water. Changes in concentrations of dissolved sulfate, chloride, and nitrate in ground water in the Grants-Bluewater area indicate variations in overall water chemistry over time. These changes probably are in part due to human activities. Ground water from west to east in the Acoma embayment area increases in specific conductance from approximately 1,000 to greater than 14,000 microsiemens. As in the Grants-Bluewater area, calcium is the dominant cation and bicarbonate and sulfate are the dominant anions in ground water near the recharge area on the western side of the Acoma embayment area. As ground water moves eastward in the Acoma embayment area, dissolved-sodium, sulfate, and chloride concentrations increase substantially. 


\section{INTRODUCTION}

The San Andres Limestone and the Glorieta Sandstone of Permian age underlie a large area of west-central New Mexico and adjacent east-central Arizona. The San Andres-Glorieta aquifer is comprised of these formations in the study area. The San Andres Limestone and, to a lesser extent, the Glorieta Sandstone yield relatively large quantities of good-quality water (dissolved-solids concentration less than $1,500 \mathrm{mg} / \mathrm{L}$ (milligrams per 1iter) to wells completed at depths of 1,000 feet or less in the Grants-Bluewater area. The San Andres-Glorieta aquifer has been extensively developed for irrigation, industrial, and domestic use in the Grants-Bluewater area.

Southeast of Grants, lands belonging to the Acoma and Laguna Indians also are underlain by the San Andres-Glorieta aquifer, but the hydrologic potential of the aquifer in this area is largely unknown because of the paucity of hydrologic data. A test well drilled on the western part of the Acoma Indian Reservation penetrated a cavernous zone at the top of the San Andres-Glorieta aquifer (San Andres Limestone). Aquifer testing indicated that large well yields are possible in this area and that water quality is good (dissolvedsolids concentration less than $1,500 \mathrm{mg} / \mathrm{L}$ ). However, the areal extent of the aquifer having large well yields and good-quality water and potential for supply is undetermined. On the eastern part of Laguna Indian Reservation, wells completed in the San Andres-Glorieta aquifer generally have small discharge rates and the water has dissolved-solids concentrations as large as $10,000 \mathrm{mg} / \mathrm{L}$.

The investigation of the San Andres-Glorieta aquifer was begun by the U.S. Geological Survey in 1983 in cooperation with the New Mexico State Engineer Office, the Pueblos of Acoma and Laguna, and the U.S. Bureau of Indian Affairs. The purpose of the study was to define the geohydrology and ground-water chemistry of the San Andres-Glorieta aquifer, to assess the effects of historical ground-water withdrawals from the San Andres-Glorieta aquifer, and to estimate the effects of any future ground-water withdrawals from the aquifer.

\section{Purpose and Scope}

This report describes the geohydrology and ground-water chemistry of the San Andres-Glorieta aquifer. Specifically, it defines hydrologic properties of the flow system and uses ground-water chemistry to better define the ground-water flow system.

Information for the study was acquired from literature review of the hydrology and geology of the area, collection of ground-water and surfacewater data, ground-water sampling for chemical analysis, surface and subsurface geophysical investigations, analysis of stratigraphic and drillstem test data from oil-test holes, field examination of rock units in the study area, and compilation of historical water-use data in the area. Several test wells were drilled in the eastern part of the study area where little or no data about the San Andres-Glorieta aquifer existed. 


\section{Location and Climate}

The study area, in west-central New Mexico, covers parts of Cibola, Catron, Socorro, Valencia, Bernalillo, Sandoval, and McKinley Counties (fig. 1). Major topographic features in the study area include Mount Taylor, the Continental Divide, and the Zuni Mountains.

At 11,301 feet in altitude in the northern part of the study area, Mount Taylor is the highest point in the study area. Mount Taylor is surrounded by basalt-covered mesas that are at altitudes of 8,000 to 9,000 feet.

The Continental Divide extends roughly north-south across the western part of the study area. Numerous cinder cones and shield volcanoes are along the Continental Divide.

In the west-central part of the study area are the Zuni Mountains, which formed as a result of the Zuni uplift. The highest point in these mountains is Mount Sedgwick, which has an altitude of 9,256 feet.

Other features include the North Plains, a basalt-covered plateau that has an altitude of about 7,000 feet. This plateau, south of the Zuni Mountains, is crossed by the Continental Divide. East of the North Plains on Acoma and Laguna Indian Reservations, basalt- and sandstone-capped mesas predominate. In some areas of the reservations, headward erosion has produced sheer-walled valleys having 300 to 400 feet of relief. North of Grants, La Jara Mesa and Mesa Montanosa are formed by northeastward-dipping sedimentary rocks. Basalt flows can be found northwest and south of Grants.

Surface-water drainage is toward the Little Colorado River in adjacent Arizona west of the Continental Divide. Surface-water drainage is toward the Rio Grande east of the Continental Divide. The Rio San Jose, which begins at the confluence of Mitchell Draw and Bluewater Creek (fig. 1), is the main drainage in the study area. The course of the Rio San Jose is southeastward across Cibola County to its confluence with the Rio Puerco. The Rio San Jose occupies a broad valley in the Grants-Bluewater area. Southeast of Grants, however, neir the junction of Interstate 40 and Highway 117 , is a constriction in this valley where the Rio San Jose crosses eastward-dipping sedimentary strata. East of this area, the valley again widens.

Cottonwood Creek and Bluewater Creek, which have headwaters into the Zuni Mountains west of Mount Sedgwick, are the major tributaries of the Rio San Jose. Both creeks flow into Bluewater Lake. Bluewater Dam was constructed in 1927 to provide a storage reservoir for irrigation in the Grants-Bluewater area.

The climate of most of the study area is semiarid to arid, and the average annual temperature is approximately 10 degrees Celsius (Gordon, 1961, p. 9). Mean annual precipitation at Grants from 1947 to 1984 was 10.1 inches (fig. 2). Mean annual precipitation at McGaffey from 1911 to 1981 was 17.7 inches (fig. 2). Differences in mean annual precipitation are due in part to differences in altitude of the precipitation stations. Generally precipitation increases with altitude in the study area. In general, precipitation was above normal from the mid-1920's to the 1 ate $1930^{\prime} \mathrm{s}$ (fig. 2). Precipitation was below normal from about 1950 to the mid-1960's. 


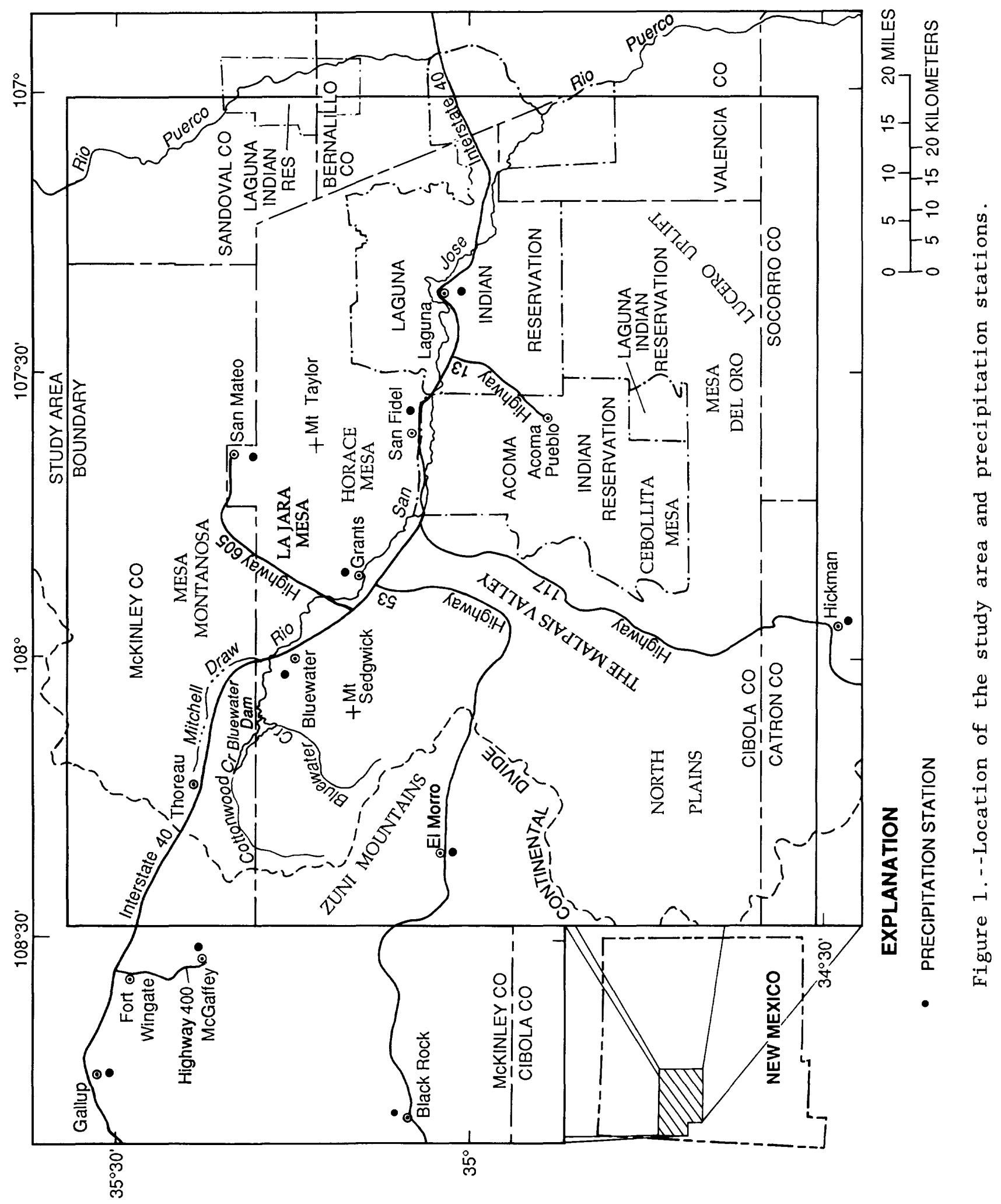



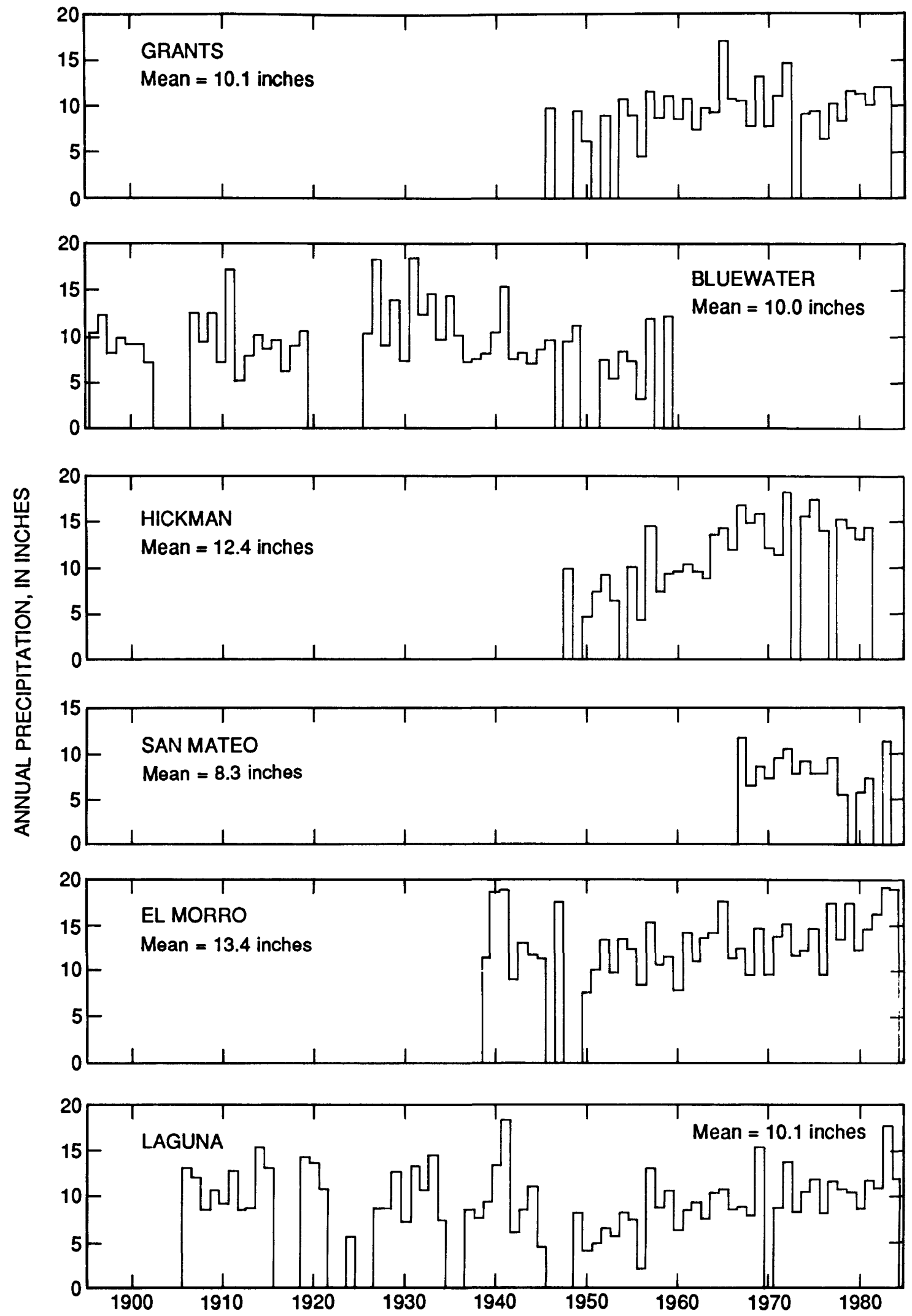

Figure 2.--Annual precipitation for selected stations within and adjacent to the study area. 

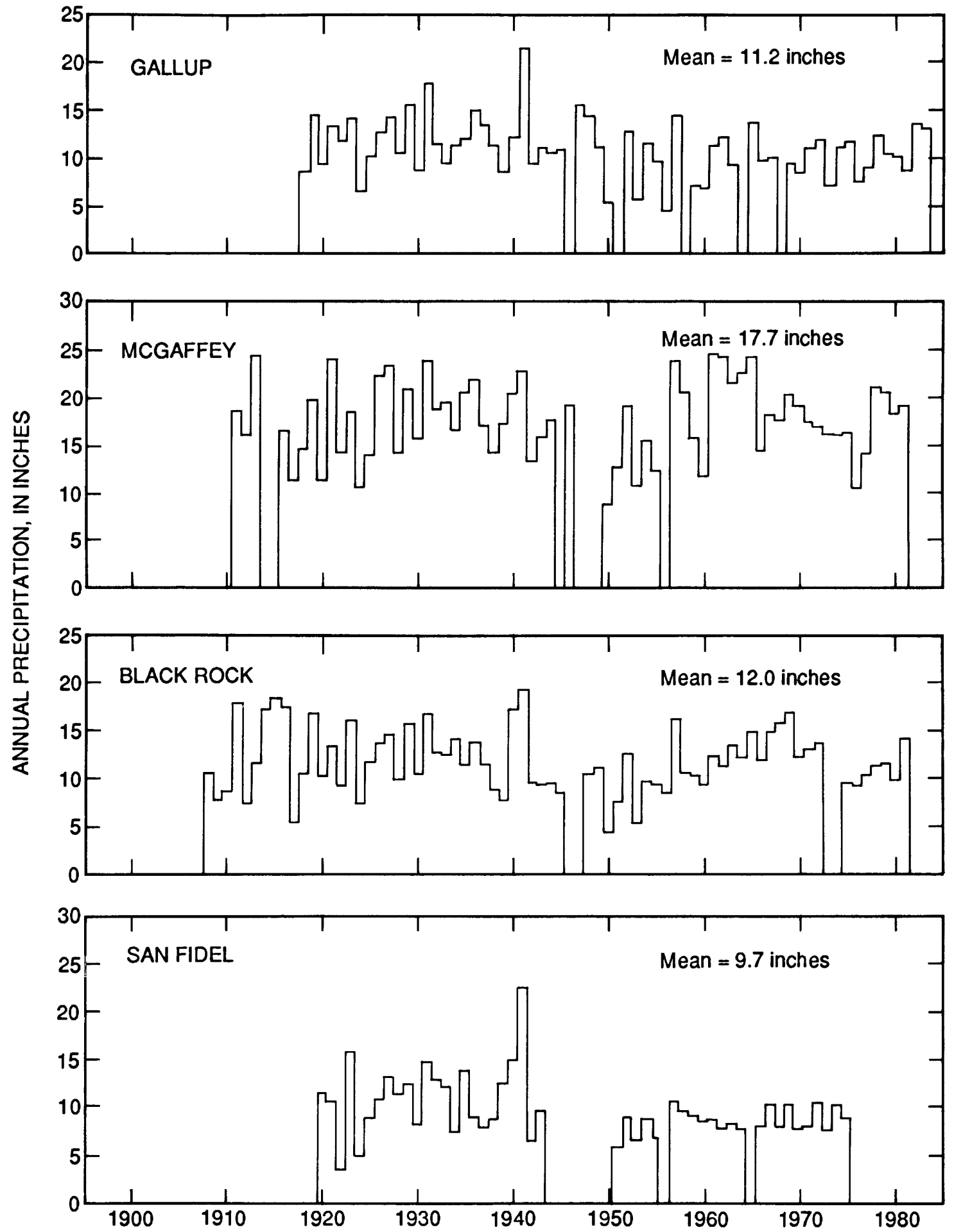

Figure 2.--Annual precipitation for selected stations within and adjacent to the study area--Concluded. 


\section{Previous Investigations}

Numerous reports describing the geology and hydrology of parts of the study area have been published. Some of the significant reports describing geology, stratigraphy, and structure include those by McKee (1933), Foster (1957), Tonking (1957), Jicha (1958), Fitzsimmons (1959), Baars (1962), Maxwell (1976), and 0'Sullivan (1977). Geological mapping is described in reports by Kelley and Wood (1946), Thaden and Ostling (1967), Thaden and others (1967a), Thaden and others (1967b and c), Green and Pierson (1971), Maxwe11 (1981), and Thaden and Zech (1984).

Significant hydrologic reports include Hodges (1938), Morgan (1938), Murray (1945), U.S. Geological Survey (1946-55), Gordon (1961), Titus (1963), Cooper and John (1968), Shomaker (1968, 1969, 1971), West (1972), HydroSearch, Inc. (1977, 1978a and b, 1981), Lyford (1979), Lyford and others (1980), Geohydrology Associates, Inc. (1981, 1984), Aqua Science, Inc. (1982), Frenzel and Lyford (1982), Risser (1982), Ward and others (1982), Risser and Lyford (1983), Stone and others (1983), U.S. Bureau of Indian Affairs (1984), and Dames and Moore (1986).

\section{Well-Numbering System}

The system of numbering wells and springs in this report is based on the common subdivision of public lands into sections (fig. 3). The well number, in addition to designating the well, locates its position to the nearest 10-acre tract in the land network. The first number denotes the township north or south of the New Mexico Base Line, the second denotes the range east or west of the New Mexico Principal Meridian, and the third denotes the section in which the well is located. The fourth number locates the well within the section to the nearest 10 acres by the system of quartering shown in figure 3. If two or more wells or springs occur in the same 10-acre tract, the wells are distinguished by letters ( $a, b$, etc.) following the location number. The use of zeros in the fourth segment of the location number indicates that the well or spring could not be located accurately: well number $10 \mathrm{~N}$..$W .25 .400$, for example, indicates that the well could not be located more accurately than the southeast quarter of section 25. Parts of Cibola County have not been subdivided by township, range, and section. Location numbers for such areas were determined by extending section lines from adjacent areas.

Some wells are tabulated by the New Mexico State Engineer office well number and also by latitude and longitude. Latitudes and longitudes were obtained from 7 1/2-minute quadrangle sheets. All well locations were verified by onsite visits. The latitude and longitude accuracy is plus or minus 1 second. Latitudes and longitudes were converted to $x-y$ coordinates for the purpose of plotting well locations. Some of the wells in table 1 (tables are in the back of the report) were used to construct potentiometricsurface and water-level contour maps. Oil-test holes used in the report are not included in table 1. 


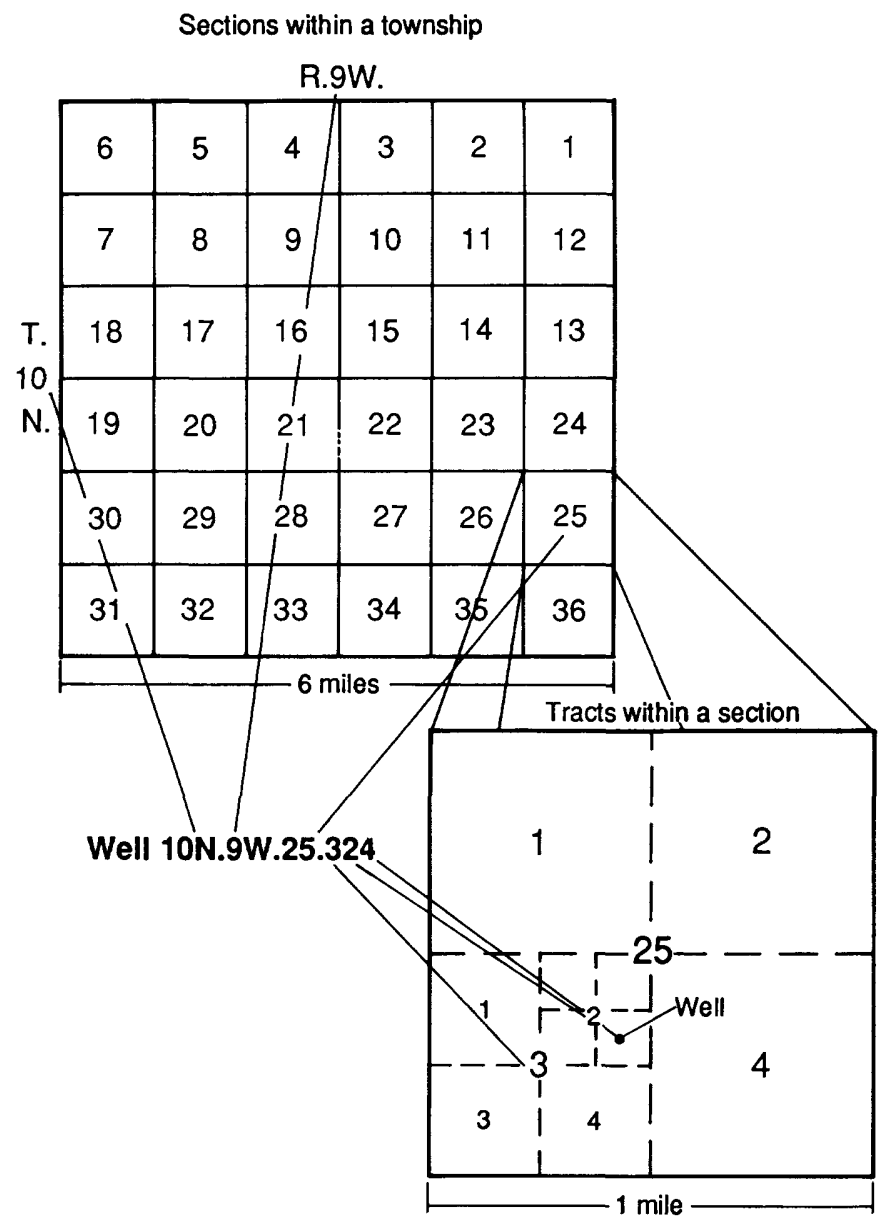

Figure 3.--System of numbering wells and springs in New Mexico.

\section{Acknowledgments}

The authors gratefully acknowledge the residents of the Acoma and Laguna Indian Reservations and the many other property owners who granted access to well sites and provided well and spring data. The study could not have been completed without their cooperation. Charles A. Wohlenberg, New Mexico State Engineer Office, provided much valuable geologic and hydrologic data. W.P. Balleau, formerly with the U.S. Bureau of Indian Affairs, provided insight about the geology and hydrology of parts of the study area. Personnel at the Bureau of Indian Affairs assisted in well site access and archeological clearance at test-well sites and provided well records and water-quality data. 


\section{GEOLOGY}

The geology section contains discussions of the geologic history, structure, and stratigraphy of the study area. Structural features and geologic units that influence the hydrology of the San Andres-Glorieta aquifer are discussed in detail.

\section{Geologic History}

Rocks ranging in age from Precambrian to Quaternary are present in the study area (fig. 4). Precambrian rocks mostly are granite with some schist, metarhyolite, gneiss, and quartzite (Gordon, 1961, p. 18). These rocks are exposed in the center of the Zuni uplift (fig. 4). Rocks from late Precambrian to Middle Pennsylvanian age are absent in the study area, suggesting that the region was a stable paleohighland where sediments either were not deposited or were subsequently eroded. The first rocks preserved after the Precambrian age were limestones and conglomerates of Late Pennsylvanian age, which were deposited in a basin formed in the southeastern part of the study area (Kelley and Wood, 1946). Deposition continued throughout Late Pennsylvanian and Early Permian time without interruption. The depositional environment from Pennsylvanian to Early Permian time changed from marine to continental and restricted marine. The Abo and Yeso Formations of Early Permian age are composed of sediments eroded from highlands northeast of the study area (Baars, 1962, p. 211). A final advance of Early Permian seas resulted in deposition of the Glorieta Sandstone and San Andres Limestone. A period of erosion at the Permian-Triassic boundary exposed the San Andres Limestone to extensive solution action and erosion in the GrantsBluewater area. This resulted in the development of karst topography.

During Triassic time the study area was a low plain. Sediments from the south spread over the partly eroded San Andres Limestone. In some areas caverns and sinkholes in the San Andres Limestone are filled with Triassic sediments. During Jurassic and Cretaceous time the depositional environment was continental and shallow marine, producing thick deposits of sandstone, siltstone, and shale. During Late Cretaceous time, seas advanced and retreated several times across the area, creating a transgressive-regressive sequence of sediments. The seas retreated from the area for the final time near the end of Cretaceous time.

During the last part of the Cretaceous Period, deformation associated with the Laramide Orogeny formed most of the existing structural features. The broad domes of the Zuni and Lucero uplifts began to form. Erosion began removing sediments that previously had accumulated during Early and middle Cretaceous time. Approximately 5,000 feet of sediments eventually were removed from the eastern part of the study area (Moench and Schlee, 1967, p. 2). 


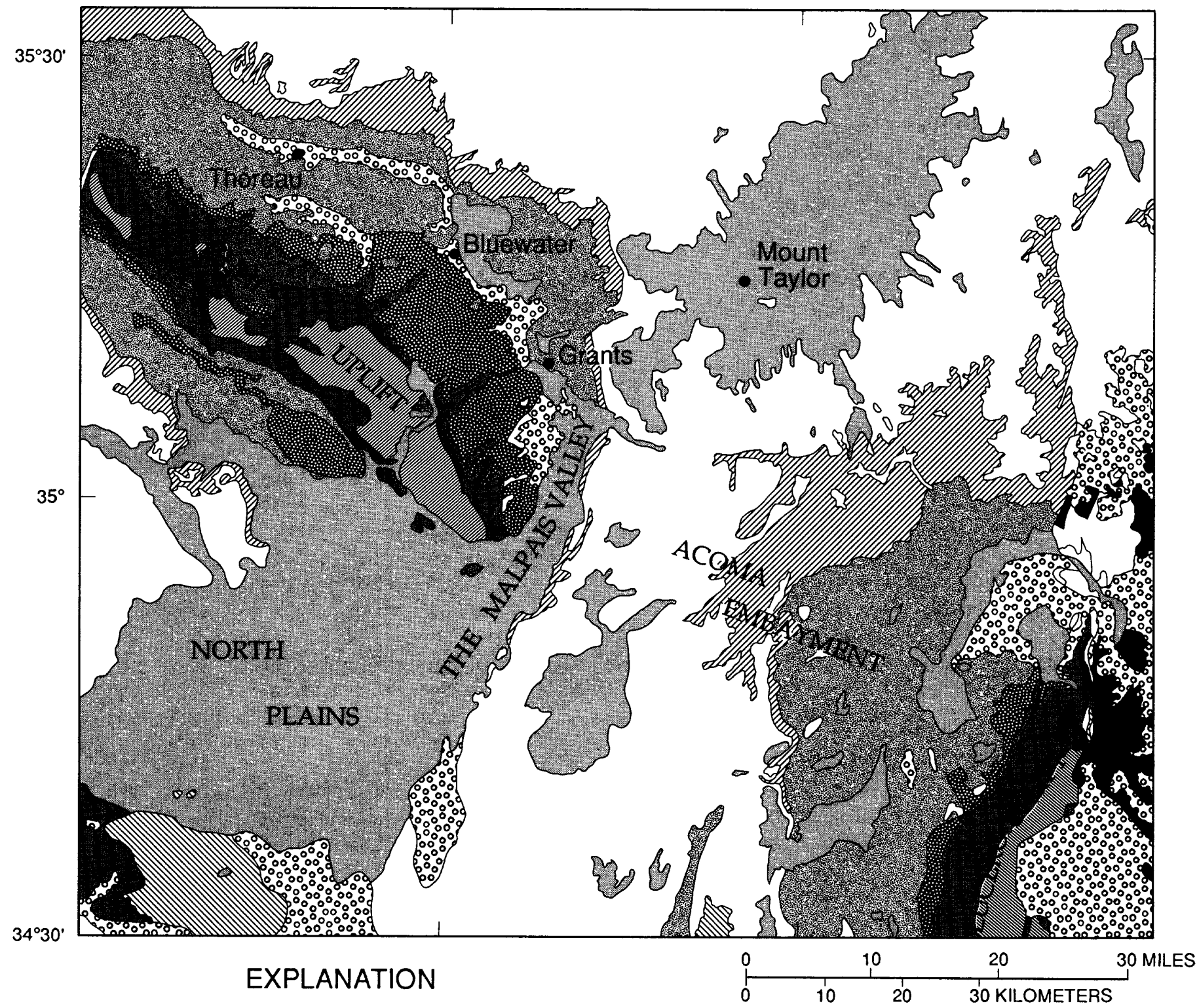

QUATERNARY [영 ALLUVIUM AND BASALT

QUATERNARY BASALT, UNDIVIDED

AND TERTIARY QUATERNARY AND TERTIARY SEDIMENTARY ROCKS, UNDIVIDED

TERTIARY $\mathbb{N}$ TERTIARY ROCKS, UNDIVIDED

CRETACEOUS $\square$ CRETACEOUS ROCKS, UNDIVIDED

JURASSIC [UT JURASSIC ROCKS, UNDIVIDED

TRIASSIC $\Gamma$ 嫼

UNCONFORMITY

PERMIAN $\mid \begin{aligned} & \text { SAN ANDRES LIMESTONE } \\ & \text { GLORIETA SANDSTONE } \\ & \text { ABO AND YESO FORMATIONS, UNDIVIDED }\end{aligned}$

PENNSYLVANIAN [ PENNSYLVANIAN ROCKS, UNDIVIDED

PRECAMBRIAN [UIAT PRECAMBRIAN ROCKS, UNDIVIDED

GEOLOGIC CONTACT

Figure 4.--General geology of the study area (modified from Dane and Bachman, 1965). 
About 2 million years ago, the central part of the study area became the site of extensive volcanism (formation of Mount Taylor). This volcanism continued intermittently until as recently as 400 years ago. Abundant volcanic maars in the Mount Taylor region formed 3.2 to 1.5 million years ago, indicating that a wet climate may have existed during this period (Crumpler, 1982, p. 294). Basalt-capped mesas such as Cebollita and Horace (fig. 1) are remnants of what was once a large basalt-covered plateau that extended over many hundreds of square miles in the central and eastern parts of the study area.

Moench and Schlee (1967, p. 54) indicated that the ancestral Rio San Jose drainage was developed before the extrusion of the basalts capping Mesa Chivato. They estimated that the level of the ancestral drainage was 650 to 700 feet above the level of the present Rio San Jose. Since the extrusion of the basalts capping Mesa Chivato, the base level of the Rio San Jose drainage has dropped and resulted in the removal of large amounts of material. Crumpler (1982, p. 293) indicated that this erosional downcutting must have been extreme in the interval 2.5 million to 500,000 years ago.

\section{Structure}

Major structural features in the study area include the Zuni uplift, Chaco slope, Acoma embayment, Lucero uplift, Rio Puerco fault zone, and the northern part of the Mogollon slope (fig. 5). These structural features affect the ground-water conditions in the San Andres-Glorieta aquifer.

The Zuni uplift is an elongate dome about 75 miles 1 ong and about 30 miles wide. The structure is oriented northwest-southeast with exposures of Precambrian granitic and metamorphic rocks in the central part of the uplift. Sedimentary rocks dip away from the uplift. Dips on the southwestern flank range from 5 to 20 degrees, and dips on the northeastern flank range from 3 to 10 degrees. Normal faults trending northeast are common in the southeastern part of the uplift.

A series of alternating cuestas and valleys has been formed by the tilted sedimentary rocks. The steep faces of the cuestas are facing toward the center of the uplifted area; long dip slopes facing outward have developed on the more resistant rocks. Long valleys running parallel to the axis of the uplift have been created by erosion of the less resistant rocks. Much of the Grants-Bluewater area lies in such a valley that has been eroded into the less resistant strata of the Chinle Formation. Dips of the sedimentary rocks surrounding the dome are somewhat steeper than the surface slopes.

Gently dipping rocks on the northeast flank of the Zuni uplift form the Chaco slope (Woodward and Callender, 1977, p. 209). A few small-scale domes interrupt the otherwise uniform dip of this structural area (pl. 1 ,

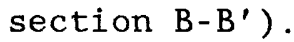




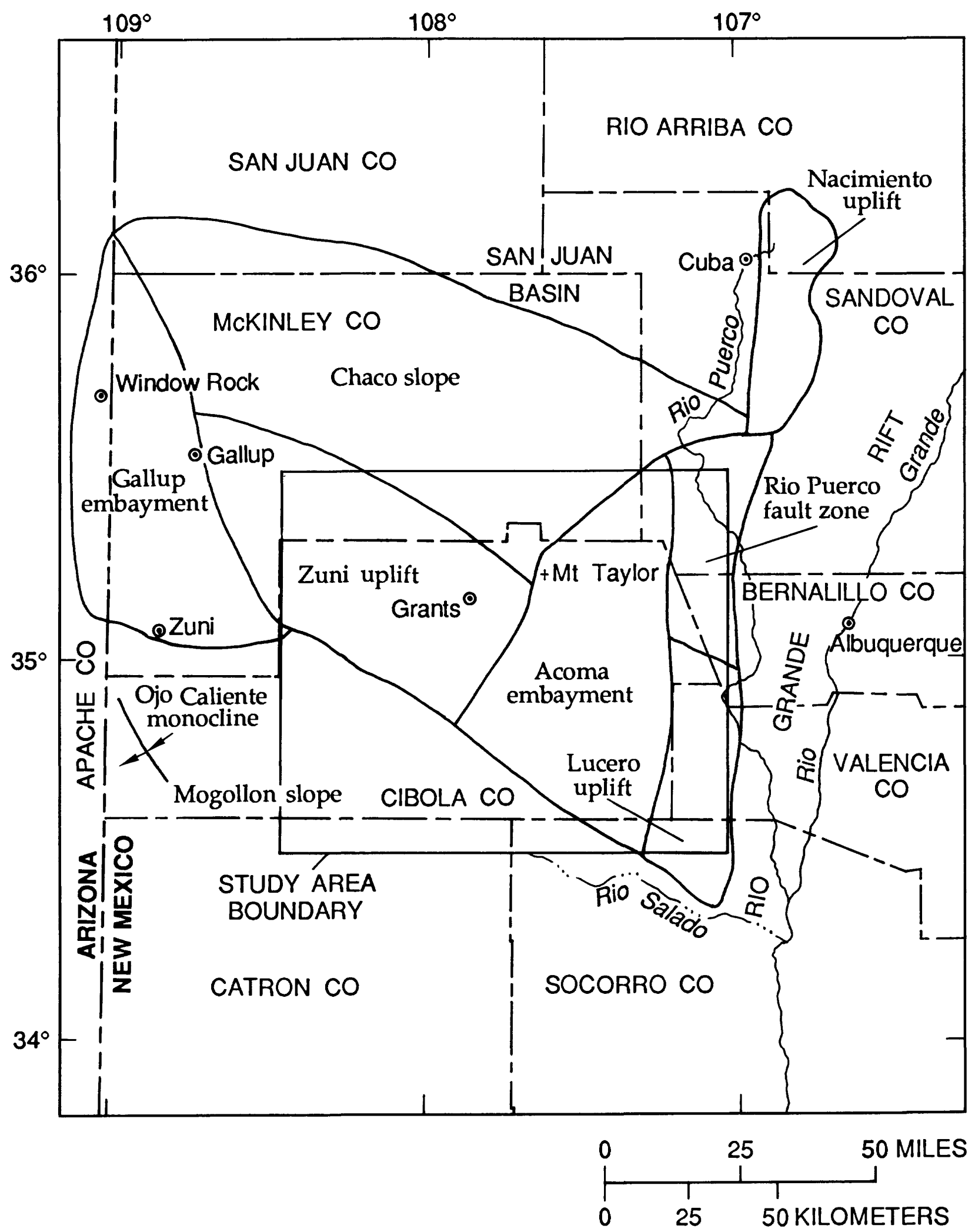

Figure 5.--Regional structural features of northwestern New Mexico (modified from Fitzsimmons, 1959, fig. 1). 
The Acoma embayment is a broad synclinal area oriented roughly northsouth that lies between the Zuni and Lucero uplifts. This embayment connects the San Juan Basin to the north and the Mogollon slope to the south. The Acoma embayment is marked by volcanic features such as Mount Taylor, smaller volcanic necks and plugs in its northern part, and volcanic dikes and sills in its southern part.

Structural features east of the Acoma embayment include the Lucero uplift and the Rio Puerco fault zone (fig. 5). The Lucero uplift borders the southeastern part of the Acoma embayment, separating it from the Rio Grande rift to the east. The uplift is about 40 miles long, as much as 10 miles wide, and forms the western flank of a north-plunging arch (Kelley and Wood, 1946). Structural relief between the uplift and the adjacent Rio Grande rift may be as much as 20,000 feet (Fitzsimmons, 1959, p. 114). Altitudes in the uplift range from 7,000 to 7,500 feet above sea level. Paleozoic and Mesozoic sedimentary rocks in the uplift dip to the west.

The Rio Puerco fault zone is a transitional zone between the Colorado Plateau to the west and the Rio Grande rift to the east. Slack and Campbell (1976, p. 51) indicated that the majority of faults in the Rio Puerco fault zone are the result of divergent wrenching during Laramide time (Late Cretaceous-early Tertiary). The zone is marked by north-trending normal faults. Displacement along the faults generally is small, but can be as much as 2,000 feet.

South of the Zuni uplift and Acoma embayment lies the Mogollon slope. Sedimentary rocks in this area dip gently to the south and are covered by volcanic rocks.

Major faults in the study area are mostly along the Zuni and the Lucero uplifts (fig. 6). Faults in the Zuni uplift generally are normal faults oriented northwest to southeast. The fault bordering The Malpais Valley on the east is downthrown on the west and the fault bordering the valley on the west is downthrown on the east. This probably has resulted in formation of a graben in the southern part of The Malpais Valley, although the area is covered by extensive basalt flows and the existence of this structure is not confirmed. Other small horst and graben structures are in the Rio San Jose valley between Bluewater Lake and Grants (fig. 6). Many of the surface-water drainages and arroyos on the northeast and southwest sides of the Zuni uplift follow fault traces.

\section{Stratigraphy}

The general surficial geology of the study area is shown in figure 4, and the thickness and stratigraphic relations of the various geologic units along selected geologic sections are shown on plate 1. Stratigraphic control was not available in many areas; therefore some thicknesses shown on the geologic sections are estimated. In areas where stratigraphic control was not available, altitudes of formation tops were estimated by subtracting estimated formation thicknesses from the altitude of the base of the Dakota Sandstone (Thaden and Zech, 1984). 


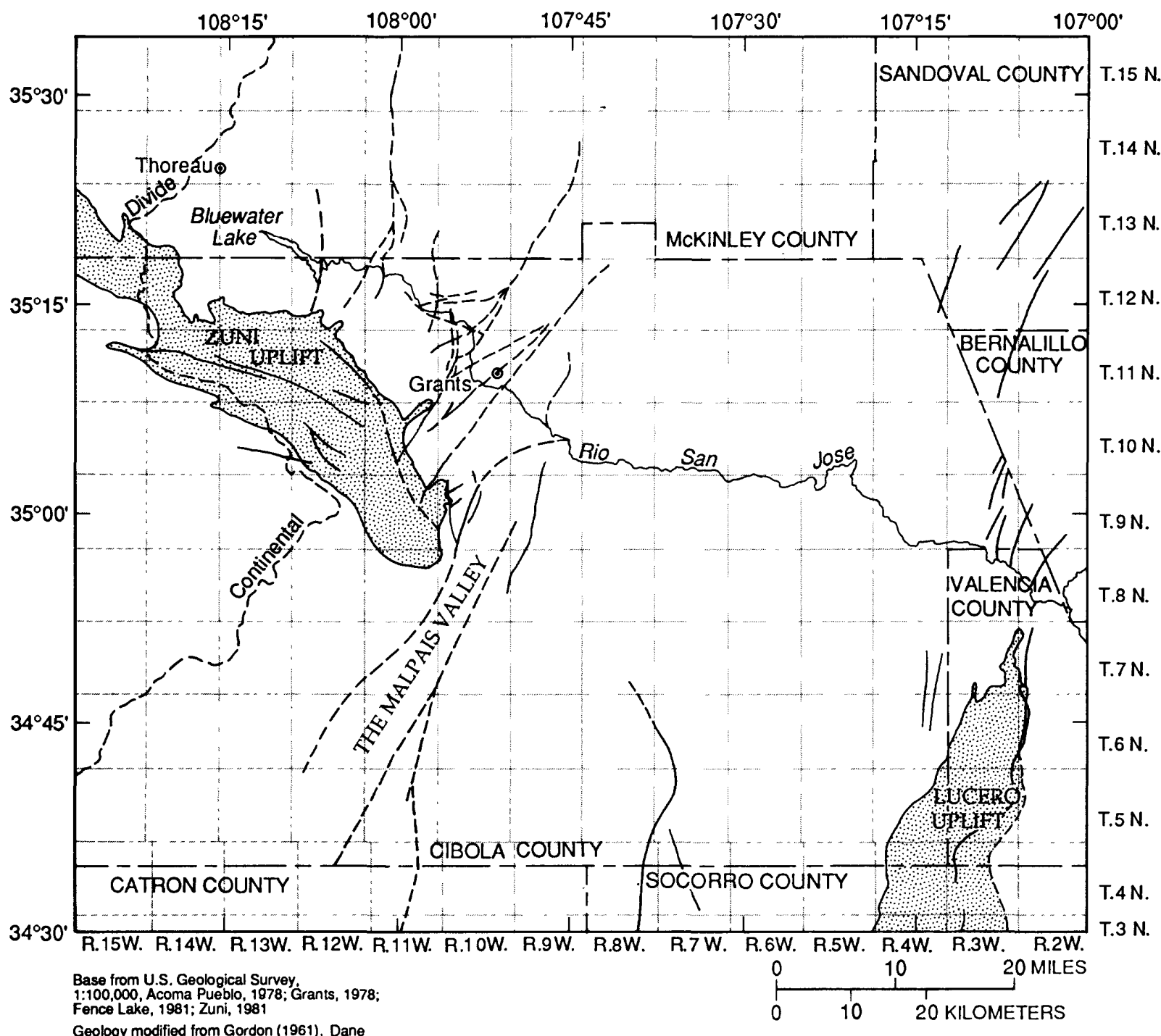

EXPLANATION

AREA WHERE SAN ANDRES LIMESTONE AND

GLORIETA SANDSTONE ARE ABSENT

FAULT -- Dashed where approximately located

Figure 6.--Location of major faults in the study area. 


\section{Precambrian Rocks}

The oldest rocks, igneous and metamorphic rocks of Precambrian age, are exposed in the Zuni Mountains (fig. 4). These rocks consist of granite, gneiss, metarhyolite, schist, and greenstone. The depth to Precambrian rocks increases away from the Zuni uplift. As much as 6,000 feet of younger rocks overlie Precambrian rocks in the northern and eastern parts of the study area (pl. 1), although the total thickness of overlying rocks may exceed 10,000 feet locally in the Mount Taylor area.

\section{Pennsylvanian Rocks}

Pennsylvanian rocks include the Sandia Formation and the overlying Madera Limestone. The following summary of these rocks is taken from Kelley and Wood (1946). The Sandia Formation consists of a thin, lower limestone member and an overlying clastic member. About 100 feet of sandstone of this clastic member is exposed in the area of the Lucero uplift. The Sandia Formation has a maximum thickness of about 400 feet, thinning toward the north and west.

The Madera Limestone is composed of three members. In ascending order, they are the Gray Mesa, Atrasado, and Red Tanks Members. The Gray Mesa Member consists of limestone with minor amounts of shale and sandstone. The Atrasado Member consists of limestone, shale, and conglomeratic sandstone. The Red Tanks Member consists of limestone, sandstone, and siltstone. The Madera Limestone is 1,600 to 1,900 feet thick in the area of the Lucero uplift, thinning toward the west (fig. 7). The unit pinches out along a northwest trend in the central part of the area (fig. 7).

\section{Permian Rocks}

Permian rocks are, in ascending order, the Abo and Yeso Formations, the Glorieta Sandstone, and the San Andres Limestone. Exposures of these rocks are present in the Zuni Mountains and along the Lucero uplift. Permian rocks are absent in the central part of the Zuni uplift where they have been removed by erosion (fig. 4).

\section{Abo Formation}

The Abo Formation is composed of reddish-brown, fine- to coarse-grained sandstone, siltstone, and shale. Conglomerate beds are found in the lower part of the unit. Mud cracks, current ripples, and plant impressions indicate that the Abo Formation was deposited under continental conditions. The Abo Formation conformably overlies Pennsylvanian rocks in the eastern one-half of the study area and unconformably overlies Precambrian rocks west of the zerothickness line (pinch-out) of Pennsylvanian rocks (fig. 7). A measured thickness of 780 feet is present in the Zuri Mountains (Gordon, 1961, p. 20). 0il-test holes have penetrated about 1,200 feet of Abo Formation in the eastern part of the study area. 


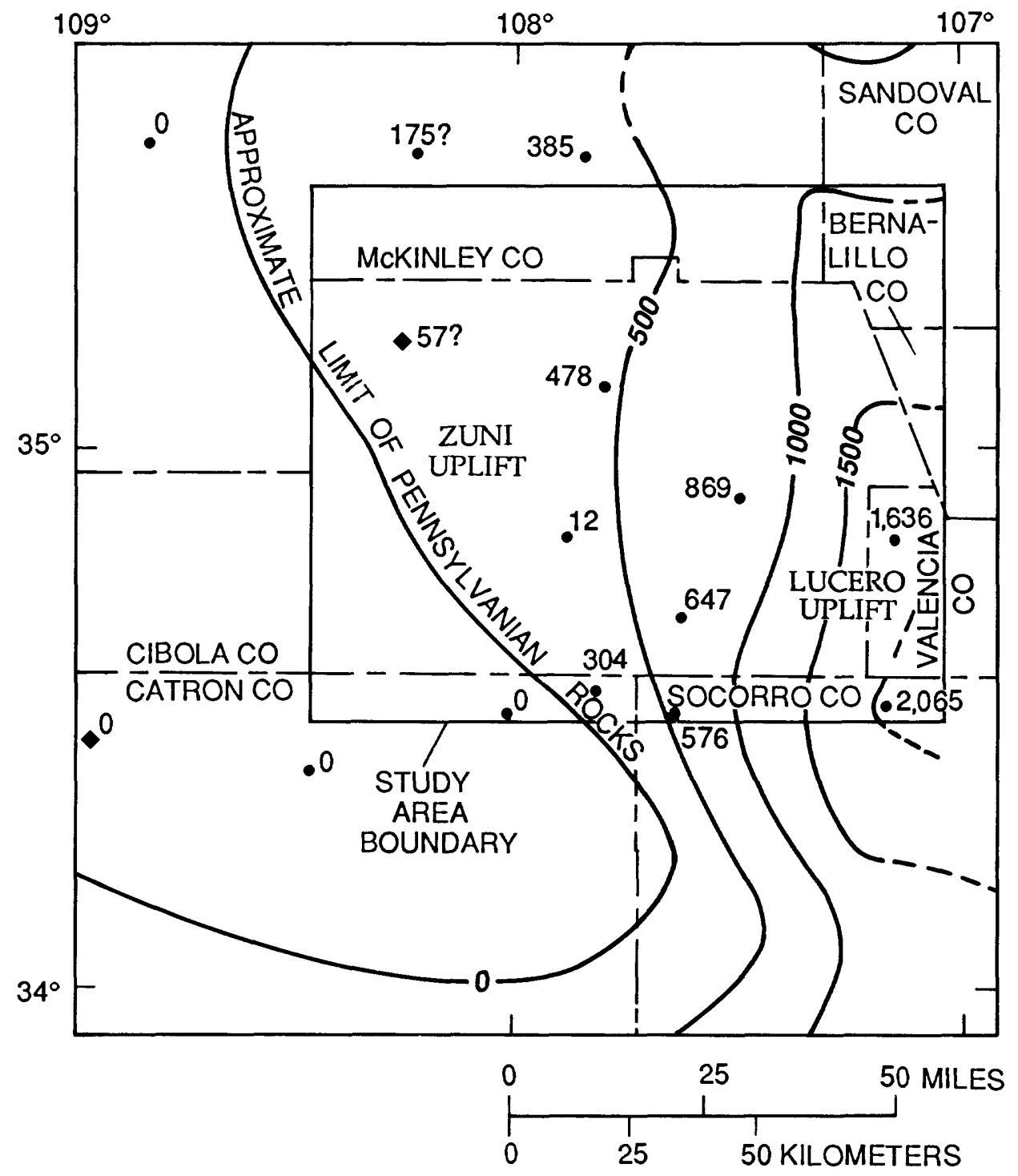

\section{EXPLANATION}

-500- - - LINE OF EQUAL THICKNESS OF PENNSYLVANIAN ROCKS--Dashed where inferred. Contour interval 500 feet

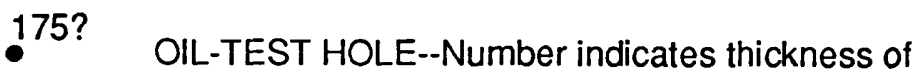
Pennsylvanian rocks, in feet; ? indicates rocks thought to be Pennsylvanian but not confirmed

-57? LOCATION OF PENNSYLVANIAN ROCK OUTCROP.Number indicates thickness of Pennsylvanian rocks, in feet; ? indicates rocks thought to be Pennsylvanian but not confirmed

Figure 7.--Thickness of undivided Pennsylvanian rocks in the study area (modified from Foster, 1957). 


\section{Yeso Formation}

The Yeso Formation underlies all of the study area with the exception of an area in the Zuni Mountains and an area in the southeastern part of the Lucero uplift where these rocks have been removed by erosion. The formation conformably overlies the Abo Formation and ranges in thickness from about 800 feet in the Grants-Bluewater area to about 1,400 feet in the eastern part of the study area.

The Yeso Formation is composed of, in ascending order, the Meseta Blanca Sandstone Member and the San Ysidro Member, both marine in origin. The Meseta Blanca Sandstone Member is a crossbedded, fine-grained sandstone with some siltstone in the basal part. In the eastern part of the study area along the Lucero uplift, the sandstone is very friable. The Meseta Blanca Sandstone Member ranges in thickness from 300 to 600 feet in the study area (Baars, 1962, fig. 15). The San Ysidro Member is an evenly bedded clayey sandstone and siltstone. In the eastern part of the study area, the upper one-half of the San Ysidro Member is predominantly gypsum or gypsiferous shale. The thickness of the San Ysidro ranges from 100 to 600 feet (Baars, 1962, fig. 16).

\section{Glorieta Sandstone}

The Glorieta Sandstone is present in most of the study area except along the Lucero uplift and in the Zuni Mountains where it has been removed by erosion (fig. 4 and $\mathrm{pl} .1$ ). The unit conformably overlies the Yeso Formation. The contact between the two formations is gradational and difficult to determine. In the Grants-Bluewater area, the Glorieta Sandstone consists of 86 to 300 feet of massive, well-sorted and well-cemented, fine- to mediumgrained sandstone (Gordon, 1961, p. 24). In the Acoma embayment, samples of the Glorieta Sandstone from test wells drilled from 1984 to 1986 are composed of well-sorted, very fine to medium-grained quartzose sandstone that may contain gypsum. At well 9N.6W.16.111, gypsum accounted for 80 of the 120 feet of Glorieta Sandstone drilled. This well probably did not penetrate the entire thickness of the Glorieta Sandstone. The sandstone is commonly pyritic and appears to be massive. At a test well at $8 \mathrm{~N} .6 \mathrm{~W} .20 .333,167$ feet of Glorieta Sandstone was penetrated. Along the Lucero uplift, in T. 4 N., R. 4 W., sec. 10, Jicha (1958, p. 14) reported a thickness of 134 feet of Glorieta Sandstone. Baars (1962, p. 200, fig. 17) showed the Glorieta Sandstone thinning gradually to the northeast to a thickness of about 100 feet in the northeastern part of the study area.

\section{San Andres Limestone}

The San Andres Limestone is present throughout the study area except along the Lucero uplift and in the central part of the Zuni uplift where it has been removed by erosion (fig. 4 and pl. 1). The San Andres Limestone was deposited under marine conditions and conformably overlies the Glorieta Sandstone. The extensive interfingering of the two units in some areas makes determination of the contact difficult. In the Grants-Bluewater area, the San Andres Limestone ranges in thickness from 80 to 150 feet (Gordon, 1961, p. 29), whereas in the vicinity of Thoreau, subsurface data indicate that the 
unit is at most 40 to 50 feet thick and often is absent. The combined thickness of the San Andres Limestone and Glorieta Sandstone is shown in figure 8 .

In the Grants-Bluewater area, the San Andres Limestone consists of an upper and lower massive, fossiliferous limestone separated by a middle sandstone unit (Gordon, 1961, p. 27). To the northwest, the upper part of the formation was removed by erosion that occurred during Late Permian and Early Triassic time, and only part of the lower massive limestone remains (Baars, 1962, p. 209). The depositional environment in these areas is believed to have been a shallow shelf carbonate sequence, much like the present-day south Florida coastal area (Baars and Stevenson, 1977, p. 136).

East of the Zuni uplift, the depositional environment (evaporite basin) resulted in a gypsiferous series (Baars, 1962, p. 208), and the thickness increases from about 150 feet in the Grants-Bluewater area to as much as 450 feet in the Lucero uplift. The increased thickness mainly is due to gypsum or anhydrite deposits in the lower part of the San Andres Limestone. Along the Lucero uplift, at T. 6 N., R. 4 W., sec. 35, the San Andres Limestone contains about 55 percent gypsum, 35 percent limestone, and about 10 percent sandstone. The total thickness was estimated to be about 600 to 700 feet. In some areas of the Acoma embayment, intrusive sills occur in the San Andres Limestone. An oil-test hole, 7N.7W.2.414, penetrated about 70 feet of intrusive material in one sill, and test well 8N.6W.20.3334 penetrated numerous thin sills in the San Andres Limestone.

The contact between the San Andres Limestone and the overlying Chinle Formation is marked by an erosional unconformity. The erosional period represented by the unconformity lasted from Early Permian to Middle or Late Triassic time (Baars, 1962, p. 209). Erosion appears to have been greater around the Zuni Mountains. This area possibly was uplifted shortly after deposition of the marine deposits of the San Andres Limestone and was at or near land surface for some time. In the Grants-Bluewater area, solution channels and cavernous zones generally are well connected (Gordon, 1961, p. 29). In some areas near Grants, caverns and sinkholes near the top of the San Andres Limestone are filled with Triassic sediments. South and southeast of Grants, cavernous zones in the San Andres Limestone also have been penetrated in oil-and hydrologic-test wells (fig. 8). These cavernous zones indicate that a south-trending structural high existed during this erosional period.

The depth to the top and the altitude of the top of the San Andres Limestone vary throughout the study area, as shown on plate 1 and in figure 9 . The formation crops out along the northeast and southwest flanks of the Zuni uplift and along the Lucero uplift. In areas where stratigraphic control was not available, the altitude of the top of the San Andres Limestone was estimated by subtracting estimated formation thicknesses from the altitude of the base of the Dakota Sandstone (Thaden and Zech, 1984). The depth to the top of the San Andres Limestone ranges from zero in the Zuni Mountains to as much as 8,300 feet below land surface in the Mount Taylor area. In the eastern part of the study area, the top of the formation generally is 2,000 to 3,000 feet below land surface. Areas where faulting has created varying amounts of offset in the San Andres Limestone are shown in figure 9. 


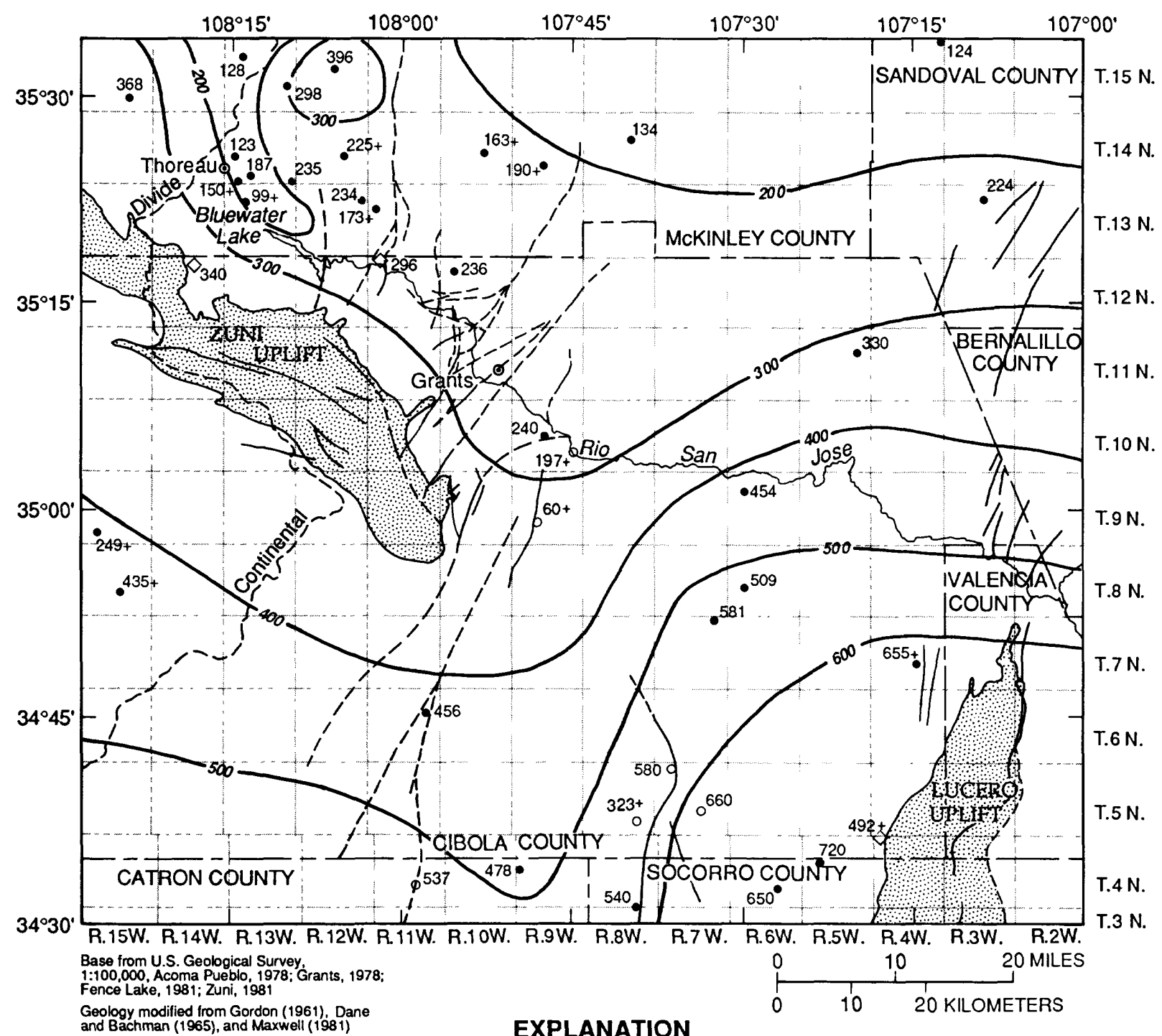

AREA WHERE SAN ANDRES LIMESTONE AND GLORIETA SANDSTONE ARE ABSENT

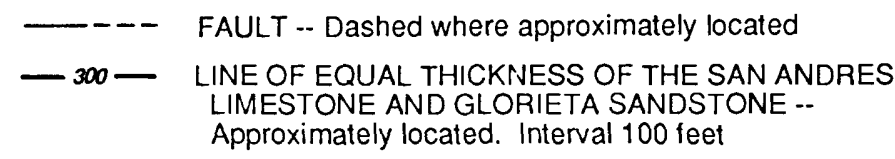

-249+ WELL -- Number is thickness of San Andres Limestone and Glorieta Sandstone penetrated by well, in feet. + indicates well did not penetrate entire thickness of both formations

$0^{660}$ OIL-TEST HOLE OR WELL WHERE CAVERNOUS OR HIGHLY FRACTURED ZONE WAS PENETRATED IN THE SAN ANDRES LIMESTONE AND GLORIETA SANDSTONE-- Number is thickness of San Andres Limestone and Glorieta Sandstone penetrated by well, in feet. + indicates well did not penetrate entire thickness of both formations

$\diamond^{340}$ OUTCROP.- Number is thickness of measured section of San Andres Limestone and Glorieta Sandstone. + indicates entire thickness of both formations was not measured

Figure 8.--Thickness of undivided San Andres Limestone and Glorieta Sandstone in the study area. 


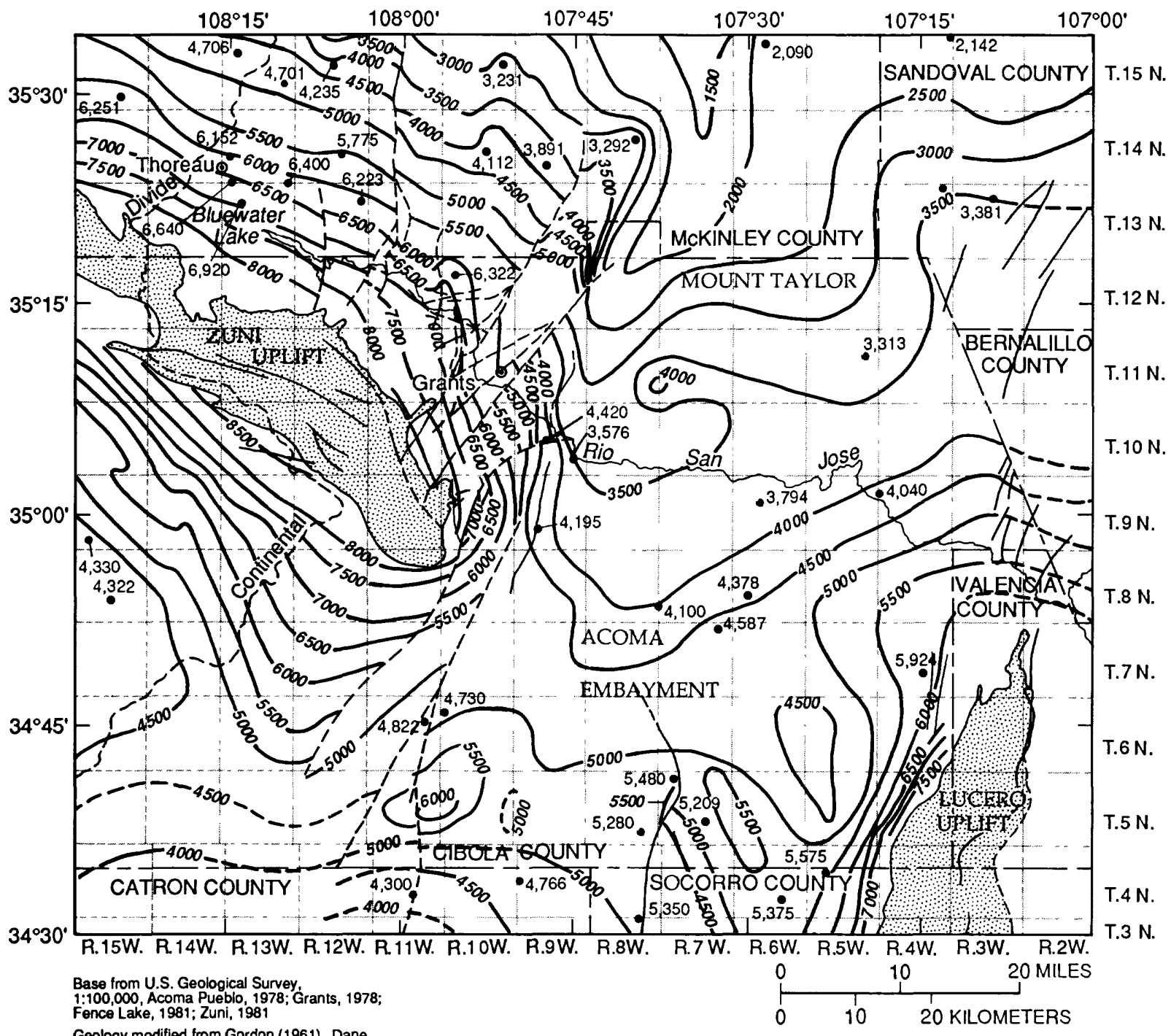

Goology modified from Gordon (1961), Dane and Bachman (1965), and Maxwell (1981)

\section{EXPLANATION}

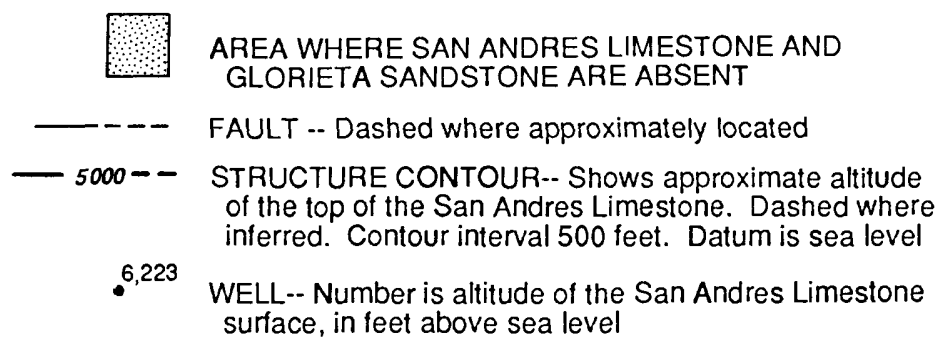

Figure 9.--Generalized structure contours on the top of the San Andres Limestone surface. 


\section{Triassic Rocks}

Triassic rocks in the study area are represented by the Chinle Formation. The Chinle Formation as described in this report includes the overlying Wingate Sandstone, where present. The Chinle Formation is composed of reddish-brown siltstone and mudstone and grayish-purple mudstone. Sandstone beds may be as much as 30 feet thick in the middle part of the Chinle Formation, but these beds vary in thickness over short distances. Lithologic and borehole-geophysical data from seven hydrologic-test wells drilled in the Acoma embayment during this study indicate that the sandstone is clayey or silty or possibly interbedded with clay and silt.

The thickness of the Chinle Formation varies considerably across the study area (fig. 10). The formation is absent in the Zuni uplift and along the Lucero uplift where it has been removed by erosion. The formation thickens toward the north across the Grants-Bluewater valley where the overlying Jurassic and Cretaceous rocks occur and the unit has not been eroded.

South of the Zuni uplift, exposures of the Chinle Formation have been covered by extensive basalt flows on the North Plains, and the zero-thickness and full-(uneroded) thickness lines in figure 10 are based on projections of dip slopes. In The Malpais Valley, south of Grants (fig. 4), exposures of the Chinle Formation also have been covered by extensive basalt flows. Geologic mapping by Maxwell (1981) and Thaden and Zech (1984) indicates that this area is a graben-type structure with bounding faults extending southwest from the vicinity of the Rio San Jose for 30 to 40 miles. Chinle exposures on the west side of The Malpais Valley and test-hole data on the east side of the area indicate that the thickness of the Chinle Formation is partly or completely preserved within the graben feature. Elsewhere in the study area, the thickness of the Chinle Formation ranges from about 1,000 to more than 1,800 feet. 


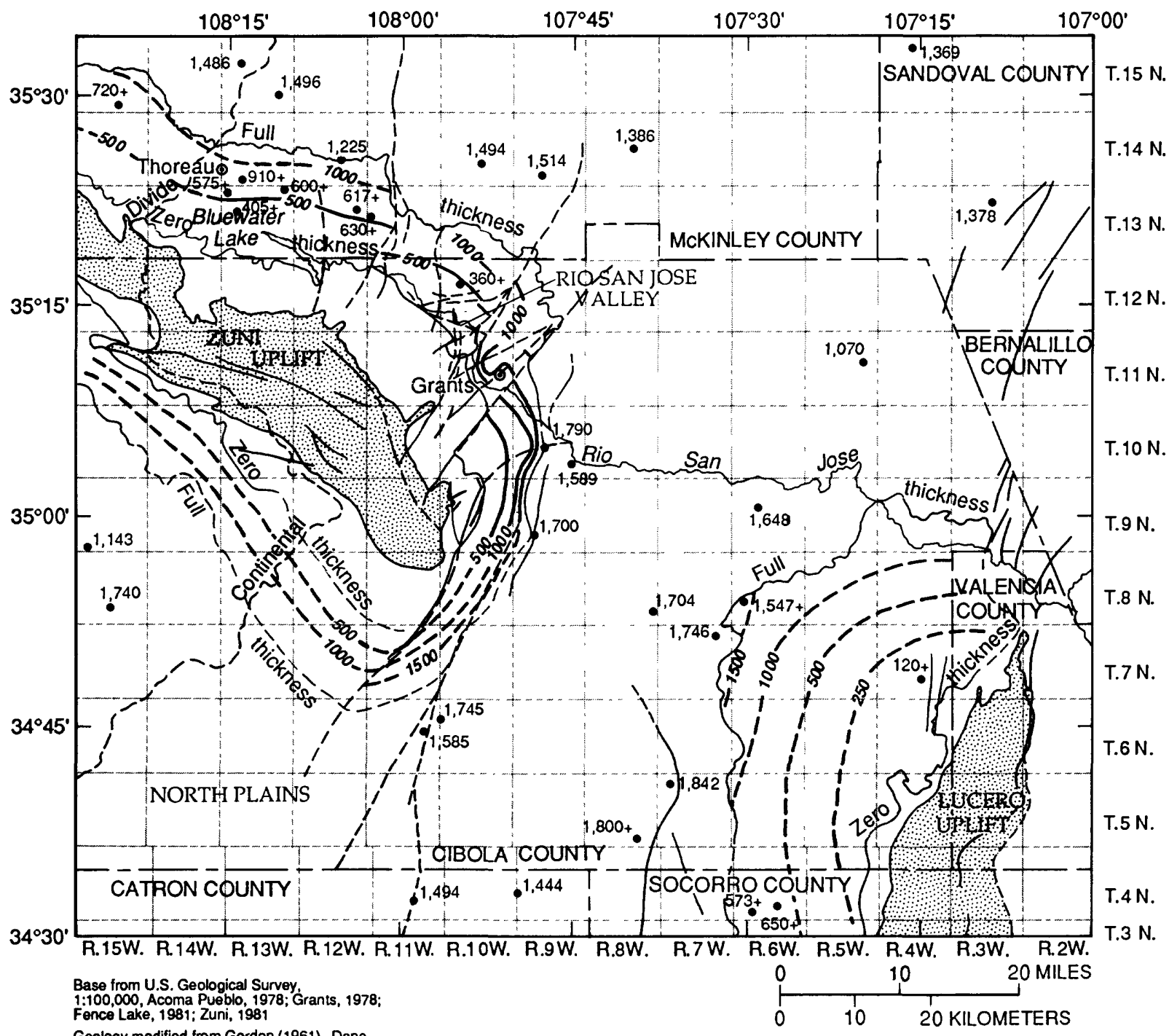

Geology modified from Gordon (1961), Dane Geology modified from Gordon (1961), Dane
and Bachman (1965), and Maxwell (1981)

\section{EXPLANATION}

AREA WHERE SAN ANDRES LIMESTONE AND GLORIETA SANDSTONE ARE ABSENT

FAULT -- Dashed where approximately located

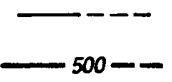

LINE OF EQUAL THICKNESS OF CHINLE FORMATION -Dashed where inferred. Contour interval 500 feet, supplemental 250 -foot contour

$.1,800+$ WELL-- Number shows thickness of Chinle Formation. + indicates eroded top of formation

Figure 10.--Thickness of the Chinle Formation in the study area. Water levels are for 1980-86. 
Rocks Younger Than Triassic and Older Than the Quaternary Valley-Fill Deposits

Rocks that are younger than Triassic and older than the Quaternary valley-fill deposits include sedimentary rocks of Jurassic, Cretaceous, and Tertiary age, and volcanic rocks of Tertiary and Quaternary age (fig. 4). Erosion has removed Jurassic rocks from a large area of the Zuni and Lucero uplifts. Following deposition of Jurassic rocks, the region was tilted toward the north. A long erosional period created a beveled surface on Jurassic rocks from the vicinity of Interstate 40 to the south. Jurassic rocks thin to a feather edge near the southern boundary of Cibola County. The thickest section occurs in the northeastern part of the study area, where about 1,100 feet of Jurassic rocks remain. About one-half of the total thickness is shale and siltstone and one-half is well-cemented sandstone.

Following the erosional period, an estimated 5,000 feet of Cretaceous rocks was deposited (Moench and Schlee, 1967, p. 2). During the last part of the Cretaceous Period, erosion removed a large amount of the original thickness of the rocks from the eastern part of the study area (fig. 4). Cretaceous rocks are about 1,000 feet thick in some parts of the study area; about one-half of this thickness is sandstone and one-half is shale.

Deposits mainly consisting of Tertiary volcanic rocks occur along the southern part of the study area. These deposits are composed of volcanic material interbedded with claystone (Guilinger, 1982, p. 52). The thickness is about 200 to 300 feet. Other Tertiary rocks include basalt flows capping mesas in the southeastern part of the study area and mesas north of Grants (fig. 4). The basalts on mesas in the Grants region probably formed a continuous sheet at the time of deposition, but erosion has since removed much of this material. Tertiary volcanic material forms the Mount Taylor composite volcano.

\section{Quaternary Valley-Fill Deposits}

Quaternary valley-fill deposits of significance include alluvium and basalt flows in the Grants-Bluewater area, The Malpais Valley, and the North Plains area (fig. 4). Valley-fill deposits in the Rio San Jose valley downstream from Horace springs (10N.9W.23.423) are not considered in this discussion because they are separated from the San Andres-Glorieta aquifer by a large thickness of Chinle Formation. 
A prolonged erosional period followed late Tertiary volcanism that had formed Mount Taylor and the adjacent basalt sheets. Regional drainage at this time was east toward the Rio Grande. In The Malpais Valley and the Rio San Jose valley northwest of Grants, erosion removed all Cretaceous and Jurassic rocks, and streams eroded into the underlying Chinle Formation and older rocks. Gordon (1961, p. 37) estimated that these streams eroded valleys from 150 to 200 feet below the altitude of the present land surface. Factors such as reduced stream gradients or a decrease in the quantity of precipitation caused the incised valleys to begin filling with alluvial deposits of sand, silt, and gravel that reached thicknesses of about 30 feet. Basaltic lava flows began to fill parts of the valleys (Gordon, 1961, p. 37), and deposition of both alluvium and basalt continued. Some interbedded basalt-alluvium sequences have been penetrated during drilling. In most areas, however, the alluvium probably was deposited adjacent to the basalt rather than on its top because of the higher topographic relief of the basalt flows.

In the Grants-Bluewater area, the alluvium consists of sand, silt, and gravel-sized material. Near the Zuni uplift, the alluvium is composed of limestone, sandstone, and chert fragments, whereas northeast of Milan, the alluvium is composed of fine-grained clay, silt, and sand material derived from Jurassic and Cretaceous rocks to the north (Hydro-Search, Inc., 1981, p. 12). Core-test holes 9 N.10W.2.000 and $12 \mathrm{~N} .11 \mathrm{~W} .14 .213$ indicate that the basalt is composed of alternating dense and vesicular layers, in some places with lava tubes.

The nature of the valley-fill deposits in The Malpais Valley is less well known. Streamflow from the south toward the Rio San Jose 1ikely formed an ancestral valley. This valley filled with alluvium and basalt that flowed down the surface-water drainages from south to north, in much the same manner as the Rio San Jose valley in the Grants-Bluewater area. Wells have been drilled only along the sides of the valley because of the extremely rough nature of the basalt flows, and no geologic information is available regarding the location, depth, or type of material in the buried valley. The gradient of the ancestral valley probably is similar to that of the ancestral Rio San Jose valley, and the depth near the mouth of the valley would be the same as the ancestral Rio San Jose valley at the confluence. Drilling records from oil-test hole 10N.9W.21.222 indicate that the valley-fill material is about 200 feet thick at this location.

An examination of topographic maps of the North Plains area indicates that the Continental Divide may have been as much as 20 to 25 miles east of its present position in prevolcanic times. The current location of the divide may be a result of the accumulation of extensive basalt flows and cinder cones extruded along a northeast-trending fault zone beneath the divide (Maxwell, 1981). If so, the drainage area for the ancestral stream draining the North Plains area would have been much smaller than the present drainage area and the ancestral valley may not contain significant thicknesses of alluvium. 


\section{HYDROGEOLOGY}

A conceptual model of the San Andres-Glorieta aquifer was developed by considering all structural, lithologic, and hydrologic data that describe how water enters, moves through, and leaves the aquifer and that describe rocks hydraulically connected to the aquifer. Rock units that are important in this discussion include Quaternary valley-fill deposits, Triassic Chinle Formation, Glorieta Sandstone and San Andres Limestone (San Andres-Glorieta aquifer), the Permian Yeso and Abo Formations, and undifferentiated Pennsylvanian rocks. Rocks of Tertiary, Cretaceous, and Jurassic age are not hydraulically connected to the San Andres-Glorieta aquifer and the hydrogeology of these rocks is not considered.

\section{Valley-Fill Deposits}

Quaternary valley-fill deposits, which consist of alluvium and basalt, form an aquifer (alluvial aquifer) of local significance in the GrantsBluewater area (fig. 11). Saturated alluvium probably also occurs in The Malpais Valley, but little is known about its thickness and extent. In the Grants-Bluewater area, saturated alluvium may rest on the Chinle Formation or on the San Andres-Glorieta aquifer. Northwest of Bluewater, a wedge of Chinle rocks extends up the flanks of the Zuni Mountains, and the alluvial aquifer rests on the Chinle Formation ( 1 l. 1, section $A_{-A^{\prime}}$ ). In this area, the alluvial aquifer is not in direct hydraulic connection with the San AndresGlorieta aquifer. From Bluewater to Grants, Chinle rocks may be absent, depending on the location of and displacement on faults (p1. 1, section D-D'). Where the alluvial aquifer rests directly on the San Andres-Glorieta aquifer, the two are hydraulically connected. North of Grants and in The Malpais Valley, the alluvial aquifer is separated from the San Andres-Glorieta aquifer by the Chinle Formation and Jurassic and Cretaceous rocks.

\section{Hydraulic Properties}

Aquifer-test data from wells in the Bluewater area indicate that hydraulic conductivity of the alluvial aquifer can range from 40 to about 60 feet per day (Dames and Moore, 1981, table 1). East of Horace Springs, hydraulic conductivity of the alluvial aquifer in the Rio San Jose valley ranges from about 2 to 300 feet per day (Risser and Lyford, 1983, table 4). Values of storage coefficient for the alluvial aquifer in the Grants-Bluewater area are not available.

\section{Ground-Water Movement}

Recharge to the alluvial aquifer under natural conditions is derived from direct precipitation, surface runoff, leakage of water from streams, spring discharge, and upward leakage from the San Andres-Glorieta aquifer. With development of ground-water resources in the study area, new sources of recharge to the alluvial aquifer have been created by leakage of water from irrigation canals and water applied to irrigated areas, leakage from milltailings piles, and recharge from injection wells. 


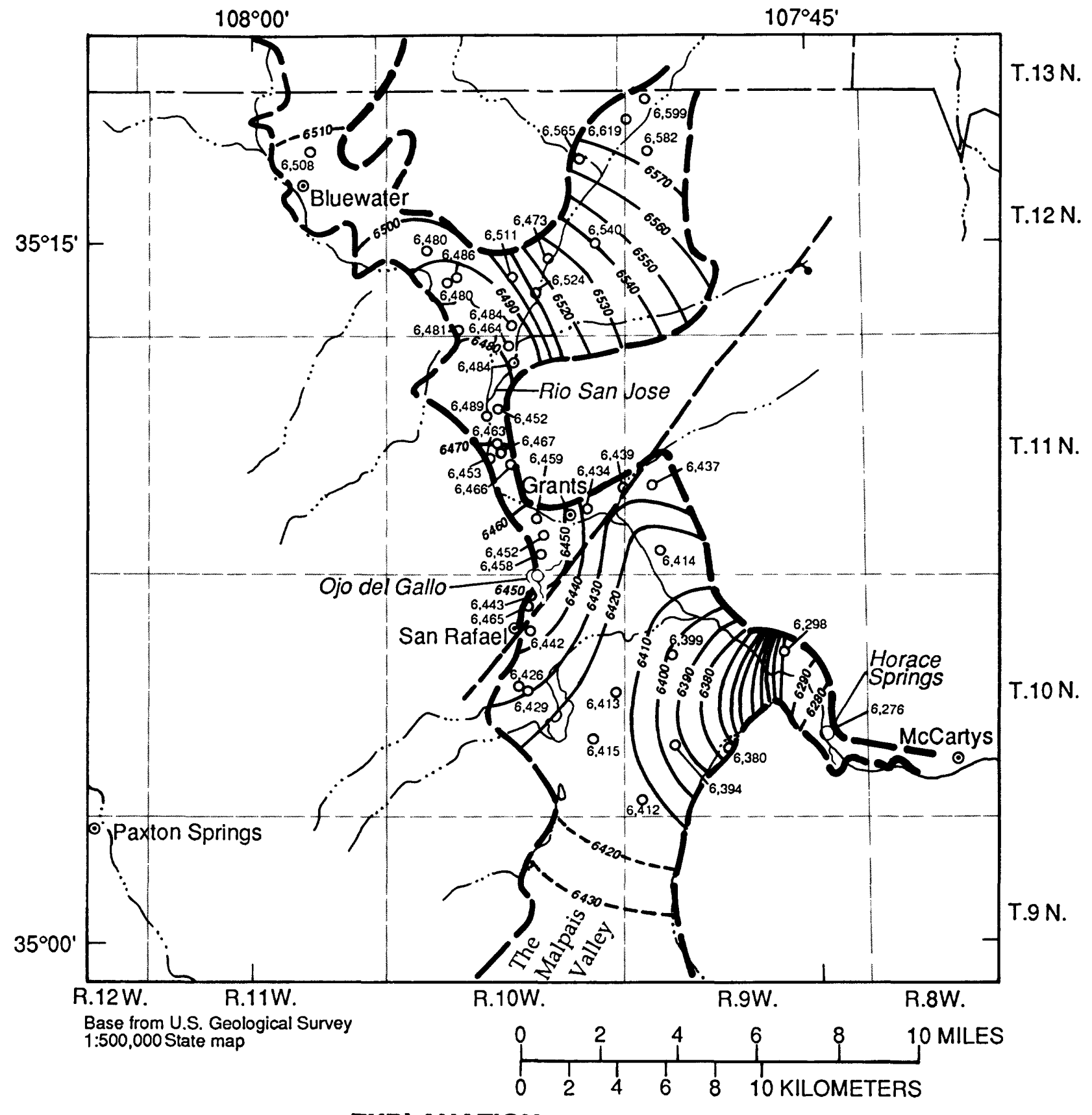

\section{EXPLANATION}

-6.460-- WATER-LEVEL CONTOUR--Shows altitude of water level, in feet. Contour interval is 10 feet. Dashed where approximate. Datum is sea level

\footnotetext{
- - APPROXIMATE LIMIT OF SATURATED VALLEY-FILL DEPOSITS

万— FAULT--Bar and ball on downthrown side

$0^{6.412}$ WELL USED TO CONSTRUCT WATER-LEVEL CONTOUR-Number is altitude of water level in well, in feet. Datum is sea level

$0^{6.276}$ SPRING--Number is altitude of the spring, in feet. Datum is sea level

Figure 11.--Water-level contours for Quaternary valley-fill deposits in the Grants-Bluewater area.
} 
The first known human-induced change in recharge to the alluvial aquifer occurred in 1870 when the flow from 0 jo del Gallo was diverted for irrigation of 600 acres south of San Rafael (Hodges, 1938, p. 373). During the winter months, the spring was allowed to flow along the original channel. The spring previously had discharged to a marsh and then to a channel that flowed east to the Rio San Jose (Hodges, 1938, p. 340). The effects of this diversion on the alluvial aquifer are not well known. Recharge to the alluvium along the original drainage path probably continued, but evapotranspiration probably also occurred, especially in the marsh area. Leakage from the diversion ditch to the alluvium most likely took place, as did recharge from excess irrigation water, but evapotranspiration from the irrigation process may have been less than evapotranspiration from the marsh.

Irrigation south of San Rafael continued until the early 1950's when discharge from 0 jo del Gallo ceased. Recharge to the alluvial aquifer east of 0 jo del Gallo decreased, starting in the early 1950's when the discharge from the spring no longer flowed east toward the Rio San Jose. Water levels are not available from wells completed in alluvium immediately east of 0 jo del Gal1o, but wells 10N.9W.17.113, 10N.9W.29.132, and 10N.9W.31.324, which are from 3.6 to 5.6 miles southeast of 0 jo del Gallo, had water-level declines of about 6 feet from the early 1950's to 1984. These water-level declines may be partially due to a decrease in recharge to the alluvium from ojo del Gallo.

In the Bluewater area, human-related recharge to the alluvial aquifer began with surface-water diversions for irrigation from Bluewater Creek. Hodges (1938, p. 373) noted that "prior to 1895, 200 acres was watered by an old ditch." Presumably this ditch diverted water directly from Bluewater Creek. An earthen dam was built on Bluewater Creek at the present site of Bluewater Dam in 1894. During 1895, storage from this reservoir was used to irrigate 1,600 acres northwest of Bluewater (Hodges, 1938, p. 373). Irrigation from reservoir releases continued until 1905 when the dam washed out. A second earthen dam was constructed at the same location but washed out in September 1909. From 1909 to 1927, some 2,000 to 2,500 acres in the Bluewater area was irrigated by diversions from Bluewater Creek (Gordon, 1961, p. 13). The present Bluewater Dam, constructed in 1927, was built to create a reservoir capable of supplying water to 10,627 acres, but runoff has been sufficient to irrigate only a small part of the original acreage. Gordon (1961, p. 14) noted that from 1944 to 1961 , surface water was available only in 1948,1949 , and 1952 to irrigate 1,500 to 2,000 acres.

Additional recharge to the alluvial aquifer in the Grants-Bluewater area began in 1945 when ground water withdrawn from the San Andres-Glorieta aquifer was used for irrigation. This recharge was a result of leakage from canals and infiltration of water from this applied irrigation. Because of the lack of surface-water runoff, ground water primarily was used for irrigation from 1945 through the early 1970's. Acreage irrigated by ground water began to decline in 1955 as ground water used for agriculture was converted to industrial use (Gordon, 1961, p. 103). Conversations with irrigation district personnel indicate that this decline continued until the early 1970's, when little or no ground water was used for irrigation. Recharge to the alluvial aquifer from this source would have decreased in a like manner. 
Leakage from ponds within tailings piles northeast of Bluewater, north of Grants, and north of Milan also has resulted in recharge to the alluvial aquifer. Water-level changes in a well at 12N.11W.14.213 indicate that recharge from a pond in a nearby tailings pile reached the well during 1956. Studies indicate that recharge from the tailings pond was as large as 1,025 gallons per minute in 1958, but decreased to a few gallons per minute from 1967 through late 1972 (Dames and Moore, 1986, p. 11). Recharge from the tailings pile ponds to the alluvial aquifer may have increased from 1973 to 1977 (Dames and Moore, 1986, p. 11).

Another source of recharge to the alluvial aquifer is a system of injection wells installed around a tailings pile north of Grants. Water for these wells is withdrawn from the San Andres-Glorieta aquifer and injected into the alluvial aquifer to create a ground-water mound downgradient of the tailings pile, thus preventing contaminated recharge from the mill tailings ponds from migrating off the site.

The direction of ground-water movement through the alluvial aquifer generally is the same as the direction of surface-water movement. The direction and rate of movement are controlled by the thickness and hydraulic conductivity of the aquifer and the volume and location of recharge. Water moves through the aquifer toward the southeast in the Rio San Jose valley (fig. 11). Some water moves from the north through alluvium in the San Mateo Creek drainage. Ground water probably moves northward toward the Rio San Jose in The Malpais Valley. The potentiometric surfaces of the alluvial aquifer and the San Andres-Glorieta aquifer intersect in the northwestern part of T. 11 N., R. 10 W. (Gordon, 1961, p1. 2). Northwest of this area, hydraulic heads in the alluvial aquifer are higher than those in the San Andres-Glorieta aquifer. Southwest of this area, potentiometric levels in the alluvial aquifer are lower than those in the San Andres-Glorieta aquifer.

Discharge from the alluvial aquifer is by downward leakage to the San Andres-Glorieta aquifer, evapotranspiration, discharge to streams, and withdrawals by wells. Evapotranspiration from the alluvial aquifer occurs from Grants southeast to Horace Springs in the Rio San Jose valley. Southeast of the fault at Grants (fig. 6), the water table is at or near land surface, as evidenced by standing water or light-colored deposits of salt on the ground. Water in this area may represent water from the San Andres-Glorieta aquifer that leaks up along the fault and enters the alluvium. The alluvium apparently is not transmissive enough to conduct the volume of leakage from the fault. Another area of evapotranspiration is east of 0 jo del Gallo. Under natural conditions, evapotranspiration from the marsh east of the spring must have been large in the summer months. Evapotranspiration from this area probably decreased from the mid-1950's through the early 1980's when Ojo del Gallo was dry. Evapotranspiration probably has begun to increase in this area with the resumption of spring flow. 


\section{Chinle Formation}

The Chinle Formation acts as a confining unit for the underlying San Andres-Glorieta aquifer. The effectiveness of this confining unit depends on the thickness and lithology of the formation. Fracturing and faulting probably have little effect on the confining nature of the rocks because the large clay content probably enables the rocks to deform and squeeze close in fault or fracture zones. During the drilling of test holes east of the Zuni uplift, clay zones in the Chinle Formation were penetrated that squeezed in and tended to seal the drill holes.

\section{Hydraulic Properties}

Hydraulic properties of the Chinle Formation are based on reported values. Laboratory tests performed on shale samples indicate that hydraulicconductivity values can range from $10^{-1}$ to 10-8 feet per day (Wolff, 1981, table 4.5). Heath (1983, p. 13) noted that hydraulic-conductivity values for unfractured shales can range from 10-5 to 10-8 feet per day.

\section{Ground-Water Movement}

The Chinle Formation probably does not contain regional ground-water flow systems in the study area. Precipitation and surface runoff recharge either the overlying alluvium or the underlying San Andres-Glorieta aquifer. Recharge to and discharge from Chinle rocks are mostly by upward and downward leakage of water through the formation. In the area around the Zuni uplift near Grants and Bluewater, some vertical leakage through Chinle rocks to the San Andres-Glorieta aquifer may occur, but hydraulic-head differences between the overlying alluvium and the underlying aquifer usually are small, thus leakage probably is small.

In areas near the Zuni uplift where hydraulic head in the San AndresGlorieta aquifer is higher than that in the alluvium, the difference also usually is small. East of San Rafael, the potentiometric surface in the alluvial material slopes toward the east, whereas the potentiometric surface of the San Andres-Glorieta aquifer is relatively flat from San Rafael east. This results in an increasing head differential toward the east, but the thickness of the Chinle Formation also increases toward the east (fig. 10), which results in more resistance to leakage. The result probably is very little upward leakage through the Chinle Formation in this area.

\section{San Andres-Glorieta Aquifer}

The San Andres-Glorieta aquifer is the major regional aquifer in westcentral New Mexico and east-central Arizona. The San Andres Limestone and the Glorieta Sandstone are considered to form one aquifer because of the gradational contact and good hydraulic connection between the units. 
Most water in the aquifer is transmitted in solution channels, cavernous zones, and fractures in the San Andres Limestone. In the Grants-Bluewater area, these channels, zones, and fractures generally are well connected (Gordon, 1961, p. 29). These features are believed to be most well developed near the Zuni uplift where the rocks were subjected to weathering, solution activity, and fracturing during periods of uplift and exposure. Areas of the aquifer farther from the uplift would be less affected by these conditions. Northwest of Bluewater, prolonged erosion has removed most or all of the San Andres Limestone.

\section{Hydraulic Properties}

To prepare a regional description of the hydraulic properties of the San Andres-Glorieta aquifer, areas of the aquifer that were subject to erosion and formation of fractures and solution channels were considered along with data from aquifer testing. In the Grants-Bluewater area, hydraulic data are available from numerous aquifer tests. In the northwestern part and the eastern half of the study area, the data on these properties are sparse; thus estimates of the properties were made from a few wells.

Temperature effects were not taken into account when estimating hydraulic properties of the aquifer. These effects are not significant in the GrantsBluewater area where water temperatures in the aquifer generally are less than 20 degrees Celsius. In the eastern half of the study area, however, temperature effects on transmissivity may be important. Throughout much of the eastern half of the study area (Acoma embayment), about 3,000 feet of rocks overlie the aquifer, and in some areas, 5,000 feet of rocks overlie the aquifer. In addition to the great depth of burial, heat-flow data indicate a geothermal anomaly in the study area (Reiter and others, 1975, p. 817). Temperatures of water from seven hydrologic-test wells in the Acoma embayment and completed in the San Andres-Glorieta aquifer range from 33.5 to 56.8 degrees Celsius (table 2). Hydraulic conductivity of rocks at temperatures greater than 46 degrees Celsius is more than double that at 16 degrees Celsius because increases in temperature result in decreases in the viscosity of water (Todd, 1959, fig. 3.3).

The study area was divided into seven transmissivity zones (zones I-VII) that were delineated on the basis of aquifer-test results and lithology (fig. 12 and table 3). The slope of the potentiometric surface (fig. 13) also was used to help delineate transmissivity zones. The potentiometric-surface map was constructed on the basis of data presented in table 1.

An area with measured transmissivity values ranging from 30 to 280 feet squared per day is in the northwest part of the study area (zone I, fig. 12). Lithologic information indicates that the San Andres Limestone is either absent or very thin (fig. 12), and that the transmissivity is representative of Glorieta Sandstone. A representative transmissivity for the zone is estimated to be 140 feet squared per day. 


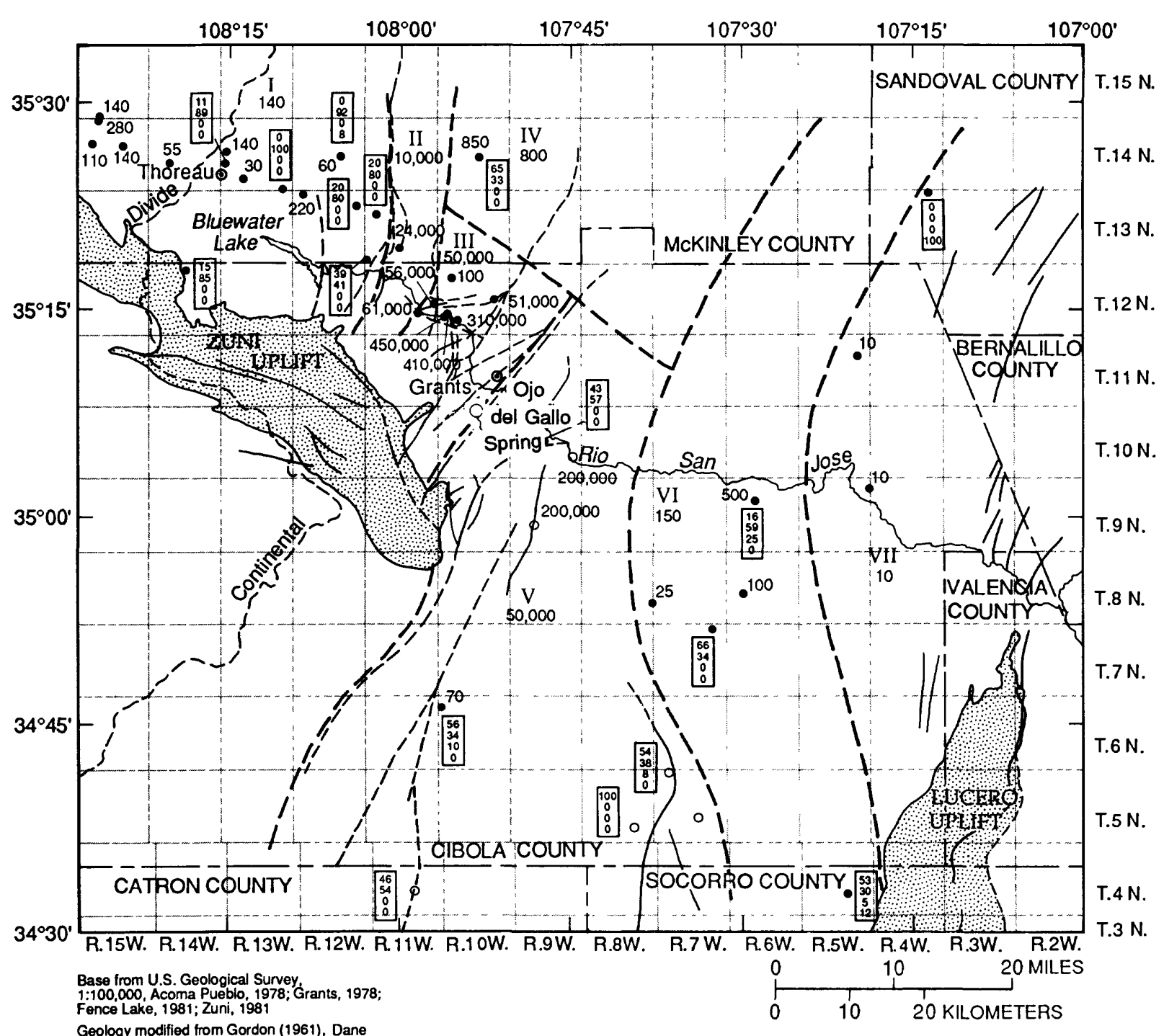

EXPLANATION

AREA WHERE SAN ANDRES LIMESTONE AND GLORIETA SANDSTONE ARE ABSENT

FAULT -- Dashed where approximately located

- $\frac{-1}{140}$ - TRANSMISSIVITY ZONE BOUNDARY--Number is estimated transmissivity, in feet squared per day

LITHOLOGIC COMPOSITION OF SAN ANDRES-

GLORIETA AQUIFER, IN PERCENT OF ROCK TYPE, FROM TOP TO BOTTOM--Carbonates, sandstone, evaporites, and shale

- OIL-TEST HOLE OR WELL WHERE CAVERNOUS OR HIGHLY FRACTURED ZONE WAS PENETRATED IN THE SAN ANDRES-GLORIETA AQUIFER

25 WELL WITH TRANSMISSIVITY DATA--Number is transmissivity, in feet squared per day

Figure 12.--Generalized transmissivity zones for the San Andres-Glorieta aquifer. 


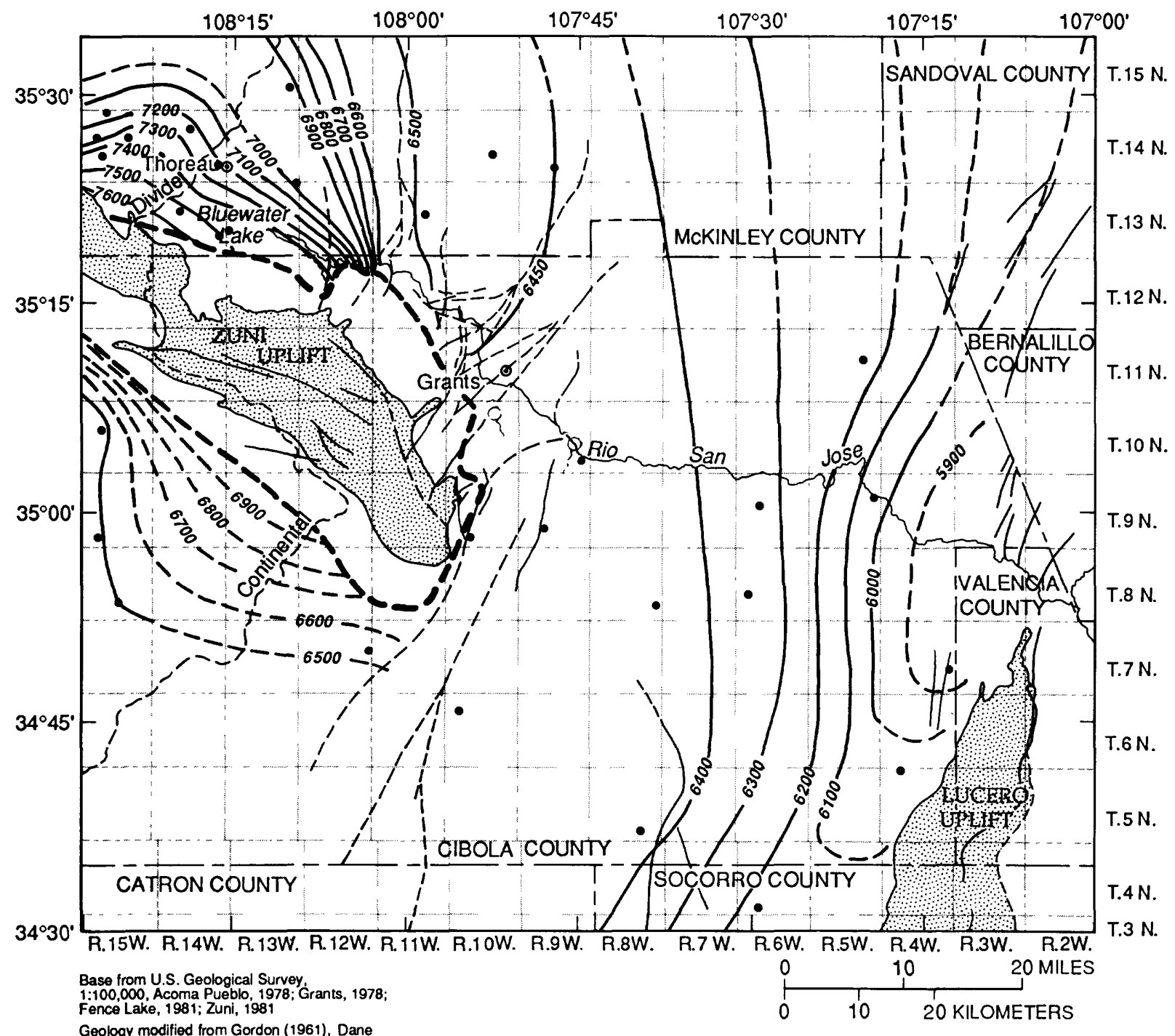

EXPLANATION

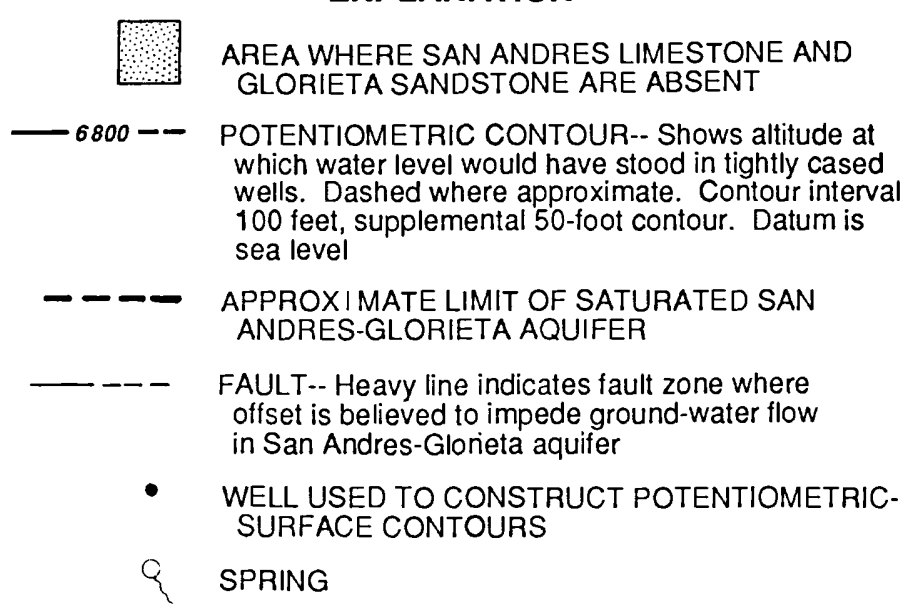

Figure 13.--Potentiometric-surface contours for the San AndresGlorieta aquifer, drawn on the basis of the highest hydraulic-head values on record. 
In the next zone to the east, zone II, lithologic and aquifer-test data are available for only one well (13N.11W.33.332). The San Andres Limestone is absent at this well, but aquifer-test data indicate a transmissivity of 24,000 feet squared per day. This well is adjacent to the Big Draw fault (of Green and Pierson, 1971) and probably is completed in fractured Glorieta Sandstone. This would account for the large transmissivity at this well. The transmissivity of this zone is estimated to be 10,000 feet squared per day.

Zone III includes the Grants-Bluewater area and has measured values of transmissivity that range from 100 to 450,000 feet squared per day (table 3 ). Well yields of as much as 2,830 gallons per minute have been recorded (Gordon, 1961, p. 105). Cavernous zones, faults, and fractures are common throughout this area, and the large range in transmissivity reflects well completions in various configurations of the faulted, fractured, and cavernous carbonate terrain.

The potentiometric surface of the San Andres-Glorieta aquifer in zone III slopes very gently to the east (fig. 13): gradients range from about 8 feet per mile in the western part to less than 1 foot per mile east toward Grants (Hydro-Search, Inc., 1981, p. 20). This gently sloping surface indicates that the aquifer is highly transmissive and that water moves through the aquifer with little loss of hydraulic head.

Areas of less transmissive aquifer material, such as dense, unweathered limestone or we11-cemented, nonfractured sandstone, or both, and the proportion of this small-transmissivity area to the large-transmissivity area need to be taken into account when estimating the areawide transmissivity of zone III. The relative proportions are unknown, but the small-transmissivity area probably is a significant part of the total aquifer framework. An estimated transmissivity of 50,000 feet squared per day was assigned to this zone.

Freeze and Cherry (1979, p. 29) and Heath (1983, p. 13) noted that hydraulic conductivity for cavernous 1 imestone can range from 1 to $1 \times 10^{4}$ feet per day. Assuming an average limestone thickness of 110 feet in the Grants-Bluewater area (Gordon, 1961, p. 29), this would result in a transmissivity range of 110 to $1.1 \times 10^{6}$ feet squared per day for the San Andres Limestone. Although the estimated transmissivity is small in comparison to this range, much of the aquifer in the northeastern part of zone III is believed to consist of small-transmissivity material, which effectively reduces the overall transmissivity of the zone.

The boundaries of transmissivity zone IV, north of the Grants-Bluewater area (fig. 12), were drawn on the basis of aquifer-test results from well 14N.10W.22.414 (Jacob, 1956, p. A-30). Those test results indicate that the transmissivity in the vicinity of the well is about 850 feet squared per day. In this zone, the aquifer thins toward the north (fig. 8) and probably does not have major fractured or cavernous zones. The transmissivity of this zone is estimated to be 800 feet squared per day. 
A transmissivity of 50,000 feet squared per day has been estimated for zone V, using 1ithologic and hydrologic data from eight hydrologic- and oiltest wells. Zone $\mathrm{V}$ is east and south of the Zuni uplift (fig. 12). Within this zone, calculated transmissivity values range from 70 to greater than 200,000 feet squared per day.

Cavernous or highly fractured rock zones have been penetrated in six wells in the area (fig. 12). Caverns as much as 15 feet deep were penetrated while drilling hydrologic-test wells from 1984 to 1986 . The existence of cavernous zones indicates that these areas were near land surface following deposition of the San Andres Limestone because large cavernous zones are generally formed when limestones are close to land surface or the area of limestone dissolution is in close proximity to the saturated-unsaturated zone interface. This area probably was a southeastern continuation of the Zuni uplift.

The cavernous and fractured rock zones in transmissivity zone $V$ probably account for only part of the total aquifer framework, as in transmissivity zone III. Data from hydrologic-test wel1 6N.10W.7.1413 (fig. 12) indicate that the San Andres Limestone is dense and noncavernous and that it contains evaporites. Similar small-transmissivity areas probably exist throughout this zone. It is possible that large- and small-transmissivity areas are aligned in response to structural or erosional patterns within the zone and that the large-transmissivity areas are interconnected. The virtually flat potentiometric surface in zone V (fig. 13) suggests a good hydraulic connection throughout the zone. The existence of a good hydraulic connection between wells at 10N.9W.25.324 (Anzac 86-1) and 9N.9W.28.1344 (Acoma 1) was confirmed during aquifer testing conducted in July 1986. These wells are about 35,000 feet apart, and aquifer testing at Anzac 86-1 resulted in measurable drawdown and recovery at Acoma 1.

Zones VI and VII, which are southeast of Grants (fig. 12), have smaller transmissivity values than areas to the west. On the basis of 1 ithologic and hydrologic data from seven wells, the transmissivity for zones VI and VII is estimated to be 150 feet and 10 feet squared per day, respectively. These two zones are partly within the evaporite basin (Baars, 1962, p. 208). The northern parts of these two zones may represent an offshore depositional environment where carbonates were not deposited. An oil-test well, $13 \mathrm{~N} .4 \mathrm{~W} .2 .000$, penetrated shale rather than the carbonate-sandstone sequence of the San Andres-Glorieta aquifer (fig. 12). 
When hydraulic heads decline in a confined aquifer such as the San Andres-Glorieta aquifer, water released from storage comes from compression of the aquifer framework and expansion of water. The nature of the storage coefficient gives an indication of the compressibility of the aquifer framework when those head declines occur. Dividing the storage coefficient by the aquifer thickness yields specific storage, defined as the volume of water released from storage from a unit volume of aquifer under a unit decline in hydraulic head. The part of specific storage that is due to expansion of water has been shown to be about $3 \times 10-7$ per foot, using a porosity of 0.2 (Heath, 1983, p. 28). The difference between this number and the total specific storage is due to compression of the aquifer. In unconfined aquifers, the storage term is referred to as specific yield. Specific yields are generally much larger than storage coefficients in confined aquifers because specific yield includes the dewatering of the aquifer in addition to the expansion of water and aquifer compaction.

Eighteen published values of storage coefficient for the San AndresGlorieta aquifer and the Glorieta Sandstone range from $1.2 \times 10-2$ to 5.3 × 10-5 (table 4) (Gordon, 1961, table 8; Dames and Moore, 1981, table 1). These values were calculated using data collected from four aquifer tests that used one to three observation wells. Several methods of analysis were used to calculate the storage coefficients using drawdown and recovery data from the aquifer tests. The largest storage coefficient measured, $1.2 \times 10-2$, is large for a confined aquifer storage coefficient (Freeze and Cherry, 1979, p. 60-61) and probably represents unconfined conditions in the aquifer (specific yield). The smallest storage coefficient, $5.3 \times 10^{-5}$, was calculated for a well completed in the Glorieta Sandstone (12N.10W.18.312) where the sandstone thickness is 278 feet. This gives a specific storage of about $2 \times 10-7$ per foot, which is about the same as the specific storage resulting from the expansion of water as discussed earlier. This indicates that the Glorieta Sandstone is incompressible.

Joints, fractures, and faults in the San Andres-Glorieta aquifer can create anisotropy (variations in hydraulic conductivity with direction of measurement). In areas where the amount of offset of faults is slight, hydraulic conductivity in a particular direction may be enhanced by development of solution channels along fault zones in the San Andres Limestone and by fracturing in the Glorieta Sandstone. Joint sets in the aquifer framework also may result in anisotropy. Kelley and Clinton (1960, p. 45) noted that joints in the Glorieta Sandstone occur regularly with respect to the strike and dip of the beds, as opposed to the San Andres Limestone, where joint-set orientations display little regularity. In the northwestern part of the study area where only the Glorieta Sandstone is present, a regular joint set may produce fewer anisotropy effects than where both the San Andres Limestone and Glorieta Sandstone are present. 


\section{Ground-Water Movement}

Recharge to the San Andres-Glorieta aquifer occurs on outcrops along the Zuni uplift by direct precipitation or by infiltration of surface flow. The quantity of recharge from infiltration of precipitation is related to the outcrop area of the aquifer. Along the east side of the Zuni uplift, the outcrop area of the San Andres-Glorieta aquifer is narrow, whereas along the north side of the Zuni uplift, the outcrop area is more extensive (fig. 4). There probably is significantly more recharge to the San Andres-Glorieta aquifer from infiltration of precipitation along the north side of the Zuni uplift compared to the east side of the Zuni uplift. Along the southwestern side of the Zuni uplift, springs along the outcrop of the aquifer are believed to represent areas where the aquifer is unable to transmit all the available recharge (Orr, 1982, p. 42). Springs have not been observed on the aquifer outcrop in the study area, indicating that the aquifer is able to transmit all available recharge.

On the southern end of the Zuni uplift, recharge to the San AndresGlorieta aquifer may occur where the aquifer subcrops beneath the volcanic rocks in The Malpais Valley. This area does not have an obvious surface-water drainage system. In the spring of 1985, a surface flow estimated to be about 5 cubic feet per second was observed emerging from a drainage on the south side of the Zuni uplift (T. 9 N., R. 12 W., sec. 12). This water flowed south into The Malpais Valley where presumably most of it recharged the aquifer.

Another source of recharge to the San Andres-Glorieta aquifer is leakage of water from Bluewater Lake. The San Andres-Glorieta aquifer crops out under part of Bluewater Lake. There was recharge from Bluewater Lake from 1894 to 1909, when an earthen dam was in place on Bluewater Creek, and from 1927 to the present (1988) because the present concrete dam was built in 1927 . The amount of leakage to the aquifer probably varies as a function of pool altitude in the reservoir. Some of the leakage from Bluewater Lake flows back into Bluewater Creek just downstream from the dam. After it leaves the dam, the creek turns sharply to the north and closely parallels the east shore of the reservoir for about a mile. At one point in this reach, only about 800 feet of rock separate the creek from the reservoir. Some water that leaks into rocks along the eastern side of the reservoir moves eastward and discharges to the northward-flowing segment of Bluewater Creek. Discharge measurements made on April 4, 1986, indicate that the discharge in the creek increased from about 50 to 150 gallons per minute at the dam to about 1,700 gallons per minute at a gaging site about 1 mile northeast of the dam. The creek turns toward the east near this gaging site, and little additional discharge is gained by the creek downstream from this gaging site. A discharge measurement of about 1,800 gallons per minute was made at a site about 5 miles east of the dam on the same day (near the diversion at $\mathrm{T} .12 \mathrm{~N}$., R. 11 W., sec. 8 ). 
Ground water that discharges to Bluewater Creek flows east and continues down the Rio San Jose. East of Big Draw fault, the course of the Rio San Jose parallels the contact between the Chinle Formation and the San Andres Limestone and the stream loses water (fig. 10). In this reach, the creek flows over alluvium underlain by the San Andres Limestone or flows directly on the San Andres Limestone. Leakage from the Rio San Jose and from canals and ditches of the Bluewater-Toltec Irrigation District moves downward to recharge the alluvium and the San Andres-Glorieta aquifer. Streamflow decreases with downstream distance from the mouth of Bluewater Canyon. The Rio San Jose flows into a borrow pit (T. $12 \mathrm{~N}$, R. $11 \mathrm{~W}$, NW $1 / 4$ of sec. 25) and, under low-flow conditions, no surface water flows out of this pit, indicating that recharge occurs in the area of the borrow pit or that all of the water in the borrow pit is evaporated. Some recharge also may occur from downward leakage of irrigation water applied to fields in the Grants-Bluewater area.

Recharge to the aquifer from rocks above and below can occur when hydraulic heads in the adjacent rocks are higher than those in the aquifer. Few data are available to determine areas where leakage of water from adjacent rocks enters the San Andres-Glorieta aquifer, but in general, ground water near the Zuni uplift leaks downward to the aquifer from overlying rocks. Farther from the uplift, the aquifer is under a greater confining pressure, and leakage into the aquifer probably is not significant.

Ground water moves outward from the Zuni uplift, as shown by potentiometric-surface contours for the San Andres-Glorieta aquifer prepared using water-level data from stock, irrigation, and domestic wells and from hydrologic-test wells drilled in the eastern part of the study area (figs. 13 and 14 and table 1). In the northwestern part of the study area, ground water moves toward the northeast. The direction of movement turns to the east at distance from the Zuni uplift. A northeast-trending fault east of Grants with as much as 2,900 feet of displacement completely offsets the aquifer, creating a barrier to ground-water flow.

South of the Zuni uplift, ground water moves south, away from the uplift, and the direction of movement is roughly parallel to the Continental Divide. The two faults south of the Zuni uplift appear to act as a barrier to prevent ground water moving to the east (fig. 13). The aquifer is completely offset along the west fault from the southeastern end of the Zuni uplift to about the middle of T. 6 N., R. 12 W. (fig. 9). The hydraulic-head difference between wells located on the east and west sides of the two faults (6N.10W.7.141 and $7 \mathrm{~N} .12 \mathrm{~W} .13 .244$ ) is about $100 \mathrm{feet}$ (water level on the west side of the fault is higher), whereas the head difference between two wells immediately east of the faults is less than 10 feet (fig. 13). The head difference across the fault indicates that the faults are a barrier to ground-water flow. 


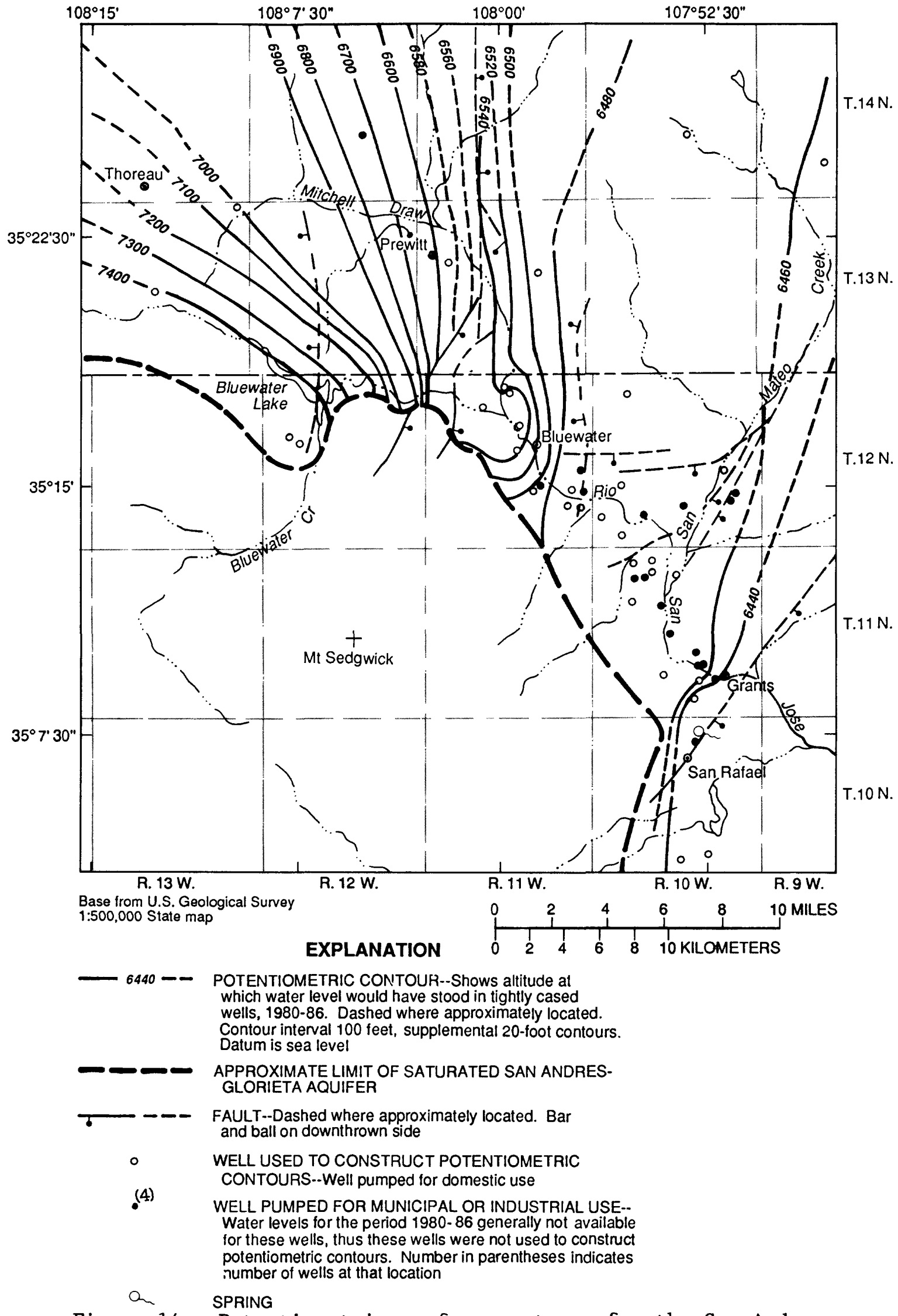

Figure 14.--Potentiometric-surface contours for the San AndresGlorieta aquifer in the Grants-Bluewater area. 
In the southeastern part of the study area, geochemical data (Goff and others, 1983) and sparse water-level data indicate that water moves west through the aquifer from recharge areas along the western flanks of the Lucero uplift (fig. 13). Recharge probably is small in this area because of the small amount of precipitation, large evapotranspiration rates, limited outcrop areas, and the extremely small transmissivity of the aquifer in this area. The ground water in this area probably moves west a short distance and then moves northward or leaks downward into the Pennsylvanian rocks. This is discussed in more detail later in the geochemistry section of the report.

The slope of the potentiometric surface ranges from about 130 feet per mile northeast of Bluewater Lake to essentially a flat surface for an area east of the Zuni uplift (fig. 13). Hydro-Search, Inc. (1981, p. 20) reported a slope on the potentiometric surface of 1 foot per mile or less south and east of the Anaconda Mill near Bluewater. The method used to establish landsurface altitudes at wells was not reported. Land-surface altitudes for wells used in the construction of the potentiometric map (fig. 13) were determined from Geological Survey 7 1/2-minute quadrangles. The land-surface altitudes may be in error by as much as plus or minus 10 feet (one-half of the contour interval).

Density-related effects were not considered in the discussion of groundwater movement through the aquifer. If ground-water flow is strictly horizontal (dip of aquifer less than 3 degrees), density-related gravity effects are not significant; also, variations in fluid density may be expressed as equivalent freshwater head (Davies, 1987, p. 889). Density effects may be significant in areas where a combination of dipping aquifer, flat potentiometric surface, and large concentrations of dissolved solids in the water exists. One area where the above factors exist is east of Grants, where the aquifer dips into the Acoma embayment (fig. 9). The dissolvedsolids concentration in water from well 10.9 .25 .3241 is $7,000 \mathrm{mg} / \mathrm{L}$, and the potentiometric surface in a large area north and south of this well has a small hydraulic gradient (fig. 13). Density-related gravity effects may be a significant component of ground-water flow in this area.

Discharge from the San Andres-Glorieta aquifer includes spring discharge, withdrawal by wells, evapotranspiration, leakage to adjacent rocks, and underflow out of the study area. Prior to development of the San Andres Glorieta aquifer near Grants, 0 jo del Gallo (rooster spring) probably was a major discharge point for that part of the aquifer lying northwest of Grants. The earliest recorded discharge of the spring was recorded by Hodges (1938, p. 339); the discharge during August and November 1937 was 7 cubic feet per second. On January 19,1938 , the discharge was estimated to be 5.2 to 5.7 cubic feet per second (Hodges, 1938, p. 339-340).

These discharges may not represent natural discharge conditions at the spring. Bluewater Dam was constructed in 1927, and surface water has been applied to fields in the Grants-Bluewater area since that time. Morgan (1938, p. 11-12) noted that reservoir leakage and irrigation infiltration to the aquifer might be greater than natural streamflow leakage, which would result in larger discharges at 0 jo del Gallo. Water levels in the aquifer in the Bluewater area were reported to have risen during 1931-37, preceding the 1937 measurement and 1938 estimate of discharge at the spring (Morgan, 1938, p. 13). 
Discharge at Ojo del Gallo may be affected by long-term precipitation trends in the study area. Above- or below-average precipitation can result in more or less recharge to the ground-water system, which in turn affects the amount of water discharging from the aquifer. Long-term trends in precipitation are shown in graphs of cumulative departure from mean precipitation ( $f i g .15)$. Steeply rising or declining parts of the curves indicate where, for several years, the recorded precipitation differed from the mean (Risser, 1982, p. 8). From the mid-1920's to the late 1930's, precipitation was greater than the mean, as seen in the cumulative departure curves for five stations in the study area (fig. 15). This could result in greater-than-average recharge to the aquifer, which may have been in part responsible for the rise in water levels noted in wells in the Bluewater area during the 1930's (Morgan, 1938, p. 13).

Discharge from the San Andres-Glorieta aquifer in the Grants-Bluewater area increased substantially in the mid-1940's when wells began to withdraw water for irrigation. Prior to this time, domestic and stock wells withdrew water from the aquifer, but the total volume was smal1. In 1945, seven irrigation wells withdrew water from the aquifer. By 1955, the number had increased to 22 (Gordon, 1961, table 7). About 85 percent of the 13,600 acrefeet of water withdrawn from the aquifer in 1955 was used for irrigation, and the rest was used for industrial and municipal use (table 5). During 1945-53, discharge at 0 jo del Gallo decreased from 4.63 cubic feet per second on October 3, 1946 (C.V. Theis, U.S. Geological Survey, written commun., 1949), to a quantity insufficient for irrigation of gardens in 1953 (Gordon, 1961, p. 47). This decrease in discharge from 0 jo del Gallo probably was partially due to the large amount of ground-water withdrawal from the San AndresGlorieta aquifer in the Grants-Bluewater area.

The discovery of uranium ore north of Grants in 1955, a population increase in the Grants-Bluewater area, and a decline in the amount of 1 and irrigated by ground water led to major changes in ground-water use in the area. Changes in the use of ground water resulted in changes in the location of ground-water withdrawals and in the volumes of ground water pumped from a specific location. A change from irrigation use to industrial or municipal use resulted in the drilling of new wells and a large volume of water pumped from several specific wells rather than smaller volumes pumped from many wel1s. By 1956 industrial use accounted for about 32 percent of the 14,210 acre-feet withdrawn, and irrigation use decreased to about 65 percent (table 5). The remainder was for municipal use. Several of the irrigation wells were converted to industrial use after 1956, and withdrawals from the aquifer decreased from the peak withdrawal in 1956. Of the approximately 6,700 acre-feet pumped in 1979 (table 5), industrial use accounted for 56 percent and municipal use accounted for 44 percent (C.A. Wohlenberg, New Mexico State Engineer office, written commun., 1983). By 1982, ground water for industrial use had decreased substantially to about 38 percent of the 3,900 acre-feet pumped (table 5) (C.A. Wohlenberg, written commun., 1983). 

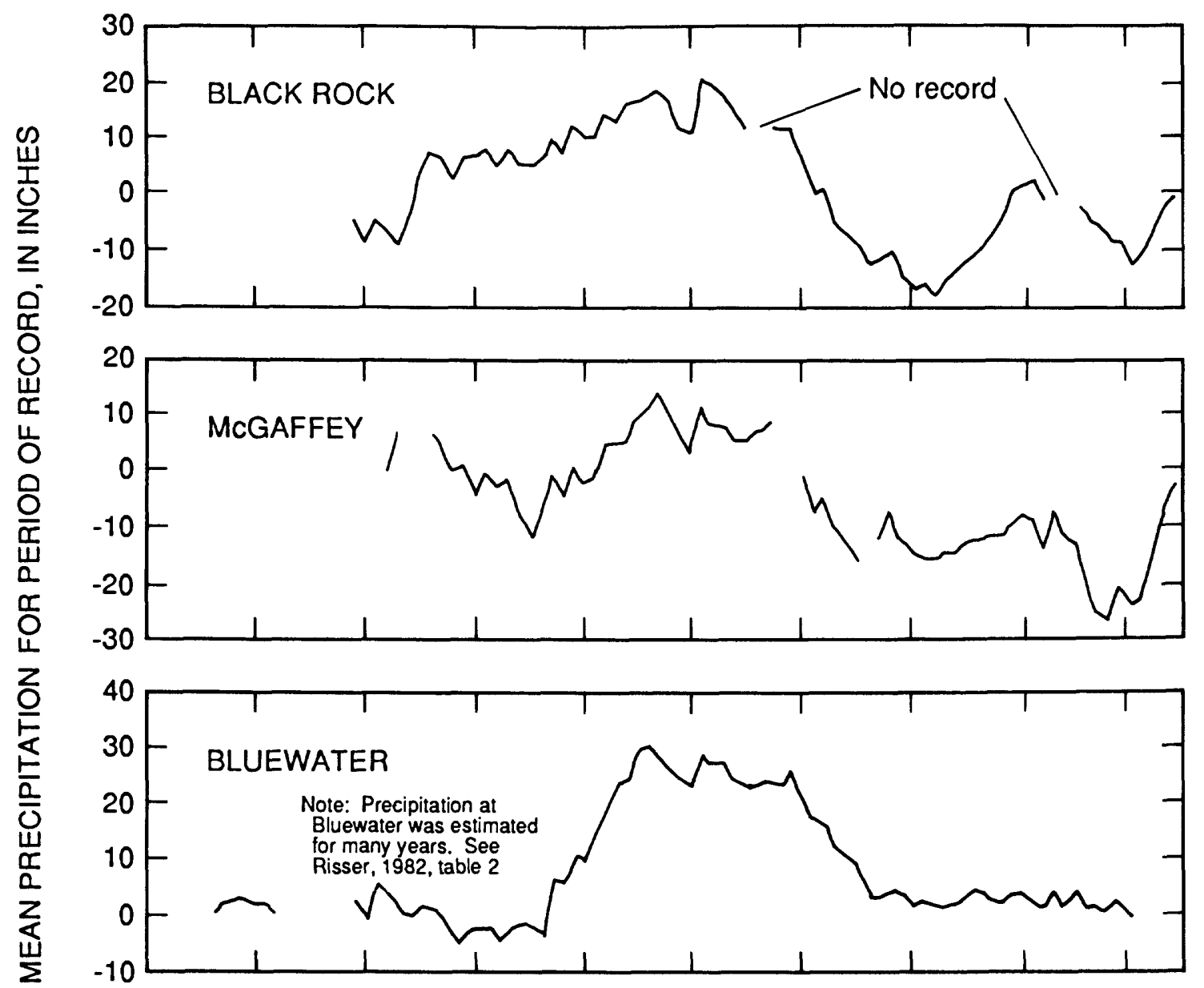

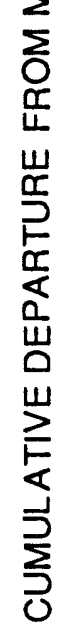

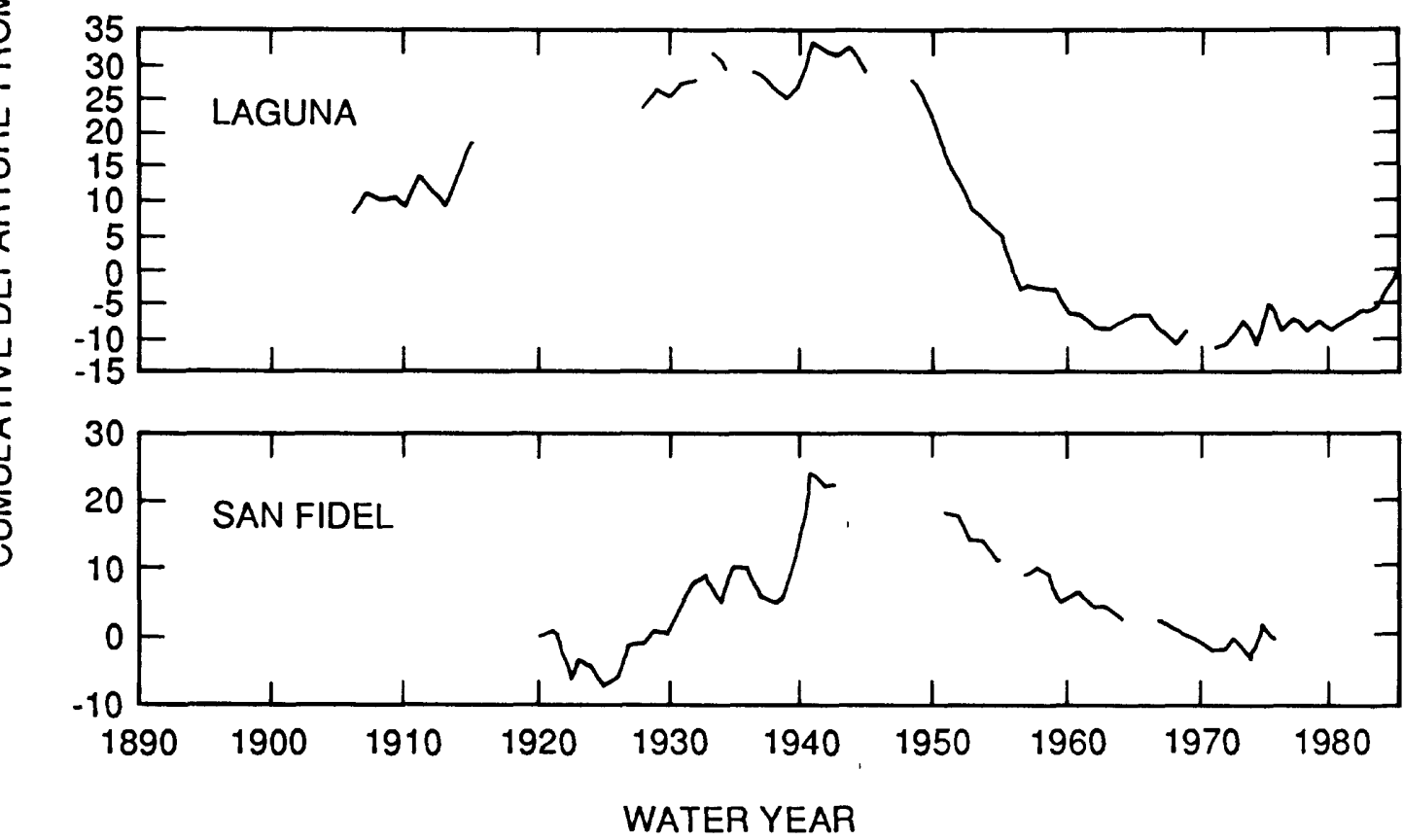

Figure 15.--Cumulative departure from mean precipitation for the period of record at stations within the study area (modified from Risser, 1982, fig. 7). 
Discharge at 0 jo del Gallo was absent from 1953 to 1982 , although a small pool was observed at the spring site in the fall of 1979 and on May 14, 1980 (U.S. Bureau of Indian Affairs, 1984, p. 22). On February 18, 1983, a discharge of 0.03 cubic foot per second was measured at the spring, which increased to 1.72 cubic feet per second by February 1986 (U.S. Geological Survey measurements). Since 1979, precipitation at most stations has been several inches greater than the mean (fig. 15). This precipitation trend and the decreases in ground-water withdrawals in the Grants-Bluewater area since 1956 may be factors in the increase in discharge at ojo del Gallo.

Horace Springs (10.9.23.423) is another possible source of discharge from the San Andres-Glorieta aquifer. Water discharges at Horace Springs where the Rio San Jose valley becomes constricted as it cuts through eastward-dipping bedrock. Discharge at Horace Springs may have at least three sources: (1) water that discharges along the fault at Grants and moves east through the alluvium along the Rio San Jose valley, (2) discharge from ojo del Gallo Spring that moves east toward the Rio San Jose, and (3) water that moves north in the alluvium of The Malpais Valley. Water in the alluvium of The Malpais Valley probably comes from recharge from precipitation. Little or no upward leakage of water probably occurs from the San Andres-Glorieta aquifer to alluvium in the vicinity of Horace Springs. The Chinle Formation underlies the Rio San Jose valley, having a minimum thickness of 100 to 200 feet near the Zuni uplift and increasing to a thickness of about 1,000 feet in the vicinity of oil-test hole 10.9.21.222 (pl. 1, section C-C'). Hydraulic-head differences between the San Andres-Glorieta aquifer and the overlying alluvium range from zero along the western side of the valley west of Grants to about 150 feet higher in the San Andres-Glorieta aquifer compared to the alluvial aquifer near Horace Springs. Water discharging from Horace Springs probably is ground water flowing eastward in the alluvium that is forced to the surface because of a reduction in the cross-sectional area of the permeable alluvial deposits in the Rio San Jose valley. Discharge from Horace Springs and the source of this discharge are discussed in more detail in the water-chemistry section of this report.

The discharge at Horace Springs contributes most of the flow of the Rio San Jose downstream from Horace Springs excluding storm runoff (Risser, 1982, p. 29). The discharge has been estimated to be about 4.9 cubic feet per second, exclusive of storm runoff and wastewater from Grants (Risser, 1982, p. 31).

Upward leakage of water to the Chinle Formation or downward leakage through the Yeso and Abo Formations to Pennsylvanian rocks may be sources of discharge from the San Andres-Glorieta aquifer east of the Zuni uplift. Springs discharging from Pennsylvanian rocks along the Lucero uplift may represent leakage from the San Andres-Glorieta aquifer. In either case, the large thickness and small hydraulic conductivity of the units above and below the San Andres-Glorieta aquifer probably limit the amount of leakage. Given the limited outcrop of the aquifer east of the Zuni uplift, recharge to the system may be small, and therefore the volume of water moving through and discharging from the aquifer may be correspondingly small. 
Underflow from the aquifer out of the study area is another source of discharge. Although quantifying underflow from the aquifer is not possible, knowledge of the lithologic and geologic conditions aids in making conceptual scenarios. The regional discharge area for ground water from the study area, on the basis of the potentiometric-surface map, is the Rio Grande rift (figs. 5 and 13). The San Andres-Glorieta aquifer is absent over much of the Lucero uplift, and recharge to the San Andres-Glorieta aquifer occurs in parts of the Lucero uplift. Ground water flows northwest from this recharge area, thus ground water can flow east into the Rio Grande rift only through the area of the Rio Puerco fault zone (fig. 5). The large number of large offsets of some of the faults in the Rio Puerco fault zone probably have displaced the San Andres-Glorieta aquifer against fine-grained sediments in some areas. Potentiometric levels in the aquifer in the rift are 600 to 1,250 feet lower than those in the San Andres-Glorieta aquifer in the eastern part of the study area (fig. 13; Kernodle and Scott, 1986, fig. 8); thus the quantity of leakage from the aquifer into rift sediments probably is very small because of the limited area in which discharge can occur, the complex nature of the Rio Puerco fault zone, and the large difference in potentiometric levels in the Rio Grande rift sediments and the San Andres-Glorieta aquifer adjacent to the rift.

Potentiometric contours indicate that water moves toward the southeast in the southeastern part of the study area except adjacent to the Lucero uplift, where recharge occurs and ground water moves west (fig. 13). No discharge points from the San Andres-Glorieta aquifer are known to exist in this area. Spiegel (1955, p. 67) noted that a spring flowing from the Madera Limestone discharges about 500 gallons per minute into the Rio Salado just south of the study area. Water from this spring may represent discharge from the San Andres-Glorieta aquifer that has leaked downward from the aquifer through Yeso and Abo strata to Pennsylvanian rocks; however, because of the limited amount of data in this area, this hypothesis cannot be proven. This hypothesis is discussed in more detail later in the report in the water chemistry section.

Water-Level Changes due to Changes in Precipitation and Ground-Water Withdrawals

Water levels in the San Andres-Glorieta aquifer correlate with the quantity of precipitation and the quantity of ground-water withdrawals. Longterm water-level trends in the San Andres-Glorieta aquifer have been monitored in the Grants-Bluewater area since the early 1940's (fig. 16). Monitoring began at approximately the same time as irrigation pumpage from the aquifer. The hydrographs from wells completed in the San Andres-Glorieta aquifer are similar, indicating declines in water levels from the time monitoring began through about 1962. Water levels declined more than 70 feet in well 12N.11W.9.221 from 1946 to 1957 (fig. 16). Ground-water withdrawals also increased significantly during this time (table 5). From 1962 to 1979, water levels generally recovered and declined twice. From 1979 to the present (1988), water levels have recovered throughout the Grants-Bluewater area, and from 1980 to the present ground-water withdrawals have decreased (fig. 16 and table 5). 


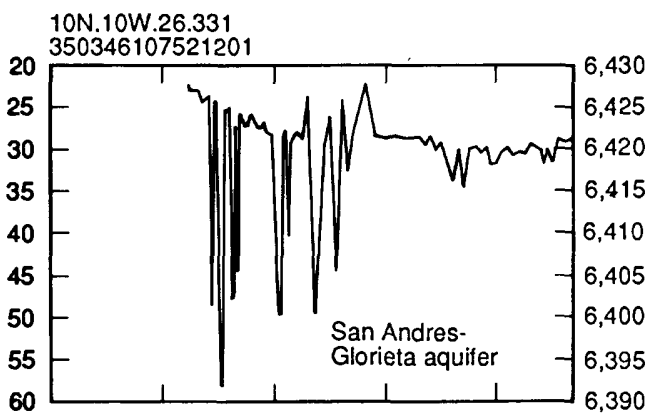

11N.10W. 9221

351211107532901

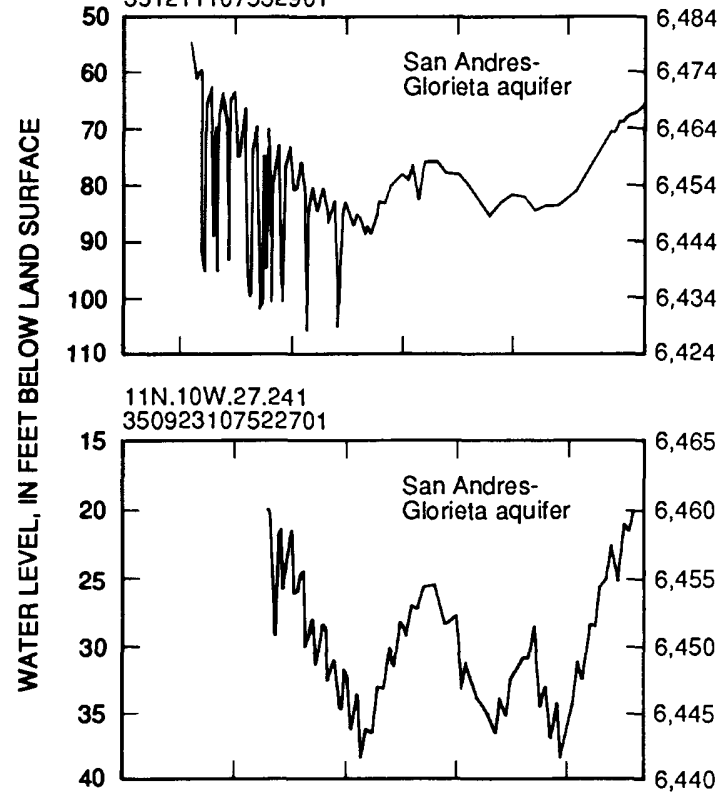

12N.10W.20.333A

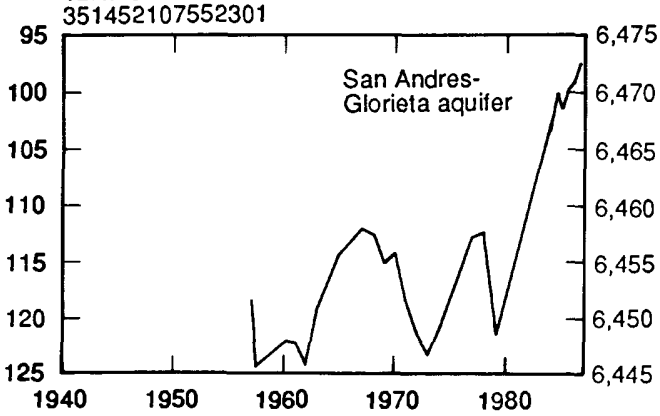

2N.10W.23.233

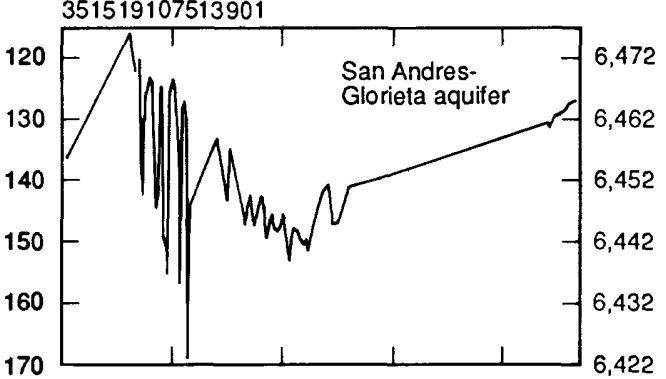

12N $11 \mathrm{~W} 9221$

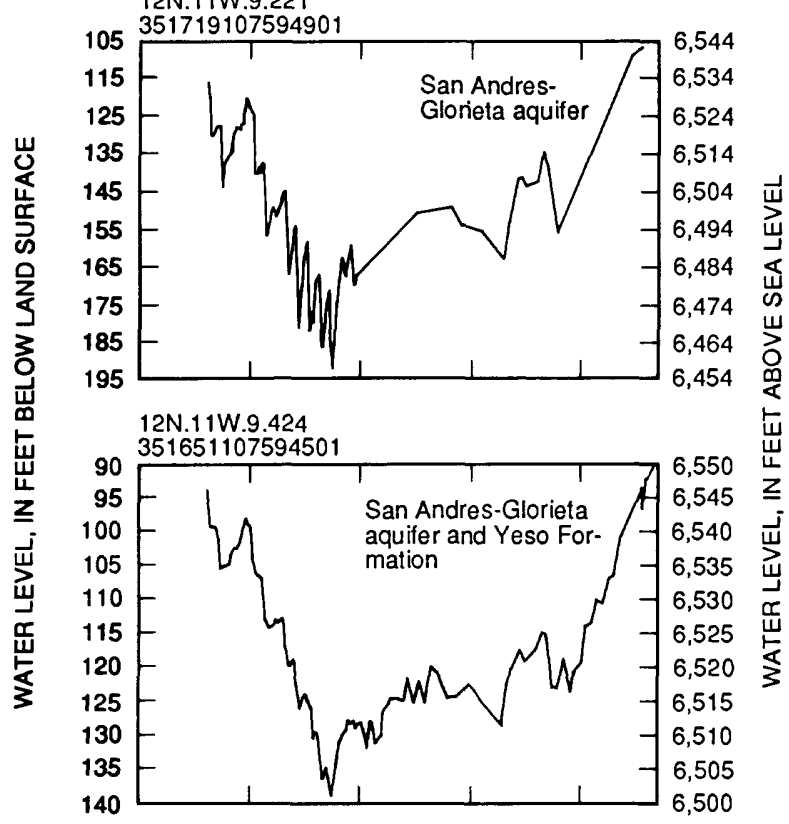

12N.11W.14.213

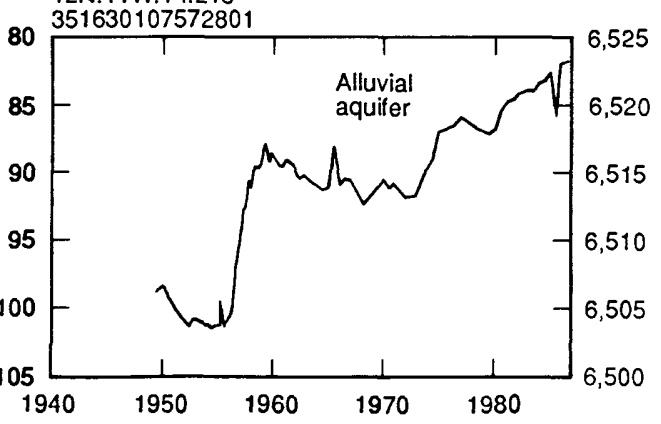

Figure 16.--Water-level hydrographs for wells in the Grants-Bluewater area. 
A comparison of cumulative departure from mean precipitation at McGaffey, ground-water withdrawals, and water levels from well 12N.11W.9.424 shows a close correlation (fig. 17). Prior to 1956, most ground-water withdrawals were used for irrigation purposes. Withdrawals were probably related to the amount of precipitation because during years of less-than-normal precipitation more ground water was needed for irrigation purposes to compensate for the decreases in the amount of soil moisture. After 1956, many irrigation we11s were taken out of production and a larger part of total ground-water withdrawals was for municipal and industrial use. The volume of ground-water withdrawals for municipal and industrial use would not be related to the amount of precipitation to the extent of ground-water withdrawal for irrigation purposes. The large decline in water levels in well 12N.11W.9.424 from 1946 to 1957 was probably due to a combination of large increases in ground-water withdrawals and less-than-normal precipitation (fig. 17). The increase in water levels in well 12N.11W.9.424 from 1957 to 1960 was probably due to greater-than-normal precipitation and to decreases in ground-water withdrawals. Although ground-water withdrawal data do not exist from 1958 to 1978, the existing data indicate that ground-water withdrawals generally decreased during this time. Comparison of the cumulative departure from mean precipitation and water levels in well $12 \mathrm{~N} .11 \mathrm{~W} .9 .424$ indicates that water levels increased during periods of greater-than-normal precipitation and decreased during periods of less-than-normal precipitation from 1958 to 1978 (fig. 17). The decrease in ground-water withdrawals and greater-than-normal precipitation during 1979 to 1985 resulted in significant increases in water levels (fig. 17).

\section{Yeso and Abo Formations}

The Yeso and Abo Formations are believed to function as a leaky confining unit, separating the overlying San Andres-Glorieta aquifer from the underlying Pennsylvanian rocks. The Yeso Formation was deposited under restricted marine conditions and the Abo Formation was deposited under subcontinental and continental conditions (Kelley and Wood, 1946). As a result, these rocks contain a smaller percentage of carbonates and a larger percentage of siltstone, shale, and sandstone than Pennsylvanian rocks (table 6).

\section{Hydraulic Properties}

Hydraulic conductivity for the Yeso and Abo Formations was measured from core samples from wel1 12N.10W.8.314 (West, 1972). Values of horizontal hydraulic conductivity for tested intervals from 613 to 1,818 feet below 1 and surface ranged from $3 \times 10-4$ to 0.6 foot per day; the largest horizontal hydraulic conductivity was for the Meseta Blanca Sandstone Member of the Yeso Formation. With the exception of the Meseta Blanca Sandstone, values of horizontal hydraulic conductivity for the Yeso and Abo Formations ranged from $3 \times 10-4$ to $1 \times 10-2$ foot per day. A weighted average horizontal hydraulic conductivity of $2.5 \times 10-2$ foot per day was calculated for the tested interval. Horizontal hydraulic conductivity for the Yeso Formation in the eastern part of the study area may be smaller than in the Grants-Bluewater area because of a larger percentage of evaporites in the eastern part of the study area. Transmissivity for a 2,000-foot-thick section of the Yeso and Abo Formations may be about 50 feet squared per day, assuming a horizontal hydraulic conductivity of $2.5 \times 10^{-2}$ foot per day. 

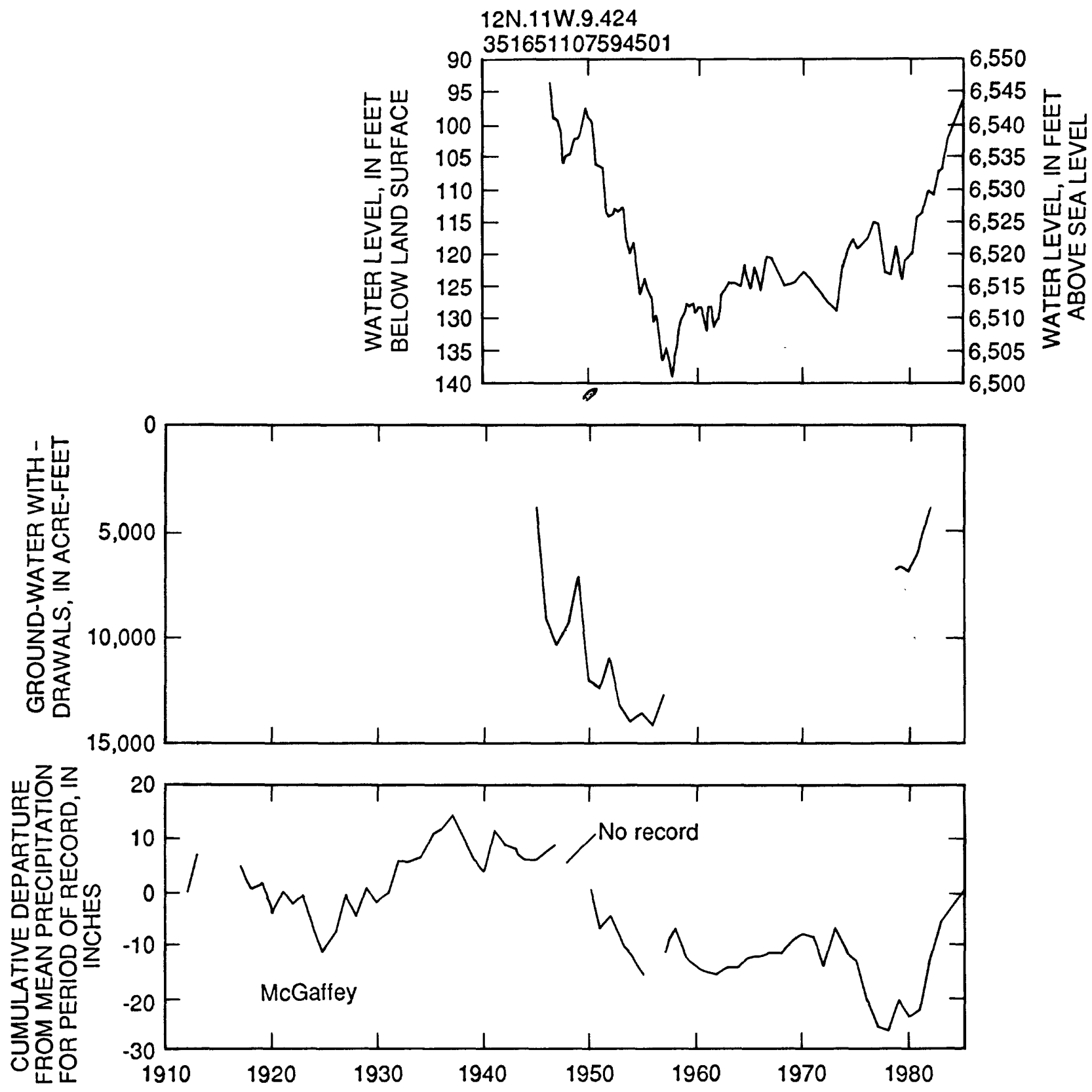

Figure 17.--Comparison of water levels, ground-water withdrawals, and cumulative departure from mean precipitation for the Grants-Bluewater area. 
Vertical hydraulic conductivity also was measured from core samples from the Yeso and Abo Formations at well 12N.10W.8.314 (West, 1972, table ${ }_{4} 3$ ). Measured values of vertical hydraulic conductivity ranged from $2.2 \times 10^{-4}$ to 0.4 foot per day. The horizontal to vertical anisotropy ratio ranged from 0.4 to 5.0 for tested intervals from 613 to 1,490 feet below land surface. A weighted average anisotropy ratio of 2.0 was calculated for the same interval. In the eastern part of the study area, this ratio may be larger due to interbedded evaporite deposits in the Yeso Formation.

\section{Ground-Water Movement}

Some ground water may enter the Yeso and Abo Formations around the margins of the Zuni uplift. However, horizontal movement of ground water in the fine-grained Yeso and Abo Formations is believed to be so small that regional ground-water flow patterns would not exist in these rocks.

Most ground water probably enters the Yeso and Abo Formations as downward leakage from the overlying San Andres-Glorieta aquifer. The quantity of downward leakage probably is small near the Zuni uplift, increasing toward the east as confining pressures in the San Andres-Glorieta aquifer increase. The quantity of downward leakage through the Yeso Formation probably is less in areas that have deposits of evaporite materials. Downward leakage of water through Yeso and Abo rocks north of the Zuri uplift also may increase with distance from the uplift as confining pressure in the San Andres-Glorieta aquifer increases. In 1960, the water level in a monitoring well completed in the San Andres-Glorieta aquifer was within a foot of the water level in a disposal well (12N.10W.8.314) completed in the Yeso and Abo Formations approximately 300 feet away (West, 1972, p. 17). In 1960, large withdrawals from the San Andres-Glorieta aquifer had resulted in water-level declines of several tens of feet in the San Andres-Glorieta aquifer in this area. If the 1960 water level in the Yeso and Abo Formations at this monitoring well was not affected by withdrawals from the San Andres-Glorieta aquifer in this area, water levels under predevelopment conditions in the San Andres-Glorieta aquifer would have been higher than the water levels in the Yeso and Abo Formations. These conditions would result in the possibility of downward leakage of water from the San Andres-Glorieta aquifer into the Yeso and Abo Formations.

Discharge of water from the Yeso and Abo Formations occurs by leakage into overlying and underlying rocks, depending on the water-level relations between the Yeso and Abo Formations and the overlying and underlying rocks. In general, discharge from the Yeso and Abo Formations probably occurs by downward leakage into underlying rocks. Several springs in the Lucero uplift area discharge from the Yeso and Abo Formations; however, the source of water could come from the Pennsylvanian rocks because of the large number of faults and dikes in the area. 


\section{Pennsylvanian Rocks}

Limestone, dolomite, sandstone, and shale of Pennsylvanian age occur throughout most of the eastern part of the study area (fig. 7). Direct measurements of aquifer properties and potentiometric head are not available for Pennsylvanian rocks because no water wells have been completed in these rocks.

\section{Hydraulic Properties}

Hydraulic conductivity was estimated by comparing lithologies from seven oil-test holes with hydraulic-conductivity values for similar rocks. The oiltest holes are in the area of the Lucero uplift, where Pennsylvanian rocks are from 1,000 to 1,500 feet thick (fig. 7). Lithologic data indicate that carbonates account for about one-half of the total thickness of Pennsylvanian rocks in this area (table 6 ). The carbonates generally are limestone that commonly is fossiliferous. No fractures or cavernous zones were noted in drilling reports. Siltstone and shale account for about 42 percent of the total Pennsylvanian thickness (table 6); most of this percentage is reported to be shale. Freeze and Cherry (1979, table 2.2) indicated that values of hydraulic conductivity for limestone and dolomite (carbonates) can range from about $5 \times 10^{-4}$ to 1 foot per day; values of hydraulic conductivity for shale are several orders of magnitude less than limestone. Because of this contrast in hydraulic conductivity, carbonates probably transmit most of the water in Pennsylvanian rocks, and the horizontal hydraulic conductivity of these rocks can range from $5 \times 10-4$ to 1 foot per day. Transmissivity for a 1,000-footthick section could range from 0.5 to 1,000 feet squared per day.

Lithologic logs of Pennsylvanian rocks in the study area indicate that the carbonates commonly are interbedded with shale and, to a lesser extent, siltstone. This stratigraphic sequence probably imparts a regional anisotropy to ground-water flow in Pennsylvanian rocks. Freeze and Cherry (1979, p. 34) noted that regional anisotropy ratios of 100:1 are common in layered systems. A ratio of this magnitude would make horizontal ground-water movement more predominant than vertical movement.

\section{Ground-Water Movement}

The source of recharge to the Pennsylvanian rocks is not well known. No significant recharge can enter Pennsylvanian rocks in the Zuni uplift because these rocks generally do not crop out in the uplift; these rocks generally pinch out east of the uplift (fig. 7). Ground water may leak downward through the Yeso and Abo Formations into Pennsylvanian rocks east of the Zuni uplift where the San Andres-Glorieta aquifer is under larger confining pressure than it is nearer to the outcrop. Faults and dikes may act as conduits for leakage in this area. East of the Zuni uplift, Pennsylvanian rocks become progressively thicker and could transmit more ground water than they could closer to the uplift (fig. 7). 
The potentiometric surface for Pennsylvanian rocks has not been determined because no wells have been completed in these rocks. However, the general direction of ground-water movement probably is from west to east toward the Rio Grande rift because numerous springs issue from the Pennsylvanian rocks near the Lucero uplift, indicating that this is a discharge area for the ground-water flow system.

Discharge of water from Pennsylvanian rocks occurs at springs along the east side of the Lucero uplift. Spring deposits are present along the eastern side of the Lucero uplift ( $\mathrm{fig} .4$ ), which have been inventoried by Wright (1946), Goff and others (1983), and Risser and Lyford (1983). Discharge of most of these springs is difficult to measure accurately because it commonly occurs as seeps or as small spring pools along arroyos. Wright (1946, table 6) pointed out this problem when he measured a cumulative discharge of about 3 gallons per minute from 14 individual springs in a small area. A discharge of about 33 gallons per minute was measured in a channel draining the area of the same springs (Wright, 1946). In addition, these discharge measurements do not account for the amount of discharge that is lost to evaporation, which probably is substantial. As an example, an area of several springs at T. 6 N., R. 3 W., sec. 5 was visited during summer 1986. Discharge from this spring area creates wet areas and pools for about one-half mile downstream, and the wetted area is about 100 feet wide. The evaporation rate in the Lucero uplift area is about 60 inches per year (U.S. Department of Agriculture, 1972). Discharge by evaporation could amount to about 20 gallons per minute from the wetted area. Wright (1946, table 6) 1isted the discharge downstream from this spring area as about 5 gallons per minute. No information is available regarding discharge by evaporation for other springs in the Lucero uplift; therefore, spring discharge from Pennsylvanian rocks cannot be estimated.

Discharge of water from the Madera Limestone into the Rio Salado southeast of the study area has been estimated to be about 500 gallons per minute (Spiegel, 1955, p. 67). Additional subsurface discharge from Pennsylvanian rocks into Quaternary and Tertiary rocks in the Rio Grande rift and subsurface discharge from Pennsylvanian rocks toward the north and northeast out of the study area also may occur. 


\section{GROUND-WATER CHEMISTRY}

Because an understanding of ground-water chemistry can help define the flow system, the chemistry of ground water in the Thoreau, Grants-Bluewater, and Acoma embayment areas is described (fig. 18). Water chemistry in other parts of the study area is not discussed because of a lack of data. The division between areas is somewhat arbitrary but generally is based on differences in water chemistry, characteristics of the ground-water flow system, and the availability of data. The water chemistry of the area south and west of the Zuni Mountains was not examined.

Most of the water-chemistry data used in this study are U.S. Geological Survey-collected data that are stored in the Survey's water-quality data base. Additional data were obtained from consulting reports, the New Mexico Environmental Improvement Division, and the U.S. Bureau of Indian Affairs. In general, only water-chemistry data from the San Andres-Glorieta aquifer are included in this report. In the eastern part of the Acoma embayment area, however, water-chemistry data from other aquifers have been included because these data are useful in understanding the flow system of the San AndresGlorieta aquifer. Piper diagrams are used in the discussion of water chemistry. For a complete discussion of Piper diagrams and their use, the reader is referred to Piper (1944) and to Freeze and Cherry (1979, p. 249-254).

The two types of permeability in the San Andres-Glorieta aquifer are: primary permeability (that of the rock matrix) and secondary permeability (that due to fractures or cavernous zones). Thus, ground water flows in the rock matrix and also through fractures or cavernous zones. Flow generally is more rapid in cavernous zones and fractures than flow through the rock matrix.

The chemical composition of water in the San Andres-Glorieta aquifer is a function of the composition of the water that recharges the aquifer, mineralogy of the aquifer, length of time water has been in the aquifer (residence time), and the concentration of individual dissolved constituents. Different minerals in the aquifer have different solubilities or resistances to withstand dissolution. The chemical composition of ground water is dependent on the residence time because the longer the water is in the aquifer, the greater the probability that the water has come in contact with and has dissolved soluble minerals. Cavernous zones in the aquifer indicate that water in the unsaturated zone or ground water has dissolved aquifer material and transported it in solution downgradient (down a flow path). As mentioned earlier, some or most of the cavernous zones probably were formed during Late Permian-Early Triassic time; however, in general, dissolution of aquifer material is occurring continuously. 


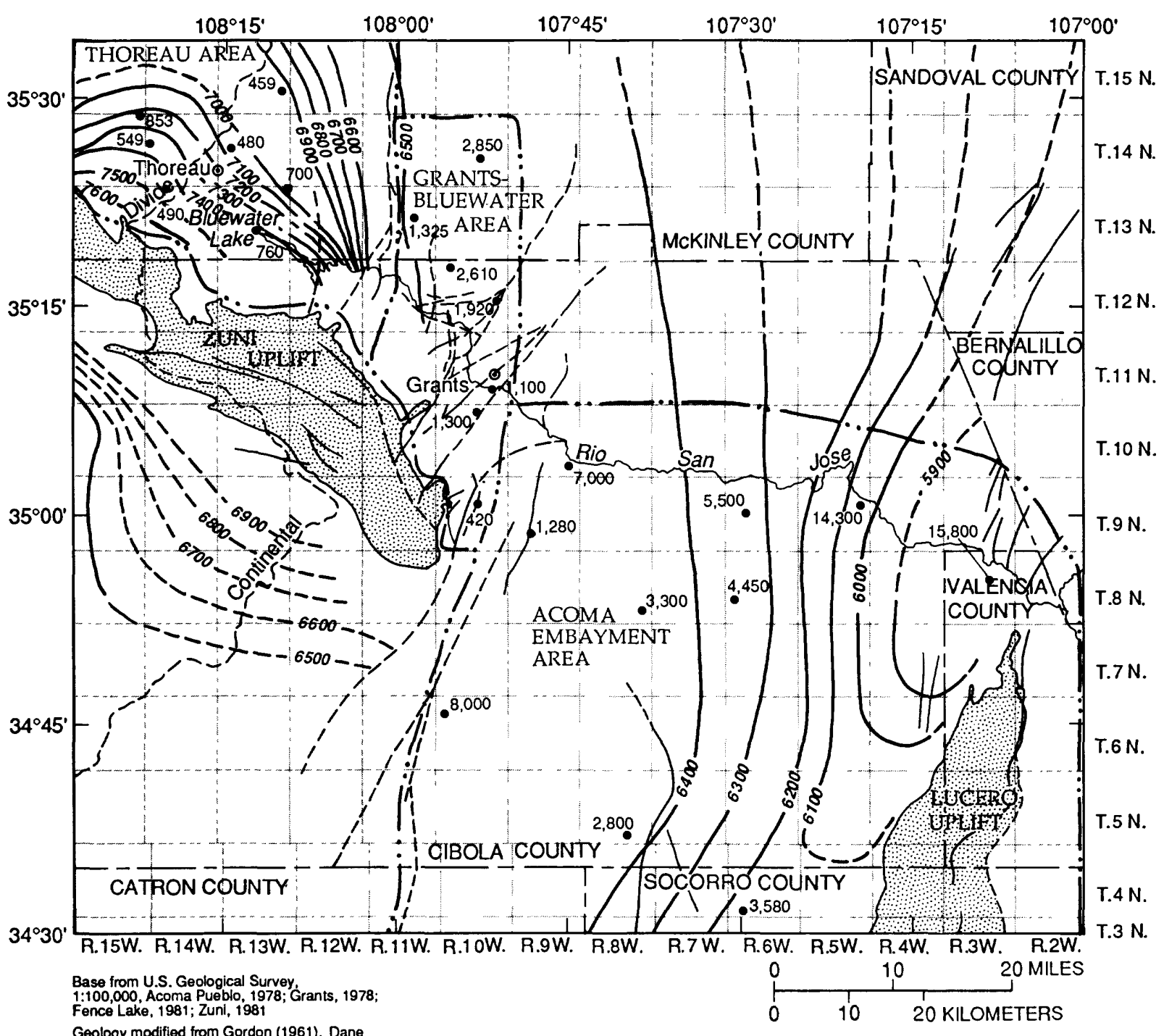

Geology modified from Gordon (1961), Dane and Bachman (1965), and Maxwell (1981)

\section{EXPLANATION}

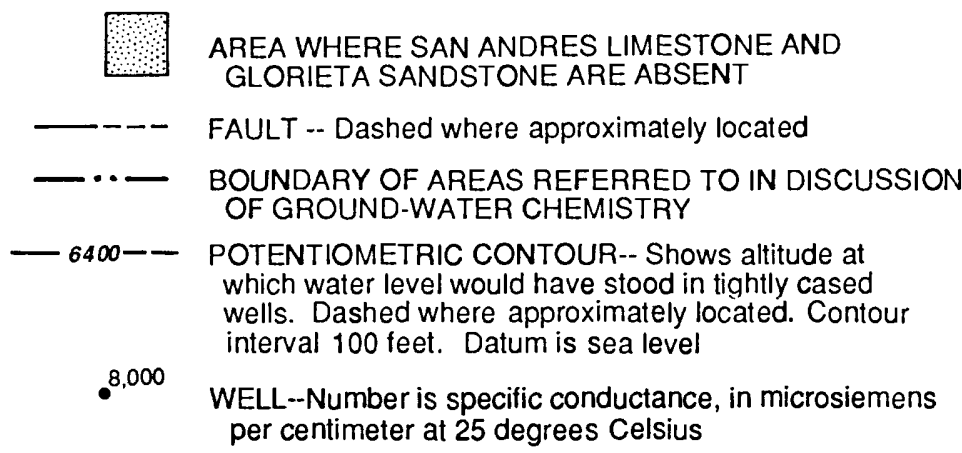

Figure 18.--Ground-water-chemistry discussion area, potentiometric surface, and specific conductance of water from the San Andres-Glorieta aquifer. 
As ground water moves from recharge areas down a flow path, the concentration of dissolved ions in the water generally increases. Ground water in recharge areas is precipitation and surface water that infiltrates through the unsaturated zone or soil zone and into the aquifer. Most recharge to the aquifer occurs in outcrop areas. Very little or no recharge can occur if the aquifer is covered by relatively small permeability, fine-grained material, such as that in the Chinle Formation. Recharge water generally contains gases such as carbon dioxide and small concentrations of dissolved ions. Because the dissolution of limestone (composed mainly of the mineral calcite, which is a calcium carbonate), a major component of the San AndresGlorieta aquifer, is affected by the concentration of carbon dioxide in water in contact with the 1 imestone, carbon dioxide-rich ground water near recharge areas can readily dissolve limestone. The amount of readily soluble material in the aquifer at any point is a function of the amount of water that has come in contact with or flowed by a particular mineral grain and in part of the concentration of dissolved ions in the water. For example, gypsum (calcium sulfate), a soluble mineral found in the San Andres-Glorieta aquifer, may be completely dissolved and removed from the aquifer in recharge areas. Ground water near this recharge area would not contain significant quantities of dissolved sulfate because the source of soluble sulfate already has been dissolved and flushed from this part of the aquifer.

\section{Thoreau Area}

The Thoreau area is in the northwestern part of the study area near Townships 12-15 and Ranges 11-15 (fig. 18). The eastern boundary of this area is somewhat arbitrary but generally is based on a difference in specific conductance of ground water and a change in potentiometric gradient. The specific conductance of ground water in the Thoreau area generally is less than that in the Grants-Bluewater area to the east. The potentiometric gradient is steep in the Thoreau area, whereas it is virtually flat in the Grants-Bluewater area. The southern boundary is the southern extent of the outcrop area of the San Andres-Glorieta aquifer. The western boundary is also that of the area of investigation. The northern boundary is based solely on the northern extent of available water-chemistry data.

Ground-water chemistry is variable in the Thoreau area. Specific conductance ranges from 470 to 1,390 microsiemens (microsiemens per centimeter at 25 degrees Celsius) (fig. 19 and table 7). 

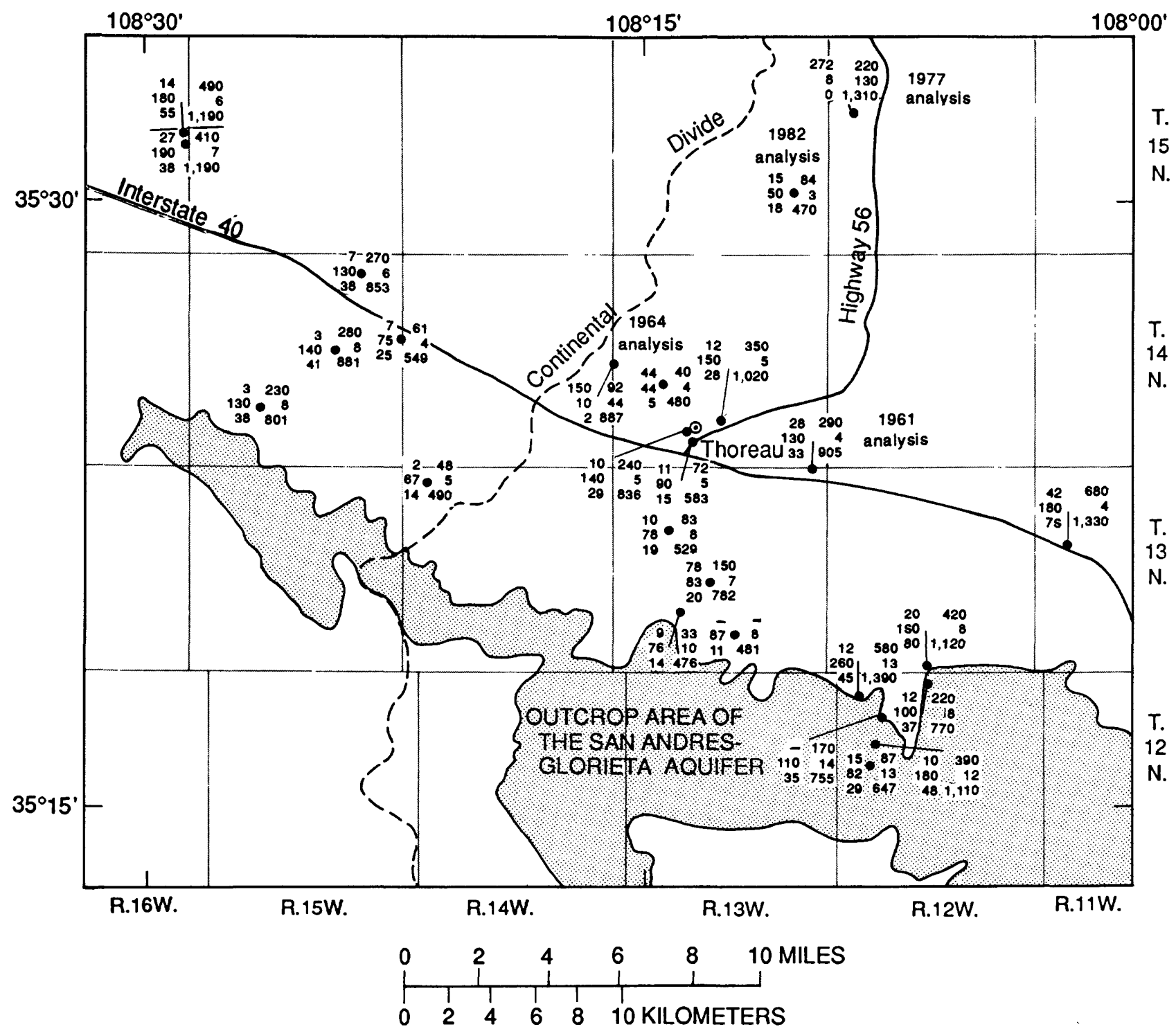

\section{EXPLANATION}

Sodium plus

potassium - $14 \quad 490$-Sulfate Calcium - $180 \bullet 6$-Chloride Magnesium- $55 \quad 1,190$-Specific conductance
WELL--Includes water-chemistry constituent values.

All values in milligrams per liter except specific conductance, in microsiemens per centimeter at 25 degrees Celsius; - , no value

Figure 19.--Selected chemical analyses of water from wells completed in the San Andres-Glurieta aquifer in the Thoreau area. 
Calcium and magnesium are the dominant cations in most ground water in the Thoreau area (fig. 20). Water from wells 15N.12W.17.111 (1977 analysis) and $14 \mathrm{~N} .13 \mathrm{~W} .19 .100$ (1964 analysis) has sodium as the dominant cation (table 7 and fig. 20). Water from these two wells also has large chloride concentrations (130 and $44 \mathrm{mg} / \mathrm{L}$ ) relative to other water in the area. Water from we11s $15 \mathrm{~N} .12 \mathrm{~W} .17 .111$ and $14 \mathrm{~N} .13 \mathrm{~W} .19 .100$ has large changes in chemistry with respect to time (table 7): in a sample collected in December 1975 from we11 15N.12W.17.111, the calcium concentration was $54 \mathrm{mg} / \mathrm{L}$ and the chloride concentration was $1.8 \mathrm{mg} / \mathrm{L}$, whereas in a sample collected in February 1977 the calcium concentration was $6 \mathrm{mg} / \mathrm{L}$ and the chloride concentration was $130 \mathrm{mg} / \mathrm{L}$ (table 7). In a sample collected in March 1964 from well 14N.13W.19.100, the calcium concentration was $10 \mathrm{mg} / \mathrm{L}$ and the chloride concentration was $44 \mathrm{mg} / \mathrm{L}$, whereas in a sample collected in July 1970 the calcjum concentration was 31 $\mathrm{mg} / \mathrm{L}$ and the chloride concentration was $150 \mathrm{mg} / \mathrm{L}$ (table 7). The reason for the large change in the water chemistry from these wells is unknown. A possible explanation for the relatively large sodium and chloride concentrations in water from these wells may be that the wells are completed in other aquifers in addition to the San Andres-Glorieta aquifer.

Chloride concentrations in ground water in the Thoreau area generally are less than $13 \mathrm{mg} / \mathrm{L}$ (fig. 19) and generally are less than chloride concentrations elsewhere in the study area. The small concentrations of chloride could be due to several reasons. Precipitation generally has chloride concentrations 1 ess than $4 \mathrm{mg} / \mathrm{L}$. If a large percentage of precipitation infiltrates and recharges the ground-water system relative to the amount of precipitation that evaporates, chloride concentrations in the ground water would be expected to be small. Smaller amounts of disseminated halite (sodium chloride) in the aquifer in the Thoreau area relative to other areas also would explain the relatively small chloride concentrations in ground water in this area because there are few or no sources of chloride in the aquifer.

Water from wells $13 \mathrm{~N} .13 \mathrm{~W} .22 .1333$ (1985 analysis) and $14 \mathrm{~N} .13 \mathrm{~W} .20 .4322$ has sodium concentrations of 77 and $43 \mathrm{mg} / \mathrm{L}$, respectively, which generally are larger than the sodium concentrations in most ground water in the Thoreau area (table 6). The percentage of sodium relative to other cations is approximately 42 in water from these wells, which also is large compared with other ground water in the area (fig. 20). Well-completion information indicates that these wells are completed in the Glorieta Sandstone (table 7). The relatively large sodium concentrations in water from these wells may indicate that ion exchange, whereby calcium in solution replaces sodium ions on clays, is an important process affecting the chemistry of this water. However, water from other wells completed in the Glorieta Sandstone does not have these relatively large sodium concentrations (table 7). 


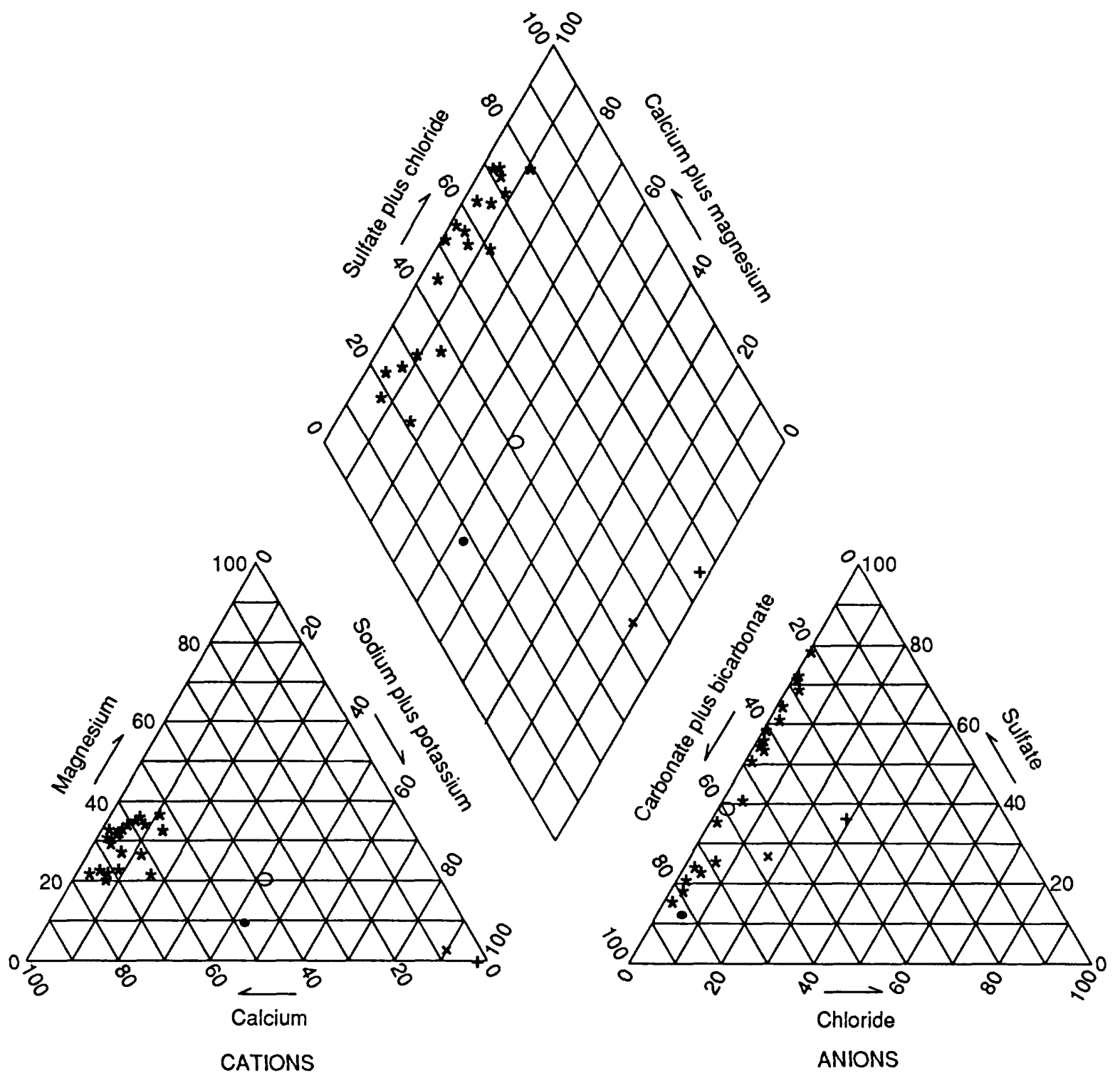

PERCENTAGE OF TOTAL IONS, IN MILLIEQUIVALENTS PER LITER

\section{EXPLANATION}

+ 15N.12W.17.111 1977 ANALYSIS

$\times \quad$ 14N.13W.19.100 1964 ANALYSIS

- 13N.13W.22.133 1985 ANALYSIS
- 14N.13W.20.432 1975 ANALYSIS

* Water from OtHer WELLS IN AREA

Figure 20.--Piper diagram of selected chemical analyses of water from wells completed in the San Andres-Glorieta aquifer in the Thoreau area. 
The percentage of bicarbonate and sulfate in water from the San AndresGlorieta aquifer falls into two general groups (fig. 20). One group has 20 to 50 percent bicarbonate ( 50 to 80 percent sulfate), and the other group has 60 to 85 percent bicarbonate (10 to 40 percent sulfate). An areal plot of the molar ratio of bicarbonate to sulfate (fig. 21) (bicarbonate concentration/61.0/sulfate concentration/96.0) indicates that water from wells in T. $12 \mathrm{~N} .$, R. $12 \mathrm{~W}$. and in T. $14 \mathrm{~N}$., R. $15 \mathrm{~W}$. generally has the smallest molar ratios, thus relatively more dissolved sulfate than bicarbonate compared with other wells in the area. Water from these wells also has larger concentrations of sulfate than water from other wells (fig. 19). The larger quantity of dissolved sulfate in water from these wells indicates that the dissolution of gypsum (calcium sulfate) is a relatively more significant process in the evolution of this water compared with other water in the Thoreau area. This also indicates more gypsum in the aquifer in this area (T. 12 N., R. 12 W., and T. 14 N., R. 15 W.) than in other areas or more fractures and thus more flow of ground water in fractures in the area having smaller sulfate concentrations (larger bicarbonate to sulfate molar ratios) (fig. 21).

\section{Grants-Bluewater Area}

The Grants-Bluewater area is in Townships 9-14 and Ranges 10 and 11 (fig. 18). The eastern boundary, which is somewhat arbitrary, is based primarily on the location of available ground-water-chemistry data and on the inclusion of ground water that is representative of recharge to the groundwater system from the eastern side of the Zuni uplift. The southern boundary is the southern extent of the outcrop area of the San Andres-Glorieta aquifer. The western boundary was chosen on the basis of a change in specific conductance and potentiometric gradient. The northern boundary is based on the availability of water-chemistry data.

Ground-water chemistry in the Grants-Bluewater area is variable with large differences in concentrations of dissolved constituents in water from adjacent wells ( 1.2 and table 8 ). The concentration of dissolved constituents in ground water in the Grants-Bluewater area generally is much greater than that in ground water in the Thoreau area (p1. 2 and fig. 19). The proportion of individual dissolved constituents, however, is relatively consistent (fig. 22). Most ground water in the Grants-Bluewater area has cations that are 30 to 60 percent calcium (15 to 47 percent sodium) and anions that are 40 to 60 percent sulfate (30 to 55 percent bicarbonate) (fig. 22). This relatively consistent proportion of dissolved constituents is unusual considering the large variation in the concentration of dissolved constituents. 

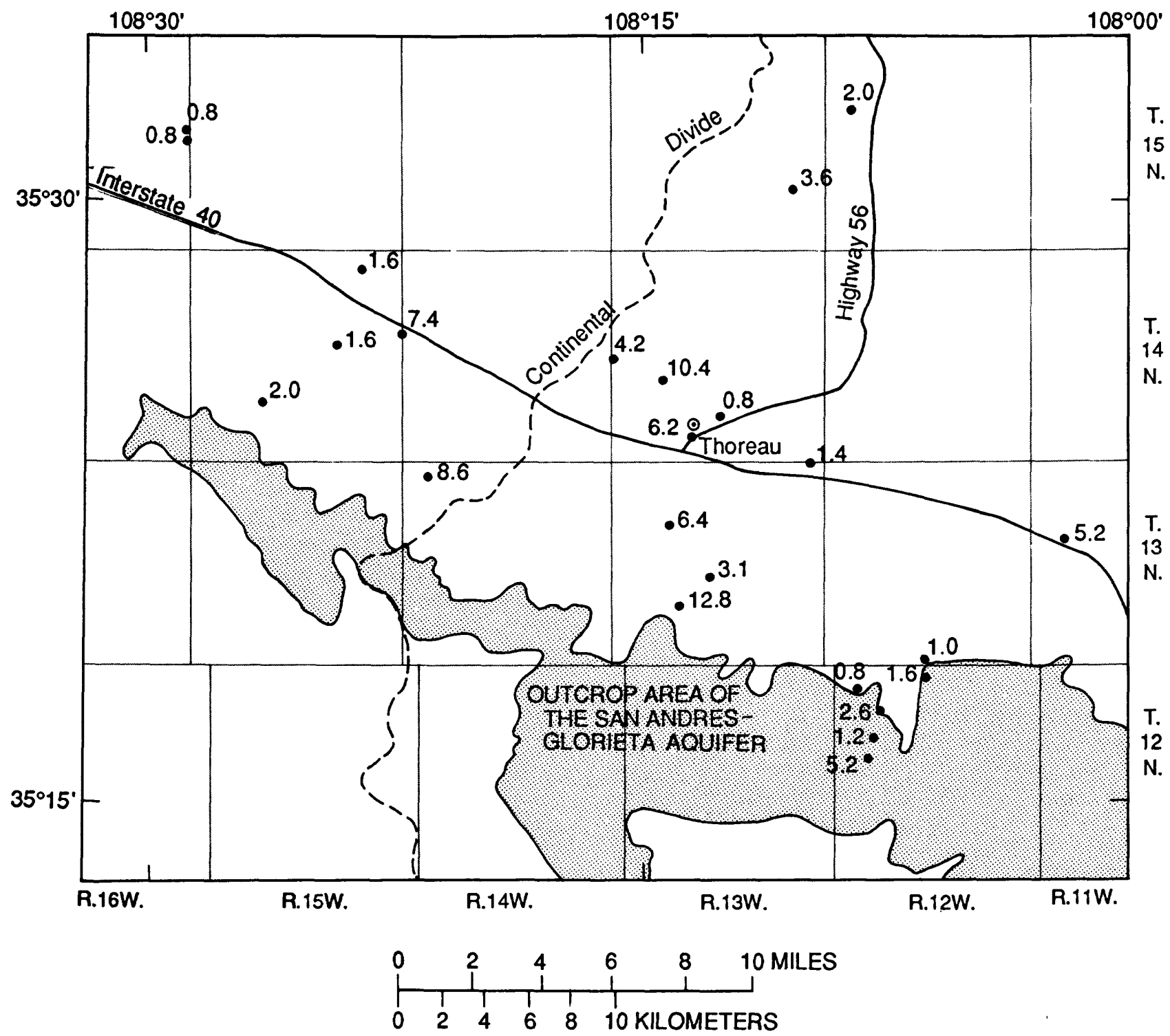

\section{EXPLANATION}

-8.6 WELL-- Number is molar ratio of bicarbonate concentration to sulfate concentration

Figure 21.--Molar ratio of bicarbonate concentration to sulfate concentration in water from selected wells completed in the San Andres-Glorieta aquifer in the Thoreau area. 


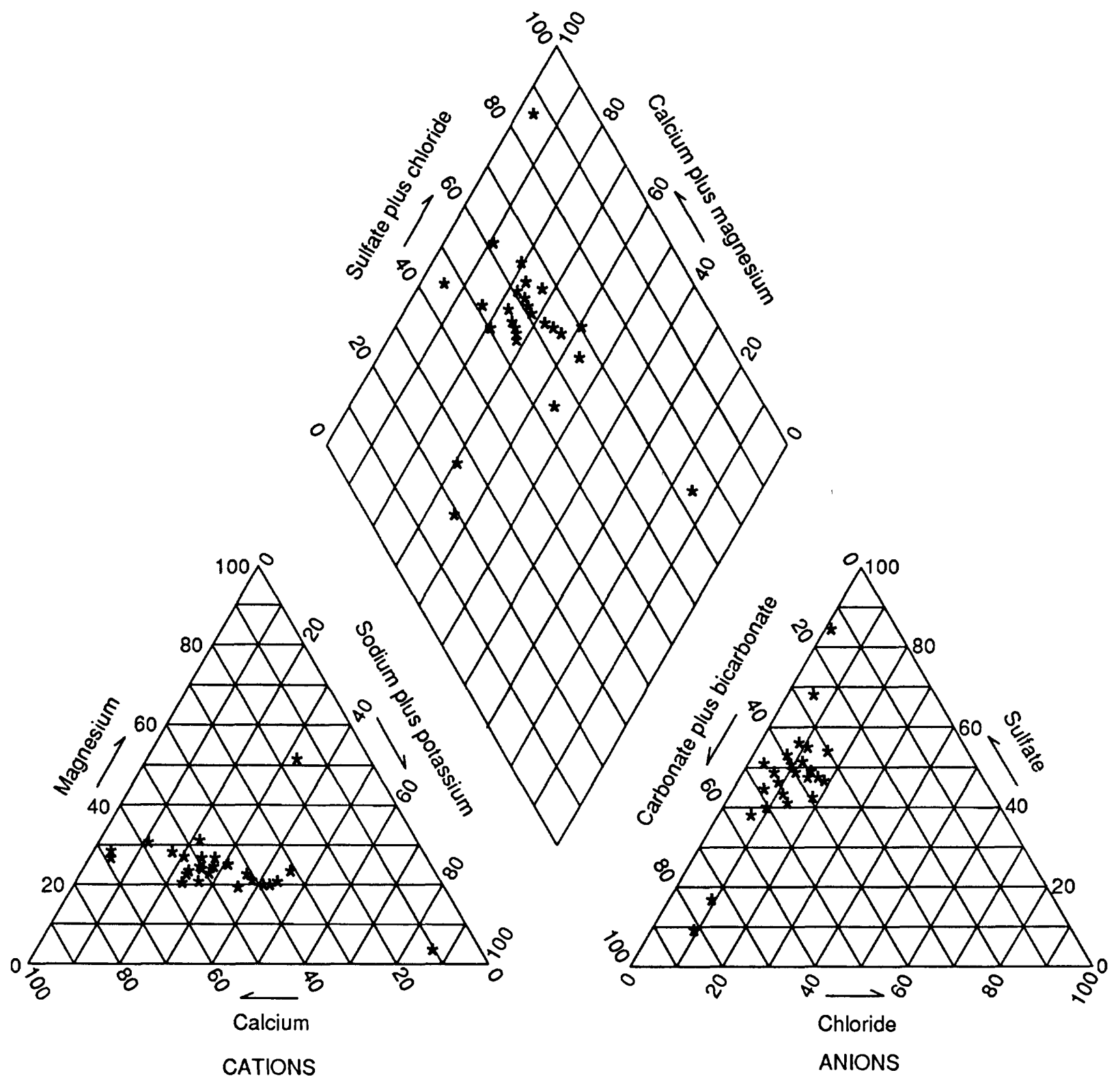

PERCENTAGE OF TOTAL IONS, IN MILLIEQUIVALENTS PER LITER

Figure 22.--Piper diagram of selected chemical analyses of water from wells completed in the San Andres-Glorieta aquifer in the Grants-Bluewater area. 
The variability of dissolved constituents in water from adjacent wells indicates that ground water has dissolved different quantities of aquifer material. This could be due to variation in the composition of the aquifer or could be the result of some ground water flowing in fractures or cavernous zones, where flow rates are faster and there is less soluble material than for ground water flowing through the rock matrix for the same distance of travel. In reality, water at a particular point in the aquifer probably has flowed through fractures or cavernous zones and through the rock matrix, and the water chemistry at any point is in part a function of the distance the water has traveled through these two different types of voids in the aquifer. The fact that there is no large variation in the proportions of individual dissolved constituents indicates that the mineralogy of the aquifer is relatively homogeneous and thus the same chemical processes affect the groundwater chemistry throughout the Grants-Bluewater area.

Water from wells 9N.10W.10.414 and 9N.10W.15.212 near the southeastern outcrop area (recharge area) of the San Andres-Glorieta aquifer generally has less dissolved ions (smaller specific conductance) and a larger proportion of bicarbonate relative to sulfate than water from other wells in the Grants Bluewater area. Water from these wells contains greater than 70 percent bicarbonate (fig. 22). Ground water in this area has smaller sulfate concentrations than elsewhere possibly because (1) there is less gypsum in the aquifer in this area, or (2) the ground water in this area may not have been in the aquifer long enough to come in contact with and dissolve much gypsum.

There have been large ground-water withdrawals from the San AndresGlorieta aquifer in the Grants-Bluewater area. The use of ground water for irrigation purposes started in 1944; by 1946,16 we11s were used for irrigation, and by 1954, 28 wells were used for irrigation (Gordon, 1961, p. 51). From 1946 to $1955,4,000$ to 6,000 acres were irrigated with ground water (Gordon, 1961, p. 103). Large-scale industrial use of ground water started in 1951. By 1955, ground-water withdrawals for agricultural use began to decline, whereas ground-water withdrawals for industrial use increased (Gordon, 1961, p. 103). This change in ground-water use was accompanied by changes in the location of ground-water withdrawals and thus changes in the location of water-level declines.

Lowering of the water levels in the San Andres-Glorieta aquifer as the result of withdrawals could result in induced leakage of water from adjacent aquifers such as alluvium, the Chinle Formation, and the Yeso Formation. If induced leakage did occur and the chemistry of the induced leakage were different than the water chemistry of the aquifer, mixing of the two waters would result in changes in the water chemistry of the San Andres-Glorieta aquifer. 
In general, the concentration of nitrate is small (1ess than $1 \mathrm{mg} / \mathrm{L}$ ) in ground water not affected by human activities, thus nitrate is a good indicator of changes in water chemistry that may be due in part to human influence. Possible sources of nitrate are the leaching of fertilizers by recharge water, leakage of industrial wastewater containing nitrogen compounds, or leakage of water containing human or animal waste. In general, nitrate is not conservative in ground water, but is removed from the water and converted to nitrogen gas by bacteria. In flow systems containing fractures or cavernous zones, ground-water flow can be relatively rapid and large nitrate concentrations can be a significant distance from outcrop or recharge areas.

The chemistry of ground water from the San Andres-Glorieta aquifer in the Grants-Bluewater area has changed since the early 1940's (table 8). An areal plot of dissolved-nitrate, dissolved-chloride, and dissolved-sulfate concentrations for 1944 to 1948 shows dissolved-nitrate concentrations as large as $7.2 \mathrm{mg} / \mathrm{L}$ in water from wells in T. $12 \mathrm{~N} ., \mathrm{R} .10 \mathrm{~W}$. (fig. 23). On the basis of available data, dissolved-nitrate concentrations seem to be greatest in the vicinity of T. $12 \mathrm{~N}$., R. $10 \mathrm{~W}$., sec. 30. Dissolved-chloride concentrations range from 12 to $98 \mathrm{mg} / \mathrm{L}$, and dissolved-sulfate concentrations range from 160 to $800 \mathrm{mg} / \mathrm{L}$ (fig. 23). An areal plot of the dissolved-nitrate, dissolved-chloride, and dissolved-sulfate concentrations for water from wells $12 \mathrm{~N} .10 \mathrm{~W} .30 .421,12 \mathrm{~N} .10 \mathrm{~W} .32 .111$, and $11 \mathrm{~N} .10 \mathrm{~W} .16 .121$ (fig. 24) shows smaller nitrate concentrations for 1956 to 1957 than for 1944 to 1948 . Dissolvedchloride and dissolved-sulfate concentrations in these wells generally increased during this time period. In this case, the nitrate concentrations, which are affected by biological processes, decrease, whereas the dissolvedchloride concentrations, which generally are not affected by biological processes, increase. The largest nitrate concentrations for 1956 to 1957 were measured in water from wells in the vicinity of T. $12 \mathrm{~N} ., \mathrm{R} .11 \mathrm{~W}$, sec. 24 (fig. 24).

Concentrations of dissolved nitrate, chloride, and sulfate were greater in water from well 12N.11W.25.213 in 1962 than in 1946 and 1957 (figs. 23-25). Water samples collected in 1962 from wells $11 \mathrm{~N} .10 \mathrm{~W} .9 .221$ and $11 \mathrm{~N} .10 \mathrm{~W} .16 .121$ had larger dissolved-nitrate concentrations than samples collected in 1956-57, although there was little or no change in dissolved-chloride and dissolvedsulfate concentrations (figs. 24 and 25). In 1980-81, dissolved-nitrate concentrations were largest in water from wells $12 \mathrm{~N} .10 \mathrm{~W} .18 .312$ and 12N.10W.19.224 (fig. 26). The dissolved-chloride and dissolved-sulfate concentrations in water from these wells and well $12 \mathrm{~N} .10 \mathrm{~W} .17 .424$ are much greater than concentrations measured in water from other wells in the area (fig. 26). The large nitrate concentrations in association with relatively large chloride and sulfate concentrations could indicate an impact of human activities on ground-water chemistry. Chloride and sulfate concentrations in water from we11 12N.11W.23.231 have increased since 1947, although nitrate concentrations decreased from $17 \mathrm{mg} / \mathrm{L}$ in 1956 to $7.3 \mathrm{mg} / \mathrm{L}$ in 1980 (figs. 23, 24, and 26). Chloride concentrations decreased from $160 \mathrm{mg} / \mathrm{L}$ in 1957 to 91 $\mathrm{mg} / \mathrm{L}$ in 1980 in water from well $12 \mathrm{~N} .11 \mathrm{~W} .15 .211$, although the sulfate and nitrate concentrations did not change significantly. Nitrate concentrations decreased in water from wells 11 N.10W.9.221 and 11 N.10W.4.333 between 1962 and 1980 (figs. 25 and 26). Chloride and sulfate concentrations also decreased in water from well 11N.10W.4.333 between 1962 and 1980 , but increased in water from we11 11N.10W.9.221. 


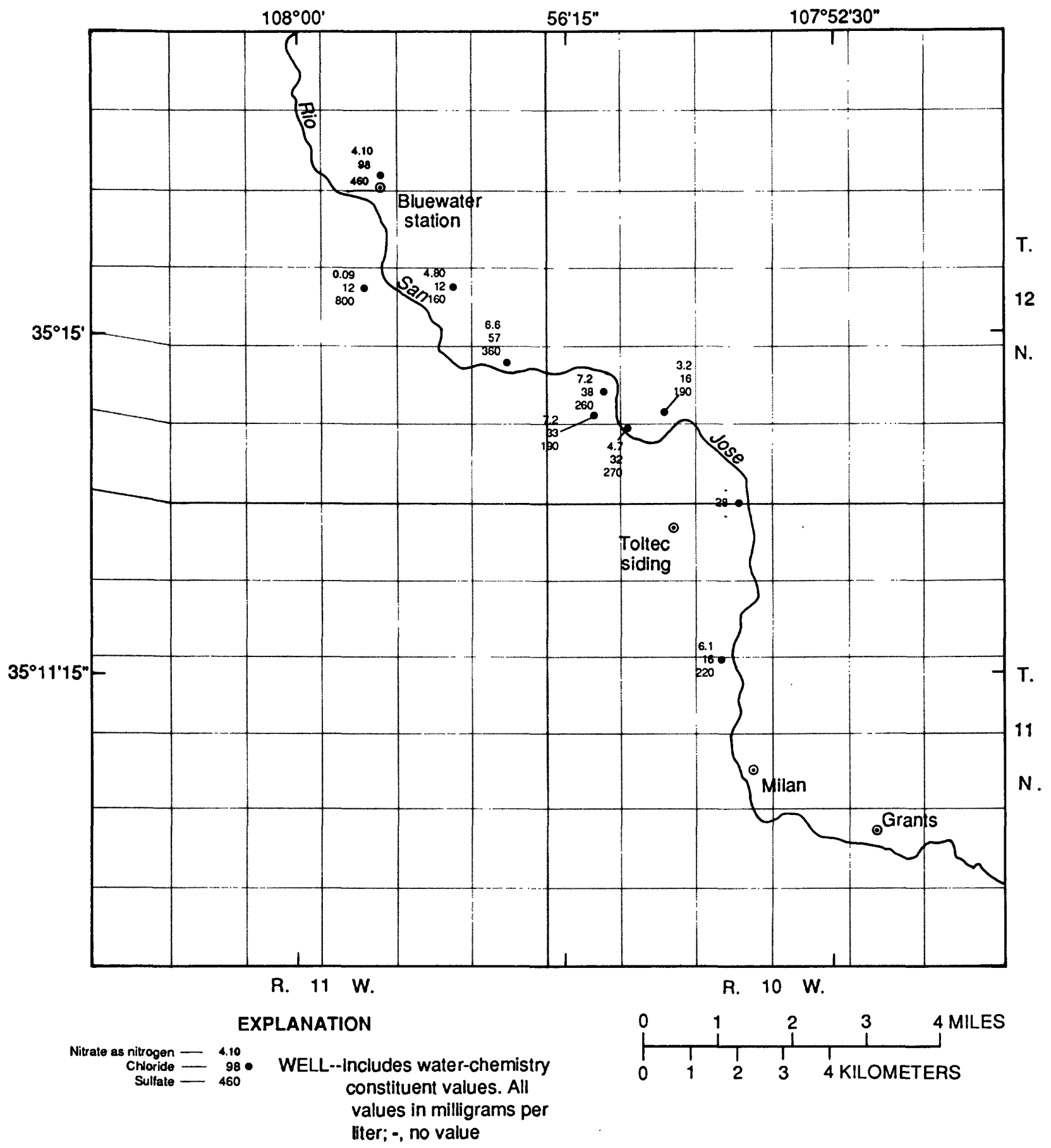

Figure 23.--Dissolved-nitrate, chloride, and sulfate concentrations in water from wells completed in the San Andres-Glorieta aquifer in the Grants-Bluewater area, 1944-48. 


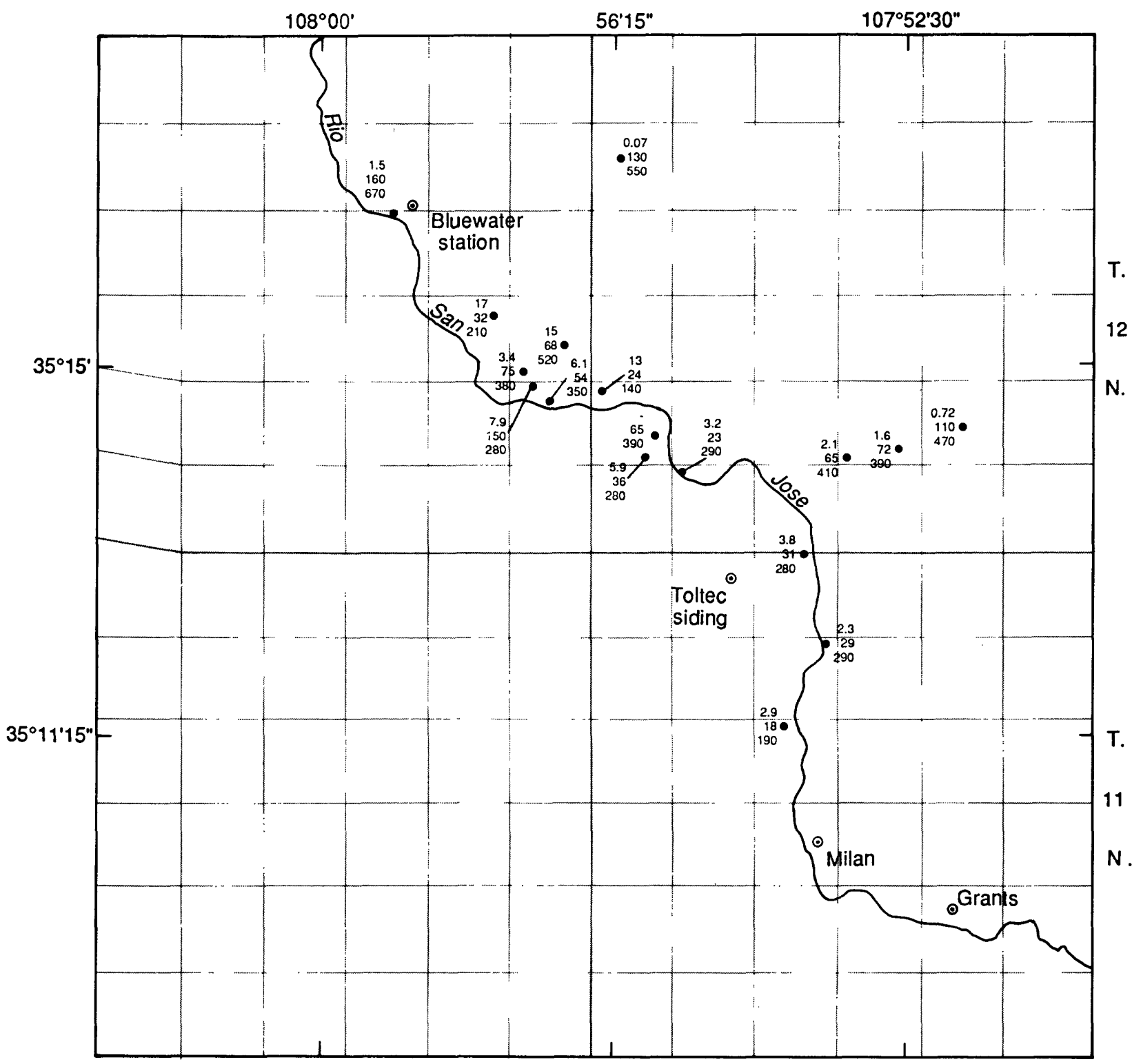

R. $11 \mathrm{~W}$.

R. $10 \mathrm{~W}$.

\section{EXPLANATION}

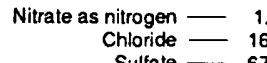

160 - WELL--Includes water-chemistry Sulfate -- $670 \quad$ constituent values. All

values in milligrams per liter; -, no value

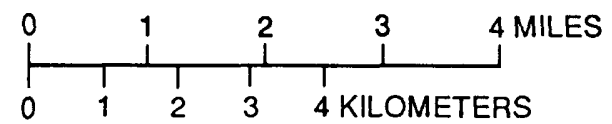

Figure 24.--Dissolved-nitrate, chloride, and sulfate concentrations in water from wells completed in the San Andres-Glorieta aquifer in the Grants-Bluewater area, 1956-57. 


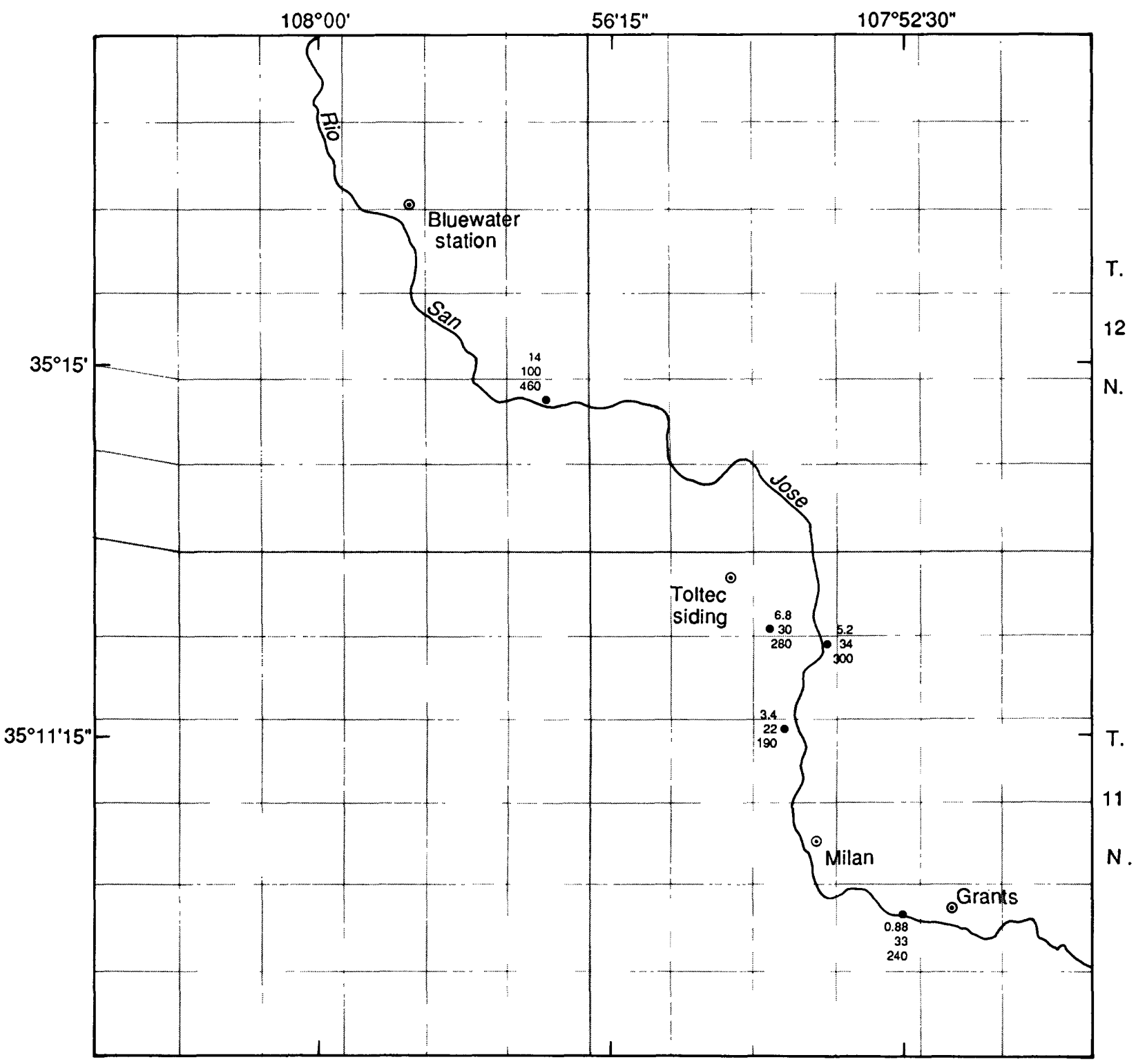

R. $11 \mathrm{~W}$.

R. $10 \mathrm{~W}$.

\section{EXPLANATION}

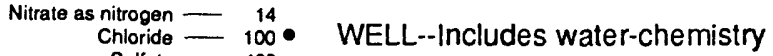
Sulfate - 460 constituent values. All values in milligrams per liter; -, no value

Figure 25.--Dissolved-nitrate, chloride, and sulfate concentrations in water from wells completed in the San Andres-Glorieta aquifer in the Grants-Bluewater area, 1962-63. 


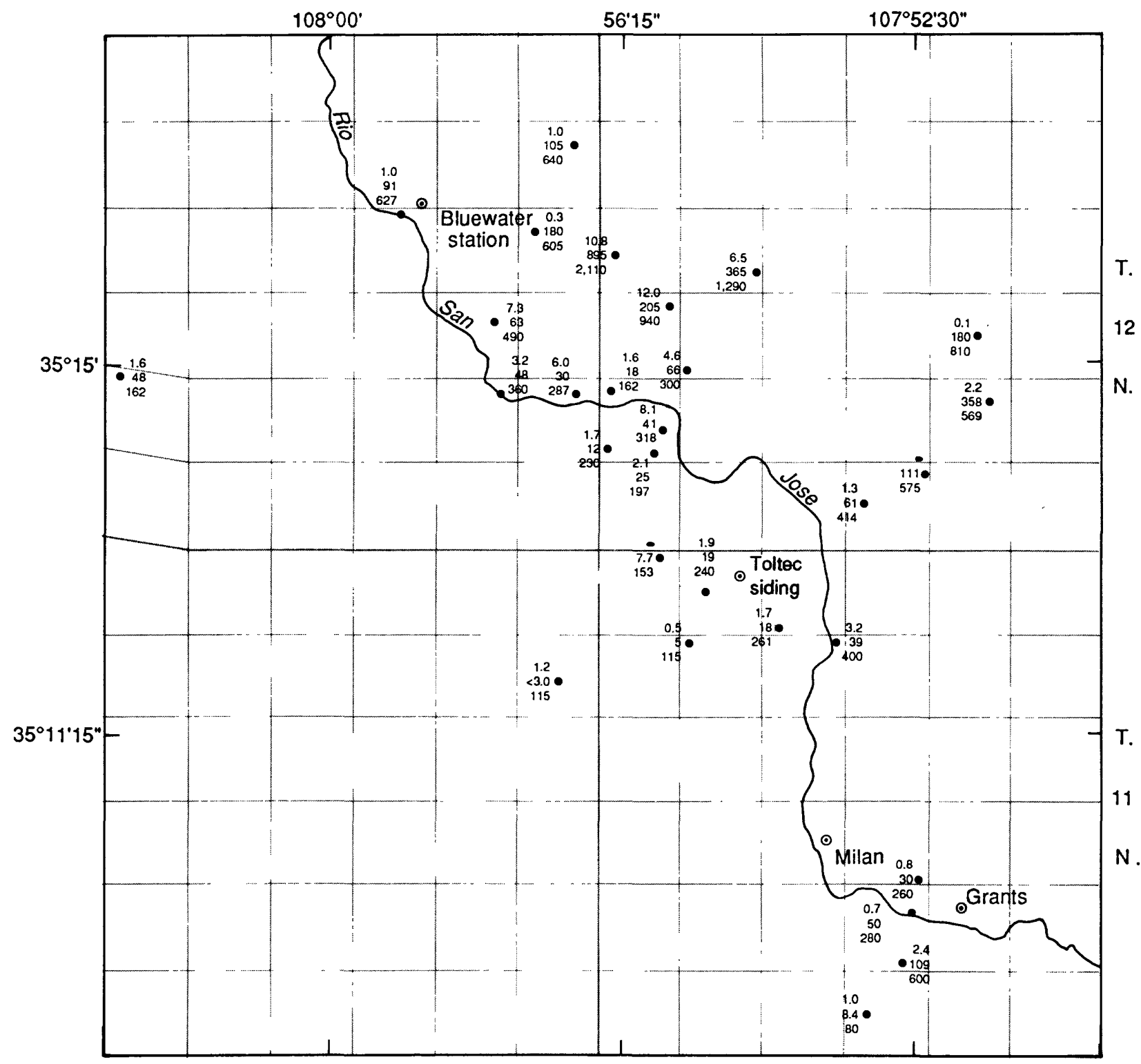

R. $11 \mathrm{~W}$.

R. $10 \mathrm{~W}$.

\section{EXPLANATION}

Nitrate as nitrogen $-\quad 1.6$

Chloride

48 WELL--Includes water-chemistry constituent values. All values in milligrams per liter; -, no value

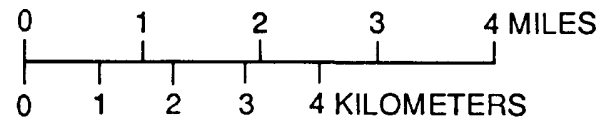

Figure 26.--Dissolved-nitrate, chloride, and sulfate concentrations in water from wells completed in the San Andres-Glorieta aquifer in the Grants-Bluewater area, 1980-81. 
These data indicate that human activity has affected ground-water chemistry in the area. Changes in the locations of areas where ground-water chemistry has been affected and differences in the chemical constituents that have changed with time in different areas probably are the result of changes in land use in the particular areas.

Ground-water flow and ground-water chemistry in the vicinity of 0 jo del Gallo (10.10.3.423) and San Rafael (p1. 2) also have changed since the 1940's. Hodges (1938) estimated the discharge of 0 jo del Gallo to be about 3,100 gallons per minute. Discharge from the spring began to decrease in the mid$1940^{\prime} \mathrm{s}$, and by 1953 the spring was dry (Gordon, 1961, p. 51). Gordon (1961, p. 47) stated that the effects of ground-water withdrawals for irrigation, industrial, and municipal use probably were the reason for the cessation of spring flow. The spring started to flow again in the early $1980^{\prime} \mathrm{s}$, and by 1986 the discharge had increased to approximately 772 gallons per minute. The municipal water supply for San Rafael comes from wells penetrating the San Andres-Glorieta aquifer less than 1 mile from Ojo del Gallo.

Chloride concentrations in water samples from 0 jo del Gallo ranged from $44 \mathrm{mg} / \mathrm{L}$ in 1946 to $110 \mathrm{mg} / \mathrm{L}$ in 1984; an intermediate concentration of $80 \mathrm{mg} / \mathrm{L}$ was measured in a sample collected in 1985 ( $\mathrm{fig} .27$ ). Chloride concentrations in water samples from the San Rafael municipal well ranged from $40 \mathrm{mg} / \mathrm{L}$ in 1962 to $94 \mathrm{mg} / \mathrm{L}$ in 1976 , decreasing to $80 \mathrm{mg} / \mathrm{L}$ in 1986 (fig. 27). The concentrations of other ions also have changed in water from 0 jo del Gallo and the San Rafael municipal wells (table 7); the maximum chloride concentration is not known but probably was greater than the maximum concentrations measured because data show that chloride concentrations have been decreasing. Chloride concentrations decreased from 1984 to 1985 in water from Ojo del Gallo and began to level off in approximately 1980 in water from San Rafael municipal wells.

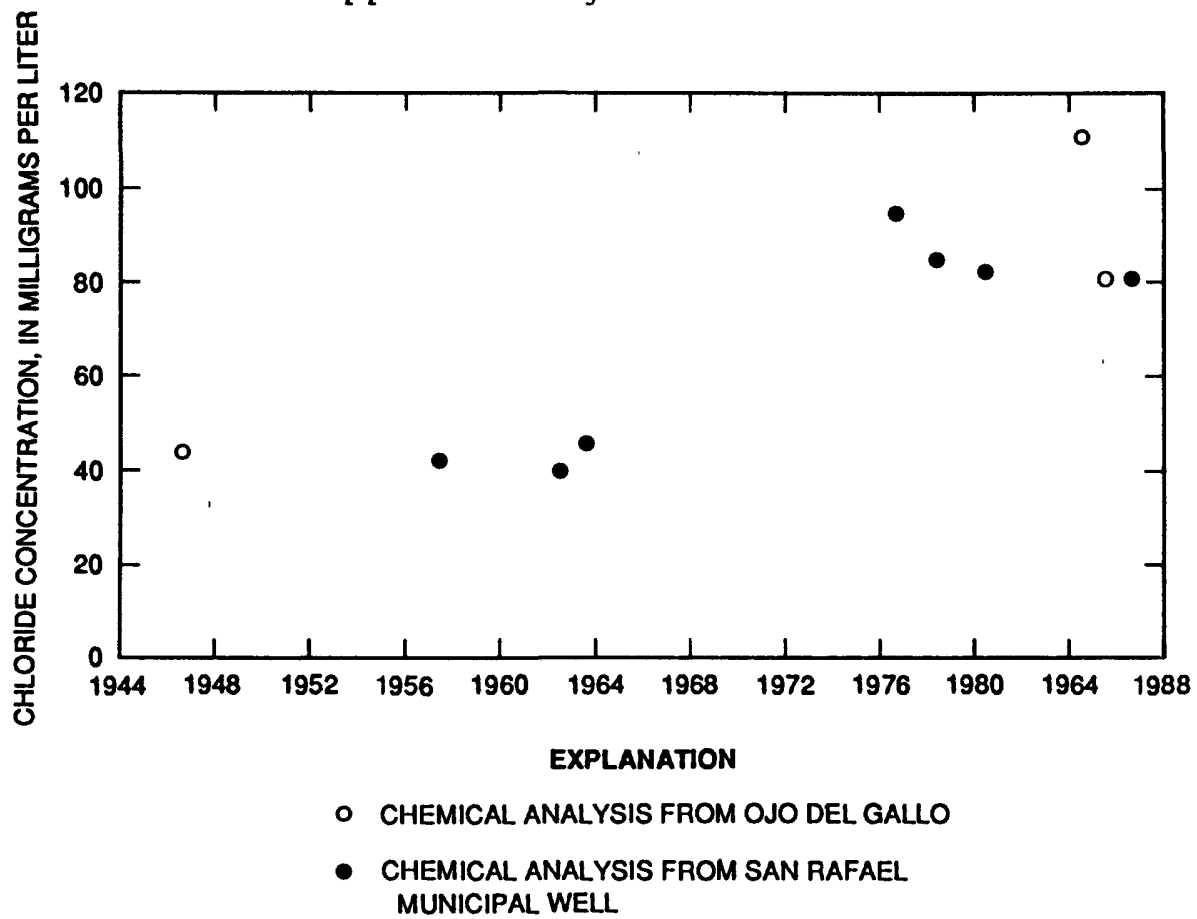

Figure 27.--Chloride concentration in water from 0 jo de Gallo and San Rafael municipal wells, 1947-86. 
One possible explanation for this change in water chemistry is that lower potentiometric heads in the San Andres-Glorieta aquifer caused by ground-water withdrawals resulted in induced leakage of ground water having a chemistry different than that of water in the aquifer. Although potentiometric heads declined in the vicinity of 0 jo del Gallo as evidenced by the cessation of flow from the spring, the head declines in the Grants area and west of Grants were much larger than those in the vicinity of 0 jo del Gallo. In areas where the San Andres-Glorieta is under artesian conditions, large potentiometrichead declines could induce downward leakage from the alluvium or Chinle Formation or upward leakage from the Yeso Formation. The amount of leakage at a particular point would be a function of the potentiometric-head declines, the potentiometric head in the rocks adjacent to the San Andres-Glorieta aquifer, and the permeability of these adjacent rocks. The potentiometricsurface map indicates that ground water in the San Andres-Glorieta aquifer flows eastward from the Grants area (area of the largest head declines) toward the ojo del Gallo area (fig. 13). Chemical analysis of water from the San Rafael municipal wells indicates a change in water chemistry between 1963 and 1976 (fig. 27). This water-chemistry change could be caused by downward leakage from the alluvium or Chinle Formation of water that has larger chloride concentrations than water in the aquifer prior to 1963 or by upward leakage from the Yeso Formation in the areas of the largest head declines. The decrease in chloride concentrations in water from ojo del Gallo between 1984 and 1985 and in water from the San Rafael municipal well between 1976 and 1986 may indicate that the amount of leakage from adjacent units is decreasing or that ground water that leaked into the San Andres-Glorieta aquifer previously is moving past the ojo del Gallo and San Rafael area and being flushed through the aquifer. If flow at ojo del Gallo increases to the quantity estimated by Hodges (1938), chloride concentrations in water from the San Andres-Glorieta aquifer in this area probably will continue to decrease to approximately the same concentrations measured prior to 1964 , assuming the water chemistry upgradient from Ojo de1 Gallo has not changed since 1964 .

\section{Acoma Embayment Area}

The eastern boundary of the Acoma embayment area is coincident with a group of faults that separate the Mesozoic and Paleozoic rocks on the west from the Tertiary alluvial-basin deposits of the Rio Grande rift (fig. 18). Because the geology, ground-water flow system, and water chemistry are complex in this part of the study area, a brief discussion of water chemistry in other aquifers has been included. The arbitrary southern boundary was chosen to be the latitude $34^{\circ} 30^{\prime}$ (fig. 18). The western and northern boundaries also are somewhat arbitrary but generally are based on the availability of data. The San Andres-Glorieta aquifer dips to the north in the Acoma embayment area, thus there are few data north of T. $10 \mathrm{~N}$. because of the large depth to the aquifer and the utilization of shallower aquifers. Water-chemistry data from the San Andres-Glorieta aquifer are sparse for the Acoma embayment area.

The direction of ground-water flow in the Acoma embayment area generally is from the west to the east as indicated by water levels in wells. However, little is known about the direction of ground-water flow at the eastern, southern, and northern margins of the Acoma embayment area (fig. 18). 
The chemistry of water from the San Andres-Glorieta aquifer in the Acoma embayment area is complex, varying significantly in concentrations of dissolved ions and in the relative proportions of specific dissolved ions (figs. 28 and 29). The concentrations of dissolved ions in ground water from the aquifer would be expected to increase from the recharge area (western side of the Acoma embayment area) to the discharge area (eastern side of the Acoma embayment area). This is observed in the water-chemistry data in the northern part of the Acoma embayment area (Townships 8 and 9). In the southern part of the area (Townships 4-7), however, ground water does not have this general increase in concentration of dissolved ions from west to east (fig. 28), indicating that the general flow from west to east may not hold true throughout the area.

On the basis of the location of the outcrop area of the San AndresGlorieta aquifer and the potentiometric-surface map, water from well 9 N.9W.28.1344 represents ground water that has traveled the shortest distance from the recharge area on the east side of the Zuni Mountains. Specific conductance of water from this well is the smallest detected in samples from the Acoma embayment area (fig. 28). Calcium is the dominant cation, and the proportion of bicarbonate with respect to the other anions is greater than in other water in the Acoma embayment area (fig. 29). The concentration of dissolved sulfate in water from this well is $300 \mathrm{mg} / \mathrm{L}$, which is the smallest sulfate concentration in the Acoma embayment area. The large proportion of calcium relative to the other cations and the large proportion of chloride relative to the other anions indicate that dissolution of limestone has been a significant process in the chemical evolution of this water. The relatively small sulfate concentration indicates less gypsum dissolution between the recharge area and this well compared with other wells in the area.

If some assumptions are made, changes in water chemistry as water moves eastward (downgradient) can be investigated by comparing the chemistry of water from well 9N.9W.28.1344 with water from the next well downgradient. These assumptions are that (1) water from we11 9N.9W.28.1344 in 1986 is representative of ground water that has flowed by this point in the past; (2) the ground-water chemistry is homogeneous along a potentiometric contour in T. $8 \mathrm{~N}$. and T. $9 \mathrm{~N}$.; and (3) the water moves downgradient (west to east). The chemical processes that affect the chemistry of ground water from well to well downgradient in T. $8 \mathrm{~N}$. and T. $9 \mathrm{~N}$. also can be postulated. However, because they have not been tested or confirmed, the processes discussed are speculative. 


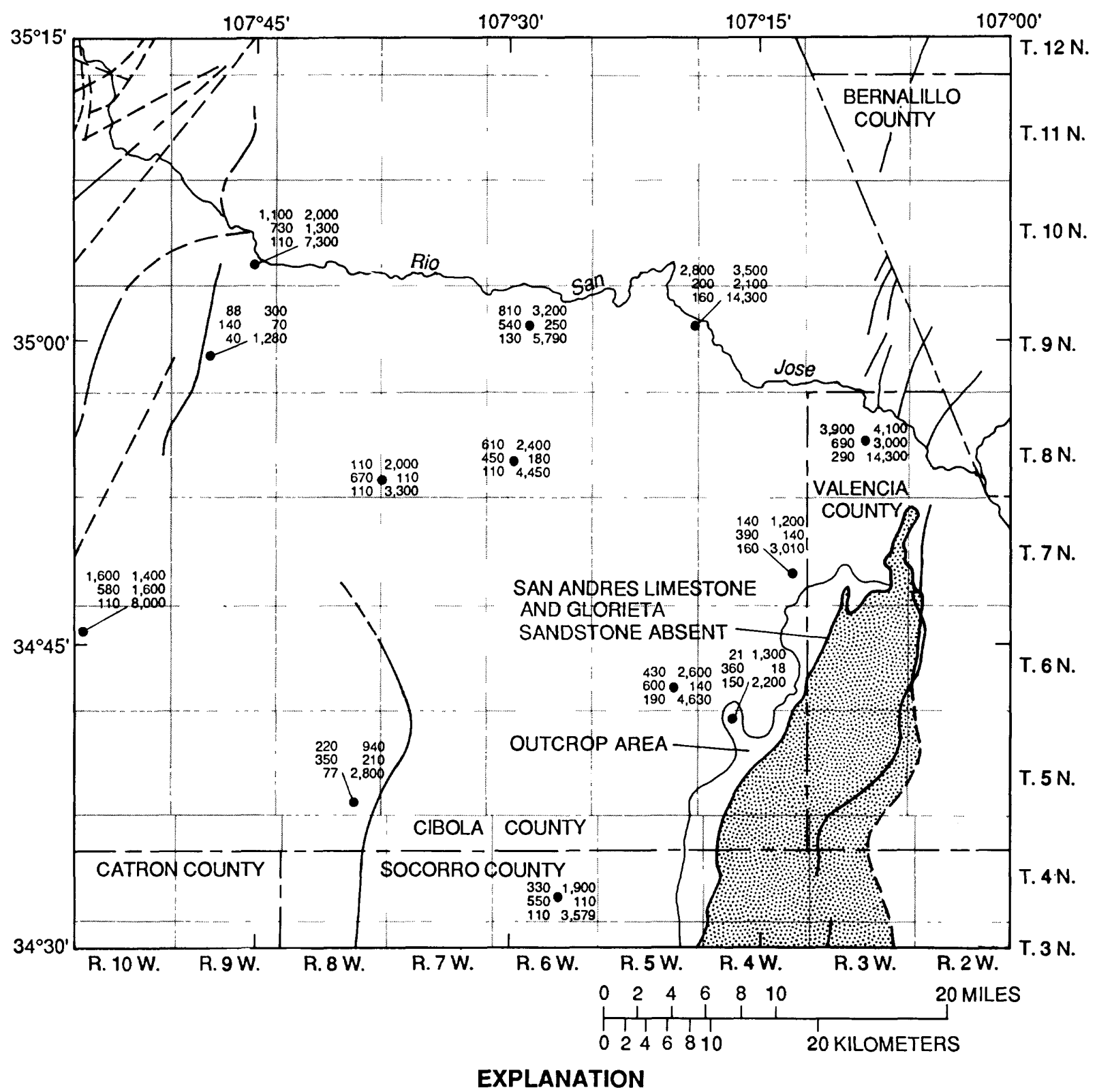

FAULT--Dashed where approximately located.

Geology modified from Dane and Bachman, 1965

Sodium - $610 \quad 2,400$ - Sulfate Calcium - 610 2,400-Sulfate

WELL--Includes water-chemistry constituent values.

All values in milligrams per liter except specific

conductance in microsiemens per centimeter

25 degrees Celsius

Figure 28.--Selected chemical analyses of water from wells completed in the San Andres-Glorieta aquifer in the Acoma embayment area. 


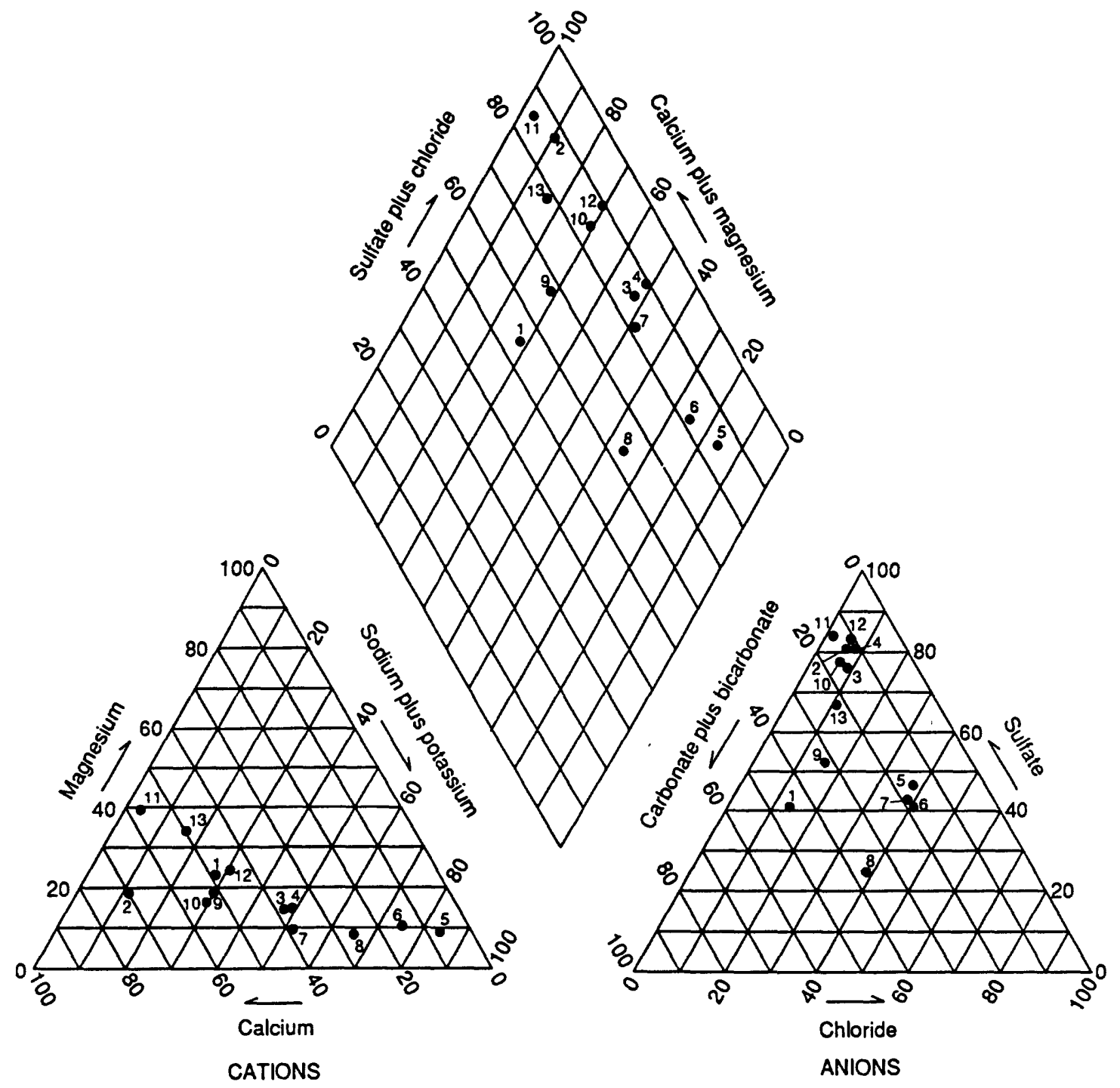

PERCENTAGE OF TOTAL IONS, IN MILLIEQUIVALENTS PER LITER

EXPLANATION
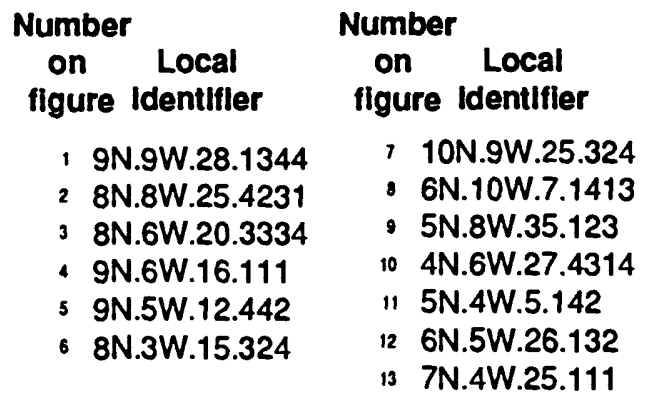

Figure 29.--Piper diagram of selected chemical analyses of water from wells completed in the San Andres-Glorieta aquifer in the Acoma embayment area. 
The mineralogy of the San Andres Limestone and Glorieta Sandstone can be used to limit the possible chemical processes that result in the changes in water chemistry. As pointed out in the geology section of the report, the San Andres Limestone and Glorieta Sandstone contain significant amounts of gypsum and anhydrite in the eastern part of the Acoma embayment. Baars (1962, p. 208) indicated that the San Andres Limestone and Glorieta Sandstone were deposited in an evaporite basin in this area. Small amounts of halite and other evaporite minerals also may have been deposited in conjunction with the gypsum and anhydrite, although these minerals have not been observed in the San Andres Limestone and Gloxieta Sandstone. Small amounts of seawater would also be trapped in the gypsum and anhydrite during precipitation. This fluid would contain relatively large concentrations of sodium, magnesium, potassium, and chloride. Kaolinite and illite are the most predominant clays found in the San Andres Limestone and Glorieta Sandstone (L.N. Plummer, U.S. Geological Survey, written commun., 1988). The presence of these clays indicates that cation-exchange reactions are possible in the San Andres-Glorieta aquifer.

Water from well $8 \mathrm{~N} .8 \mathrm{~W} .25 .4231$, the next well downgradient from well 9 N.9W.28.1344, has significantly larger concentrations of dissolved calcium and sulfate than water from well 9N.9W.28.1344 (fig. 28), indicating the dissolution of gypsum as water moves eastward. Water from well 8N.6W.20.3334, the next well downgradient, has less dissolved calcium, significantly more dissolved sodium, and more dissolved sulfate than water from well 8N.8W.25.4231 (fig. 28). The decrease in dissolved calcium and increase in sodium could indicate cation exchange, where two sodium ions fixed on a clay particle are exchanged for a calcium ion. This is indicated on the Piper diagram by the increase in the proportion of sodium (fig. 29). The increase in dissolved sulfate indicates that gypsum continues to dissolve as the ground water moves east. Water from well 9N.6W.16.111, the next well downgradient, has more dissolved calcium, sodium, and sulfate than water from well 8 N.6W.20.3334 (fig. 28), indicating that gypsum dissolution and cation exchange continue. Little change in the proportion of cations and anions compared with water from wells $9 \mathrm{~N} .6 \mathrm{~W} .16 .111$ and $8 \mathrm{~N} .6 \mathrm{~W} .20 .3334$ is shown in the Piper diagram, indicating no large change in the chemical processes affecting the water chemistry between these wells. This seems to support the assumption that, in general, ground-water chemistry is homogeneous along a potentiometric contour in T. $8 \mathrm{~N}$. and T. $9 \mathrm{~N}$.

There is a substantial difference in the water chemistry of well 9 N.6W.16.111 and that of well 9N.5W.12.442 (fig. 28). Although the calcium concentration decreases from 540 to $200 \mathrm{mg} / \mathrm{L}$ (fig. 28 and table 9), the sodium concentration increases from 810 to $2,800 \mathrm{mg} / \mathrm{L}$, bicarbonate concentration increases from 548 to $1,500 \mathrm{mg} / \mathrm{L}$, sulfate concentration increases from 3,200 to $3,500 \mathrm{mg} / \mathrm{L}$, and chloride concentration increases from 250 to $2,100 \mathrm{mg} / \mathrm{L}$. The decrease in calcium and increase in bicarbonate are difficult to account for but may be due to dissolution of limestone in conjunction with cation exchange. The increase in sulfate indicates continued gypsum dissolution. The substantial increase in sodium and chloride concentrations could indicate dissolution of halite. 
There are increases in all dissolved constituents in water from well 8 N.3W.15.324, the next well downgradient, compared with water from well 9N.5W.12.442 (fig. 28 and table 9). This probably means that gypsum, limestone, and halite dissolution continues to occur; however, the increase in calcium may indicate that cation exchange is not as significant between wells 9 N. 5W.12.442 and 8 N. 3W.15.324 as it is between wells 9 N.6W.16.111 and 9N.5W.12.442. The large increase in the concentration of potassium (12 mg/L in water from wel1 9N.5W.12.442 and $120 \mathrm{mg} / \mathrm{L}$ in water from wel1 8N.3W.15.324) may indicate dissolution of sylvite (potassium chloride), which is an evaporite mineral commonly found in conjunction with anhydrite and halite deposits. Relatively small changes in the proportion of cations and anions are seen in the Piper diagram, indicating little change in the chemical processes affecting the water chemistry between we11s 9N.5W.12.442 and 8N.3W.15.324 (fig. 29).

The chemical composition of water from well 10N.9W.25.3241 is anomalous compared with water from other wells in the vicinity (fig. 28). The sodium concentration of $1,100 \mathrm{mg} / \mathrm{L}$ and the chloride concentration of $1,300 \mathrm{mg} / \mathrm{L}$ (fig. 28) possibly indicate that halite dissolution has been important in the evolution of water from this well. The proportion of anions in water from this well is similar to water from wells $8 \mathrm{~N} .3 \mathrm{~W} .15 .324$ and $9 \mathrm{~N} .5 \mathrm{~W} .12 .442$ (fig. 29). Water from wells $8 \mathrm{~N} .3 \mathrm{~W} .15 .324$ and $9 \mathrm{~N} .5 \mathrm{~W} .12 .442$ represents ground water that has been in the San Andres-Glorieta aquifer a relatively long time and that has evolved chemically to the present composition (large specific conductance and large sodium and chloride concentrations). A relatively long residence time also may be the explanation for the relatively large specific conductance and large sodium and chloride concentrations in water from well 10N.9W.25.3241. Ground-water flow may be relatively slow in this part of the aquifer. Another explanation could be that the water has come in contact with a considerable quantity of soluble evaporite minerals in a relatively short time; thus, the water may not have been in the aquifer a long time but instead has traveled through parts of the aquifer containing a significant quantity of soluble material.

Water from well 6N.10W.7.1413 also is anomalous compared with water from other wells in the vicinity (fig. 28). Sodium and chloride concentrations are relatively large in water from this well, as they are in water from well 10N.9W.25.3241 (fig. 28). The potassium and bicarbonate concentrations in water from well 6N.10W.7.1413 also are relatively large compared with water from other wells in the Acoma embayment area. Water from this well probably has been in the San Andres-Glorieta aquifer a relatively long time.

Water from we11 5N.8W.35.123 has a specific conductance of 2,800 microsiemens and a sulfate concentration of $940 \mathrm{mg} / \mathrm{L}$ (table 9), which are small compared with water from wells a similar distance from the outcrop areas of the San Andres-Glorieta aquifer. The small sulfate concentration indicates that gypsum dissolution is not as significant a process in the chemical evolution of water from this well as it is in water from most other wells in the Acoma embayment area. The chloride concentration of $210 \mathrm{mg} / \mathrm{L}$ generally is larger than that in water from other wells in the area. On the basis of the proportion of the individual cations and anions, water from well 5N.8W.35.123 is similar to water from well 9N.9W.28.1344 (fig. 29), which represents 
recharge water to the San Andres-Glorieta aquifer in the area. The explanation for the relatively dilute nature of water from this well compared with other water in the Acoma embayment area is unknown; however, the relatively small sulfate concentrations indicate that water from this well has not come in contact with or dissolved as much gypsum as water from many of the other wells in the Acoma embayment area.

In water from wel1s 5N.4W.5.142, 7N.4W.25.111, 6N.5W.26.132, and 4 N.6W.27.4314 calcium is the dominant cation and sulfate is the dominant anion (fig. 29). The specific conductance and concentration of dissolved ions in water from these wells are mich smaller than in water from wells $8 \mathrm{~N} .3 \mathrm{~W} .15 .324$ and 9 N.5W.12.442, which are approximately the same distance from the outcrop or recharge area of the San Andres-Glorieta aquifer on the eastern side of the Zuni uplift.

The chemistry of water from we11s 5N.4W.5.142, 7N.4W.25.111, and $6 \mathrm{~N} .5 \mathrm{~W} .26 .132$ indicates that this water flows westward (fig. 18) and is recharged along the outcrop area of the San Andres-Glorieta aquifer on the south and east sides of the Acoma embayment area (fig. 28). Water from well 5 N.4W.5.142, which is on the outcrop area of the aquifer, has the smallest specific conductance and chloride concentration of these three wells (fig. 28). Water from this well probably is representative of recharge water to the San Andres-Glorieta aquifer along the east side of the Acoma embayment area. The San Andres-Glorieta aquifer contains a large quantity of gypsum in the southeastern part of the Acoma embayment area, thus water recharging the aquifer would come in contact with and probably dissolve gypsum. The dissolution of gypsum probably is the reason for the large dissolved-sulfate concentrations in water from the three wells, which are relatively close to the outcrop or recharge area. Chloride concentrations of $140 \mathrm{mg} / \mathrm{L}$ in water from wells 7 N.4W.25.111 and 6 N.5W.26.132 probably indicate that this water has dissolved halite. The San Andres-Glorieta aquifer probably contains relatively more halite in this area of the Acoma embayment because the large thickness of gypsum in the aquifer in this area was deposited in a constricted evaporite basin and halite probably was deposited in conjunction with the gypsum.

If recharge does occur on the eastern side of the Acoma embayment area and this water flows westward, there must be a mechanism for discharge of this water from the San Andres-Glorieta aquifer and for recharge water along the eastern side of the Zuni uplift that flows eastward. The mechanism for and location of the discharge are not known, although by using available geologic and water-chemistry data from other aquifers, some possible mechanisms for discharge can be conjectured. Jicha (1958, p. 53) mapped and discussed a large travertine deposit of late Tertiary or Pleistocene age in $\mathrm{T}$. $6 \mathrm{~N}$., R. $5 \mathrm{~W}$. and T. $5 \mathrm{~N}$., R. $5 \mathrm{~W}$. This deposit is as much as 150 feet thick and in excess of 100 million tons. The travertine, composed of approximately 97.5 percent calcium carbonate (Jicha, 1958, p. 53), probably was deposited by water from springs discharging in the area, which presently are not active. It is possible that these springs were discharging from the San AndresGlorieta aquifer. Water in the San Andres-Glorieta aquifer west of this area presently contains relatively large bicarbonate concentrations and effervesces carbon dioxide. This water generally is supersaturated with respect to 
calcite (calcium carbonate) at the partial pressure of carbon dioxide at land surface. Presently (1988), water levels in wells completed in the San AndresGlorieta aquifer near the travertine deposits are approximately 300 feet below the deposits (land surface). Potentiometric levels in the San Andres-Glorieta aquifer may have been higher in the past for several reasons. The outcrop areas along the east and west sides of the Acoma embayment area probably were at a higher altitude (erosion has since lowered the outcrop areas). Precipitation and thus recharge also probably were greater in the past (during the Pleistocene), which could cause higher potentiometric levels in the San Andres-Glorieta aquifer. If the potentiometric surface in the San AndresGlorieta aquifer was above land surface near these spring deposits in the late Tertiary or Pleistocene and the composition of water in the aquifer was similar to the present composition west of the travertine deposits, the large travertine deposit could have been deposited by ground-water discharge from the aquifer moving upward along faults or dikes.

Discharge from the San Andres-Glorieta aquifer currently may be leaking downward into older Permian and Pennsylvanian rocks. Saline springs (specific conductance of water greater than 20,000 microsiemens) issue from rock units of varying ages (table 9) along the eastern margin of the Lucero uplift. Many of these springs are near the fault zone that separates the Cretaceous and older rocks of the Acoma embayment from the Quaternary and Tertiary deposits of the Rio Grande rift. The chemical similarity of water from these saline springs indicates that the water from these springs is derived from the same aquifer (Titus, 1963, p. 46). The fact that some of these springs discharge from Pennsylvanian rocks could indicate that they are derived from the Pennsylvanian rocks (Titus, 1963, p. 46). Many of the springs discharge from rocks younger than Pennsylvanian age at the surface, but the actual source of the water could be the Pennsylvanian rocks from which the water moves upward along fault zones to discharge from younger strata at land surface (Titus, 1963, p. 46). The altitude of these springs generally is lower than the present altitude of the potentiometric surface of the aquifer. The source of saline water in the Pennsylvanian rocks is unknown because these rocks do not crop out in the Zuni uplift or anywhere close to the discharge area, thus there is no obvious recharge area for the flow system in these rocks. Water from the San Andres-Glorieta aquifer may be leaking downward into Lower Permian and Pennsylvanian rocks along faults and dikes in the area west of the outcrop of the aquifer in the Lucero uplift. Jicha (1958, p1. 1) showed a large number of dikes and sills in the area and indicated that, on the basis of drill-hole data and structures observed in the outcrop of the Chinle Formation, these dikes and sills may be quite extensive in the subsurface. Water could flow eastward in the Lower Permian and Pennsylvanian rocks and discharge east of the outcrop area of the San Andres-Glorieta aquifer after leaking downward along dikes (fig. 30). 


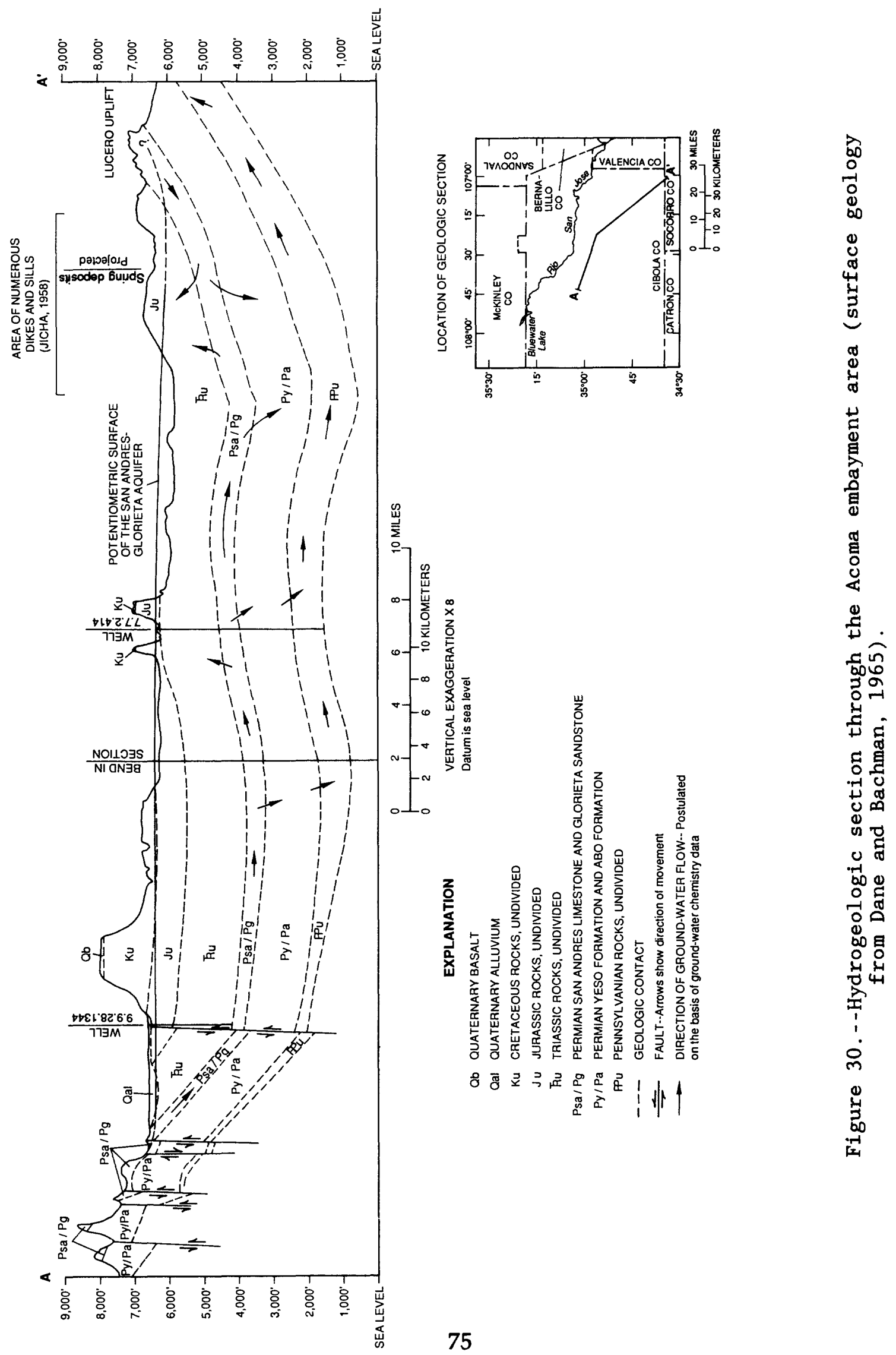


The location of the saline springs along the eastern side of the Lucero uplift seems to be controlled by faults and emergence altitude. A few saline springs are present in T. $4 \mathrm{~N}$. and $T$. $5 \mathrm{~N}$. but most of the known springs are in T. $7 \mathrm{~N}$ and T. $8 \mathrm{~N}$. (fig. 31). The springs in T. $4 \mathrm{~N}$. and T. $5 \mathrm{~N}$. generally are in the bottom of arroyo channels close to a large, structurally complex fault zone. In T. $5 \mathrm{~N}$., this fault zone juxtaposes Pennsylvanian rocks (permeable rocks) with Precambrian rocks (impermeable rocks) in the subsurface (Callender and Zilinski, 1976), and the saline springs may be the result of the large contrast in the permeability of the Pennsylvanian and Precambrian rocks. In areas where the Pennsylvanian rocks are juxtaposed with rocks of similar permeability, springs would not be expected to exist.

The saline springs in T. $7 \mathrm{~N}$. and T. $8 \mathrm{~N}$. also are along a fault zone, and travertine is found in the area (Kelley and Wood, 1946). The emergence altitude of these springs generally is 300 to 700 feet lower than the springs in $T .4 \mathrm{~N}$. and $\mathrm{T} .5 \mathrm{~N}$. The springs in this area also may be the result of a permeability contrast similar to the proposed mechanism of the springs in T. $4 \mathrm{~N}$. and T. $5 \mathrm{~N}$. The geometry of the fault in this area is not known, but because of the complex nature of the fault zone, the Pennsylvanian and Permian rocks possibly are juxtaposed with less permeable rocks. If a permeability contrast is the cause of the saline springs along the eastern side of the Acoma embayment area, not all of the ground water flowing eastward in the Permian and Pennsylvanian rocks would be forced to the surface as spring flow. Some of the water would continue to flow eastward to discharge into the basinfill aquifer in the Albuquerque-Belen Basin.

The chemical composition of ground water varies in the eastern Acoma embayment area where chloride concentrations range from 6 to $27,000 \mathrm{mg} / \mathrm{L}$ (fig. 31). Water from the San Andres-Glorieta aquifer south of T. $8 \mathrm{~N}$. has chloride concentrations less than $150 \mathrm{mg} / \mathrm{L}$, whereas water from the aquifer in T. $8 \mathrm{~N}$. and T. $9 \mathrm{~N}$. has chloride concentrations greater than $2,000 \mathrm{mg} / \mathrm{L}$ (fig. 31).

Water from two large springs, Suwanee Spring (8N.3W.10.222) and Dipping Vat Spring, has chloride concentrations of 340 and $380 \mathrm{mg} / \mathrm{L}$, respectively. By contrast, chloride concentrations are greater than $2,000 \mathrm{mg} / \mathrm{L}$ in water from the San Andres-Glorieta aquifer in this area. The large difference in chloride concentration in this water and in water from the two springs indicates that the source of water in Suwanee and Dipping Vat Springs is not the San Andres-Glorieta aquifer. 


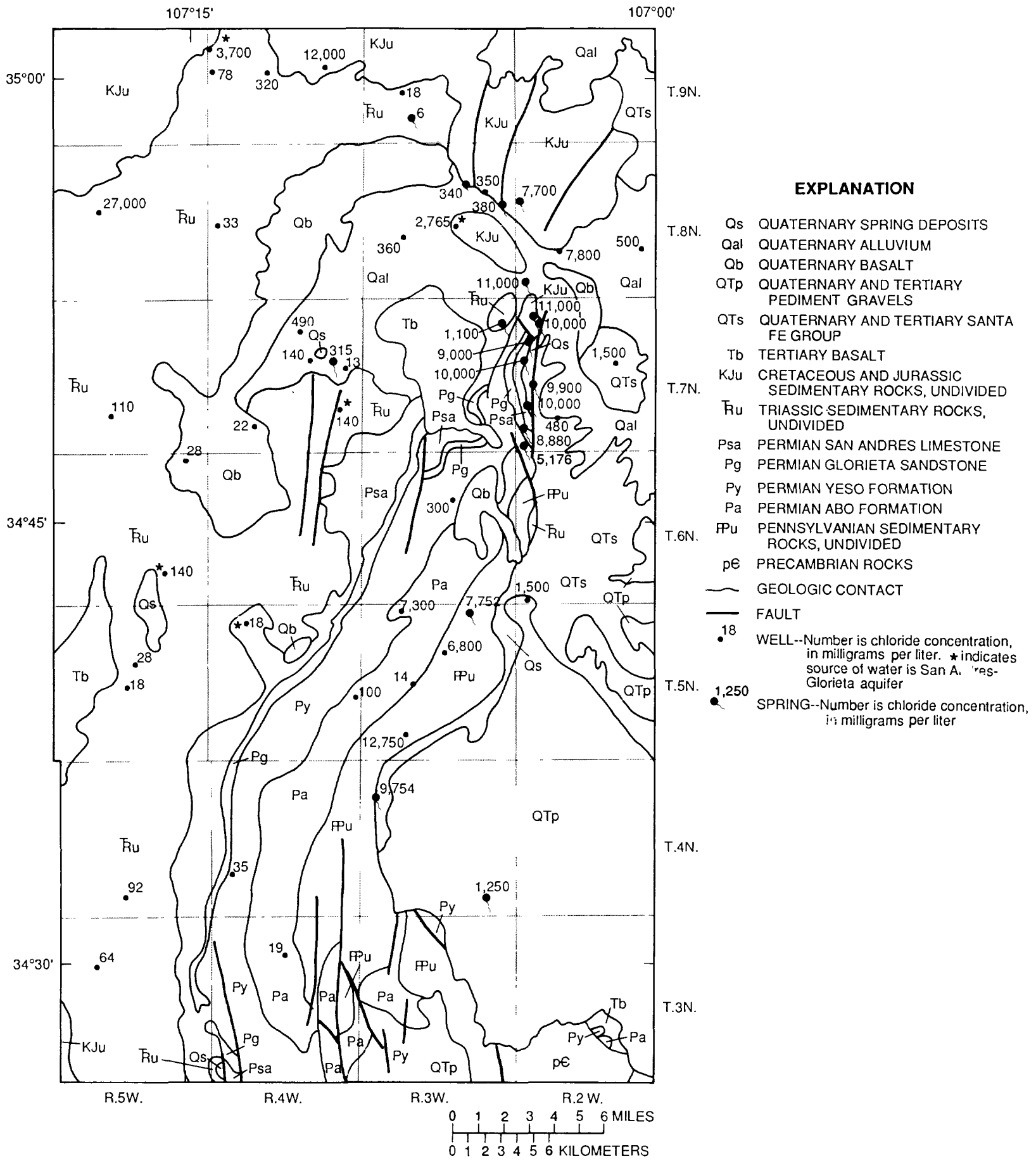

Figure 31.--Generalized geologic map and dissolved-chloride concentration in water from selected wells and springs in the eastern part of the Acoma embayment area (geology from Dane and Bachman, 1965). 
Specific conductance of water from the saline springs generally is greater than 20,000 microsiemens, and chloride concentration generally is greater than $6,000 \mathrm{mg} / \mathrm{L}$ (table 9 and $\mathrm{fig} .31$ ). Sodium and chloride are the dominant dissolved ions in water from these springs (fig. 32). The bicarbonate concentration in water from these springs is relatively large, greater than $1,500 \mathrm{mg} / \mathrm{L}$ ( table 8 ), and the water presently deposits travertine. Water discharging from these springs has a larger specific conductance and concentration of dissolved ions than water in the San AndresGlorieta aquifer, although the proportion of cations and anions is similar to water from wells 8 N.3W.15.324 and 9N.5W.12.442 (figs. 29 and 32). The larger specific conductance in water from the springs discharging from the older rocks east of the outcrop of the San Andres-Glorieta aquifer probably is due to water leaking downward from the aquifer into the older rocks west of the outcrop area of the aquifer; the water in the older rocks then dissolves aquifer material as it moves eastward. The large variation in the mineralogy of saline water from the springs (table 9) may be the result of mixing of saline water with water containing less dissolved ions and of variations in the composition of the aquifer with which the water has come into contact. At the present time (1988), data are not sufficient to do more than postulate discharge mechanisms and areas of discharge for the San Andres-Glorieta aquifer. Collection of more hydrologic and water-chemistry data would be useful for a better understanding of the flow system of the San AndresGlorieta aquifer and the source of water discharging from the saline springs.

\section{Horace Springs}

The source of ground water that discharges into the Rio San Jose from Horace Springs (10N.9W.23.423) is not known; however, the available waterchemistry data can be used to evaluate several possible sources. A comparison of the water chemistry from Horace Springs and from well 10N.9W.25.3241, which is completed in the San Andres-Glorieta aquifer and is about 1 mile from Horace Springs, shows that water from the well contains significantly larger concentrations of dissolved ions than water from Horace Springs (table 8). The chloride concentration in water from the well is $1,300 \mathrm{mg} / \mathrm{L}$, whereas the chloride concentration in water from Horace Springs is only $120 \mathrm{mg} / \mathrm{L}$ (1986 analysis; table 8). A comparison of the water chemistry from Horace Springs (1957 analysis) and from 0jo del Gallo (10N.10W.3.423, 1946 analysis), which discharges water from the San Andres-Glorieta aquifer and is about 8 miles upgradient from Horace Springs, indicates slight differences in composition. 


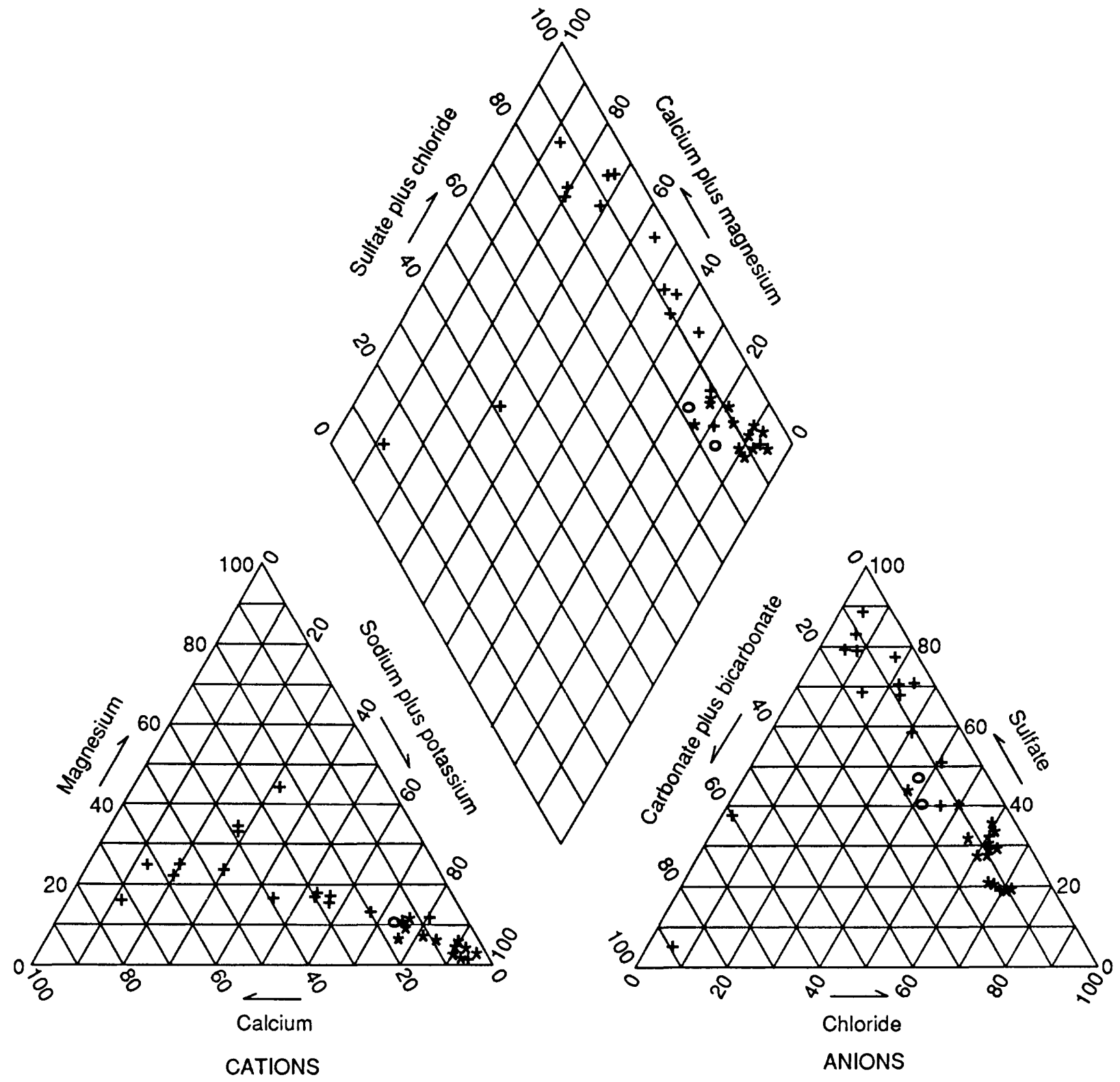

PERCENTAGE OF TOTAL IONS, IN MILLIEQUIVALENTS PER LITER EXPLANATION

* SALINE SPRINGS

- WATER FROM WELLS

8N.3W.15.324 AND

9N.5W.12.442

+ WATER FROM OTHER

WELLS AND SPRINGS

IN THE AREA

Figure 32.--Piper diagram of selected chemical analyses of water from wells and springs in the eastern part of the Acoma embayment area. 
Calcium and bicarbonate concentrations are $3 i$ and $80 \mathrm{mg} / \mathrm{L}$ larger in water from Ojo del Gallo than in water from Horace Springs. Sodium plus potassium, sulfate, and chloride concentrations are $55 \mathrm{mg} / \mathrm{L}, 20 \mathrm{mg} / \mathrm{L}$, and $44 \mathrm{mg} / \mathrm{L} 1$ arger in water from Horace Springs than in water from ojo del Gallo. The source of water discharging from Horace Springs probably is not the San Andres-Glorieta aquifer because water would have to move about 8 miles through the aquifer from the 0 jo del Gallo area to the Horace springs area and then move vertically through approximately 1,600 feet of Chinle Formation and approximately 1,000 feet of Jurassic and Cretaceous rocks (figs. 9 and 10) with little change in water chemistry. Large chemical gradients also would be needed in the San Andres-Glorieta aquifer between the Horace Springs area and well 10N.9W.25.3241 to explain the source of water discharging from Horace Springs as the San Andres-Glorieta aquifer. The relatively large concentrations of dissolved ions in water from well 10N.9W.25.3241 probably are more representative of water from the San Andres-Glorieta aquifer in the Horace Springs area than water from 0 jo del Gallo; thus the 1 arge difference in the concentration of dissolved ions in water from well 10N.9W.25.3241, which is completed in the San Andres-Glorieta aquifer, and water from Horace Springs seems to indicate that the source of water discharging from Horace Springs is not the San Andres-Glorieta aquifer.

If the source of water discharging from Horace Springs is not the San Andres-Glorieta aquifer, the water must be coming from another aquifer. Comparison of the concentration of selected dissolved ions in water from wells completed in aquifers in Jurassic rocks near Horace springs indicates that water from Horace Springs has larger concentrations of dissolved ions than water from aquifers in Jurassic rocks. Water from well 10N.9W.25.324, which is completed in the Dakota Sandstone, however, has larger sulfate concentrations than water from Horace Springs (fig. 33). Water from well $10 \mathrm{~N} .8 \mathrm{~W} .32 .312$, which is completed in the Mancos shale, has much smaller concentrations of chloride than water from Horace Springs (fig. 33).

The concentration of dissolved ions in water from alluvium and basalt aquifers in the vicinity of Horace springs varies considerably (fig. 33 ). Water from spring 10N.9W.6.442 and well 10N.9W.17.113 has sodium, sulfate, and chloride concentrations greater than those in water from Horace Springs (fig. 33). Water from well 10N.9W.29.132, however, has sodium, sulfate, and chloride concentrations less than those in water from Horace springs (fig. 33). Water in the alluvium and basalt aquifers in The Malpais Valley area flows northward and eastward (fig. 33); water in the alluvium and basalt aquifers along the Rio San Jose valley generally flows eastward (fig. 33). These ground waters in the alluvium and basalt aquifers converge in the vicinity of Horace springs (fig. 33) because of a reduction in the extent of the aquifers. Therefore, the water from Horace Springs may be a mixture of water from spring $10 \mathrm{~N} .9 \mathrm{~W} .6 .442$ and wells $10 \mathrm{~N} .9 \mathrm{~W} .17 .113$ and 10N.9W.29.132. 


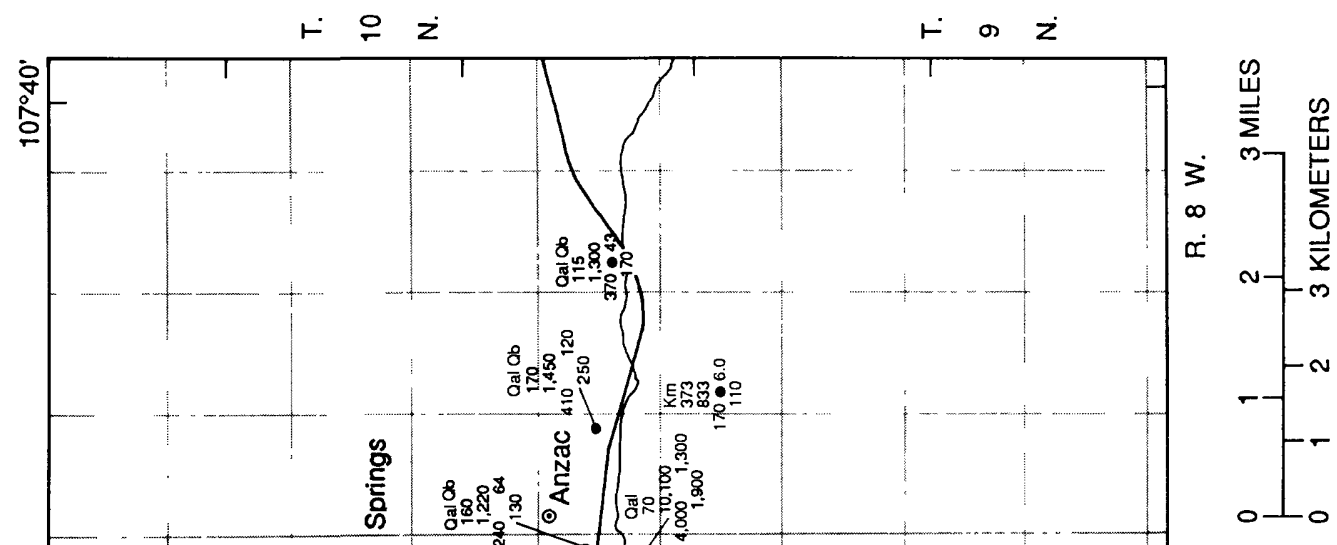

0
0
.
.7
0
0
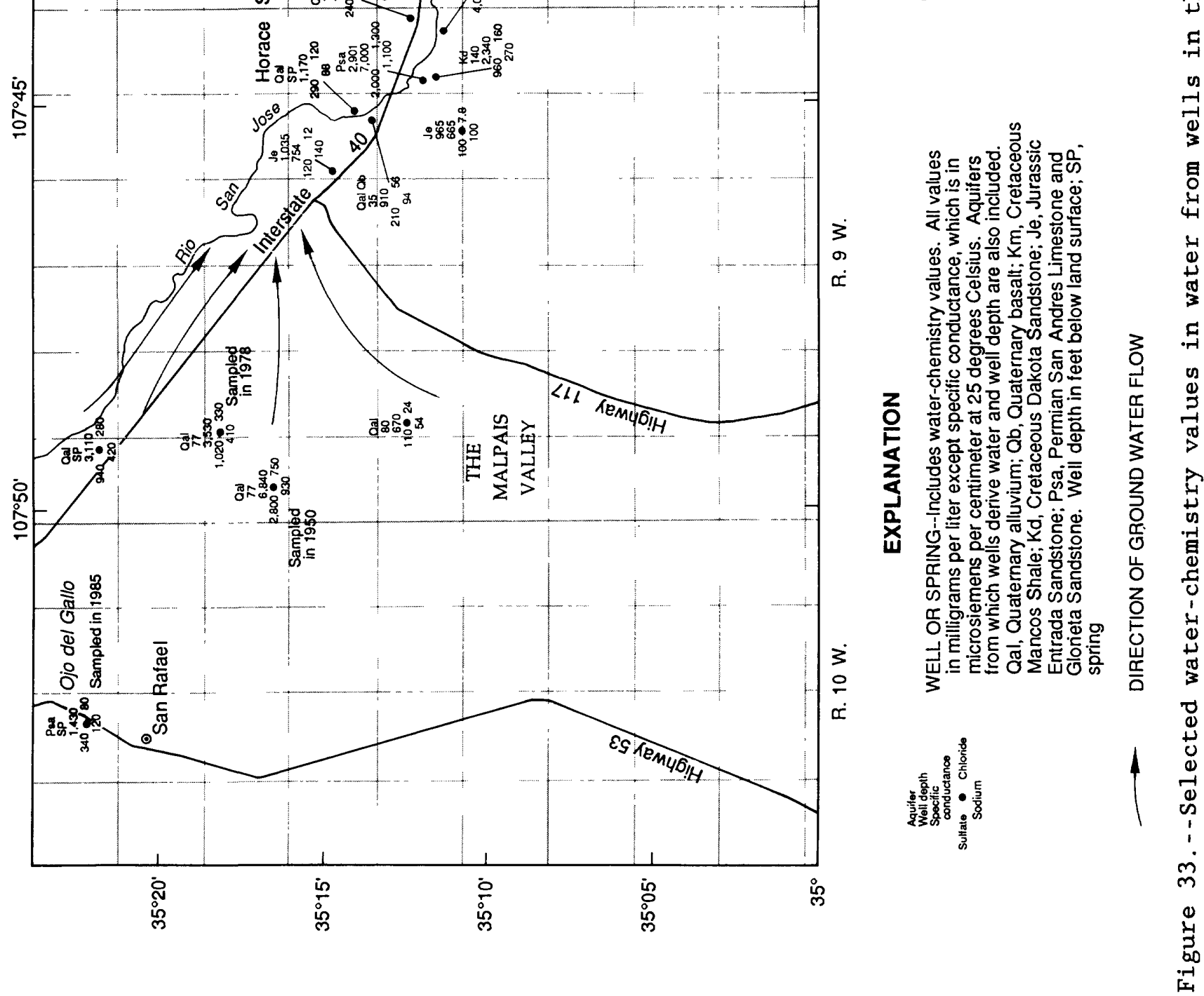
A comparison of two chemical analyses of water from wel1 10N.9W.17.113 collected in 1950 and 1978 indicates a general decrease in the concentration of dissolved ions (table 9 and fig. 33). Chloride concentrations decreased from $750 \mathrm{mg} / \mathrm{L}$ in 1950 to $330 \mathrm{mg} / \mathrm{L}$ in 1978. The ratio of sodium to chloride is approximately the same in the two analyses, which may indicate that the difference in the chemical composition of water from the well may be the result of differences in the amount of evapotranspiration occurring in the vicinity of the well. Prior to the cessation of flow of 0 jo del Gallo in the early $1950^{\prime} \mathrm{s}$, water levels in the area of well 10N.9W.17.113 probably were close to land surface because part of the water from 0 jo del Gallo flowed near this well, infiltrated, and recharged the alluvial aquifer. After 0 jo del Gallo ceased to flow, water levels probably decreased in this area because of the reduced amount of recharge. The amount of evapotranspiration and thus concentration of dissolved ions in water probably were greatest prior to the cessation of flow of 0 jo del Gallo because the water levels were closer to land surface.

The chloride concentration of water from Horace Springs generally has increased since 1962 (fig. 34). This change in chloride concentration also is evident in water in the Rio San Jose just downstream from Horace Springs at the gaging station Rio San Jose near Grants (fig. 34). During periods of low flow in the Rio San Jose, most water downstream from Horace Springs is the result of flow from Horace springs (Risser, 1982, p. 29). Risser (1982, p. 31) indicated that wastewater from the city of Grants began to reach Horace Springs intermittently in 1957; however, the quantity of this water was not large enough to result in measurable differences in streamflow at the gaging station until the $1970^{\prime} \mathrm{s}$. Risser (1982, p. 31) estimated the flow of Horace Springs to be approximately 5 cubic feet per second and the increase in streamflow at the Rio San Jose near Grants gaging station due to wastewater from Grants to be approximately 1 cubic foot per second in the 1970's. The reason for the change in the chemical composition of water from Horace Springs is not known but may be related to the change in the flow and chemical composition of 0 jo del Gallo, the change in chemical composition of water from well 10N.9W.17.113, or the flow of Grants wastewater.

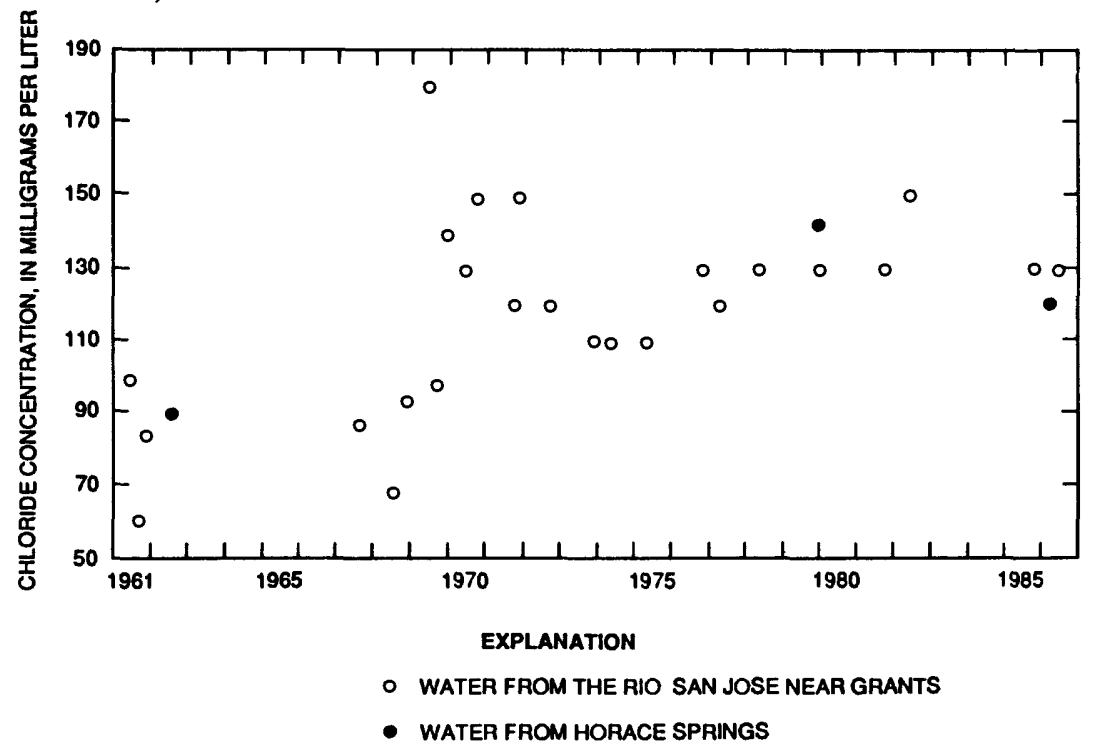

Figure 34.--Concentration of chloride in water from Horace Springs and the Rio San Jose near Grants, 1961-86. 


\section{SUMMARY}

The San Andres Limestone and the underlying Glorieta Sandstone of Permian age comprise the San Andres-Glorieta aquifer in west-central New Mexico. The San Andres Limestone is composed mainly of limestone with some sandstone and is unconformably overlain by the Chinle Formation. The erosional period represented by the unconformity lasted from Early Permian to Middle Triassic time, and in the area of the Zuni uplift cavernous zones developed. The Glorieta Sandstone conformably overlies the Yeso Formation and is composed of wel1-sorted, well-cemented, fine- to medium-grained sandstone. In the Lucero uplift area, the San Andres Limestone contains gypsum and anhydrite, and the Glorieta Sandstone is thin or absent.

Most water in the San Andres-Glorieta aquifer is transmitted in solution channels, cavernous zones, and fractures in the San Andres Limestone. These solution channels, cavernous zones, and fractures are believed to be best developed near the Zuni uplift, where the San Andres Limestone was subjected to weathering, solution activity, and fracturing during periods of uplift and erosion. Seven transmissivity zones, delineated on the basis of aquifer-test results and the lithology of the aquifer, were identified in the study area. Transmissivity of the zones ranges from 10 to 50,000 feet squared per day. Zones having values of transmissivity of 50,000 feet squared per day are in the Grants area and in an area east and south of the Zuni uplift. Cavernous zones, faults, and fractures are common in many of these areas. We11 yields of as much as 2,830 gallons per minute have been measured. The transmissivity of a zone near Bluewater Lake and Thoreau is 140 feet squared per day. The zone with the smallest transmissivity ( 10 feet squared per day) is at the eastern margin of the study area. In this area, the aquifer contains less limestone and more gypsum and anhydrite than in other parts of the study area.

Recharge to the San Andres-Glorieta aquifer occurs on outcrops along the Zuni uplift by infiltration of precipitation and by infiltration of surface flow. The quantity of recharge is related to the areal extent of outcrops of the aquifer. Along the eastern side of the Zuni uplift, the outcrop area of the San Andres-Glorieta aquifer is narrow and the amount of recharge probably is small, whereas along the northern side of the Zuni uplift, the outcrop area is extensive and the amount of recharge to the aquifer is larger. Some recharge to the San Andres-Glorieta aquifer also occurs south of the Zuni uplift where the aquifer subcrops in The Malpais Valley.

Another source of recharge to the San Andres-Glorieta aquifer is leakage of water from Bluewater Lake and Bluewater Creek. Surface water and ground water used for irrigation also may infiltrate and recharge the aquifer in the Grants-Bluewater area.

Ground-water movement in the San Andres-Glorieta aquifer generally is outward from the Zuni uplift (recharge area). In the northwestern part of the study area, ground water moves to the northeast, but the direction of movement changes to the east at distance from the Zuni uplift. Ground water moves to the east away from the Zuni uplift and toward the Rio Grande rift in the eastern part of the study area; however, in the Lucero uplift area there is some recharge to the San Andres-Glorieta aquifer. The ground water near this localized recharge area moves to the west. 
Discharge of water from the San Andres-Glorieta aquifer occurs by spring discharge, withdrawal from wells, underflow out of the study area, and leakage to adjacent rocks. Prior to development of ground-water resources in the Grants area, 0jo del Gallo probably was a major discharge point in the part of the aquifer northwest of Grants. The earliest recorded discharge of the spring, measured in August and November 1937, was 7 cubic feet per second. Discharge did not occur at Ojo del Gallo from 1953 to 1982. The decrease in discharge at 0 jo del Gallo probably was due to ground-water withdrawal in the Grants-Bluewater area. In February 1983, discharge from 0jo del Gallo was 0.03 cubic foot per second, which increased to 1.72 cubic feet per second by February 1986. Concentrations of dissolved constituents in ground water discharging from Ojo del Gallo also increased between 1946 and 1984 .

Discharge from the San Andres-Glorieta aquifer at Horace Springs has been postulated. However, evaluation of hydrologic, geologic, and water-chemistry data seems to indicate that water discharging from Horace Springs is derived from the alluvial aquifer.

Discharge of water from the San Andres-Glorieta aquifer in the GrantsBluewater area increased substantially in the mid-1940's when irrigation wells began to withdraw water for irrigation. In 1955, 85 percent of the 13,600 acre-feet of water withdrawn from the aquifer was used for irrigation. However, the discovery of uranium ore north of Grants in 1955, a population increase in the Grants-Bluewater area, and a decline in the amount of land irrigated by ground water led to major changes in ground-water use and the location of ground-water withdrawals after 1955. Ground-water withdrawals peaked in 1956 when 14,210 acre-feet was pumped from the aquifer. Industrial use accounted for 32 percent and irrigation accounted for 65 percent of the withdrawals. By 1982, ground-water pumpage had decreased to 3,900 acre-feet. The large amount of ground-water pumpage and the change in location of pumpage with time probably resulted in changes in the direction of ground-water movement in the aquifer. Water-chemistry data indicate that changes in ground-water chemistry also occurred during this time. The mechanism for discharge of ground water from the San Andres-Glorieta aquifer east of the Zuni uplift is not known, but several possibilities exist. Underflow of ground water into the Rio Grande rift sediments is one possibility; however, in the area north of the Lucero uplift where this underflow possibly could occur, the San Andres-Glorieta aquifer is probably in fault contact with finegrained sediments and the amount of leakage into these sediments is thought to be very small. Another possibility is discharge from Pennsylvanian rocks east of the San Andres-Glorieta aquifer in the Lucero uplift area. The source of this water may be downward leakage from the San Andres-Glorieta aquifer through the Yeso and Abo Formations. No obvious recharge areas for the Pennsylvanian rocks are known so the source of water discharging from these rocks may be leakage (discharge) from the San Andres-Glorieta aquifer along faults and dikes in the Acoma embayment area. Water-chemistry data indicate that the relative proportions of dissolved constituents are similar between ground water in the San Andres-Glorieta aquifer near the Lucero uplift area and ground water discharging from the Pennsylvanian rocks in this same area. However, the concentration of dissolved constituents in ground water in the San Andres-Glorieta aquifer is smaller than in water discharging from the Pennsylvanian rocks. 
Specific conductance of ground water derived from the San Andres-Glorieta aquifer in the Thoreau area ranges from 470 to 1,390 microsiemens per centimeter at 25 degrees Celsius. Calcium and magnesium are the dominant cations and bicarbonate and sulfate are the dominant anions in ground water in this area. Ground-water chemistry in the Grants-Bluewater area is variable, although, in general, calcium is the dominant cation and bicarbonate and sulfate are the dominant anions. Changes in the concentrations of dissolved sulfate, chloride, and nitrate have occurred in ground water in the GrantsBluewater area. These changes probably are, in part, due to human activities. Ground water in the Acoma embayment area increases in specific conductance from west to east from approximately 1,000 to greater than 14,000 microsiemens. Calcium is the dominant cation and bicarbonate and sulfate are the dominant anions in ground water near the recharge area on the western side of the Acoma embayment area. As ground water moves eastward in the Acoma embayment area, dissolved-sodium, sulfate, and chloride concentrations increase significantly. On the basis of ground-water chemistry, some ground water recharges the San Andres-Glorieta aquifer in the Lucero uplift area along the southeastern margin of the Acoma embayment. 


\section{SELECTED REFERENCES}

Aqua Science, Inc., 1982, Study of the Rio San Jose basin above the Acoma Indian Reservation: Consultant's report to the Pueblo of Acoma, March $1982,370 \mathrm{p}$.

Baars, D.L., 1962, Permian system of Colorado Plateaus: American Association of Petroleum Geologists Bulletin, v. 46, no. 2, p. 149-218.

Baars, D.L., and Stevenson, G.M., 1977, Permian rocks of the San Juan Basin, in Guidebook of San Juan Basin III, northwestern New Mexico: New Mexico Geological Society, 28th Field Conference, p. 133-138.

Billings and Associates, Inc., and S.S. Papadopulos \& Associates, Inc., no date, Hydrogeologic investigation to evaluate the effects of Plains' applications, file numbers B-72 and B-72-S into 1605 and $B-17$ et al Comb.; B-43-H into 1605 and B-17 et al Comb.; B-43-F and B-43-I into 1605 and B-17 et al Comb.; B-87-C into 1605 and B-17 et al Comb.; B-87-D into 1605 and $B-17$ et al Comb.: Consultants' report to Plains Electric Generation and Transmission Cooperative, Inc., 38 p., 6 pls.

Callender, J.F., and Zilinski, R.E., Jr., 1976, Kinematics of Tertiary and Quaternary deformation along the eastern edge of the Lucero Uplift, central New Mexico: New Mexico Geological Society Special Publication 6, p. 53-61.

Cooper, J.B., and John, E.C., 1968, Geology and ground-water occurrence in southeastern McKinley County, New Mexico: New Mexico State Engineer Technical Report 35, 108 p.

Crumpler, L.S., 1982, Volcanism in the Mount Taylor region, in Albuquerque Country II: New Mexico Geological Society, 33d Field Conference, p. 291-298.

Dames and Moore, 1981, Volume VIII--Pumping test evaluations, Bluewater Uranium Mill vicinity near Grants, New Mexico, for Anaconda Copper Company: Consultant's report to Anaconda Copper Company, October 15, $1981,7 \mathrm{p}$.

1986, Ground water model, above-grade tailings impoundment, Bluewater Mil1 and vicinity near Grants, New Mexico, for Anaconda Minerals Company: Consultant's report to Anaconda Copper Company, job 4010-091-06, 26 p., 99 pls., 2 appendices.

Dane, C.H., and Bachman, G.0., 1965, Geologic map of New Mexico: U.S. Geological Survey, scale 1:500,000, 2 sheets.

Davies, P.B., 1987, Modeling areal, variable-density, ground-water flow using equivalent freshwater head--Analysis of potentially significant errors: NWWA Conference on Solving Ground Water Problems with Models, February 10-12, 1987, Denver, Colo., Proceedings, v. 2, p. 888-903. 


\section{SELECTED REFERENCES--Continued}

Fitzsimmons, J.P., 1959, The structure and geomorphology of west-central New Mexico, in Guidebook of west-central New Mexico: New Mexico Geological Society, 10th Field Conference, p. 112-116.

Foster, R.W., 1957, Stratigraphy of west-central New Mexico, in Geology of southwestern San Juan Basin: Four Corners Geological Society, Second Field Conference, p. 62-72.

Freeze, R.A., and Cherry, J.A., 1979, Groundwater: Englewood Cliffs, N.J., Prentice-Hall, 604 p.

Frenzel, P.F., 1992, Simulation of ground-water flow in the San AndresGlorieta aquifer in the Acoma embayment and eastern Zuni uplift, westcentral New Mexico: U.S. Geological Survey Water-Resources Investigations Report 91-4099, $381 \mathrm{p}$.

Frenze1, P.F., and Lyford, F.P., 1982, Estimates of vertical hydraulic conductivity and regional ground-water flow rates in rocks of Jurassic and Cretaceous age, San Juan Basin, New Mexico and Colorado: U.S. Geological Survey Water-Resources Investigations Report 82-4015, 59 p.

Geohydrology Associates, Inc., 1981, In the matter of the plan of replacement of Plains Electric Generation and Transmission Cooperative, Inc.: Consultant's report to Plains Electric Generation and Transmission Cooperative, Inc., Albuquerque, N. Mex., September, 1981, 81 p.

1983, In the matter of items relating to the declaration of water rights for land owned by Mr. Henry Andrews, Jr.: Consultant's report to Mr. Henry Andrews, June 1983, Albuquerque, N. Mex., 6 p.

1984, Summary of well and aquifer performance test of Plains wel1s B-18 and B-19, Yager and McBride wells, near Grants, New Mexico: Consultant's report to Plains Electric Generation and Transmission Cooperative, Inc., Albuquerque, N. Mex., August 1984, 47 p.

Goff, F.E., McCormick, T., Gardner, J.N., Trujillo, P.E., Counce, D., Vidale, Rosemary, and Charles, R.W., 1983, Water geochemistry of the Lucero uplift, New Mexico--A geothermal investigation of 1 ow-temperature mineralized fluids: Los Alamos National Laboratories Report LA-9738-OBES, Apri1 1983, 26 p.

Gordon, E.D., 1961, Geology and ground-water resources of the Grants-Bluewater area, Valencia County, New Mexico, with a section on Aquifer characteristics, by N.L. Reeder, and a section on Chemical quality of the ground water, by J.L. Kunkler: New Mexico State Engineer Technical Report 20, 109 p.

Green, M.W., and Pierson, C.T., 1971, Geologic map of the Thoreau NE quadrangle, McKinley County, New Mexico: U.S. Geological Survey Geologic Quadrangle Map GQ-954, scale 1:24,000. 


\section{SELECTED REFERENCES--Continued}

Guilinger, D.R., 1982, Geology and uranium potential of the Tejona MesaHubbell Draw area, Catron County, New Mexico: Socorro, New Mexico Bureau of Mines and Mineral Resources Open-File Report 176, 129 p.

Heath, R.C., 1983, Basic ground-water hydrology: U.S. Geological Survey Water-Supply Paper 2220, 84 p.

Hodges, P.V., 1938, Report on irrigation and water supply of the pueblos of New Mexico in the Rio Grande basin: U.S. Department of the Interior, Indian Irrigation Service, 438 p.

Hydro-Search, Inc., 1977, Hydrogeology of the Bluewater Mill tailings pond area, Valencia County, New Mexico: Consultant's report to Anaconda Copper Company, October 17, 1977, 111 p.

1978a, Supplement to the hydrogeology report of October 17, 1977 , Bluewater Mill area, Valencia County, New Mexico: Consultant's report to Anaconda Copper Company, November 15, 1978, 69 p.

1978b, Ground-water monitoring program, Bluewater Mill area, Valencia County, New Mexico: Consultant's report to Anaconda Copper Company, November $15,1978,25 \mathrm{p}$.

1981, Regional ground-water hydrology and water chemistry, GrantsBluewater area, Valencia County, New Mexico: Consultant's report to Anaconda Copper Company, May 15, 1981, 85 p., 9 pls., 6 appendices, 2 v.

Jacob, C.E., 1956, Preliminary report on mine drainage and groundwater supply in Ambrosia Lake area, McKinley County, New Mexico: Consultant's report to Kermac Nuclear Fuels Corporation, Grants, N. Mex., October 1957 , 24 p., 10 appendices.

Jicha, H.L., 1958, Geology and mineral resources of Mesa del Oro quadrangle, Socorro and Valencia Counties, New Mexico: Socorro, New Mexico Bureau of Mines and Mineral Resources Bulletin 56, 67 p.

Kelley, V.C., and Clinton, N.J., 1960, Fracture systems and tectonic elements of the Colorado Plateaus: Albuquerque, University of New Mexico Press, Publications in Geology, no. 6, 104 p.

Kelley, V.C., and Wood, G.H., 1946, Geology of the Lucero uplift, Valencia, Socorro, and Bernalillo Counties, New Mexico: U.S. Geological Survey Oil and Gas Inventory Preliminary Map 47, scale 1:63,360.

Kernodle, J.M., and Scott, W.B., 1986, Three-dimensional model simulation of steady-state ground-water flow in the Albuquerque-Belen Basin, New Mexico: U.S. Geological Survey Water-Resources Investigations Report 84-4353, $58 \mathrm{p}$.

Lohman, S.W., 1972, Ground-water hydraulics: U.S. Geological Survey Professional Paper 708, 80 p. 


\section{SELECTED REFERENCES--Continued}

Lyford, F.P., 1979, Ground water in the San Juan Basin, New Mexico and Colorado: U.S. Geological Survey Water-Resources Investigations 79-73, $22 \mathrm{p}$.

Lyford, F.P., Frenze1, P.F., and Stone, W.J., 1980, Preliminary estimates of effects of uranium-mine dewatering on water levels, San Juan Basin, in Geology and mineral technology of the Grants uranium region, 1979: Socorro, New Mexico Bureau of Mines and Mineral Resources Memoir 38 , p. $320-333$.

Maxwel1, C.H., 1976, Stratigraphy and structure of the Acoma region, New Mexico, in Woodward, L.A., and Northrop, S.A., eds., Tectonics and mineral resources of southwestern North America: New Mexico Geological Society Special Publication 6, p. 95-101.

1981, Geologic map of El Malpais Instant Study area and adjacent areas, Valencia County, New Mexico: U.S. Geological Survey Miscellaneous Field Studies Map MF-1375-A, scale 1:62,500.

McKee, E.D., 1933, The Coconino Sandstone--Its history and origin: Carnegie Institute of Washington Publication 440, p. 77-115.

Moench, R.H., and Schlee, J.S., 1967, Geology and uranium deposits of the Laguna District, New Mexico: U.S. Geological Survey Professional Paper 519,117 p.

Morgan, A.M., 1938, Ground-water conditions in a portion of the Rio San JoseBluewater valley in the vicinity of Grants, New Mexico: U.S. Geological Survey open-file report, $16 \mathrm{p}$.

Murray, C.R., 1945, Preliminary conclusions on ground-water conditions in the Bluewater area, Valencia County, New Mexico: U.S. Geological Survey Open-File Report, 4 p.

Orr, B.0., 1987, Water resources of the Zuni tribal lands, McKinley and Cibola Counties, New Mexico: U.S. Geological Survey Water-Supply Paper 2227, $76 \mathrm{p}$.

O'Sullivan, R.B., 1977, Triassic rocks in the San Juan Basin of New Mexico and adjacent areas, in Guidebook of San Juan Basin III, northwestern New Mexico: New Mexico Geological Society, 28 th Field Conference, p. $139-146$.

Piper, A.M., 1944, A graphic procedure in the geochemical interpretation of water analyses: American Geophysical Union Transactions, v. 25 , p. $914-923$.

Reiter, Marshal1, Edwards, C.L., Hartman, Harold, and Weidman, Charles, 1975, Terrestrial heat flow along the Rio Grande Rift, New Mexico and southern Colorado: Geological Society of America Bulletin, v. 86, p. 811-818. 


\section{SELECTED REFERENCES--Continued}

Risser, D.W., 1982, Estimated natural streamflow in the Rio San Jose upstream from the Pueblos of Acoma and Laguna, New Mexico: U.S. Geological Survey Water-Resources Investigations Report 82-4096, 51 p.

Risser, D.W., and Lyford, F.P., 1983, Water resources on the Pueblo of Laguna, west-central New Mexico: U.S. Geological Survey Water-Resources Investigations Report 83-4038, 308 p.

Shomaker, J.W., 1968, Site study for a water well, Fort Wingate Army Ordinance Depot, McKinley County, New Mexico: U.S. Geological Survey Open-File Report, $28 \mathrm{p}$.

1969, Drilling and testing of well 340, Fort Wingate Army Depot, McKinley County, New Mexico: U.S. Geological Survey Open-File Report, $57 \mathrm{p}$.

1971, Water resources of Fort Wingate Army Depot and adjacent areas, McKinley County, New Mexico: U.S. Geological Survey Open-File Report, $230 \mathrm{p}$.

Slack, P.B., and Campbe11, J.A., 1976, Structural geology of the Rio Puerco fault zone and its relationship to central New Mexico tectonics, in Woodward, L.A., and Northrop, S.A., eds., Tectonics and mineral resources of southwestern North America, 1976: New Mexico Geological Society Special Publication 6, p. 46-51.

Spiege1, Zane, 1955, Geology and ground-water resources of northeastern Socorro County, New Mexico: Socorro, New Mexico Bureau of Mines and Mineral Resources Ground-Water Report 4, 99 p.

Stone, W.J., Lyford, F.P., Frenzel, P.F., Mizel1, N.H., and Padgett, E.T., 1983, Hydrogeology and water resources of San Juan Basin, New Mexico: Socorro, New Mexico Bureau of Mines and Mineral Resources Hydrologic Report 6,69 p.

Thaden, R.E., and Ostling, E.J., 1967, Geologic map of the Bluewater quadrangle, Valencia and McKinley Counties, New Mexico: U.S. Geological Survey Geologic Quadrangle Map GQ-679, scale 1:24,000.

Thaden, R.E., Merrin, Seymour, and Raup, O.B., 1967a, Geologic map of the Grants SE quadrangle, Valencia County, New Mexico: U.S. Geological Survey Geologic Quadrangle Map GQ-682, scale 1:24,000.

Thaden, R.E., Santos, E.S., and Raup, O.B., 1967b, Geologic map of the Dos Lomas quadrangle, Valencia and McKinley Counties, New Mexico: U.S . Geological Survey Geologic Quadrangle Map GQ-680, scale 1:24,000.

1967c, Geologic map of the Grants quadrangle, Valencia County, New Mexico: U.S. Geological Survey Geologic Quadrangle Map GQ-681, scale $1: 24,000$. 


\section{SELECTED REFERENCES--Concluded}

Thaden, R.E., and Zech, R.S., 1984, Preliminary structure contour map on the base of the Cretaceous Dakota Sandstone in the San Juan Basin and vicinity, New Mexico, Arizona, Colorado, and Utah: U.S. Geological Survey Miscellaneous Field Studies Map MF-1673, scale 1:500,000.

Titus, F.B., Jr., 1963, Geology and ground-water conditions in eastern Valencia County, New Mexico: Socorro, New Mexico Bureau of Mines and Mineral Resources Ground-Water Report 7, 113 p.

Todd, D.K., 1959, Ground water hydrology: New York, John Wiley and Sons, $336 \mathrm{p}$.

Tonking, W.H., 1957, Geology of Puertocito quadrangle, Socorro County, New Mexico: Socorro, New Mexico Bureau of Mines and Mineral Resources Bulletin $41,67 \mathrm{p}$.

U.S. Bureau of Indian Affairs, 1984, Bluewater Basin--Withdrawals and sources of water: Bureau of Indian Affairs, Albuquerque, N. Mex., $36 \mathrm{p}$.

U.S. Department of Agriculture, 1972, Gross annual lake evaporation--New Mexico, in U.S. Bureau of Reclamation, 1976, New Mexico water resources assessment for planning purposes: U.S. Bureau of Reclamation Map 8.

U.S. Geological Survey, 1946-55, Water levels and artesian pressures in observation wells in the United States, Pt. 6, Southwestern States and Territory of Hawaii: Water-Supply Papers 1076, 1101, 1131, 1161, 1170, $1196,1226,1270,1326$, and 1409 .

Walton, W.C., 1970, Ground-water resource evaluation: New York, McGraw-Hill, 664 p.

Ward, J.J., Walters, G.R., Alweis, S.J., Axen, G.J., and Bentley, H.W., 1982, Effects of uranium mine dewatering on the resources of the Pueblo of Laguna, New Mexico: Consultant's report to Pueblo of Laguna, New Mexico.

West, S.A., 1972, Disposal of uranium-mill effluent by well injection in the Grants area, Valencia County, New Mexico: U.S. Geological Survey Professional Paper 386-D, 28 p.

Wolff, R.G., 1981, Porosity, permeability, distribution coefficients, and dispersivity, in Touloukian, Y.S., Judd, W.R., and Roy, R.F., 1981, Physical properties of rocks and minerals: New York, McGraw Hill/CINDAS, v. II-2, p. 45-81.

Woodward, L.A., and Callender, J.F., 1977, Tectonic framework of the San Juan Basin, in Guidebook of San Juan Basin III, northwestern New Mexico: New Mexico Geological Society, 28th Field Conference, p. 209-212.

Wright, H.E., Jr., 1946, Tertiary and Quaternary geology of the 1ower Rio Puerco area, New Mexico: Geological Society of America Bulletin, v. 57, no. 5, p. $383-456$. 
SUPPLEMENTAL INFORMATION 
This Supplemental Information section contains the results of aquifer tests conducted on hydrologic-test wells that were drilled in areas where little or no data were available when the study began. Different types of analyses were done depending on the data obtained during the test. When sufficient water-level-recovery data were available, the Jacob straight-line method and the recovery method (Lohman, 1972, p. 19-27) were used to calculate a transmissivity of the tested interval. A method of estimating transmissivity using specific-capacity data (Walton, 1970, p. 314-321) obtained during an aquifer test was used when the available data were not adequate for more detailed analysis.

\section{Flow Test Conducted at Laguna Casa Blanca 86-1 Well $(9 \mathrm{~N} .6 \mathrm{~W} .16 .111)$ on July 8,1986}

On July 8, 1986, an aquifer test was conducted at Laguna Casa Blanca 86-1 well ( $9 \mathrm{~N} .6 \mathrm{~W} .16 .111$ ) to determine aquifer properties. The hole was open to 328 feet of the San Andres Limestone and 120 feet of the Glorieta Sandstone of the San Andres-Glorieta aquifer. The shut-in pressure at 1330 hours, just prior to the start of the test, was 159.5 pounds per square inch at a measuring point 1.6 feet above land surface. This pressure was not corrected for barometric effects. Converted to feet of head, the water would stand 368 feet above land surface. Land surface is approximately 5,990 feet above sea level at this well; therefore, the potentiometric surface at this well is approximately 6,358 feet above sea level.

At 1330 hours July 8, 1986, the valve on the well was opened and the well was allowed to flow freely. Discharge was measured by diverting the discharge into a 55-gallon barrel and measuring the time it took to fill the barrel. At 1915 hours July 11, 1986, the well was shut in. The average discharge for the 4,665-minute flow test was 46 gallons per minute. Water-level-recovery data were collected after shut-in using a pressure transducer and a data logger. A 0 - to 200-pound-per-square-inch pressure gage was used as a check and backup to the pressure transducer. The gage was marked in divisions of 2 pounds per square inch. The linearity and accuracy of the gage were checked using a dead-weight tester. The gage response was linear over the range of 0 to 200 pounds per square inch and had an accuracy of 1 pound per square inch \pm 0.5 pound per square inch. Checks between the pressure transducer and the pressure gage indicated that the pressure-transducer readings were within the accuracy of the pressure gage.

The Jacob straight-1ine method and the recovery method (Lohman, 1972, p. 19-27) were used to calculate the transmissivity (figs. 35 and 36). An average discharge of 46 gallons per minute was used in the calculation of transmissivity. A transmissivity of 506 feet squared per day was calculated using the Jacob straight-line method (fig. 35) and a transmissivity of 579 feet squared per day was calculated using the recovery method (fig. 36). 


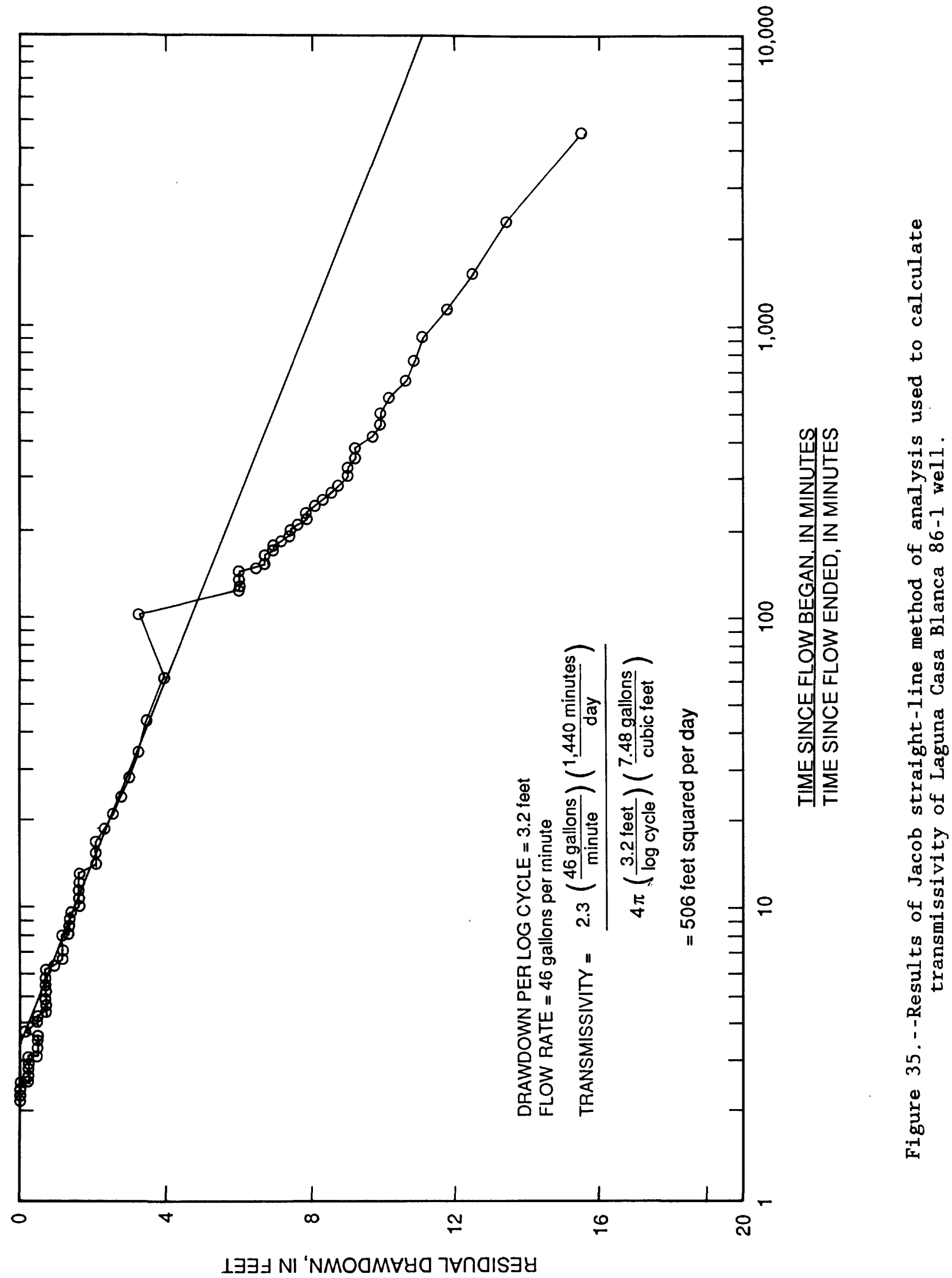




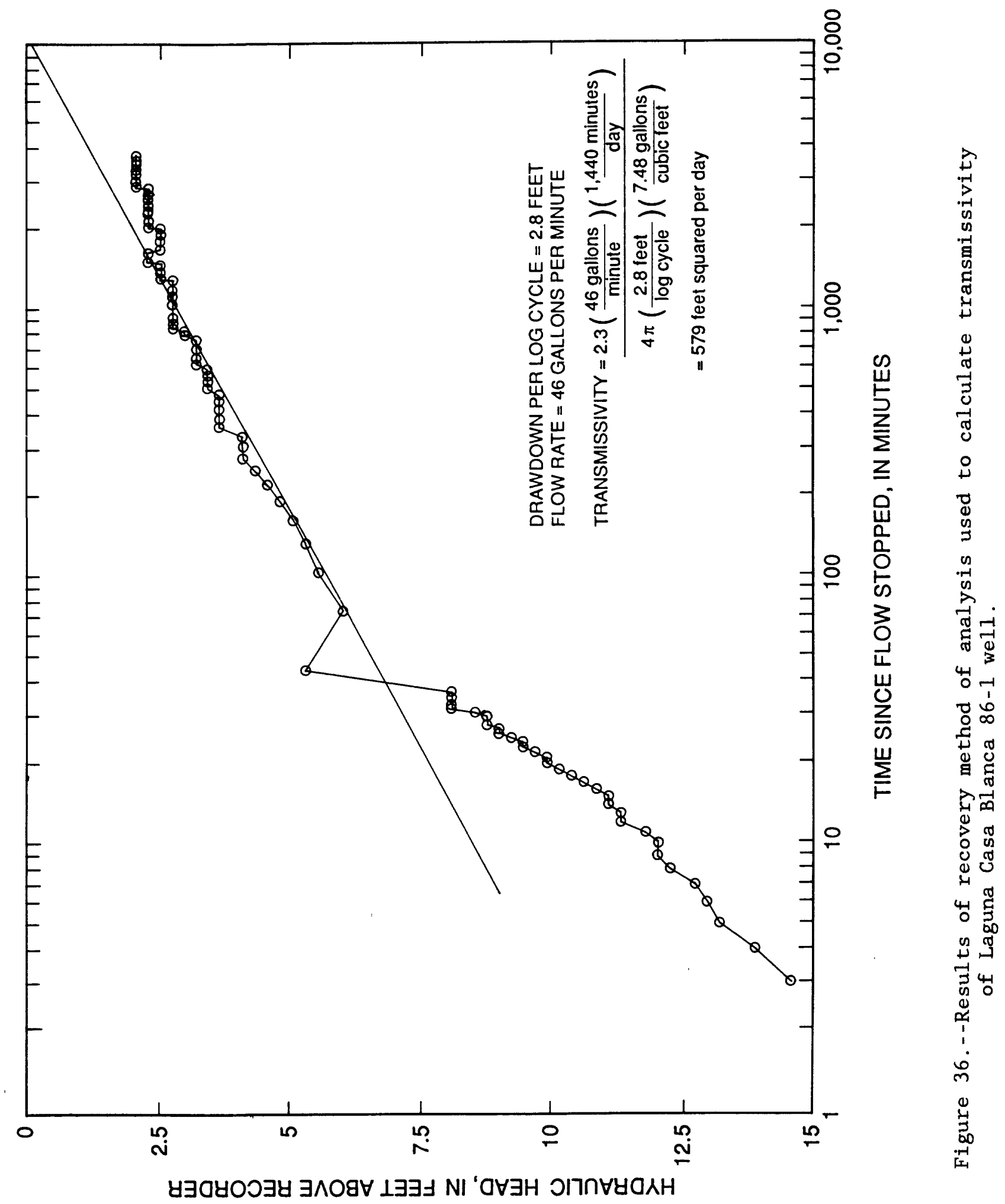




\section{Flow Test Conducted at Laguna Sand Canyon 86-1 We11}

(8N.6W.20.333) on May 23, 1986

On May 23, 1986, a flow test was conducted at Laguna Sand Canyon 86-1 well (8N.6W.20.333) to determine aquifer properties of the San Andres-Glorieta aquifer. The hole was open to 89 feet of the Chinle Formation, 342 feet of the San Andres Limestone, 167 feet of the Glorieta Sandstone, and 33 feet of the Yeso Formation. The shut-in pressure at 1300 hours May 23, 1986, just prior to the test, was 156.4 pounds per square inch measured with a pressure transducer at 7.3 feet above land surface. The pressure was not corrected for barometric effects. Converted to feet of head, the water would stand 365 feet above land surface. Land surface is approximately 6,025 feet above 1 and surface, so the potentiometric surface at this well is approximately 6,390 feet above sea level. At 1530 hours May 23, 1986, the valve on the well was opened and the well was allowed to flow freely. Discharge was measured by diverting the discharge into a 55-gallon barrel and measuring the time it took to fill the barrel. Discharge at 1300 hours on May 24, 1986 (1,290 minutes since flow began), was 40.7 gallons per minute. Discharge at 1048 hours on May 27, 1986 (5,490 minutes since flow began), was 38.8 gallons per minute. The well was shut in at 1100 hours, May 27, 1986, and water-1evel-recovery data were collected using a pressure transducer and data logger. A 0 - to $200-$ pound-per-square-inch pressure gage was used as a check and backup to the pressure transducer. The gage was marked in increments of 2 pounds per square inch. The linearity and accuracy of the gage were checked using a dead-weight tester. The gage response was linear over the range of 0 to 200 pounds per square inch and had an accuracy of 1 pound per square inch \pm 0.5 pound per square inch. The Jacob straight-1ine method and the recovery method (Lohman, 1972 , p. 19-27) were used to calculate transmissivity (figs. 37 and 38 ). A discharge of 40 gallons per minute was used in the calculation of transmissivity. A transmissivity of 100 feet squared per day was calculated using the Jacob straight-line method (fig. 37), and a transmissivity of 117 feet squared per day was calculated using the recovery method (fig. 38).

\section{Flow Test Conducted at Acoma-Sky City 86-1 Wel1 $(8 \mathrm{~N}, 8 \mathrm{~W} .25,423)$ on December $4-8,1986$}

December 4 through December 8, 1986, an aquifer test was conducted at Acoma-Sky City 86-1 well (8N.8W.25.423) to determine aquifer properties of the San Andres-Glorieta aquifer. The hole was open to 355 feet of the San AndresGlorieta aquifer. The static water level on June 8, 1987, in this well was 14.2 feet above 1 and surface. Land surface at this well is approximately 6,400 feet; therefore, the potentiometric surface at this well is 6,414.2 feet above sea level. 


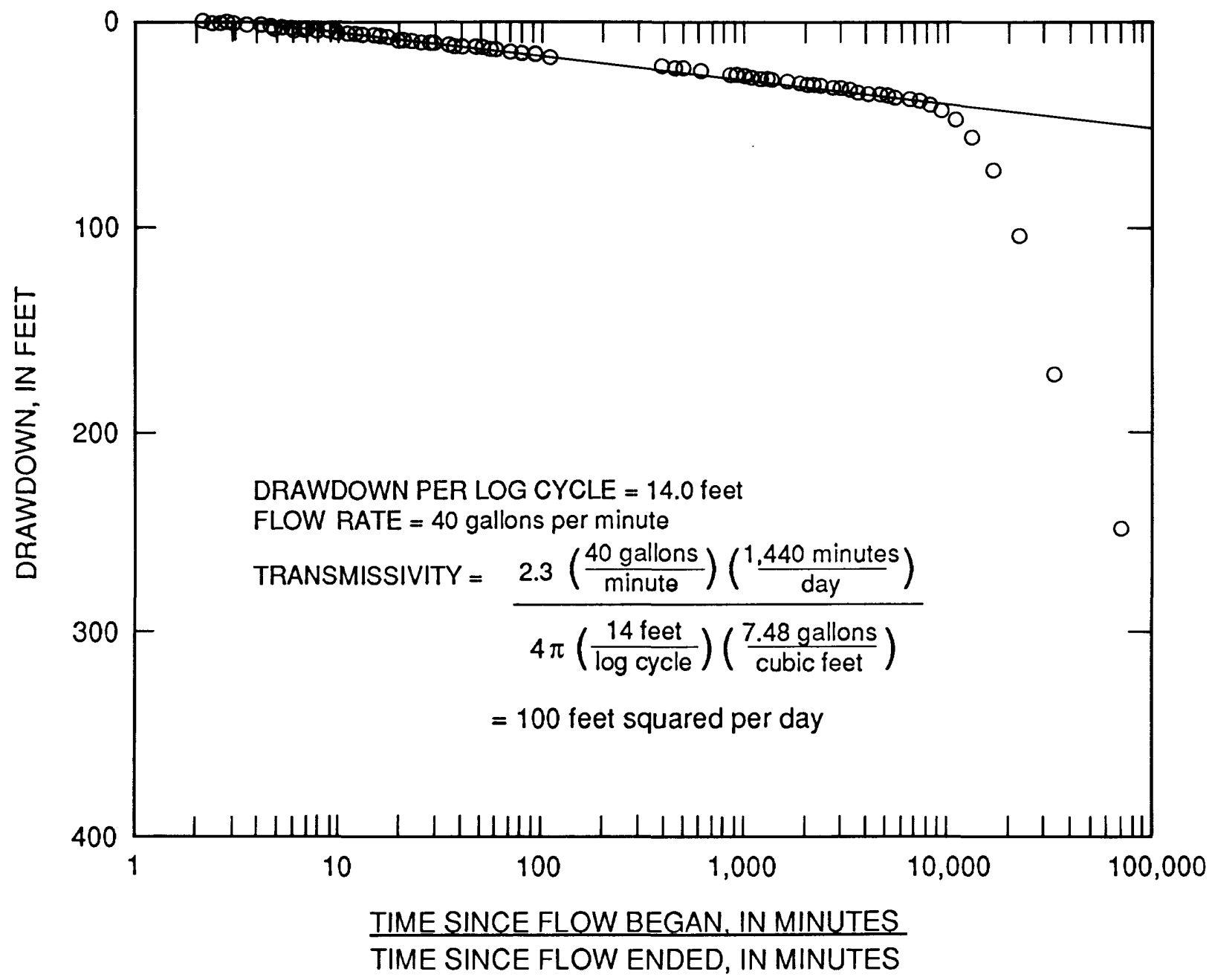

Figure 37.--Results of Jacob straight-line method of analysis used to calculate transmissivity of Laguna Sand Canyon 86-1 well.

At 0725 hours on December 4, 1986, the pumping part of the aquifer test was begun with a 10-horsepower pump. Before pumping, the well was flowing at 2.9 gallons per minute over the top of the casing, which was 1.4 feet above land surface. The pump ran continuously until 0800 hours on December 7, 1986. The total volume of water pumped, measured with a flowmeter, was 157,868 gallons during the 4,355 minutes of pumping. The average discharge for the pumping period was 36.2 gallons per minute. At 0725 hours on December 7 , 1986, the drawdown was 401.5 feet below land surface. The drawdown below the static water level was 415.7 feet. The specific capacity of the well at 0725 hours on December 7, 1986, assuming an average discharge of 36.2 gallons per minute, was approximately 0.1 gallon per minute per foot of drawdown. The estimated transmissivity using the above specific capacity, assuming a 24-hour pumping period, is approximately 25 feet squared per day (Walton, 1970 , p. 318). 


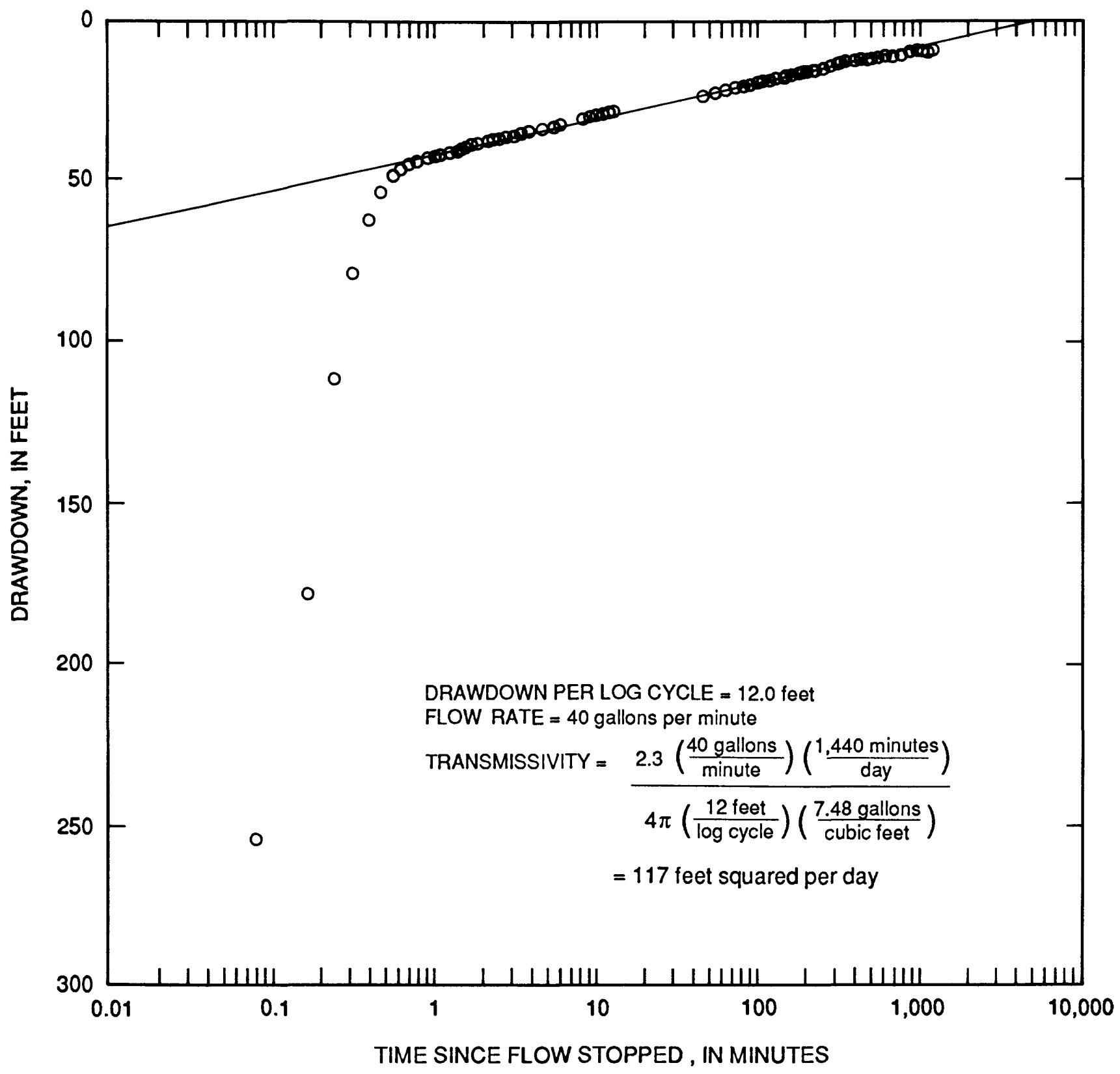

Figure 38.--Results of recovery method of analysis used to calculate transmissivity of Laguna Sand Canyon 86-1 wel1. 
$\frac{\text { Flow Test Conducted at BLM-North Pasture 86-1 Wel1 }}{\text { (6N.10W.7.141) on November } 26.1986}$

On November 26, 1986, an aquifer test was conducted at BLM-North Pasture 86-1 we11 (6N.10W.7.141) to determine aquifer properties of the San AndresGlorieta aquifer. The hole was open to 45 feet of the Chinle Formation and 383 feet of the San Andres Limestone and Glorieta Sandstone. The static water level in this wel1 is 711 feet below land surface. Land surface at this well is approximately 7,130 feet above sea level; therefore, the potentiometric surface at this well is 6,419 feet above sea level.

At 0914 hours on November 26, 1986, the pumping part of the aquifer test was begun with a 15-horsepower pump. The pump ran continuously until 1830 hours on November 26, 1986. A total volume of 21,761 gallons of water was pumped during the 556 minutes of the test. The average flow rate for the test was 39 gallons per minute. At 1700 hours, November 26, the pumping water level was 845.3 feet below land surface and drawdown was 134.3 feet. The specific capacity of the well at 1700 hours, assuming an average discharge of 39 gallons per minute, is 0.3 gallon per minute per foot. The estimate of transmissivity using the calculated specific capacity, assuming 8 hours of pumping, is about 70 feet squared per day (Walton, 1970, p. 317).

\section{Flow Test Conducted at Red Lake Ranch-La Mosca 86-1 Well (5N.8W. 35.123) on December 14-18, 1986}

December 14 through December 18, 1986, an aquifer test was conducted at Red Lake Ranch-La Mosca 86-1 we11 (5N.8W.35.123) to determine the aquifer properties of the San Andres-Glorieta aquifer. The hole was open to 1 foot of the Chinle Formation and 323 feet of the San Andres Limestone. A 10-foot cavernous zone and three 2 -foot cavernous zones were penetrated in the San Andres Limestone during the drilling of this hole. The static water level in this well on December 14, 1986, prior to the start of the test, was 552.8 feet below land surface. Land surface at this well is approximately 6,977 feet above sea level; therefore, the potentiometric surface at this well is about 6,424 feet above sea level.

At 1546 hours on December 14, 1986, the pumping part of the test was begun with a 40-horsepower pump. The pump was stopped at 0900 hours on December 16,1986 . A total volume of 356,557 gallons was pumped during the 2,474 minutes of pumping. The average flow rate was 144 gallons per minute. At approximately 0845 hours on December 16, 1986, the drawdown was 3.8 feet. This drawdown can be attributed to head loss due to friction in the 1 iner and casing in the well. This indicates that the pumping rate used during the test of this well was not large enough to sufficiently stress the aquifer. Therefore, no quantitative estimate of the transmissivity of the aquifer at this well can be made. The presence of cavernous zones and the lack of drawdown in the well during the aquifer test do indicate that the transmissivity of the San Andres-Glorieta aquifer in this area is large. 
On Ju1y 9, 1986, an aquifer test was conducted at Anzac 86-1 wel1 (10.9.25.3241) to determine aquifer properties. This well had been shut in since June 6, 1986, when drilling operations at the well were completed. The well was equipped with an 8 -inch shutoff valve on top of the casing. The top of the shutoff valve, referred to hereafter as the measuring point, is 2.0 feet above land surface. Land surface is estimated to be 6,280 feet above sea level from a Geological Survey topographic map. Shut-in pressure on June 11, 1986, was 62 pounds per square inch, measured with a pressure gage at a point 4.0 feet above land surface. The pressure reading was not corrected for barometric effects. Converted to feet of head, water would stand at $147 \mathrm{feet}$ above land surface. Potentiometric surface at this pressure is at an altitude of 6,427 feet.

For the flow test, the well was equipped with a 6 -inch tee on the 8 -inch valve, and a 40-foot-1ong, 6-inch-diameter discharge pipe was run from the 6inch tee. A 4-foot section of 6-inch pipe was added to the 40 -foot pipe to accommodate a Clampitron ${ }^{1}$ discharge meter. Tubing for a pressure transducer also was installed in the 4-foot section of pipe. Downstream from the 4-foot section a 6-inch McCrowmeter was installed.

A 6-inch shutoff valve was installed on the downstream end of the McCrowmeter to provide back pressure for discharge control. Approximately 300 feet of 6-inch pipe was added to carry the discharge water to the Rio San Jose.

Monitoring equipment for the test included a pressure transducer mounted 0.9 foot above the measuring point, 0 - to 60- and 0 - to 200-pound-per-squareinch pressure gages mounted 0.1 foot below the measuring point, a McCrowmeter discharge meter with discharge and totalizer readings, and a Clampitron flowmeter. Shut-in pressure on July 9, 1986, before the test was started, was 59.8 pounds per square inch, or about 139.9 feet of head above land surface.

\footnotetext{
1Use of brand names in this report is for identification purposes only and does not constitute endorsement by the U.S. Geological Survey.
} 
The test, started July 9, was run as a step-drawdown test and the discharge was measured with the McCrowmeter and the Clampitron flowmeters. The Clampitron flowmeter malfunctioned at 1630 hours, July 9 . On July 10, it became apparent that the discharge measurements made with both flowmeters were in error. The discharge water contained a considerable amount of gas. It is believed that the gas resulted from degassing of the discharge water as it was raised from the aquifer to land surface. The gas in the discharge water probably caused both flowmeters to underestimate the actual discharge. On July 10 , a modified 6-inch Parshall flume was installed in a concrete irrigation ditch into which the discharge was directed. The discharge was measured at 2,820 gallons per minute. The McCrowmeter indicated a discharge of 1,100 gallons per minute. The step intervals, McCrowmeter measurements, and the Parshall flume measurement are listed below. Numbers in parentheses were interpolated from observed flowmeter and Parshall flume measurements made during step 8. The average discharge rate for the flow test was 2,360 gallons per minute.

\begin{tabular}{|c|c|c|c|}
\hline \multirow[b]{2}{*}{ Step } & \multirow[b]{2}{*}{ Time } & \multicolumn{2}{|c|}{$\begin{array}{c}\text { Discharge } \\
\text { (gallons per minute) }\end{array}$} \\
\hline & & McCrowmeter & Parshall flume \\
\hline 1 & 0800-0900 July 9 & 100 & $(260)$ \\
\hline 2 & $0900-1030$ & 240 & $(620)$ \\
\hline 3 & $1030-1230$ & 400 & $(1,020)$ \\
\hline 4 & $1230-1412$ & 550 & $(1,410)$ \\
\hline 5 & $1412-1530$ & 750 & $(1,920)$ \\
\hline 6 & $1530-1835$ & 950 & $(2,440)$ \\
\hline 7 & $1835-1900$ & 1,200 & $(3,080)$ \\
\hline 8 & 1900-1500 July 10 & 1,100 & 2,820 \\
\hline
\end{tabular}

The initial increase in head from 0800 to about 0900 hours probably was due to thermal expansion or degassing of the column of water. Thermal expansion or degassing of the water may have continued past 0900 hours.

The well was shut in at 1500 hours, July 10,1986 , and the head was monitored through 1140 hours, July 14, 1986. After the well was shut in, the transducer and pressure gage were moved to the well head to allow the drilling crew to remove the discharge pipe. At this new location the transducer was mounted at 1.8 feet above the measuring point and the pressure gage was mounted at 3.0 feet above the measuring point. 


\section{Recovery at Acoma 1 We11}

Acoma 1 well (9.9.28.1344) was equipped with a Fischer-Porter analog digital recorder, set on 1/2-hour punch intervals. The recorder therefore collected water levels 48 times per day. The recorder was driven by a float and counterweight, and clock time was advanced by a battery-driven digital clock. Punched tapes are removed from the recorder at approximately 3 -month intervals. When the tape was removed from the recorder on August 1, 1986, two drawdown and recovery intervals were recorded.

The first drawdown and recovery interval at Acoma 1 well coincided with drilling of the Anzac 86-1 well during June 4-6, 1986, when the well flowed freely from the San Andres-Glorieta aquifer. The second drawdown and recovery period at Acoma 1 coincided with flow testing of Anzac 86-1 on July 9-10, 1986. Water-level data from Acoma 1 well for this recovery period were run through a smoothing program to reduce the amount of "noise" due to barometric and earth-tide fluctuations. Recovery data from Acoma 1 well for 1730 hours, July 10, to 1400 hours, August 1, 1986, were then plotted as time since flow stopped versus recovery in feet on a semilog plot (fig. 39). The recorder clock time at Acoma 1 probably was not synchronized with watch time used at Anzac 86-1. The distance from Anzac 86-1 to Acoma 1 is approximately 35,000 feet.

Water-level monitoring at Acoma 1 indicates that from January 1984 through September 1985 water levels in the well fluctuated over a range of about 0.8 foot but did not show long-term rises or declines (fig. 40). However, in mid-September 1985, a water-level decline of about 0.5 foot occurred, followed by a gradual rise in water level. This water-level rise continued through mid-March 1986 when a second decline of about 0.8 foot occurred. Water levels in the well then began a second period of long-term water-level rise. The water-level decline that took place in September 1985 could be due to the Mexico City earthquake of September 19, 1985, at 0719 hours (local time). Effects of this earthquake were noted in several other wells in New Mexico.

The cause of the March 1986 water-level decline is unclear. Approximately 45,000 gallons of water was pumped from the well from March 7 through March 10 at a pumping rate of 12 gallons per minute prior to collecting water samples from the well. The recorder was removed from the well from March 7 through March 12 while the well was pumped. Results of a pumping test conducted at the well during October 1984 indicated that water levels in the well recovered to levels above the prepumping water level within 2 minutes after the pump was shut off. (Recovery above the prepumping water level was due to the heated column of water in the casing.) The pumping rate for this test was 500 gallons per minute. It does not seem likely that the small pumping rate for the sample collection caused the March 1986 water-level decline. Following the water-level decline in March 1986, a water-level rise of 1.5 feet per year began. This trend continued through october 1986 .

The long-term water-level trend was subtracted from the smoothed data, and a line with the corrected slope, plotted below the uncorrected curve (fig. 39), was used to determine the transmissivity value at the well. A transmissivity value of about 200,000 feet squared per day was calculated from the corrected straight-1ine plot. 


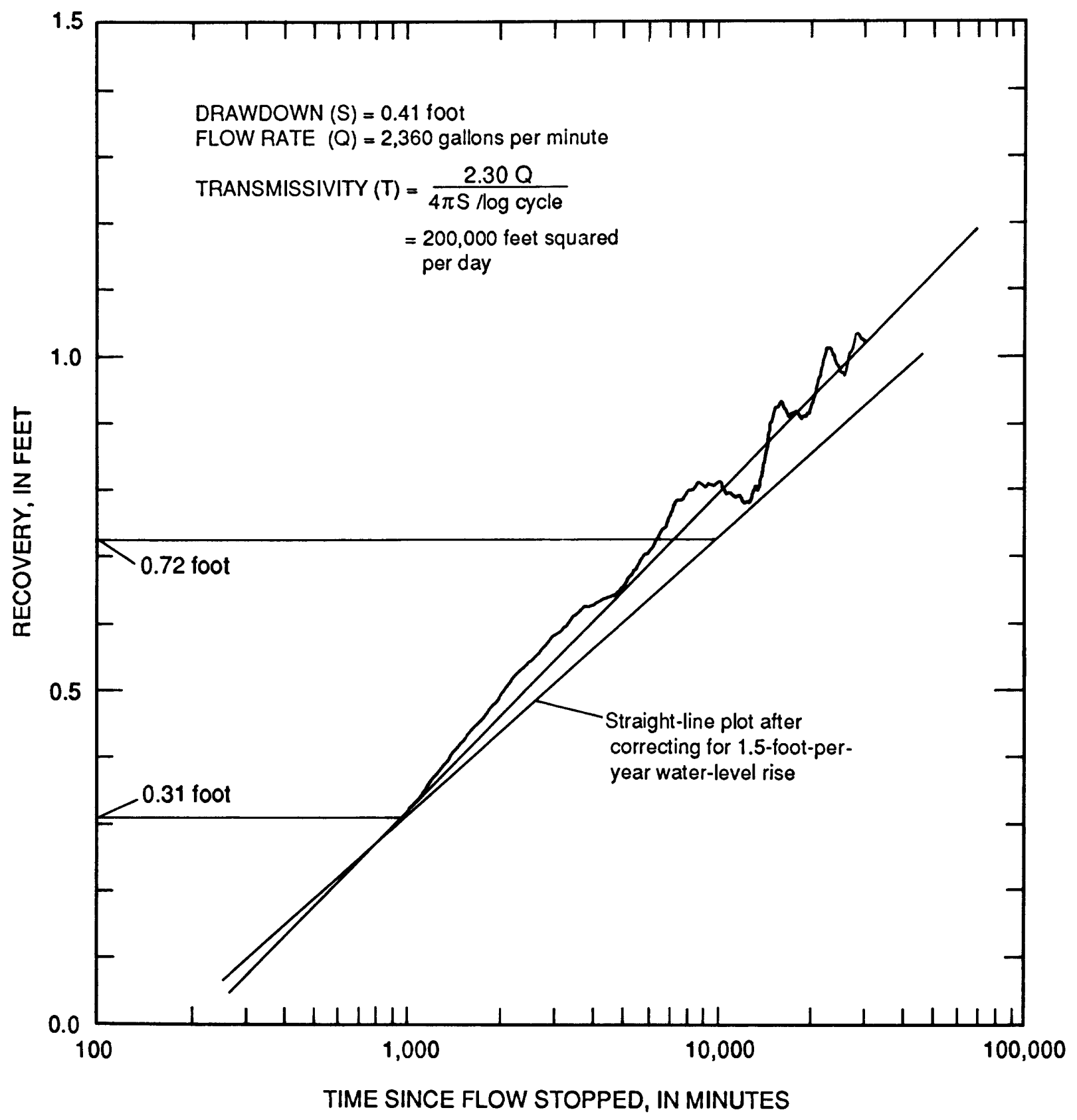

Figure 39.--Recovery at Acoma 1 observation well (9.9.28.1344) from flow test at Anzac 86-1 (10.9.25.3241). 
$\perp \exists \exists \exists N$ 의 $\exists \circ \cap \perp \perp 7 \forall 7 \exists \wedge \exists า-y \exists \perp \forall M$

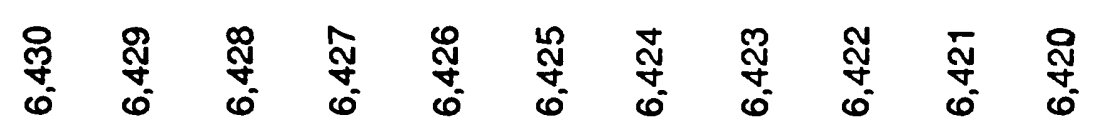

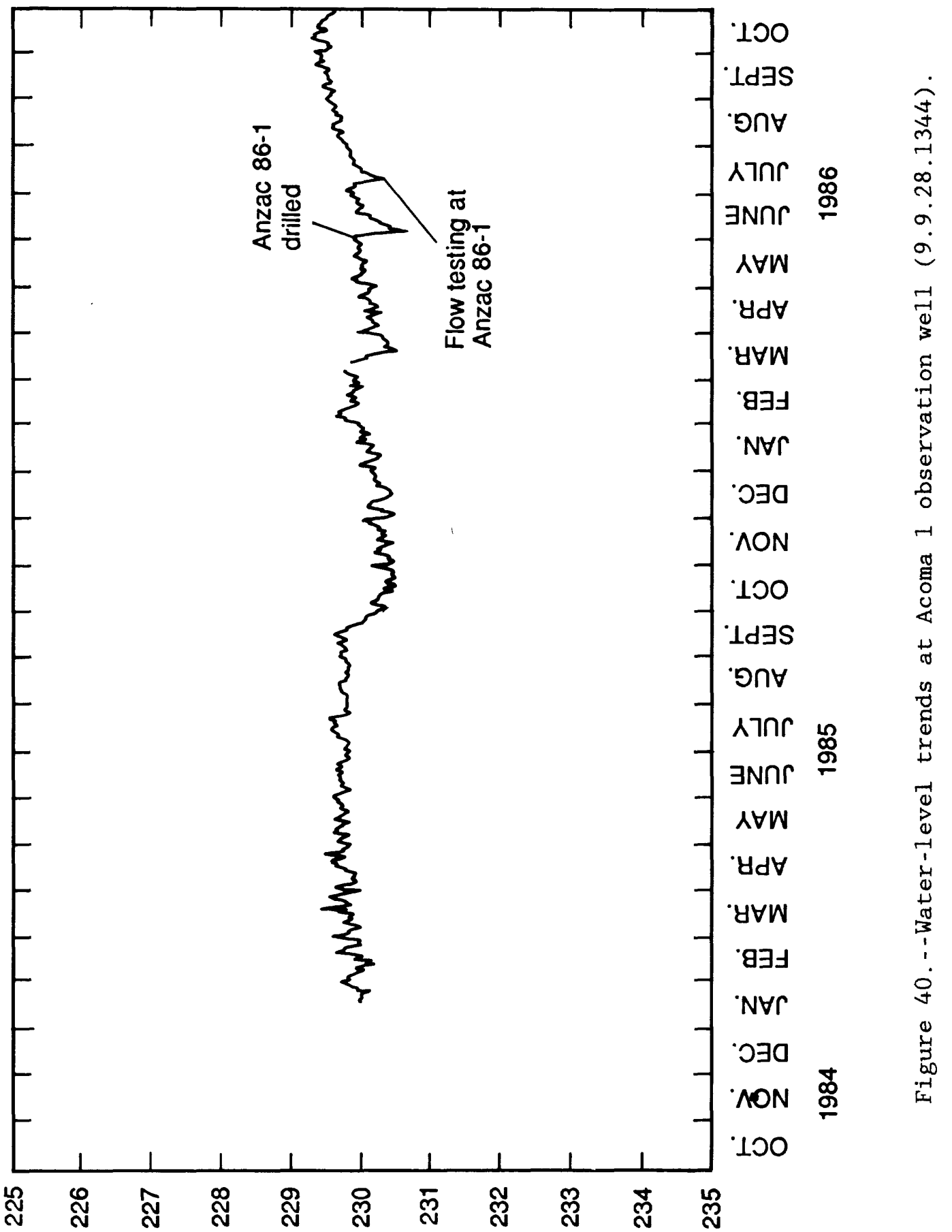

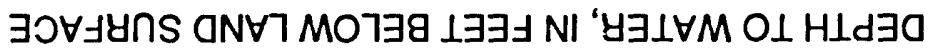


Table 1.-Records of wells and springs in the Acoma Embayment and eastern Zuni uplift

\section{EXPLANATION}

Local identifier: see text for explanation. Station number: the first six numbers are the latitude, the next seven numbers are the longitude, and the last two numbers are the sequence number. Contributing unit: $U$, unknown; $P$, principal aquifer; $N$, no contribution; $S$, secondary aquifer. Aquifer code indicates source of water: $111 \mathrm{MCCR}$, Quaternary McCartys Basalt flow; 000EXRV, extrusive rocks; 110AVMB, Quaternary and Tertiary alluvium; 210MNCS, Cretaceous Mancos Shale; 211DKOT, Cretaceous Dakota Sandstone; 221TDLT, Jurassic Todilto Limestone Member of Wanakah Formation; 221ENRD, Jurassic Entrada Sandstone; 231CHNL, Triassic Chinle Formation; 231SNSL, Triassic Sonsela Sandstone Bed of Petrified Forest Member of Chinle Formation; 313SADG, Permian San Andres Limestone and Glorieta Sandstone, undivided; 313SADR, Permian San Andres Limestone; 310GLRT, Permian Glorieta Sandstone; 313SADY, Permian San Andres Limestone and Yeso Formation, undivided; 310YESO, Permian Yeso Formation. Water levels: R, reported. Primary use of water: $S$, stock; $U$, unused; $H$, domestic; $T$, institutional; $P$, public supply; $\mathrm{J}$, industrial (cooling); I, irrigation; N, industrial; $\mathrm{Z}$, other; E, power; $R$, recreation. - , no data. 


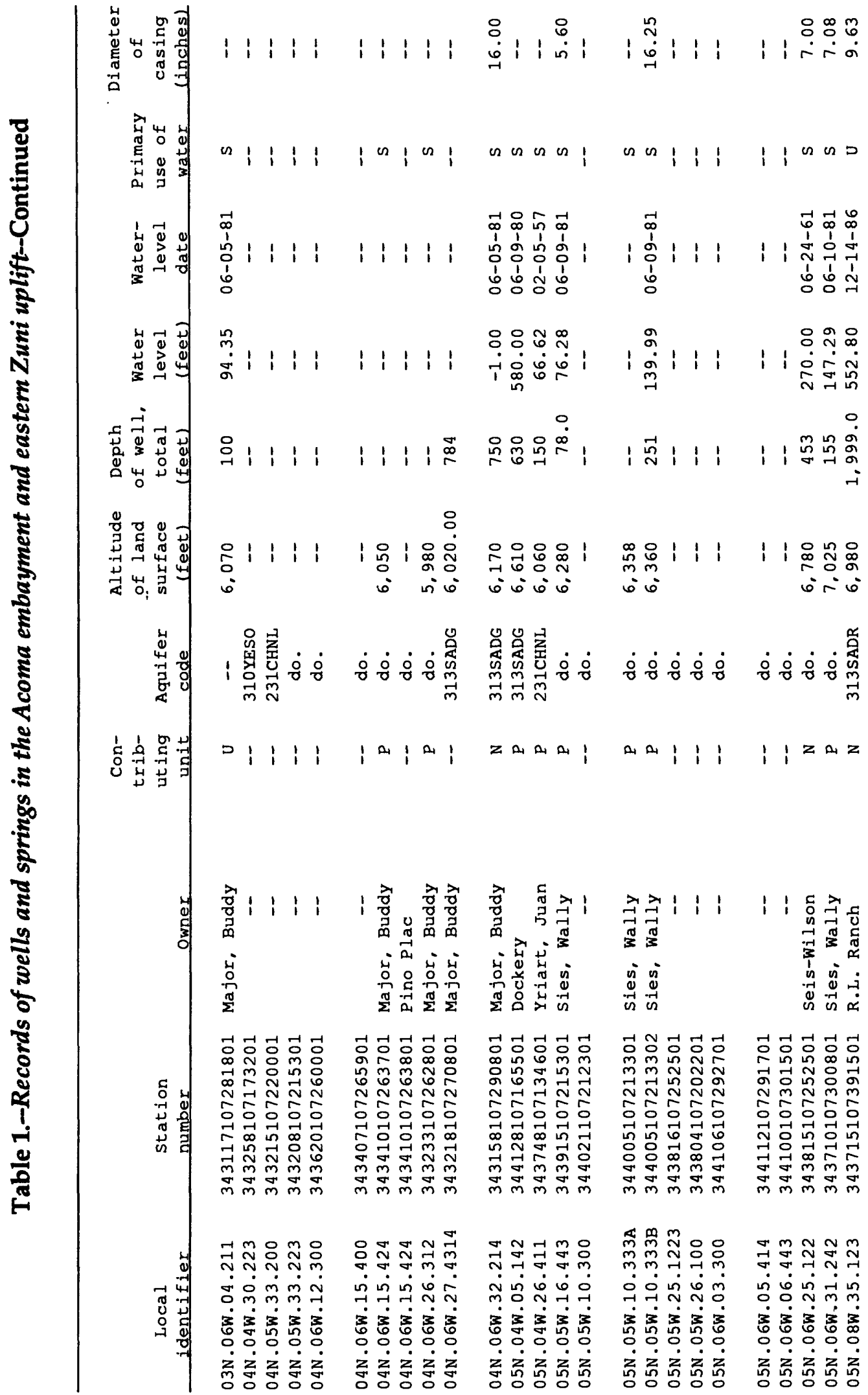




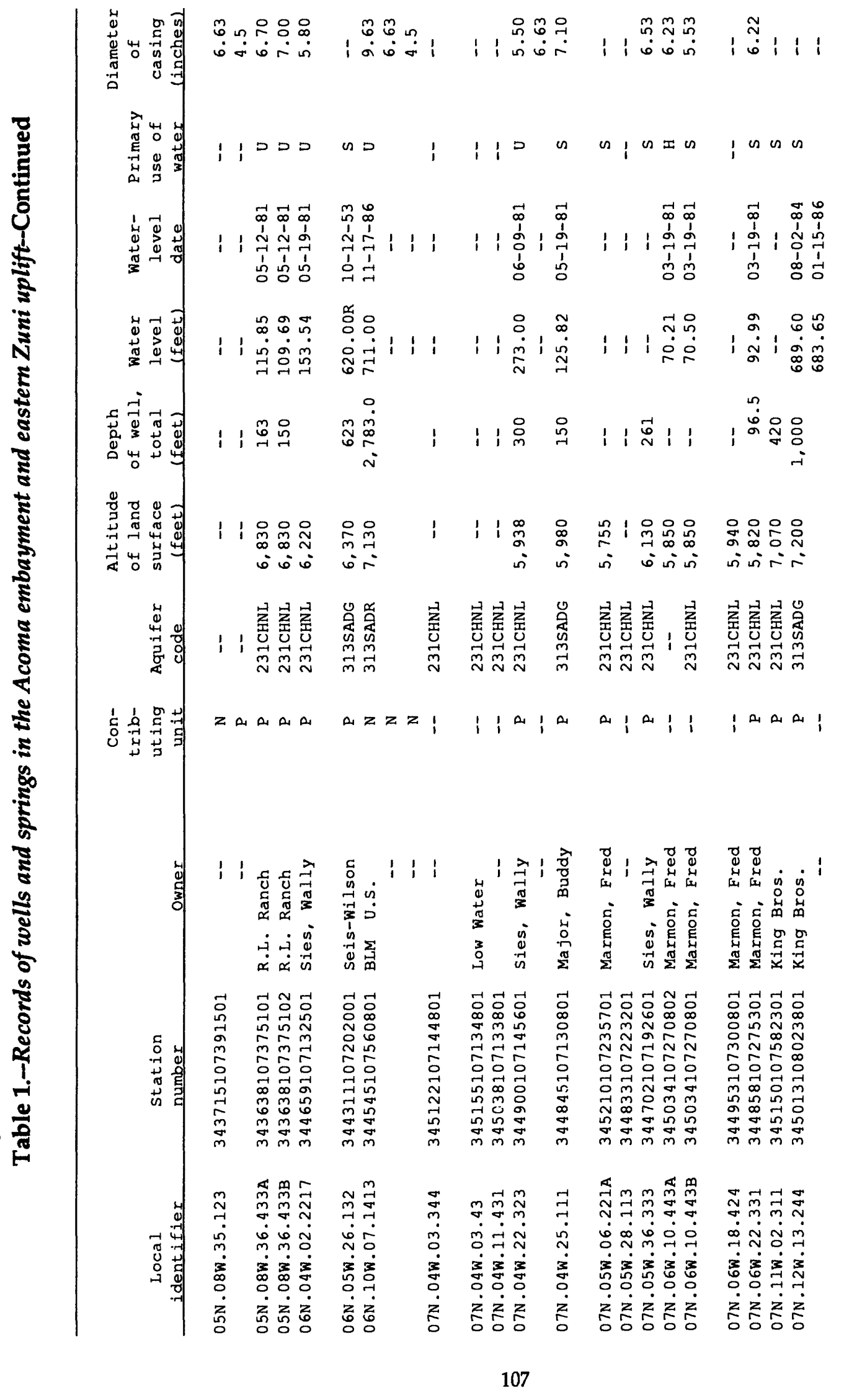




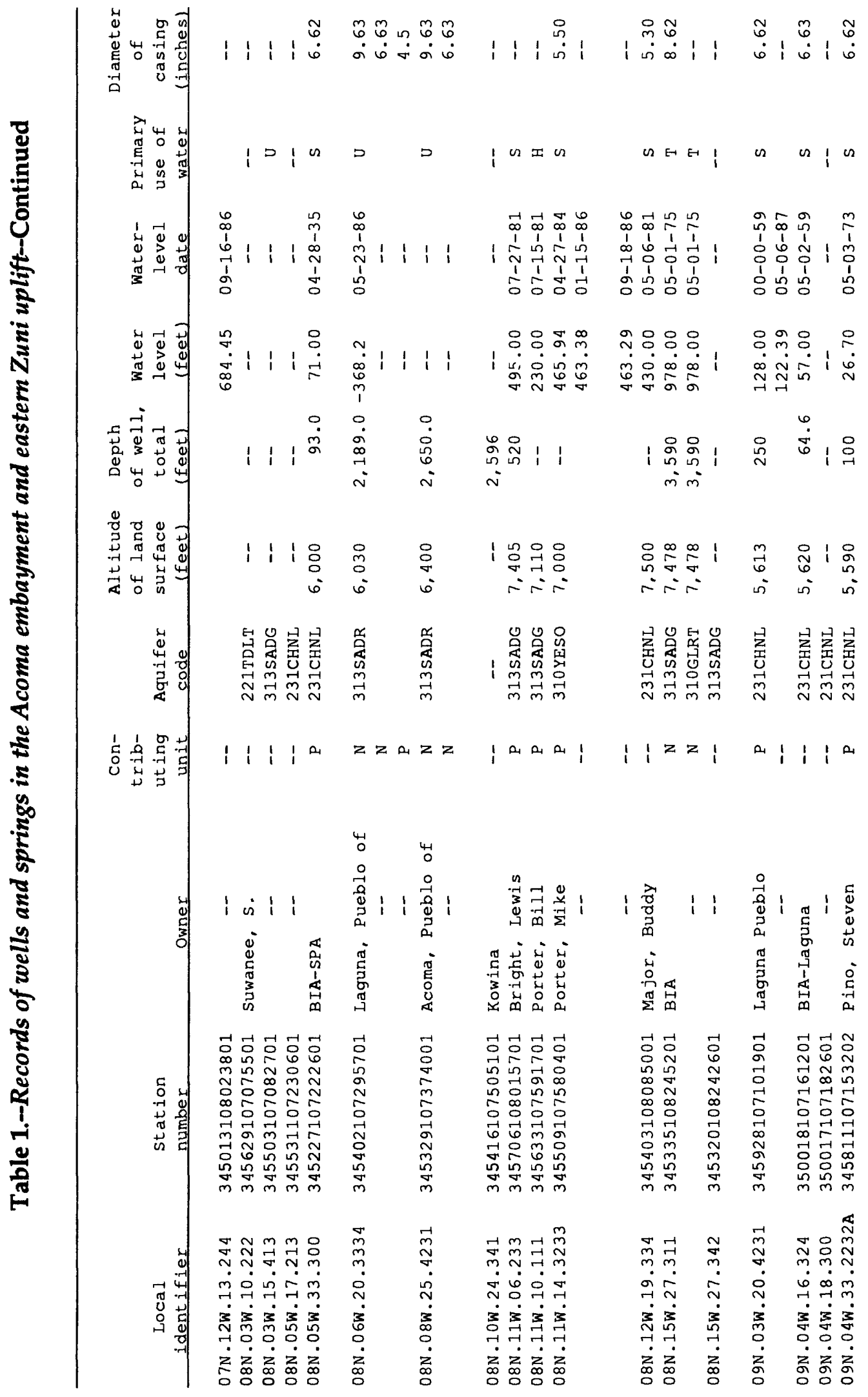




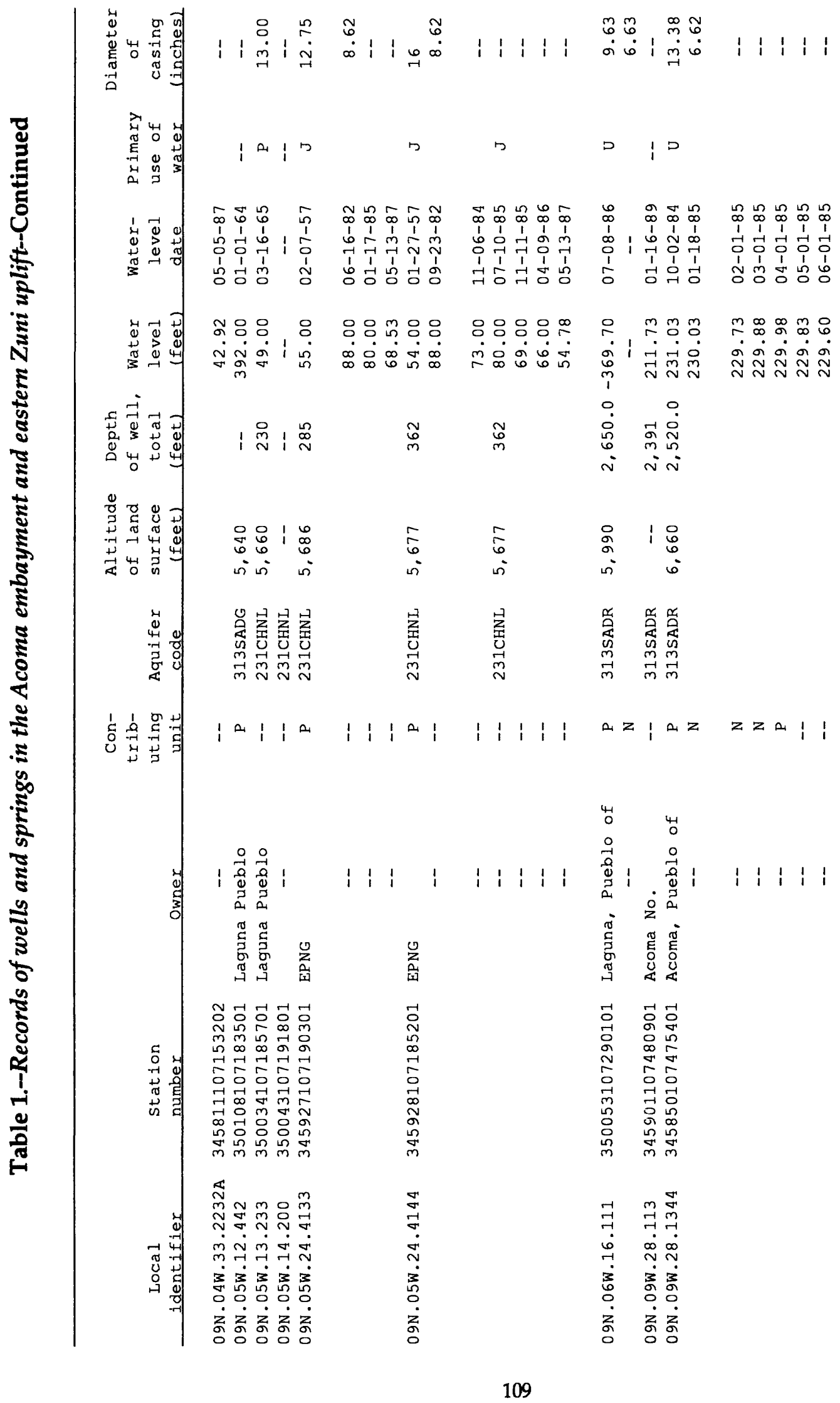




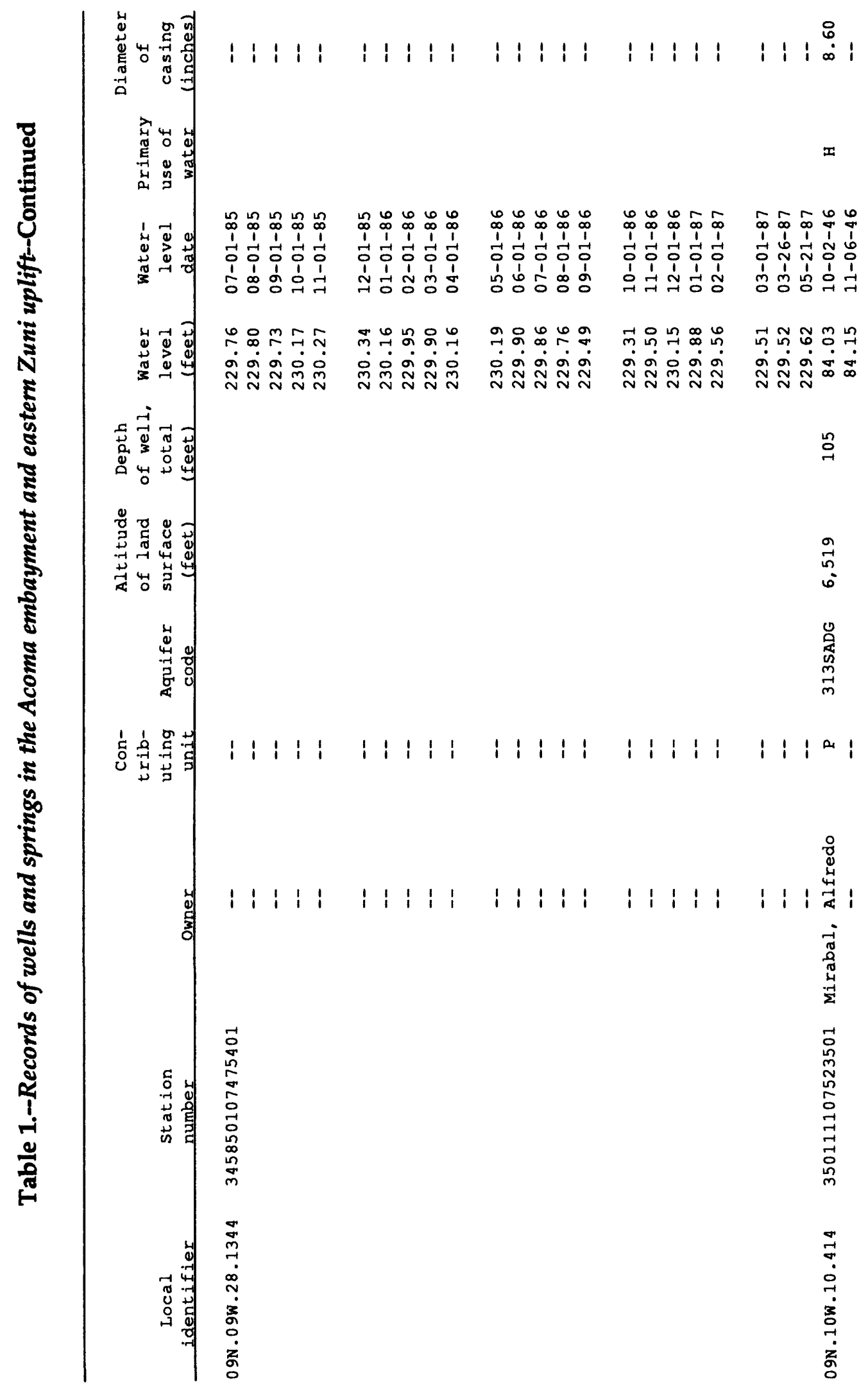




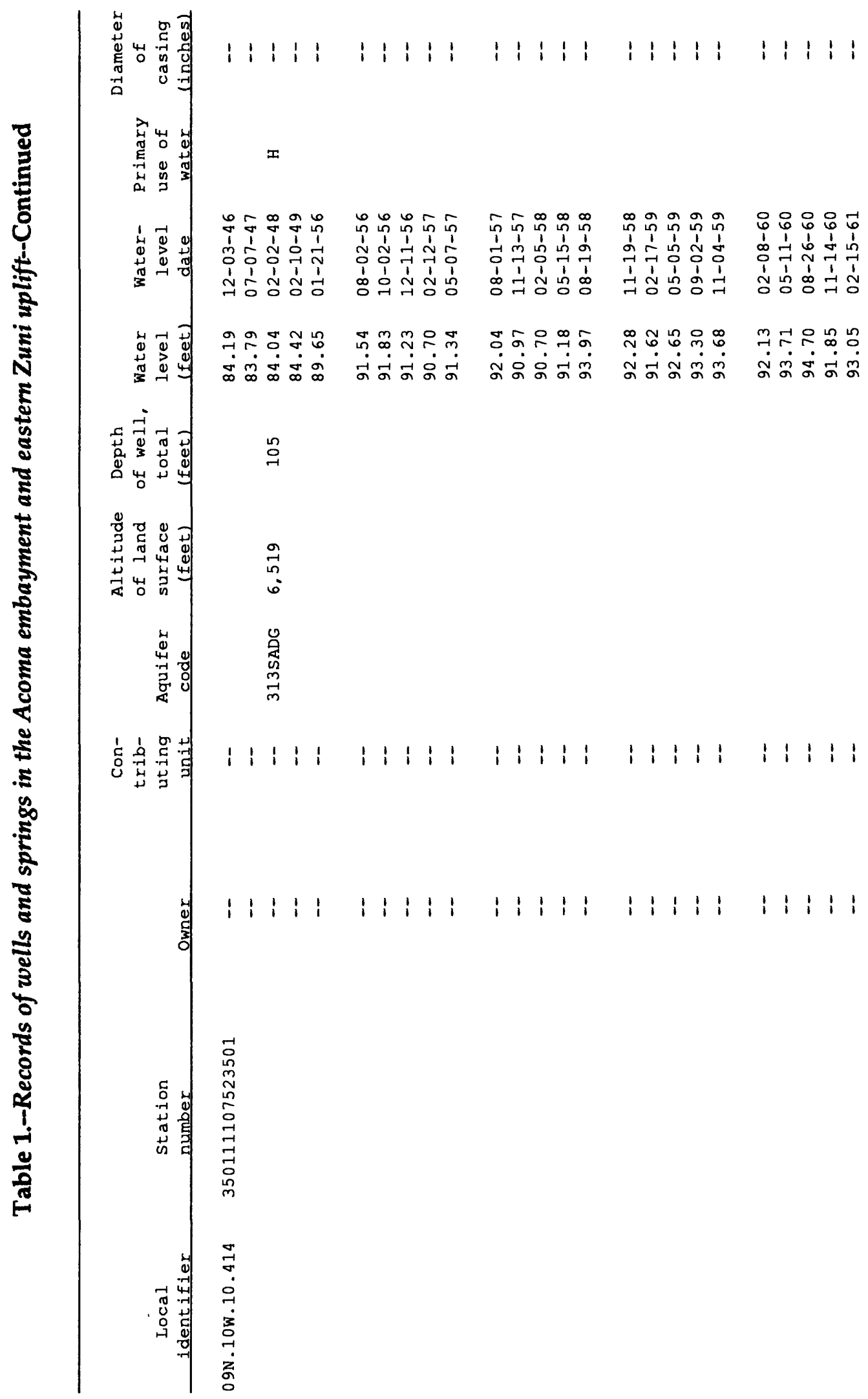




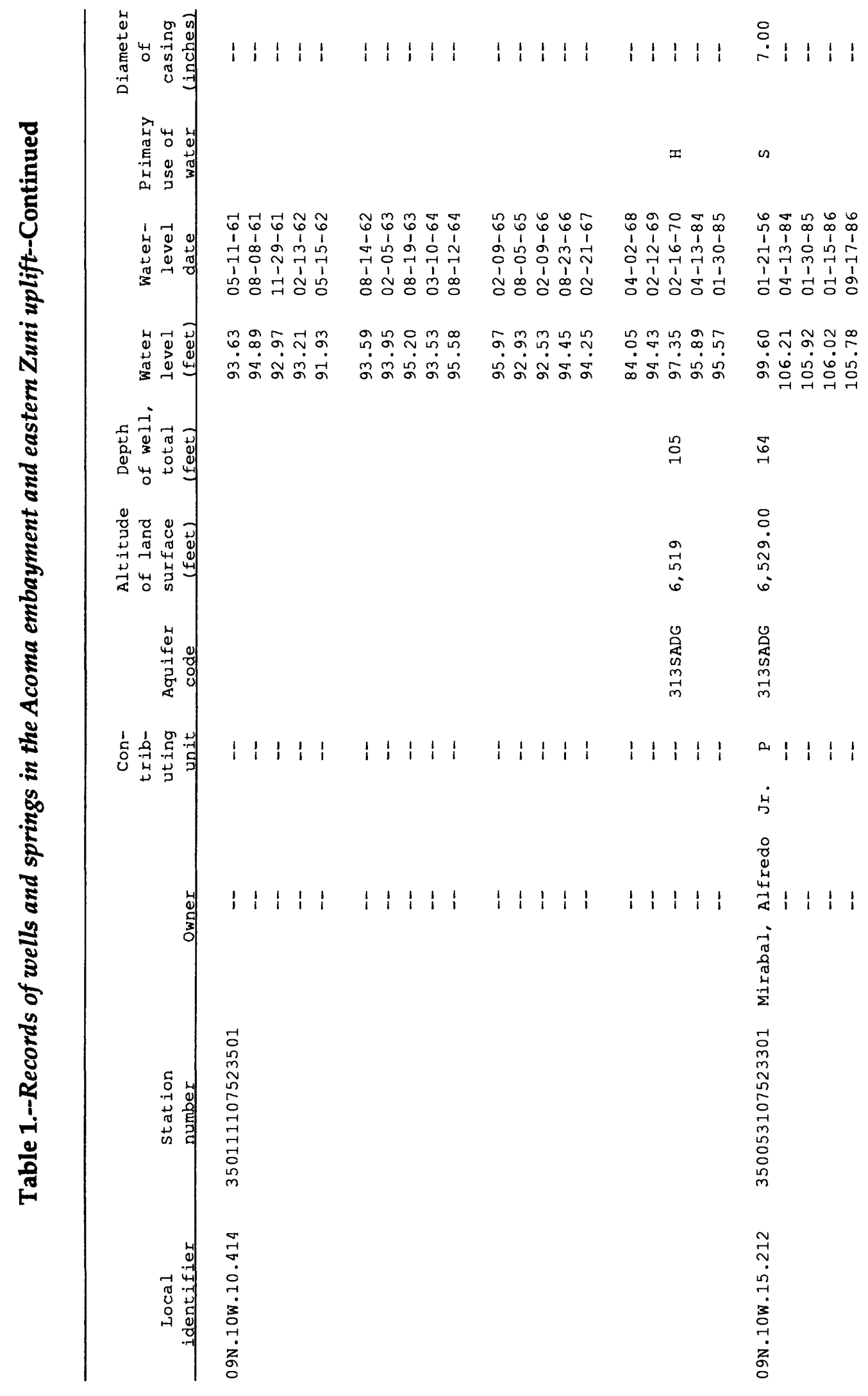




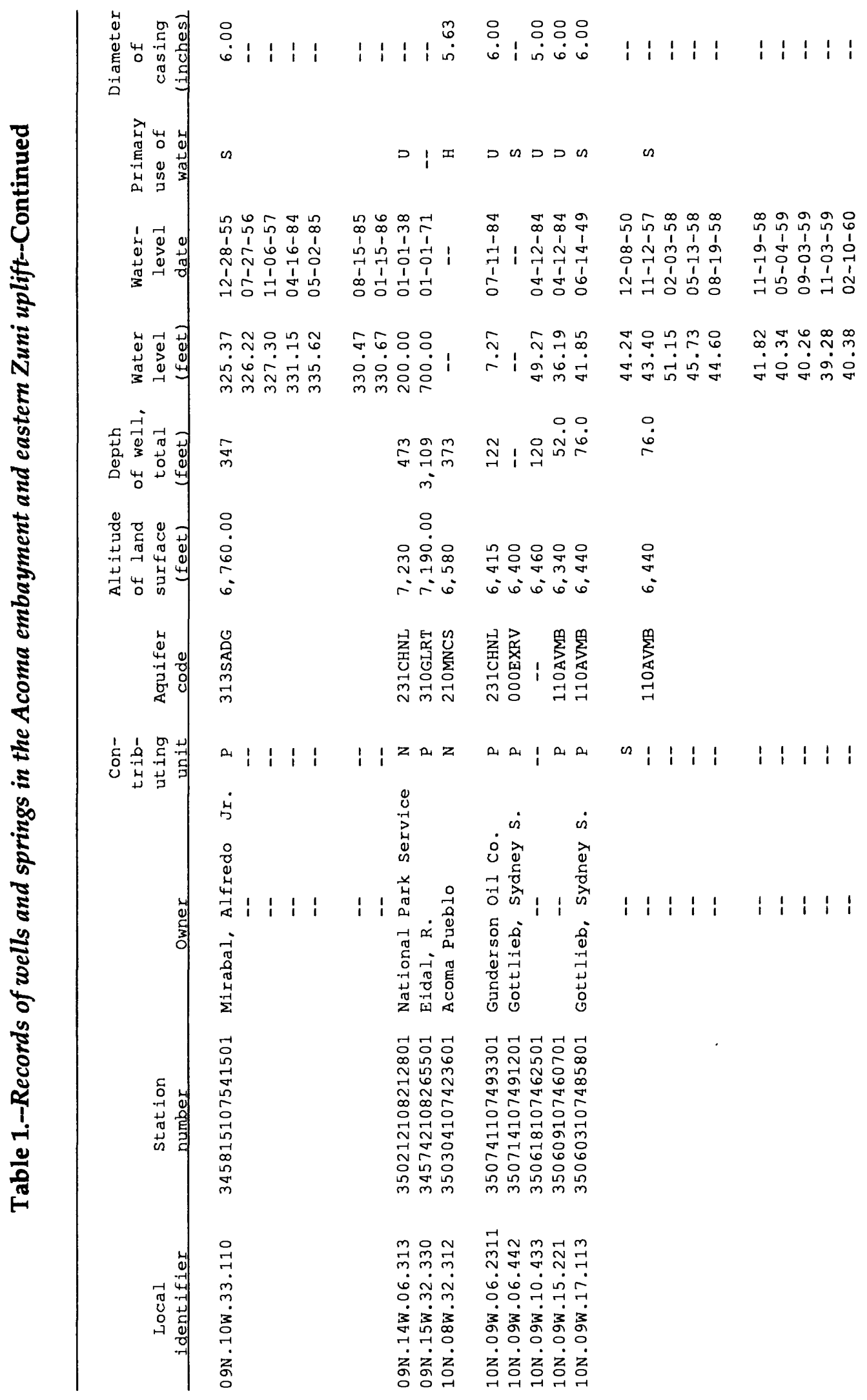




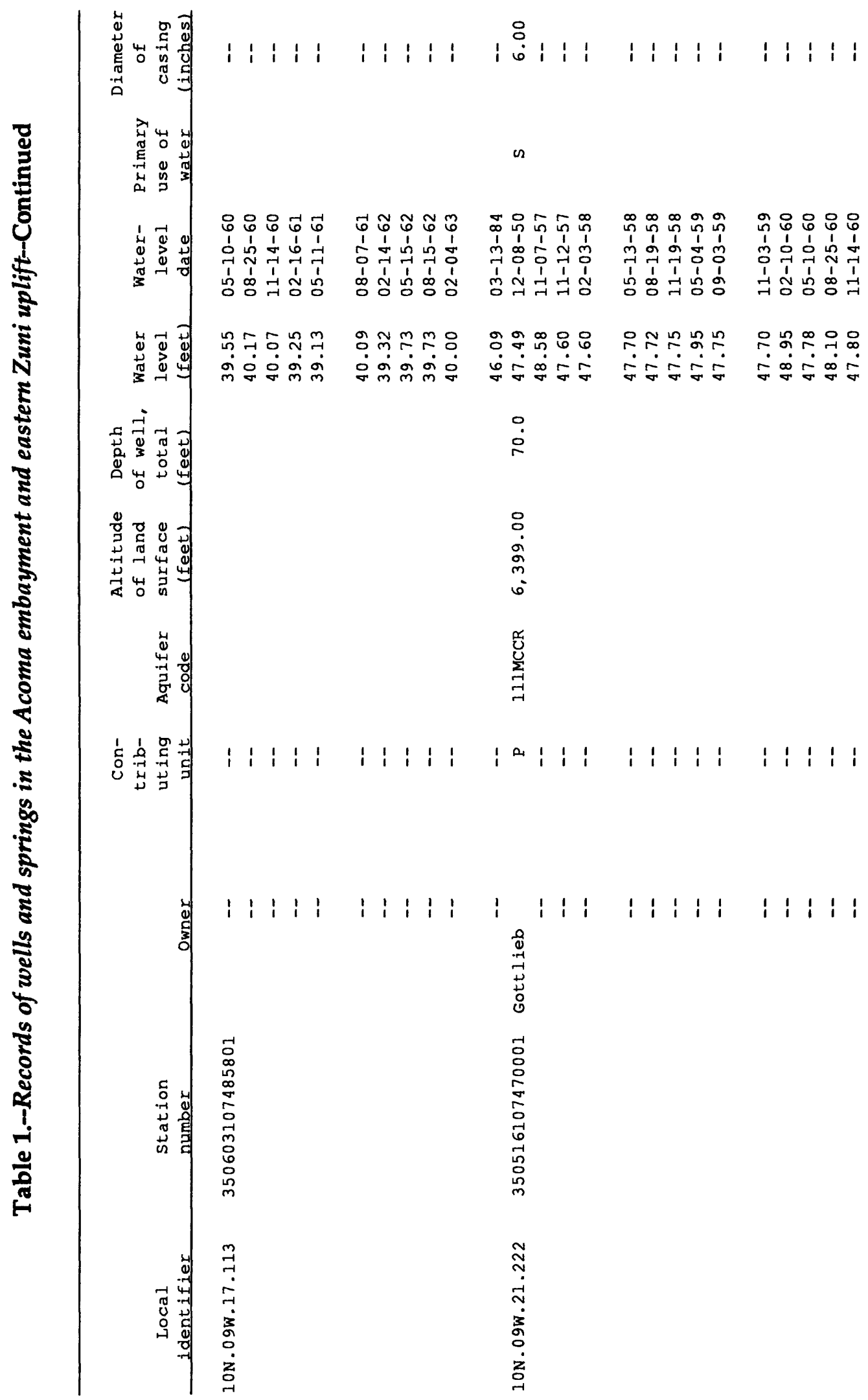




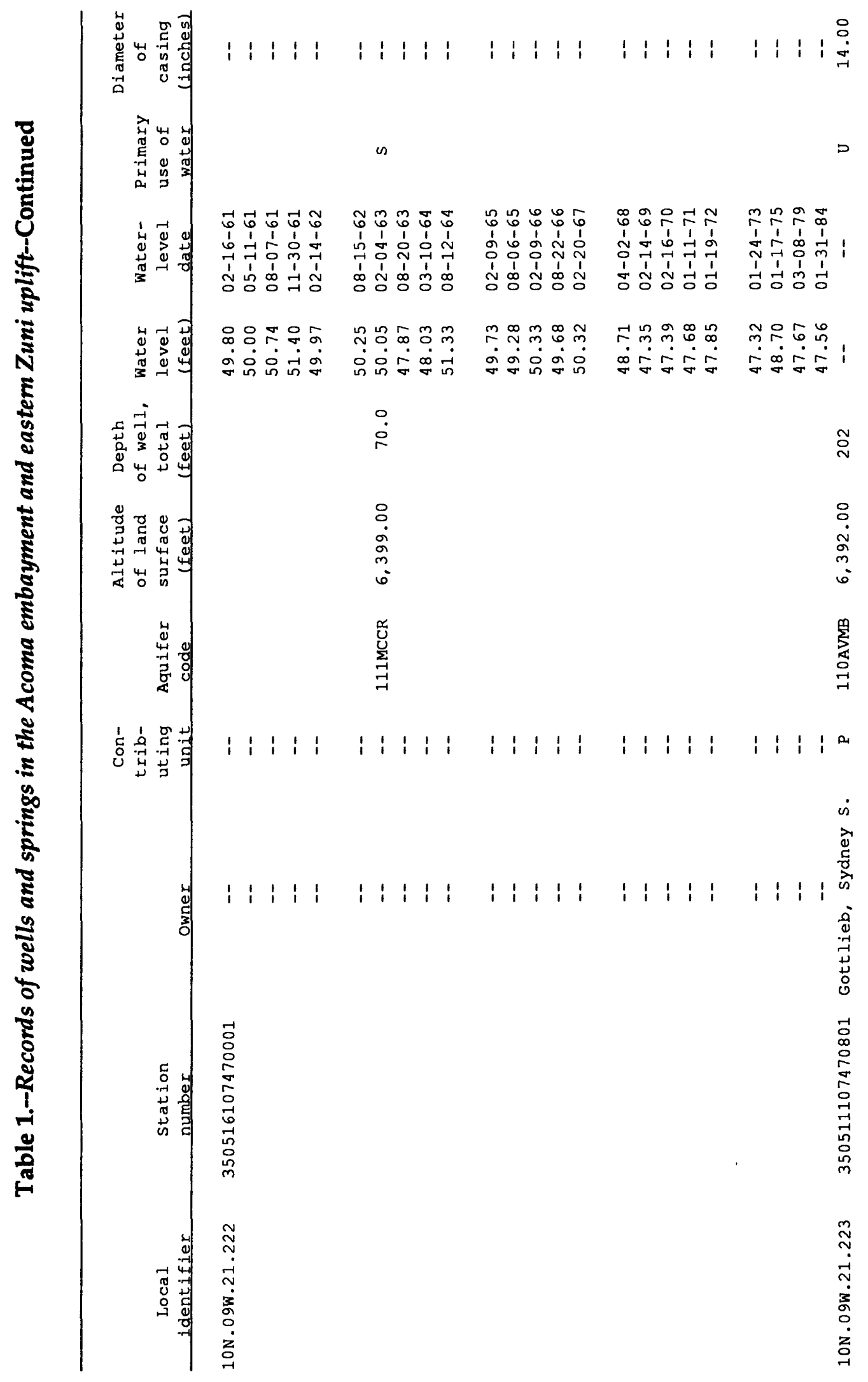




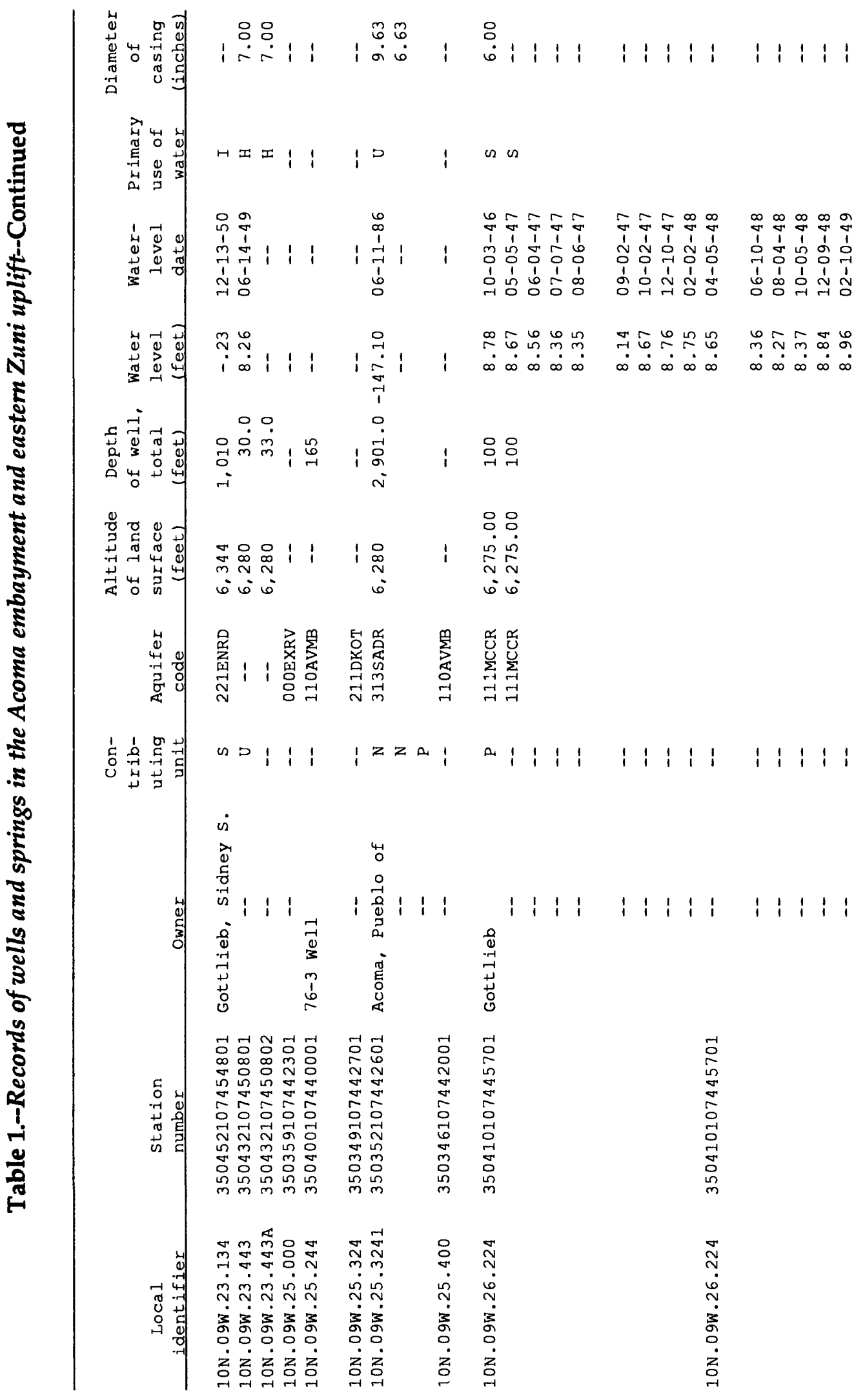




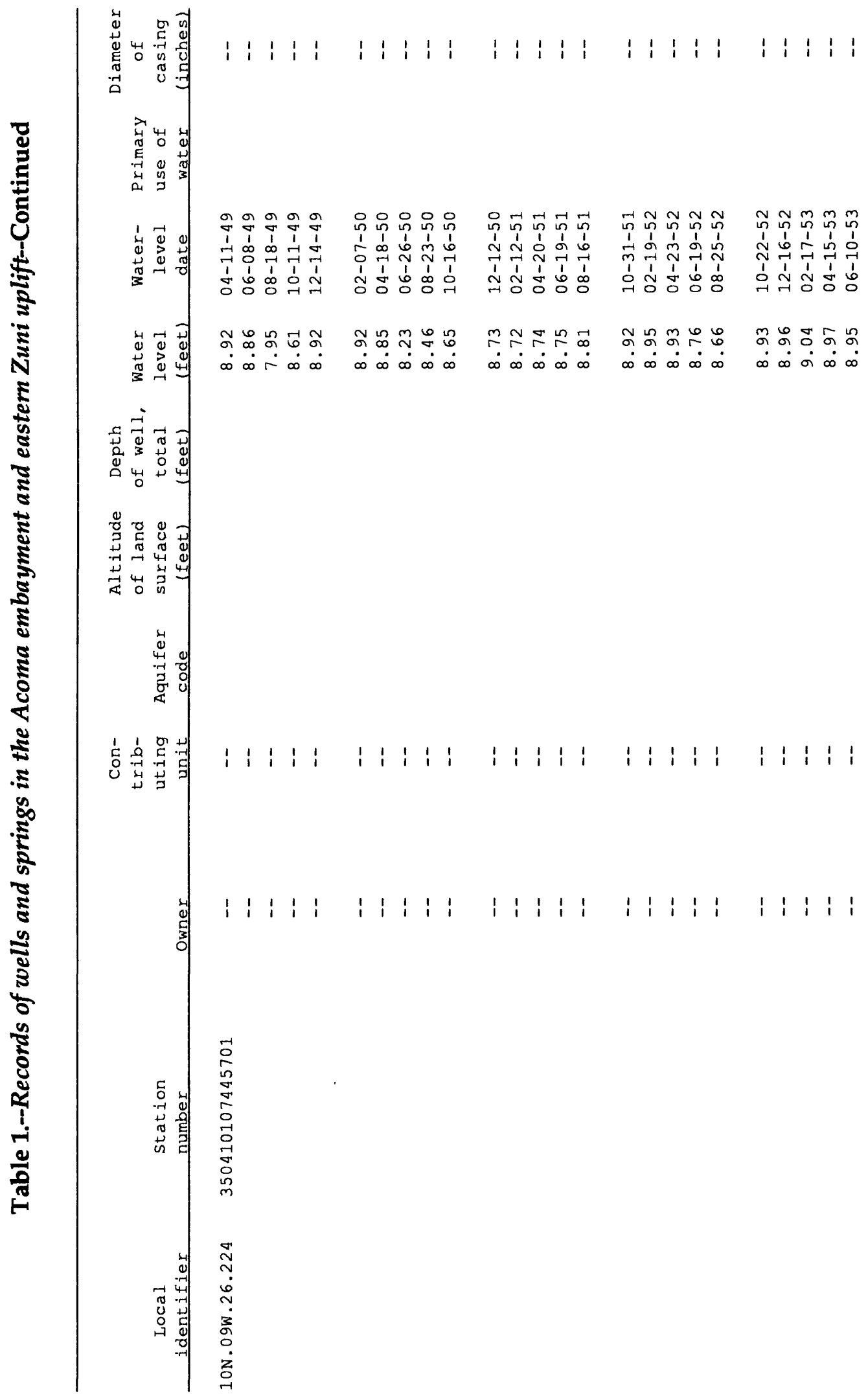




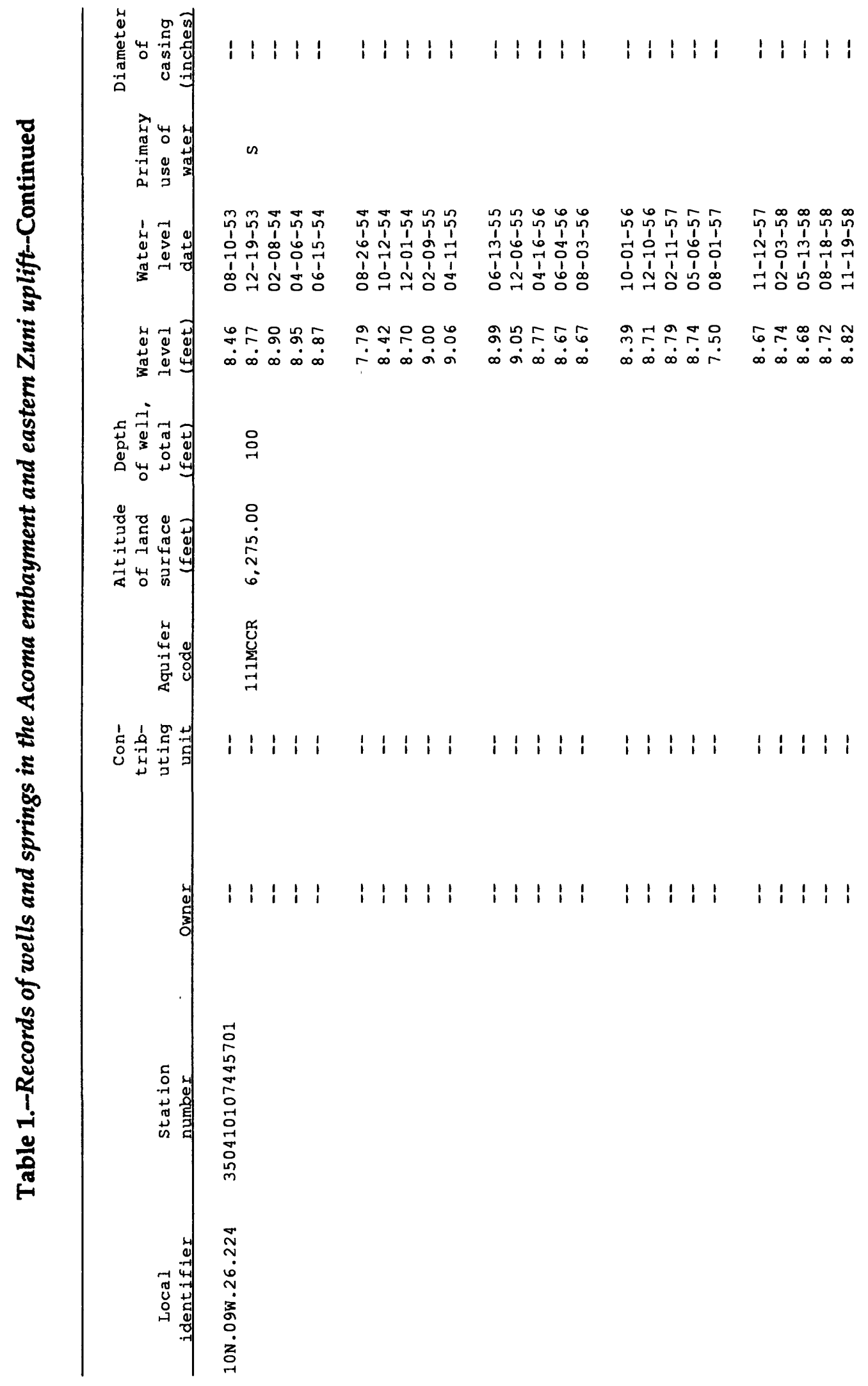




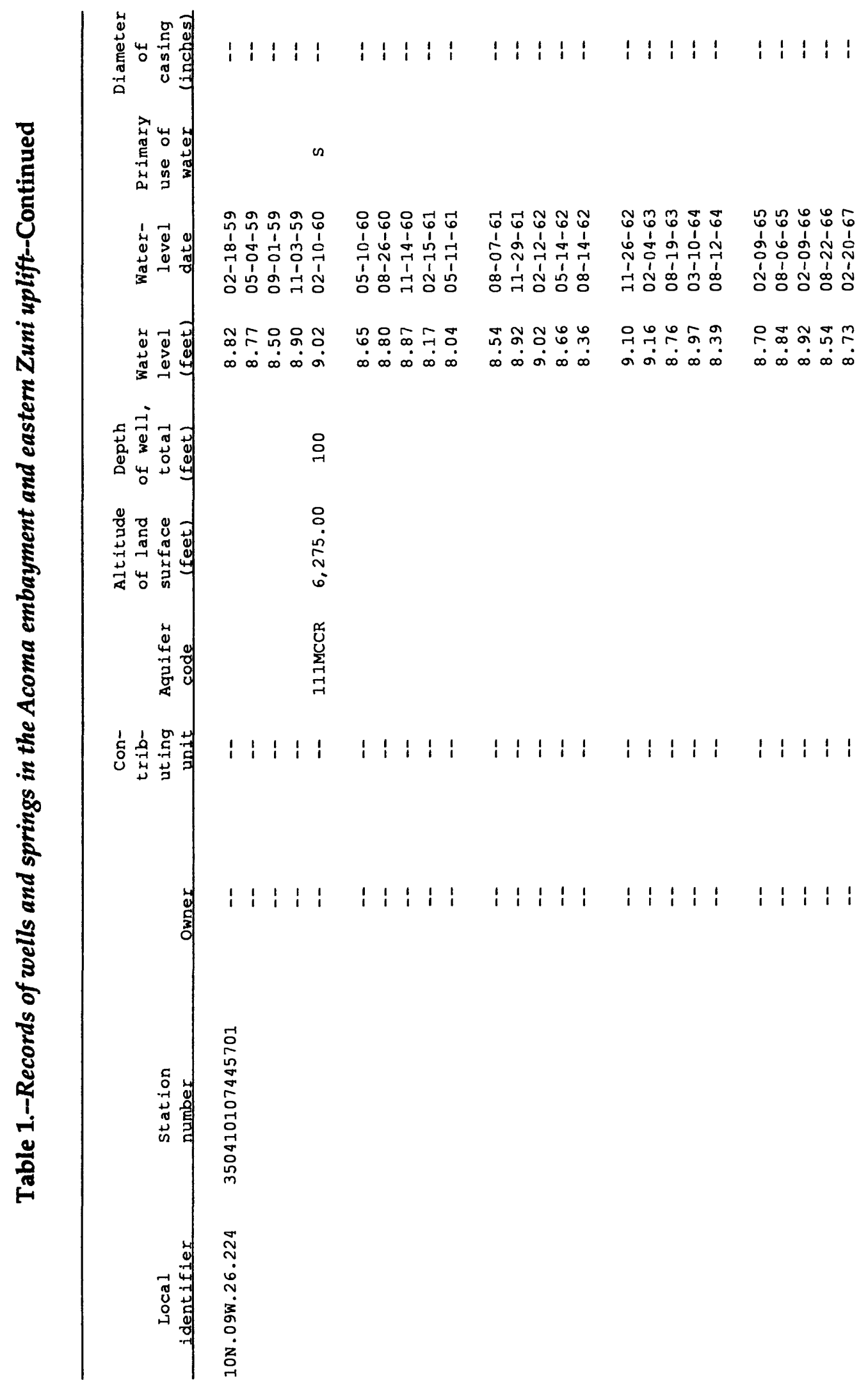




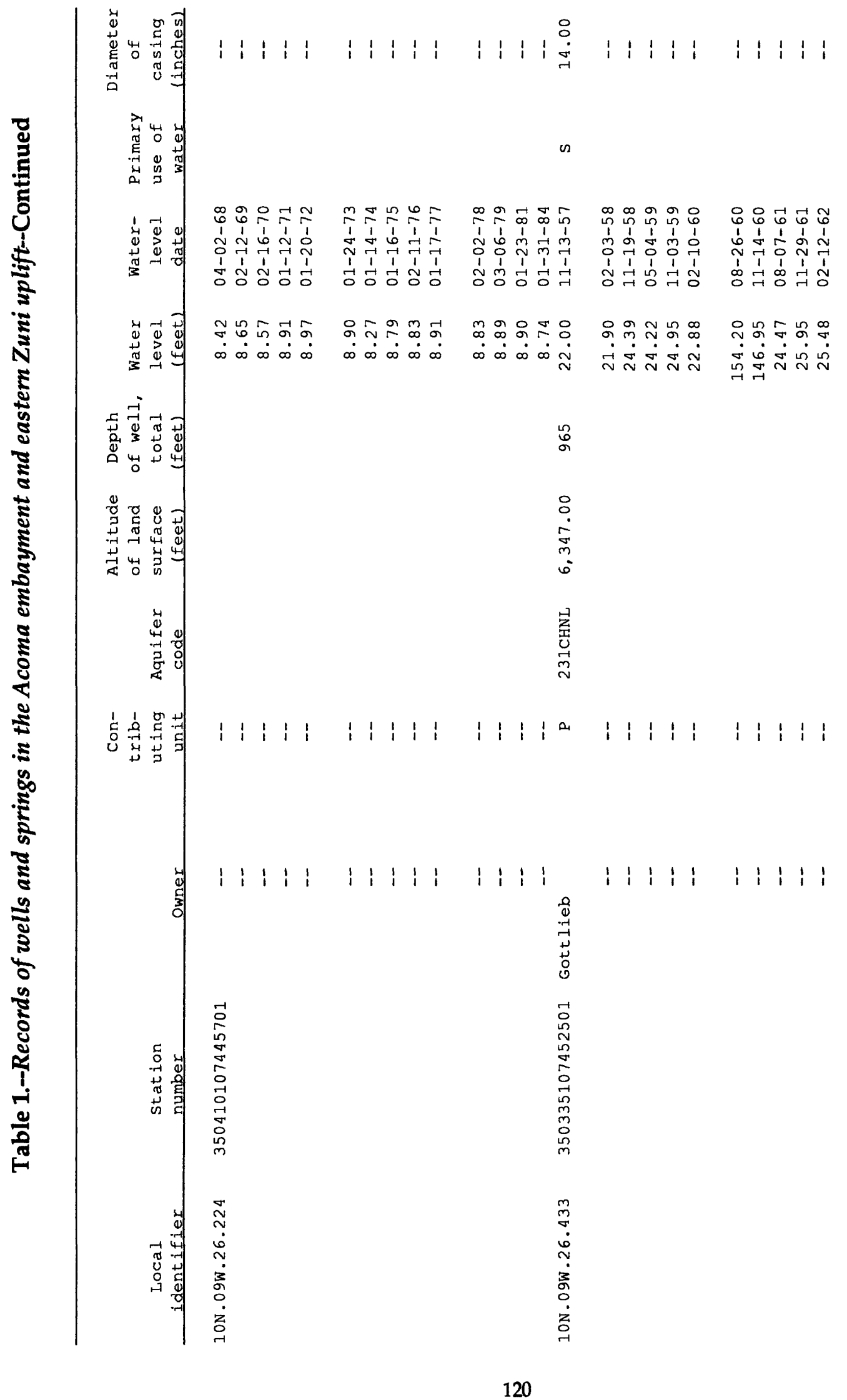




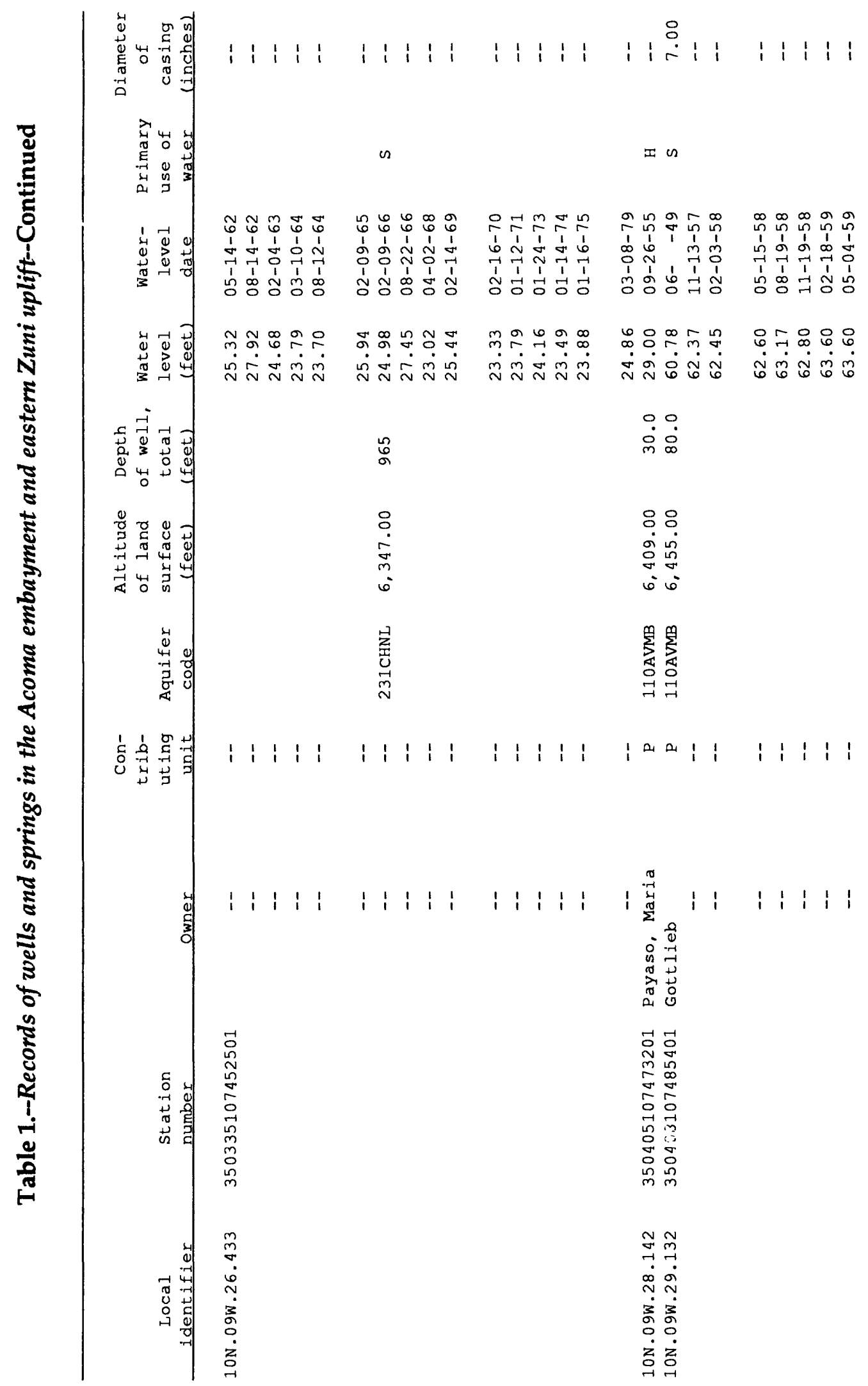




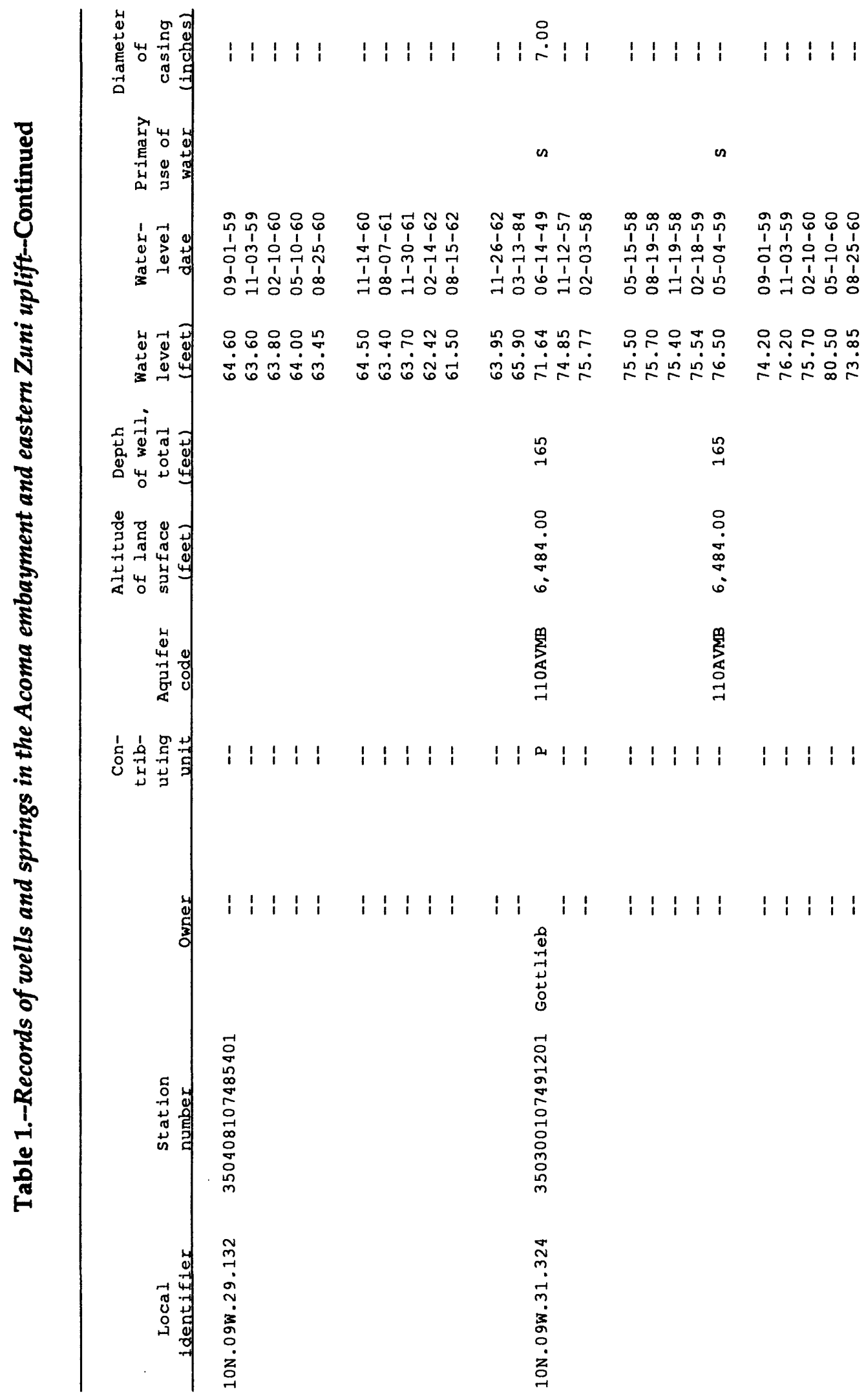




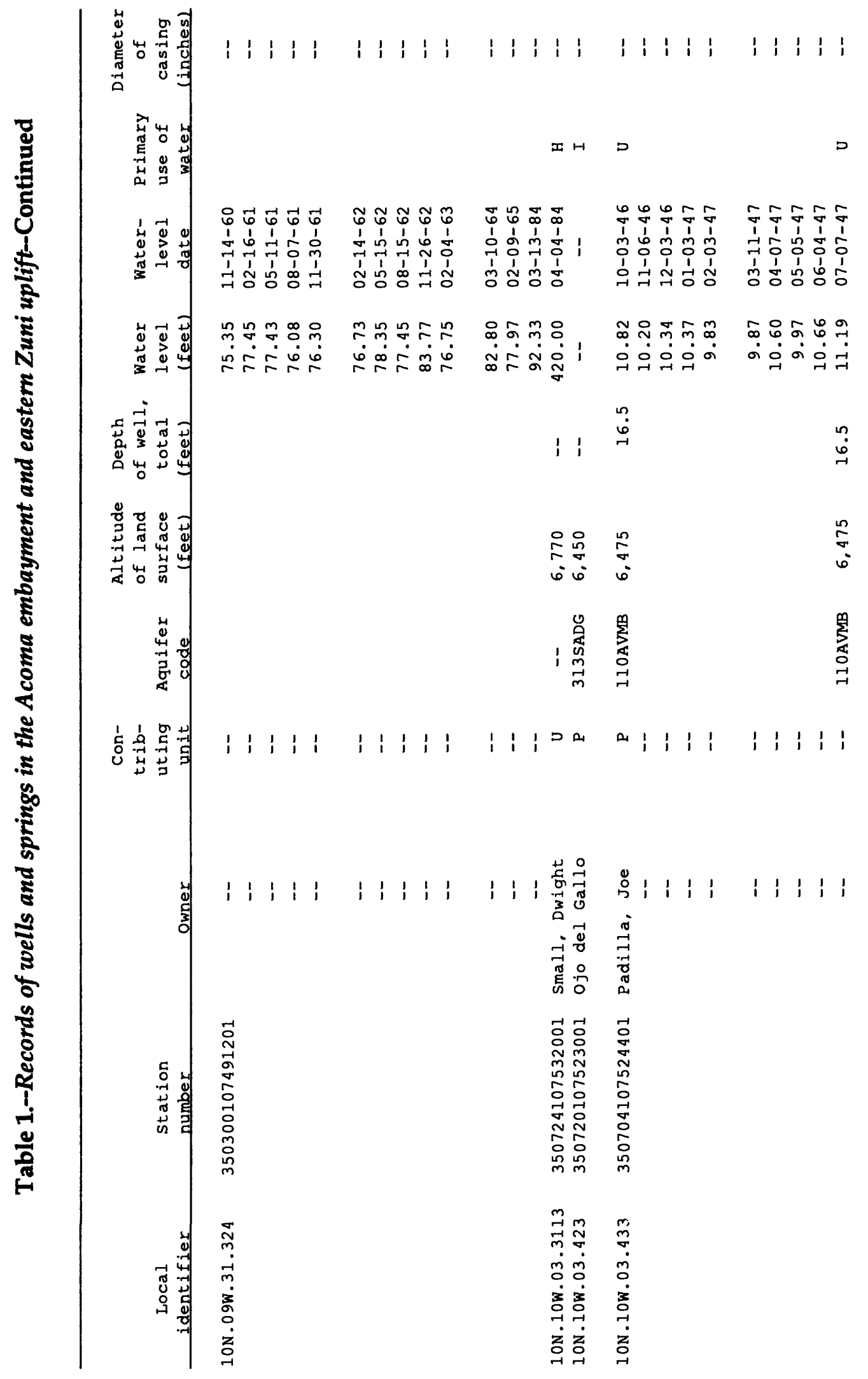




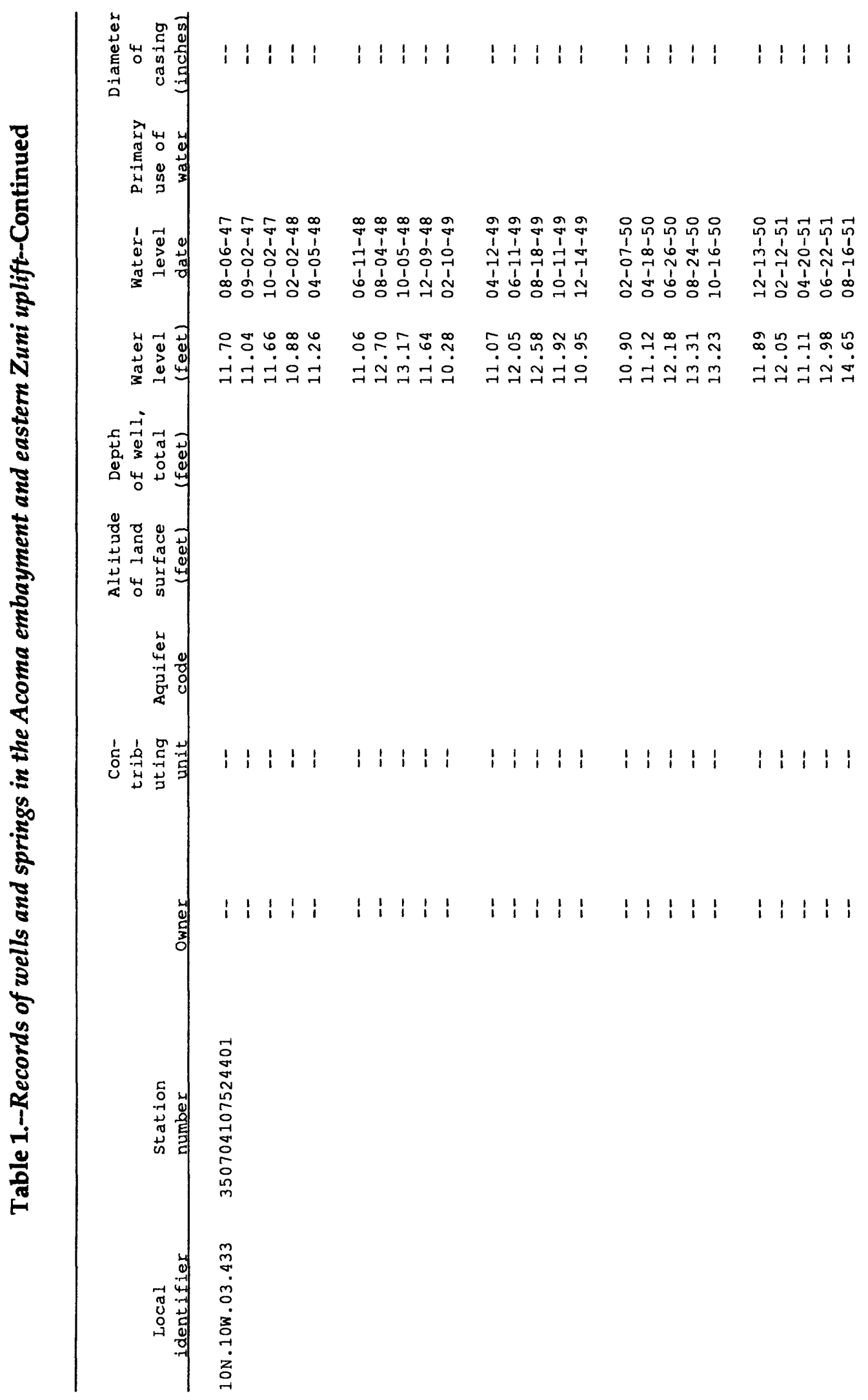




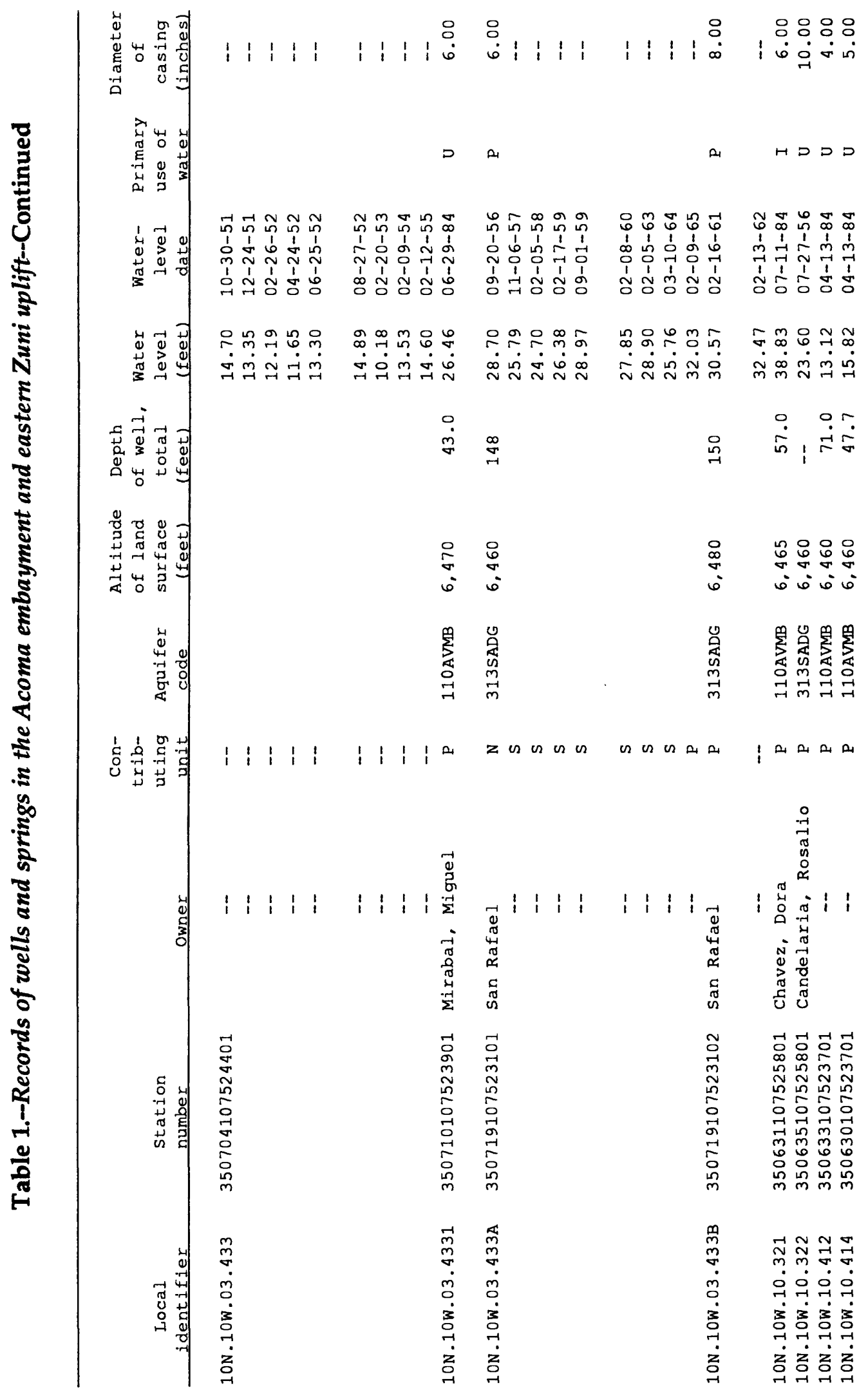




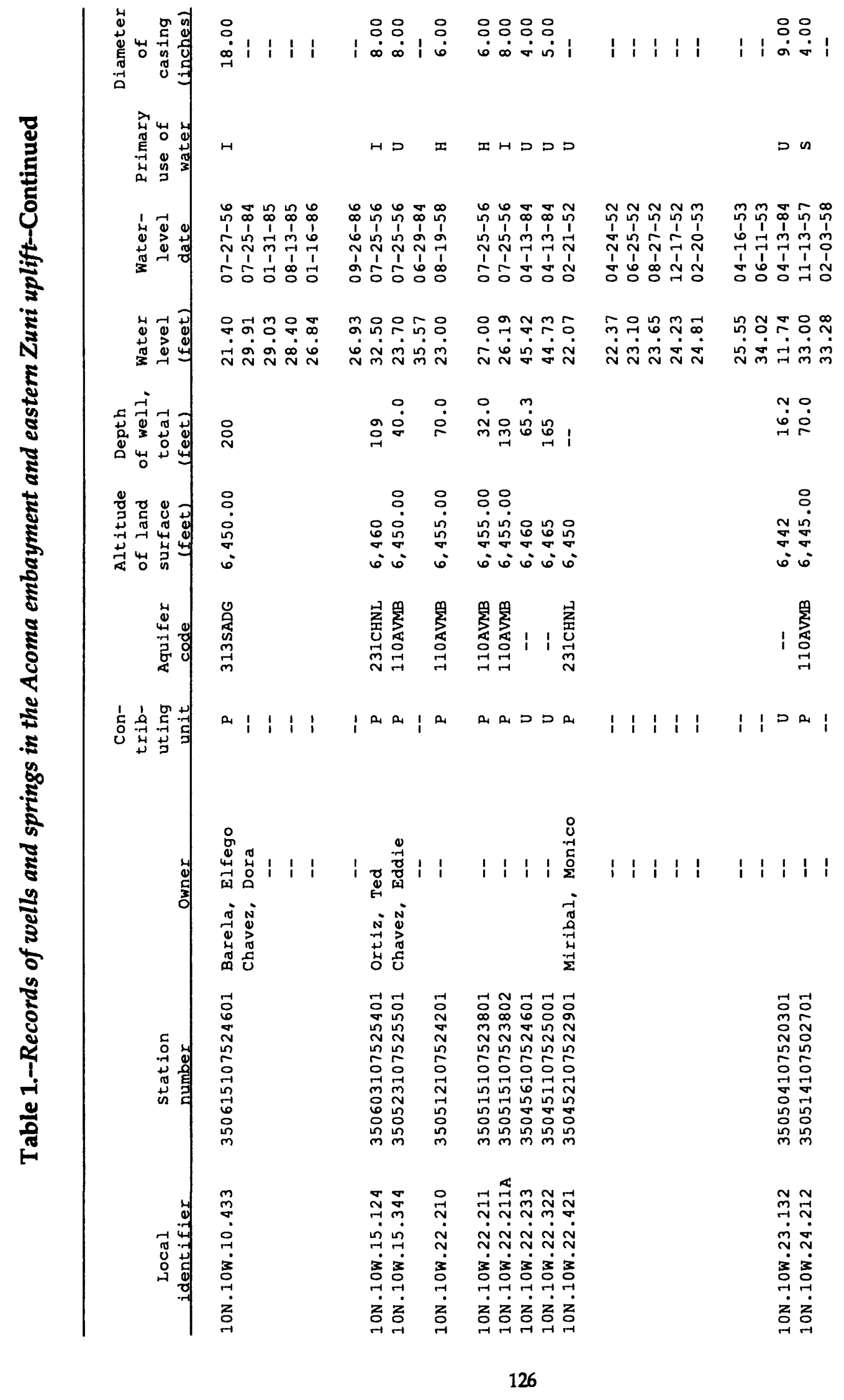




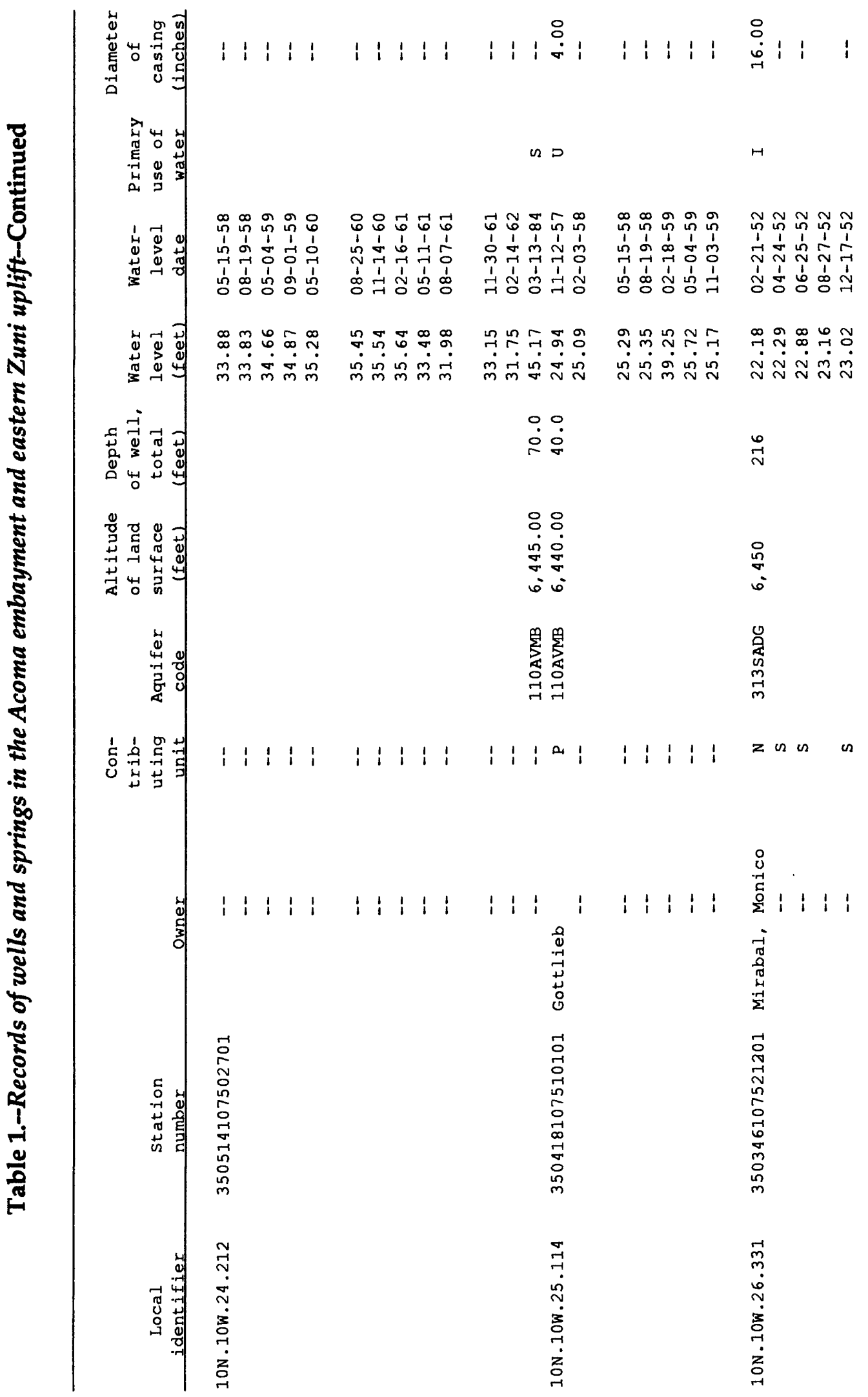




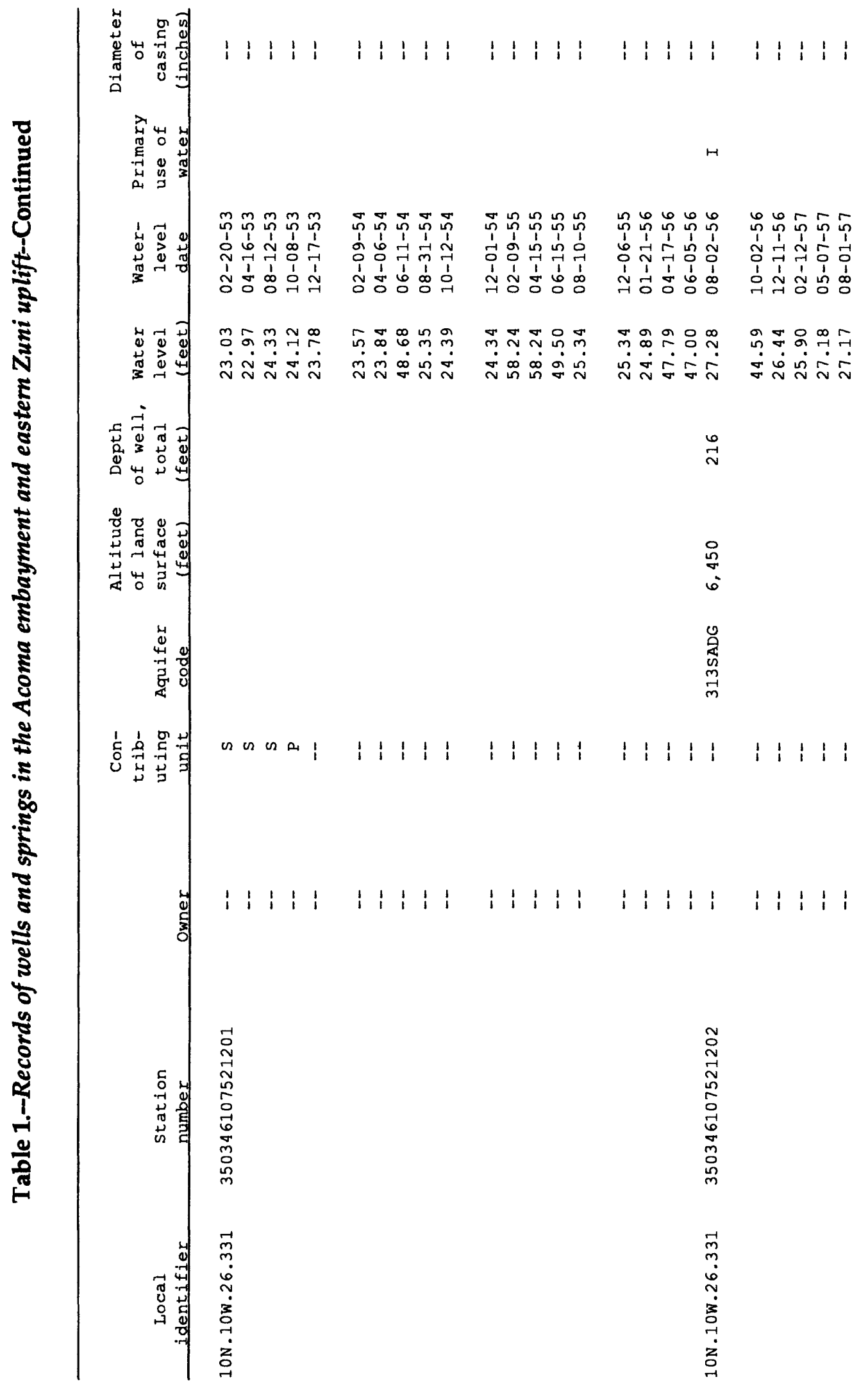




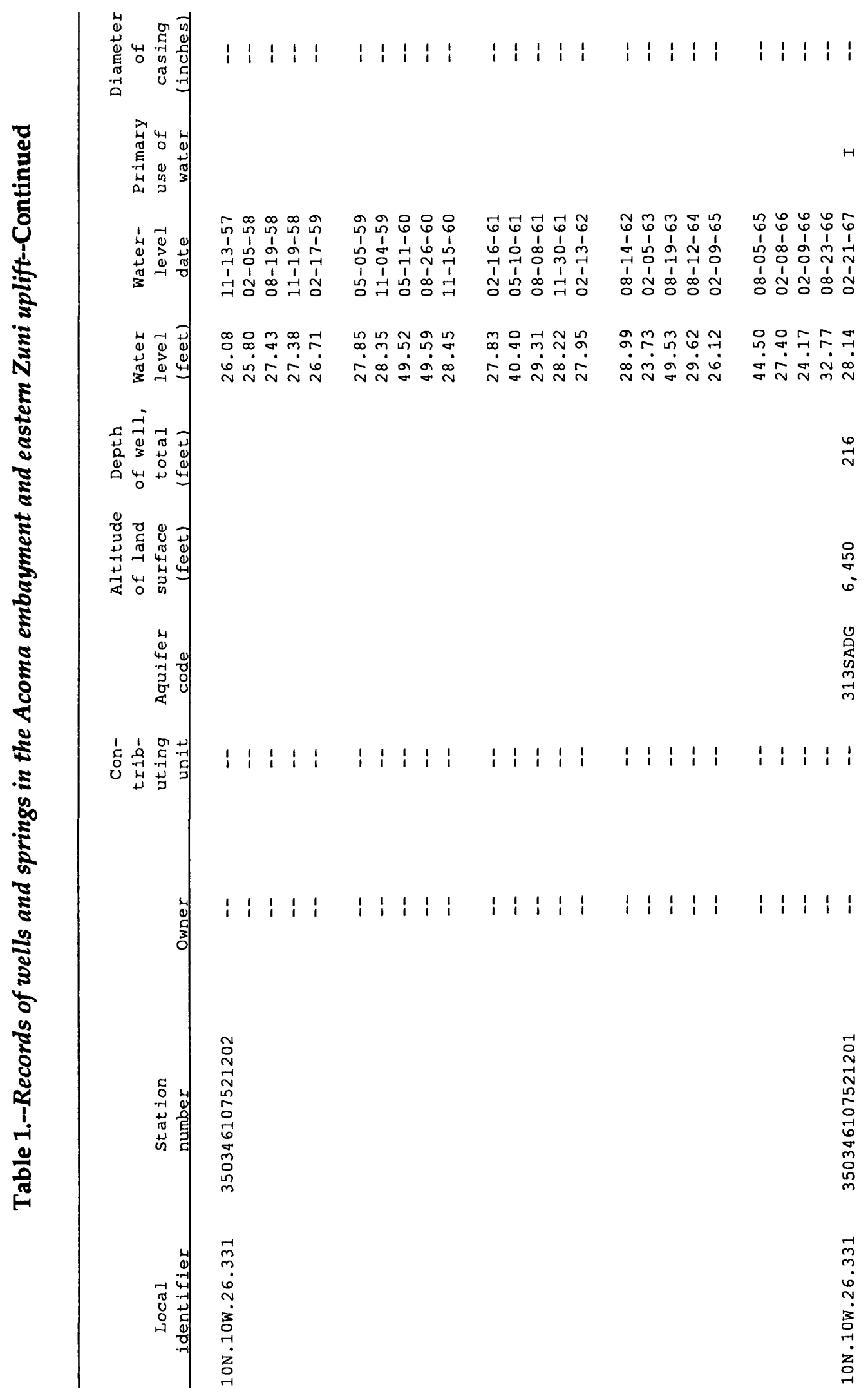




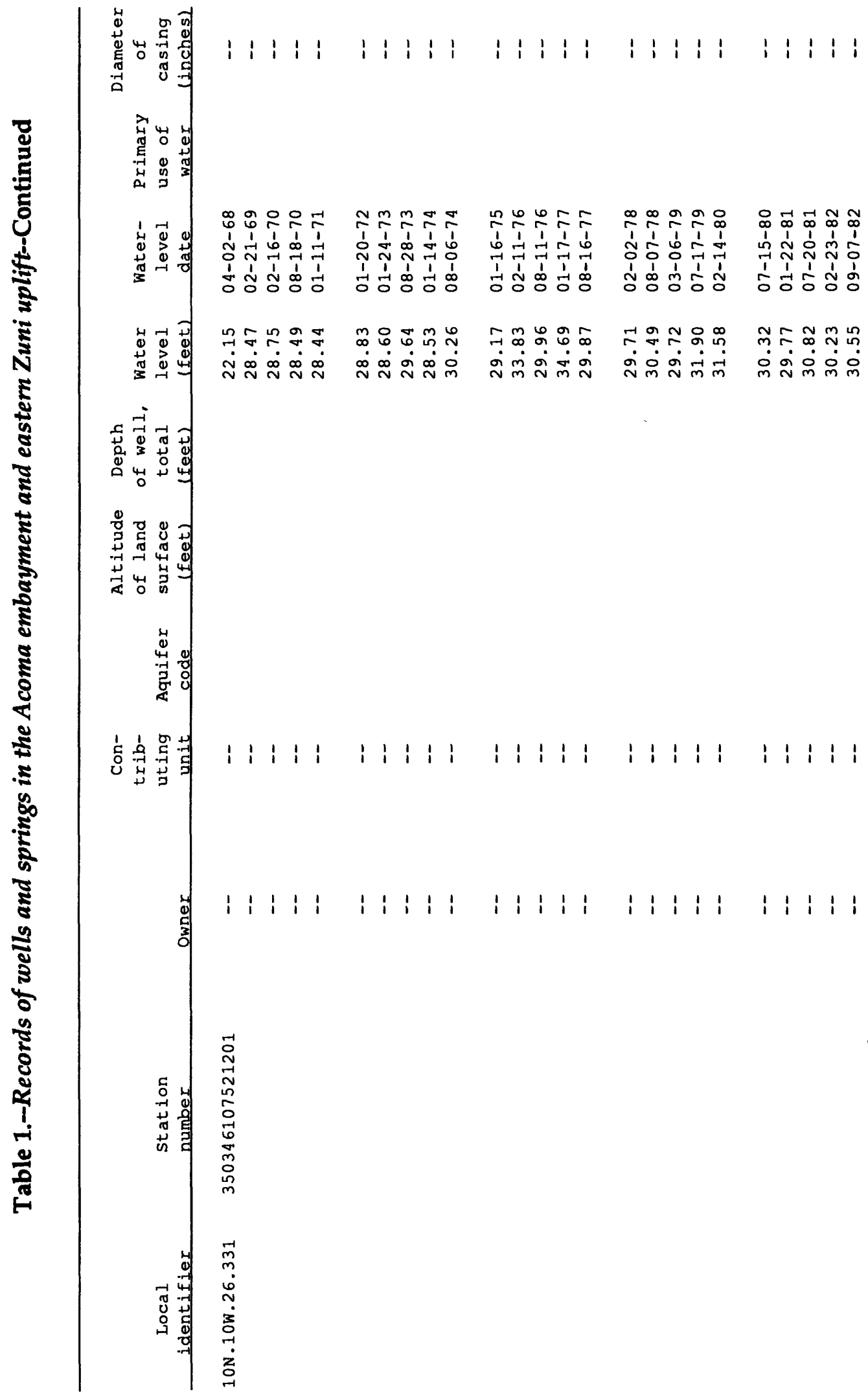




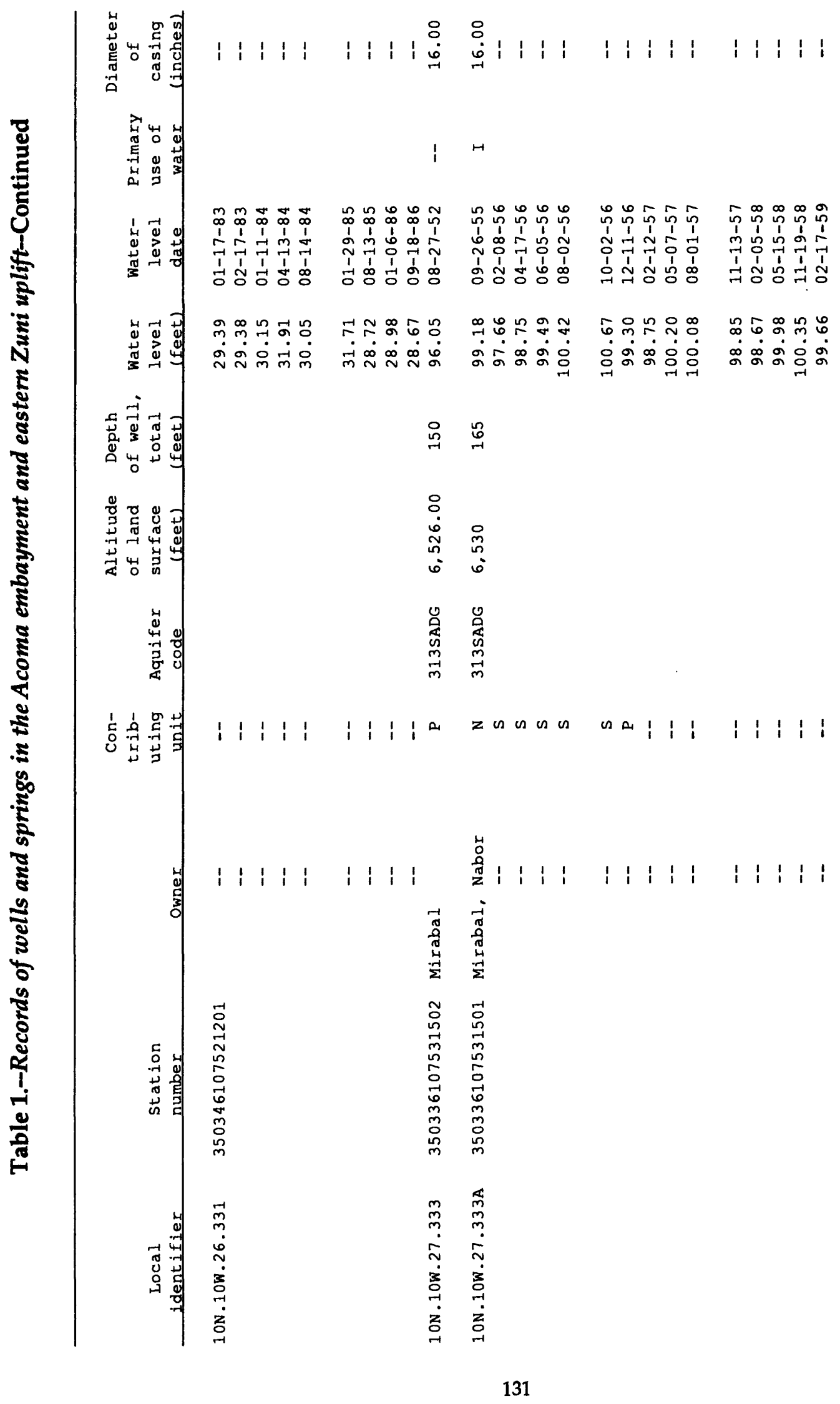




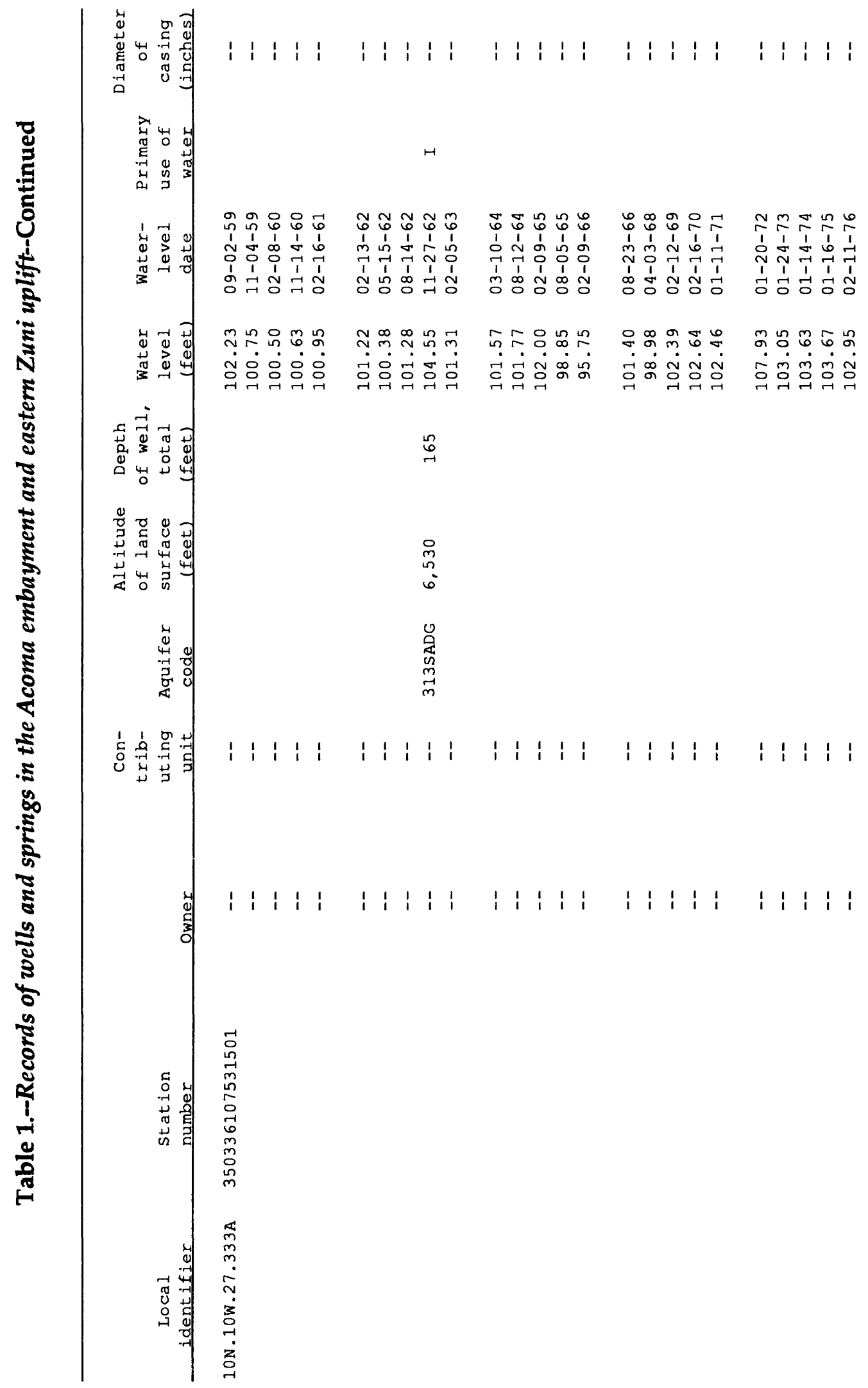




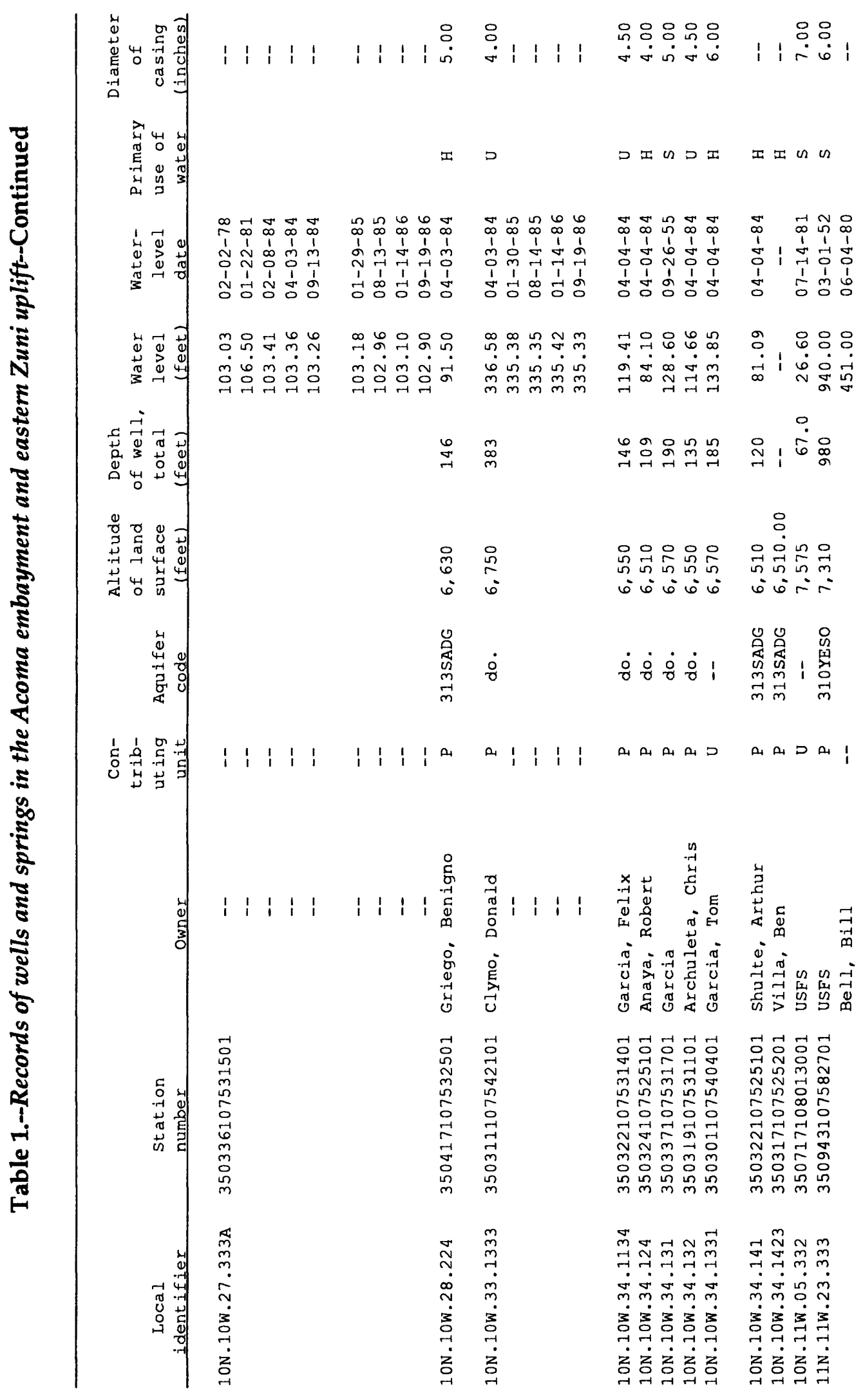




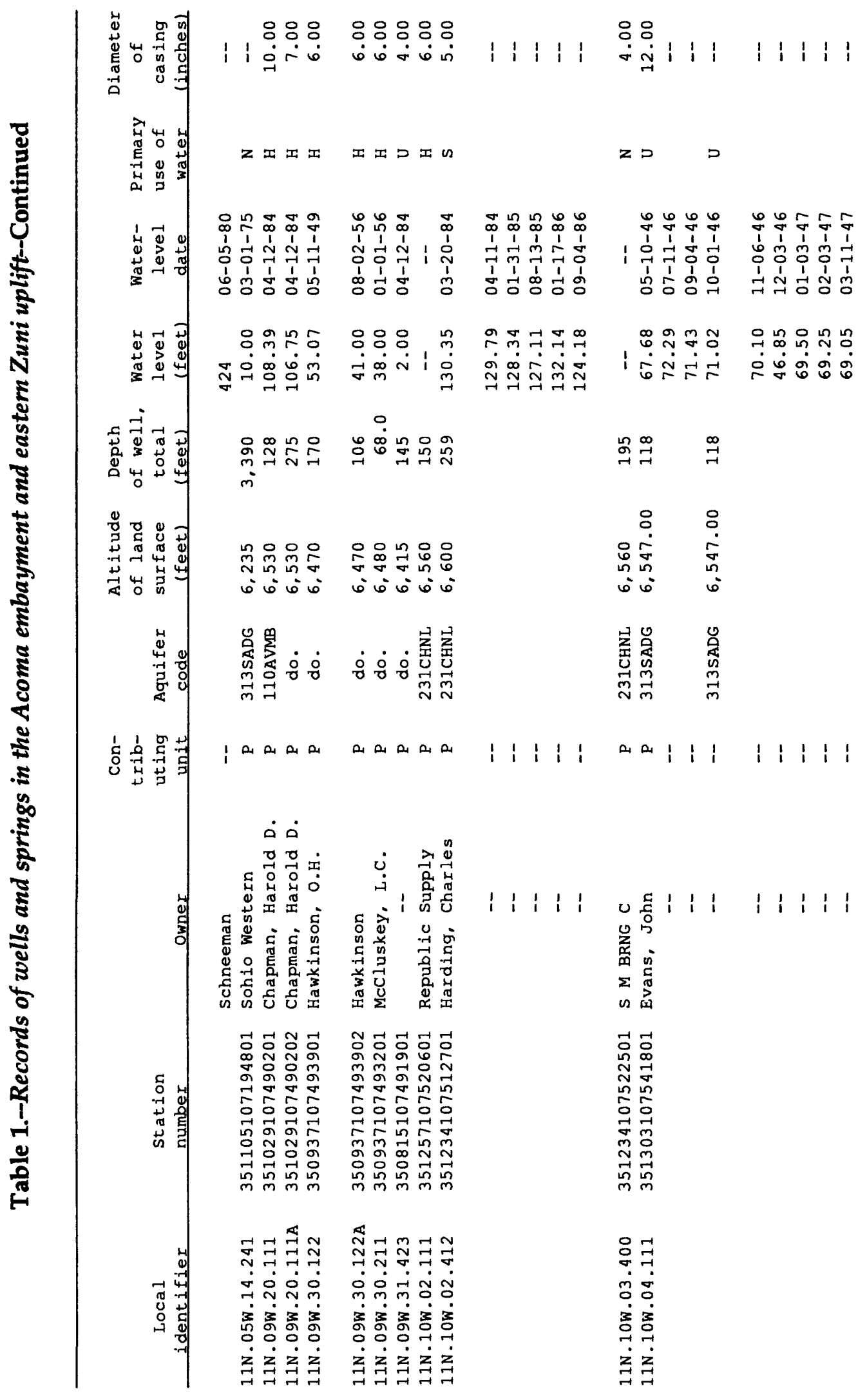




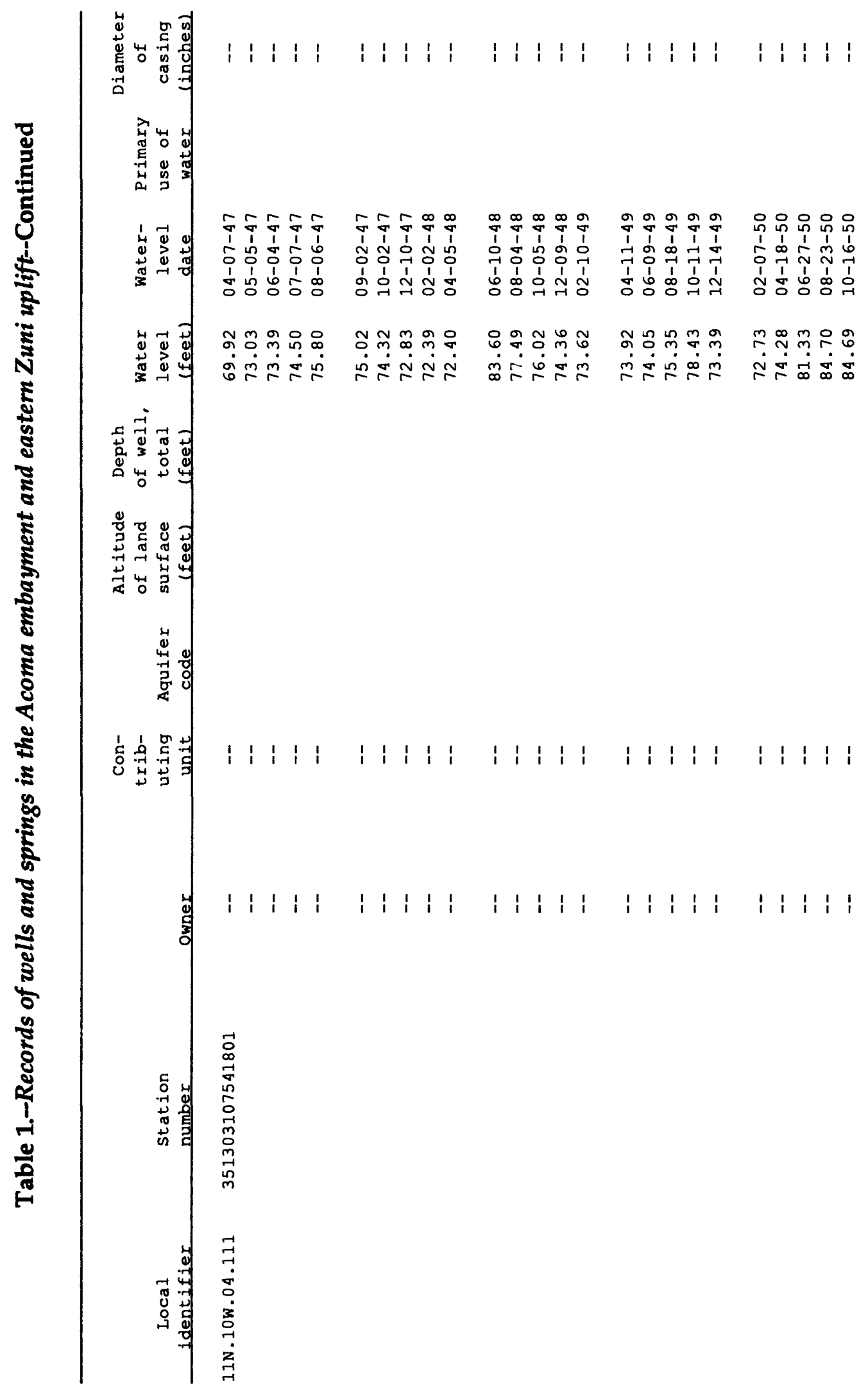




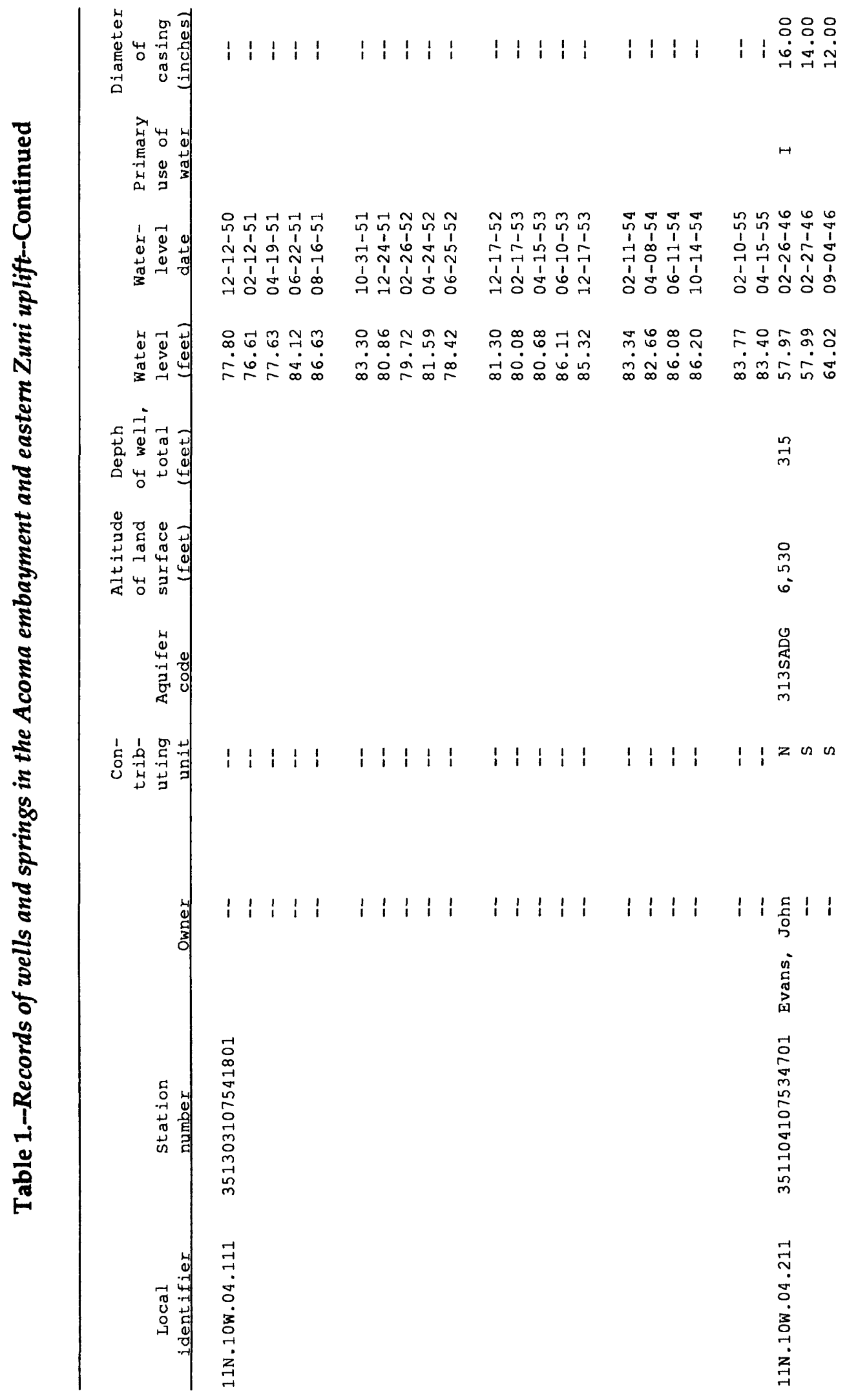




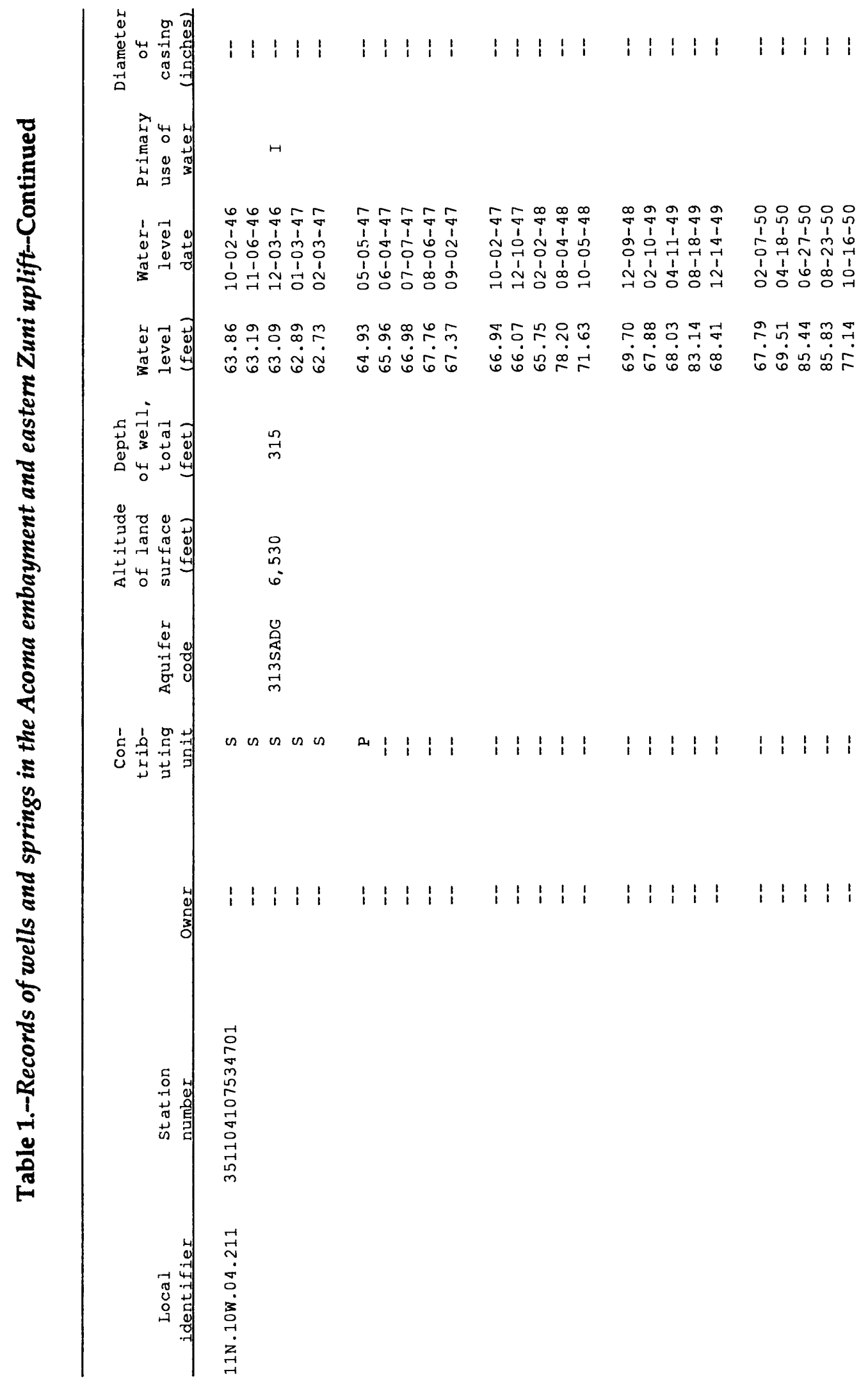




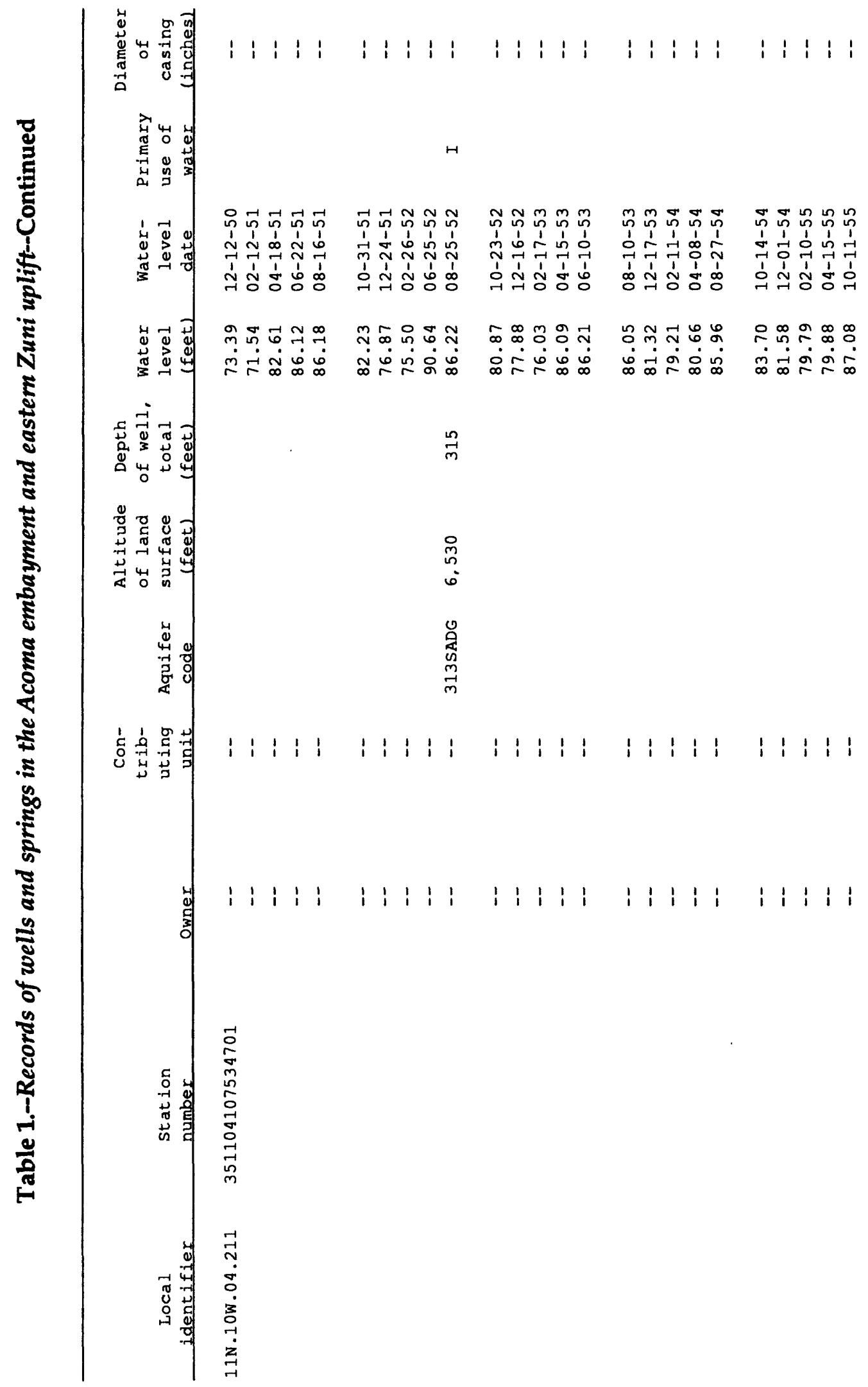




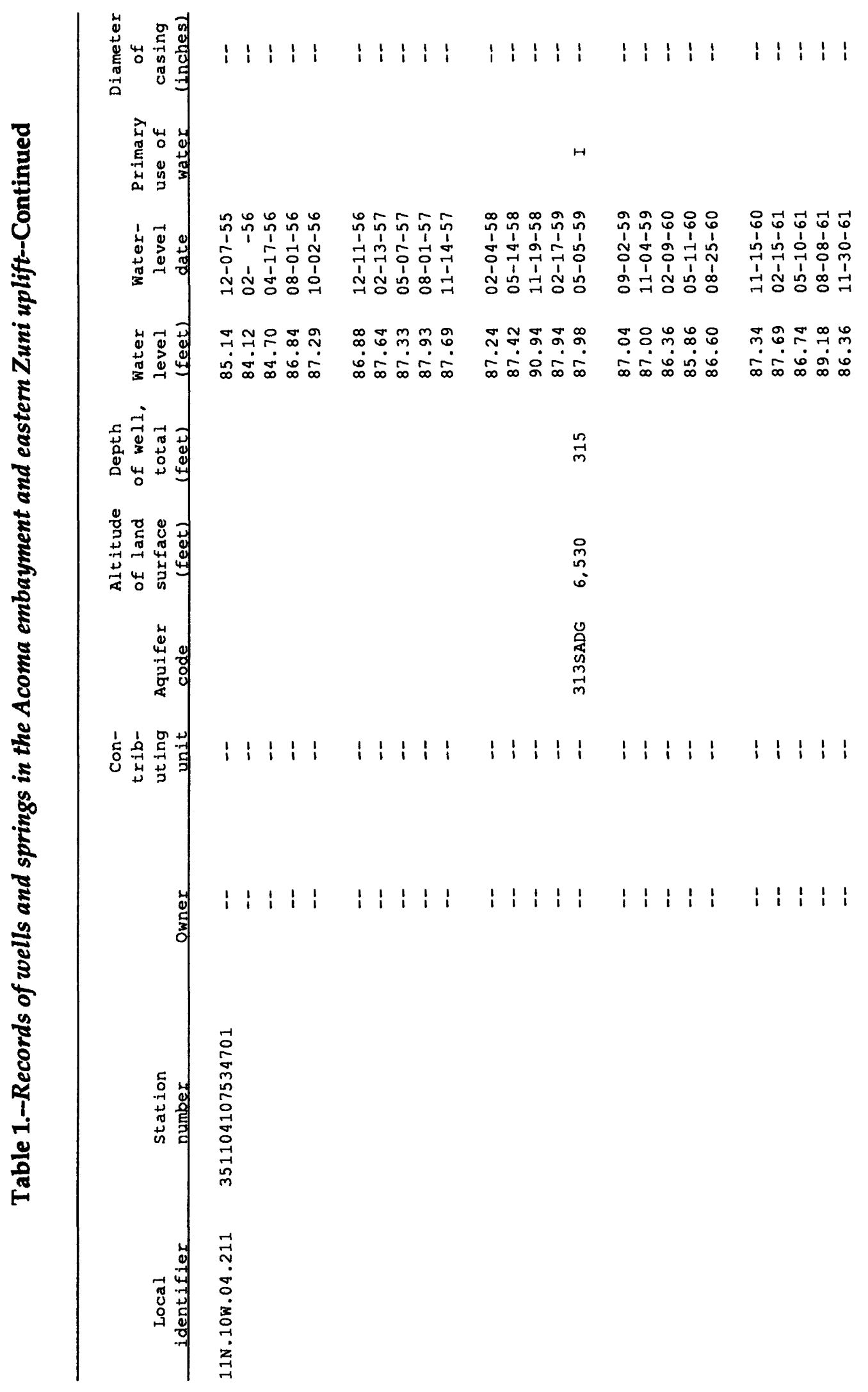




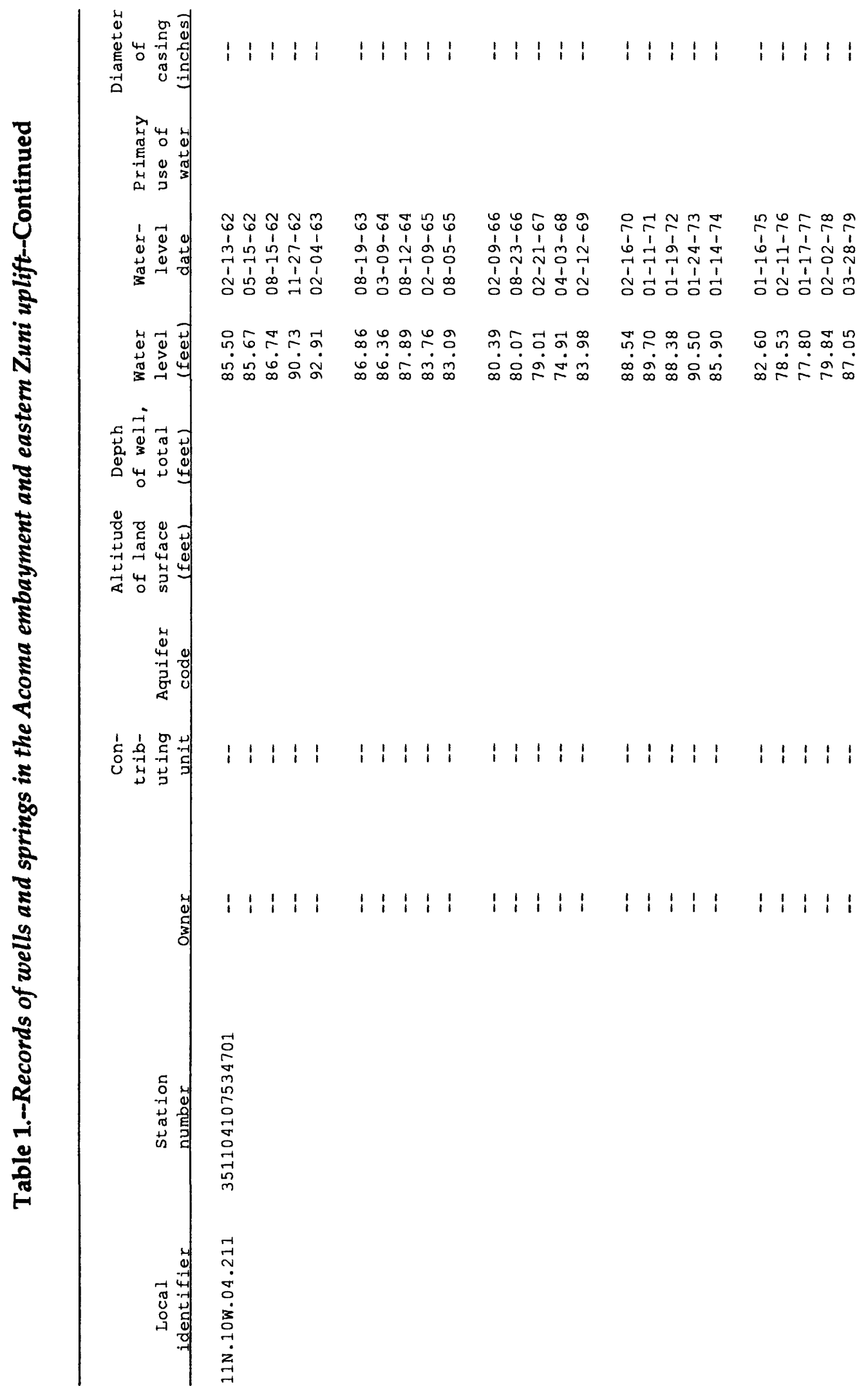




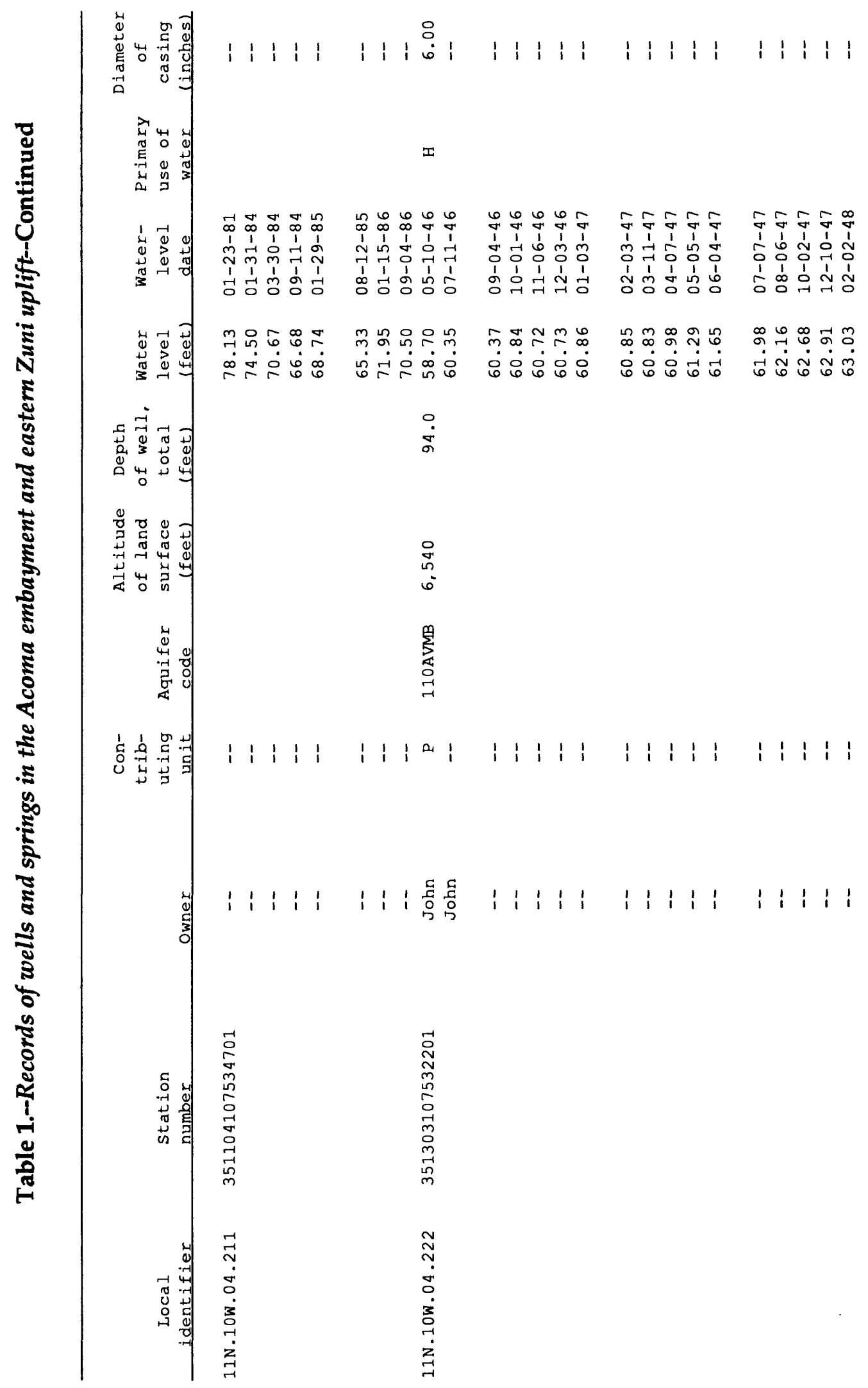




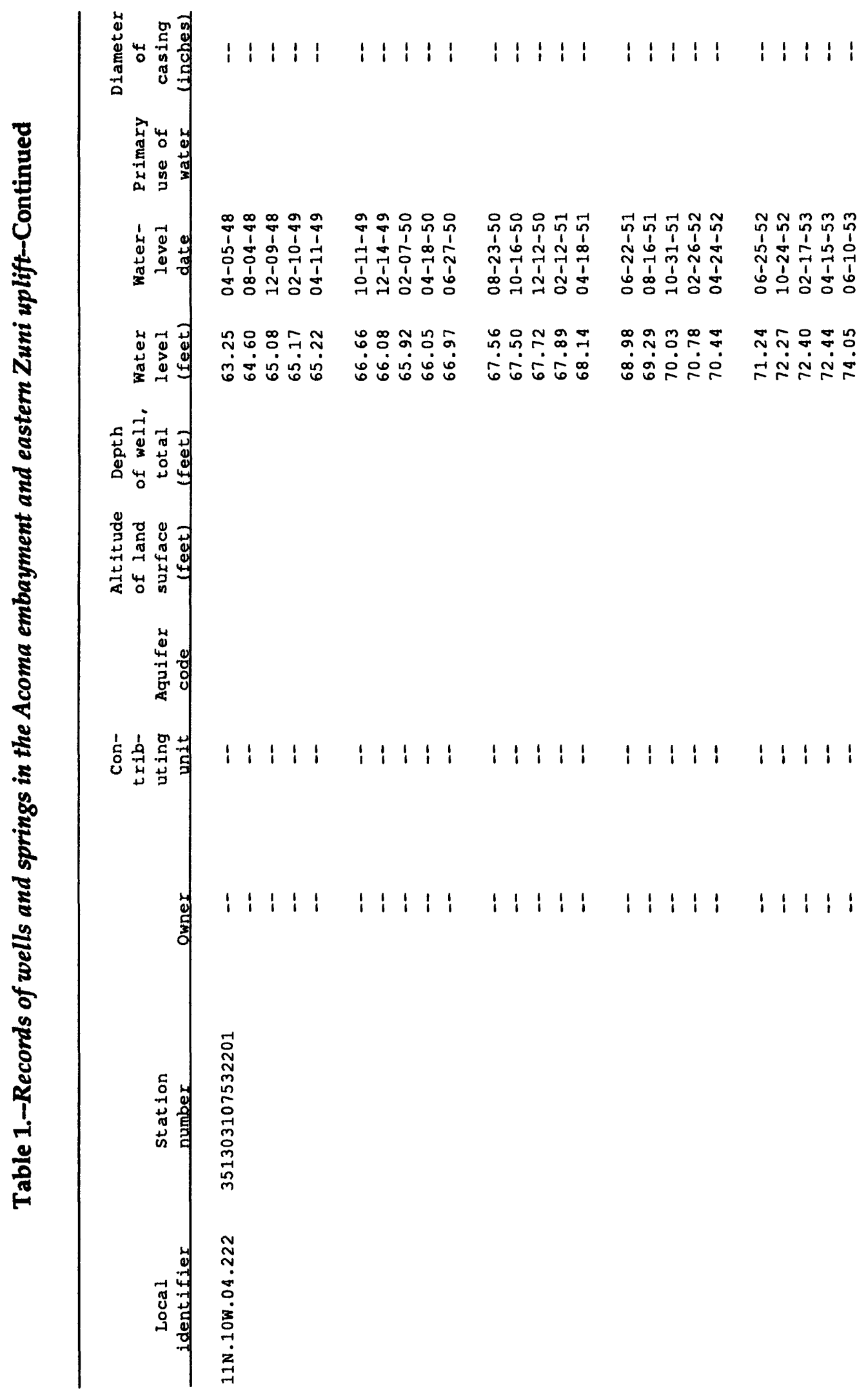




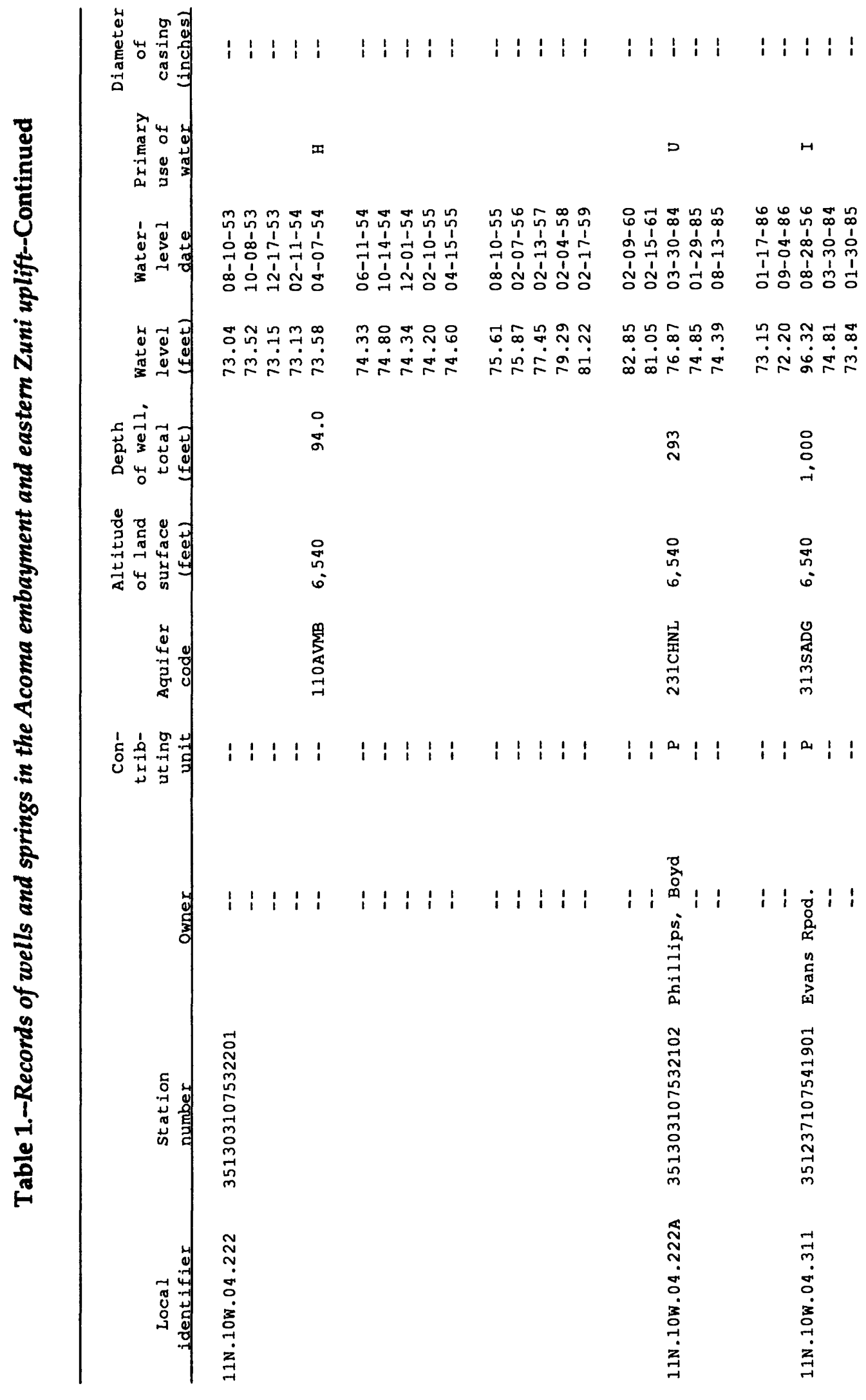




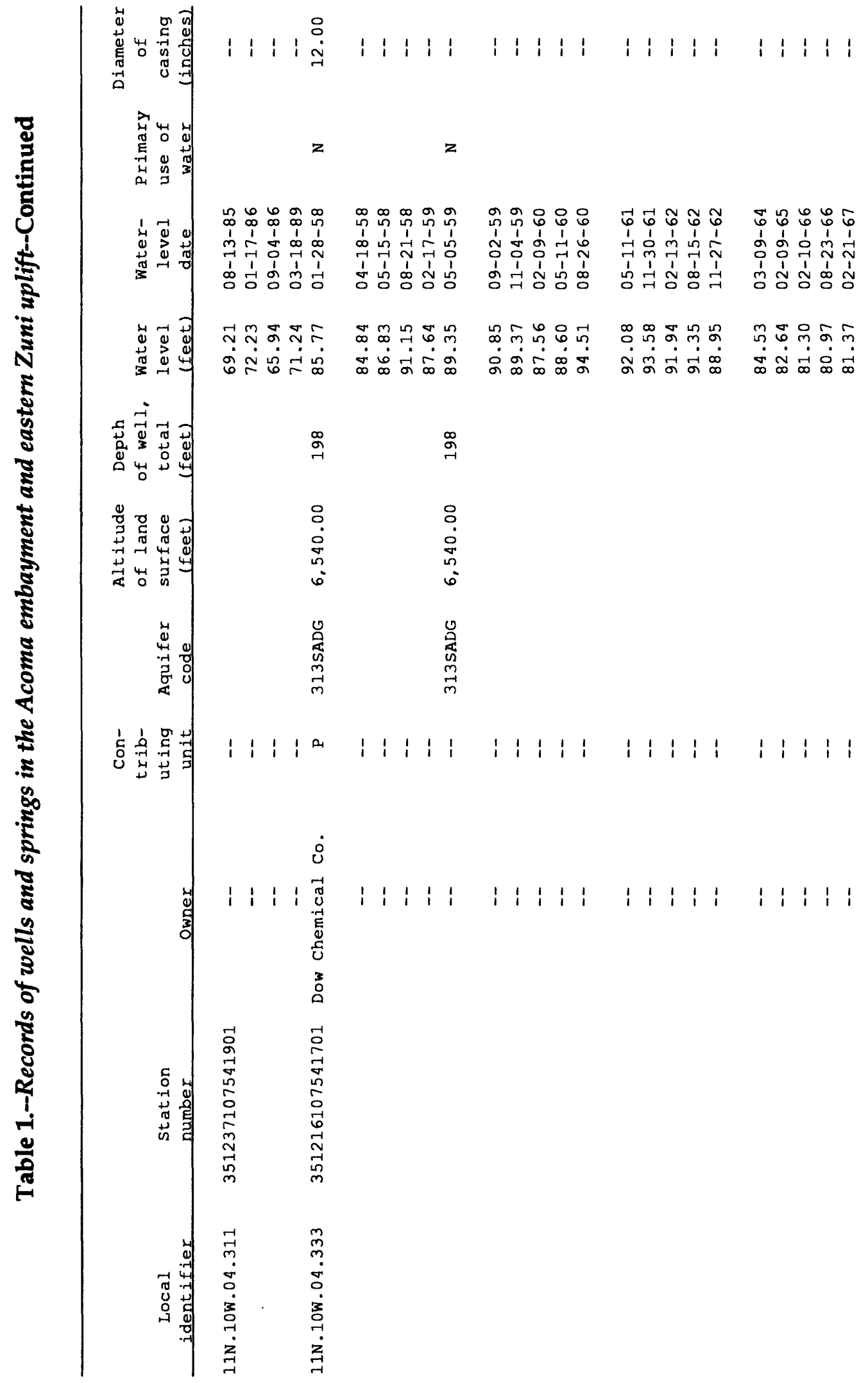




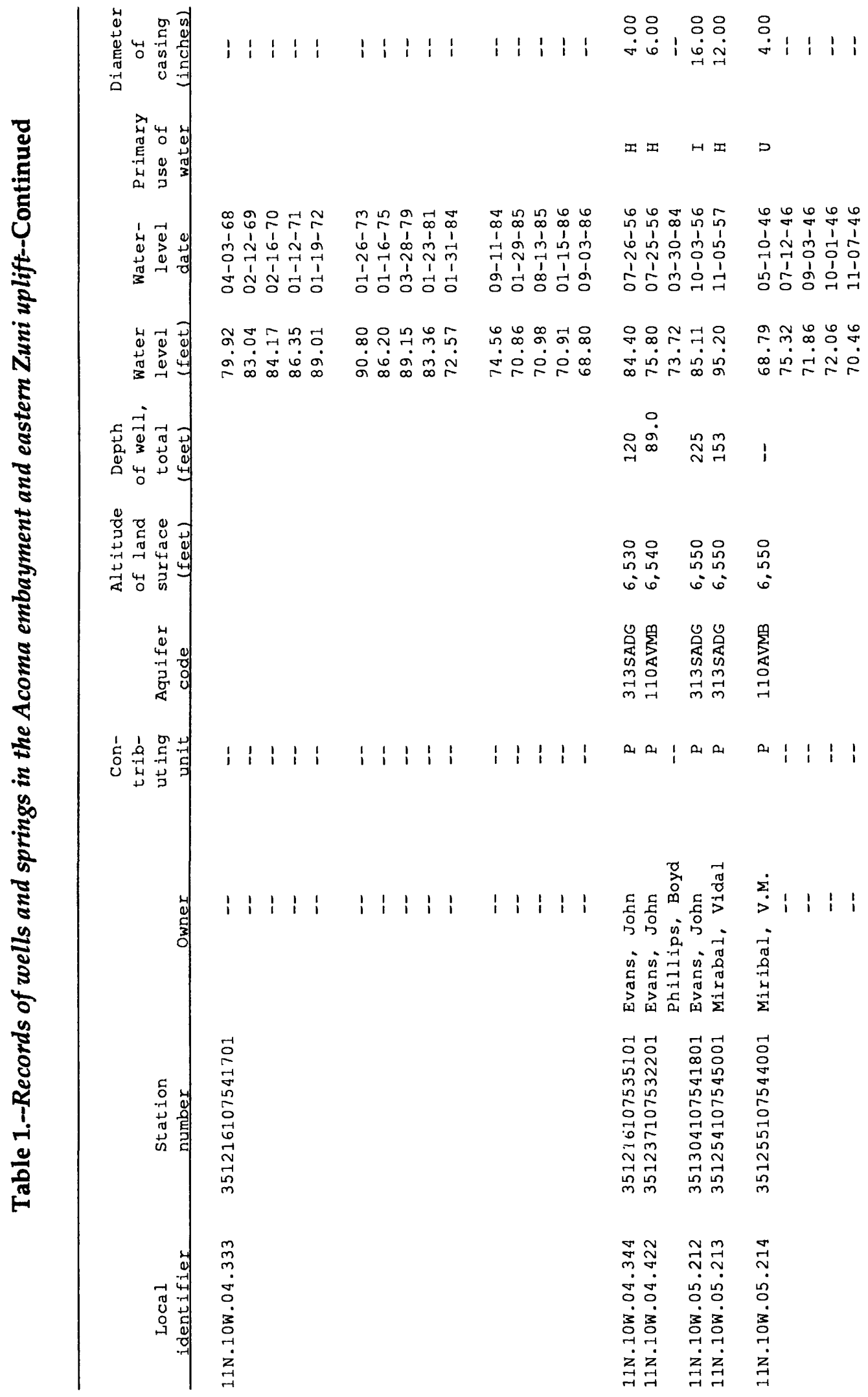




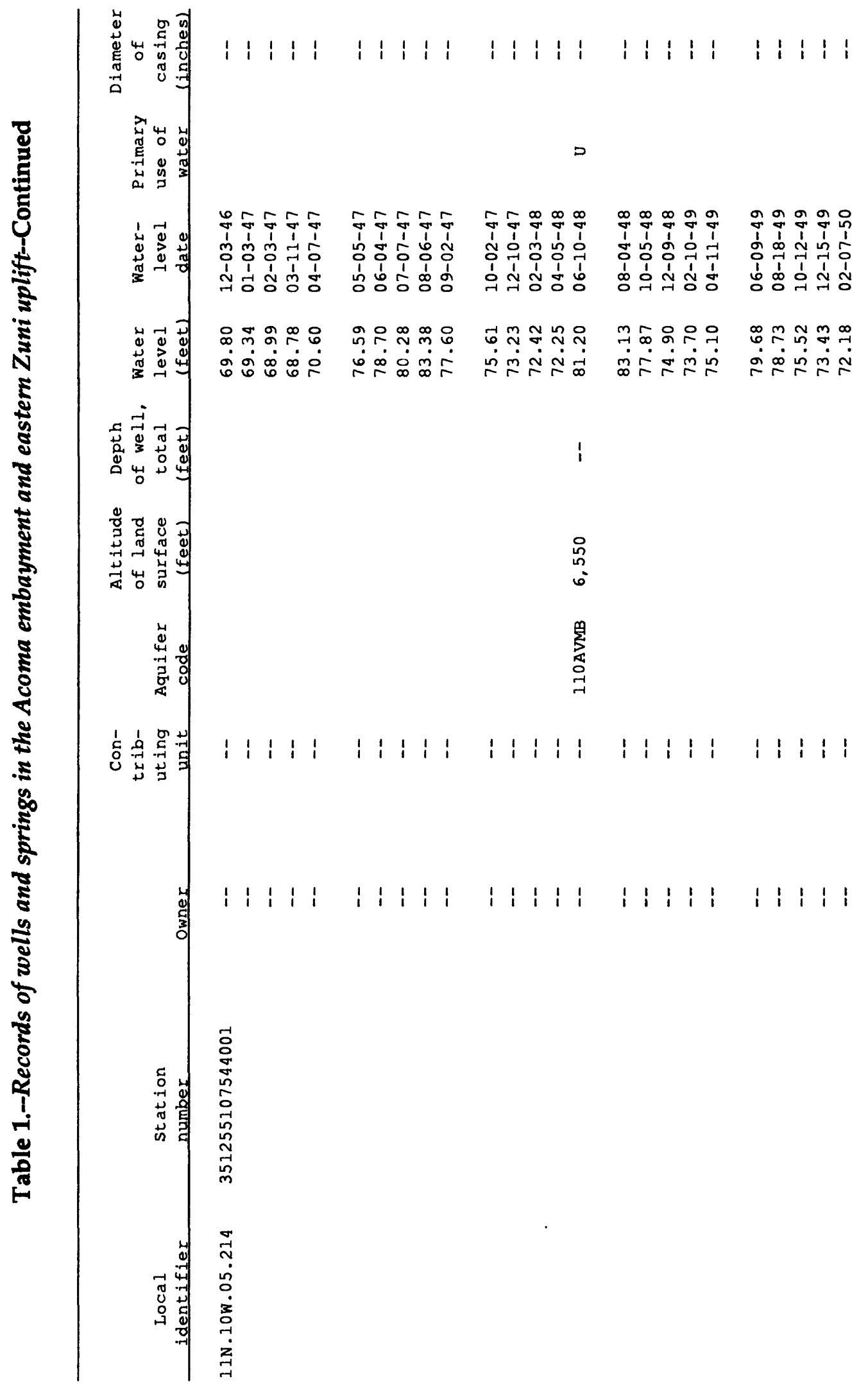




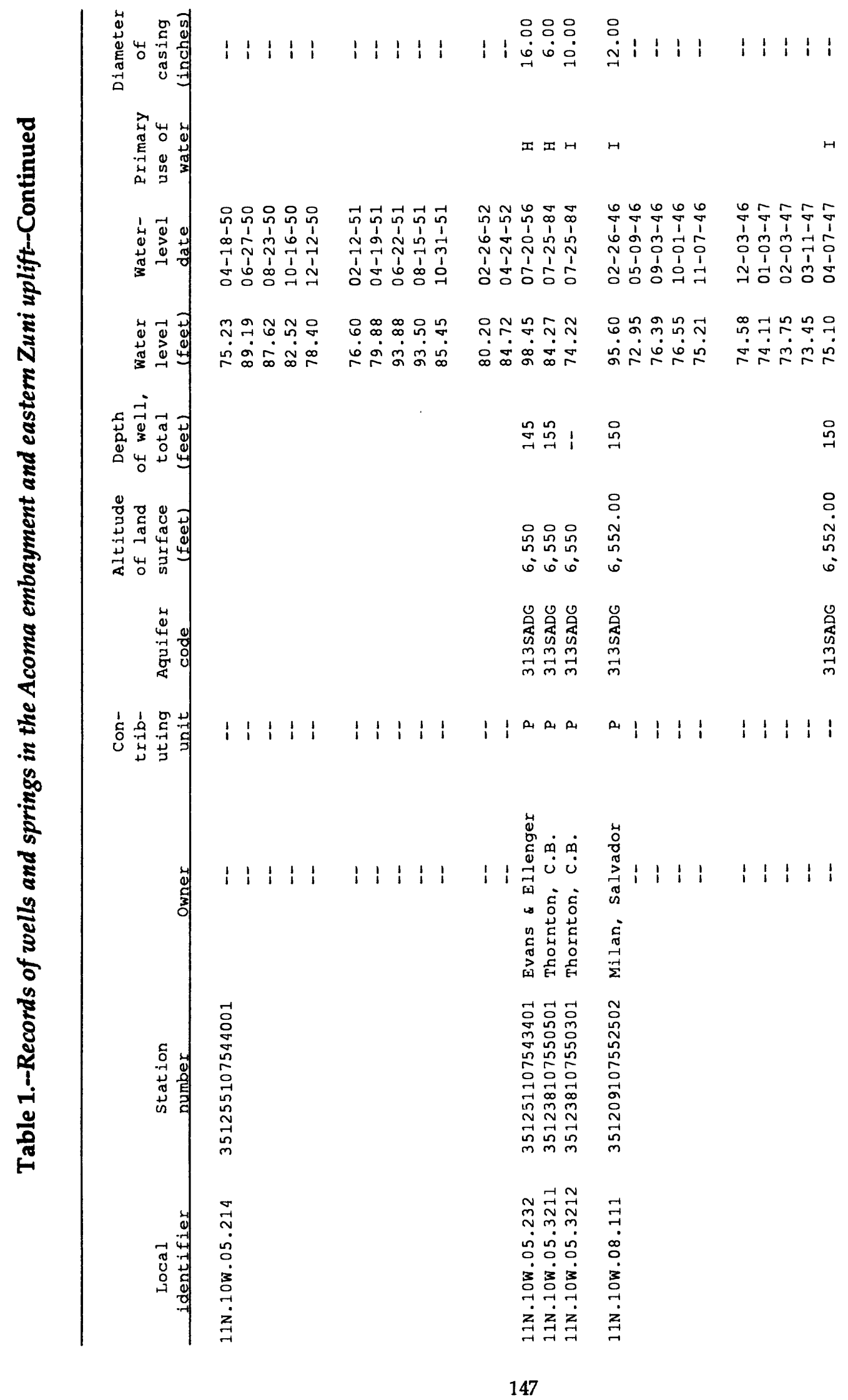




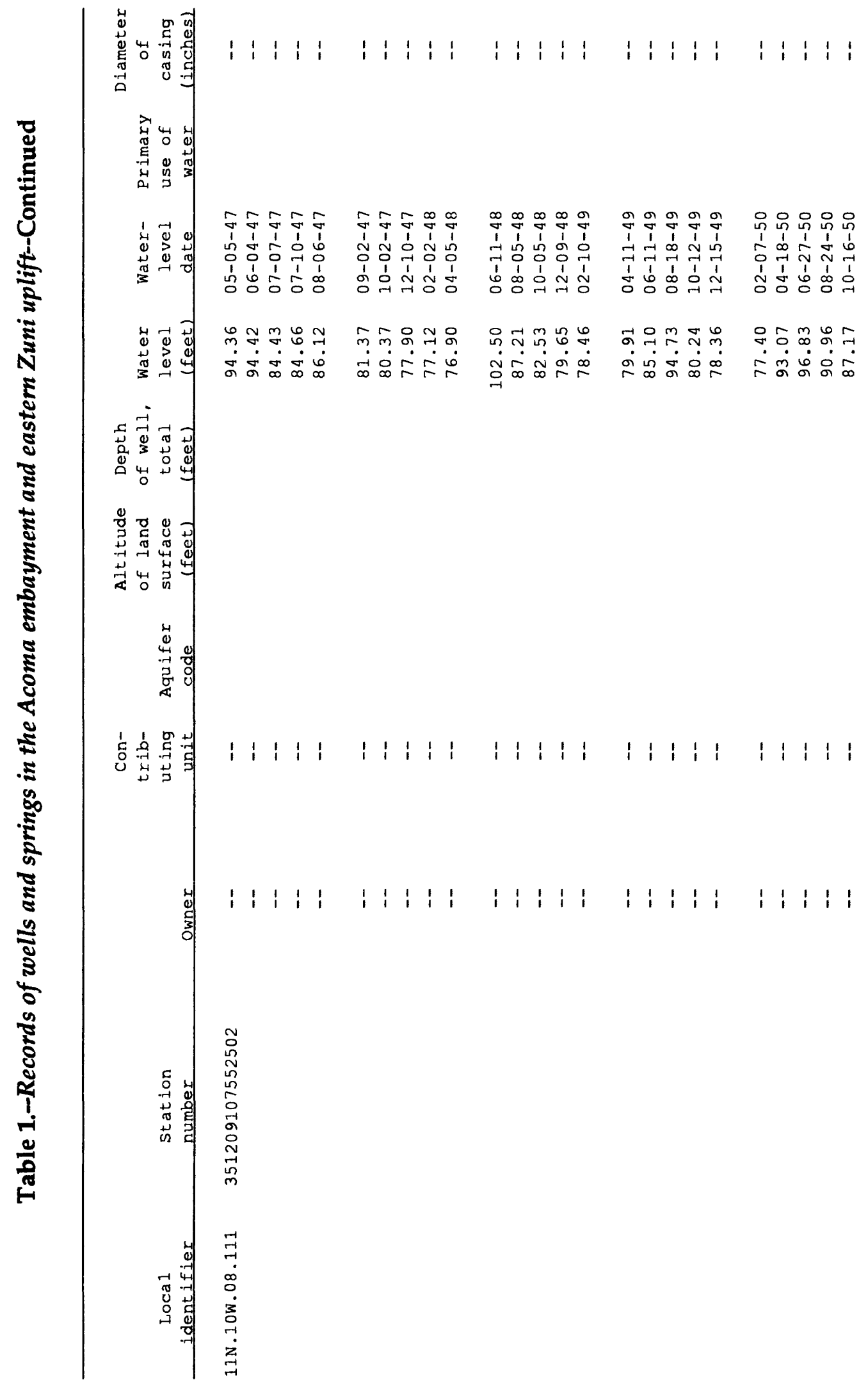




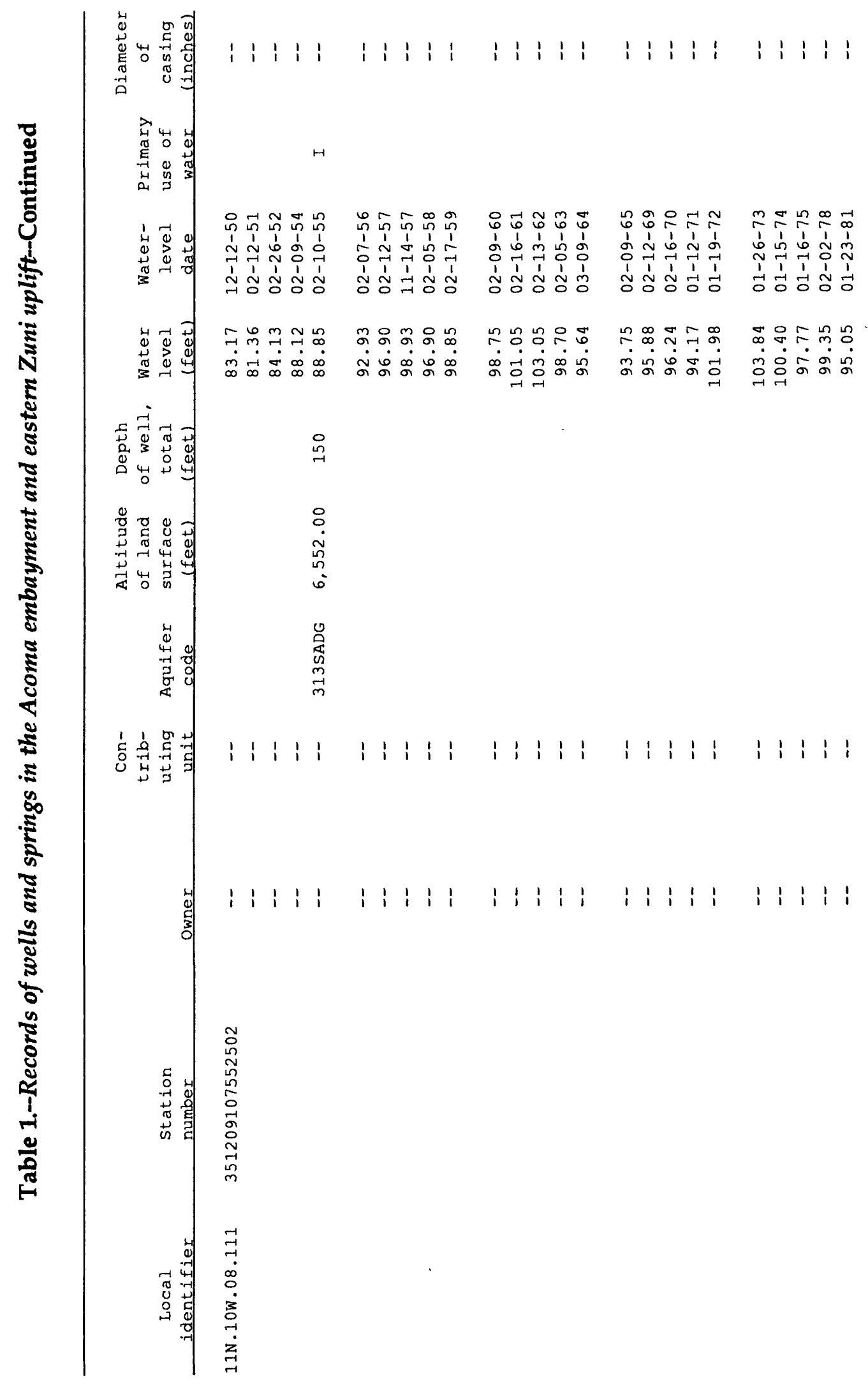




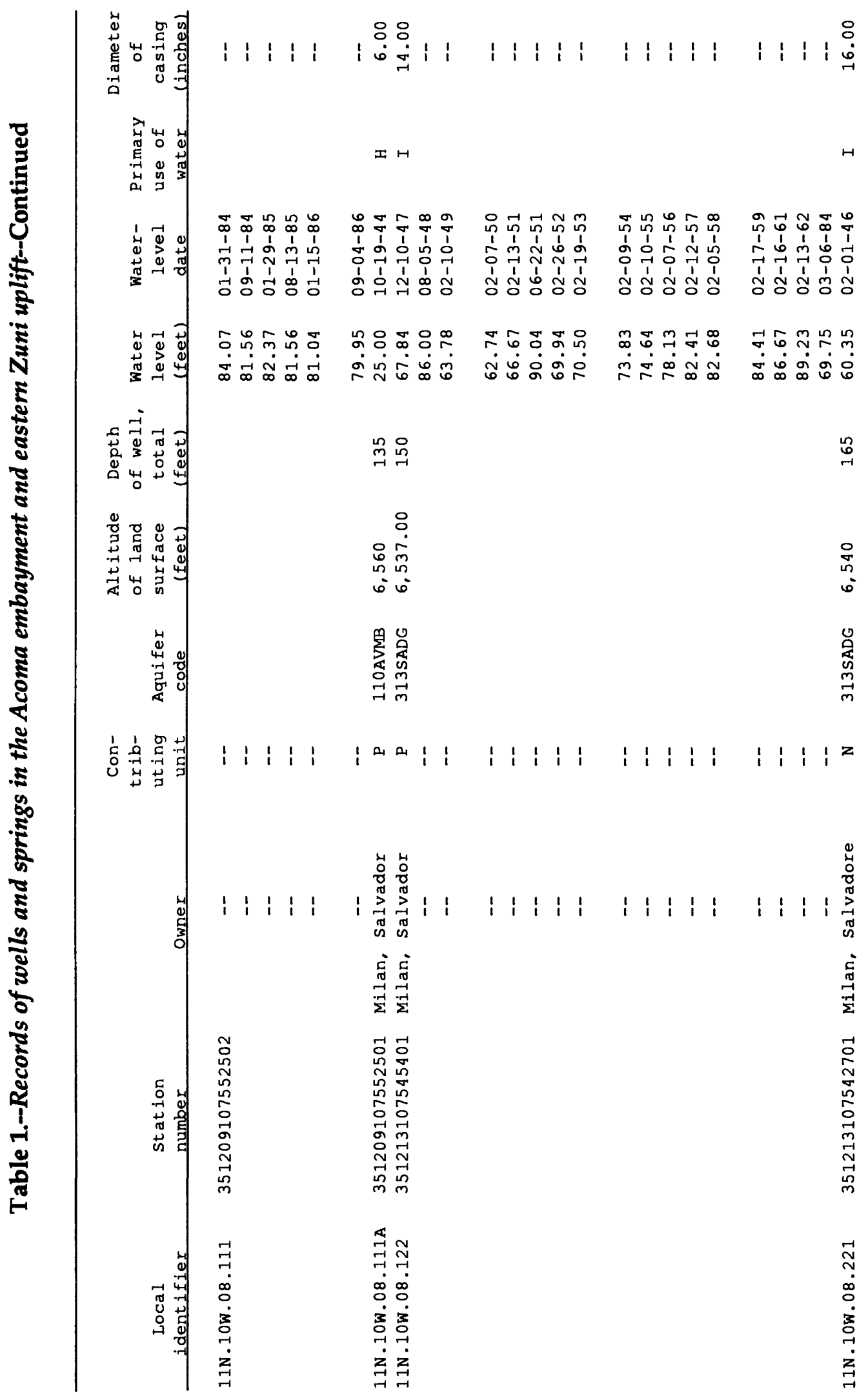




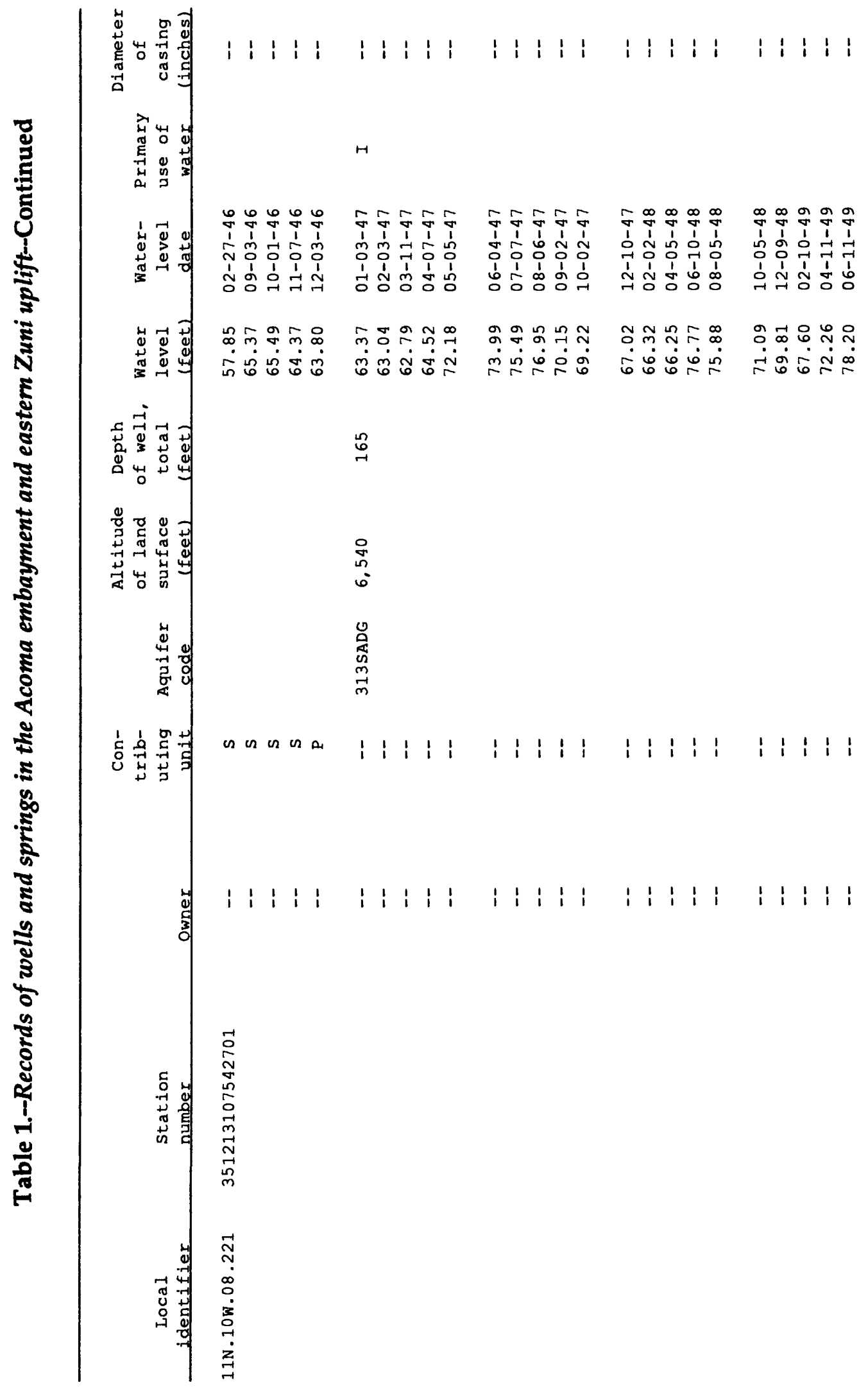




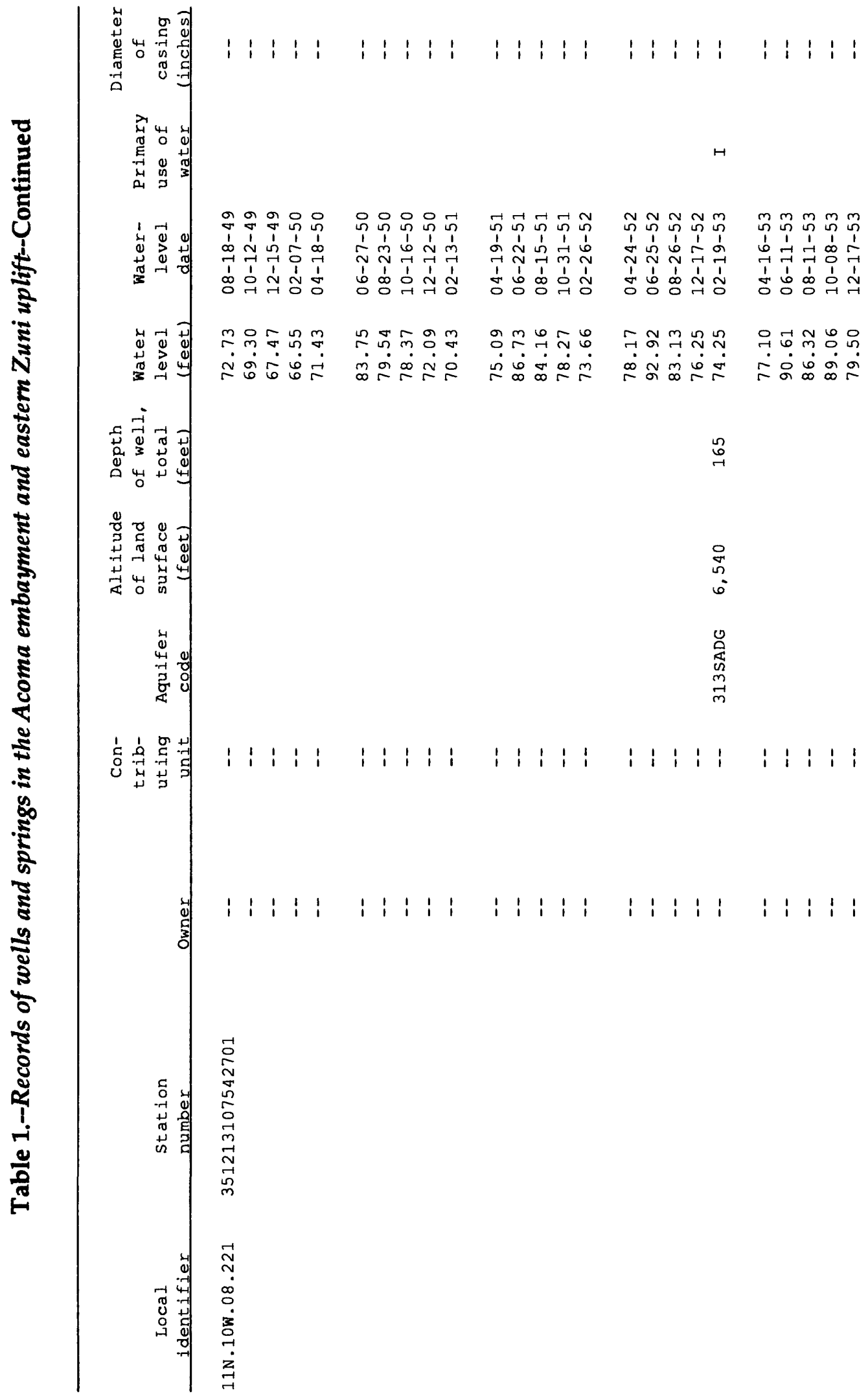




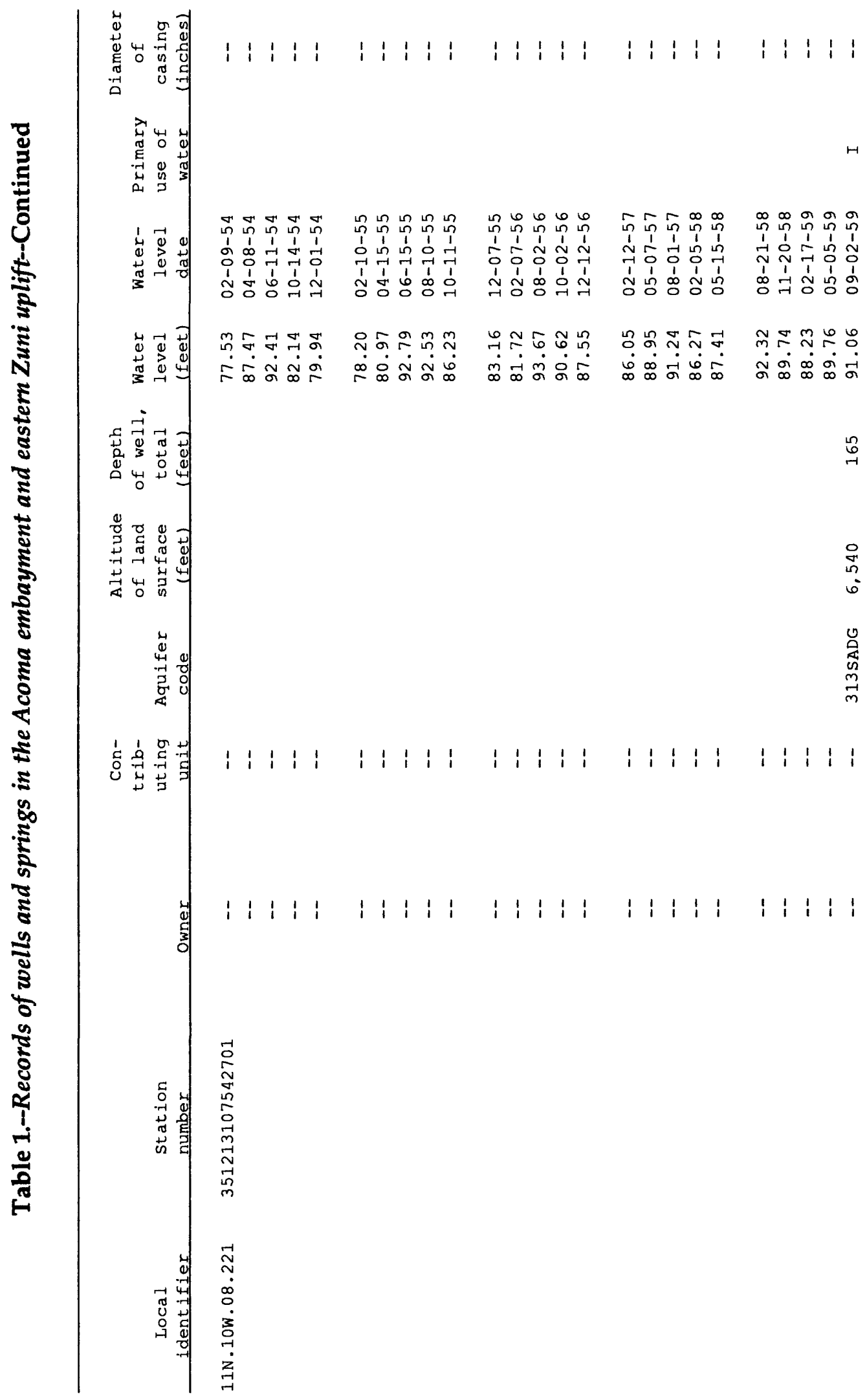




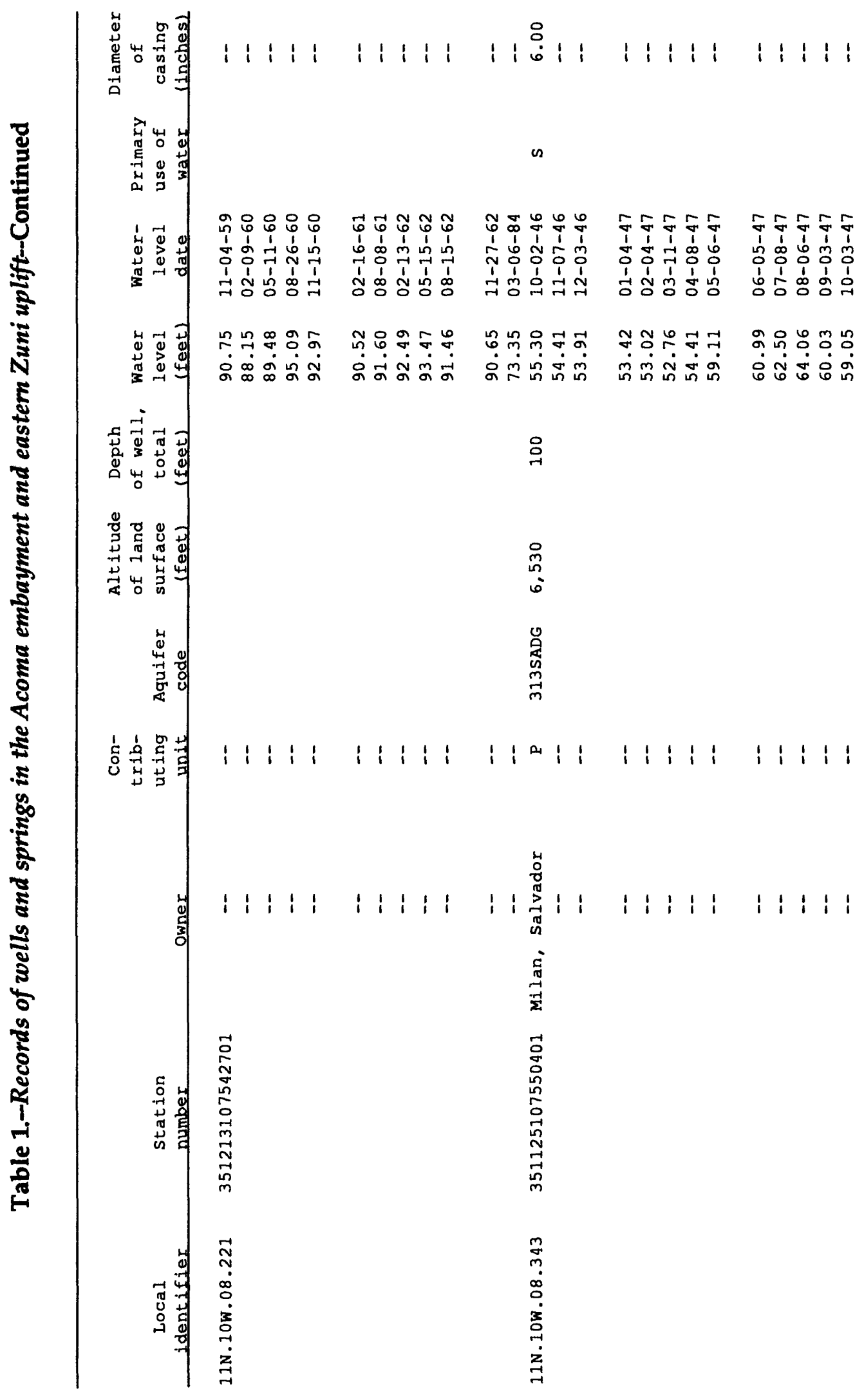




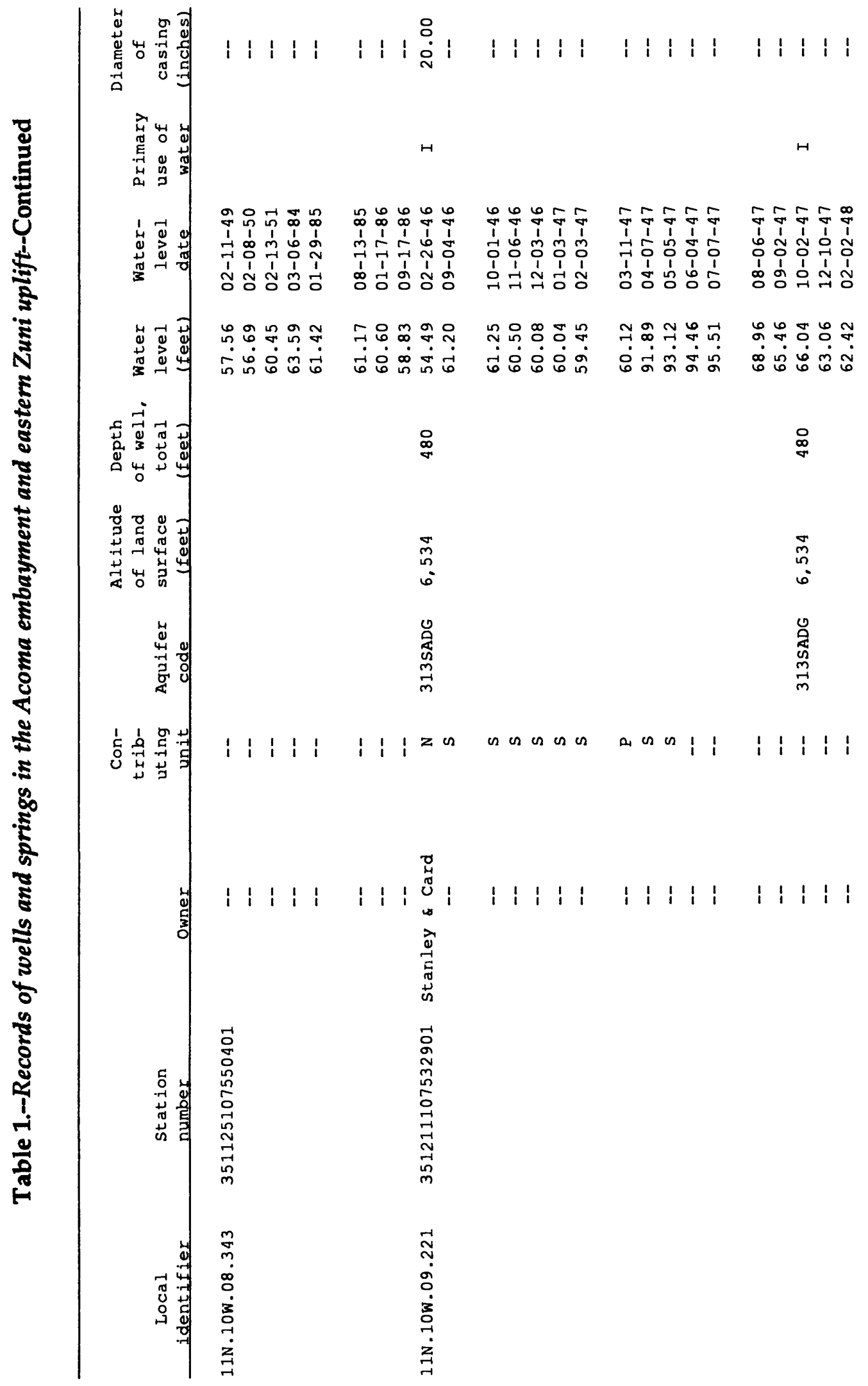




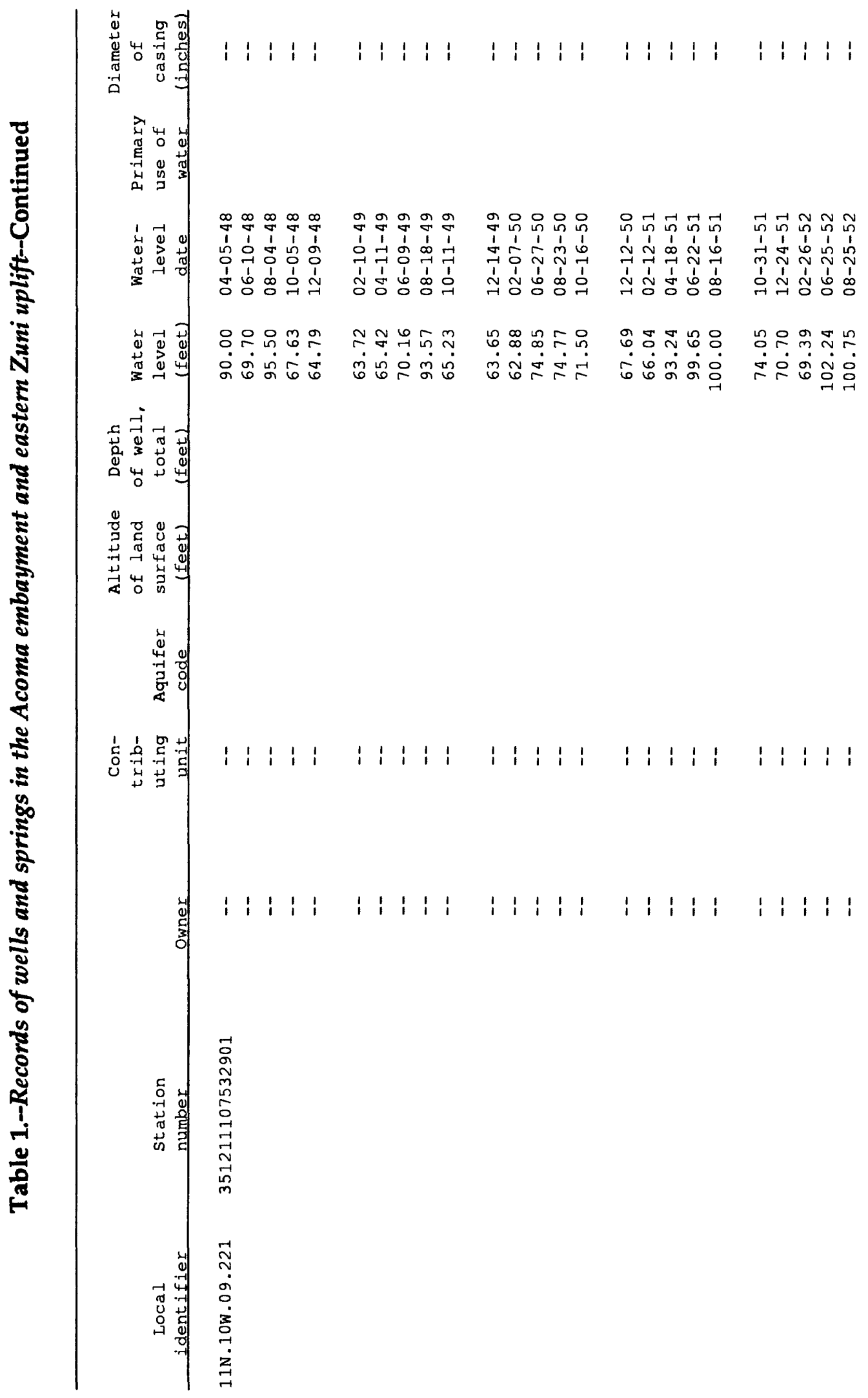




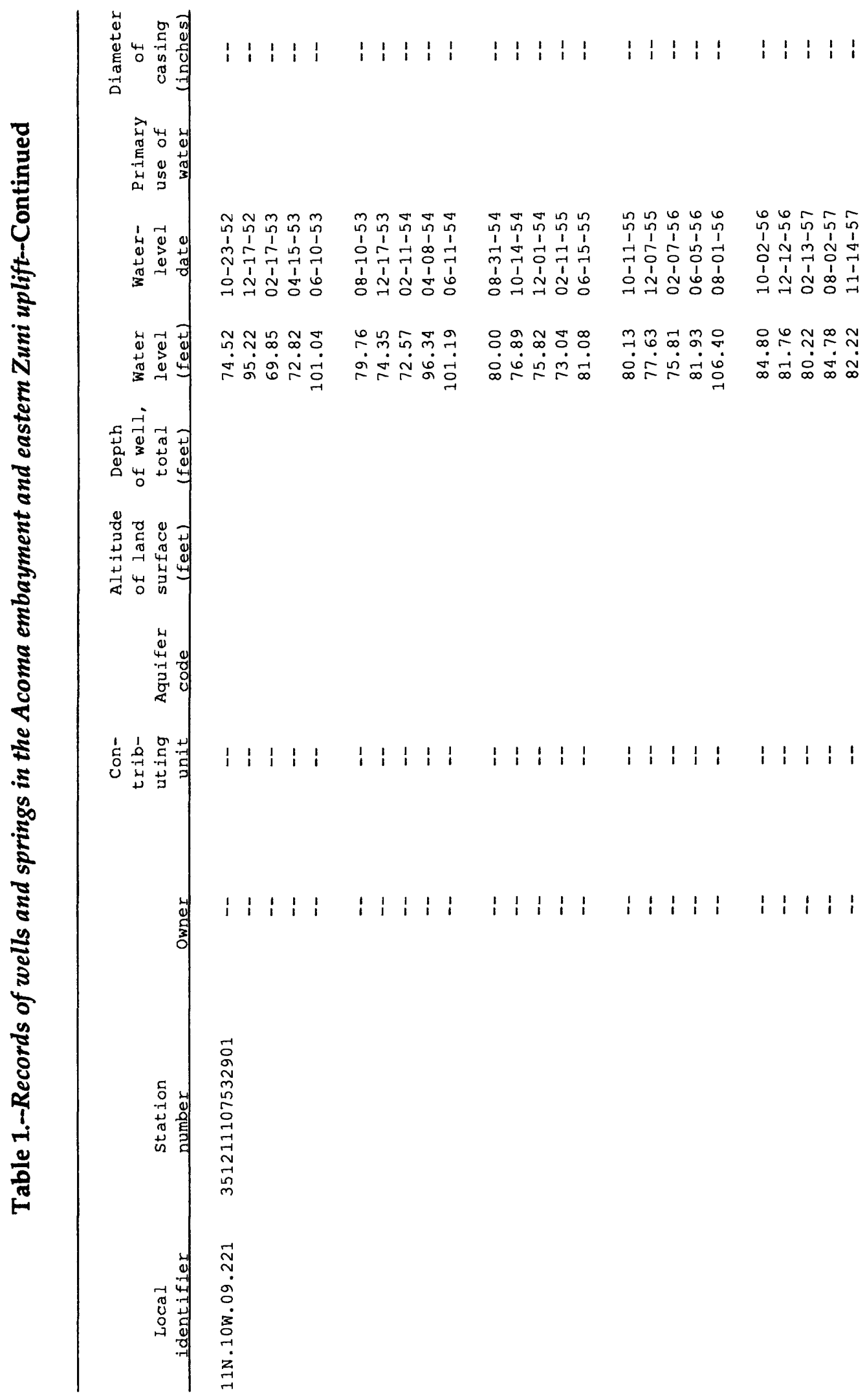




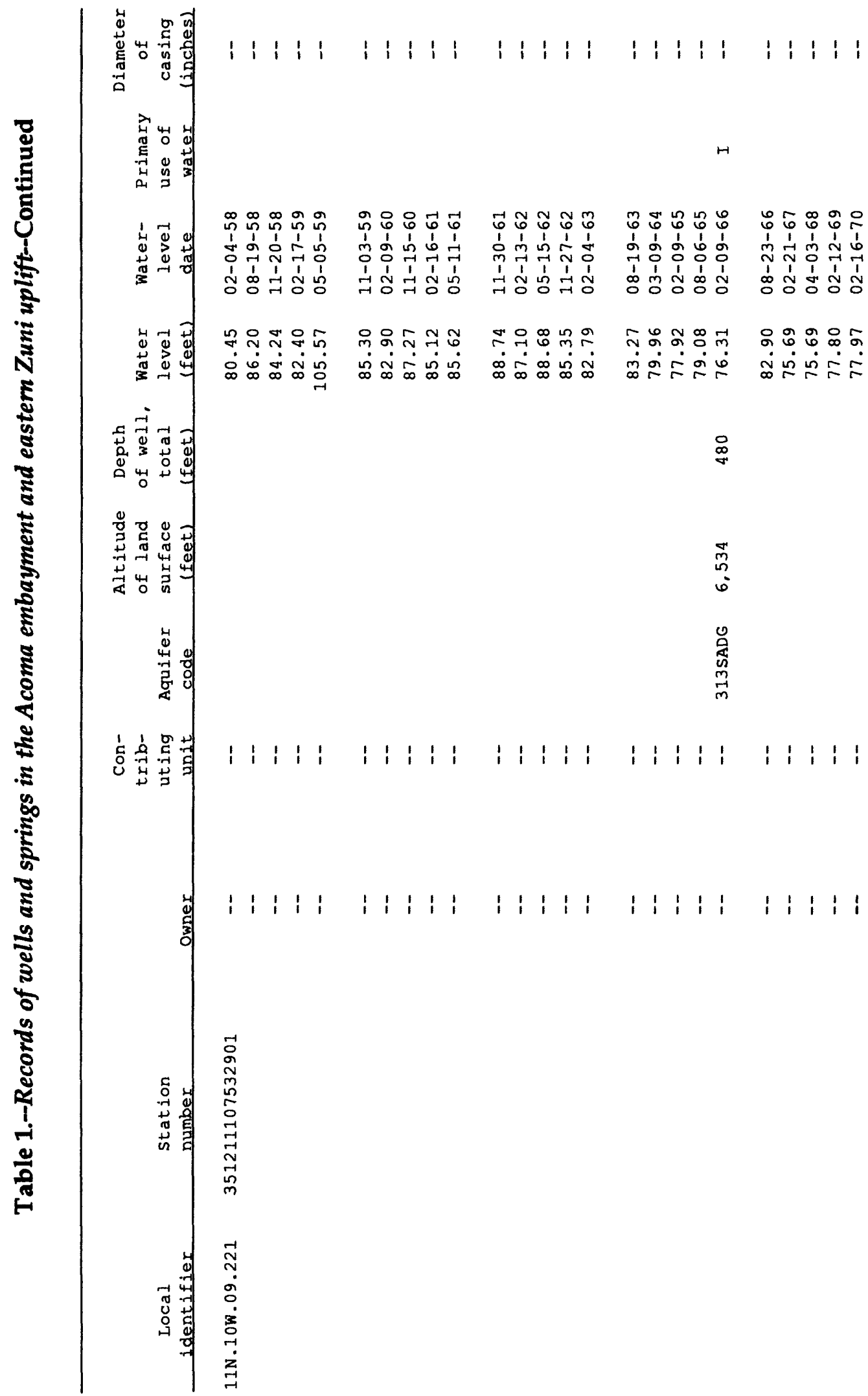




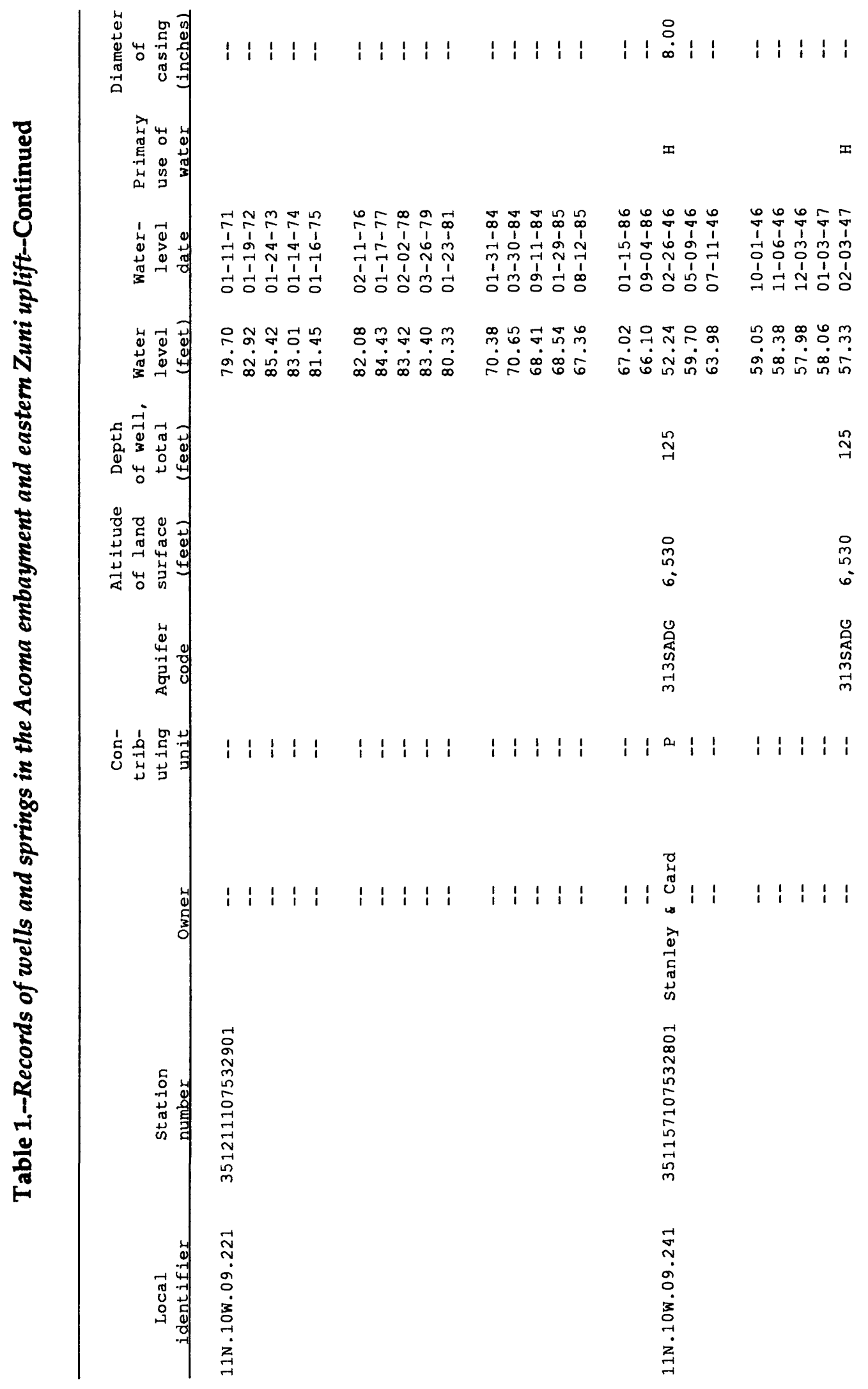




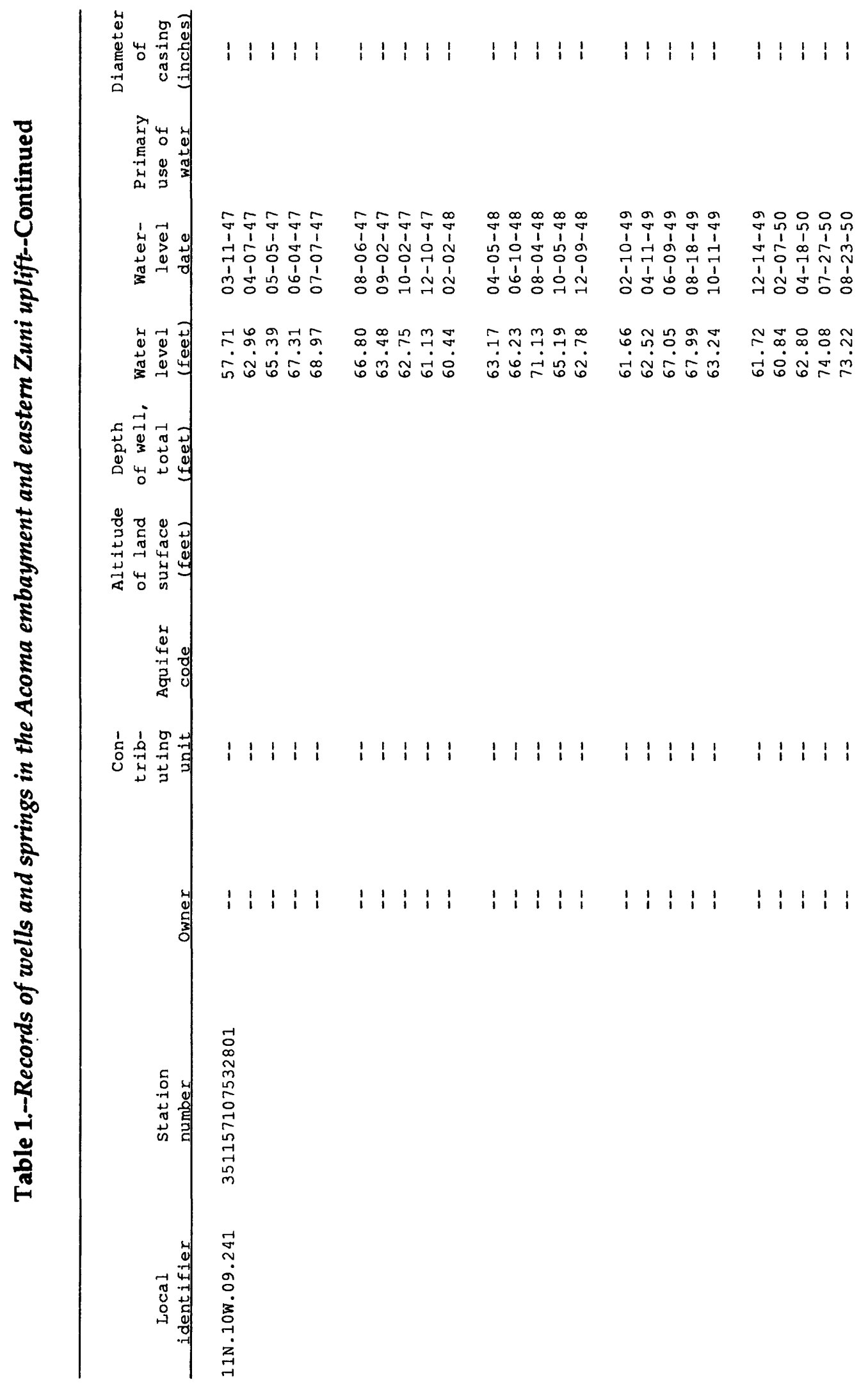




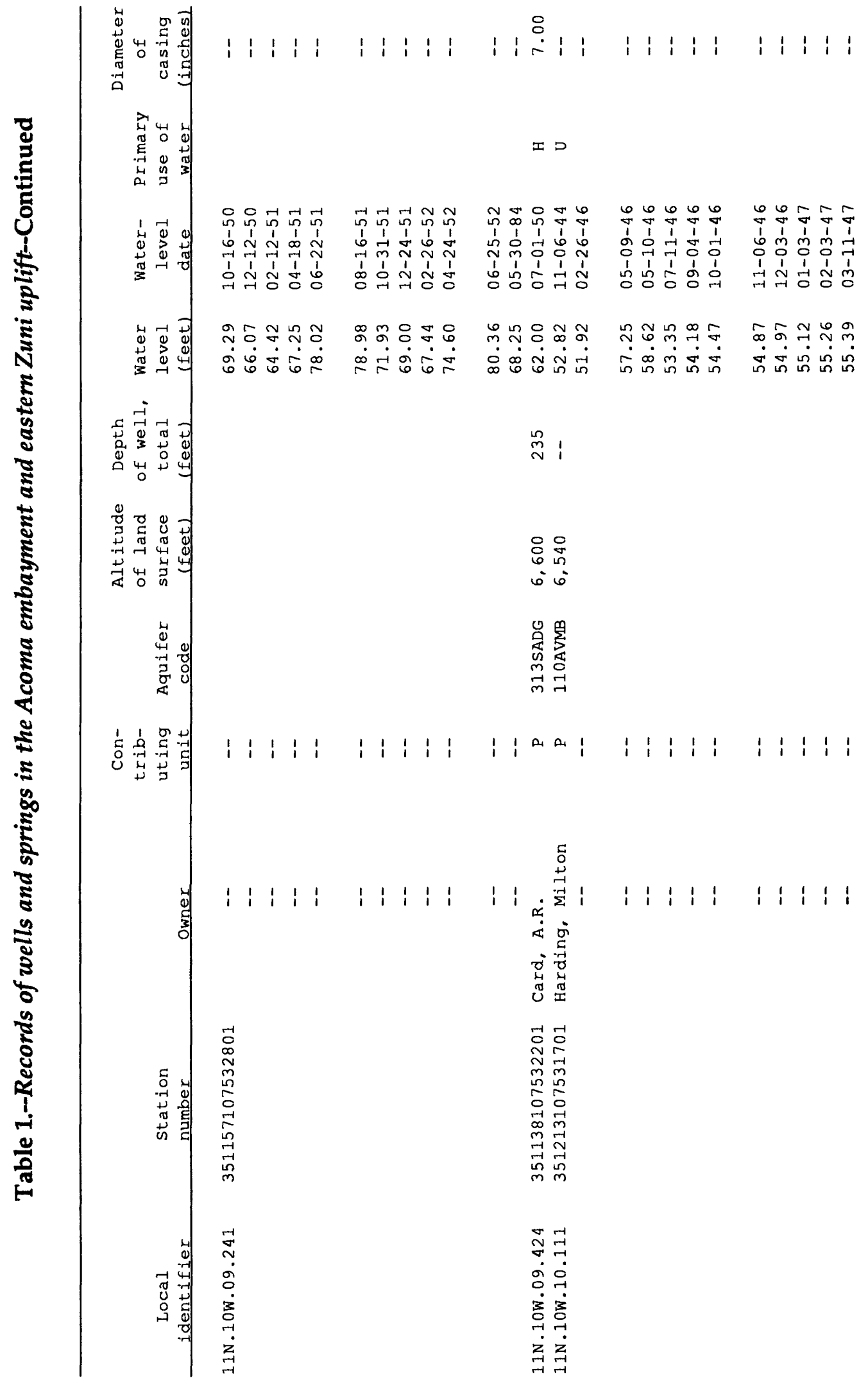




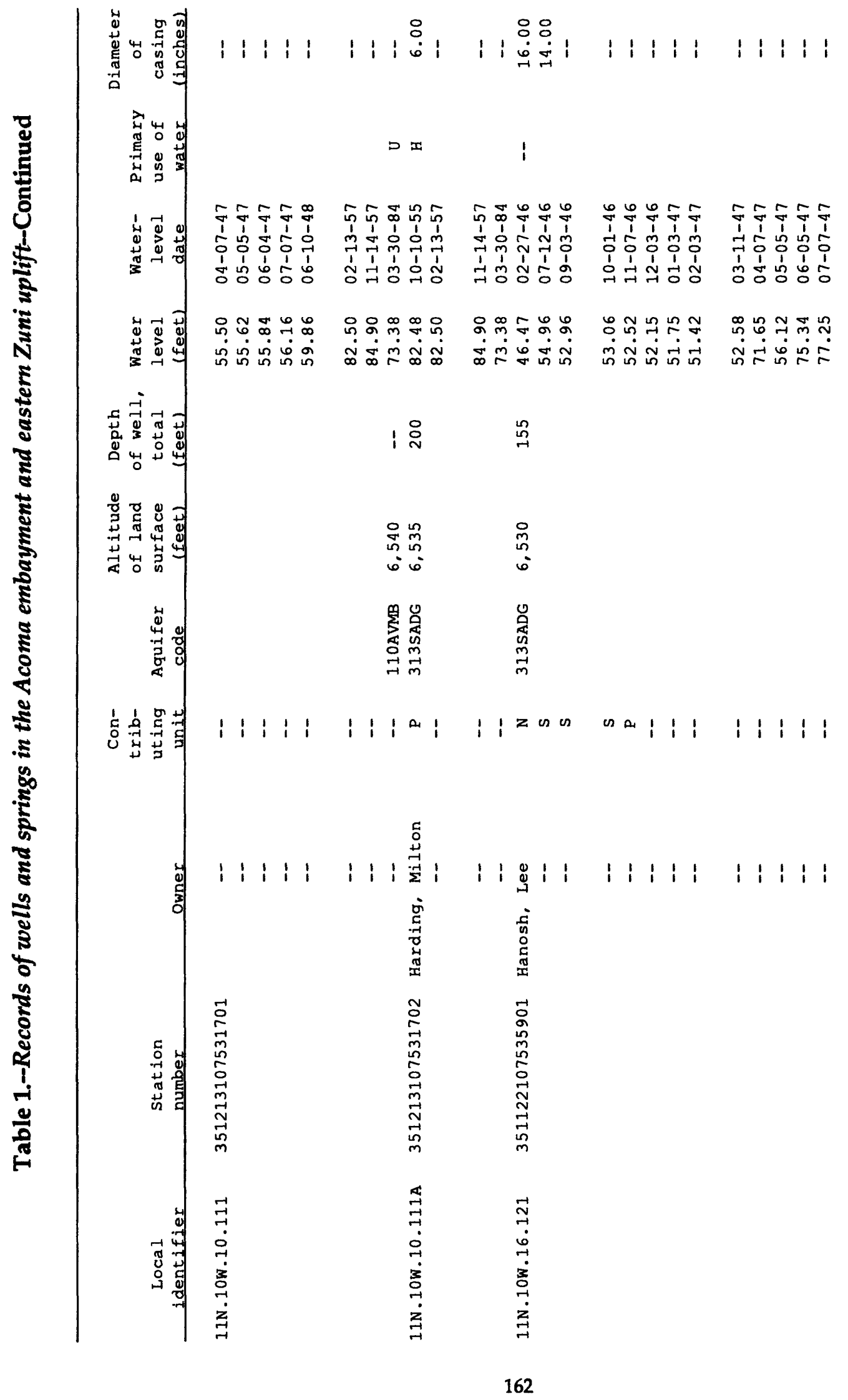




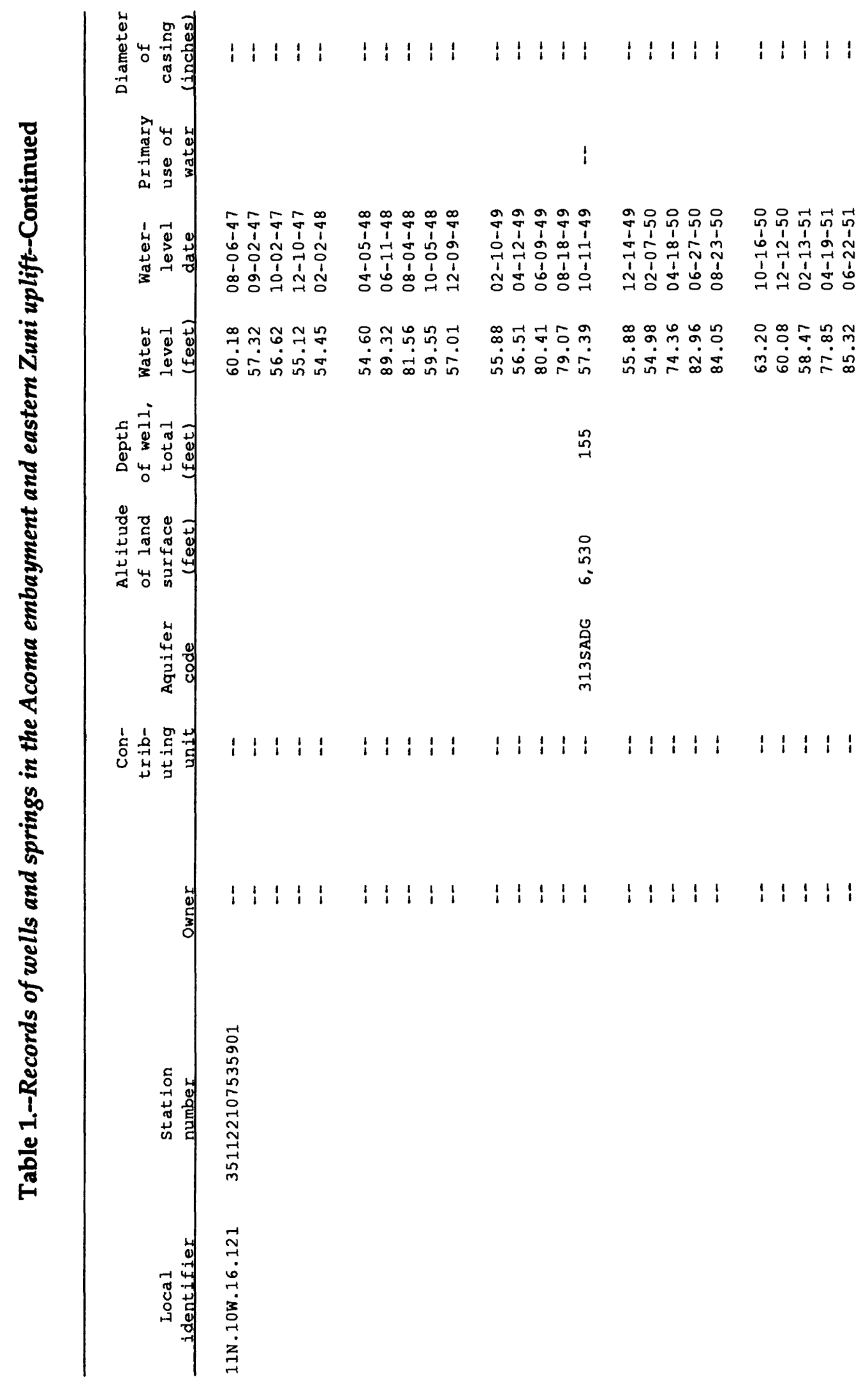




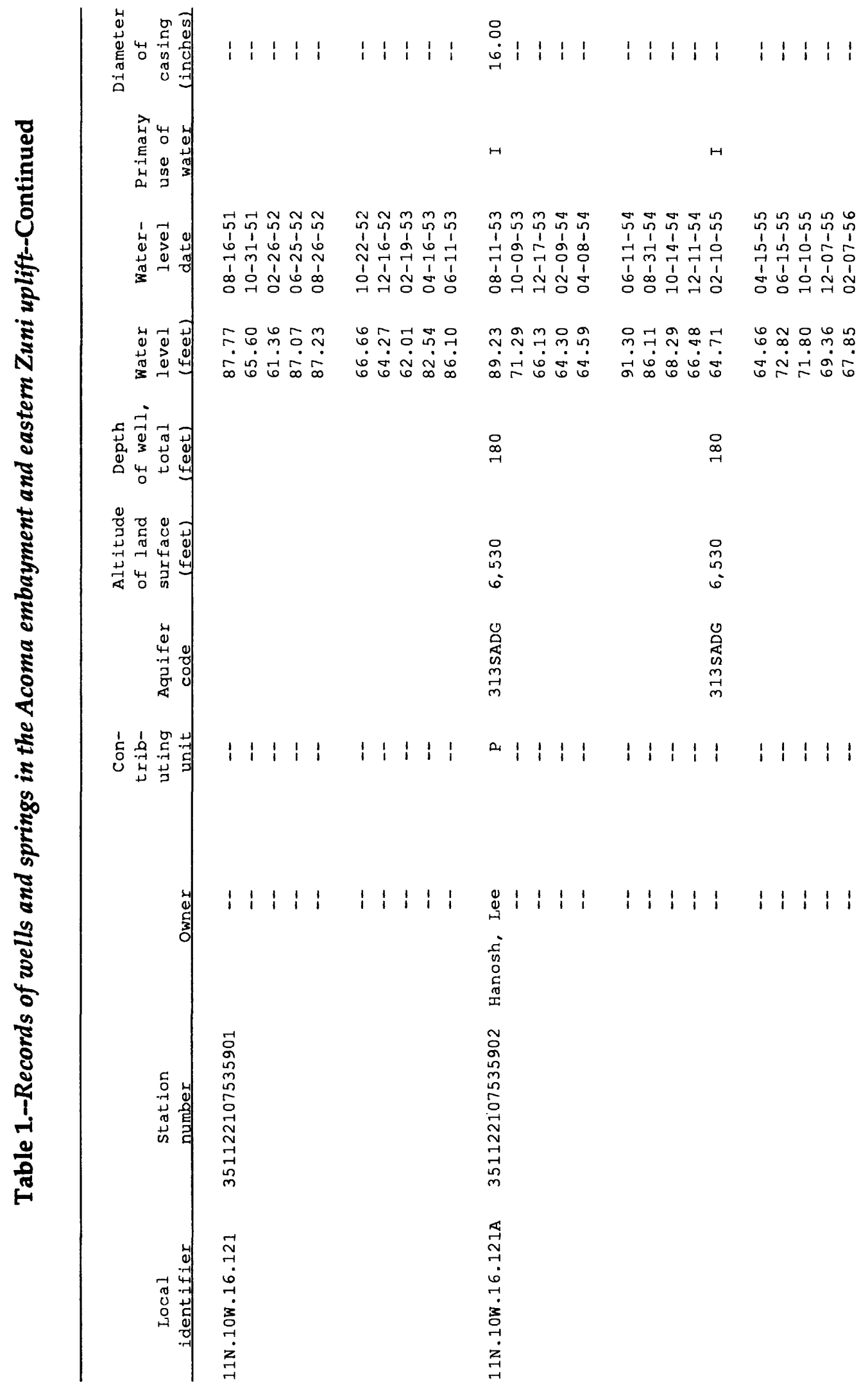




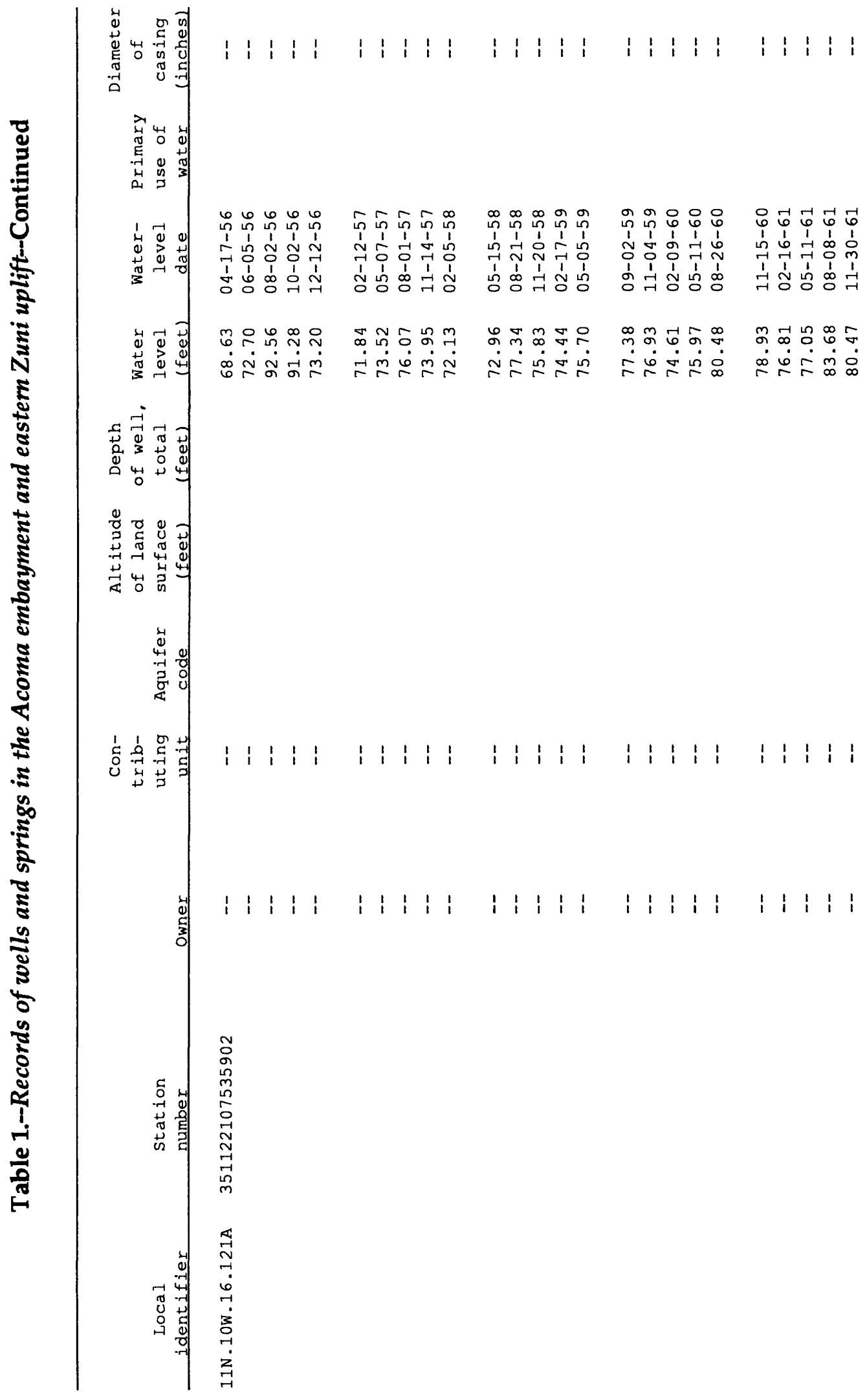




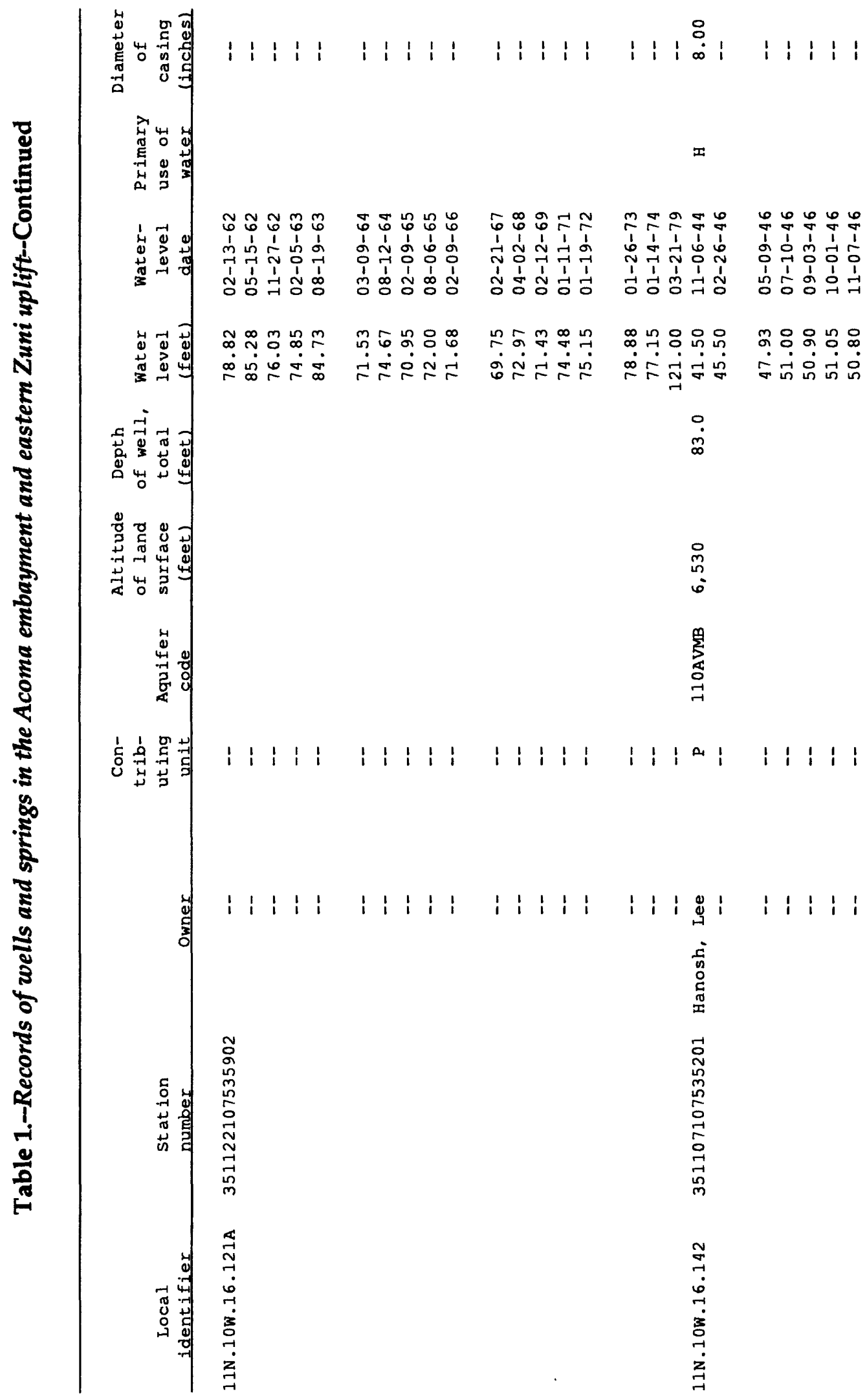




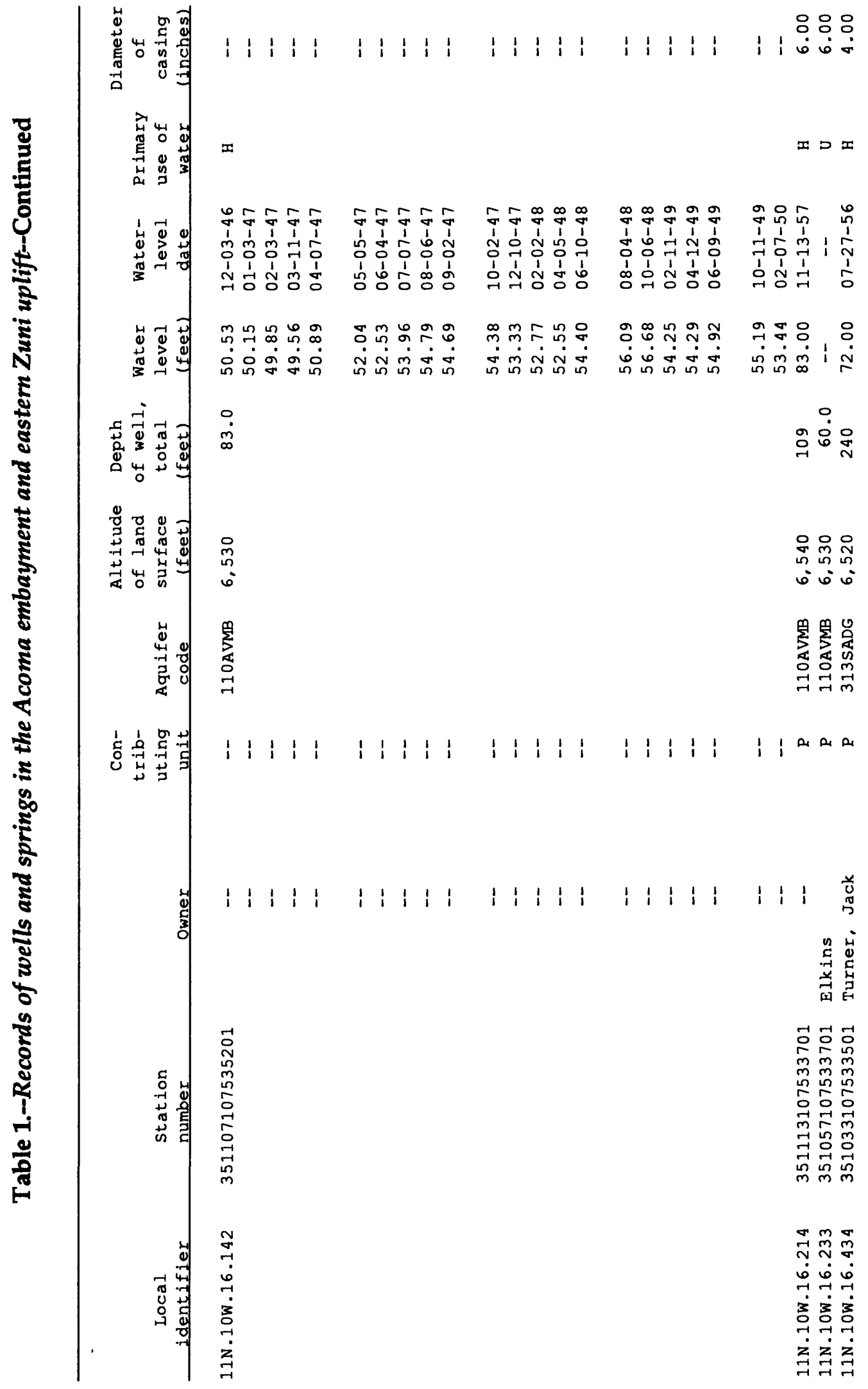




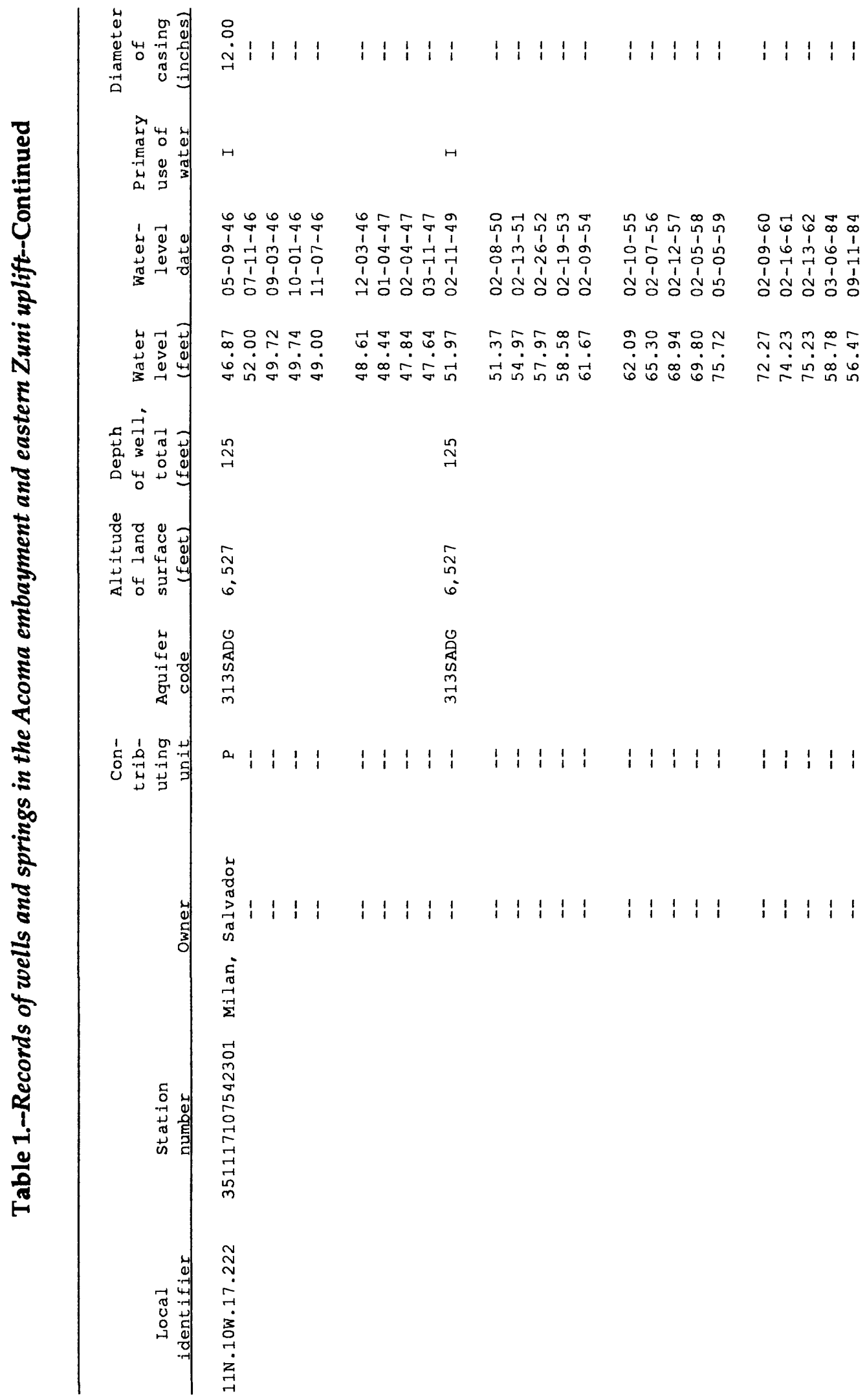




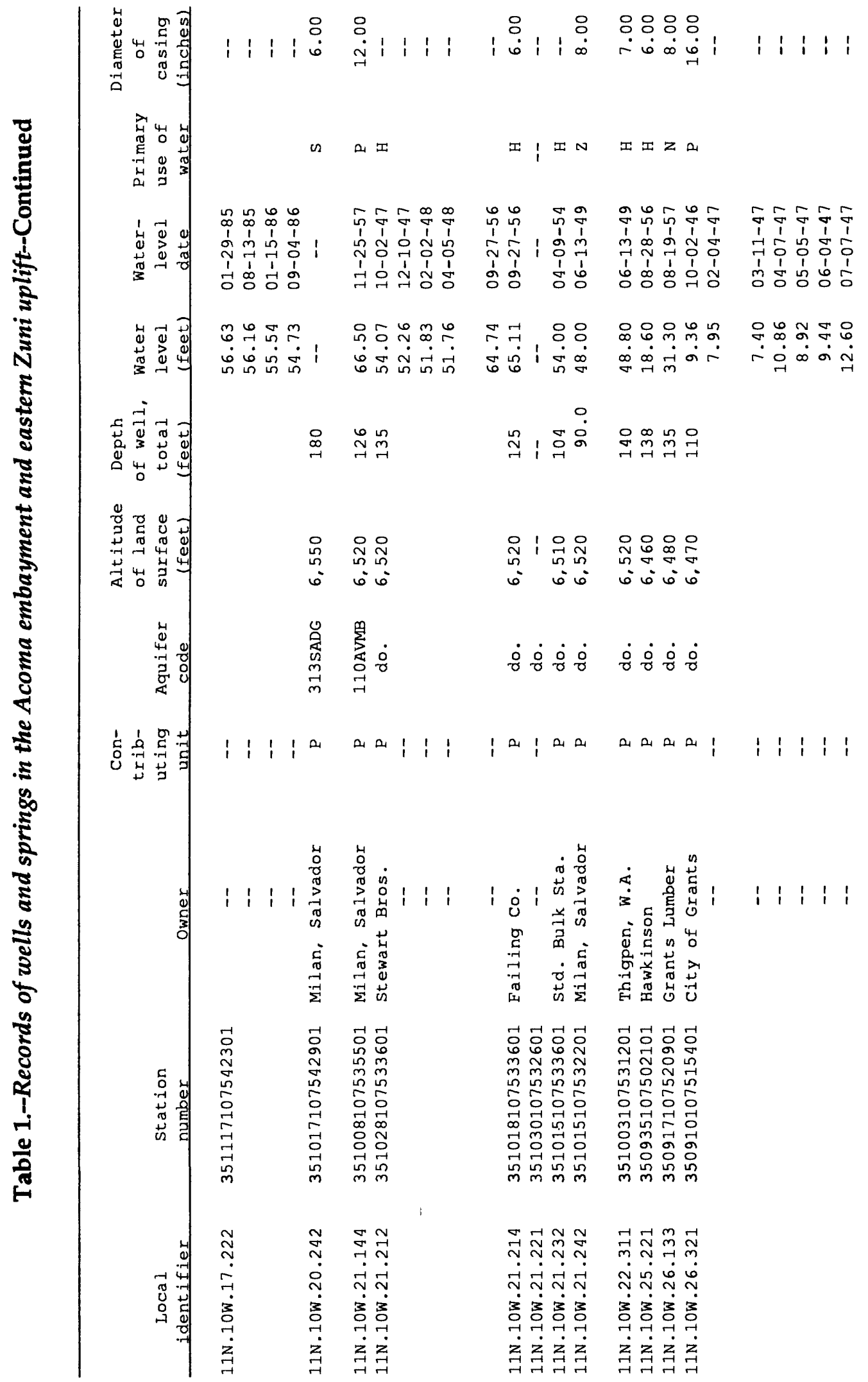




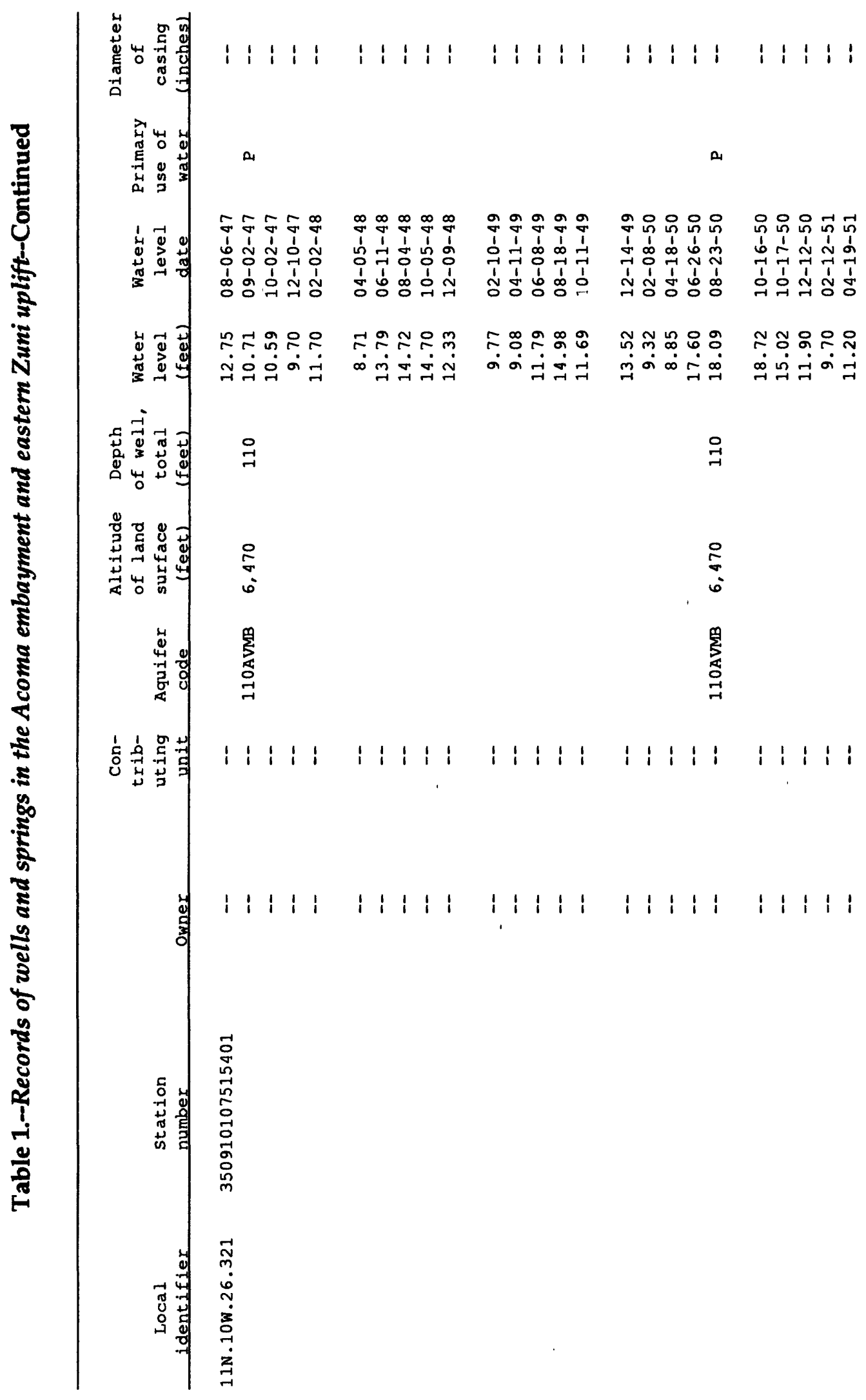




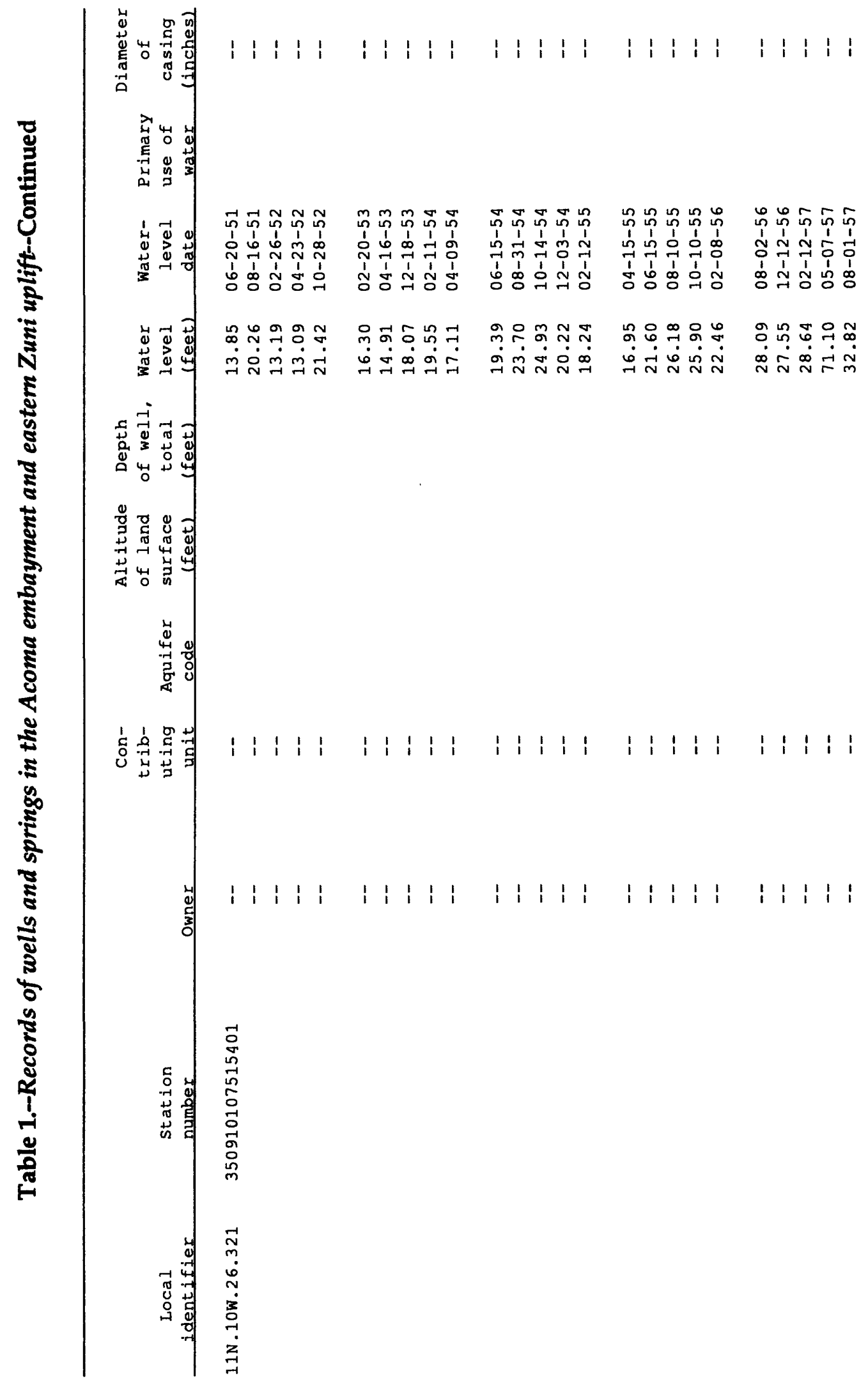




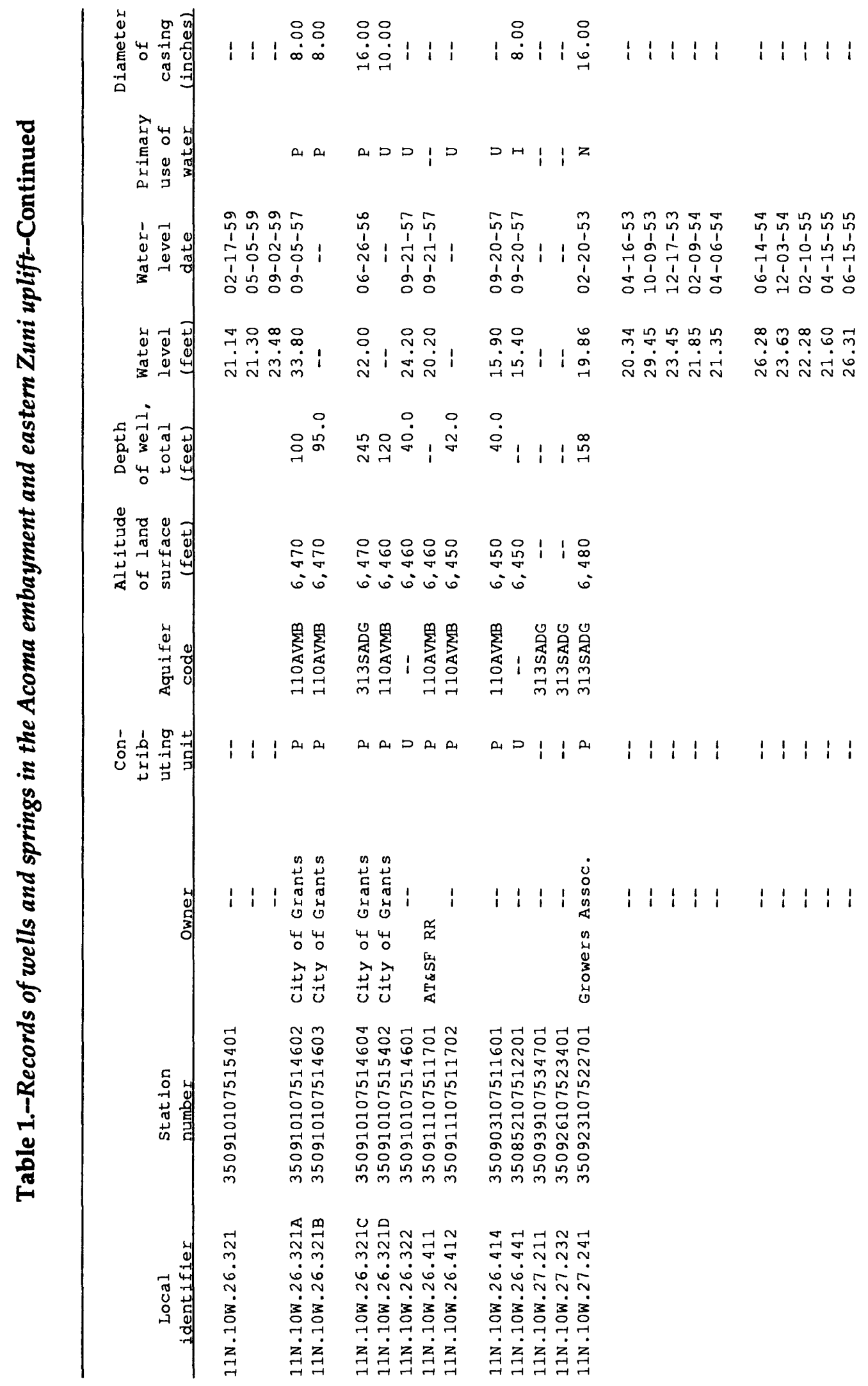




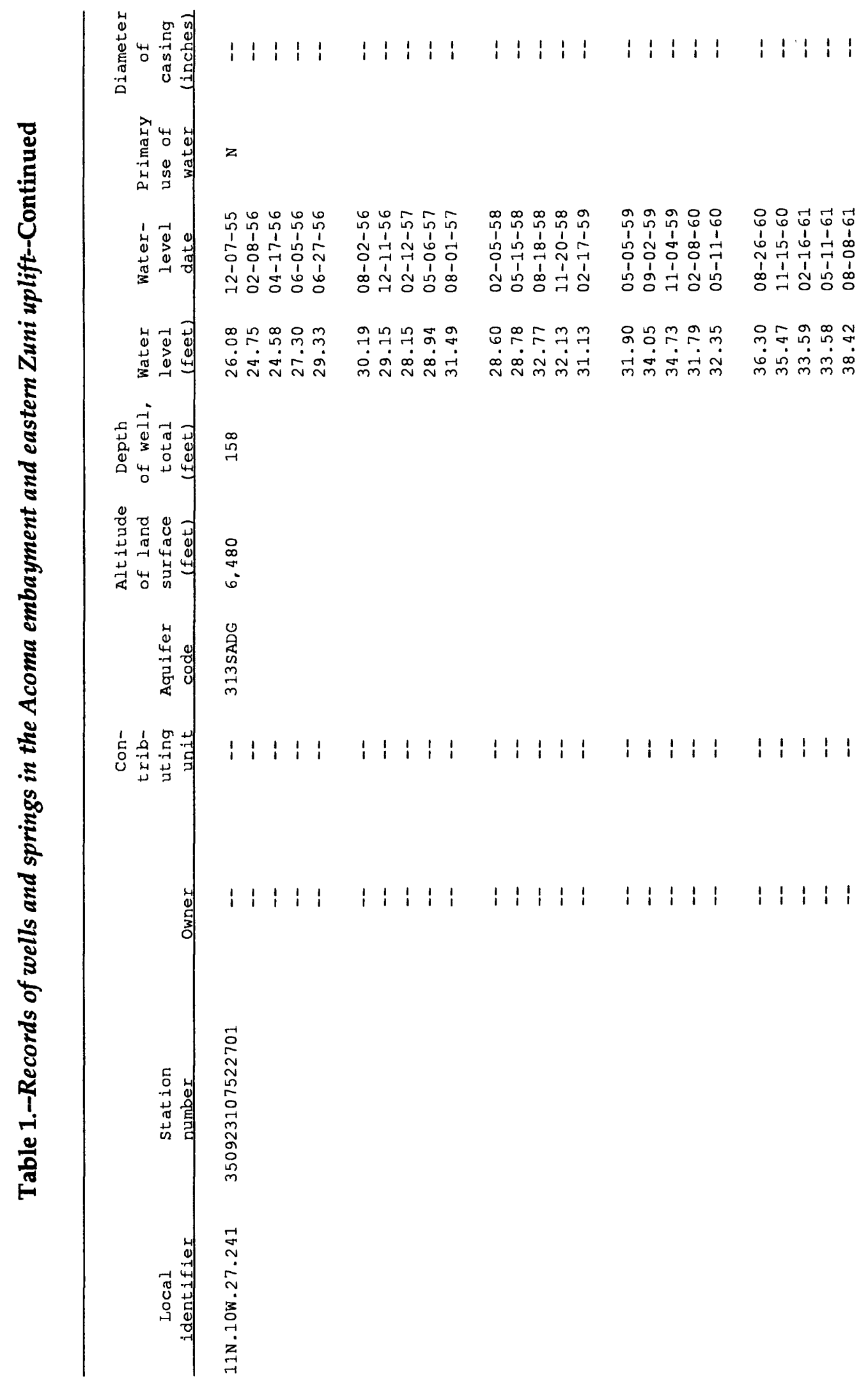




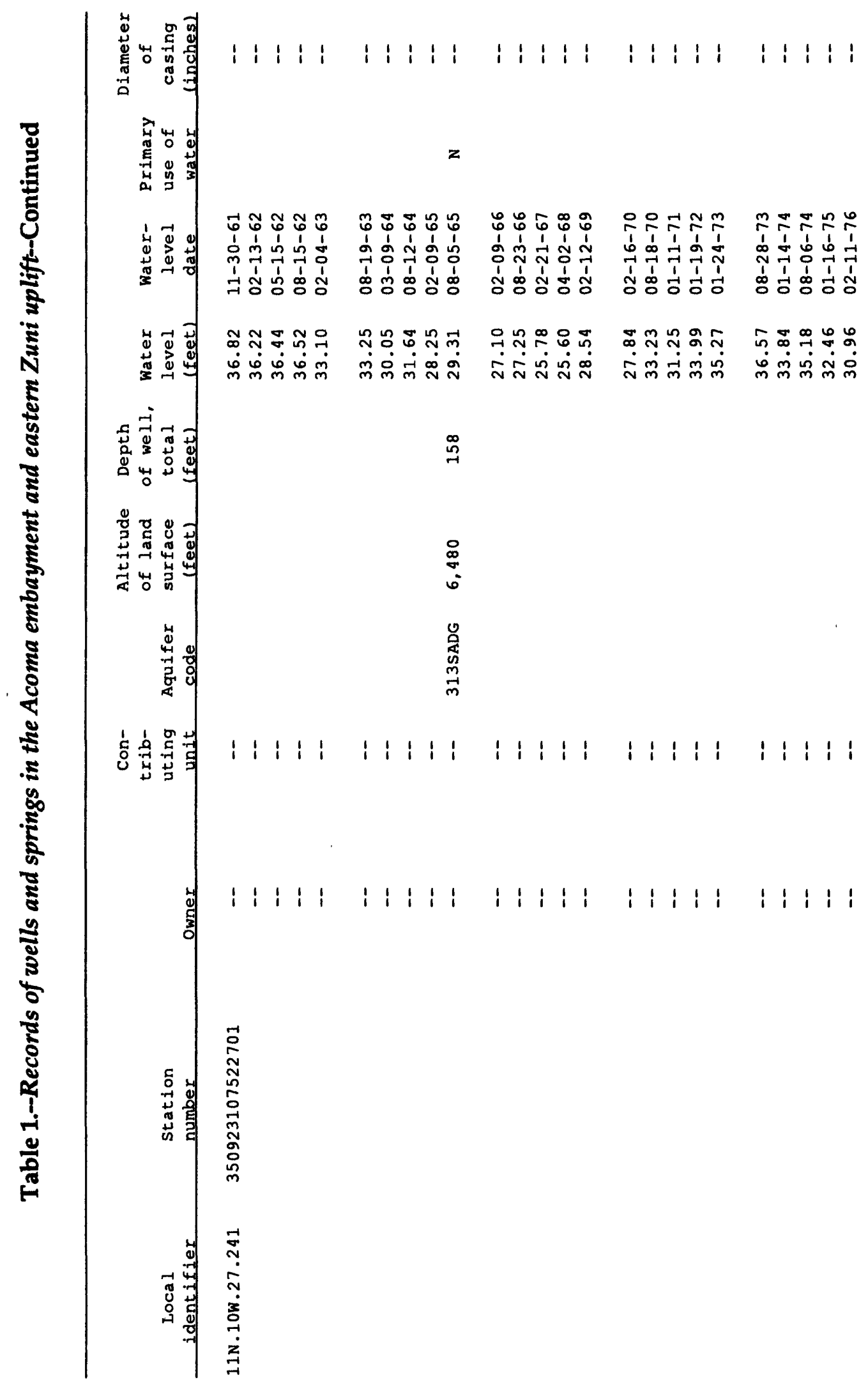




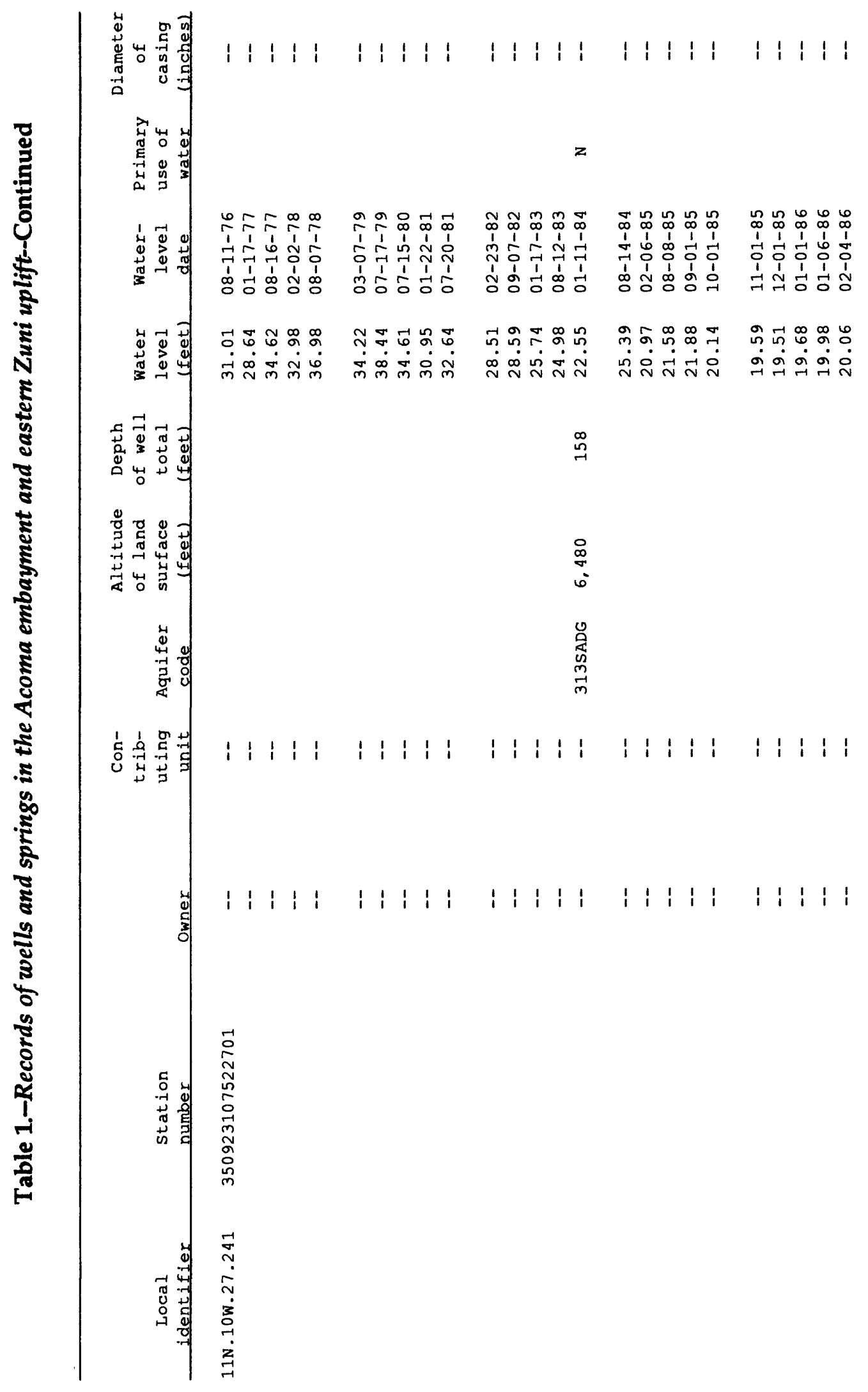




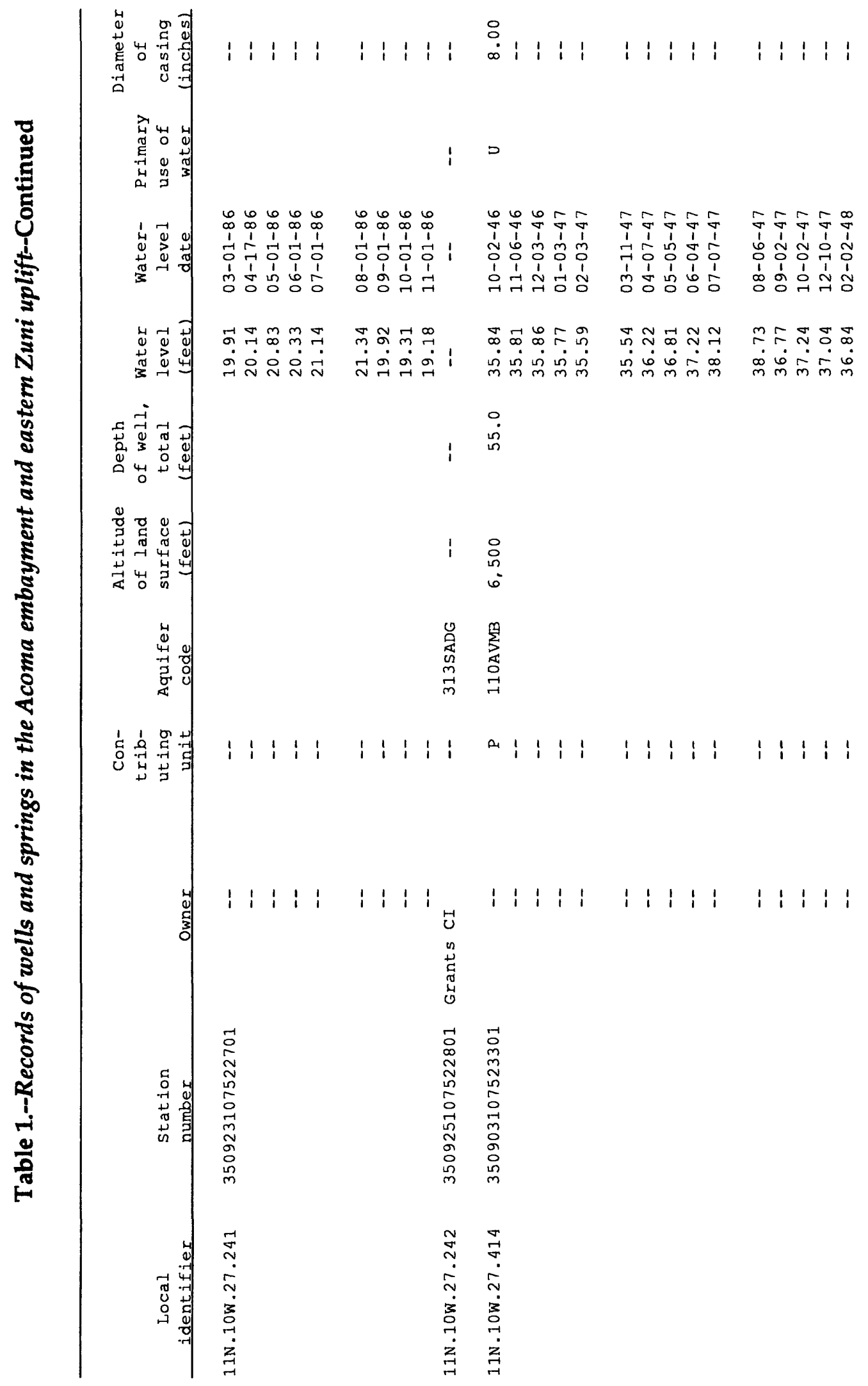




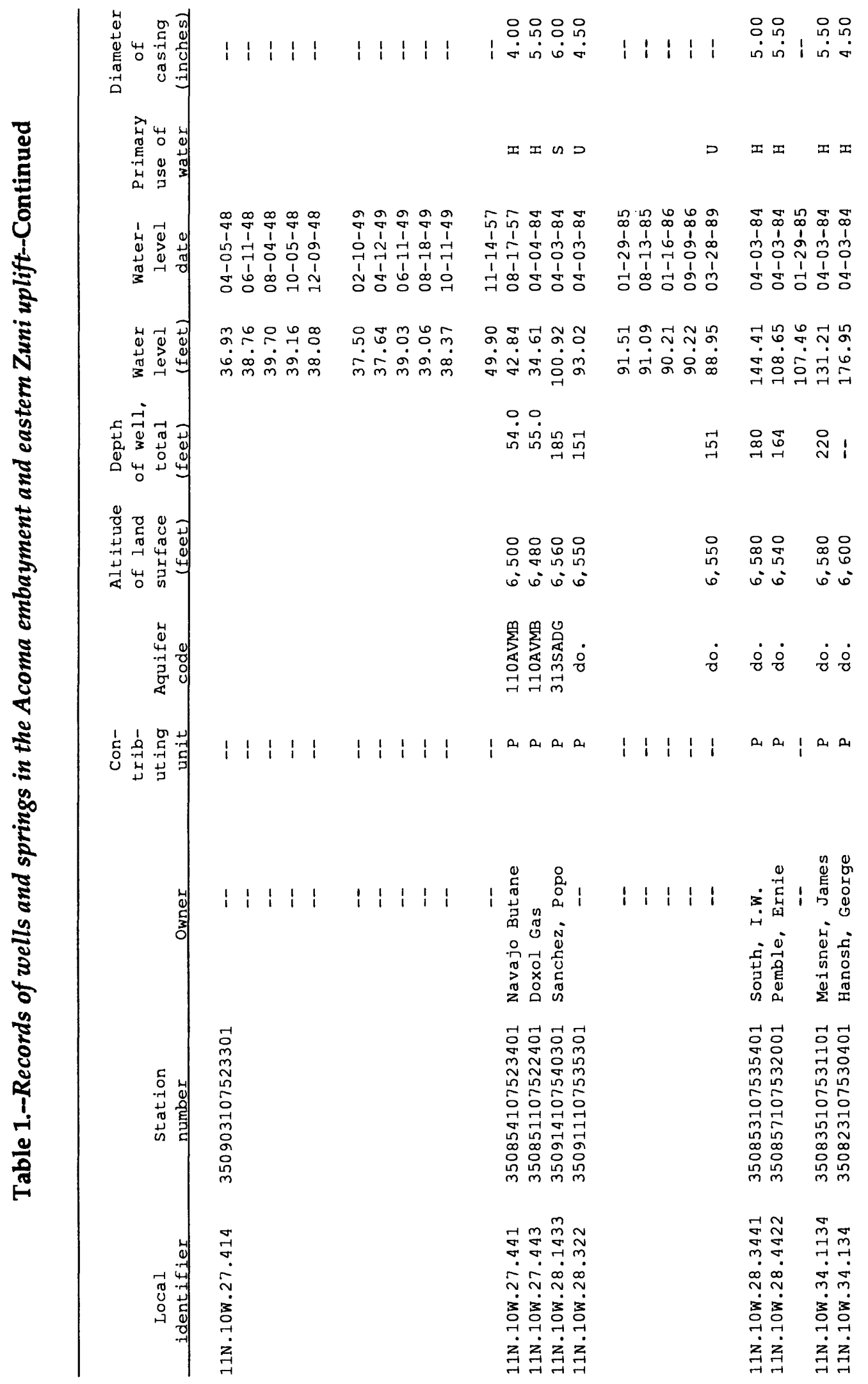




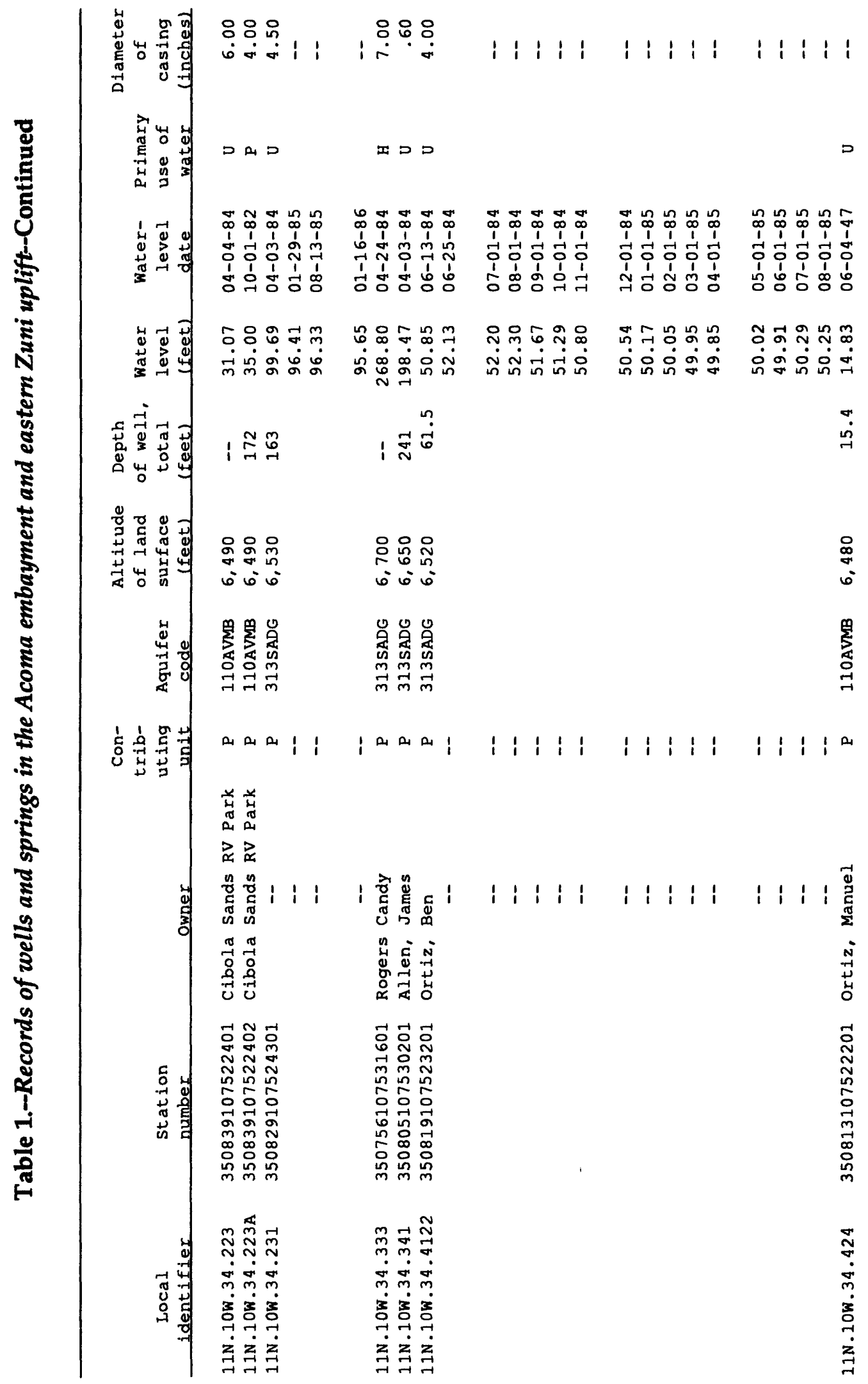




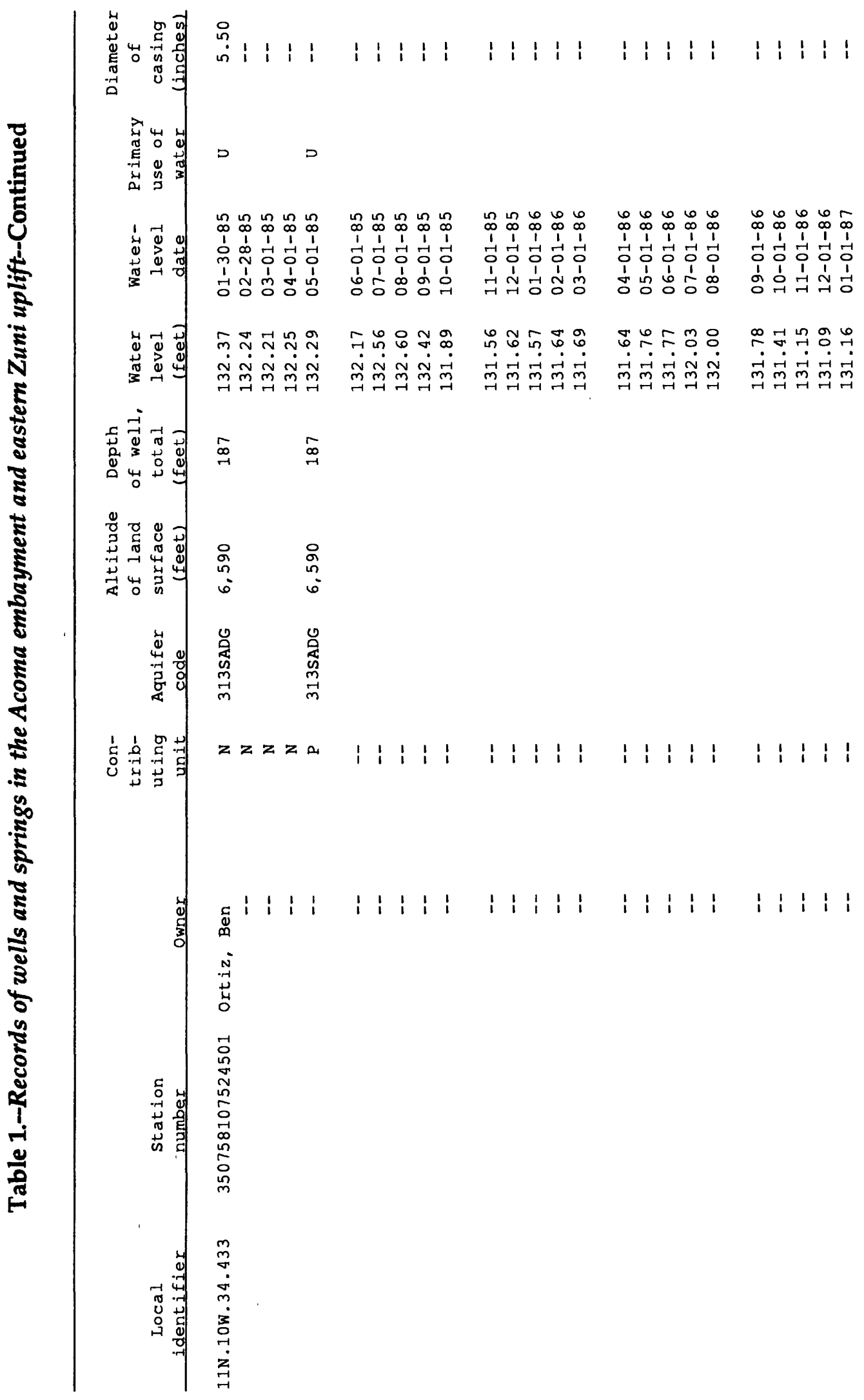




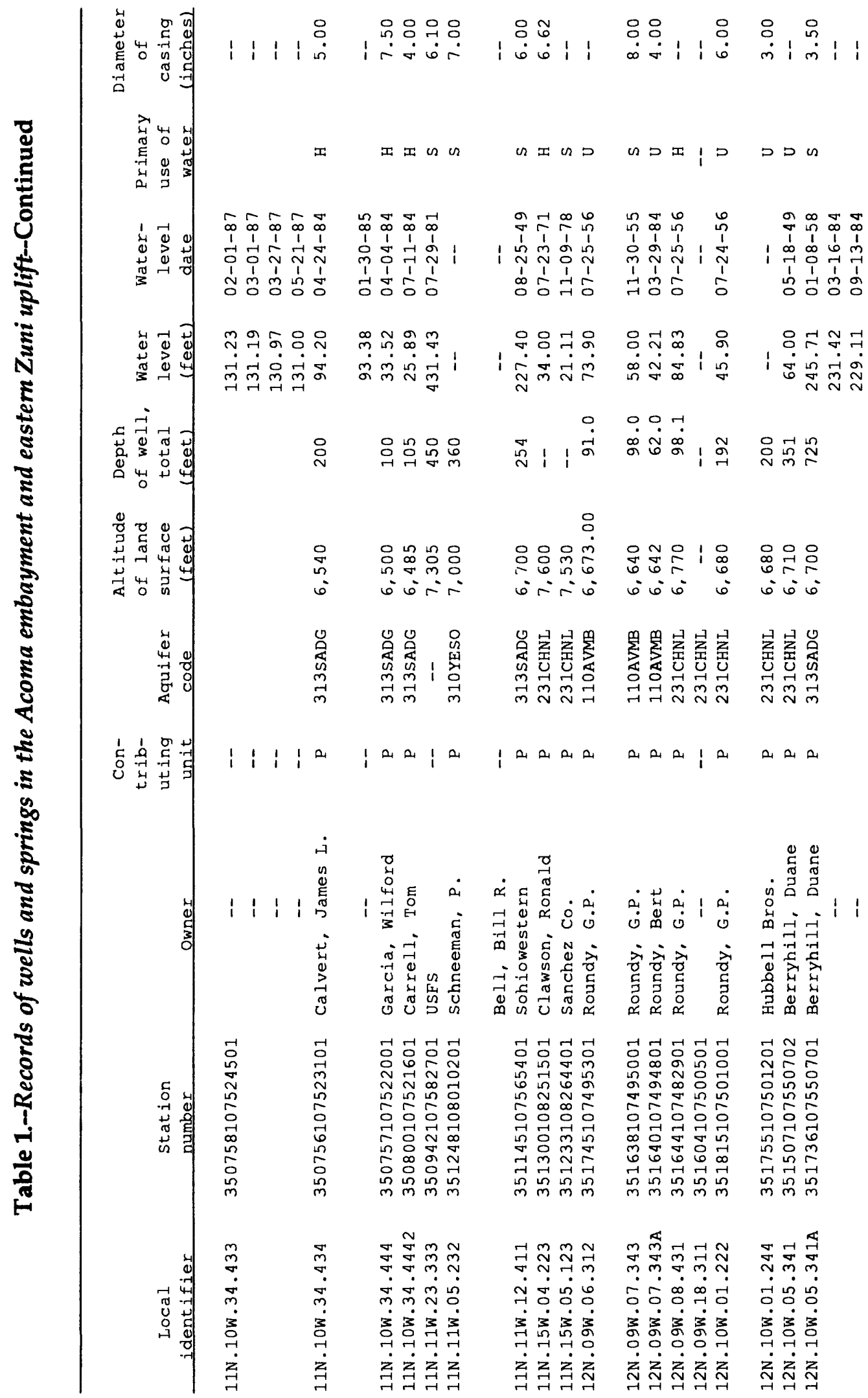




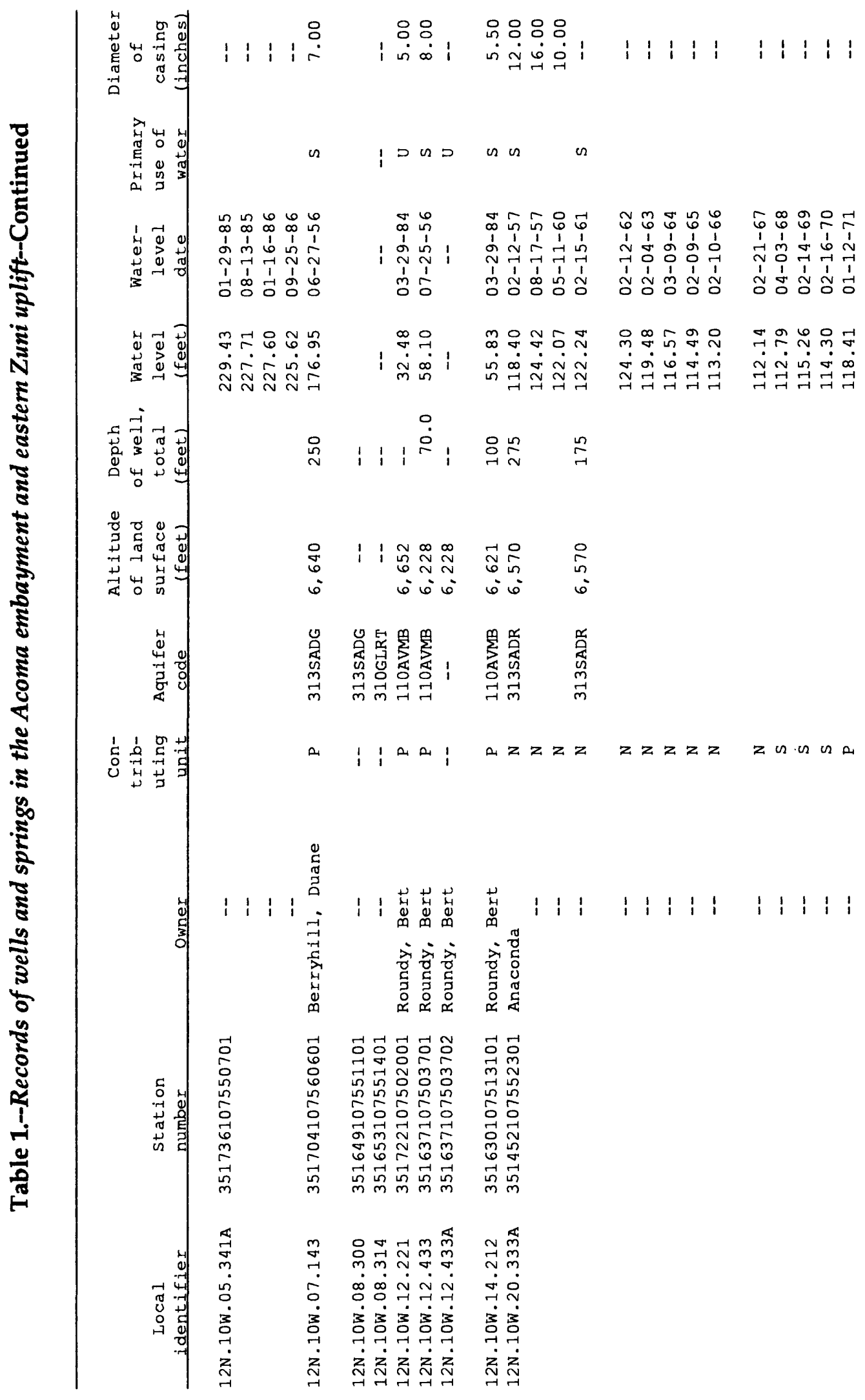




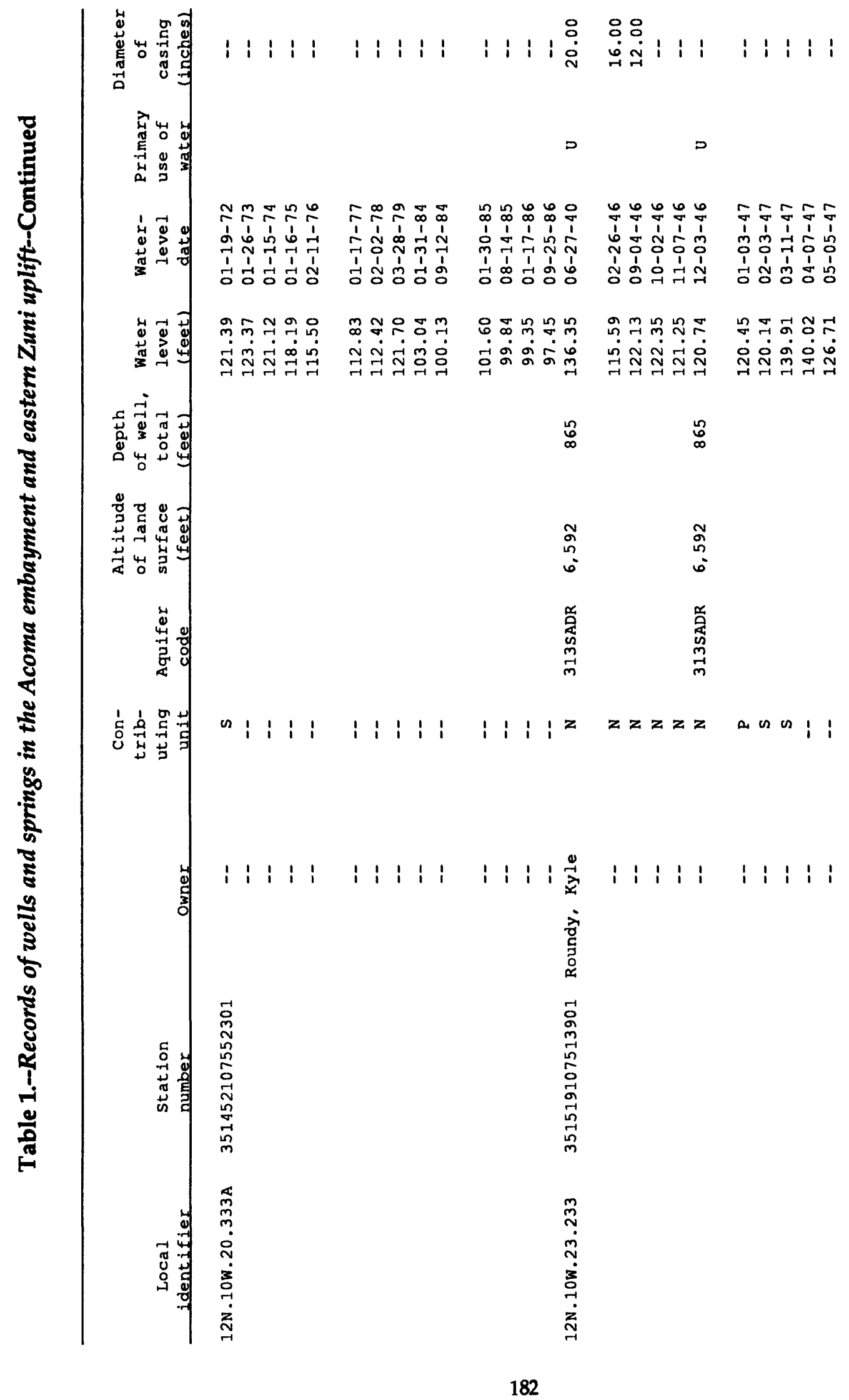




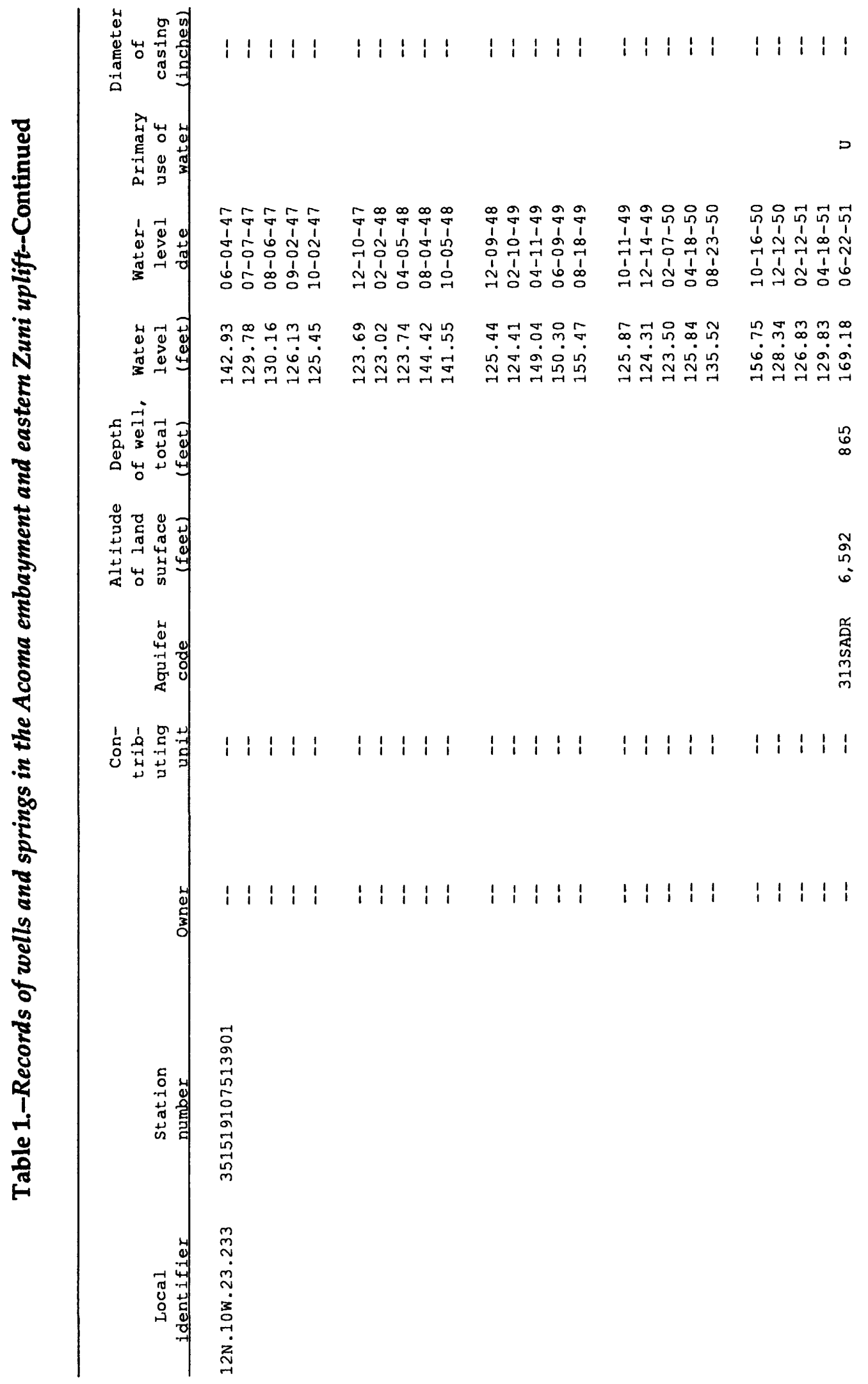




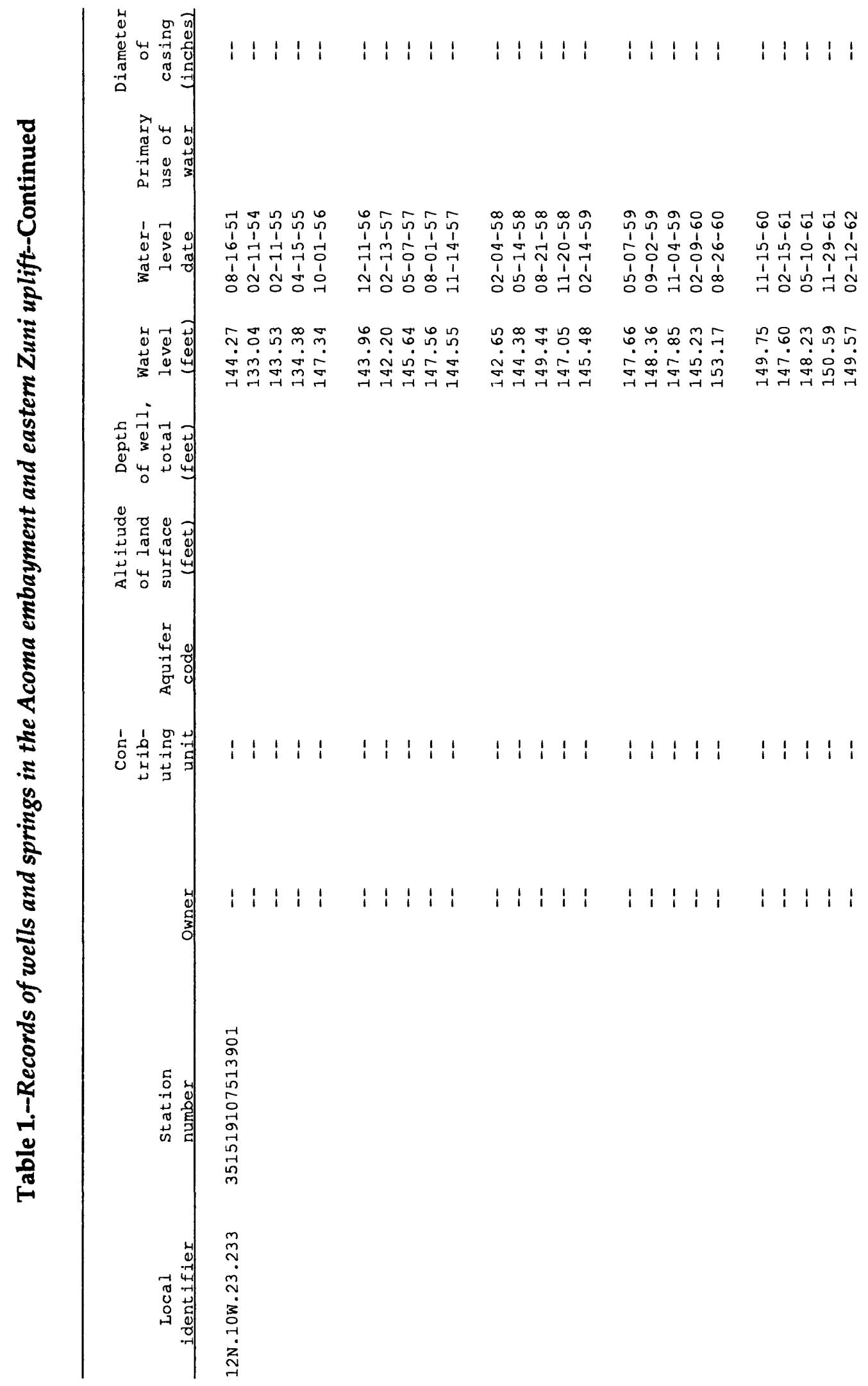




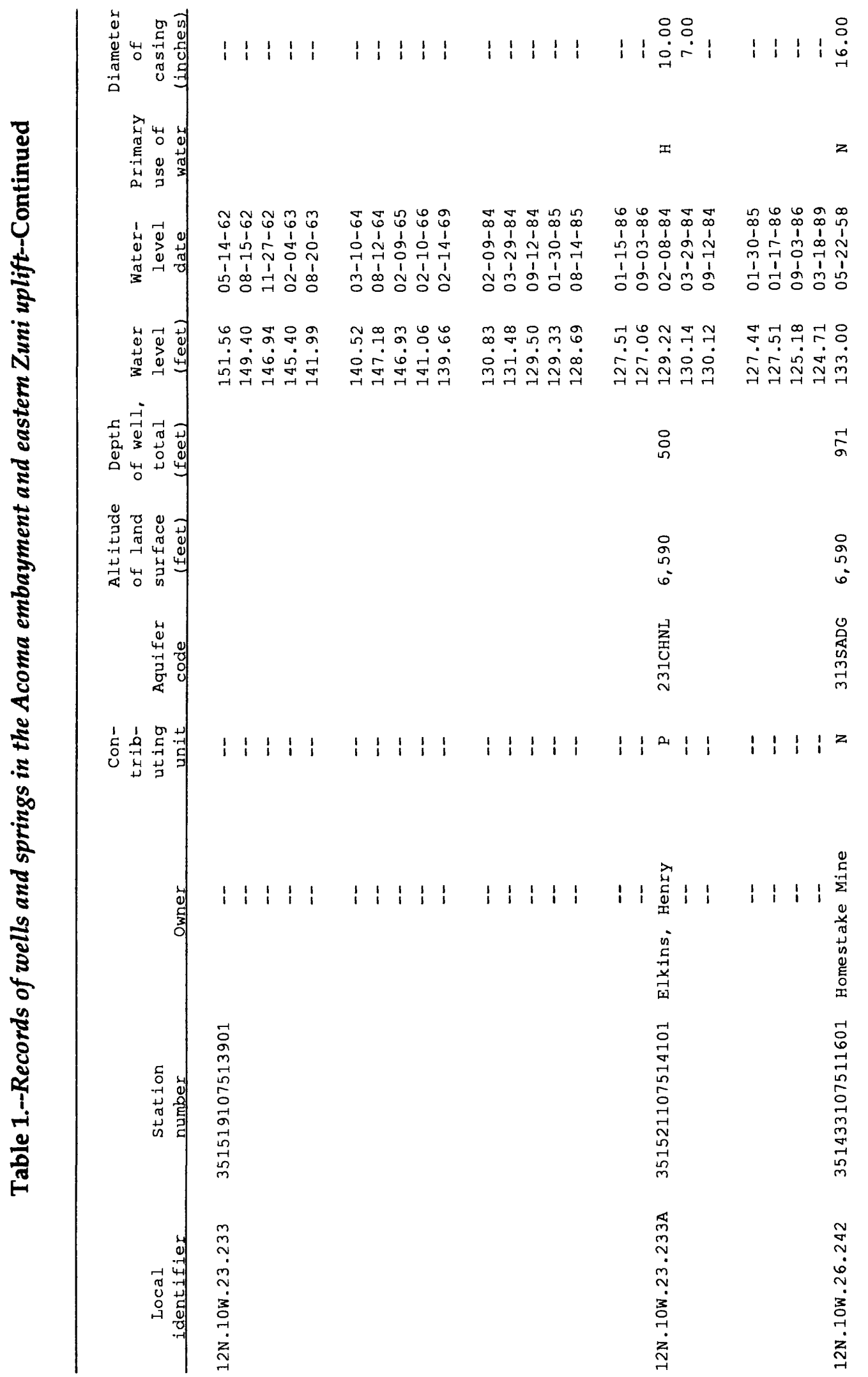




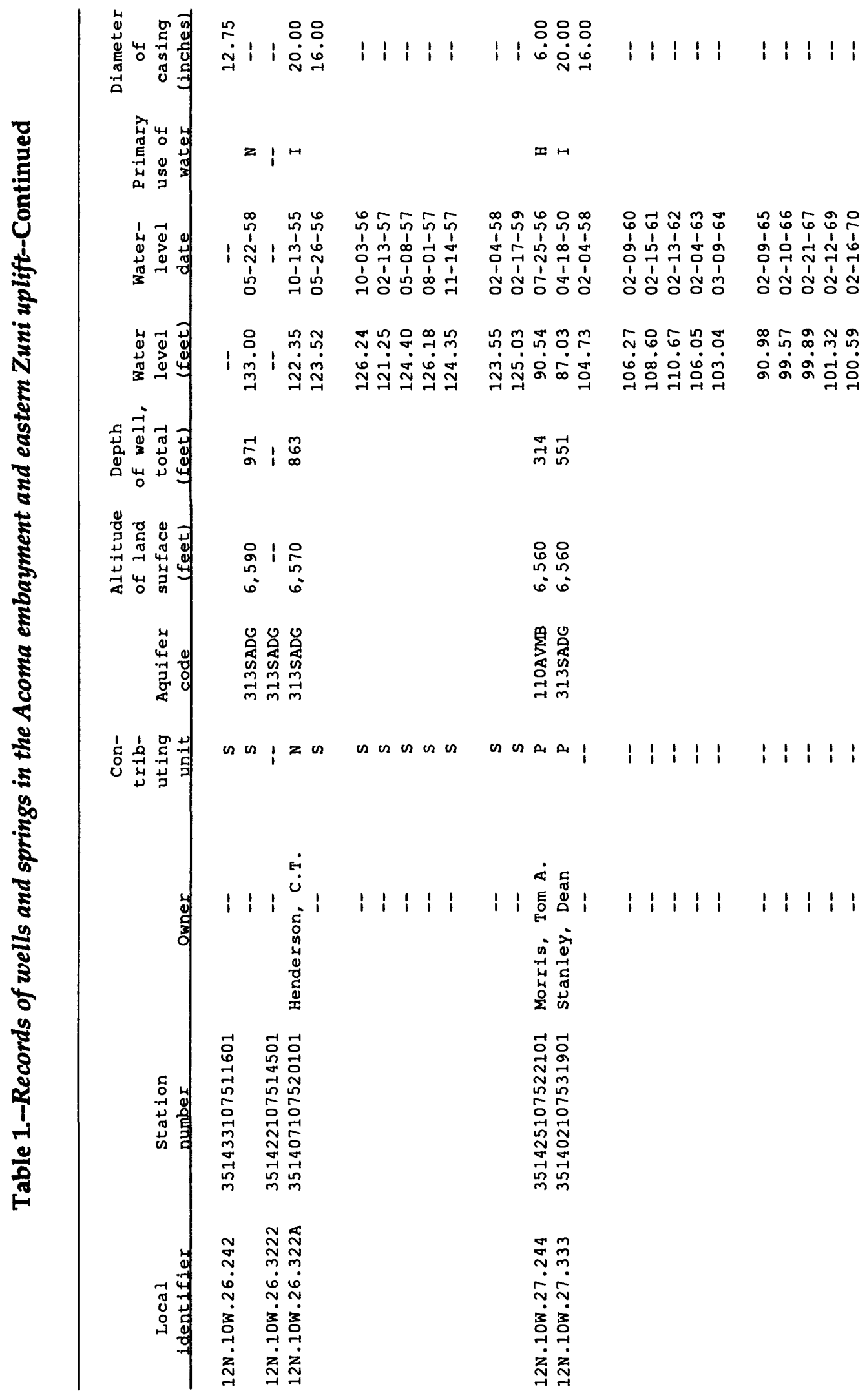




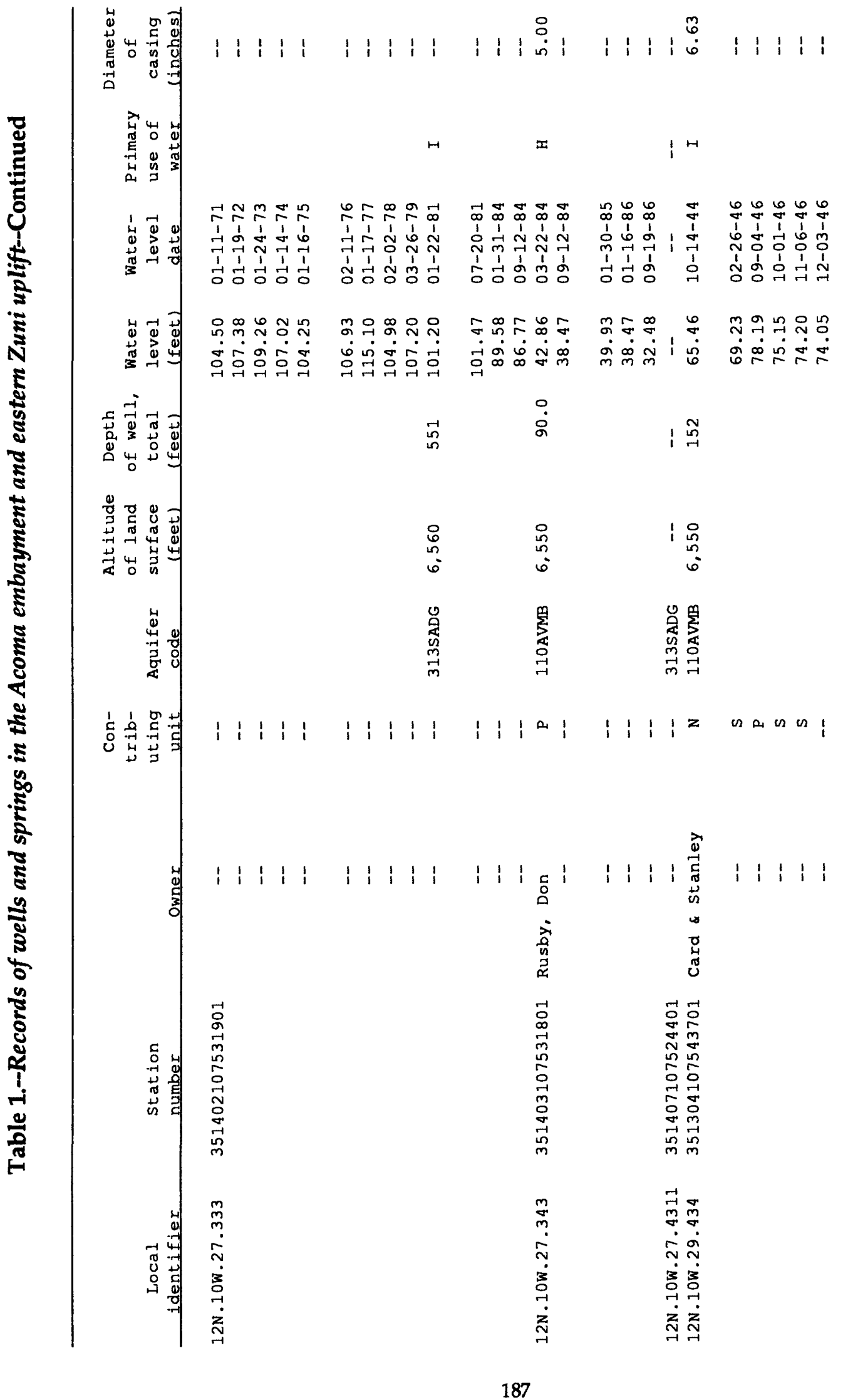




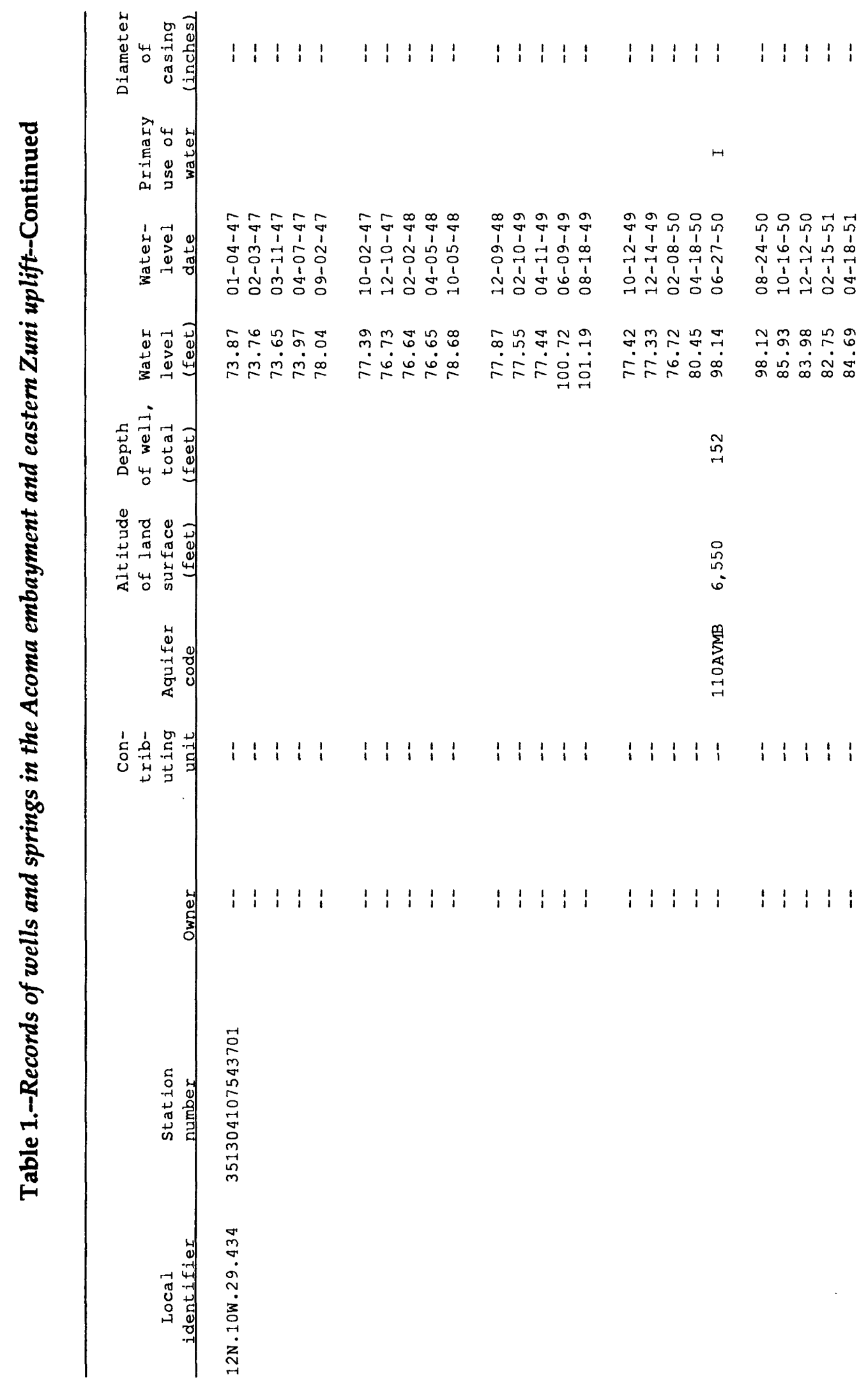




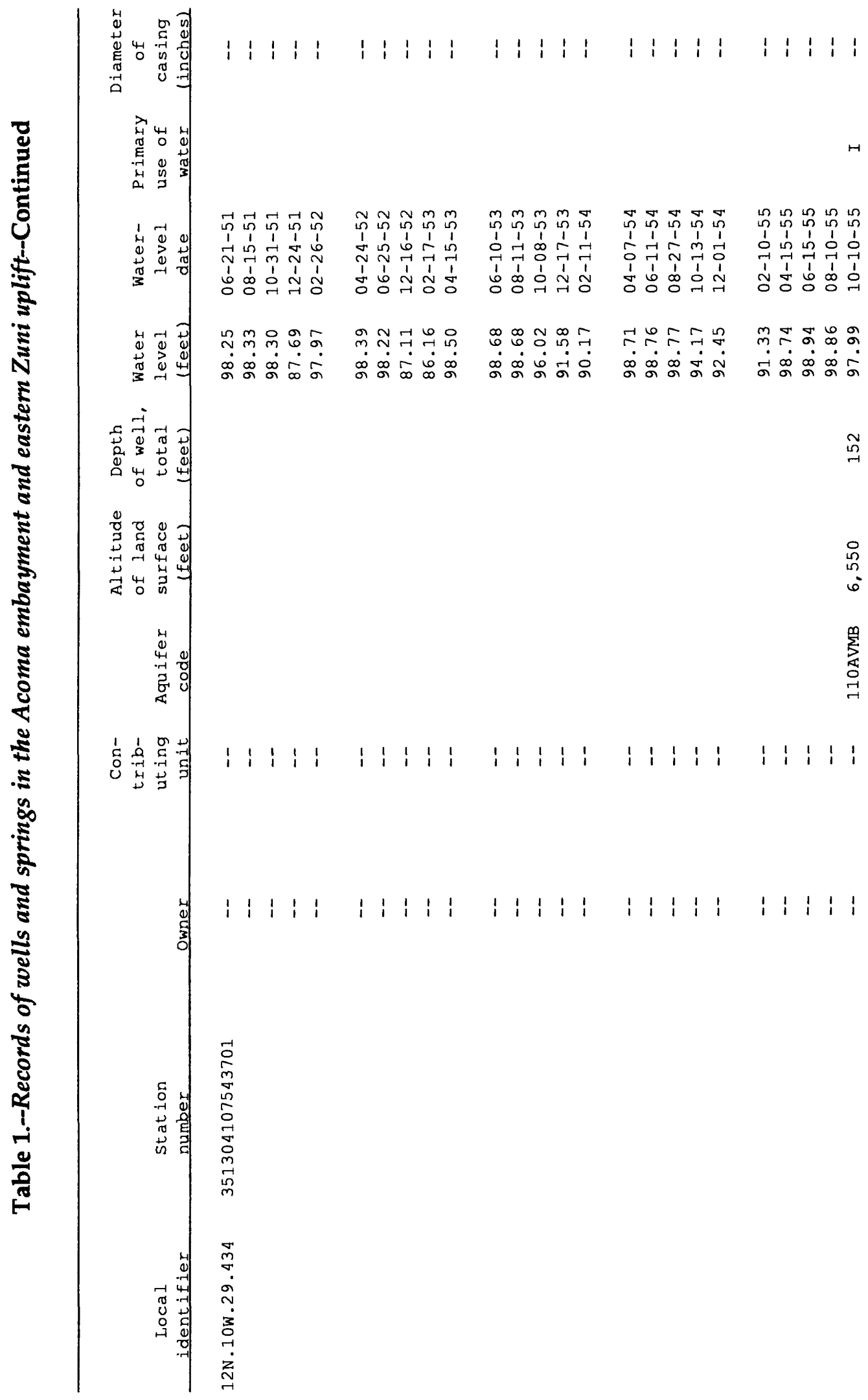




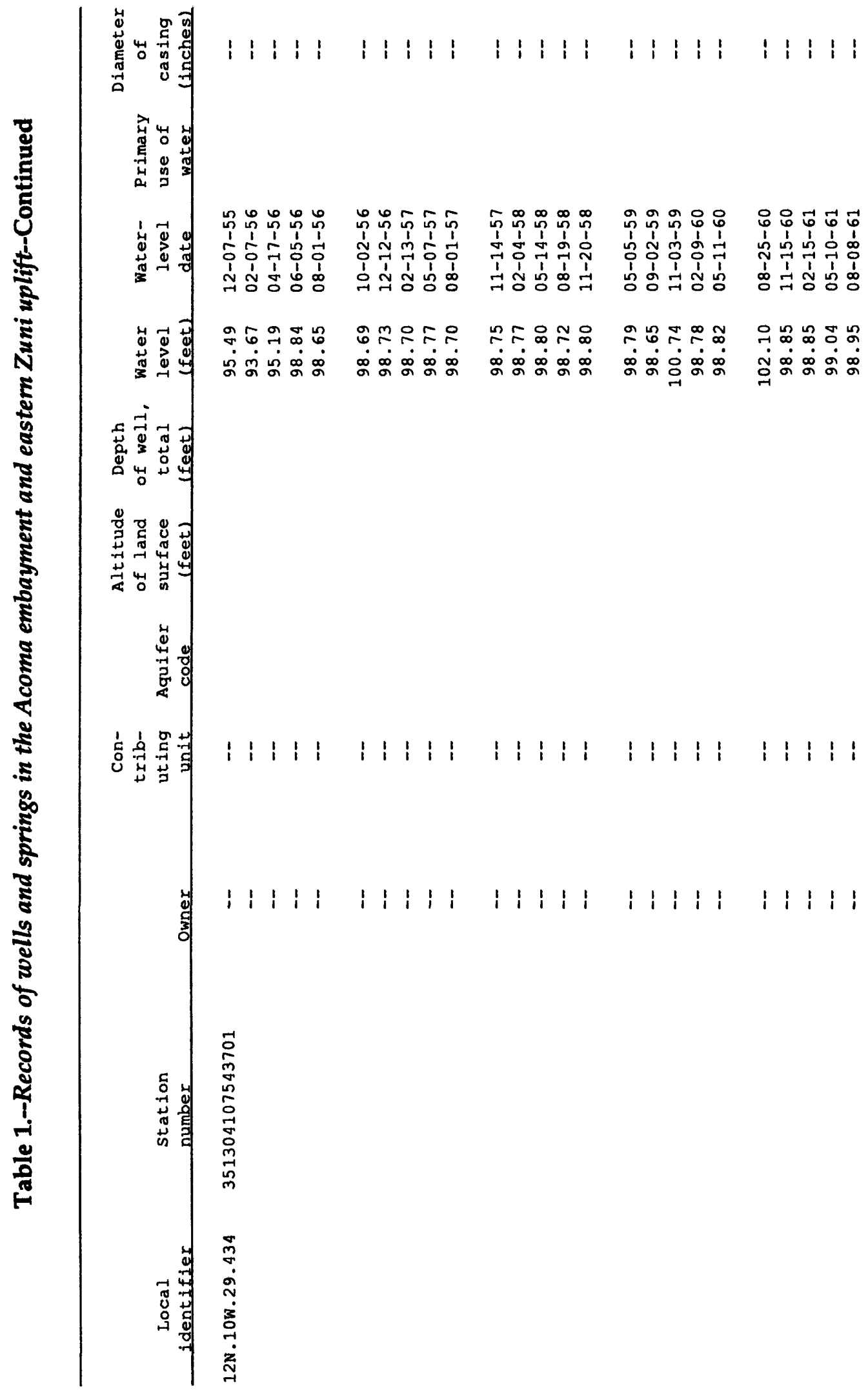




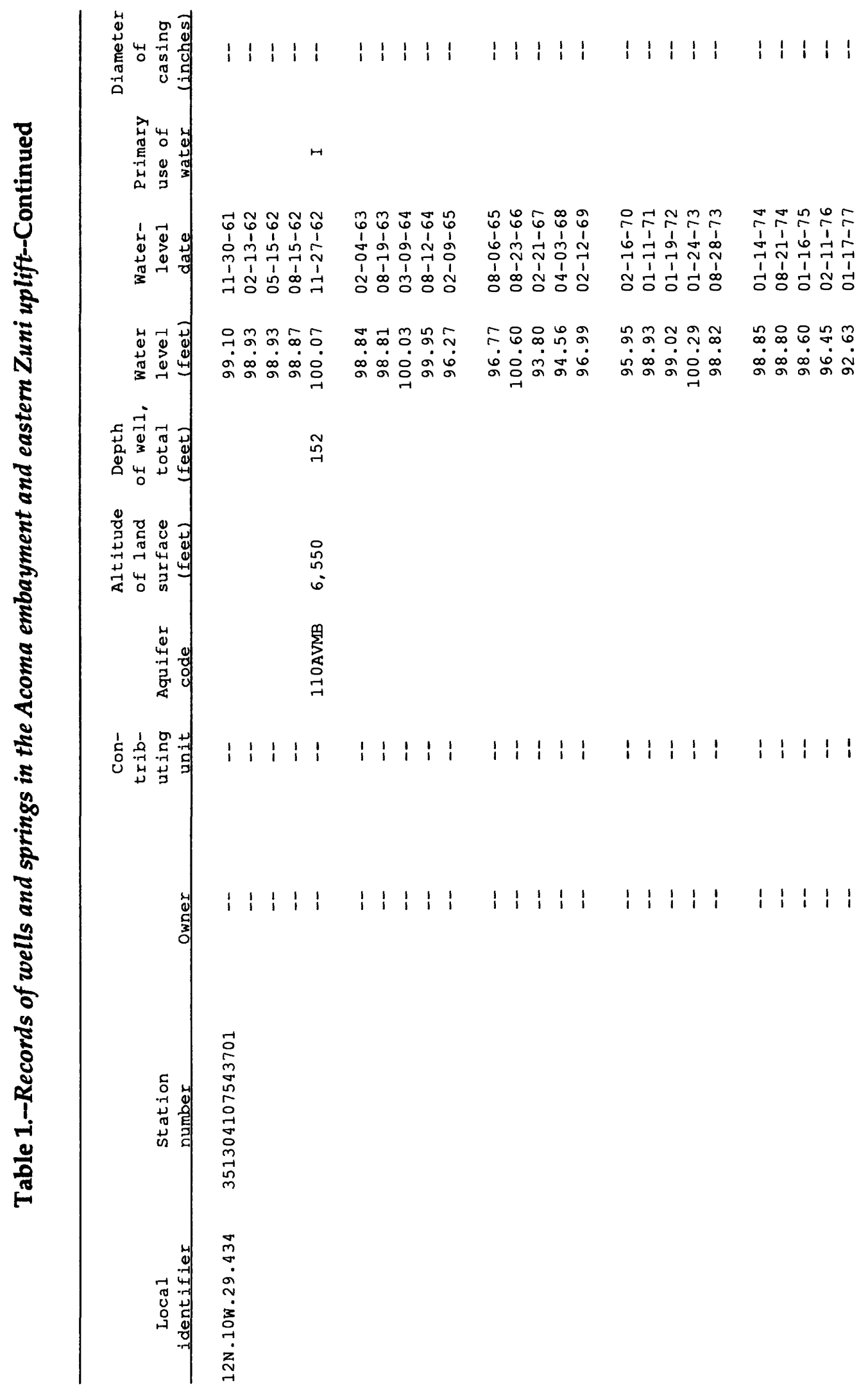




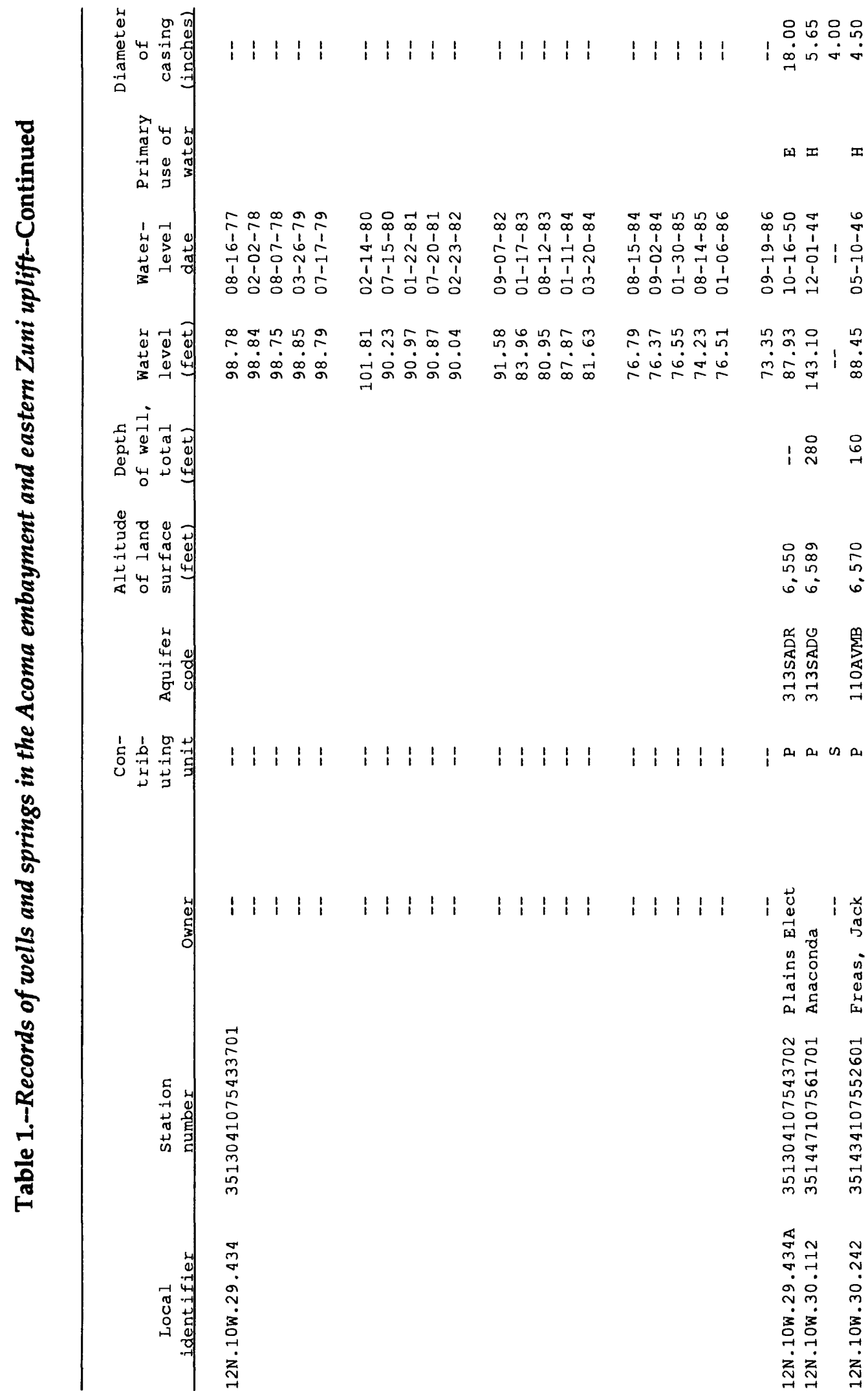




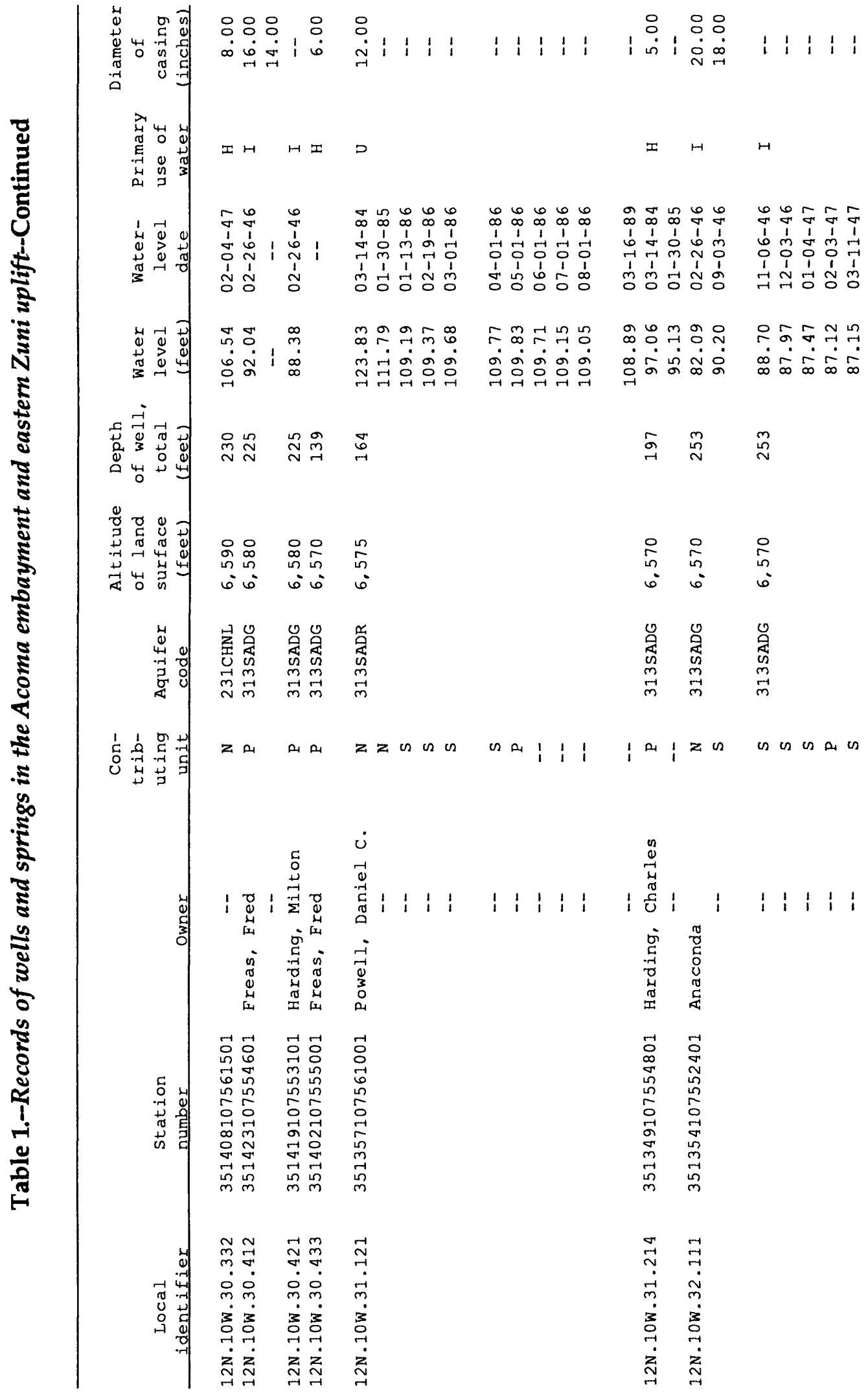




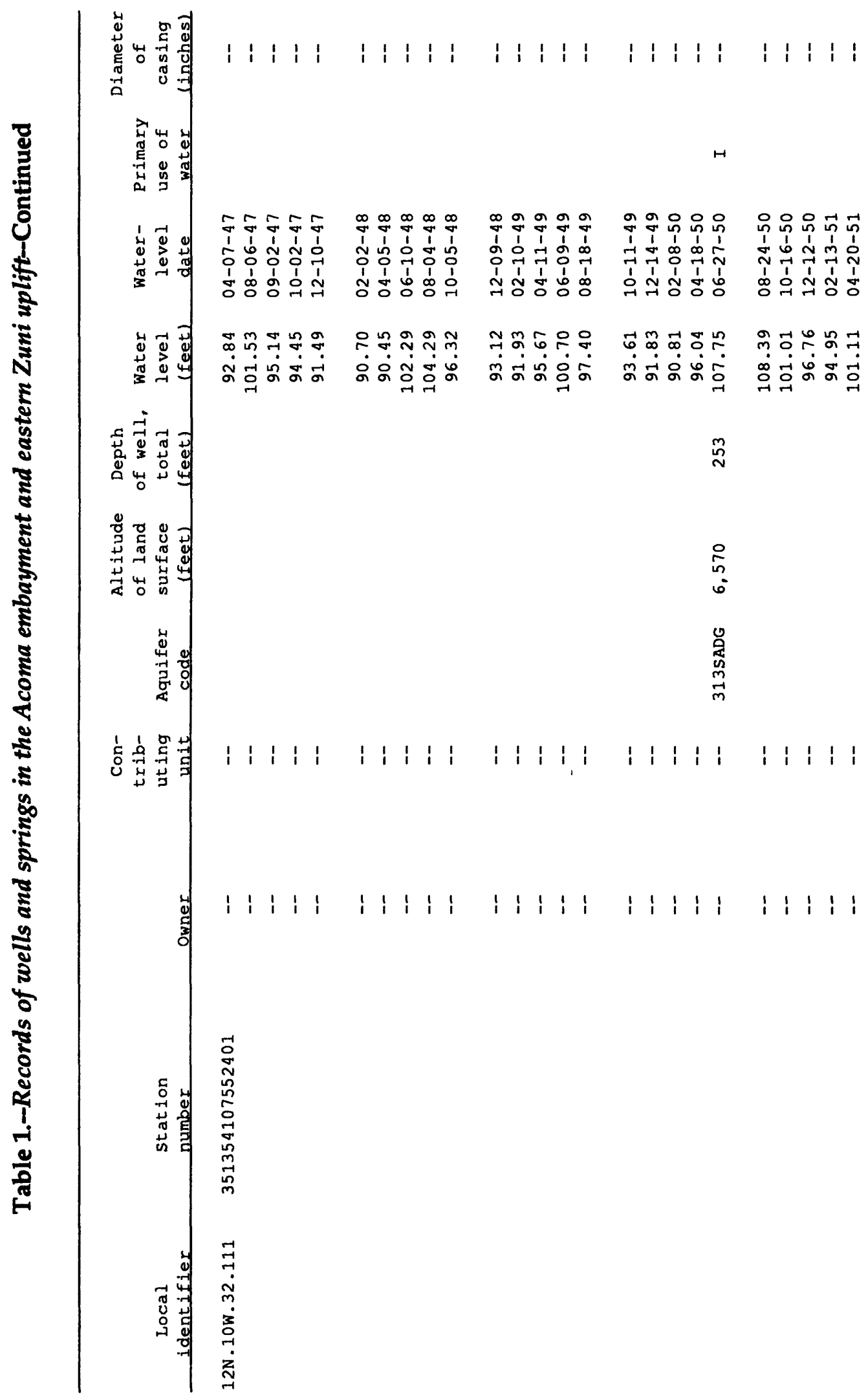




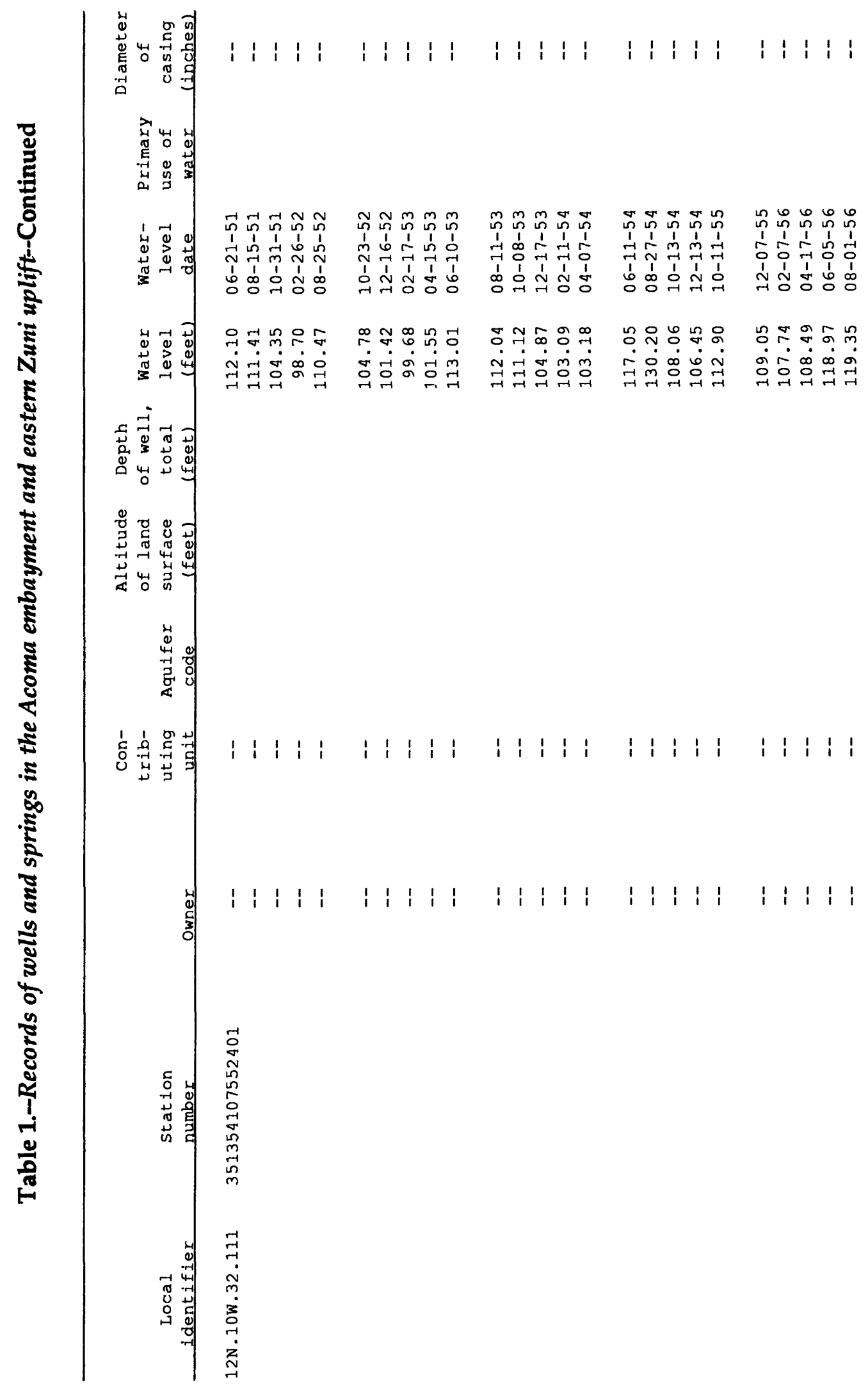




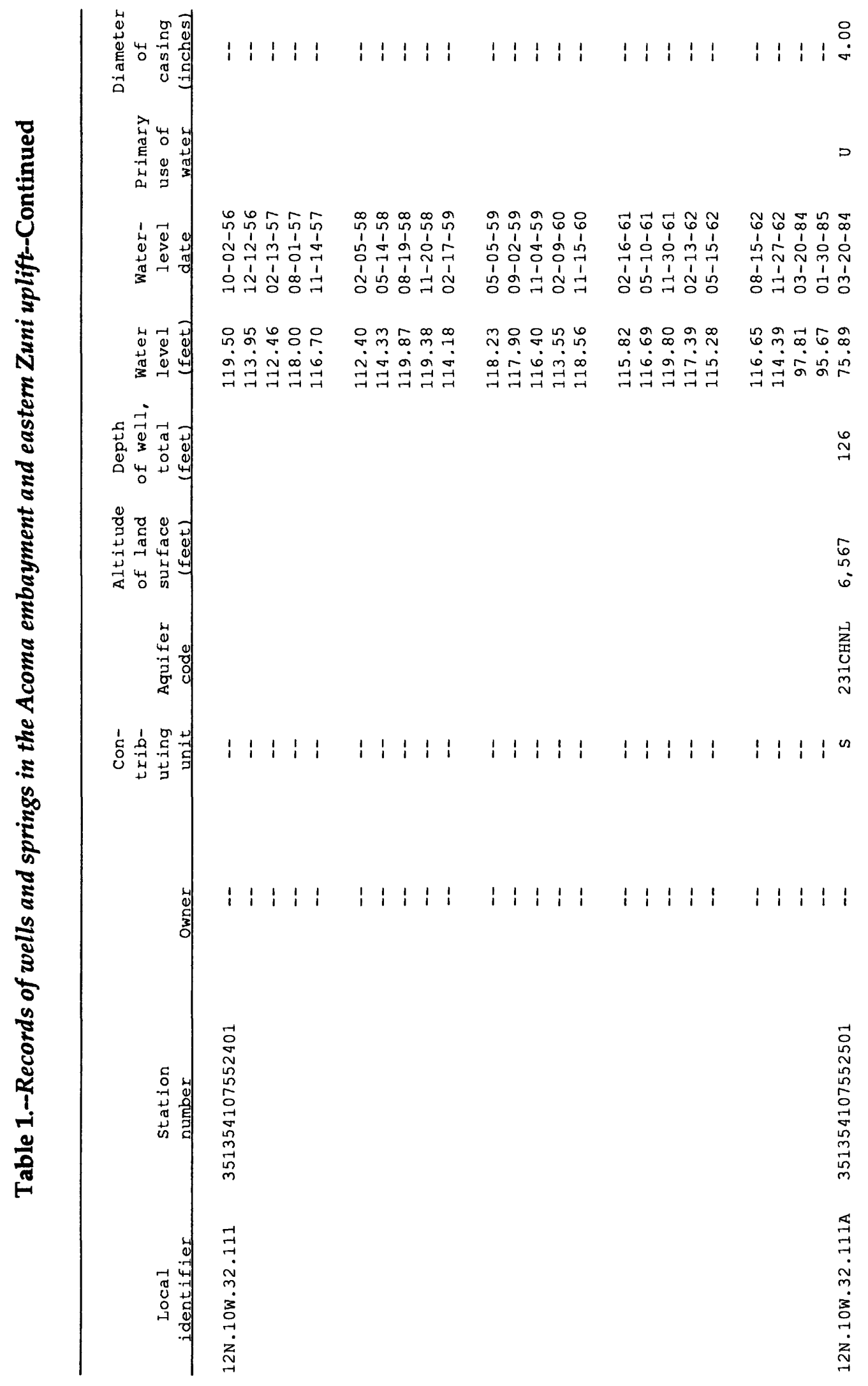




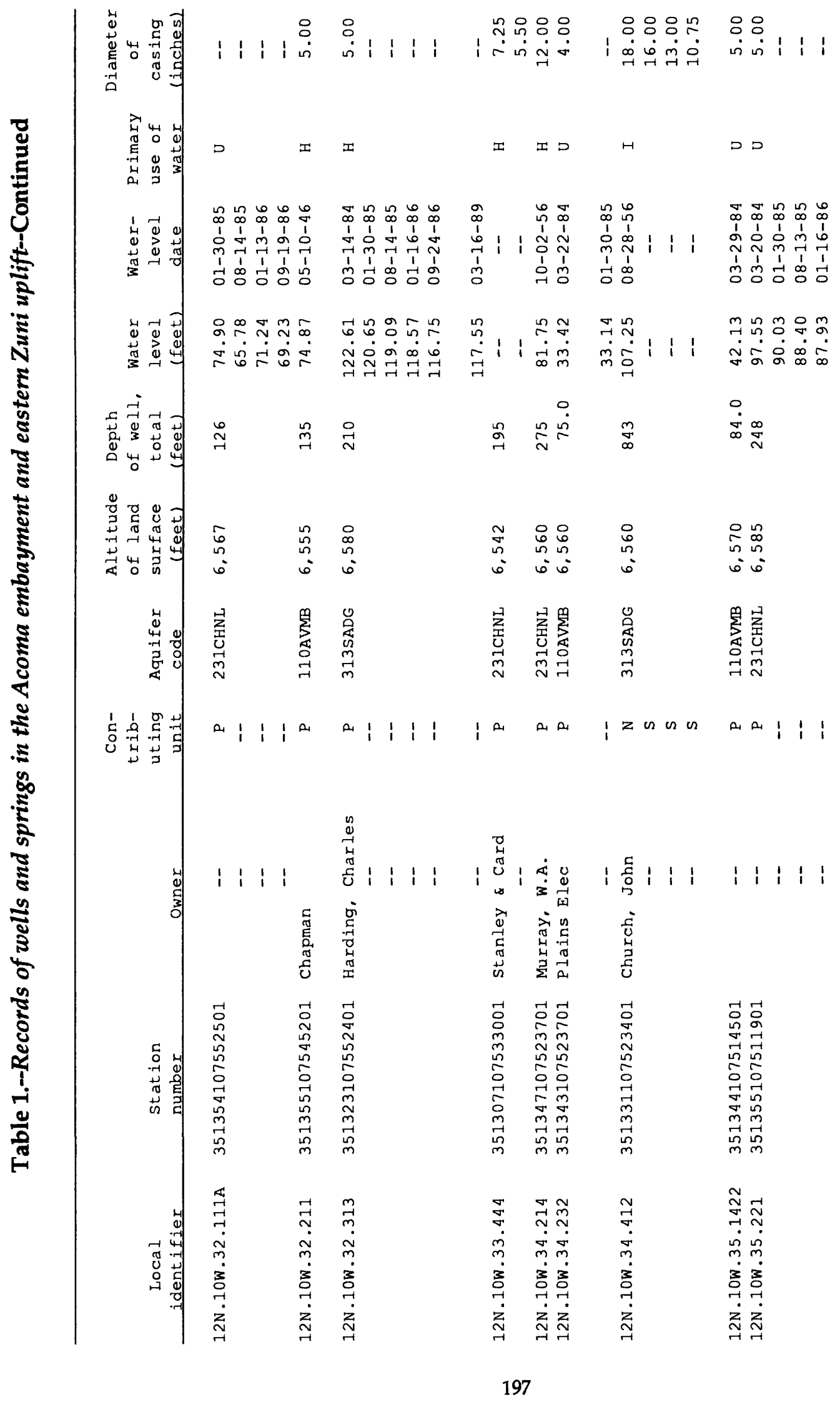




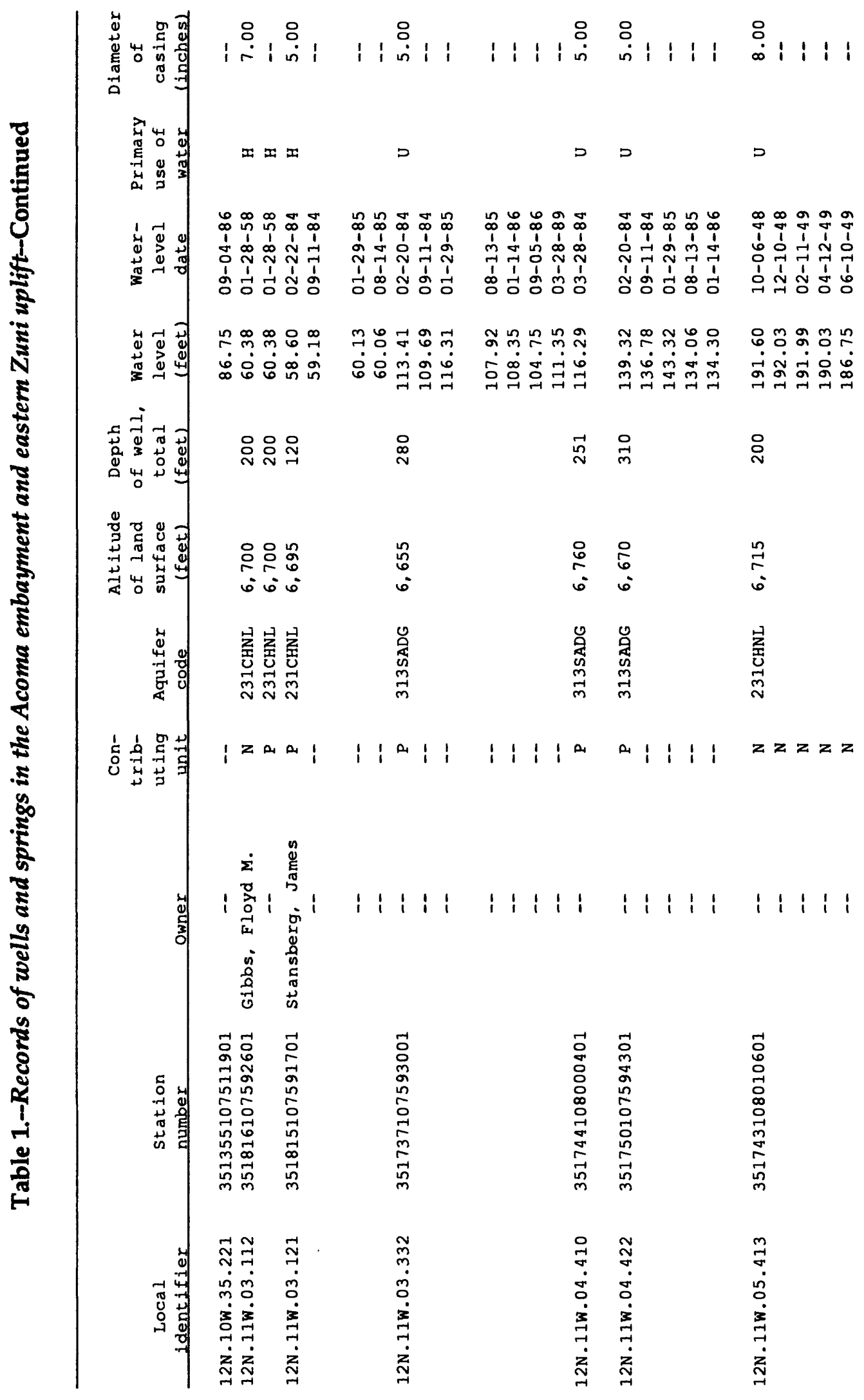




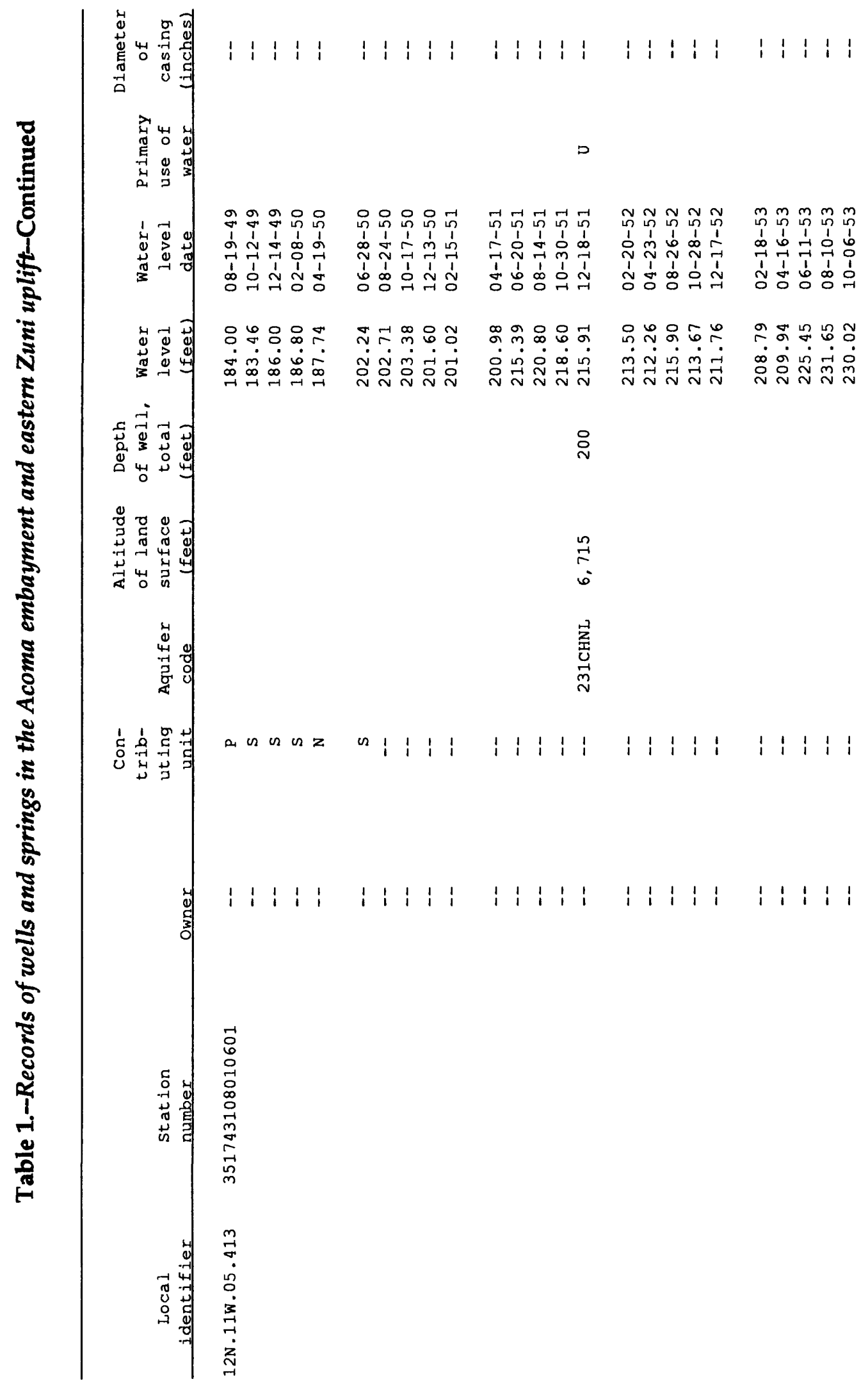




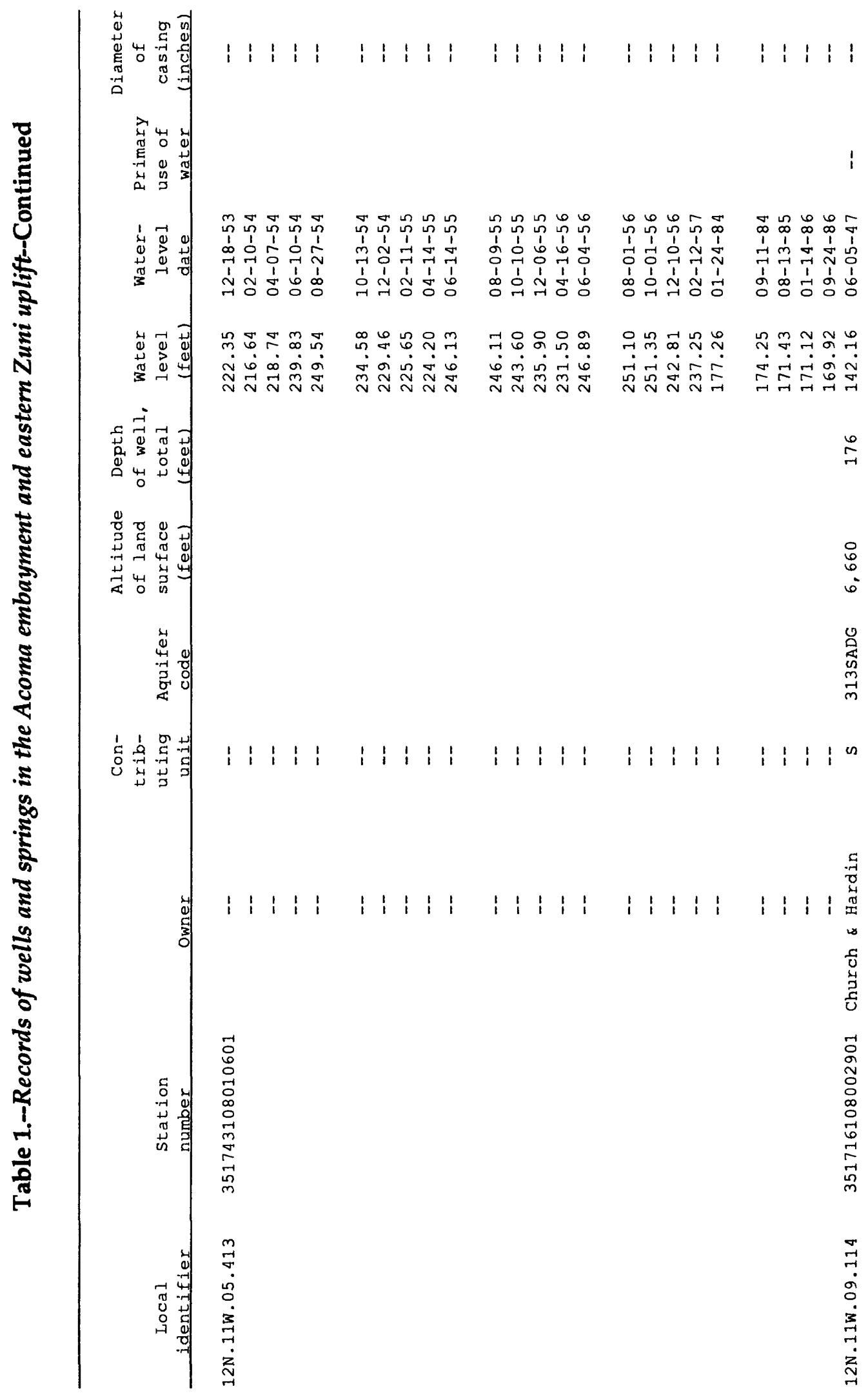




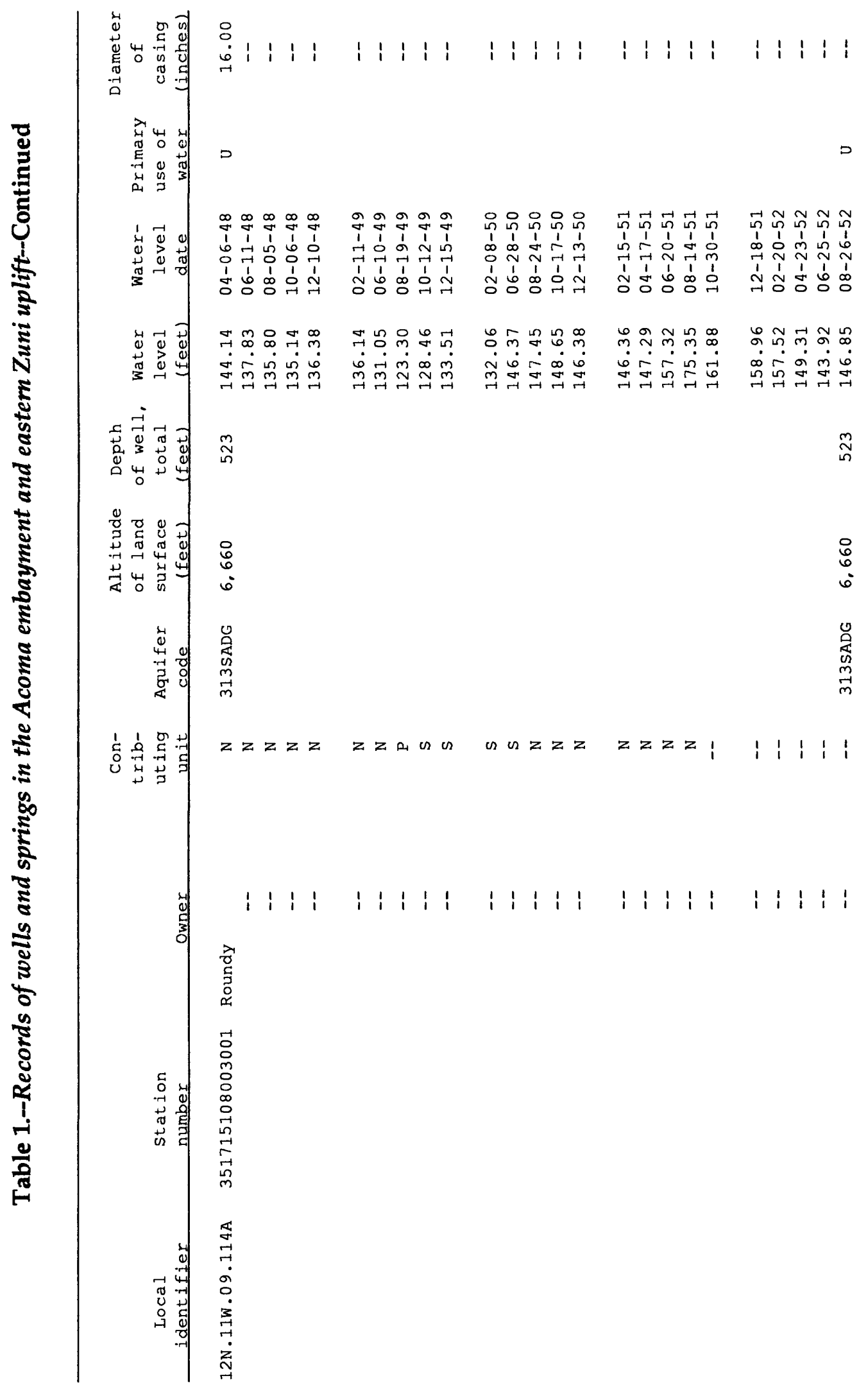




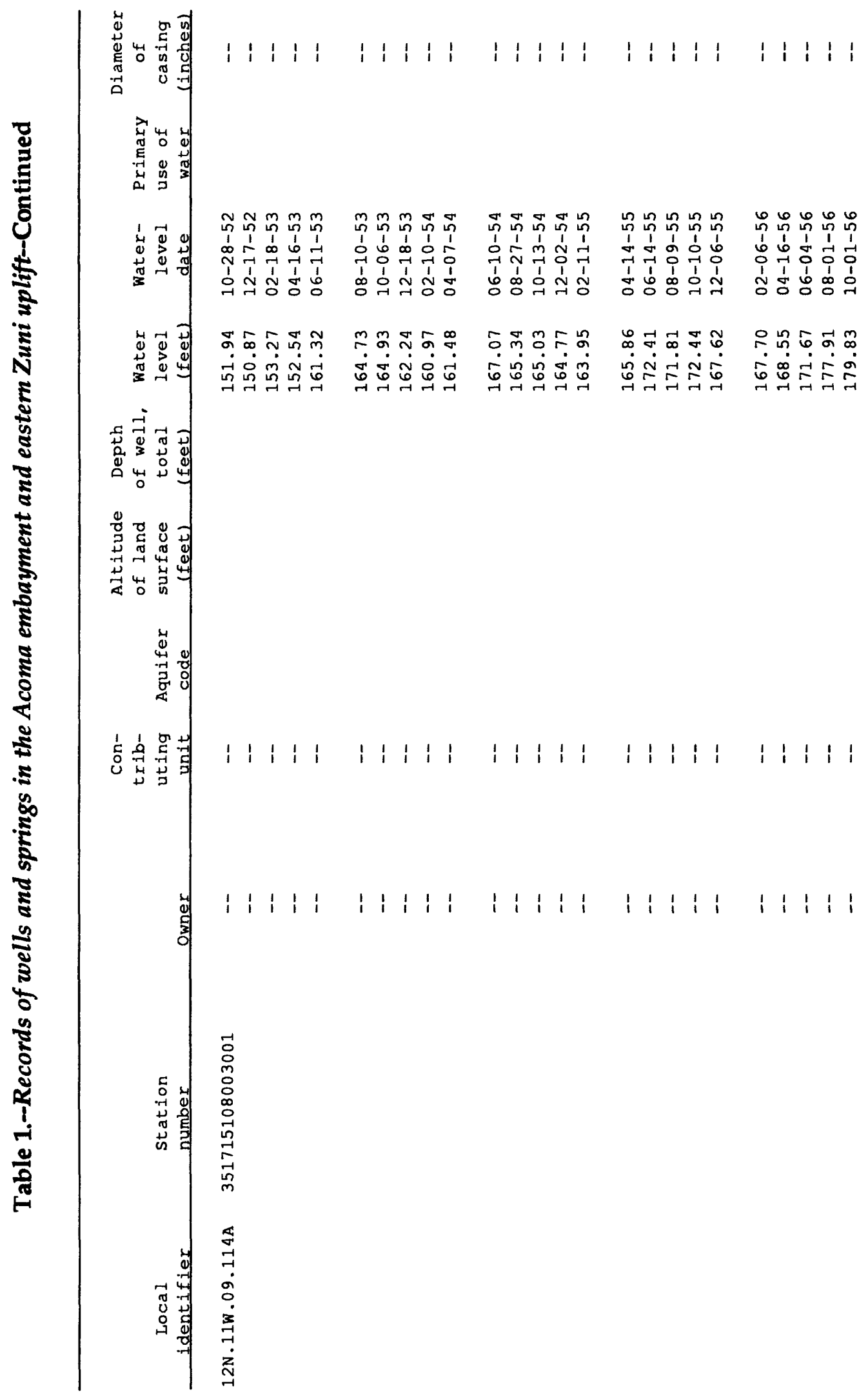




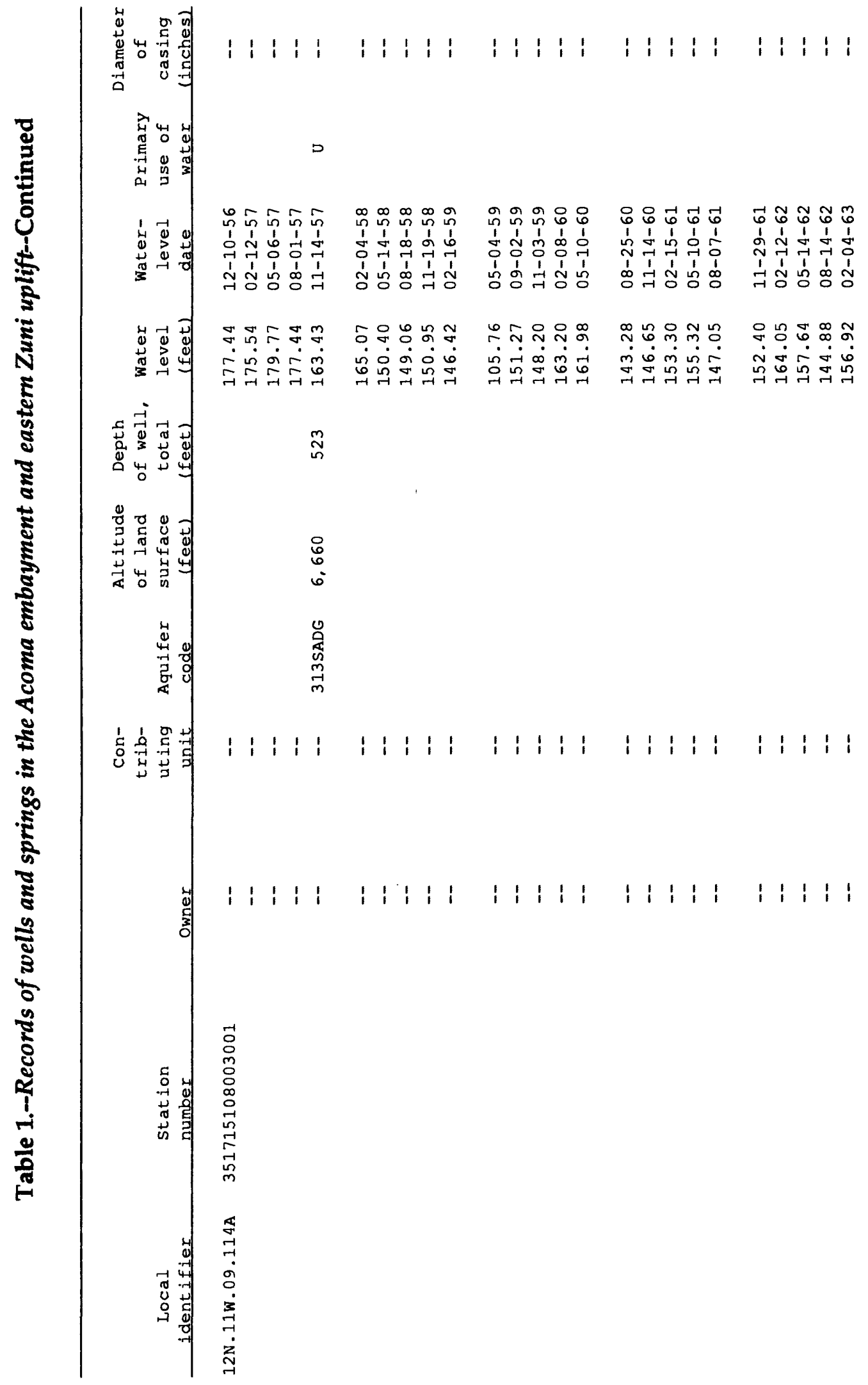




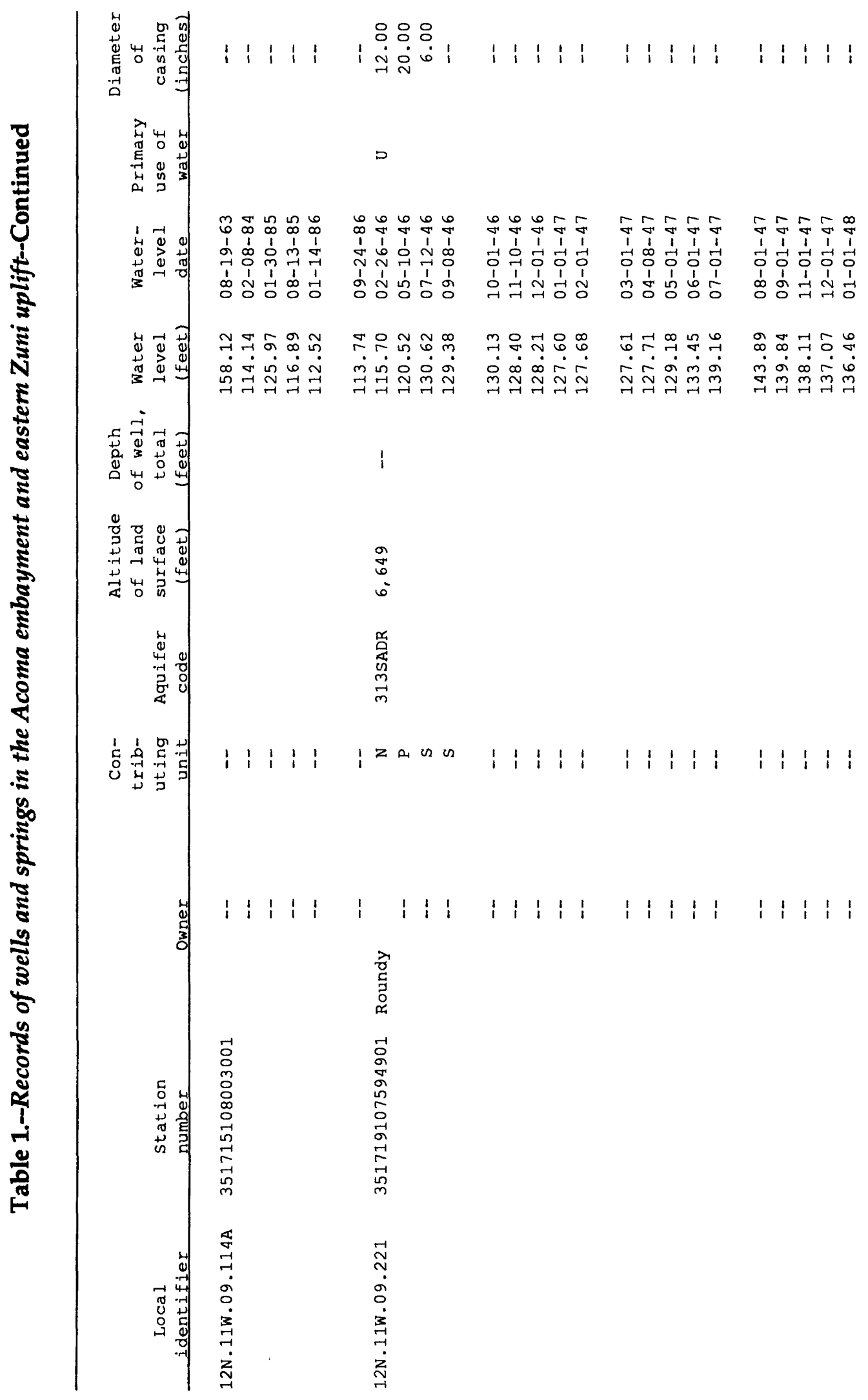




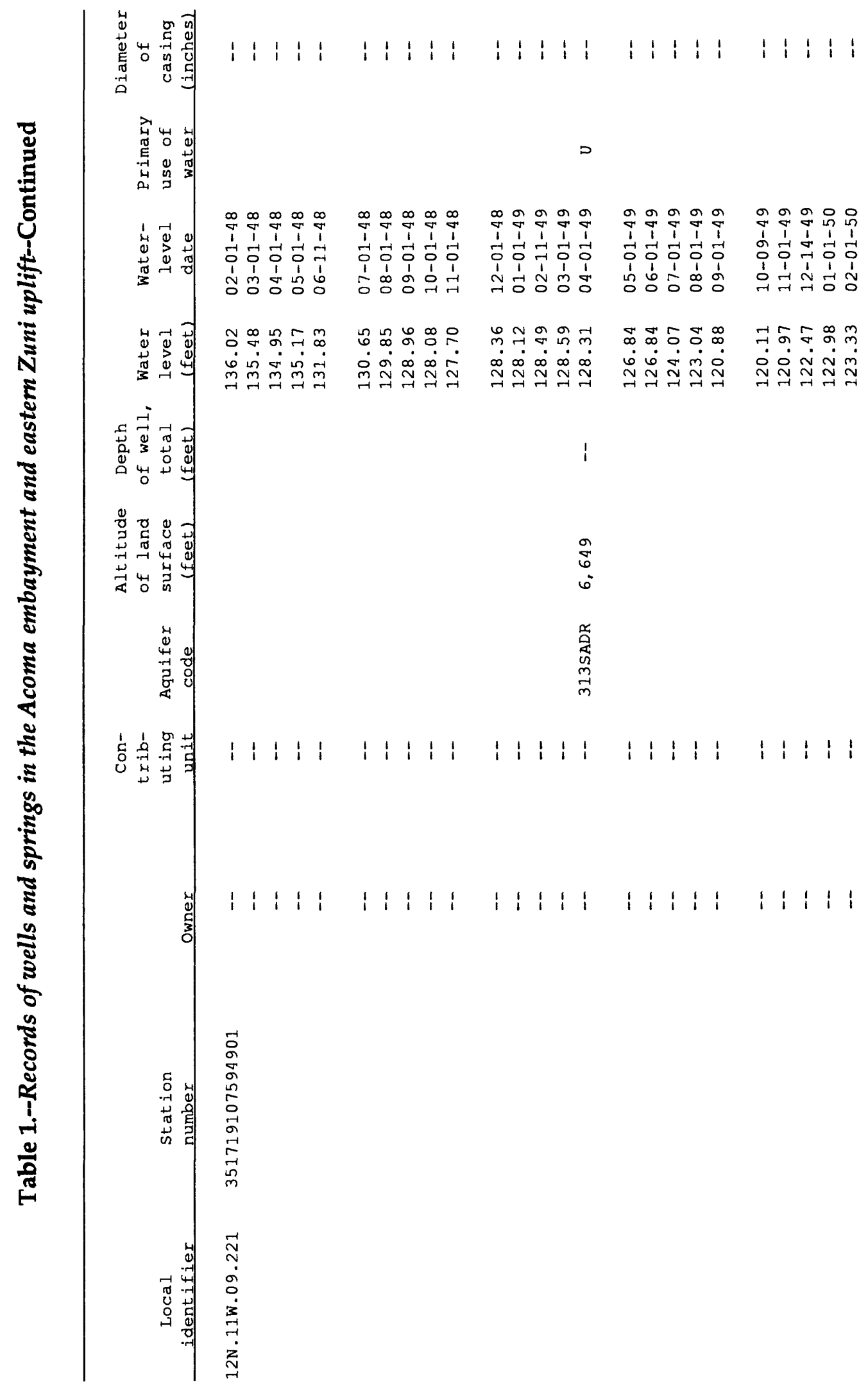




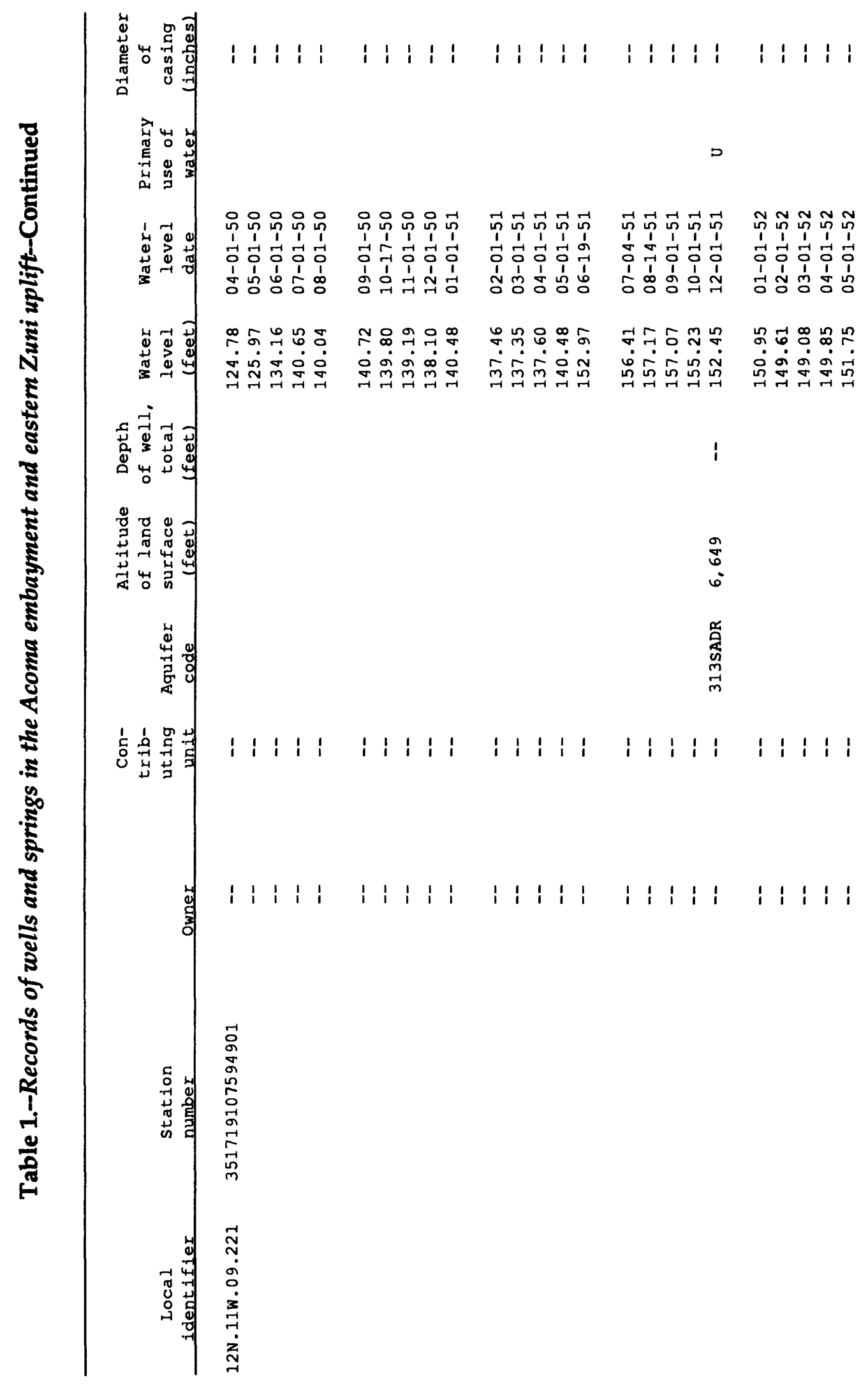




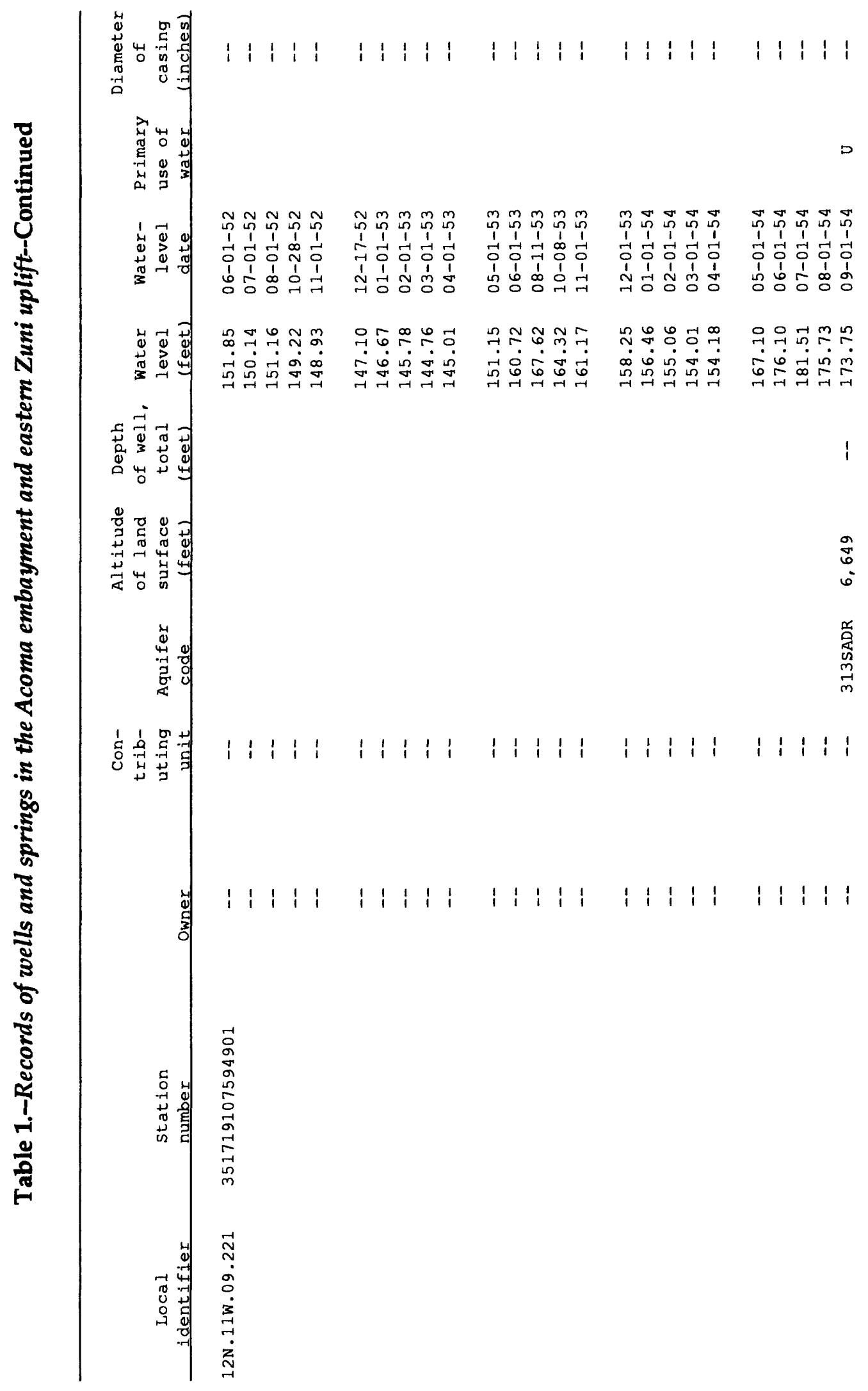




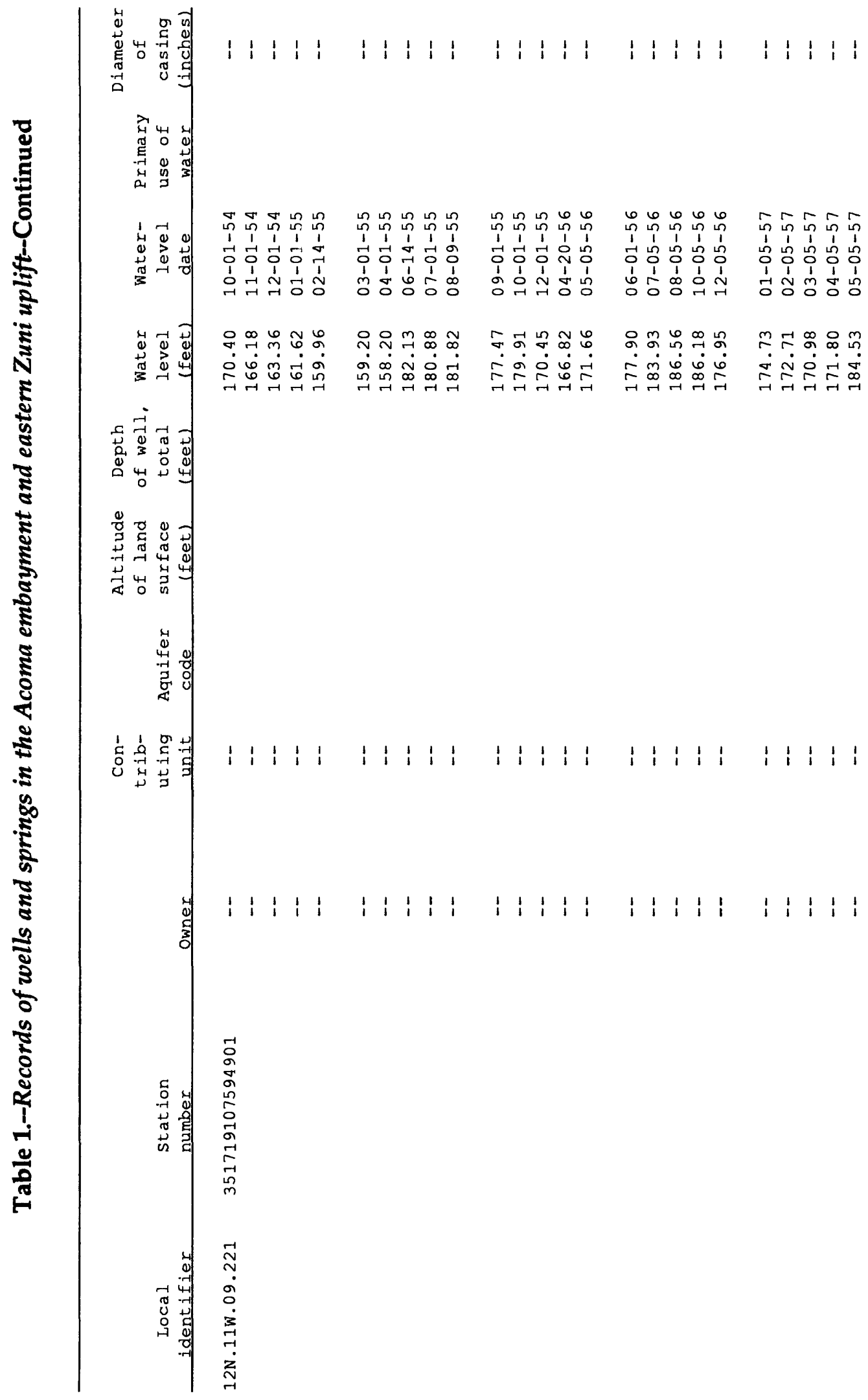




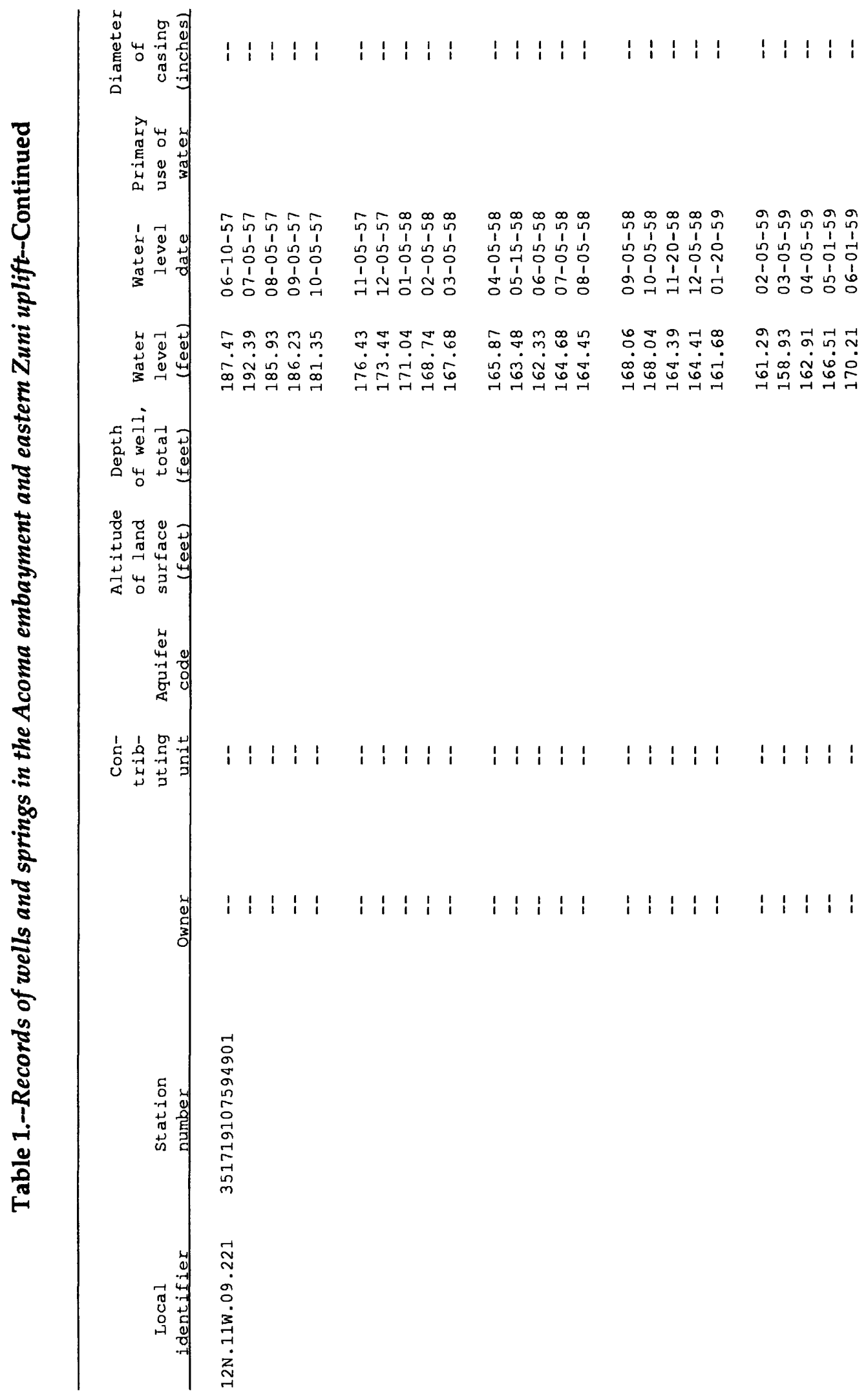




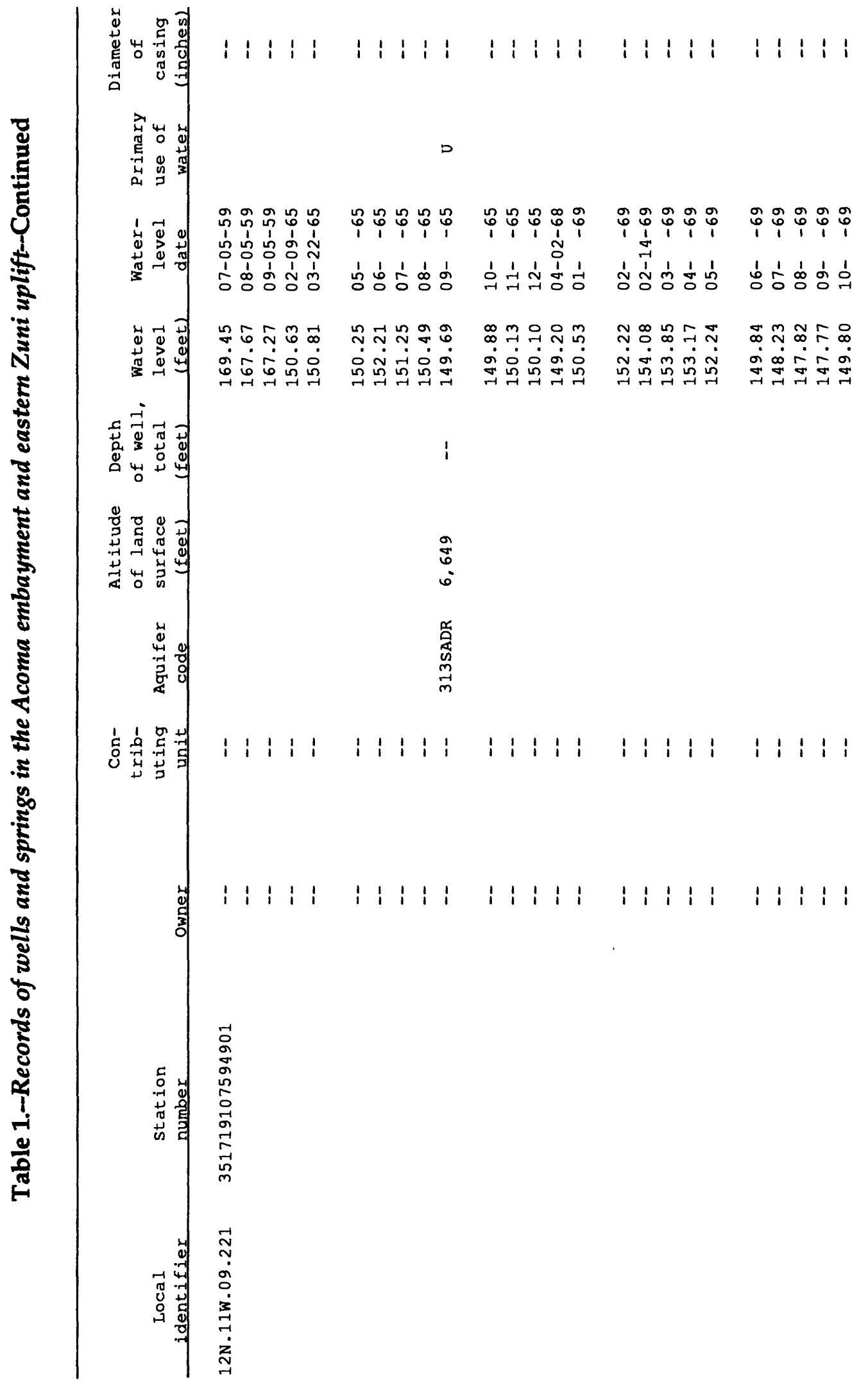




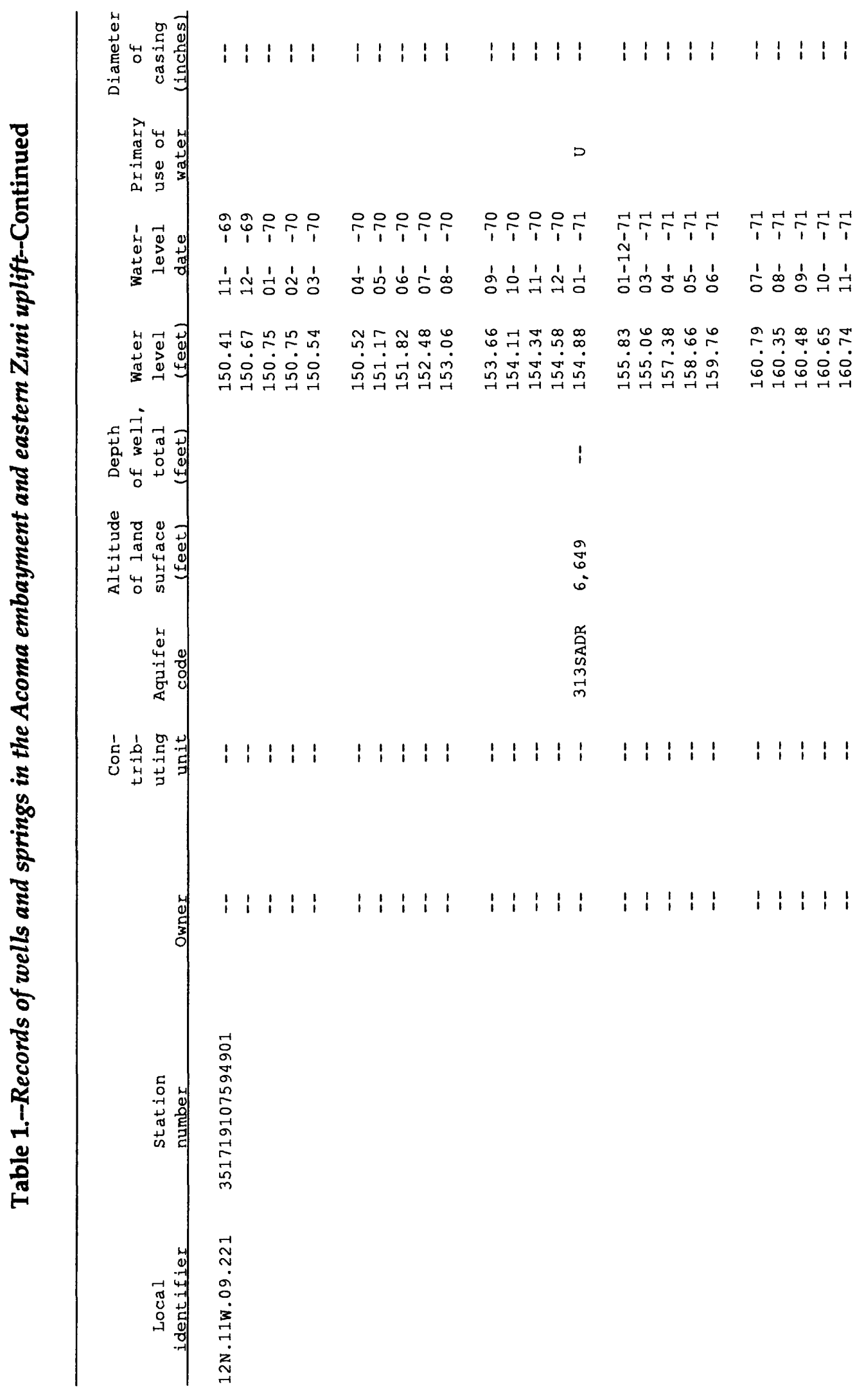




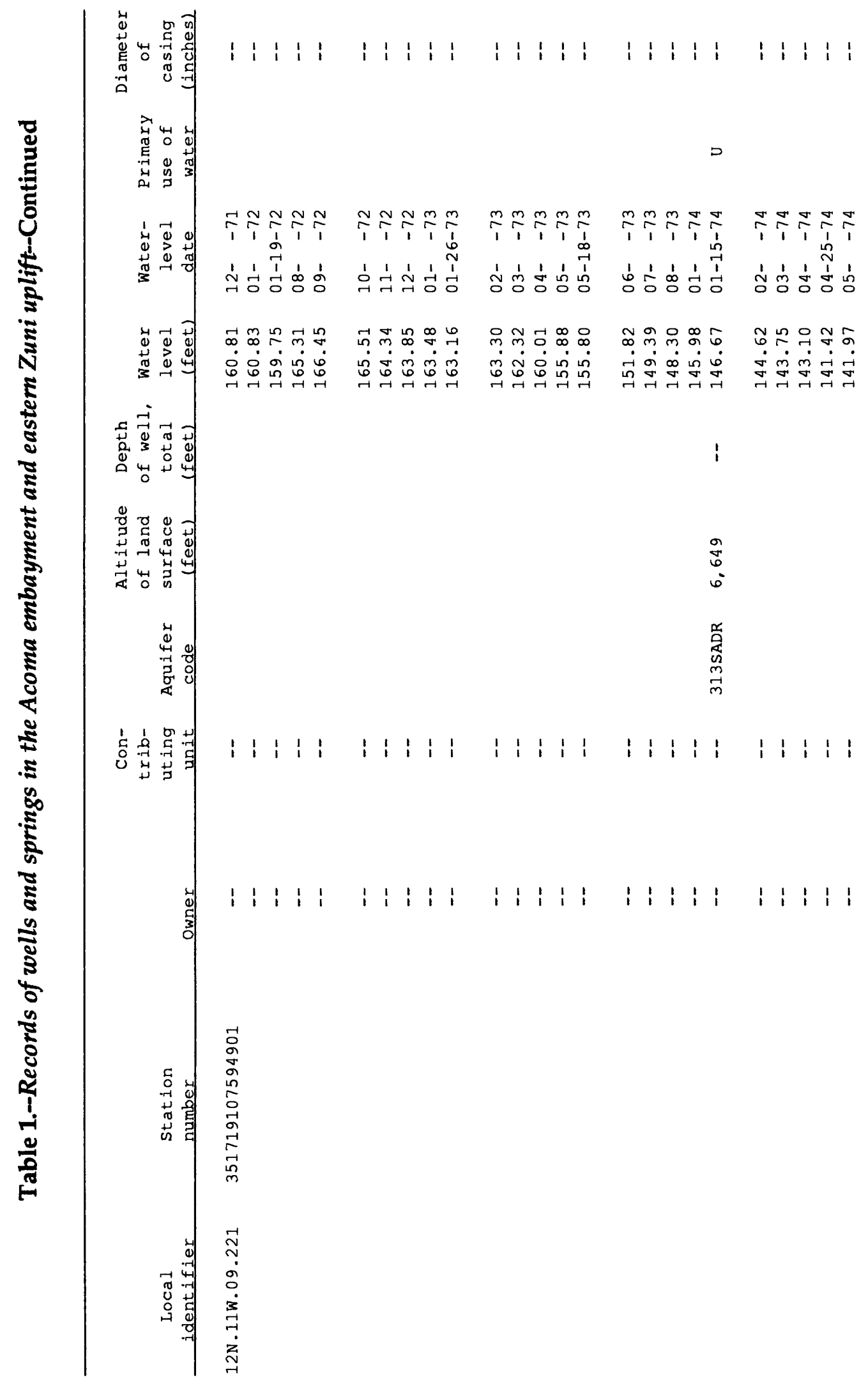




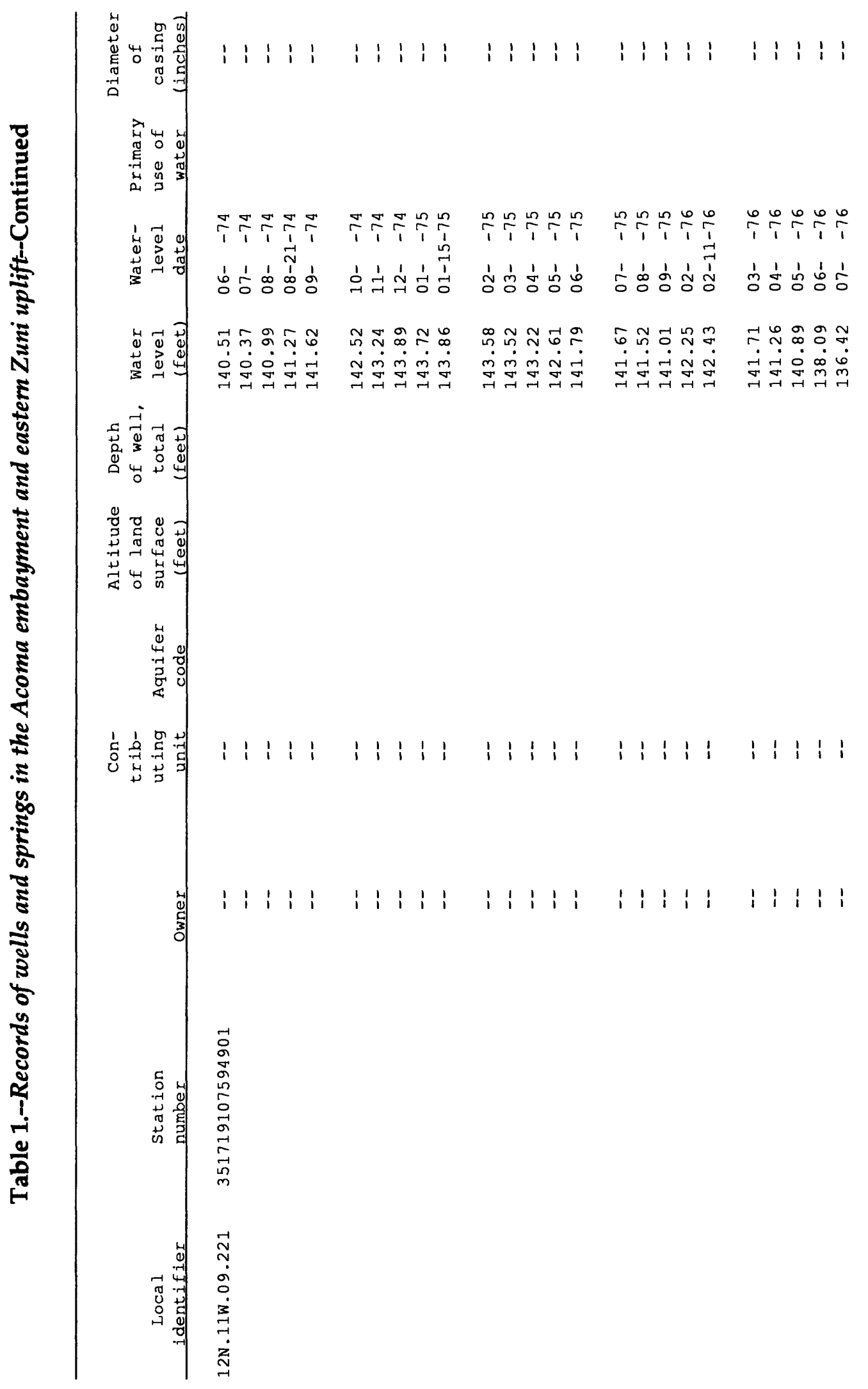




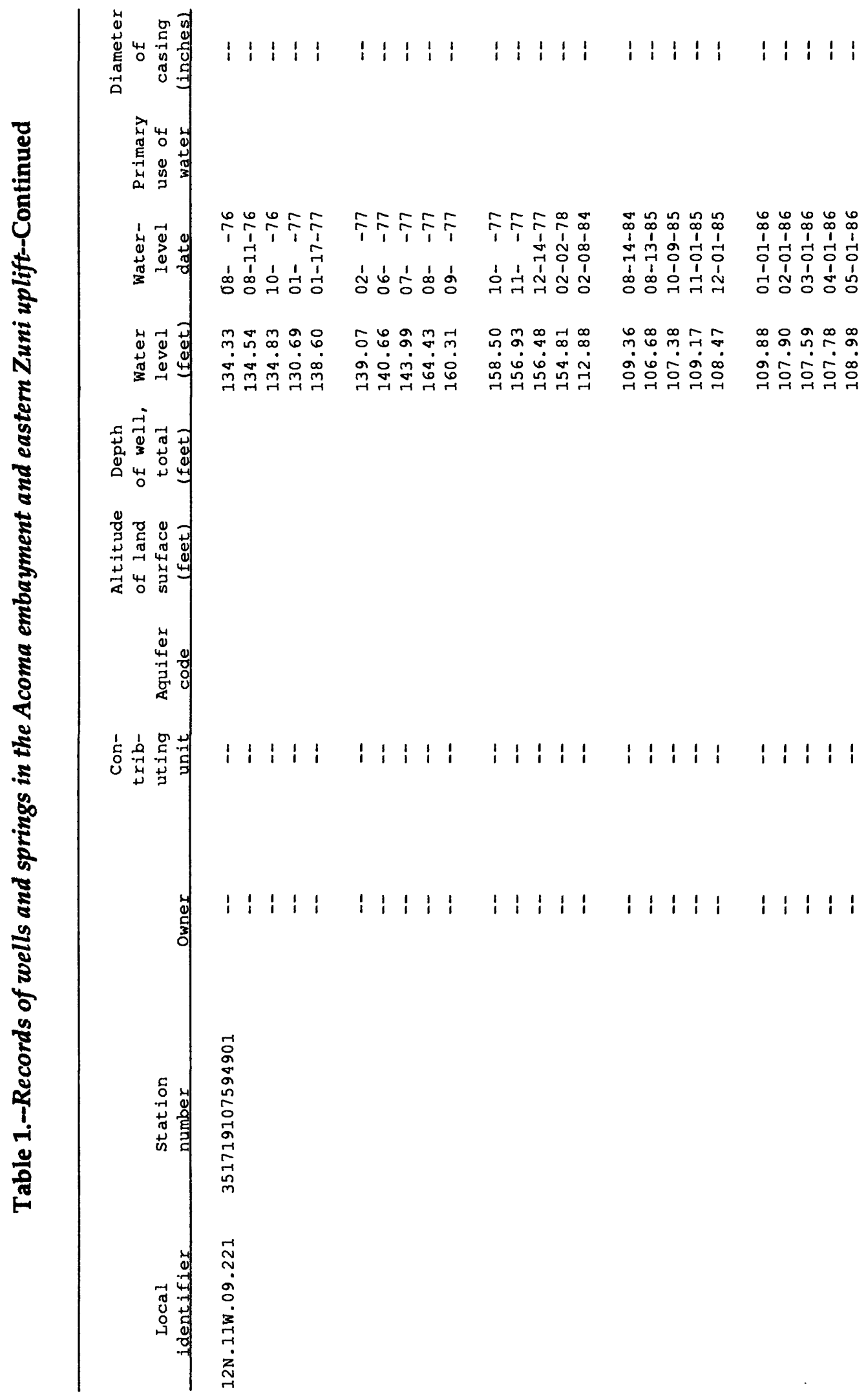




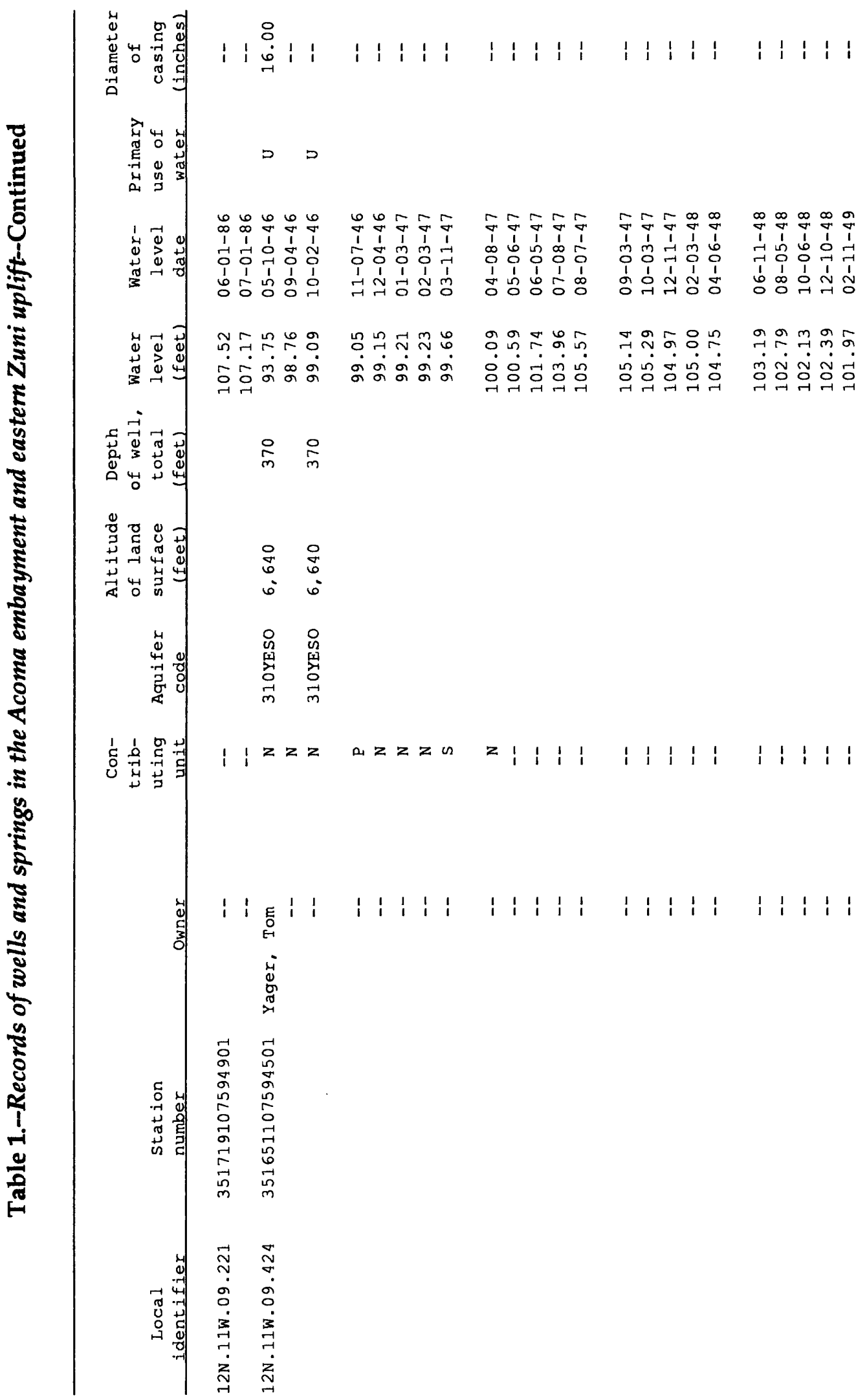




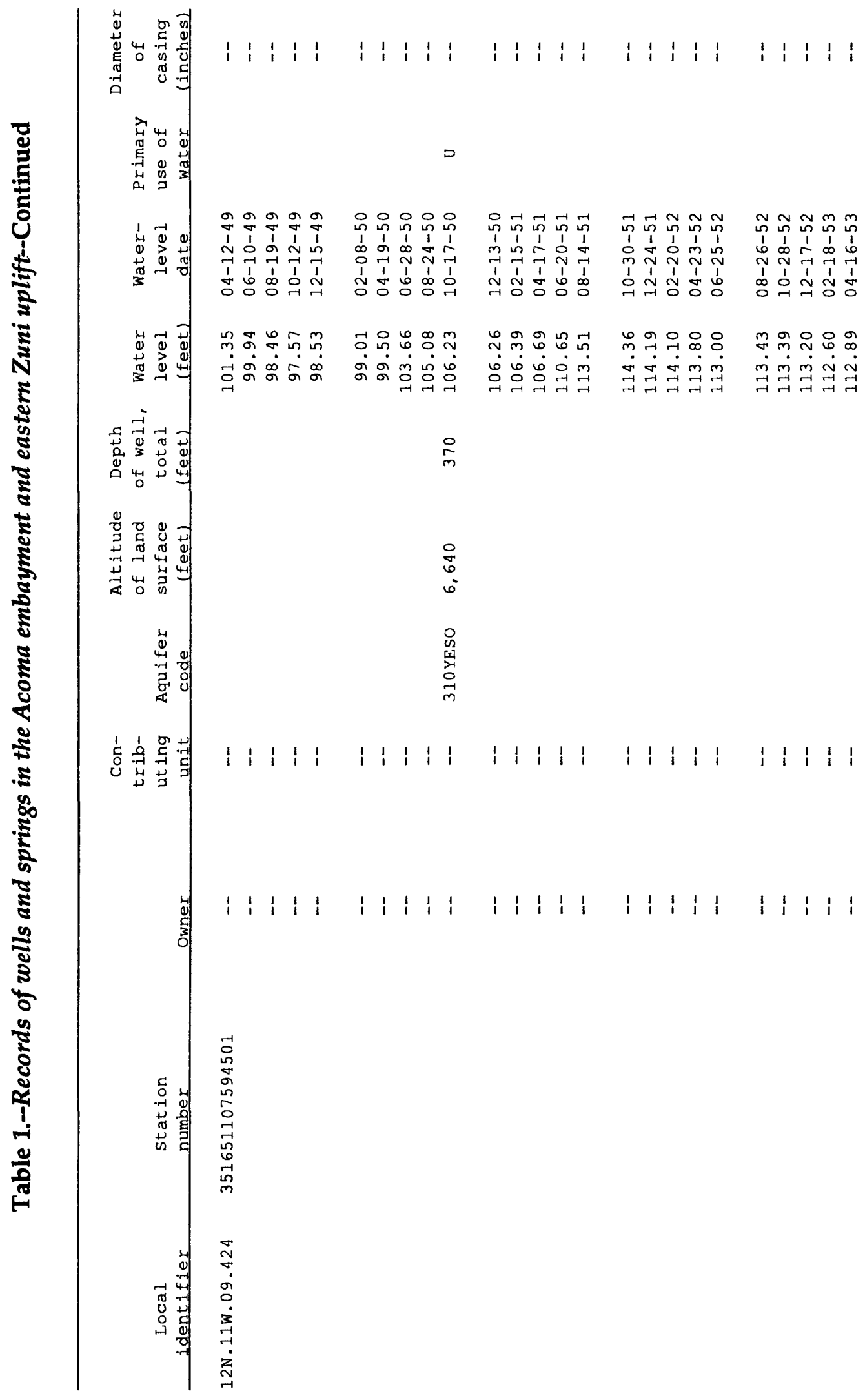




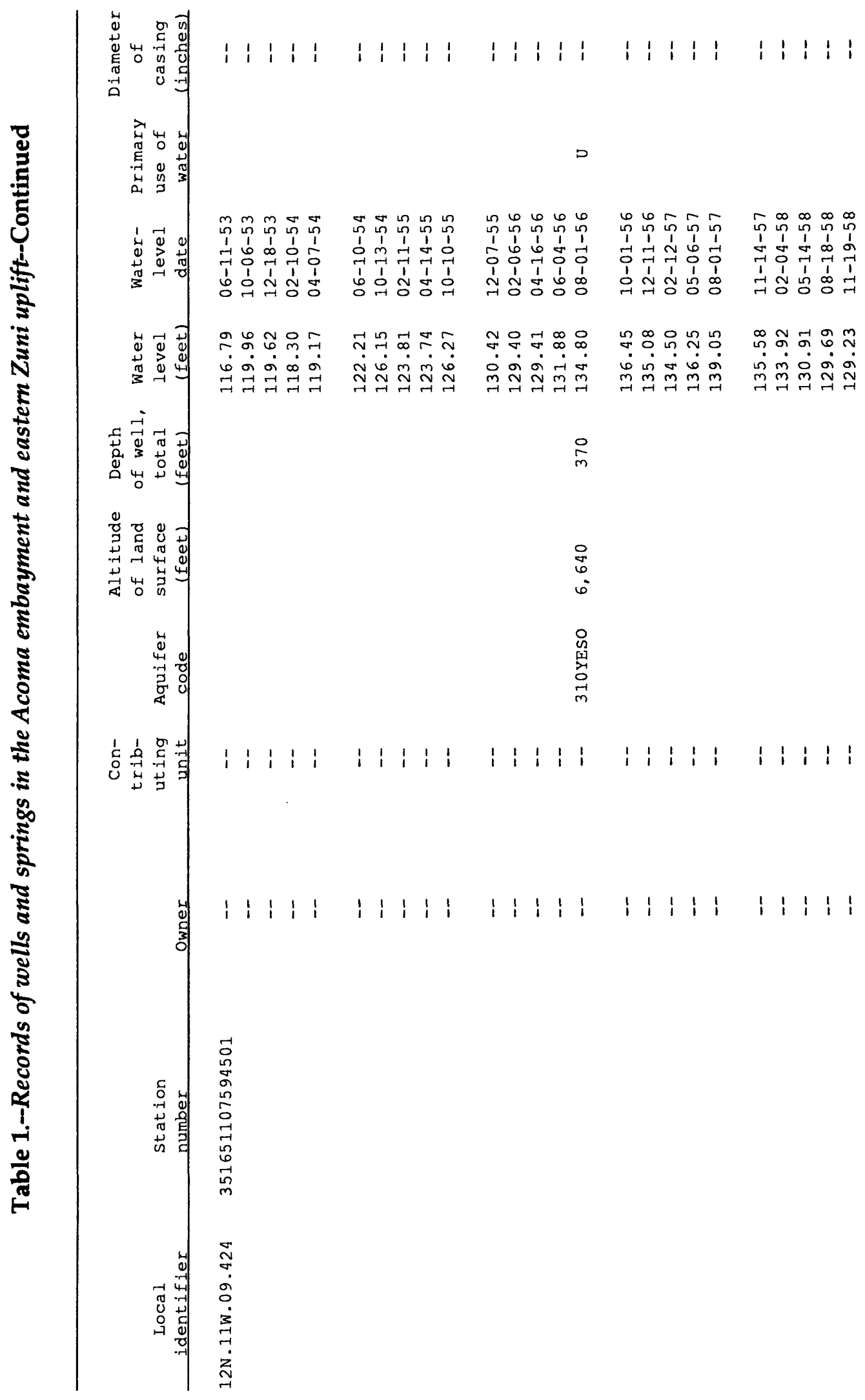




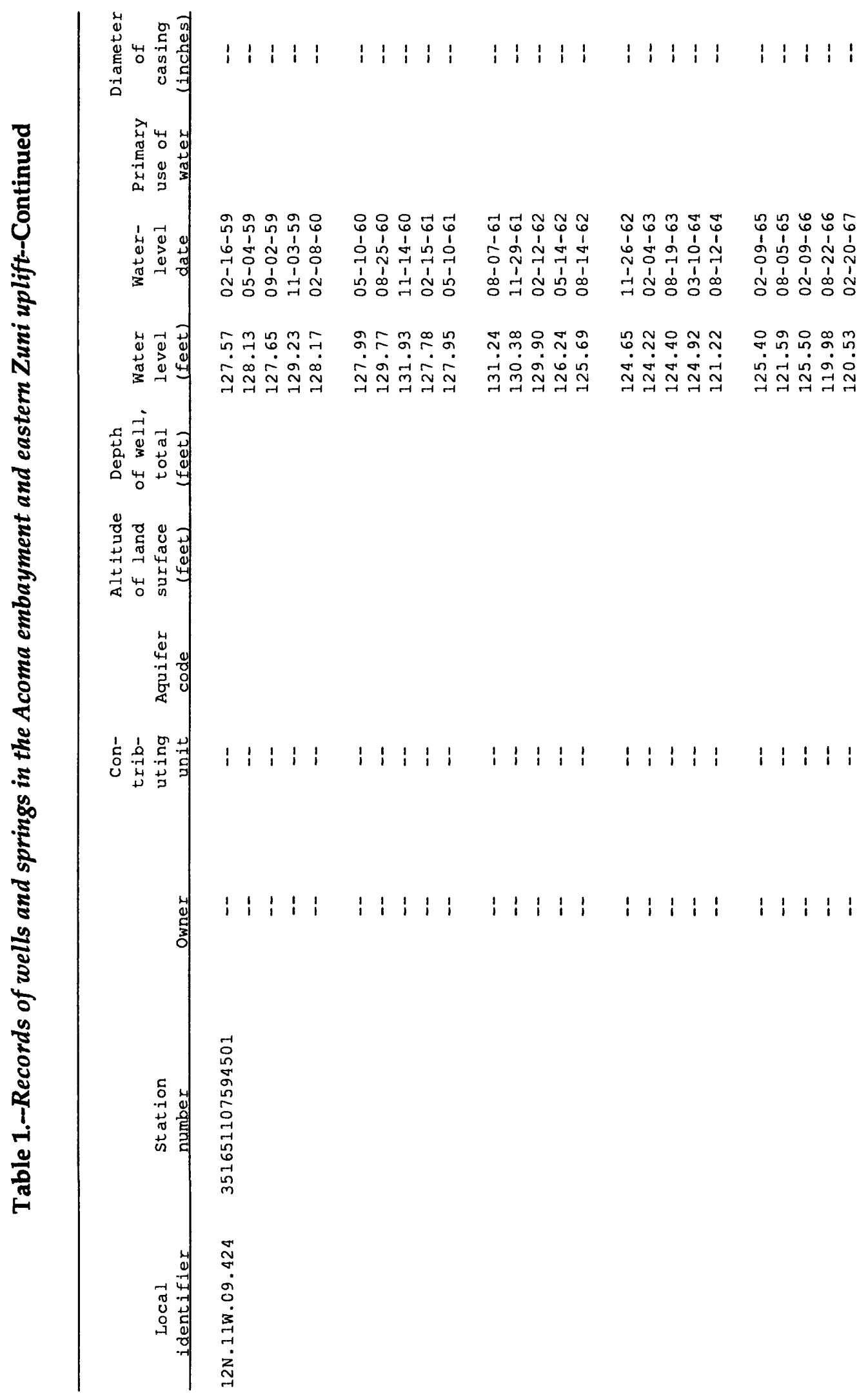




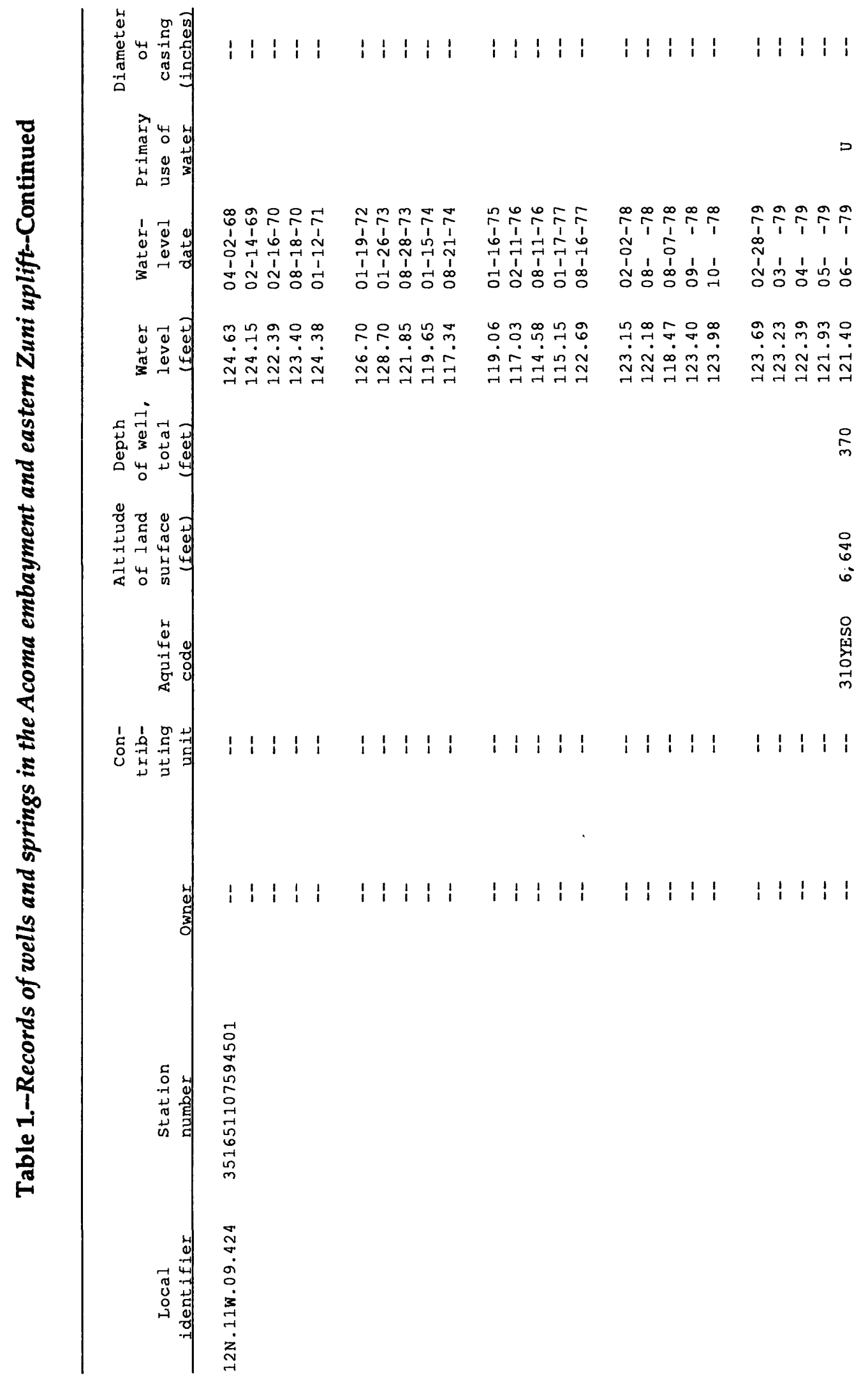




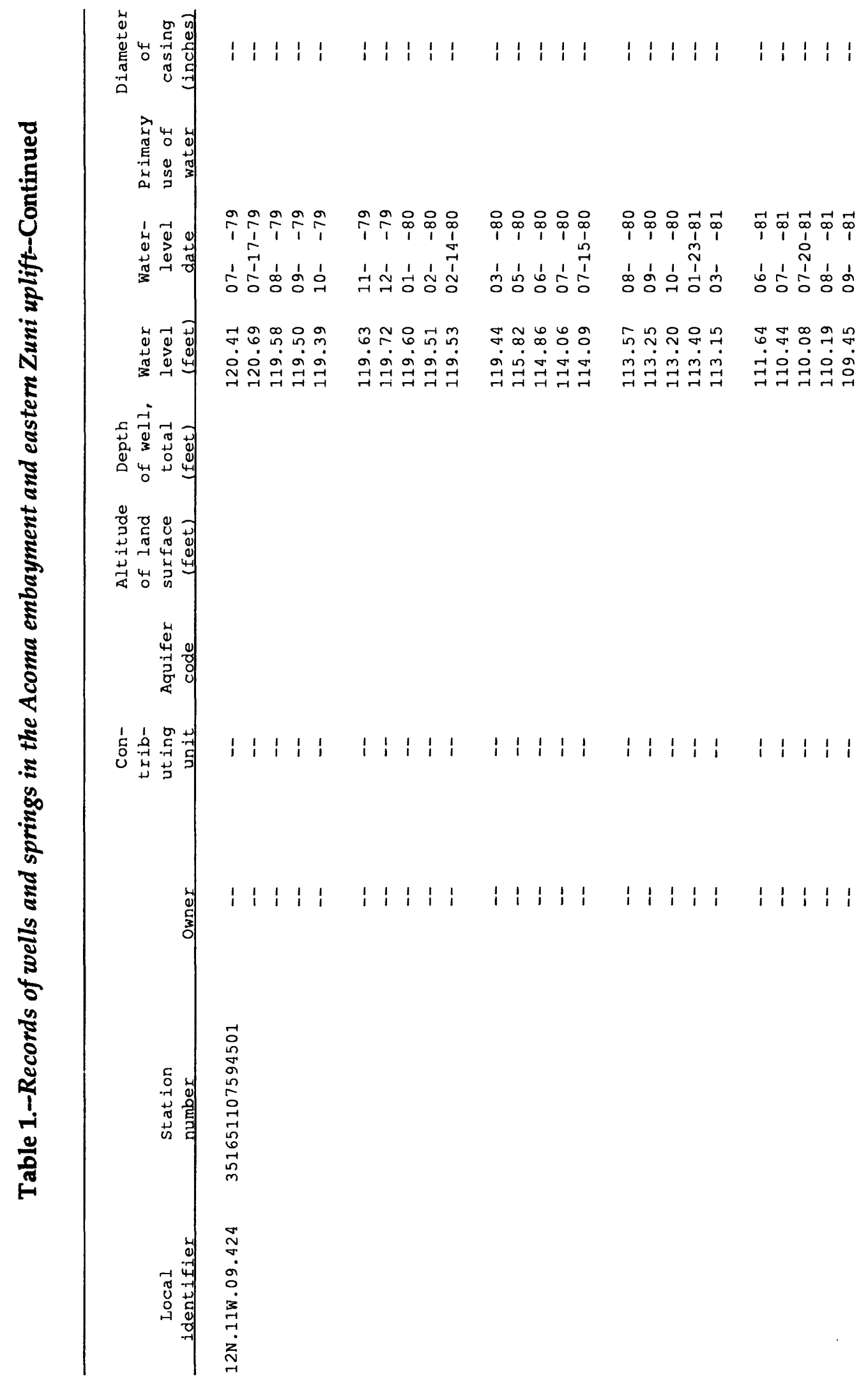




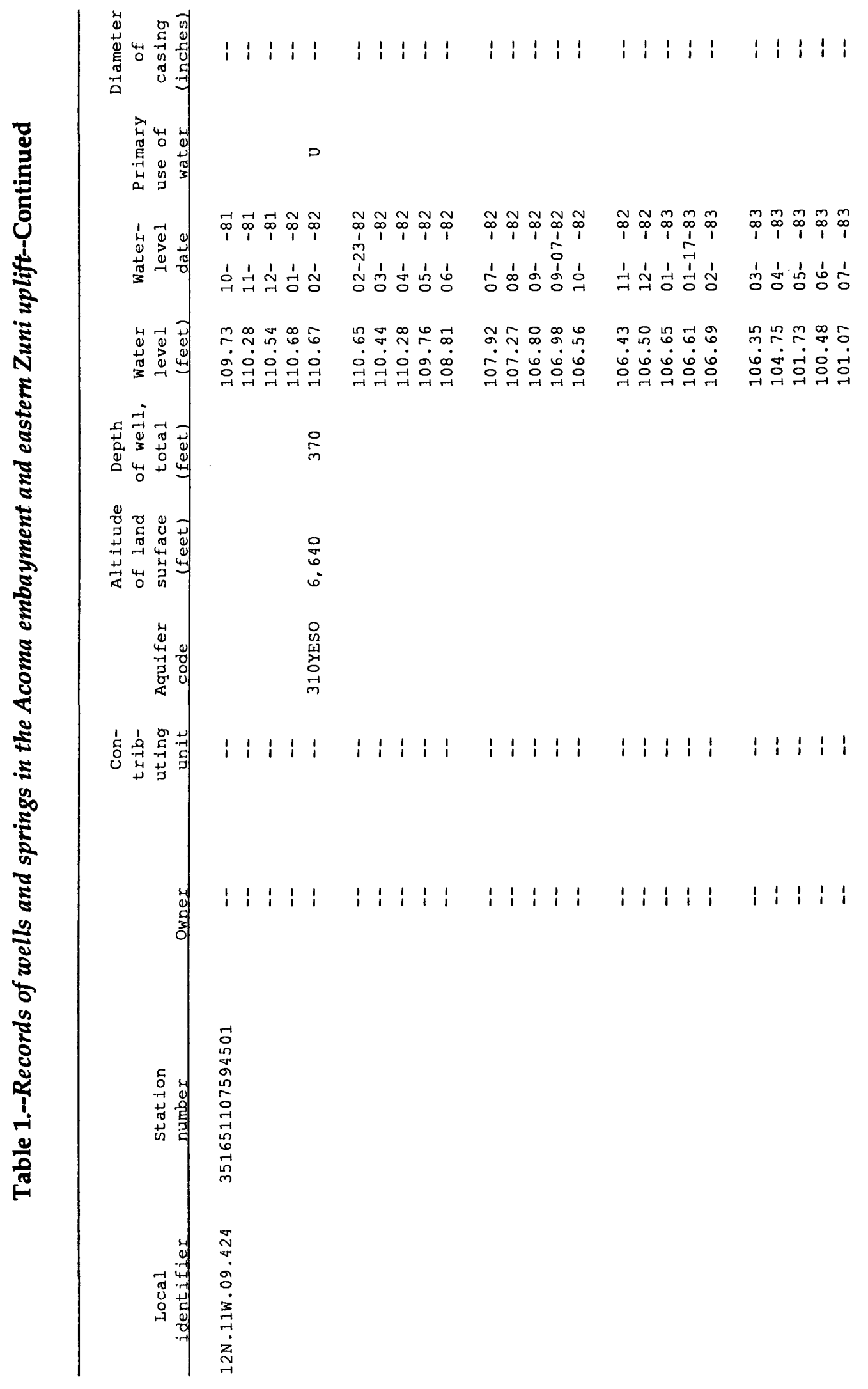




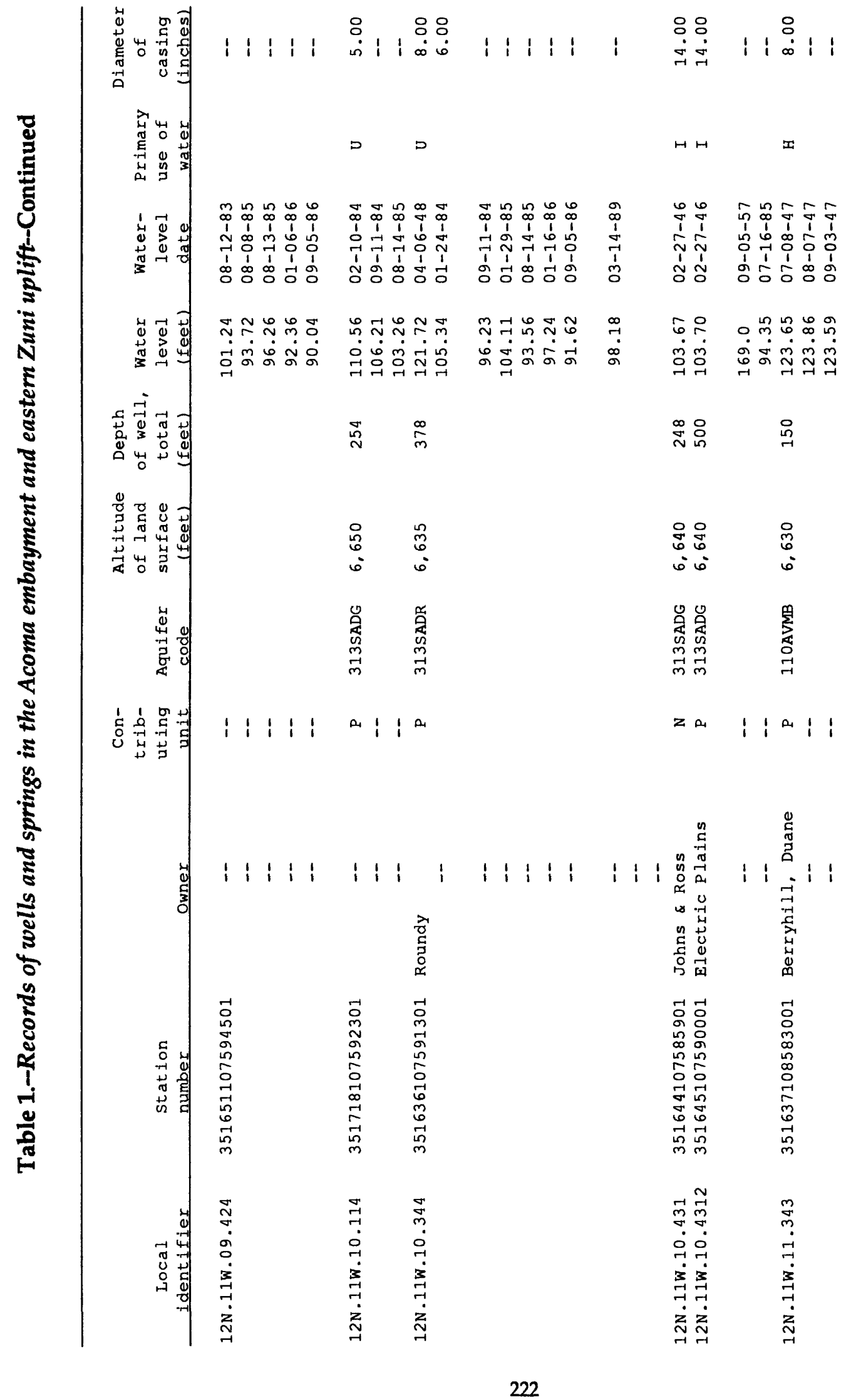




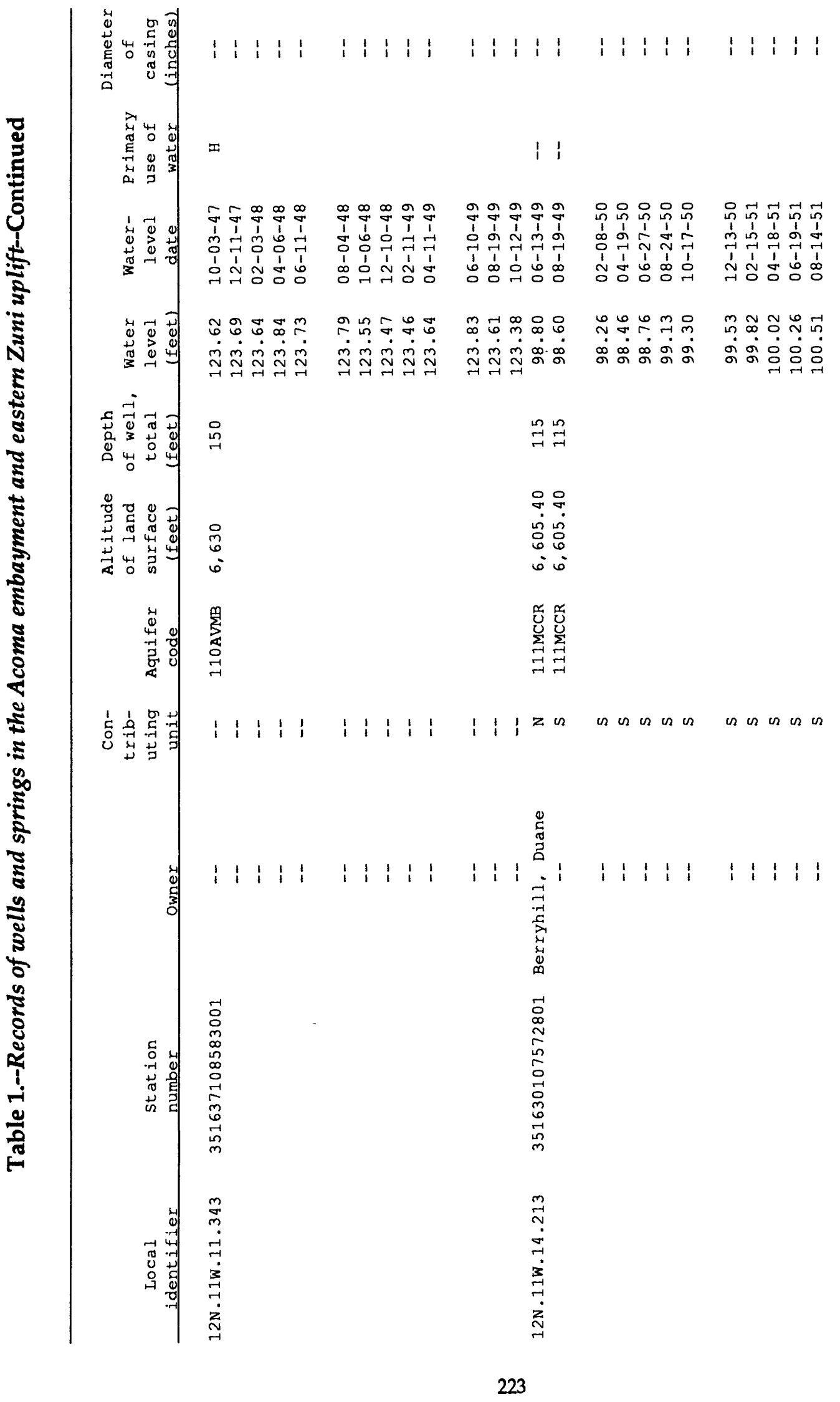




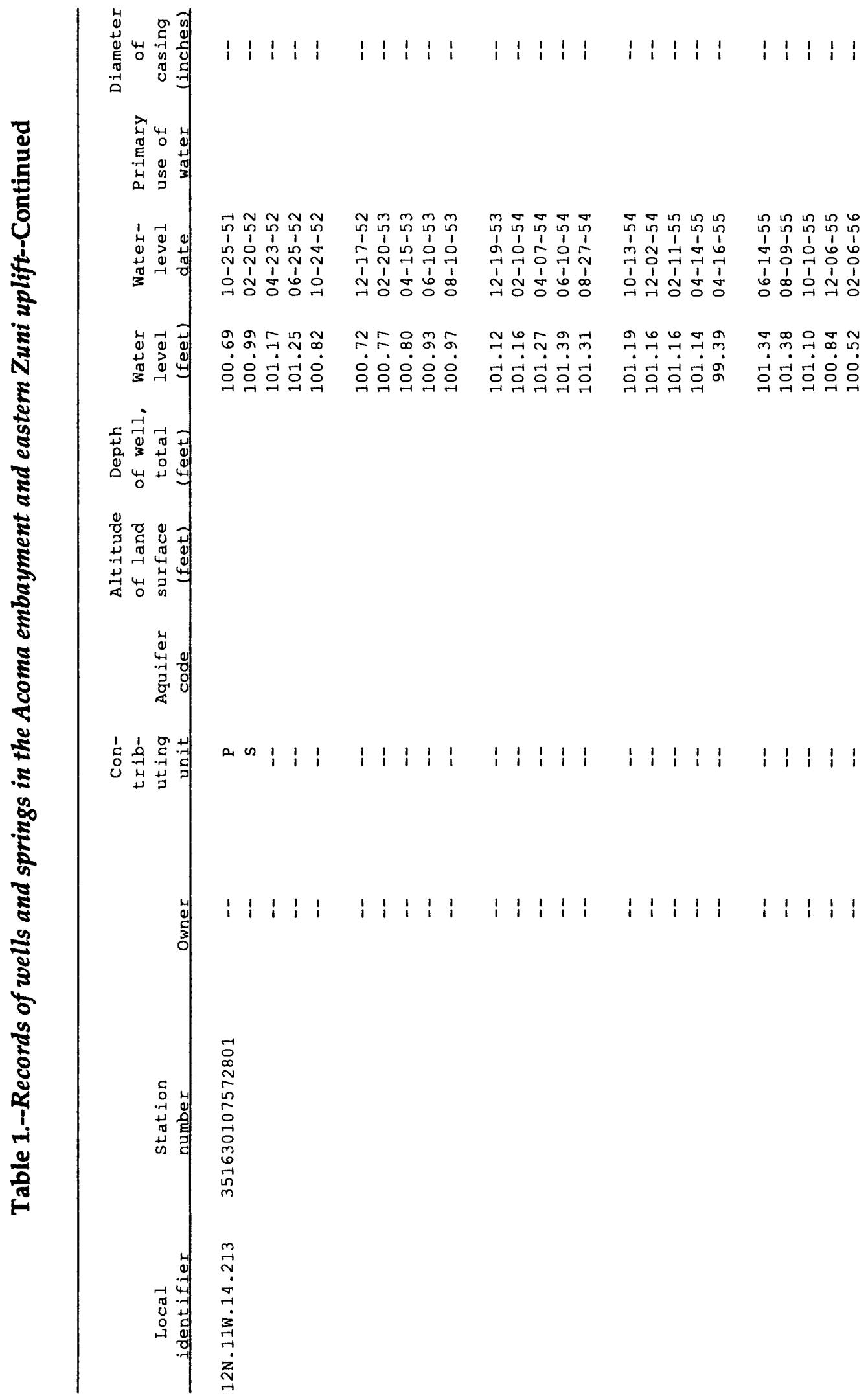




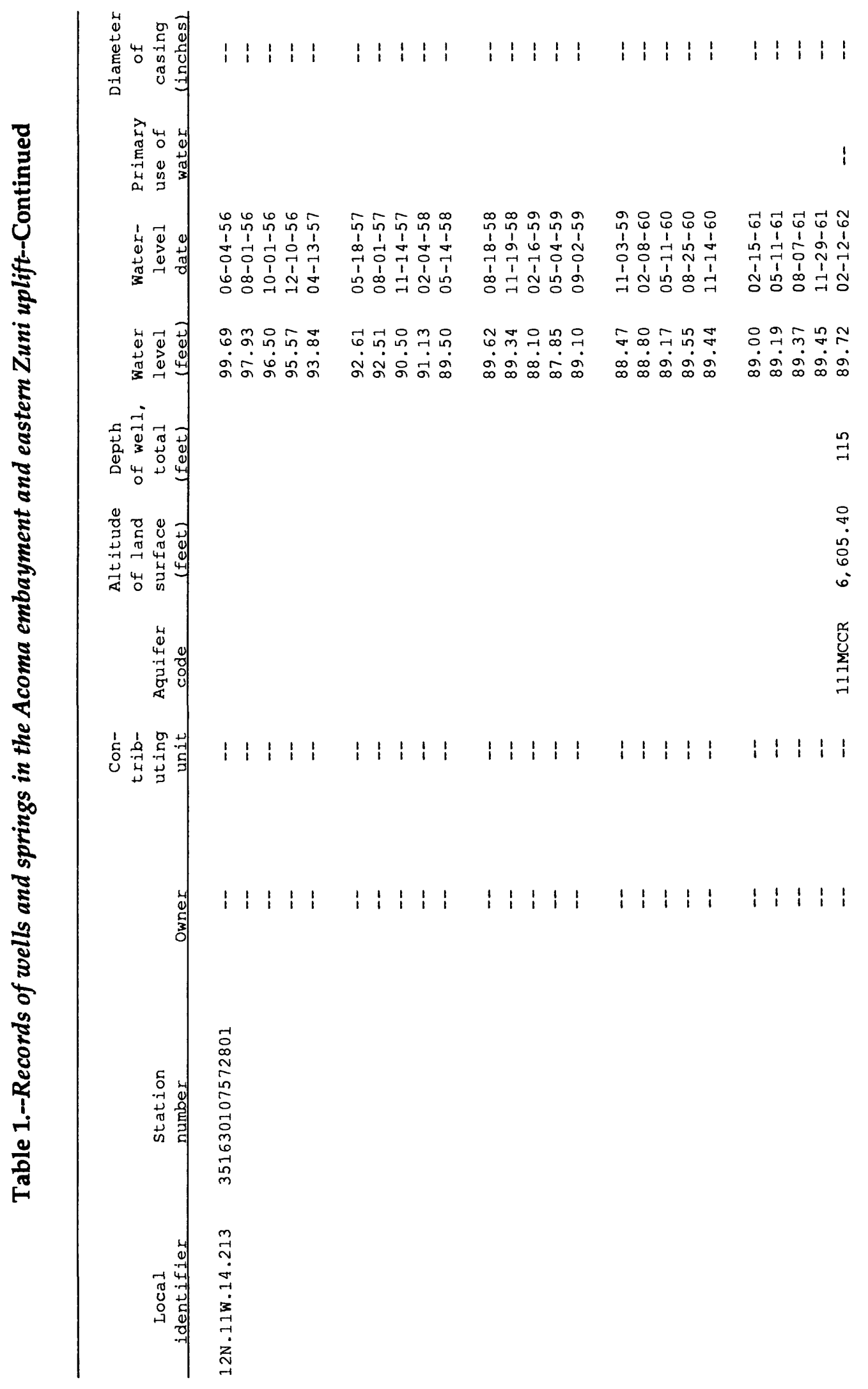




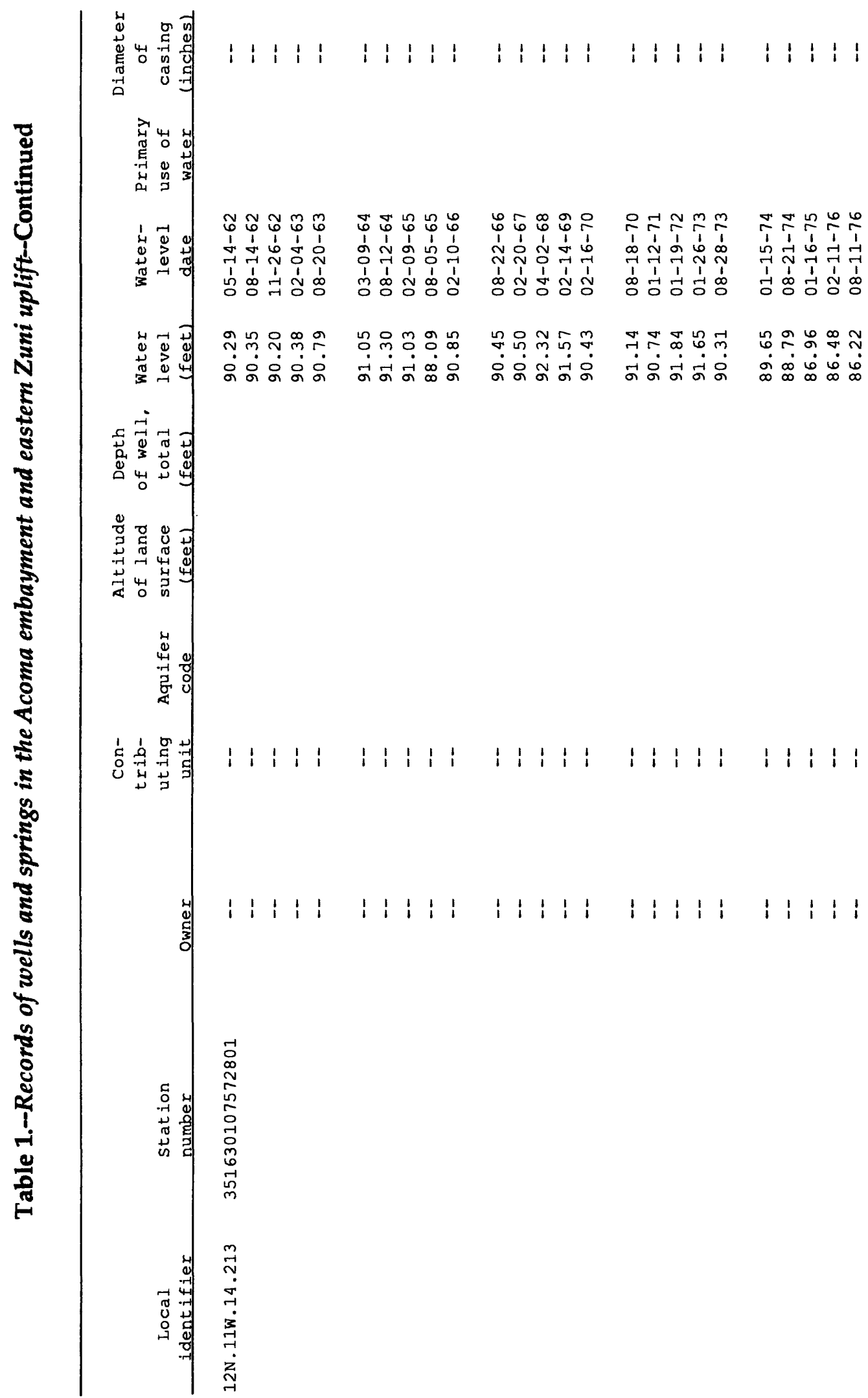




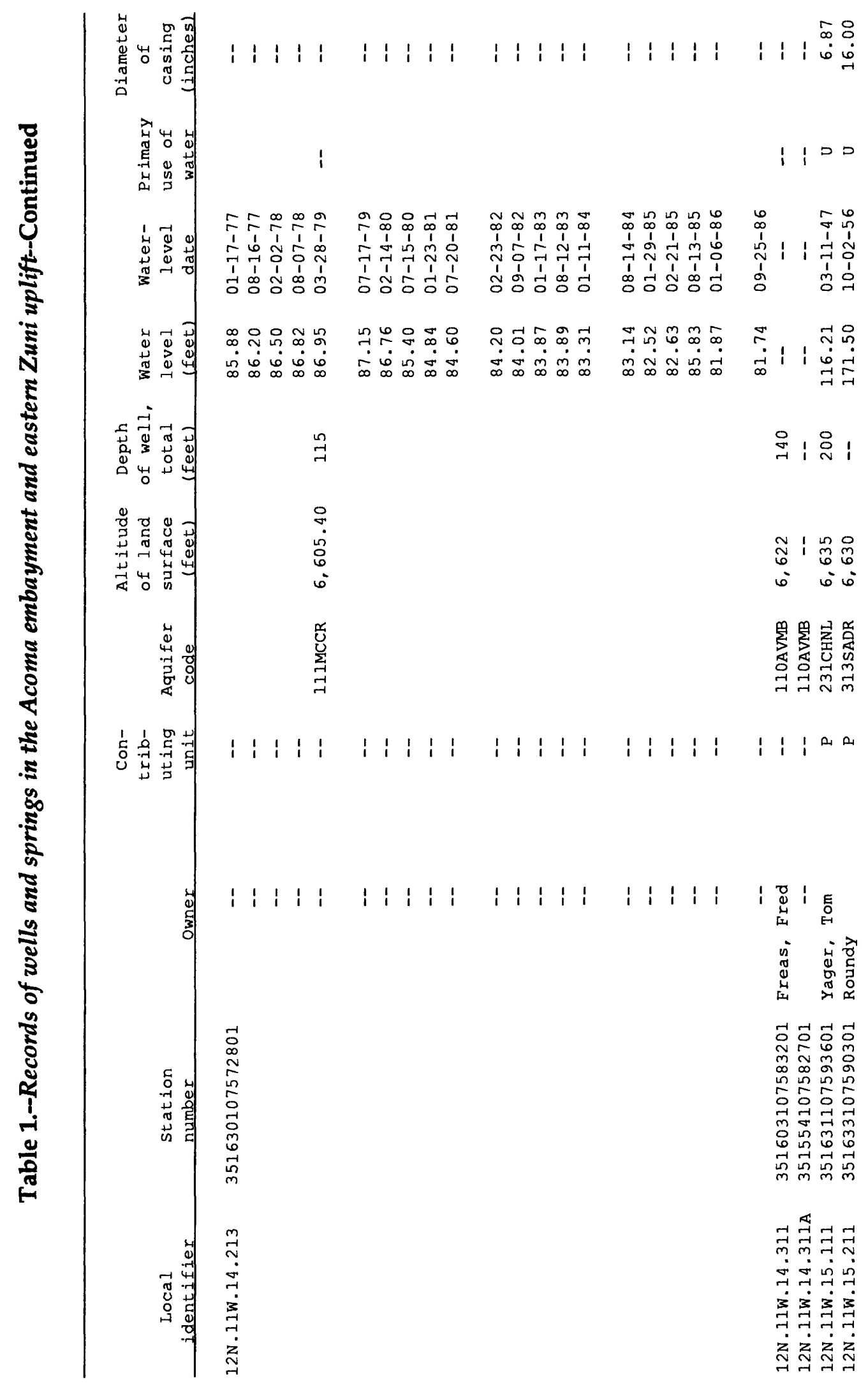




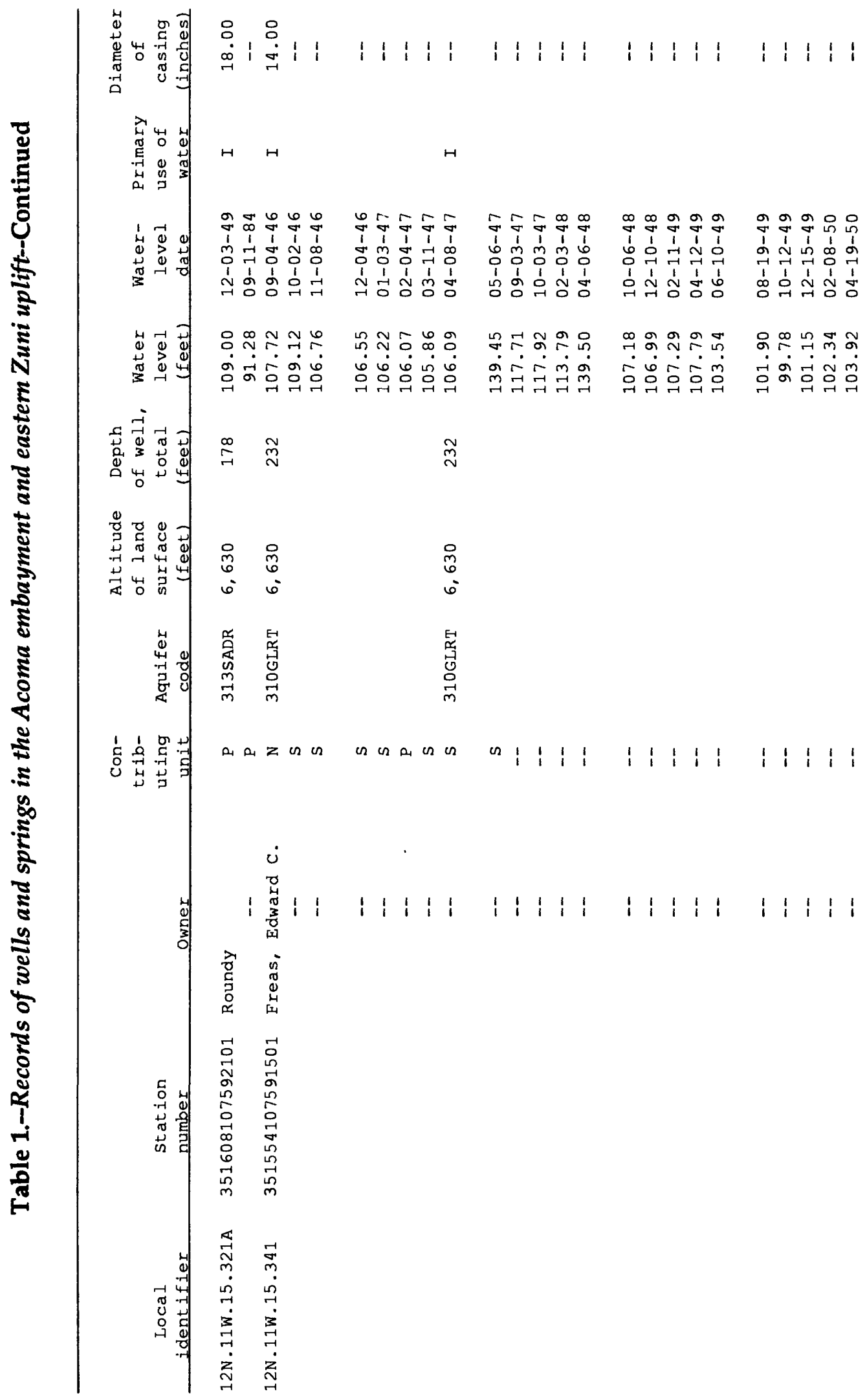




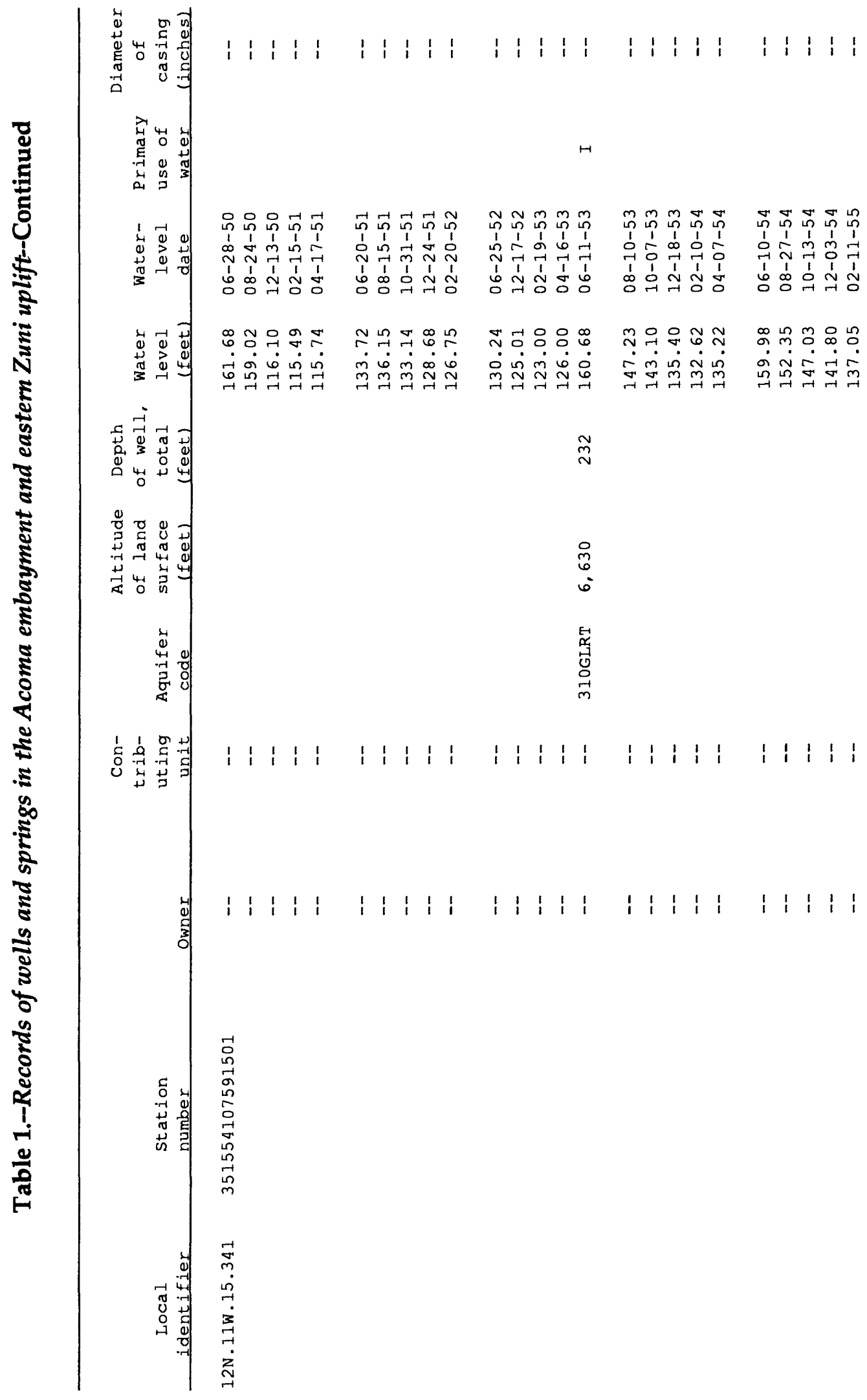




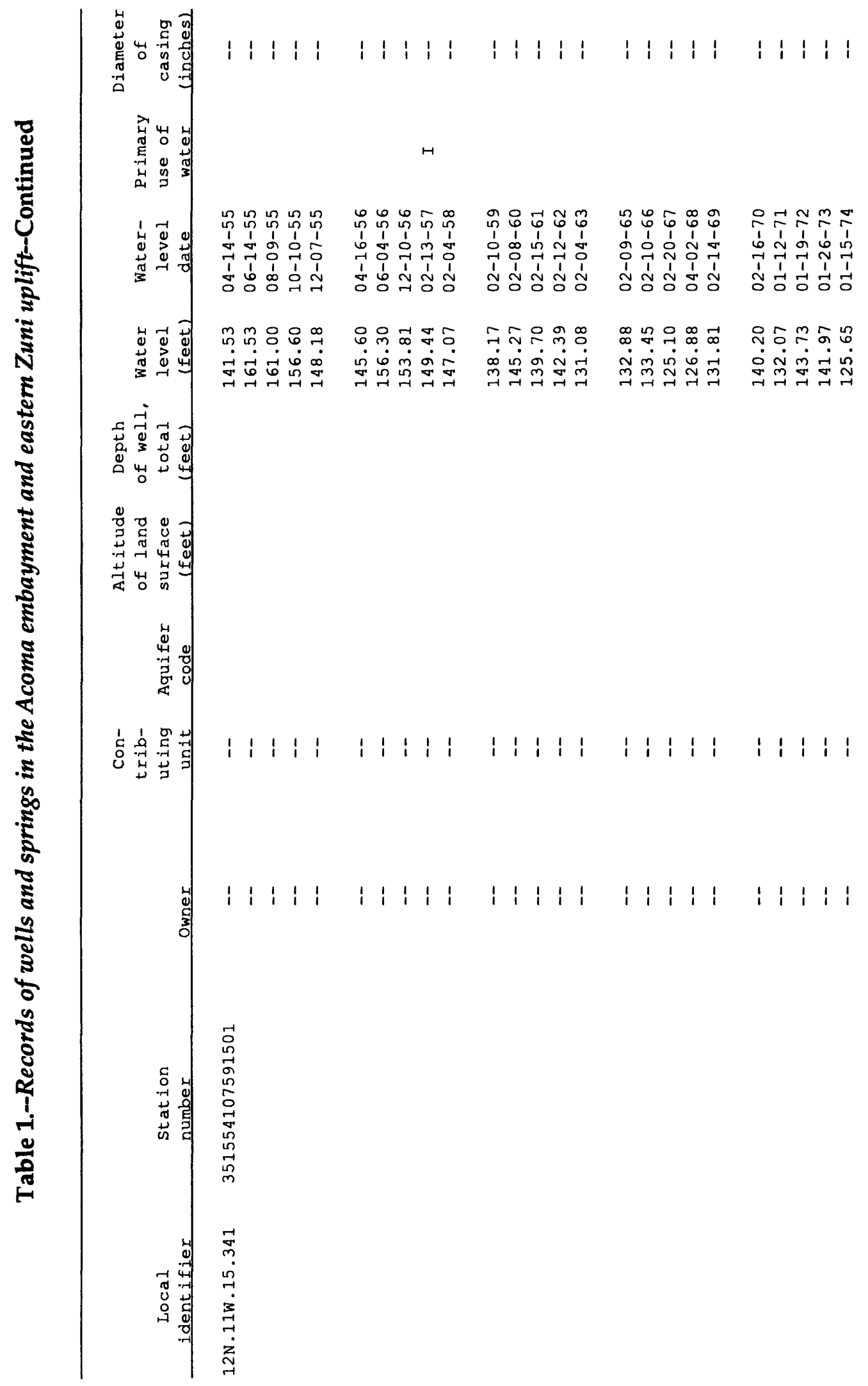




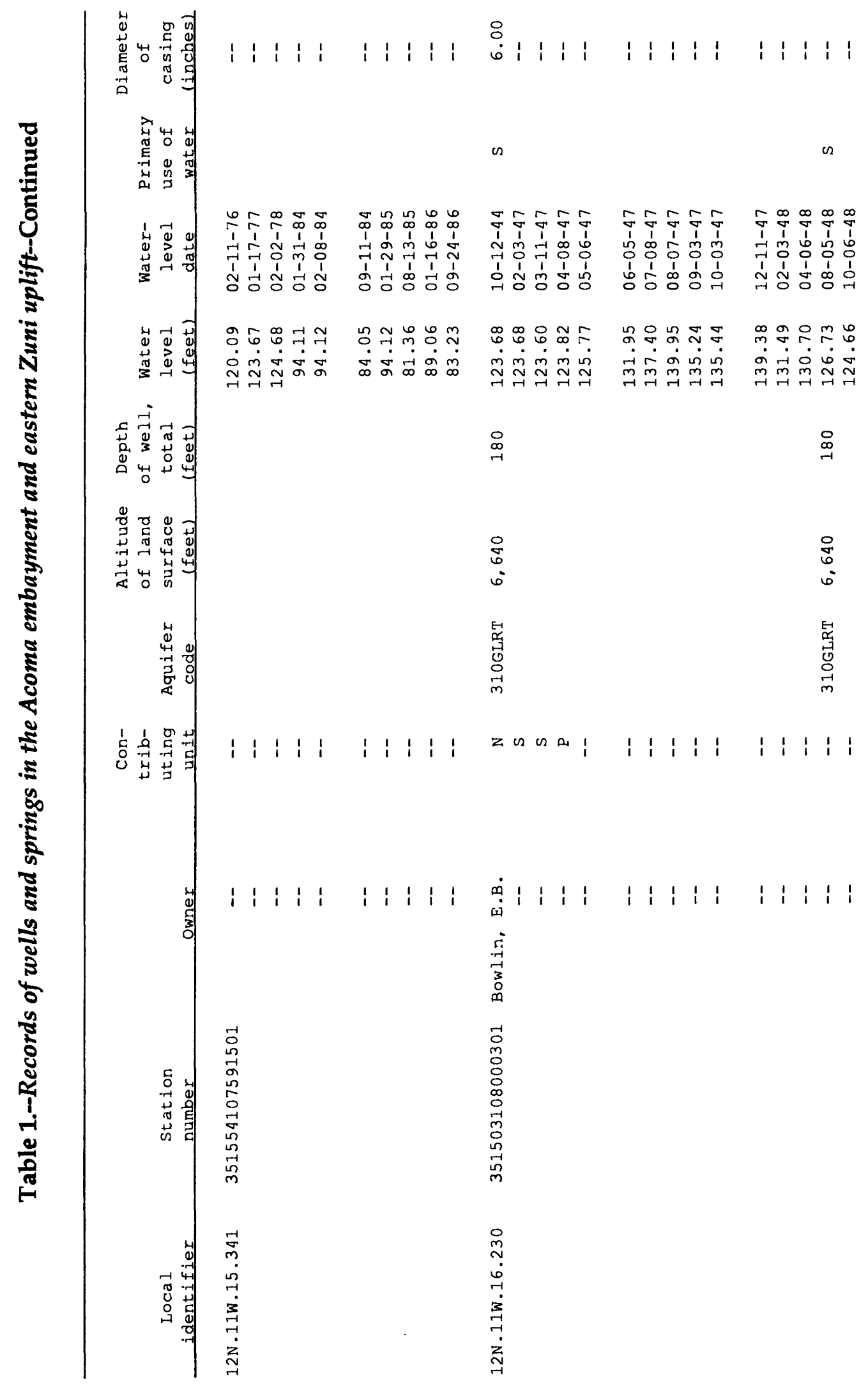




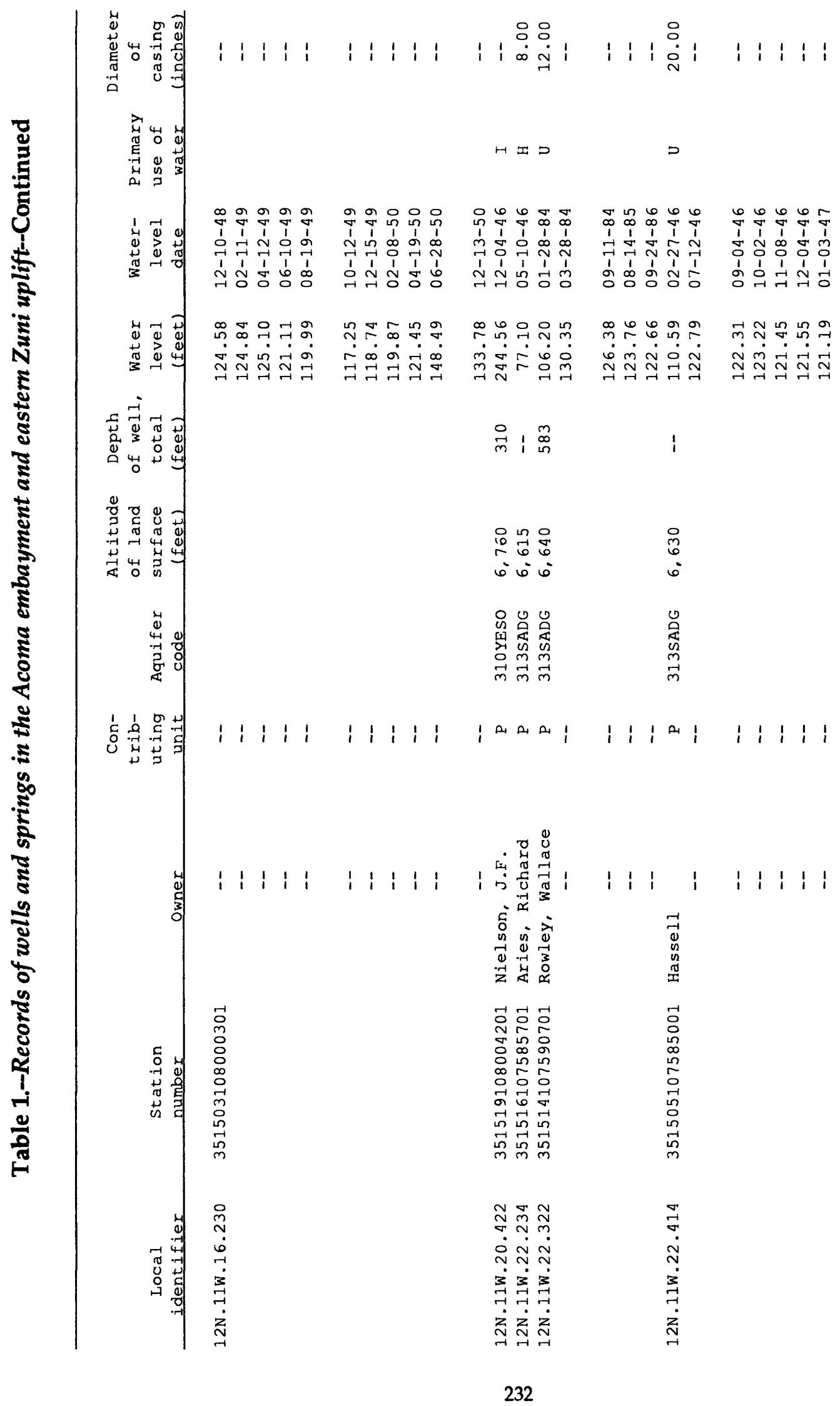




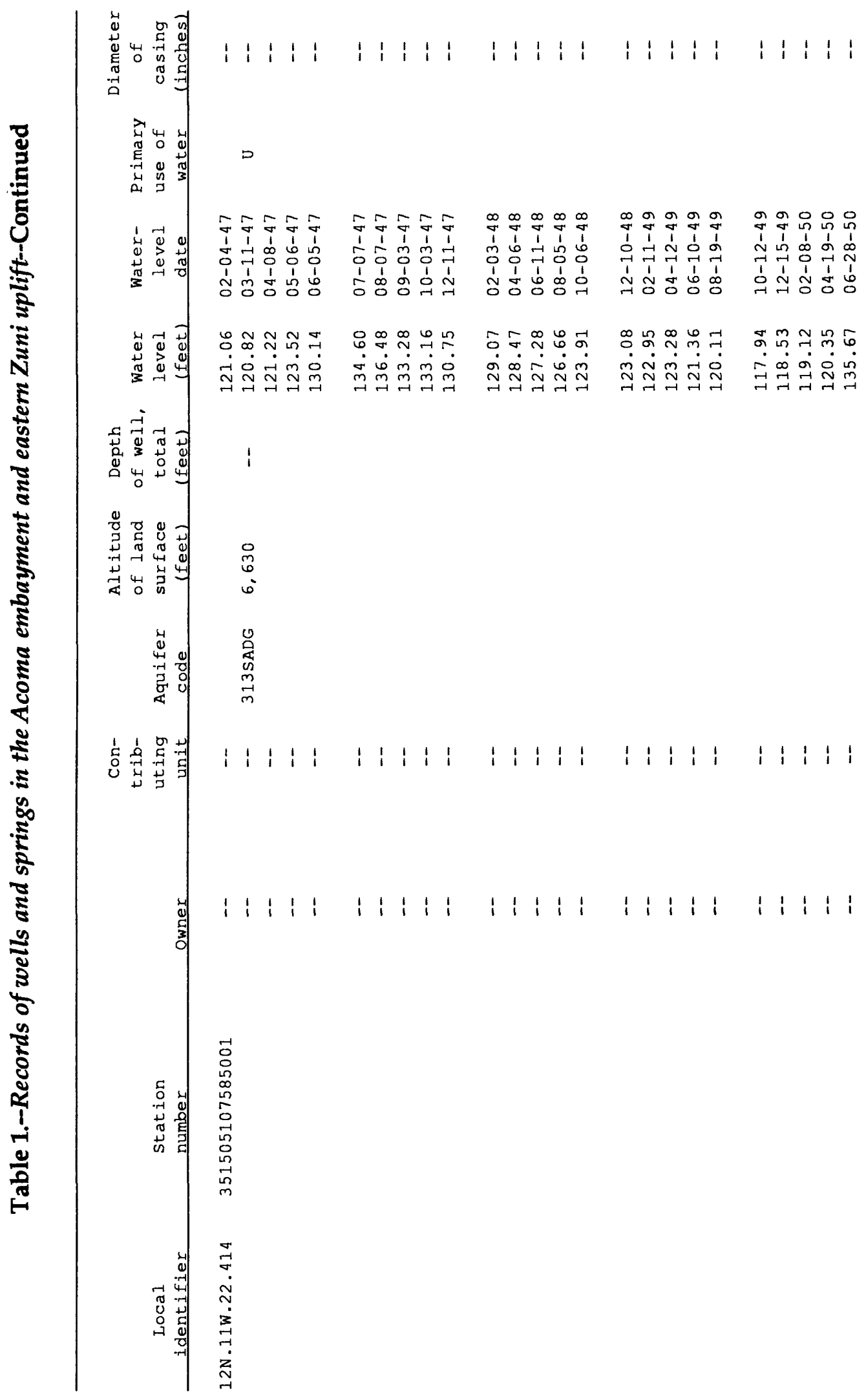




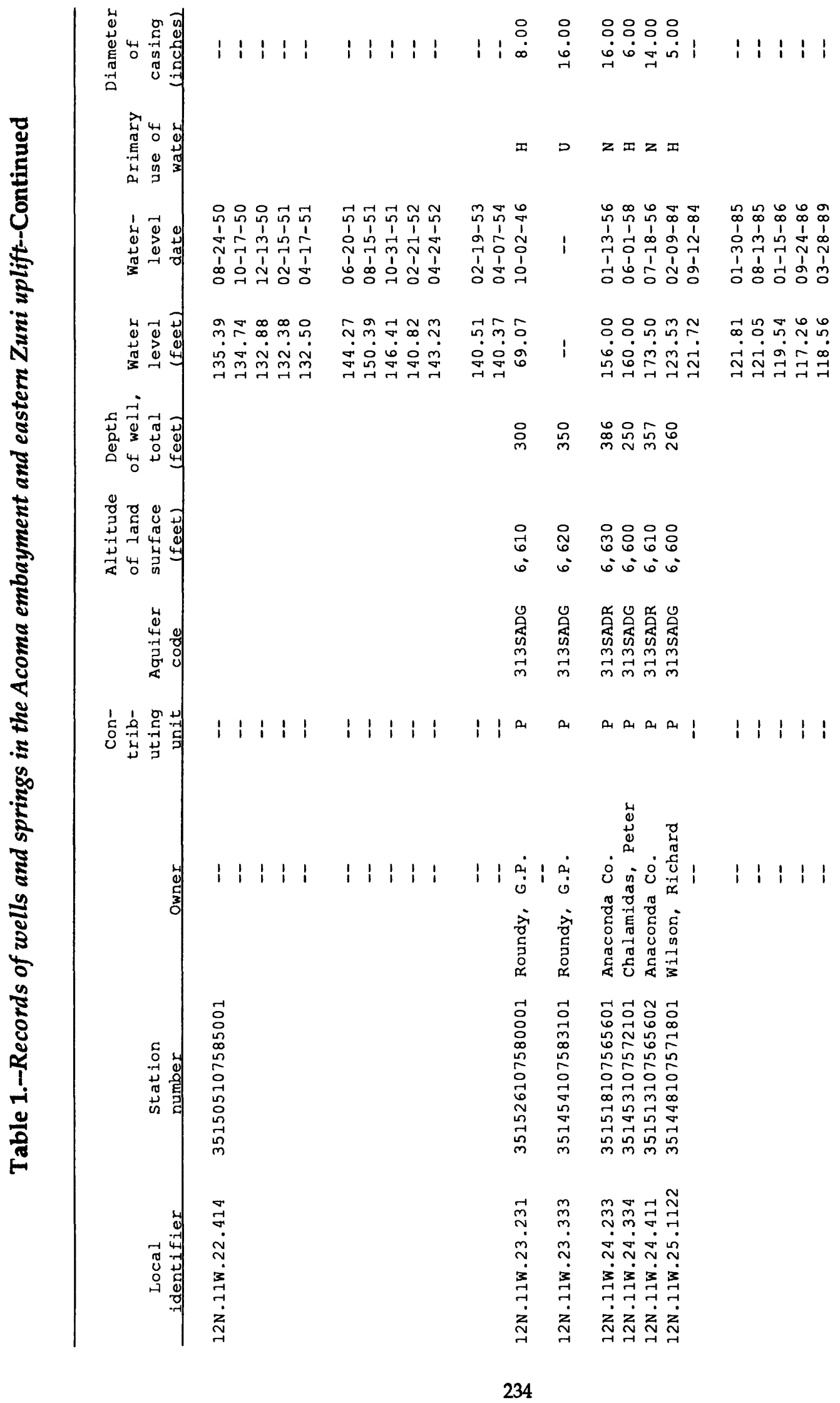




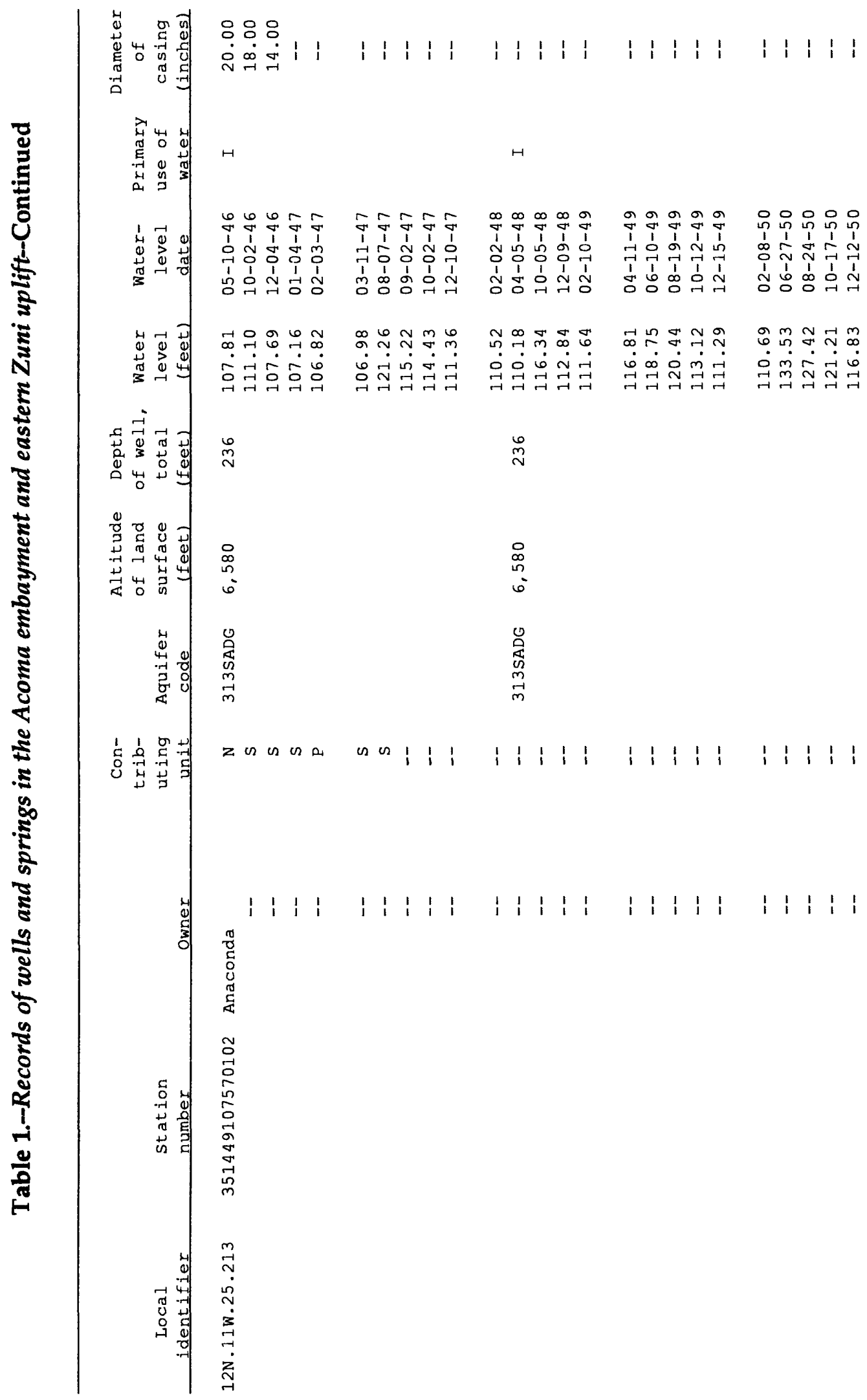




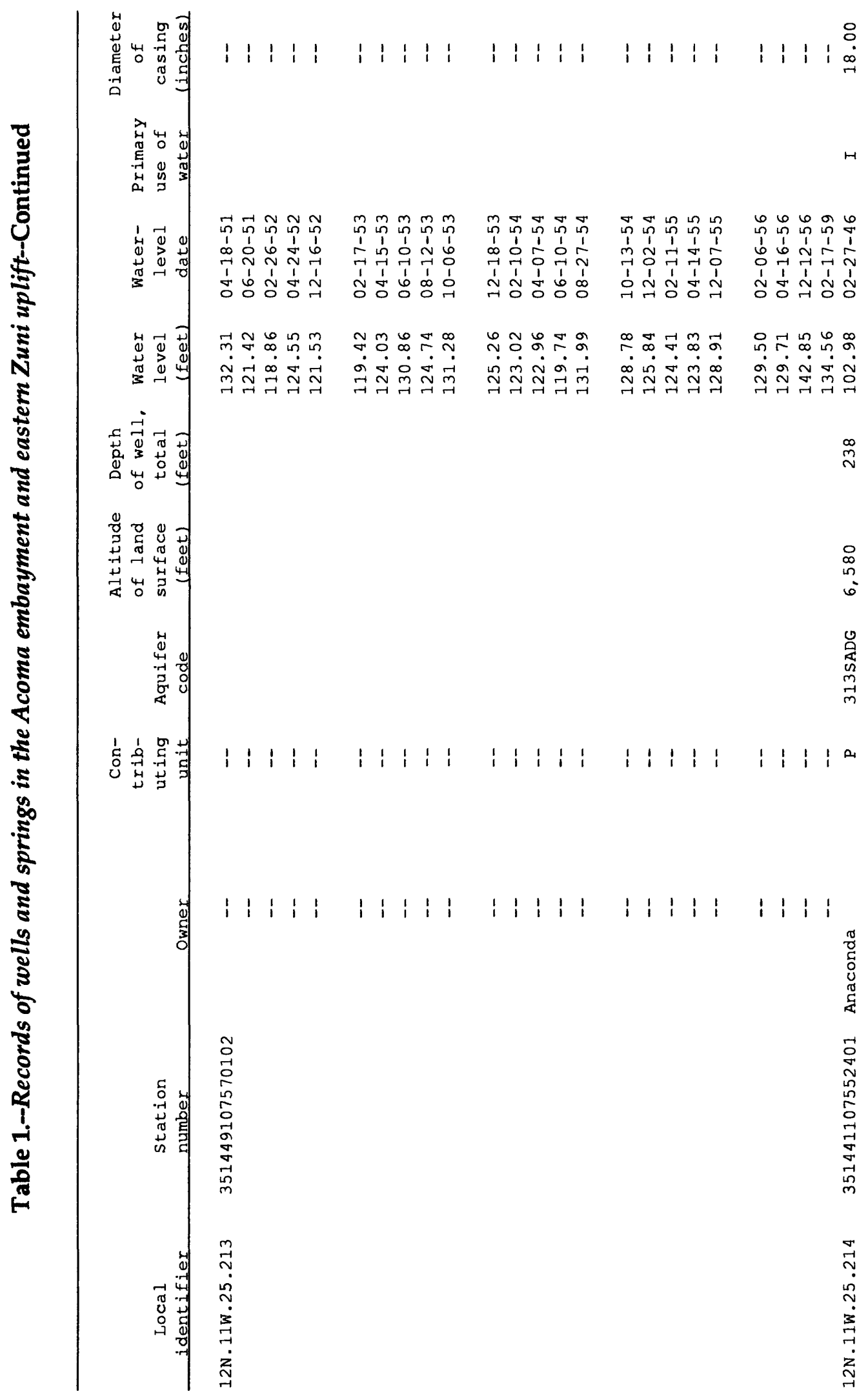




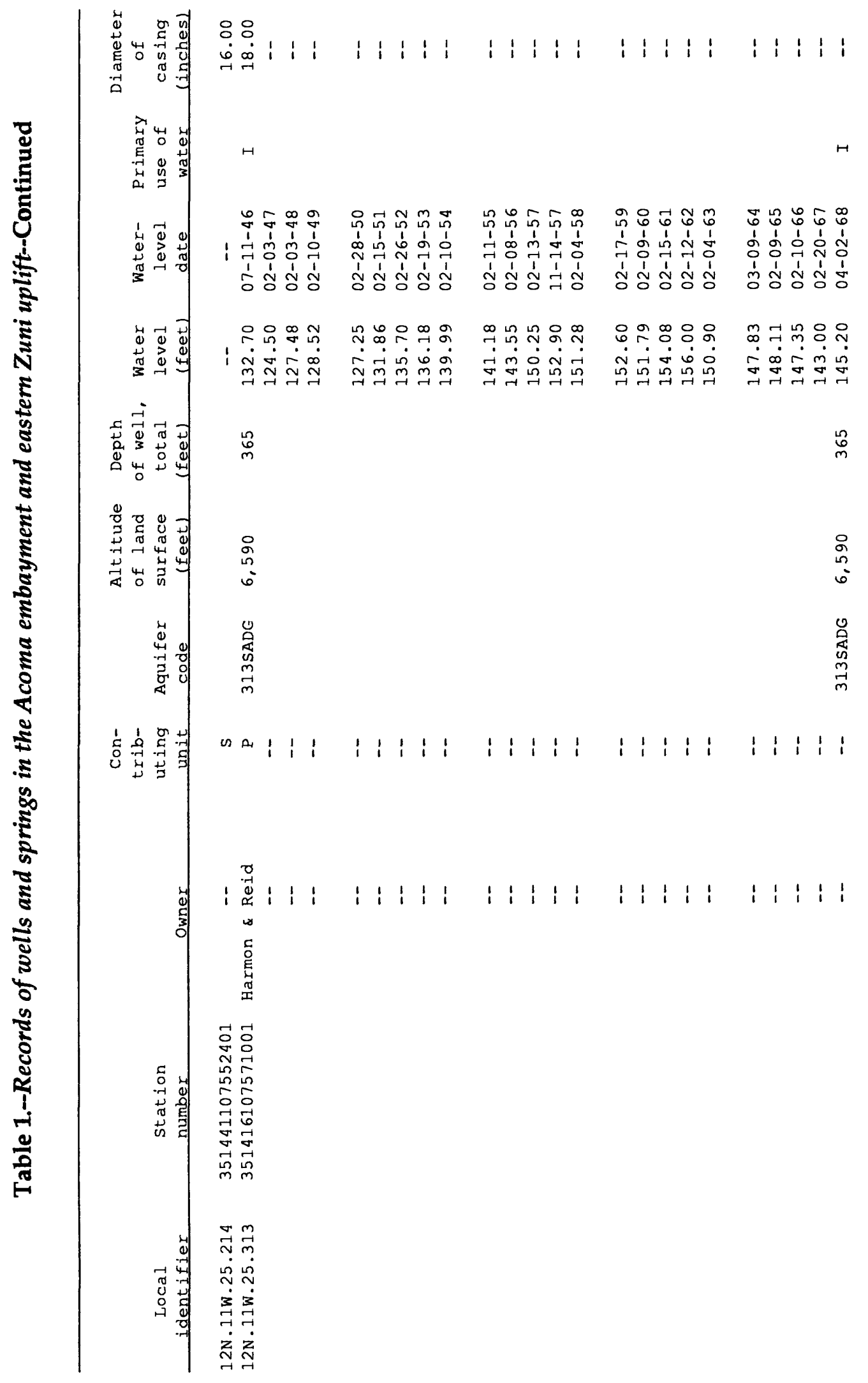




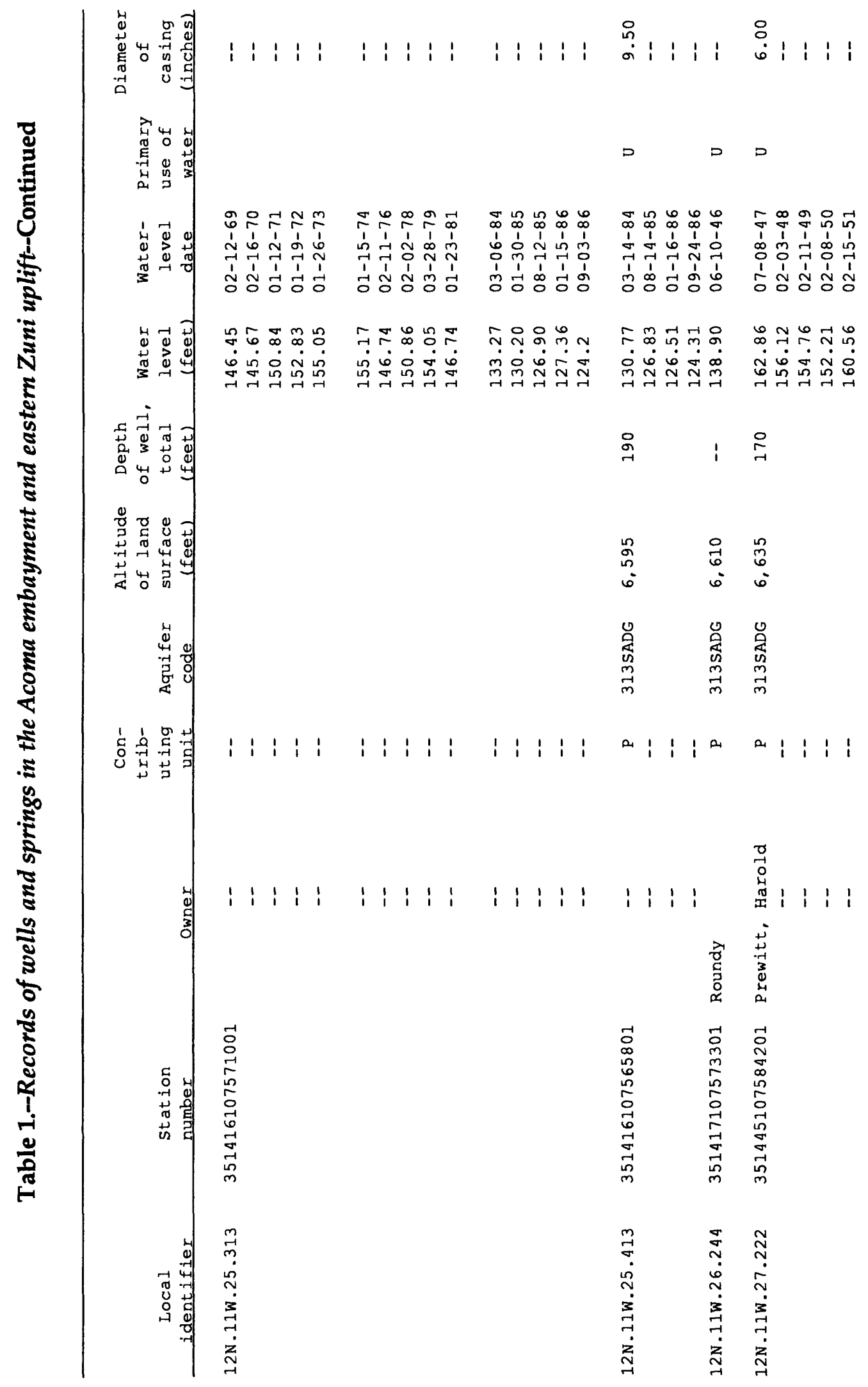




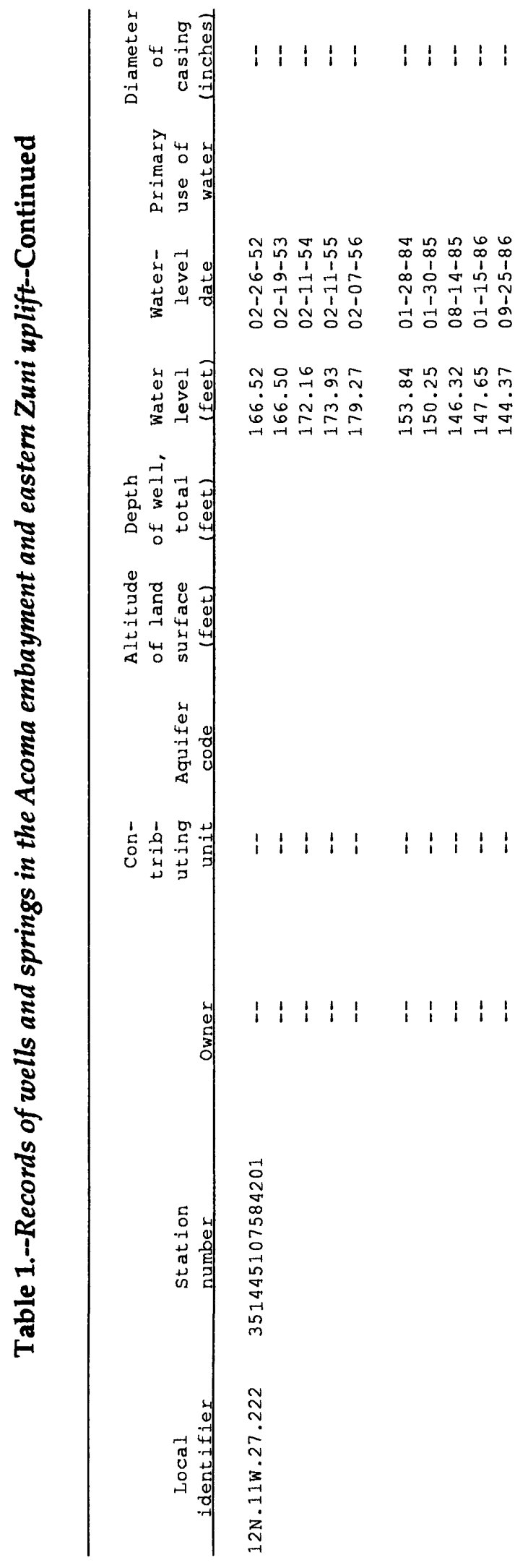

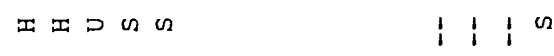

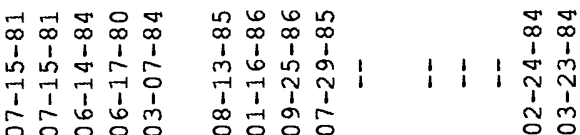

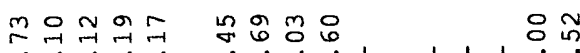

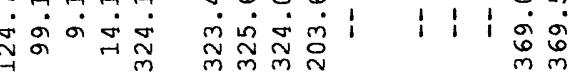

0.

윰ำ

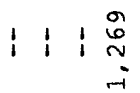

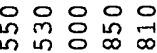

$\therefore$ in

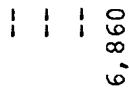

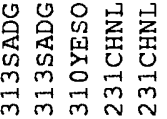

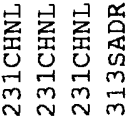

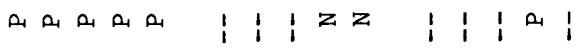

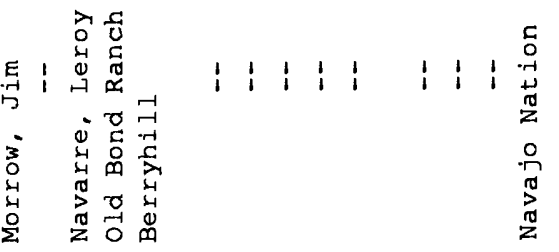

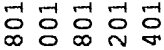

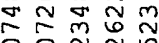

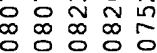

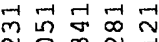

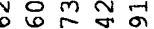

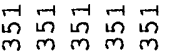

동ㅎㅇㅇㄷㅇㅇㅇㅇ

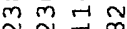

응요

$\begin{array}{cccc}\infty & \infty & \infty & 5 \\ 0 & 0 & 0 & 0 \\ -1 & -1 & -1 & 0 \\ 0 & -1 & \end{array}$

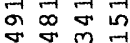

거메 $\approx$

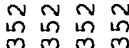

$m \sim \underset{m}{m} \underset{m}{m} \stackrel{\sigma}{\sigma}$

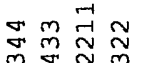

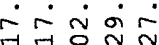

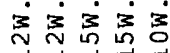

ㄷㅇㅇㅁㅇ

$3 \sum_{3} \leq$

$\dot{z} \dot{z} \dot{z} z$

我安

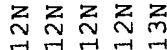

$z_{m=1} z_{m=1}^{z} z_{m=1}^{z}$ 


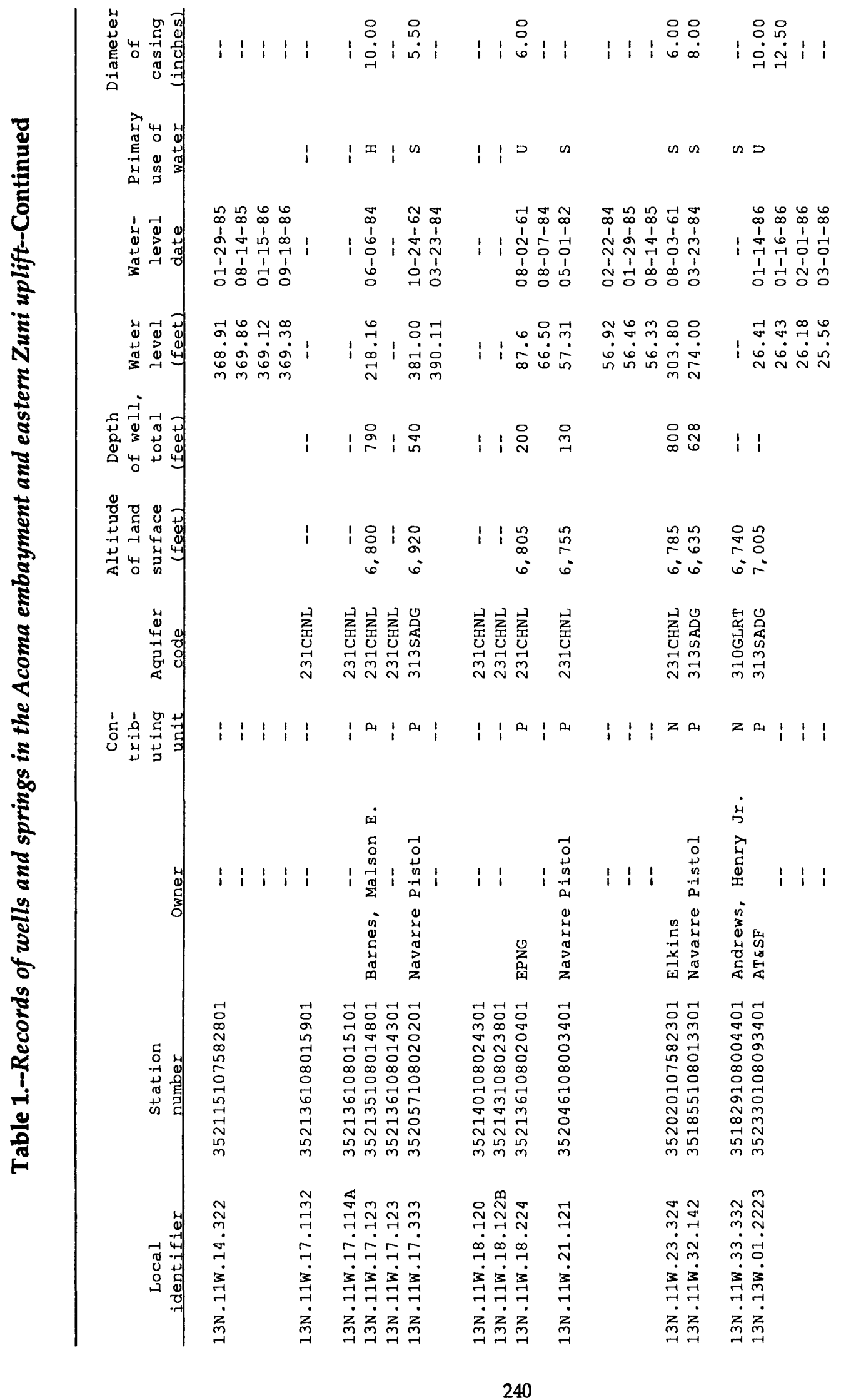




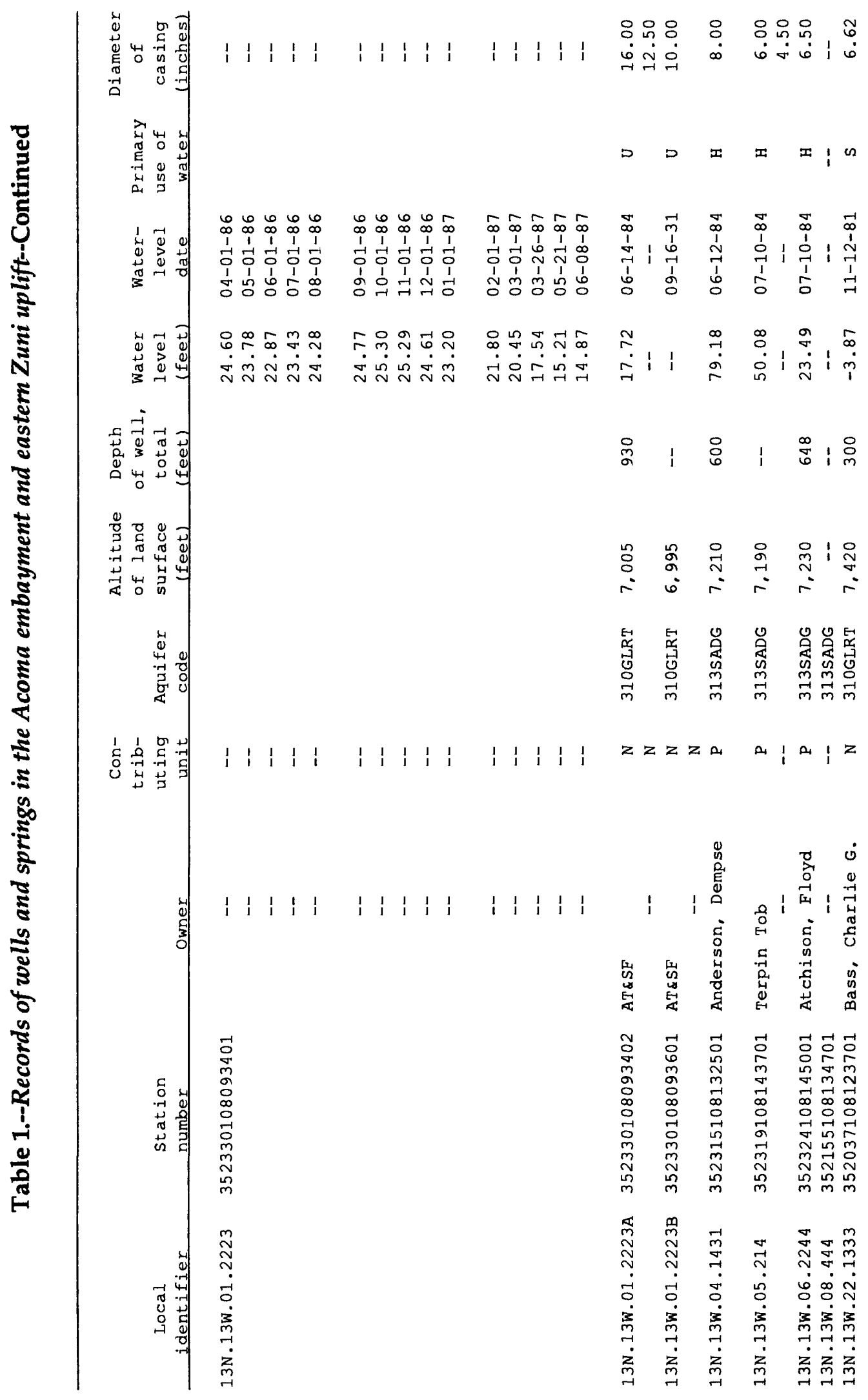




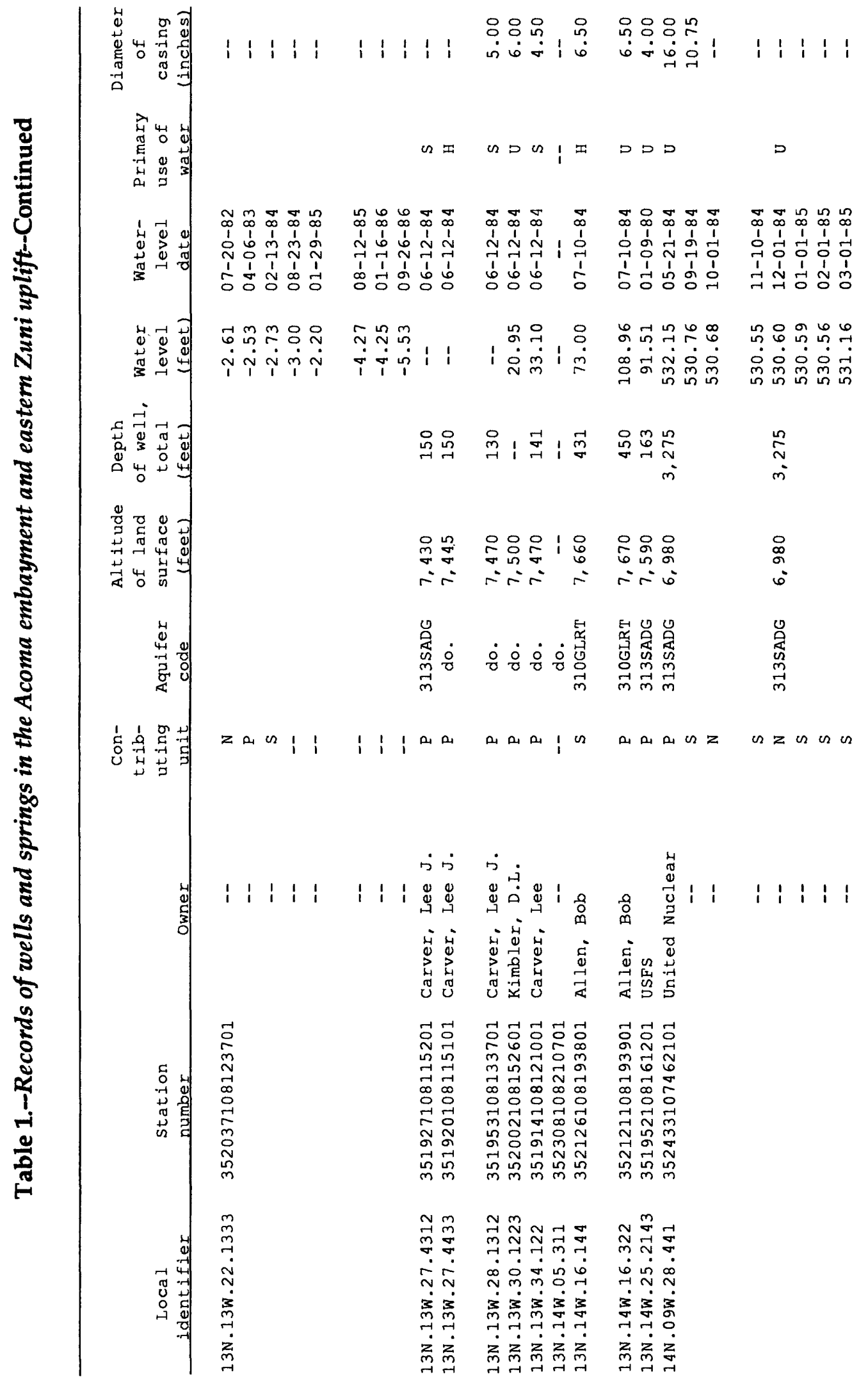




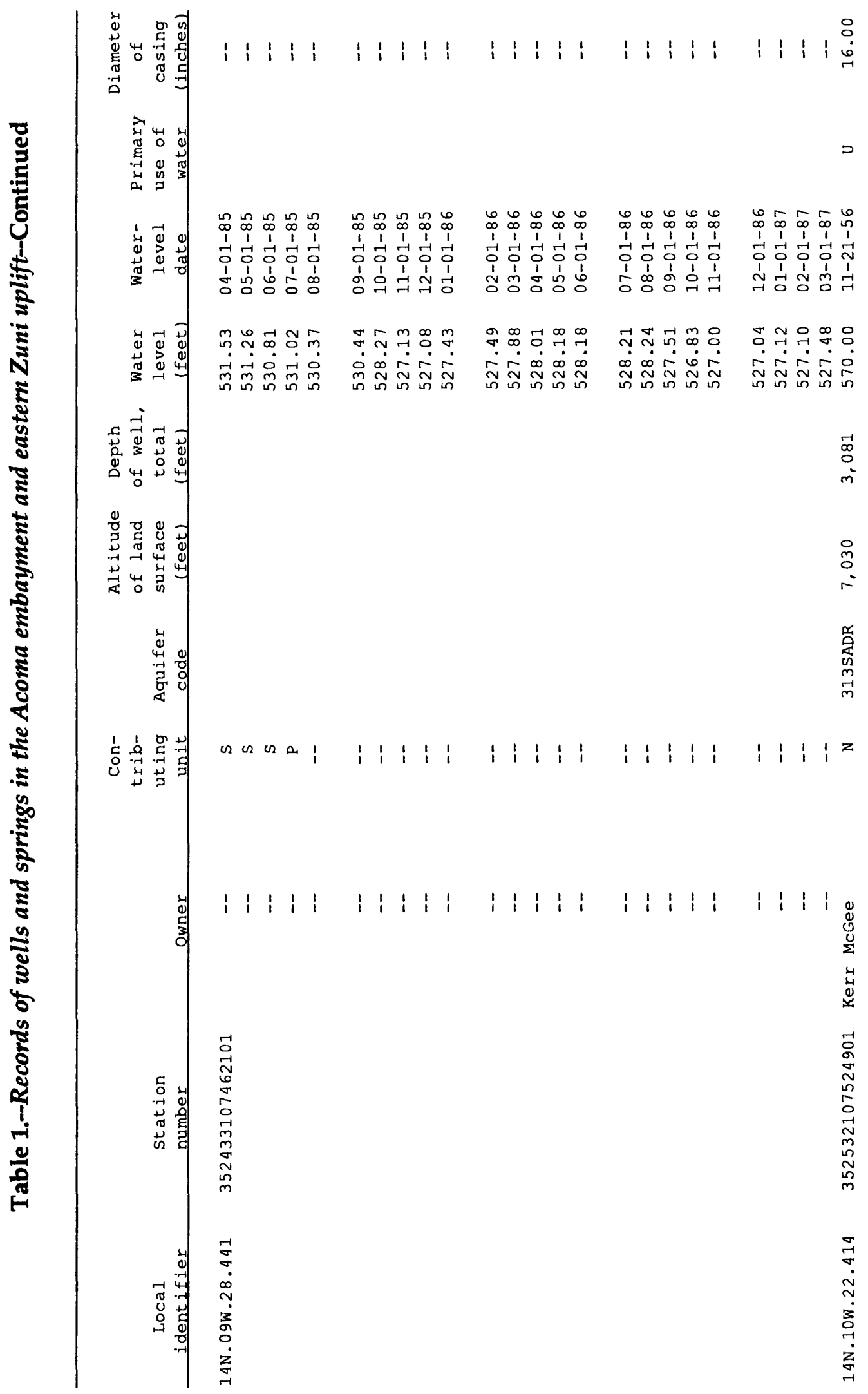




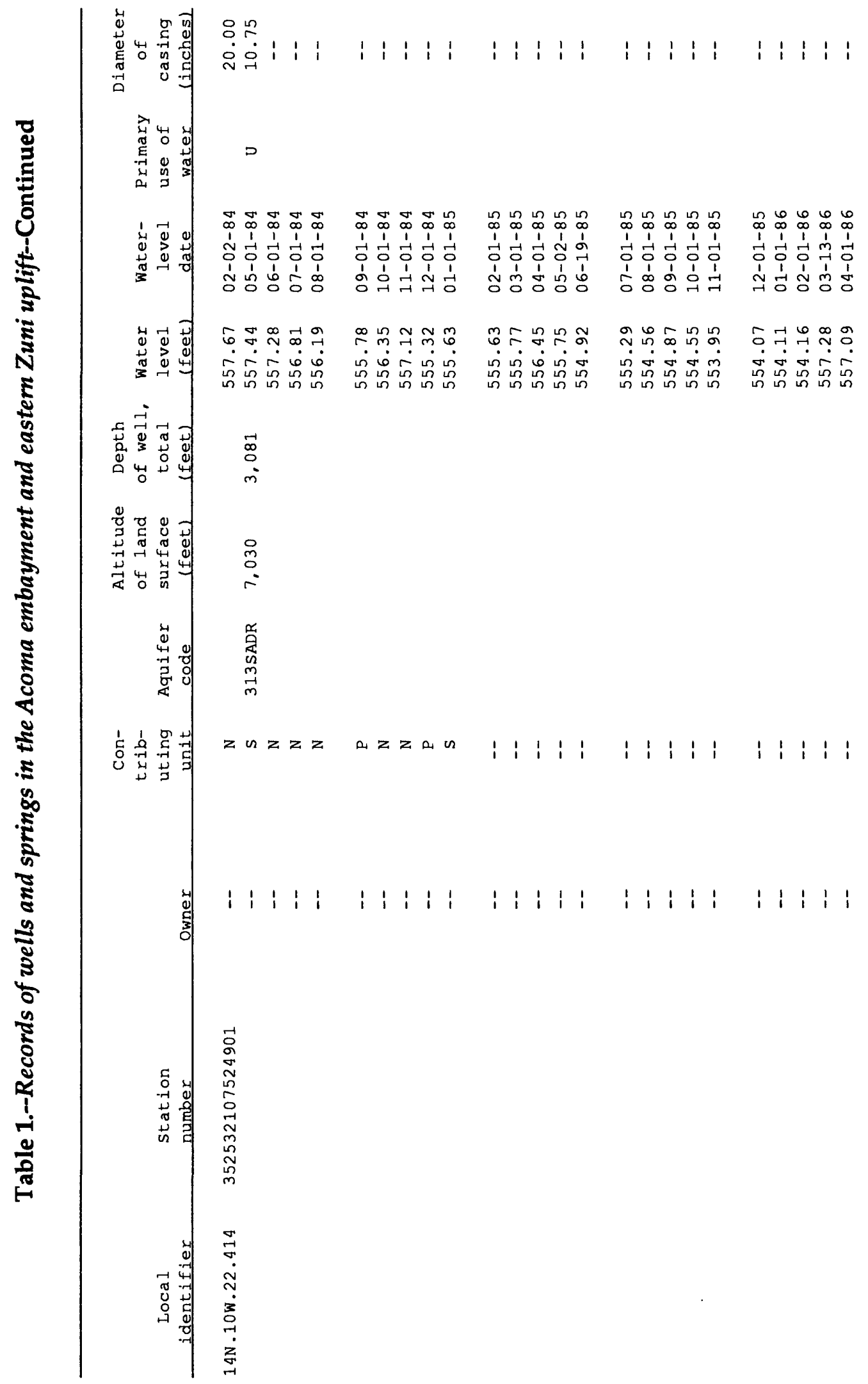




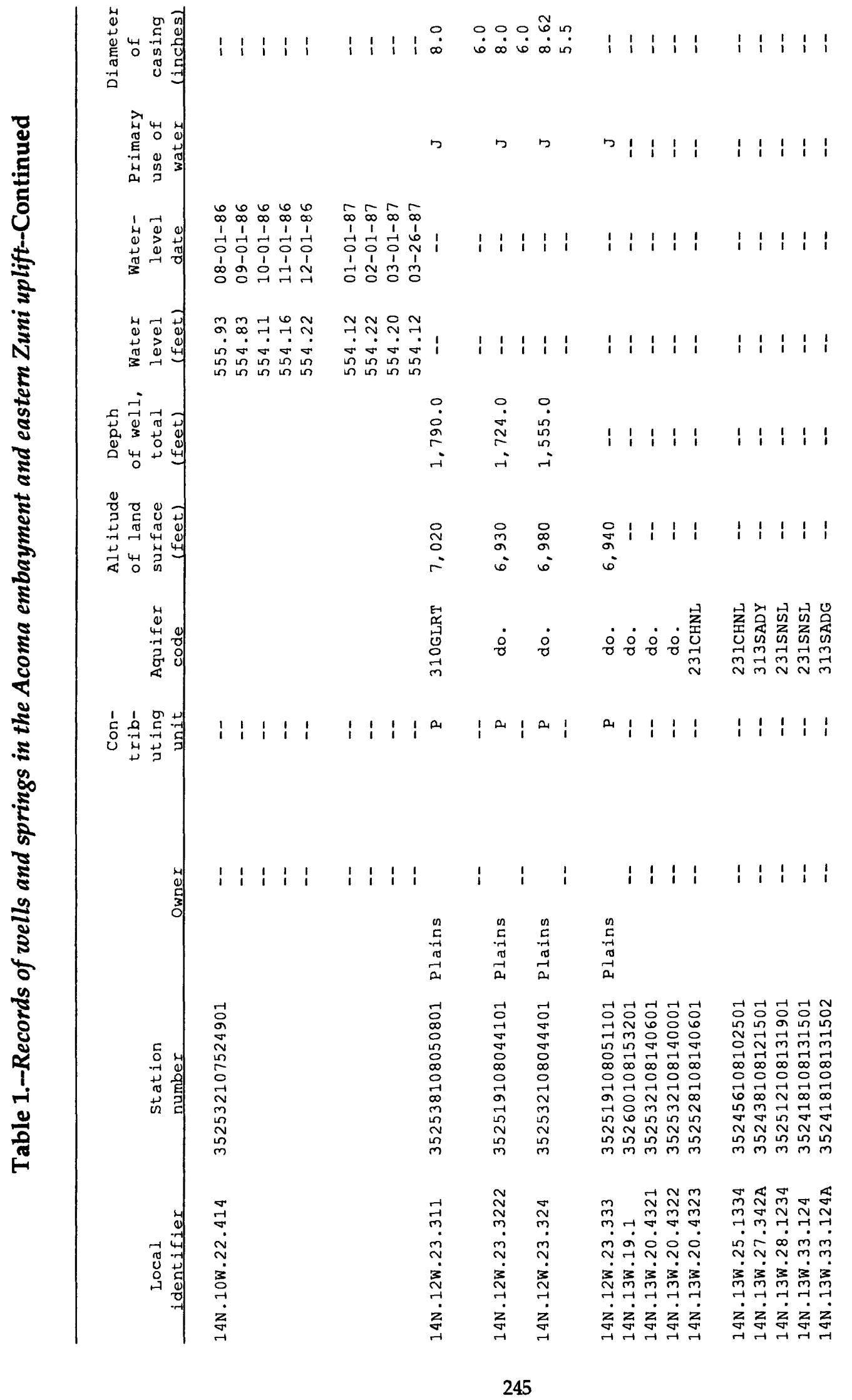




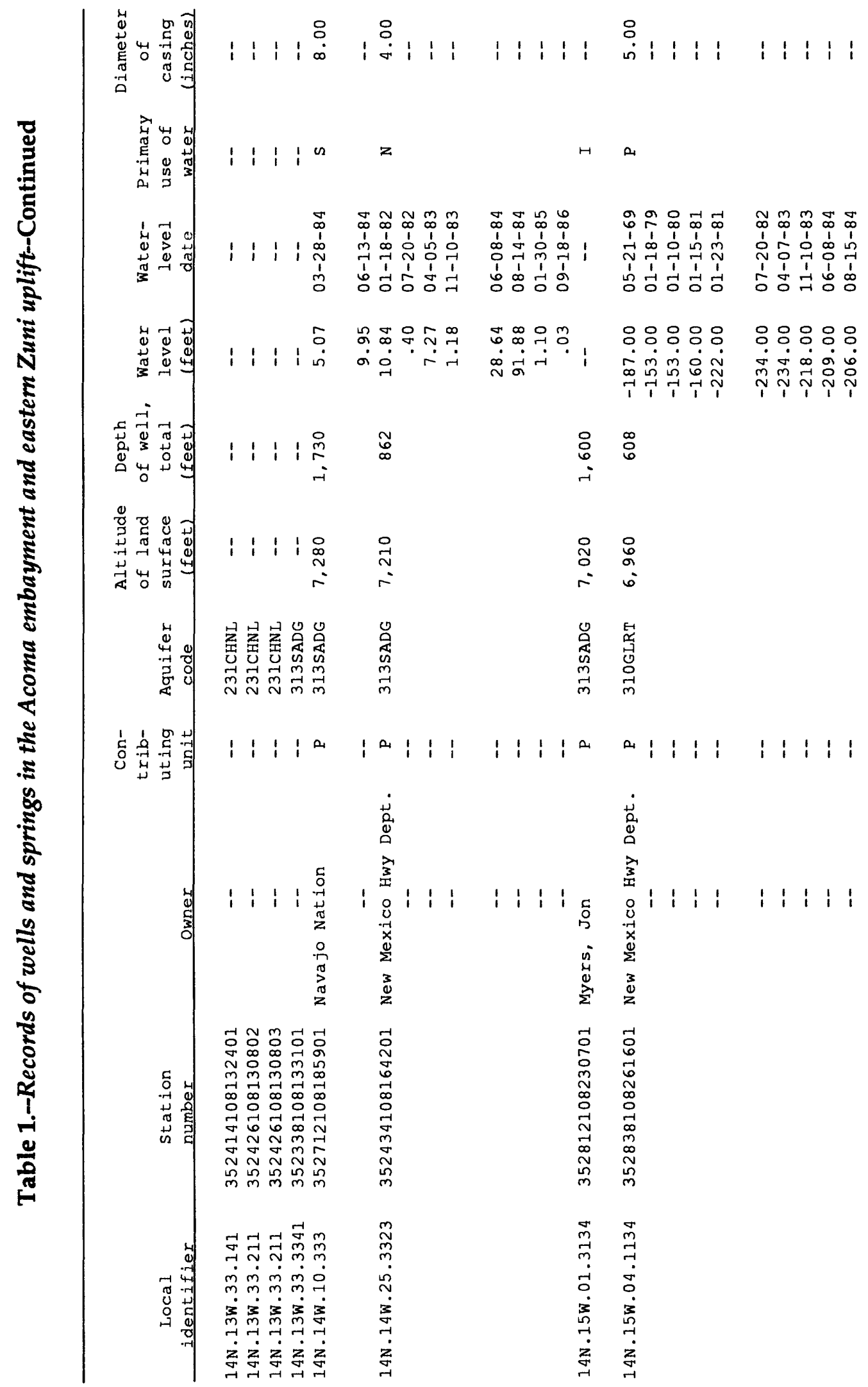




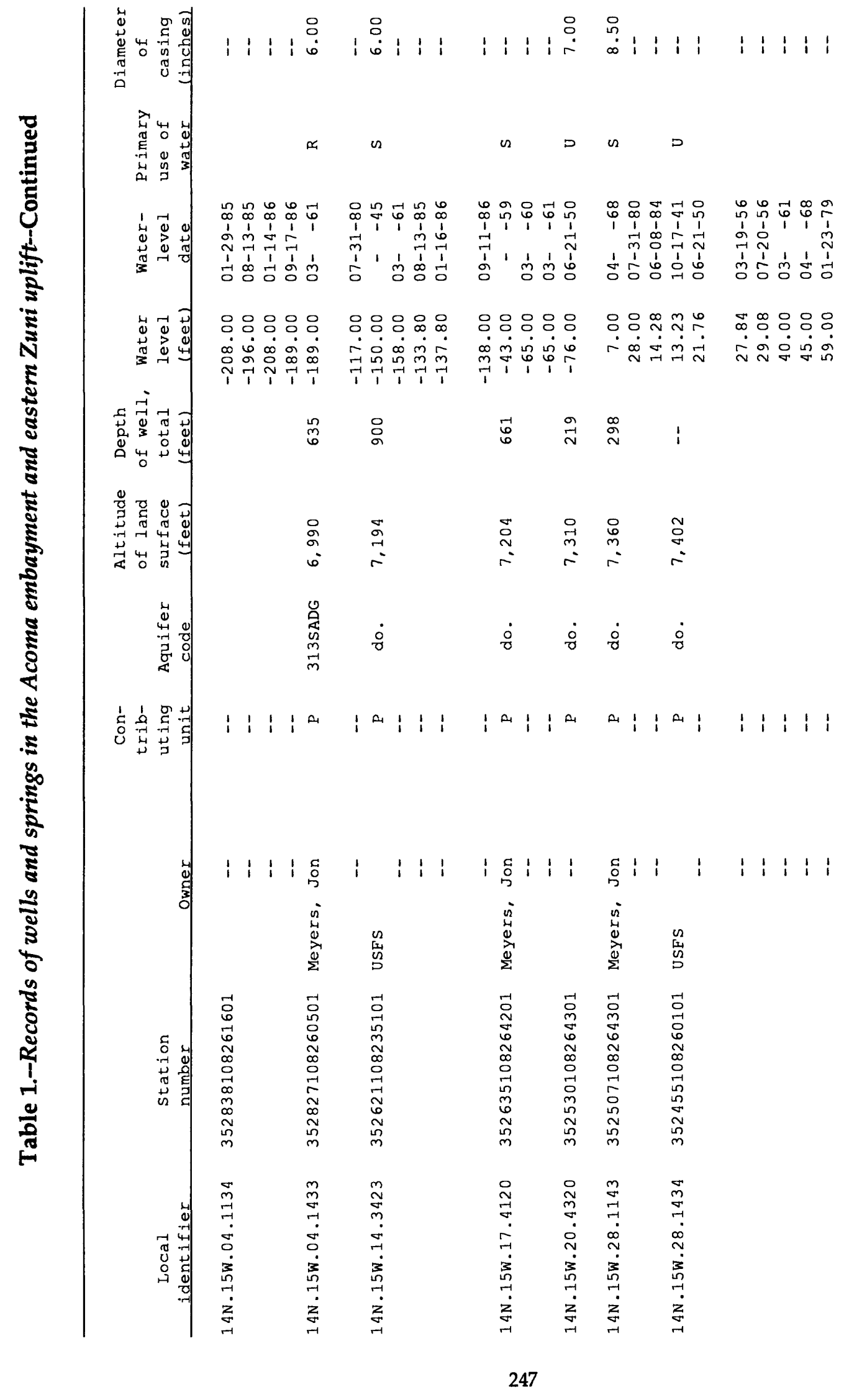




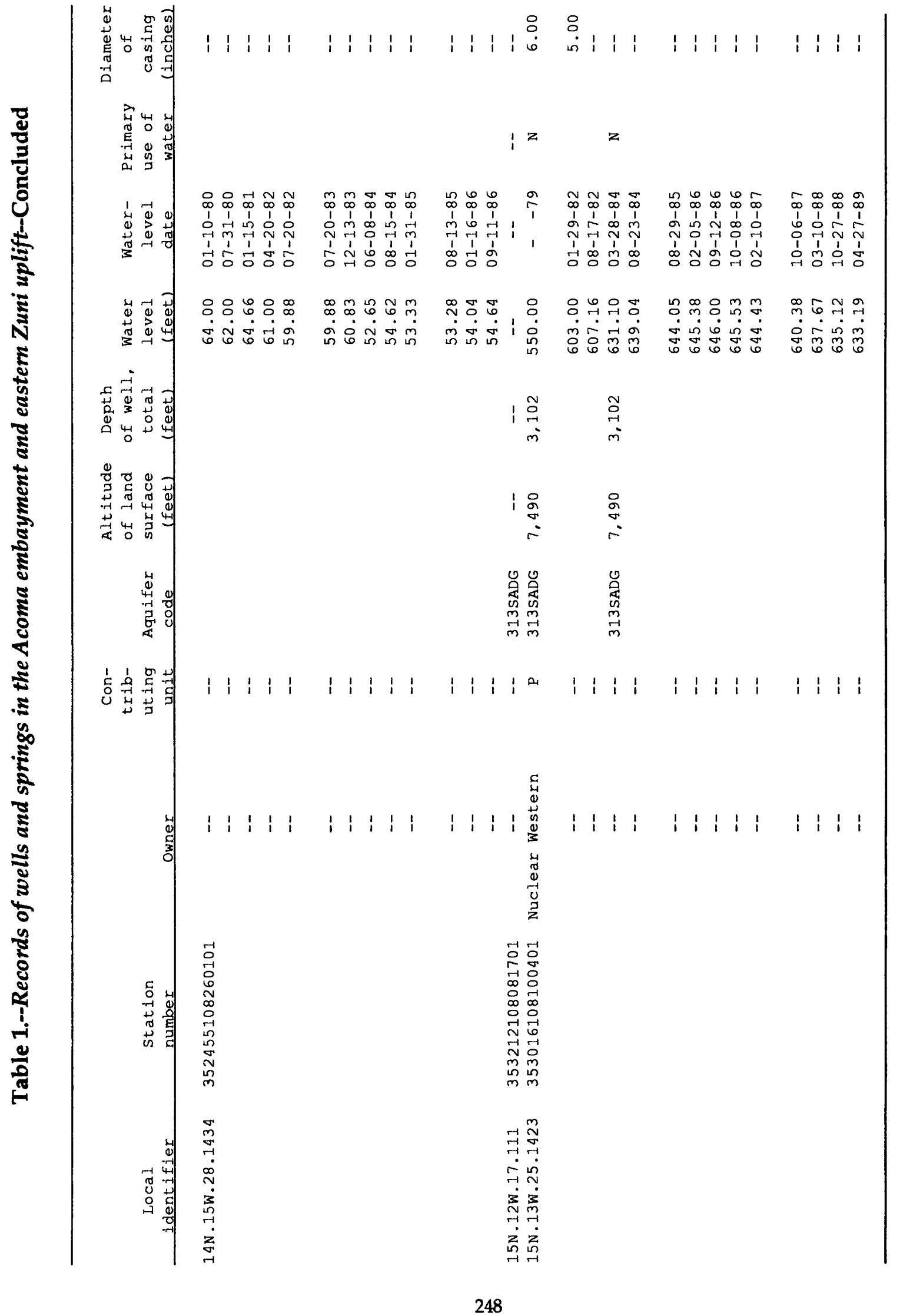


Table 2.--Temperature, geothermal gradient, and specific conductance for hydrologic-test wells in the Acoma embayment

[Microsiemens, microsiemens per centimeter at 25 degrees Celsius]

\begin{tabular}{|c|c|c|c|c|c|}
\hline $\begin{array}{c}\text { Well } \\
\text { 1ocation }\end{array}$ & $\begin{array}{c}\text { Temperature } \\
\text { (degrees } \\
\text { Celsius) }\end{array}$ & $\begin{array}{l}\text { Ad justed } \\
\text { temperature } \\
\text { (minus } 16 \\
\text { degrees } \\
\text { Celsius) }\end{array}$ & $\begin{array}{l}\text { Depth } \\
\text { (feet } \\
\text { below } \\
\text { land } \\
\text { surface) }\end{array}$ & $\begin{array}{l}\text { Geothermal } \\
\text { gradient } \\
\text { (degrees Celsius } \\
100 \text { feet) }\end{array}$ & $\begin{array}{c}\text { Specific } \\
\text { conductance } \\
\text { (microsiemens) }\end{array}$ \\
\hline 5.8 .35 .123 & 41.0 & 25.0 & 2,019 & 1.2 & 2,800 \\
\hline 6.10 .7 .1413 & 33.5 & 17.5 & 2,783 & 0.63 & 8,000 \\
\hline 8.6 .20 .3334 & 40.0 & 24.0 & 2,203 & 1.1 & 4,450 \\
\hline 8.8 .25 .4231 & 36.5 & 20.5 & 2,650 & 0.77 & 2,900 \\
\hline 9.6 .16 .111 & 39.0 & 23.0 & 2,650 & 0.87 & 5,100 \\
\hline 9.9 .28 .1344 & 41.0 & 25.0 & 2,515 & 0.99 & 1,400 \\
\hline 10.9 .25 .3241 & 56.8 & 40.8 & 2,901 & 1.4 & 7,300 \\
\hline
\end{tabular}


Table 3.--Transmissivity values of the San Andres-Glorieta aquifer in the study area

\section{EXPI.ANATION}

[Geohydrologic unit: 313SADG, San Andres Limestone and Glorieta Sandstone, undivided; 310GLRT, Glorieta Sandstone. USGS, U.S. Geological Survey;

PHS, Public Health Service; SEO, New Mexico State Engineer Office]

\begin{tabular}{|c|c|c|c|}
\hline Wel1 location & $\begin{array}{c}\text { Geo- } \\
\text { hydro- } \\
\text { logic } \\
\text { unit }\end{array}$ & $\begin{array}{c}\text { Trans- } \\
\text { missivity } \\
\text { (feet } \\
\text { squared } \\
\text { per day) }\end{array}$ & Source of data \\
\hline $6 \mathrm{~N} .10 \mathrm{~W} .7 .1413$ & 313 SADG & 70 & USGS \\
\hline 8 N. 6 W. 20.333 & do. & 100 & USGS \\
\hline $8 \mathrm{~N} .8 \mathrm{~W} .25 .423$ & do. & 25 & USGS \\
\hline 9N.5W. 12.442 & do. & 10 & Risser and Lyford, 1983 \\
\hline $9 \mathrm{~N} .6 \mathrm{~W} .16 .111$ & do. & 500 & USGS \\
\hline 9 N.9W. 28.134 & do. & 200,000 & USGS \\
\hline 10 N.9W. 25.324 & do. & 200,000 & USGS (estimated from flow rate) \\
\hline $11 N .5 W .14 .241$ & do. & 5 & Risser and Lyford, 1983 \\
\hline 11 N. 10W. 8.122 & do. & 264,000 & Geohydrology Associates, Inc., 1984 \\
\hline $11 \mathrm{~N} .10 \mathrm{~W} .8 .221$ & do. & 304,000 & Geohydrology Associates, Inc., 1984 \\
\hline 12 N.10W. 8.314 & 310GLRT & 100 & West, 1972 \\
\hline $12 \mathrm{~N} .10 \mathrm{~W} .18 .311$ & $310 G L R T$ & 4,200 & Dames and Moore, 1981 \\
\hline $12 \mathrm{~N} .10 \mathrm{~W} .18 .312$ & 310GLRT & 3,300 & Dames and Moore, 1981 \\
\hline 12 N. 10W. 23.233 & 313SADG & 51,000 & Dames and Moore, 1981 \\
\hline $12 \mathrm{~N} .10 \mathrm{~W} .30 .412$ & do. & 450,000 & Gordon, 1961 , table 4 \\
\hline 12 N. 10 W. 30.421 & do. & 420,000 & Gordon, 1961, table 4 \\
\hline $12 \mathrm{~N} .10 \mathrm{~W} .32 .111$ & do. & 300,000 & Gordon, 1961, table 4 \\
\hline $12 \mathrm{~N} .11 W .10 .334$ & do. & 129,000 & Geohydrology Associates, Inc., 1984 \\
\hline $12 \mathrm{~N} .11 \mathrm{~W} .10 .344$ & do. & 60,000 & Geohydrology Associates, Inc., 1984 \\
\hline $12 \mathrm{~N} .11 \mathrm{~W} .10 .431$ & do. & 76,000 & Geohydrology Associates, Inc., 1984 \\
\hline $12 \mathrm{~N} .11 \mathrm{~W} .15 .211$ & do. & 57,000 & Geohydrology Associates, Inc., 1984 \\
\hline 12 N. 11 W. 24.233 & do. & 66,000 & Dames and Moore, 1981 \\
\hline $12 \mathrm{~N} .11 \mathrm{~W} .24 .234$ & do. & 20,000 & Dames and Moore, 1981 \\
\hline $12 \mathrm{~N} .11 \mathrm{~W} .24 .411$ & do. & 26,000 & Dames and Moore, 1981 \\
\hline $12 \mathrm{~N} .11 \mathrm{~W} .24 .411$ & do. & 55,000 & Dames and Moore, 1981 \\
\hline
\end{tabular}


Table 3.--Transmissivity values of the San Andres-Glorieta aquifer in the study area-Concluded

\begin{tabular}{|c|c|c|c|c|}
\hline Well location & $\begin{array}{l}\text { Geo- } \\
\text { hydro- } \\
\text { logic } \\
\text { unit }\end{array}$ & $\begin{array}{c}\text { Trans- } \\
\text { missivity } \\
\text { (feet } \\
\text { squared } \\
\text { per day) }\end{array}$ & Source of data & \\
\hline 12 N.11W. 26.244 & 313SADG & 61,000 & Gordon, 1961, table 4 & \\
\hline $13 \mathrm{~N} .11 \mathrm{~W} .33 .332$ & 310GLRT & 24,000 & Geohydrology Associates, & Inc., 1983 \\
\hline $13 \mathrm{~N} .12$ W. 5.314 & 313SADG & 220 & PHS, unpublished data & \\
\hline $14 \mathrm{~N} .10 \mathrm{~W} .22 .414$ & 313SADG & 850 & Jacob, 1956 & \\
\hline $14 \mathrm{~N} .12 \mathrm{~W} .23 .324$ & 310GLRT & 70 & SEO, unpublished data & \\
\hline $14 \mathrm{~N} .12 \mathrm{~W} .23 .333$ & 310 GLRT & 60 & SEO, unpublished data & \\
\hline 14 N.13W.19.121 & 313SADG & 140 & PHS, unpublished data & \\
\hline $14 \mathrm{~N} .13 \mathrm{~W} .19 .224$ & do. & 80 & PHS, unpublished data & \\
\hline $14 \mathrm{~N} .13 \mathrm{~W} .33 .143$ & do. & 30 & Geohydrology Associates, & Inc., 1981 \\
\hline $14 N .14 W .28 .111$ & do. & 55 & Geohydrology Associates, & Inc., 1981 \\
\hline $14 \mathrm{~N} .15 \mathrm{~W} .4 .113$ & do. & 140 & Geohydrology Associates, & Inc., 1981 \\
\hline $14 \mathrm{~N} .15 \mathrm{~W} .4 .143$ & do. & 280 & Geohydrology Assaciates, & Inc., 1981 \\
\hline $14 \mathrm{~N} .15 \mathrm{~W} .14 .342$ & do. & 140 & Geohydrology Associates, & Inc., 1981 \\
\hline $14 \mathrm{~N} .15 \mathrm{~W} .17 .441$ & do. & 110 & Geohydrology Associates, & Inc., 1981 \\
\hline
\end{tabular}


Table 4.--Storage coefficients calculated from four aquifer tests

\begin{tabular}{|c|c|c|c|c|}
\hline $\begin{array}{l}\text { Pumped } \\
\text { wel1 }\end{array}$ & $\begin{array}{l}\text { Observation } \\
\text { well }\end{array}$ & $\begin{array}{c}\text { Storage } \\
\text { coefficient }\end{array}$ & $\begin{array}{c}\text { Source of } \\
\text { data }\end{array}$ & $\begin{array}{l}\text { Rocks } \\
\text { tested }\end{array}$ \\
\hline \multirow[t]{8}{*}{$12 \mathrm{~N} .10 \mathrm{~W} .30 .412$} & $12 \mathrm{~N} .10 \mathrm{~W} .30 .421$ & $5.2 \times 10^{-4}$ & Gordon, 1961 & $\begin{array}{l}\text { San Andres } \\
\text { Limestone }\end{array}$ \\
\hline & $12 \mathrm{~N} .10 \mathrm{~W} .30 .421$ & $4.7 \times 10^{-4}$ & do. & Do. \\
\hline & $12 \mathrm{~N} .10 \mathrm{~W} .30 .421$ & $4.2 \times 10^{-4}$ & do. & Do. \\
\hline & $12 \mathrm{~N} .10 \mathrm{~W} .30 .421$ & $4.2 \times 10^{-4}$ & do. & Do. \\
\hline & $12 \mathrm{~N} .10 \mathrm{~W} .32 .111$ & $1.4 \times 10^{-3}$ & do. & Do. \\
\hline & $12 \mathrm{~N} .10 \mathrm{~W} .32 .111$ & $9.7 \times 10^{-4}$ & do. & Do. \\
\hline & $12 \mathrm{~N} .10 \mathrm{~W} .32 .111$ & $8.1 \times 10^{-4}$ & do. & Do. \\
\hline & $12 \mathrm{~N} .10 \mathrm{~W} .32 .111$ & $1.1 \times 10^{-3}$ & do. & Do. \\
\hline $12 \mathrm{~N} .11 \mathrm{~W} .24 .233 \mathrm{a}$ & $12 \mathrm{~N} .11 \mathrm{~W} .24 .411$ & $1.3 \times 10^{-4}$ & Dames and & San Andres \\
\hline \multirow[t]{7}{*}{$12 \mathrm{~N} .11 \mathrm{~W} .24 .233 \mathrm{~b}$} & $12 \mathrm{~N} .11 \mathrm{~W} .24 .233 \mathrm{c}$ & $3.2 \times 10^{-4}$ & $\begin{array}{c}\text { Moore, } 1981 \\
\text { do. }\end{array}$ & $\begin{array}{l}\text { Limestone } \\
\text { Glorieta }\end{array}$ \\
\hline & & & & Sandstone \\
\hline & $12 \mathrm{~N} .11 \mathrm{~W} .24 .233 \mathrm{c}$ & $6.0 \times 10^{-5}$ & do. & Do. \\
\hline & $12 \mathrm{~N} .11 \mathrm{~W} .24 .233 \mathrm{a}$ & $1.4 \times 10^{-2}$ & do. & Do. \\
\hline & $12 \mathrm{~N} .11 \mathrm{~W} .24 .233 \mathrm{a}$ & $1.2 \times 10^{-2}$ & do. & Do. \\
\hline & $12 \mathrm{~N} .11 \mathrm{~W} .24 .411$ & $1.3 \times 10^{-3}$ & do. & Do. \\
\hline & $12 \mathrm{~N} .11 \mathrm{~W} .24 .411$ & $8.1 \times 10^{-4}$ & do. & Do. \\
\hline \multirow[t]{3}{*}{$12 \mathrm{~N} .10 \mathrm{~W} .18 .312 \mathrm{a}$} & $12 \mathrm{~N} .10 \mathrm{~W} .18 \cdot 312 \mathrm{~b}$ & $5.3 \times 10^{-5}$ & do. & Do. \\
\hline & $12 \mathrm{~N} .10 \mathrm{~W} .18 .311$ & $8.9 \times 10^{-5}$ & do. & Do. \\
\hline & 12N.10W.18.311 & $2.8 \times 10^{-4}$ & do. & Do. \\
\hline
\end{tabular}


Table 5.--Ground-water withdrawals for $1945-57$ and

1979-82 in the Grants-Bluewater area

\begin{tabular}{lccc}
\hline Year & $\begin{array}{l}\text { Ground-water } \\
\text { withdrawals } \\
\text { (acre-feet) }\end{array}$ & Year & $\begin{array}{c}\text { Ground-water } \\
\text { withdrawals } \\
\text { (acre-feet) }\end{array}$ \\
\hline 1945 & 3,700 & 1954 & 14,080 \\
1946 & 9,200 & 1955 & 13,600 \\
1947 & 10,500 & 1956 & 14,210 \\
1948 & 9,500 & 1957 & 12,800 \\
1949 & 7,125 & & \\
& & 1979 & 6,700 \\
1950 & 12,050 & 1980 & 7,000 \\
1951 & 12,500 & 1981 & 5,900 \\
1952 & 10,970 & 1982 & 3,900 \\
1953 & 13,320 & & \\
\hline
\end{tabular}

Table 6.--Lithology percentages for Pennsylvanian rocks and the Yeso and Abo Formations in the study area

Sandstone Siltstone-shale Carbonates Evaporites

\begin{tabular}{ccccc} 
Pennsylvanian & 10 & 42 & 48 & 0 \\
$\begin{array}{c}\text { Yeso and Abo } \\
\text { Formations }\end{array}$ & 34 & 50 & 7 & 9 \\
\hline
\end{tabular}


Table 7.-Selected water analyses from wells in the Thoreau area

\section{EXPLANATION}

Local identifier: see text for explanation. Station number: the first six numbers are the latitude, the next seven numbers are the longitude, and the last two numbers are the sequence number. Geologic unit indicates source of water: 310GLRT, Permian Glorieta Sandstone; 313SADG, Permian San Andres Limestone and Glorieta Sandstone, undivided; 313SADY, Permian San Andres Limestone and Yeso Formation, undivided. $\mu \mathrm{S} / \mathrm{cm}$, microsiemens per centimeter at 25 degrees Celsius; $\operatorname{deg} \mathrm{C}$, degrees Celsius measured onsite; $\mathrm{mg} / \mathrm{L}$, milligrams per liter; $\mu \mathrm{g} / \mathrm{L}$, micrograms per liter; $\mathrm{E}$, estimated; <, less than; $>$, greater than; bicarbonate or carbonate wh wat total field, bicarbonate or carbonate whole water sample, not filtered, done onsite; --, no data. 


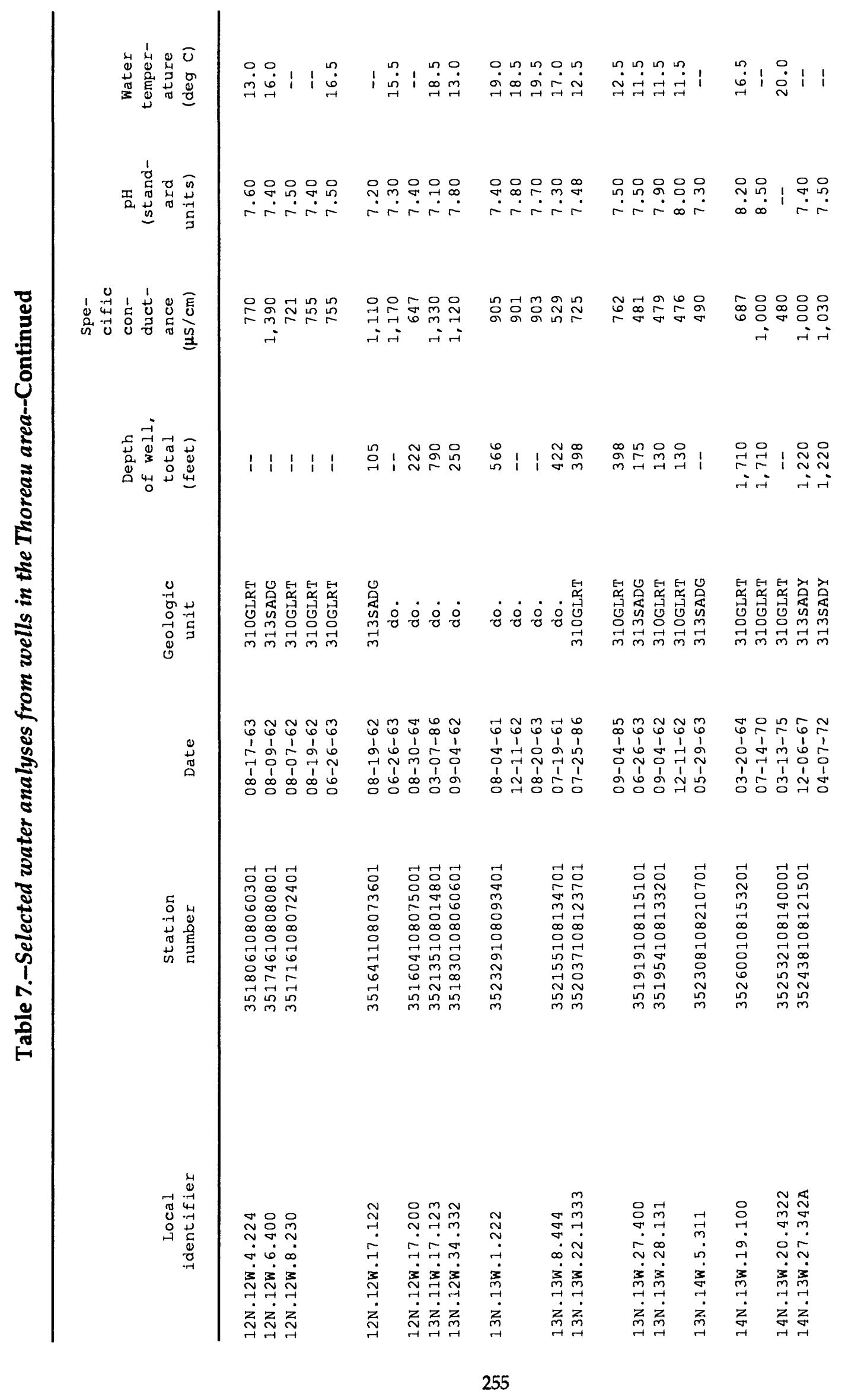




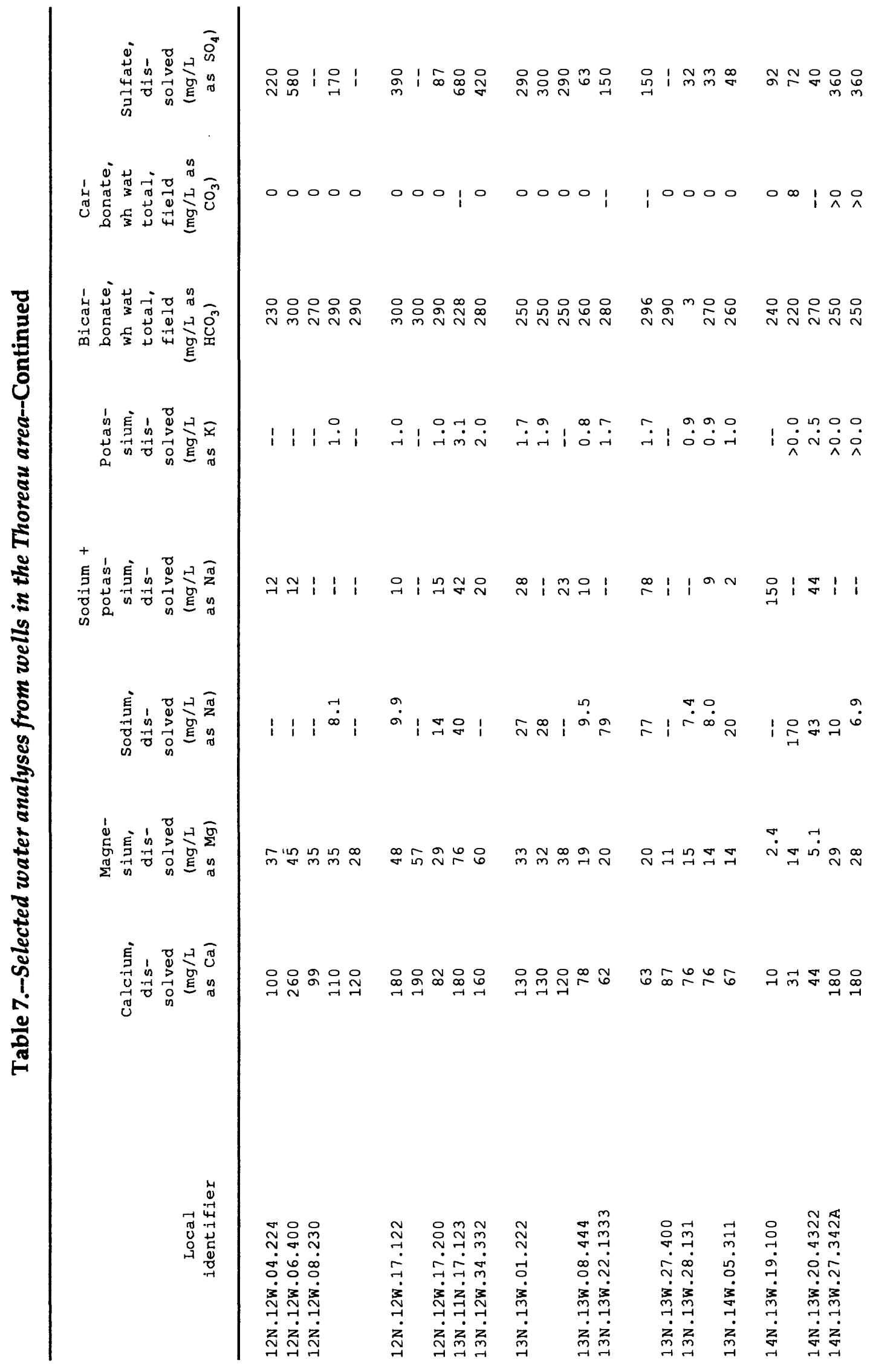




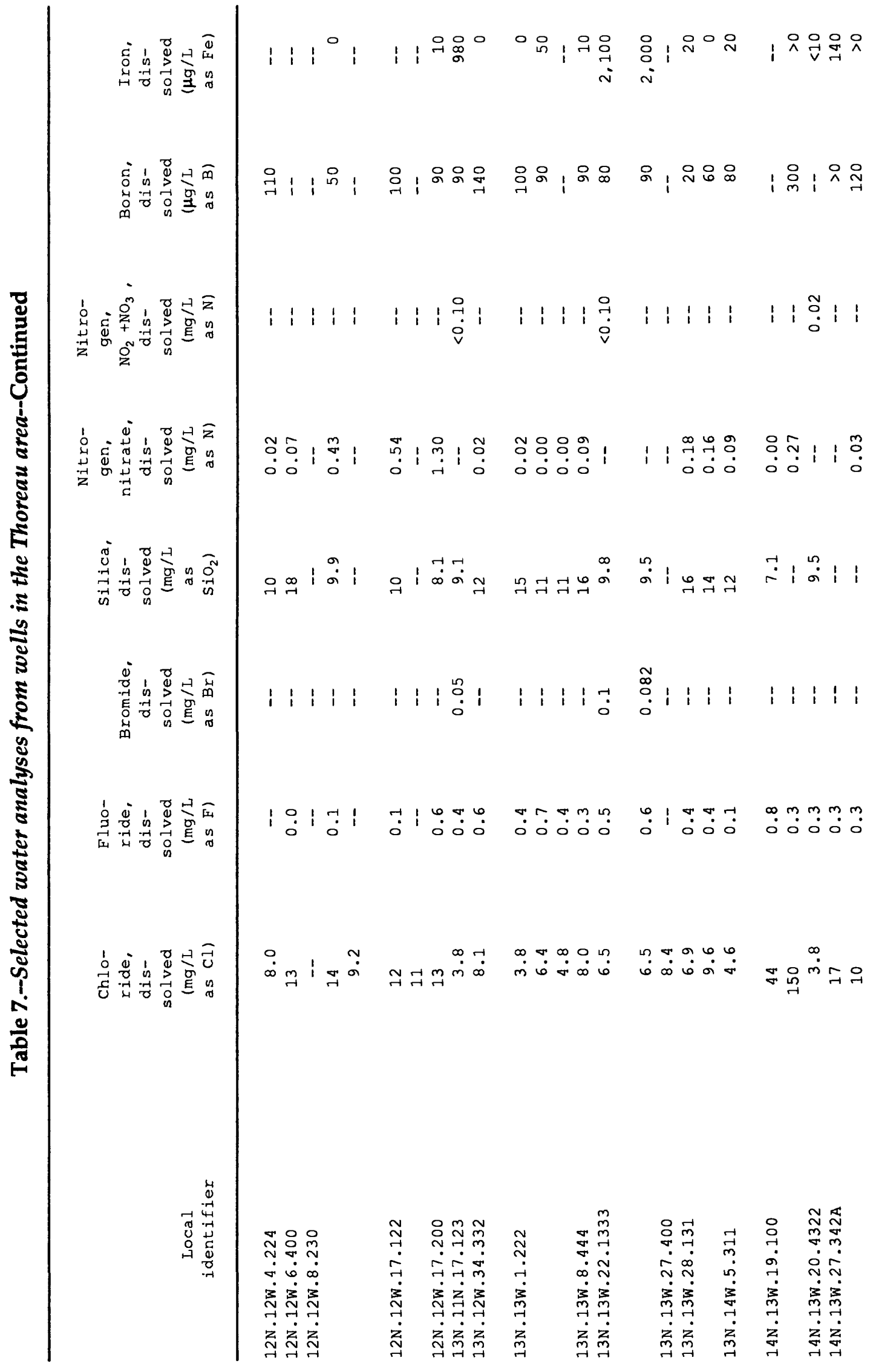




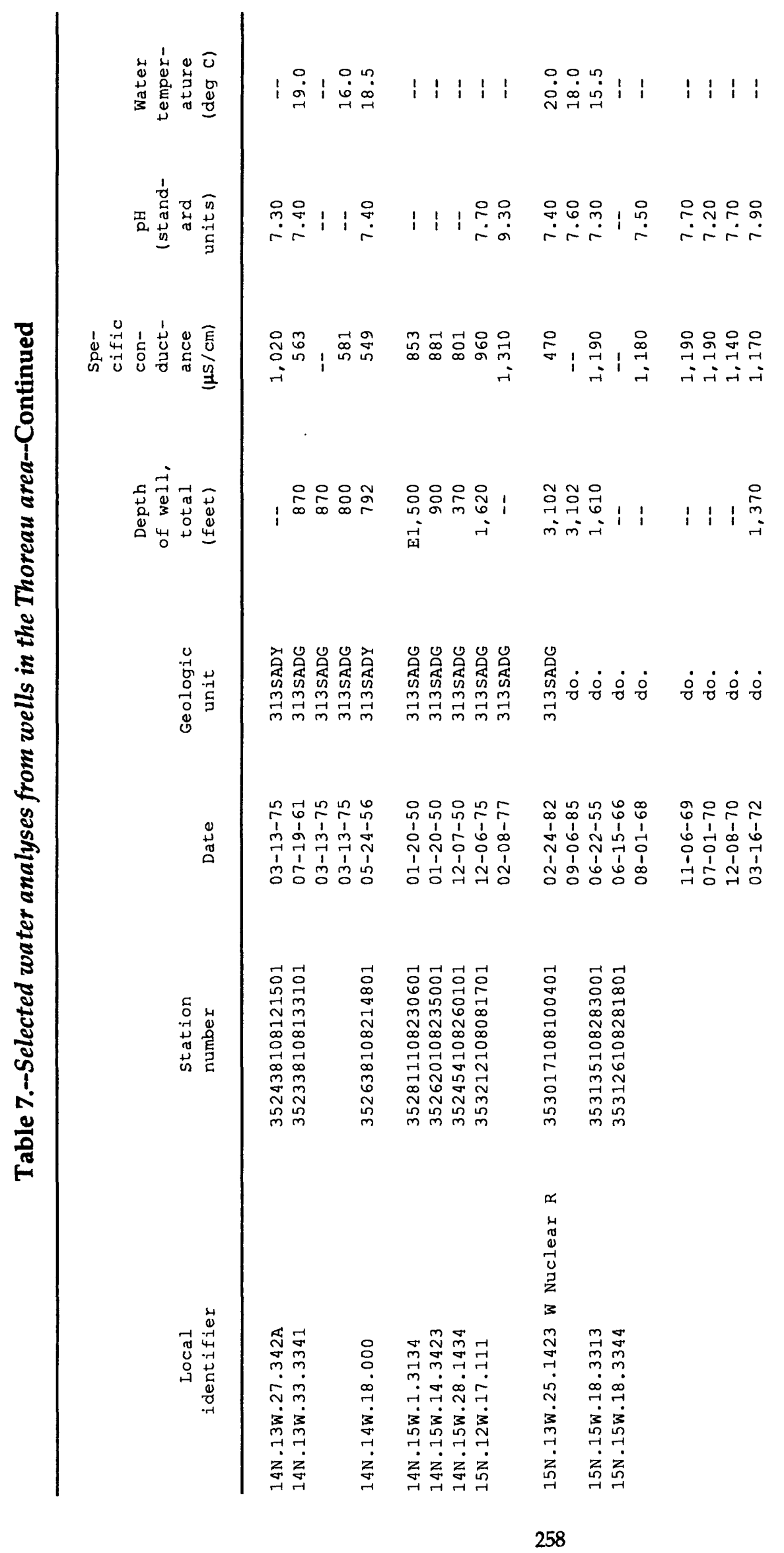




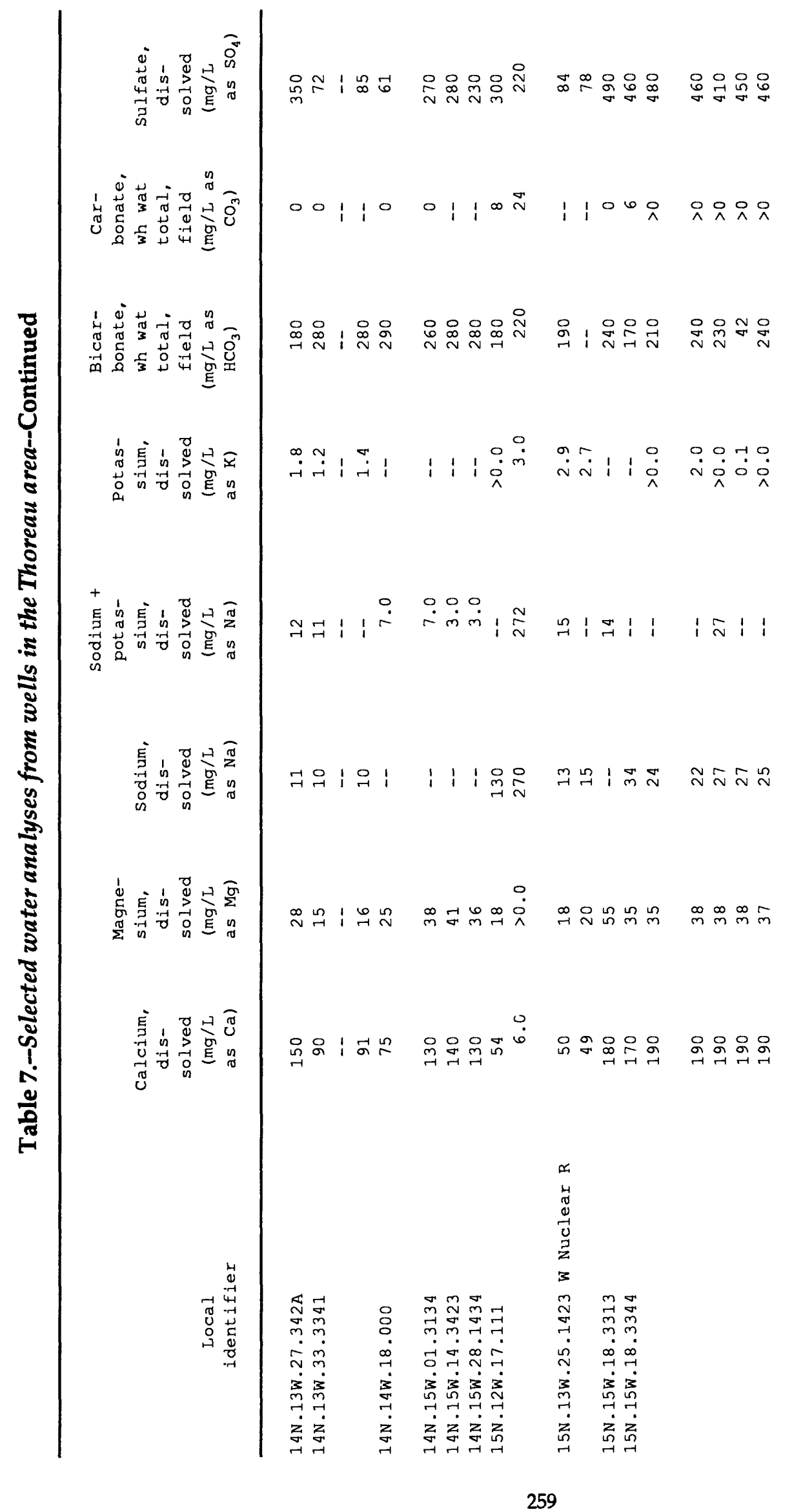




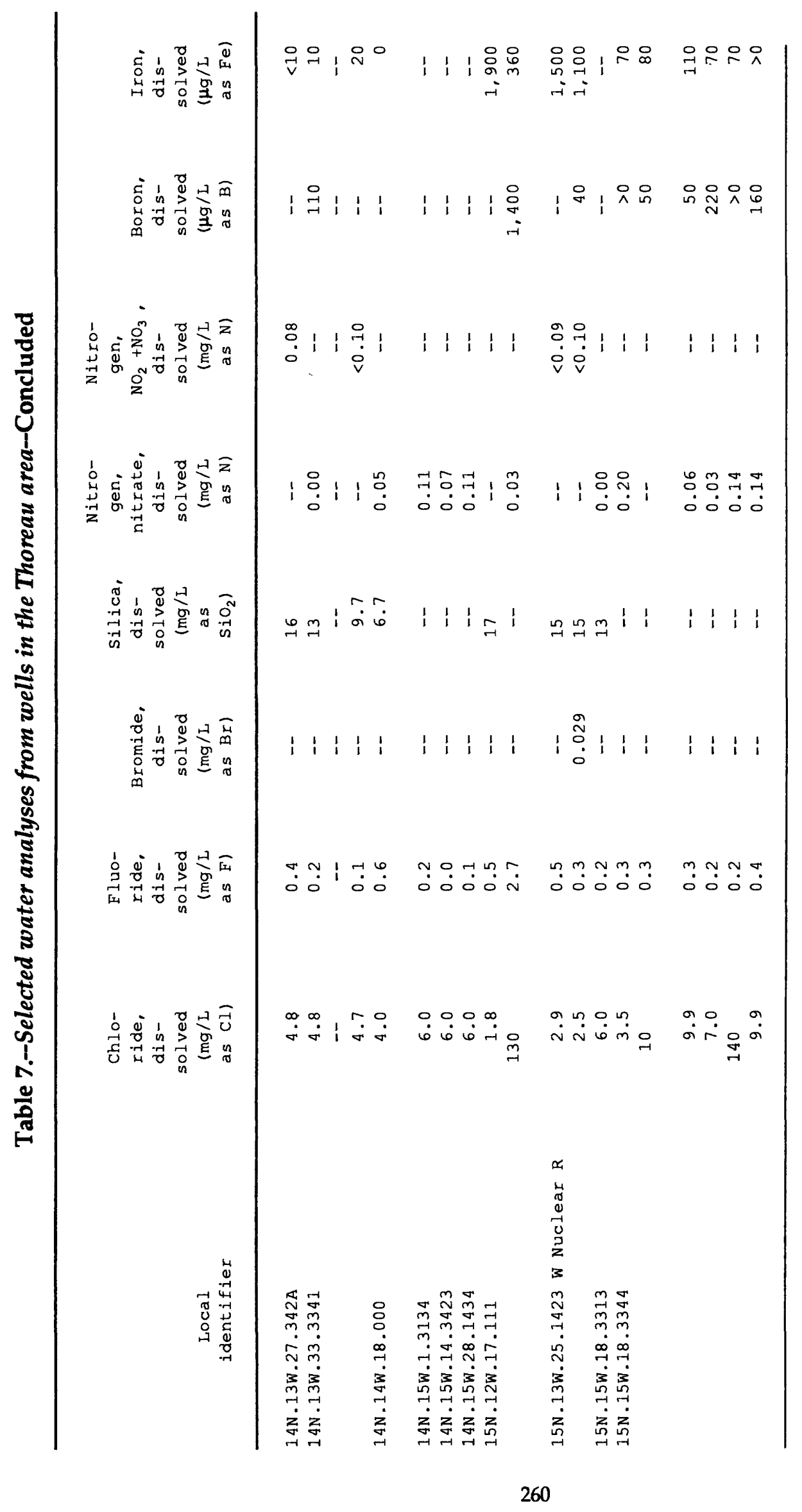




\section{EXPLANATION}

Local identifier: see text for explanation. Station number: the first six numbers are the latitude, the next seven numbers are the longitude, and the last two numbers are the sequence number. Geologic unit indicates source of water: 313SADG, Permian San Andres Limestone and Glorieta Sandstone, undivided; 110AVMB, Alluvium, bolson deposits, and other surface deposits; 111MCCR, Quaternary McCartys basalt flow; 313SADR, Permian San Andres Limestone; 310GLRT, Permian Glorieta Sandstone. $\mu \mathrm{S} / \mathrm{cm}$, microsiemens per centimeter at 25 degrees Celsius; deg C, degrees Celsius measured onsite; $\mathrm{mg} / \mathrm{L}$, milligrams per liter; $\mu \mathrm{g} / \mathrm{L}$, micrograms per liter; E, estimated; <, less than; >, greater than; bicarbonate or carbonate wh wat total field, bicarbonate or carbonate whole water sample, not filtered, done onsite; --, no data. 


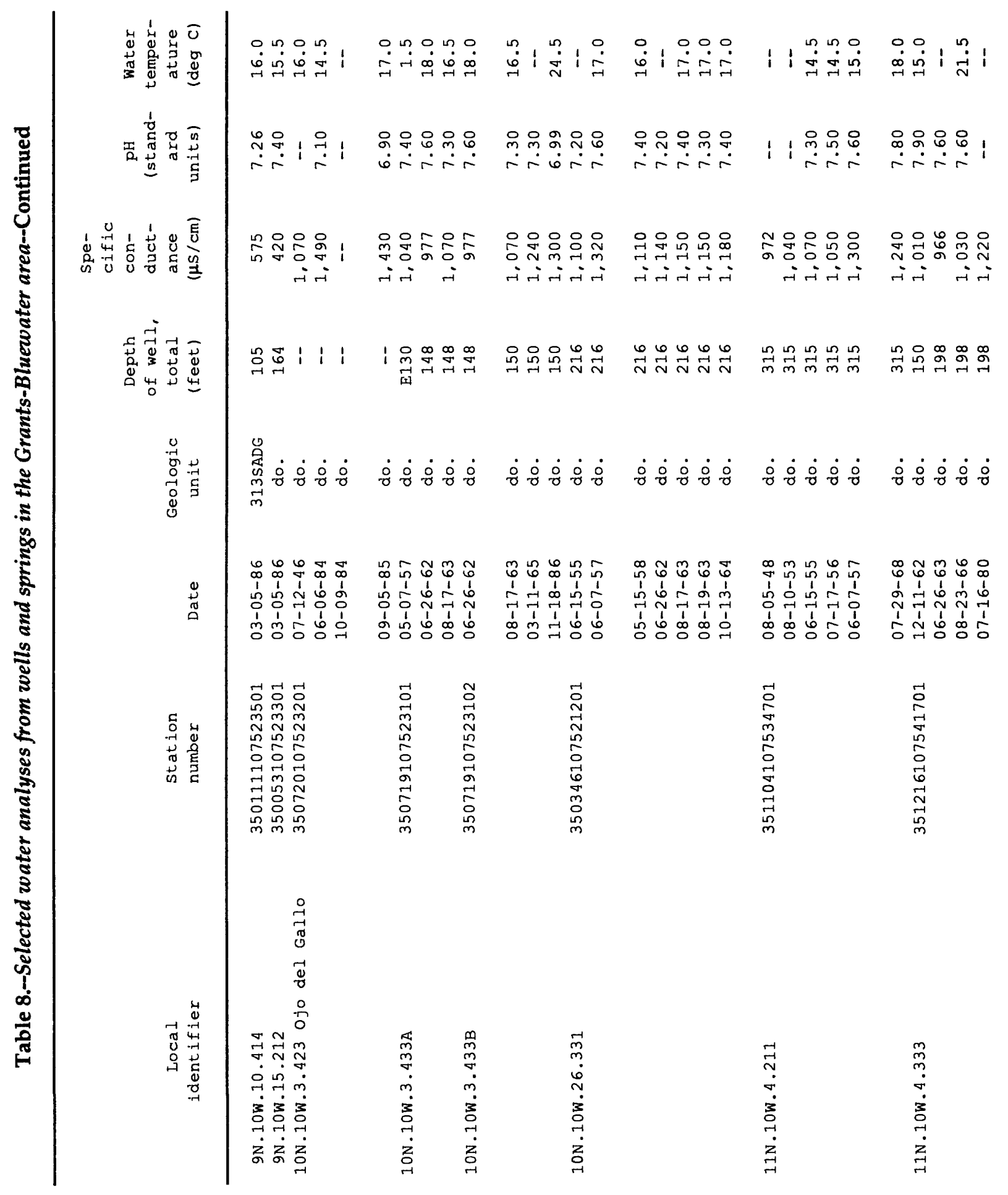




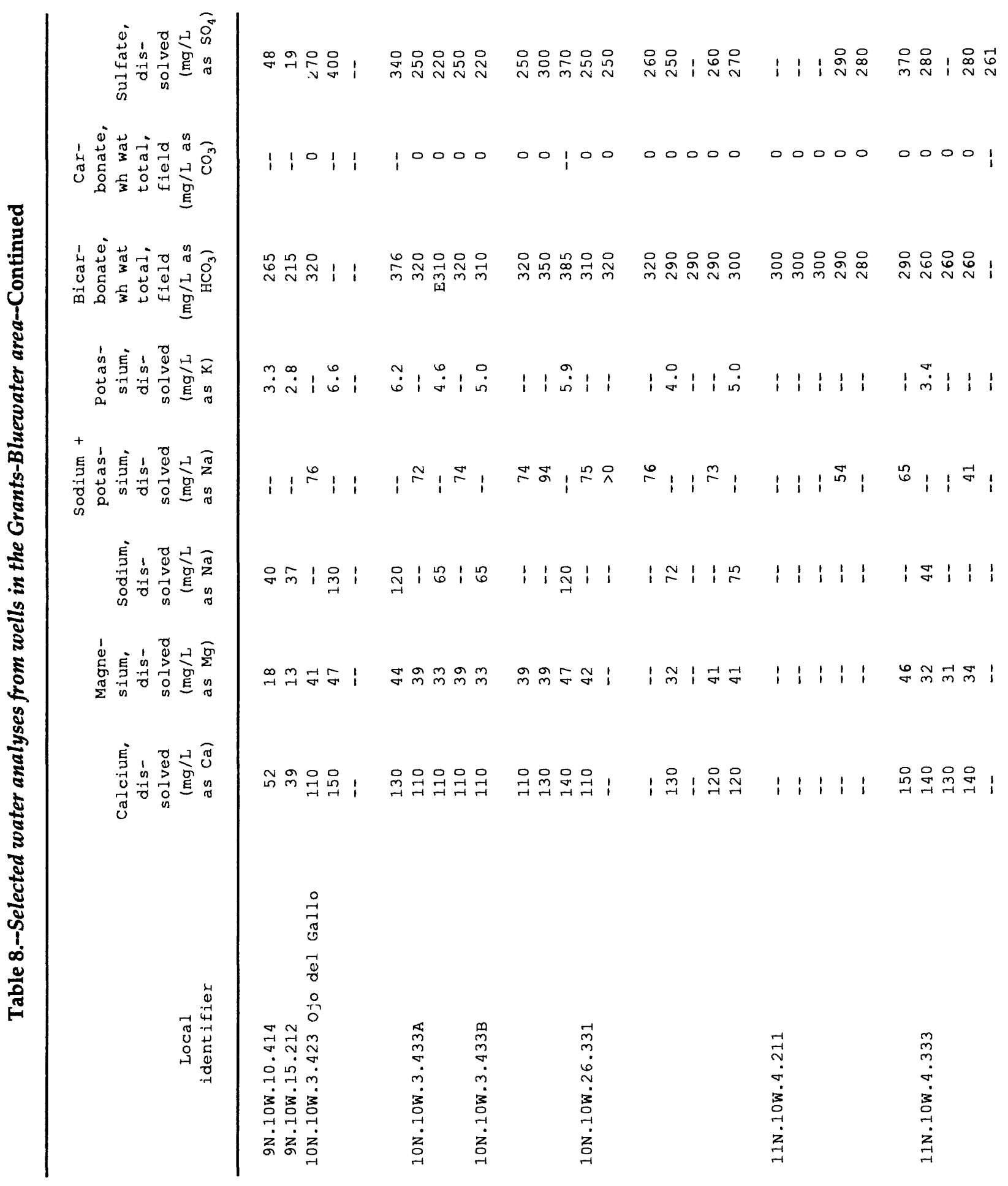




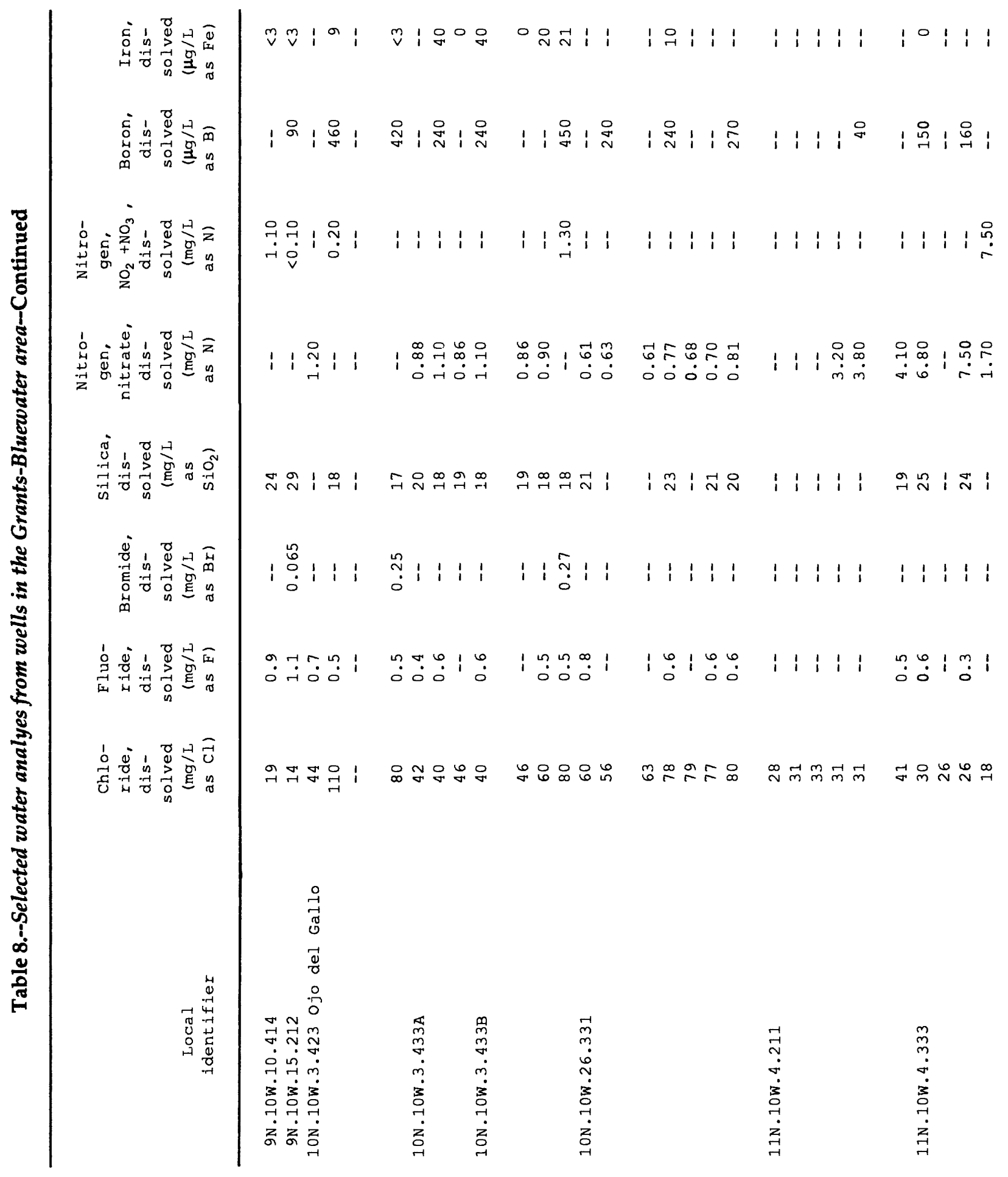




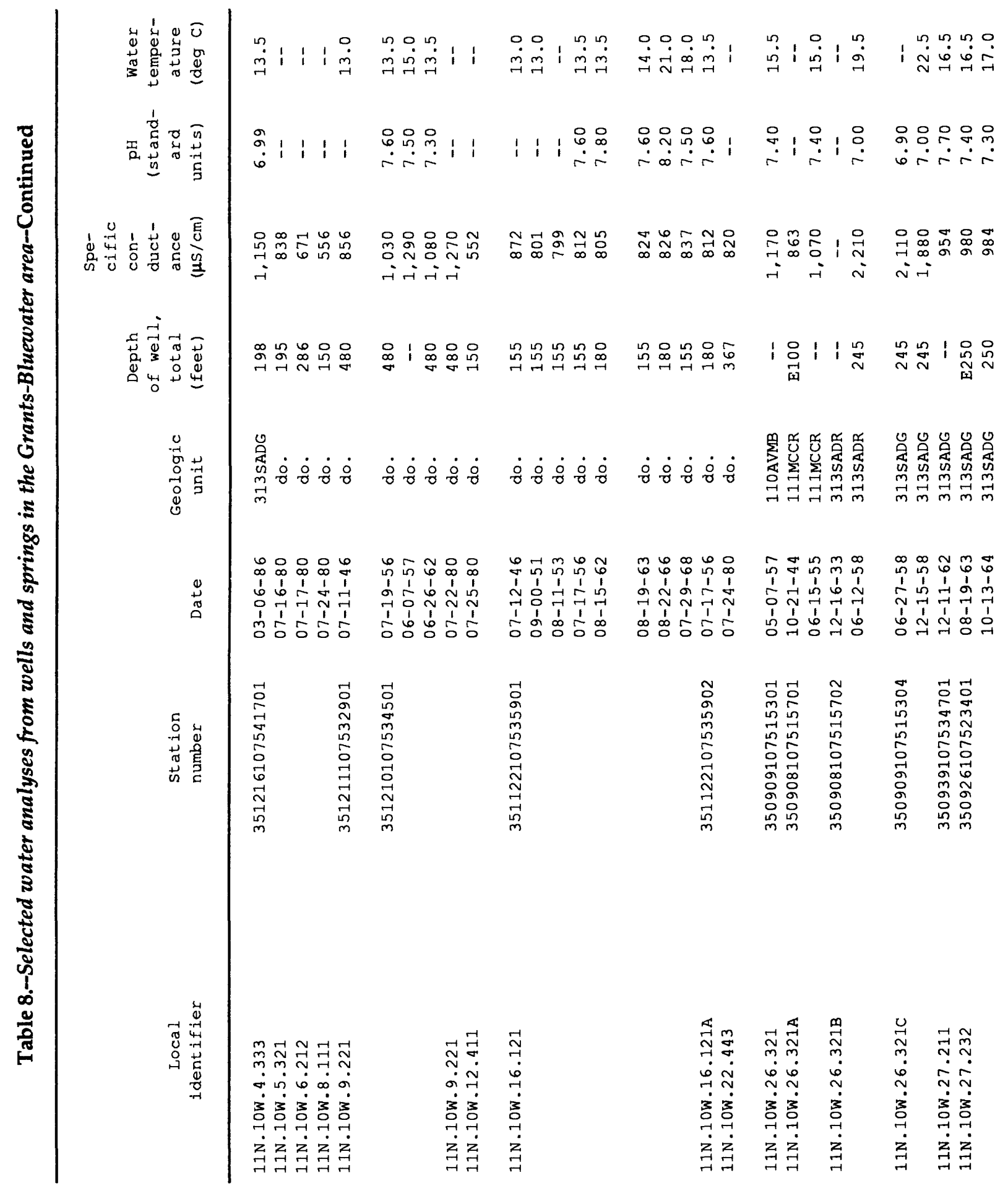




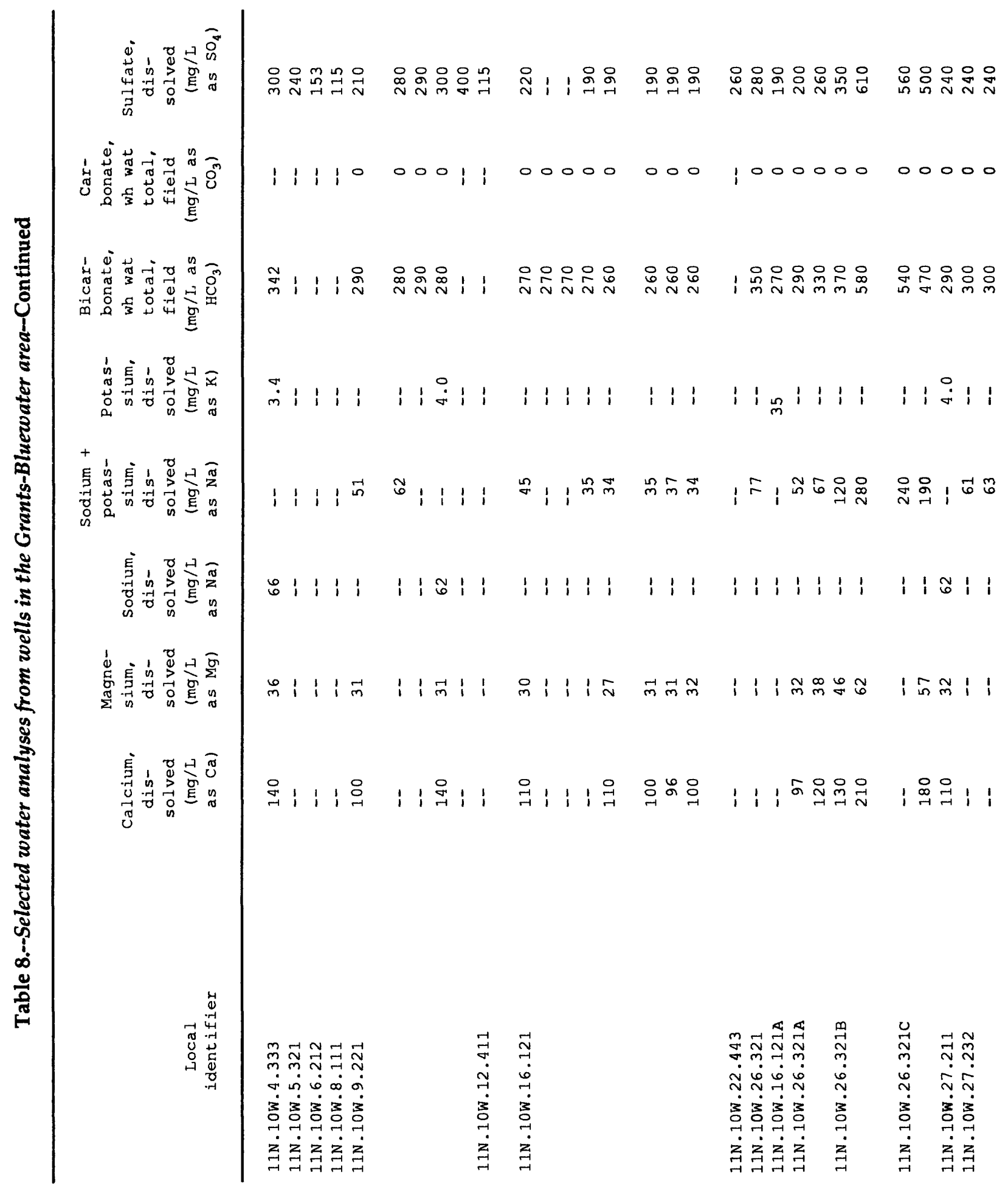




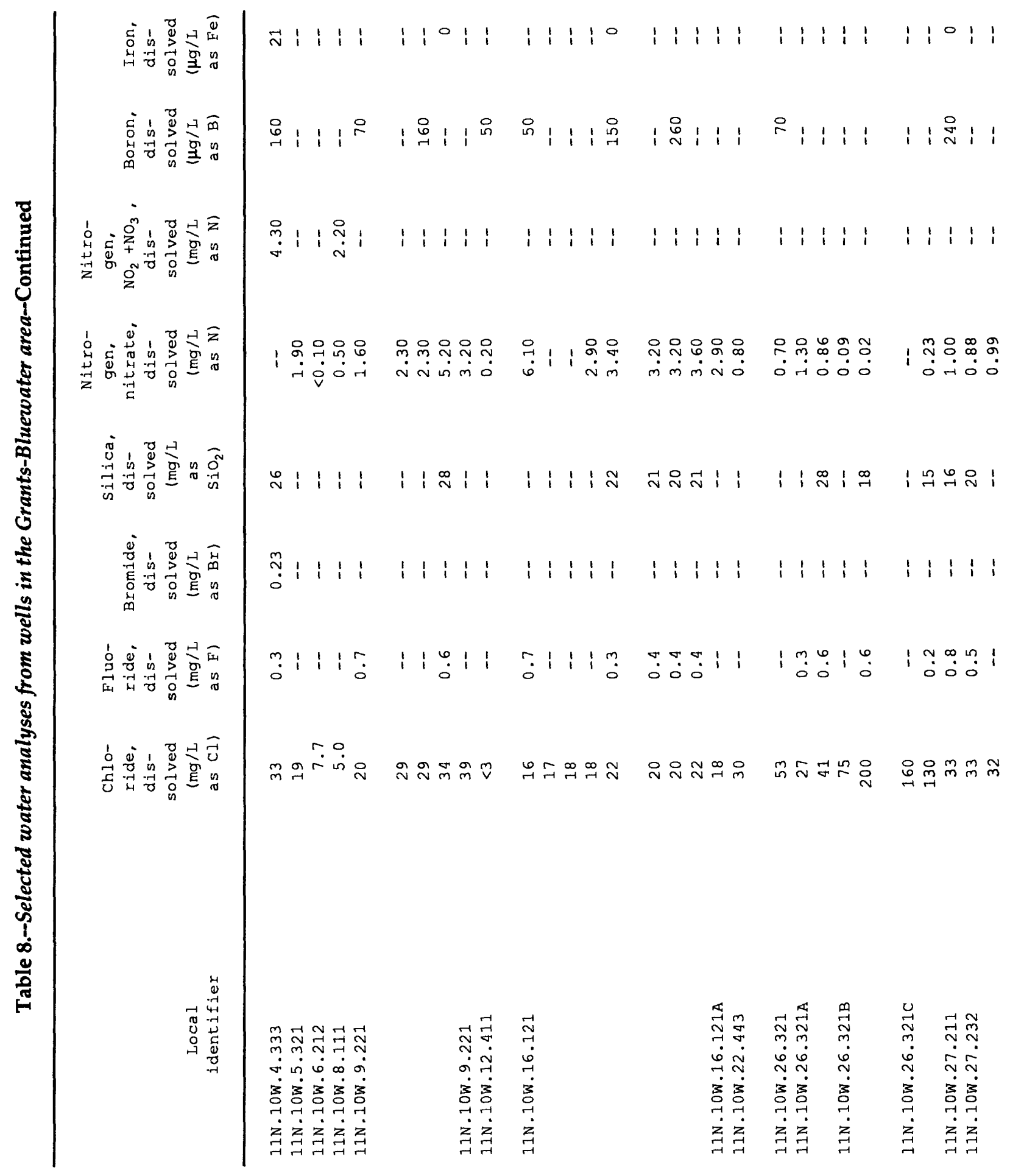




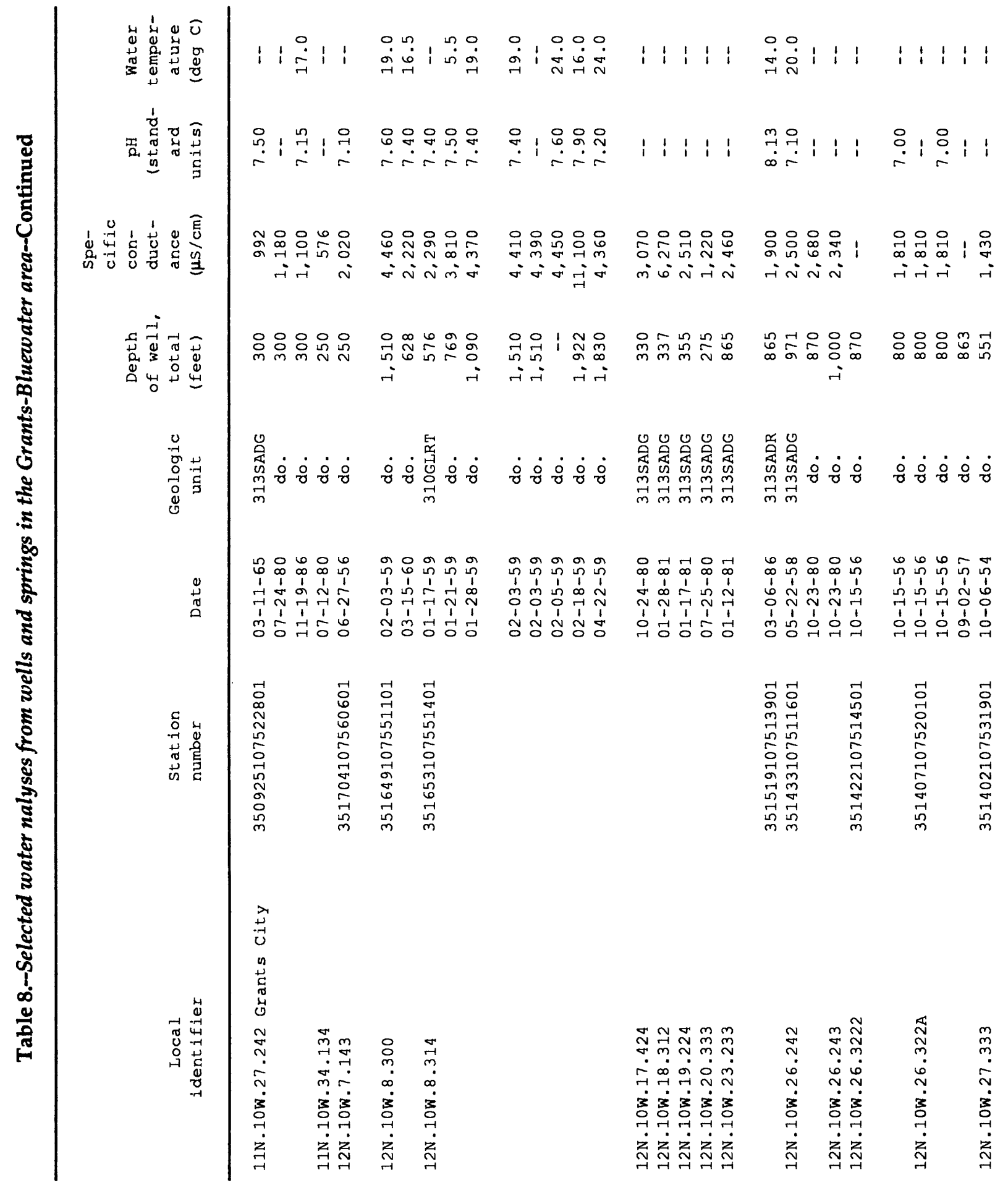




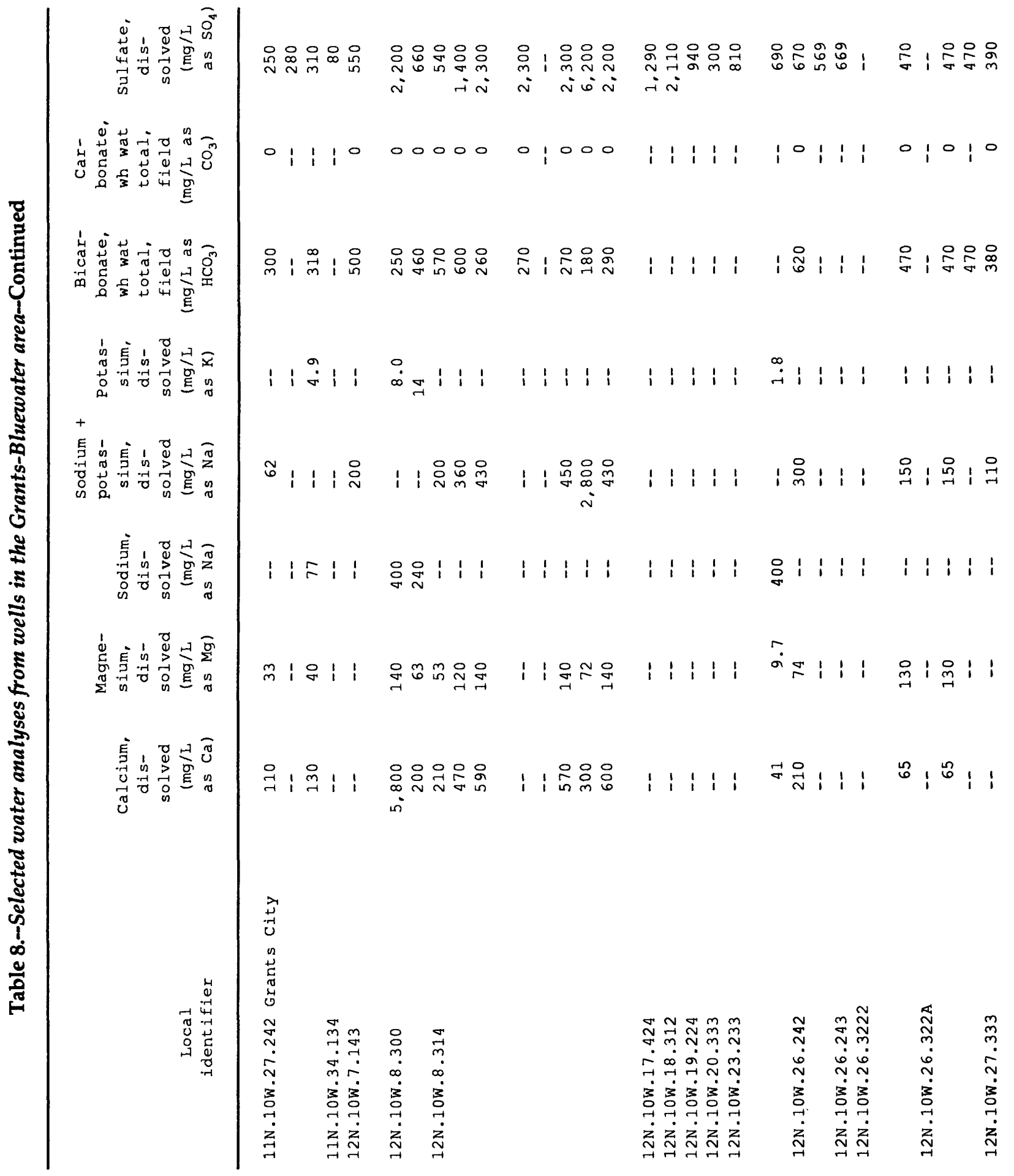




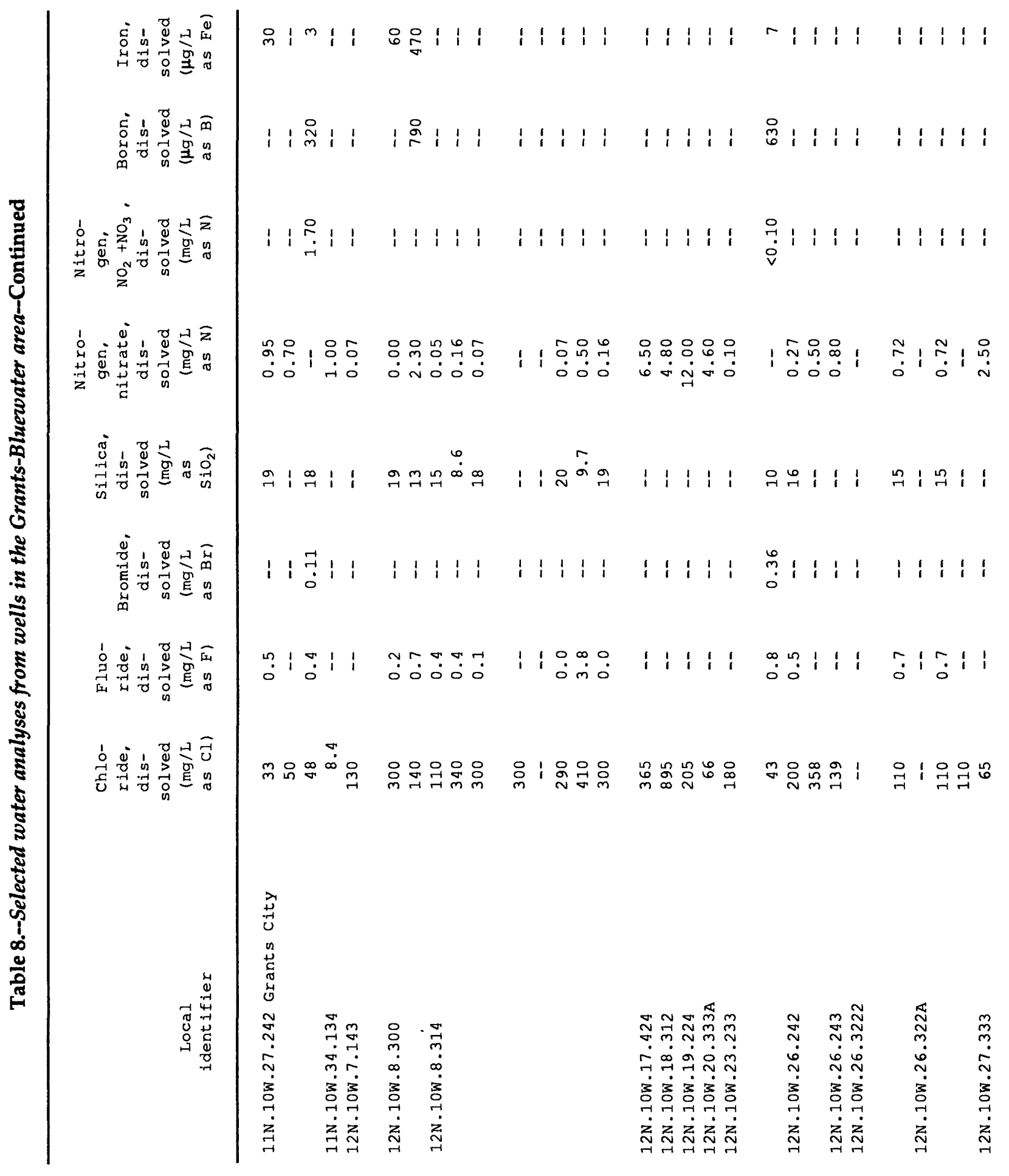




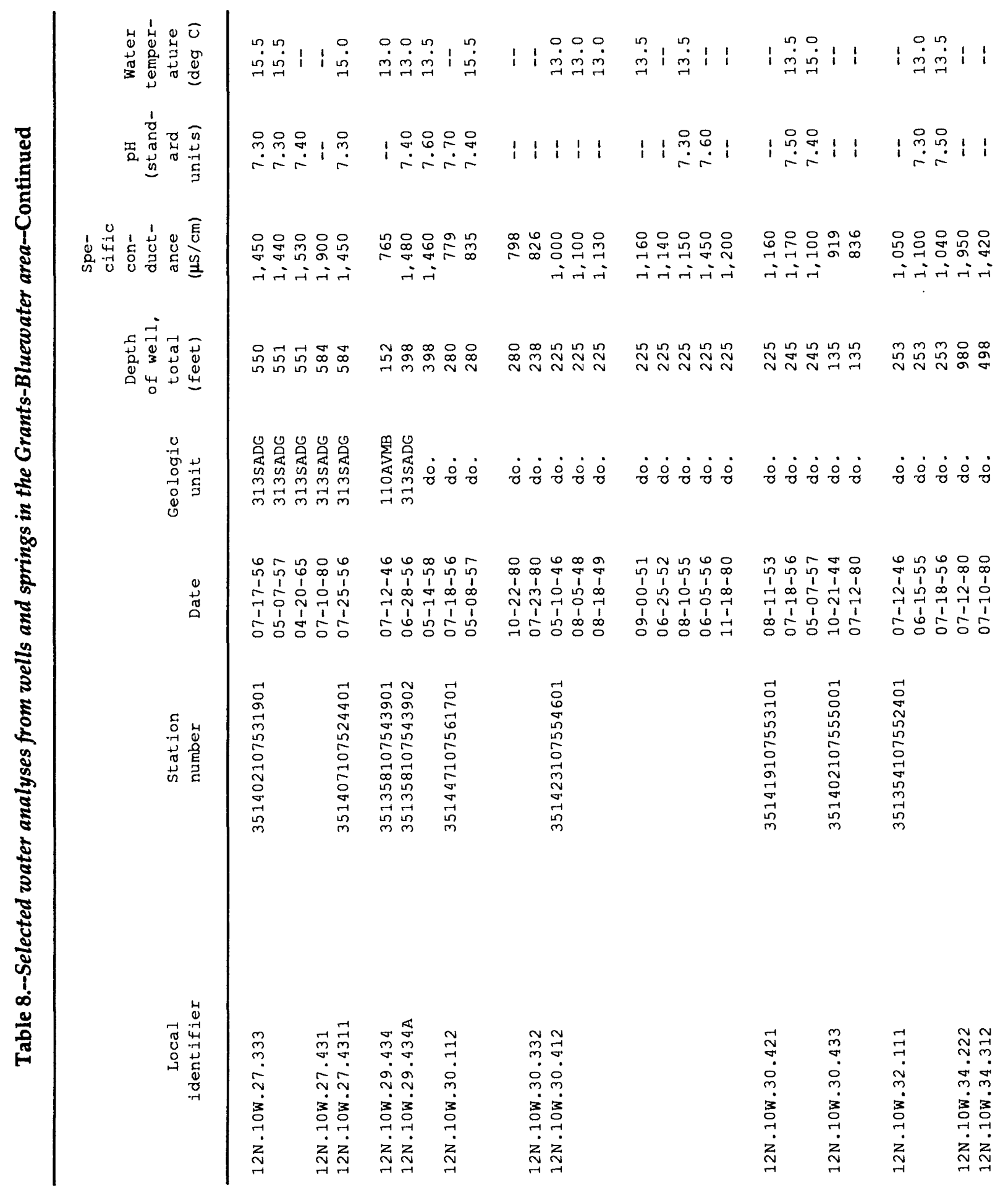




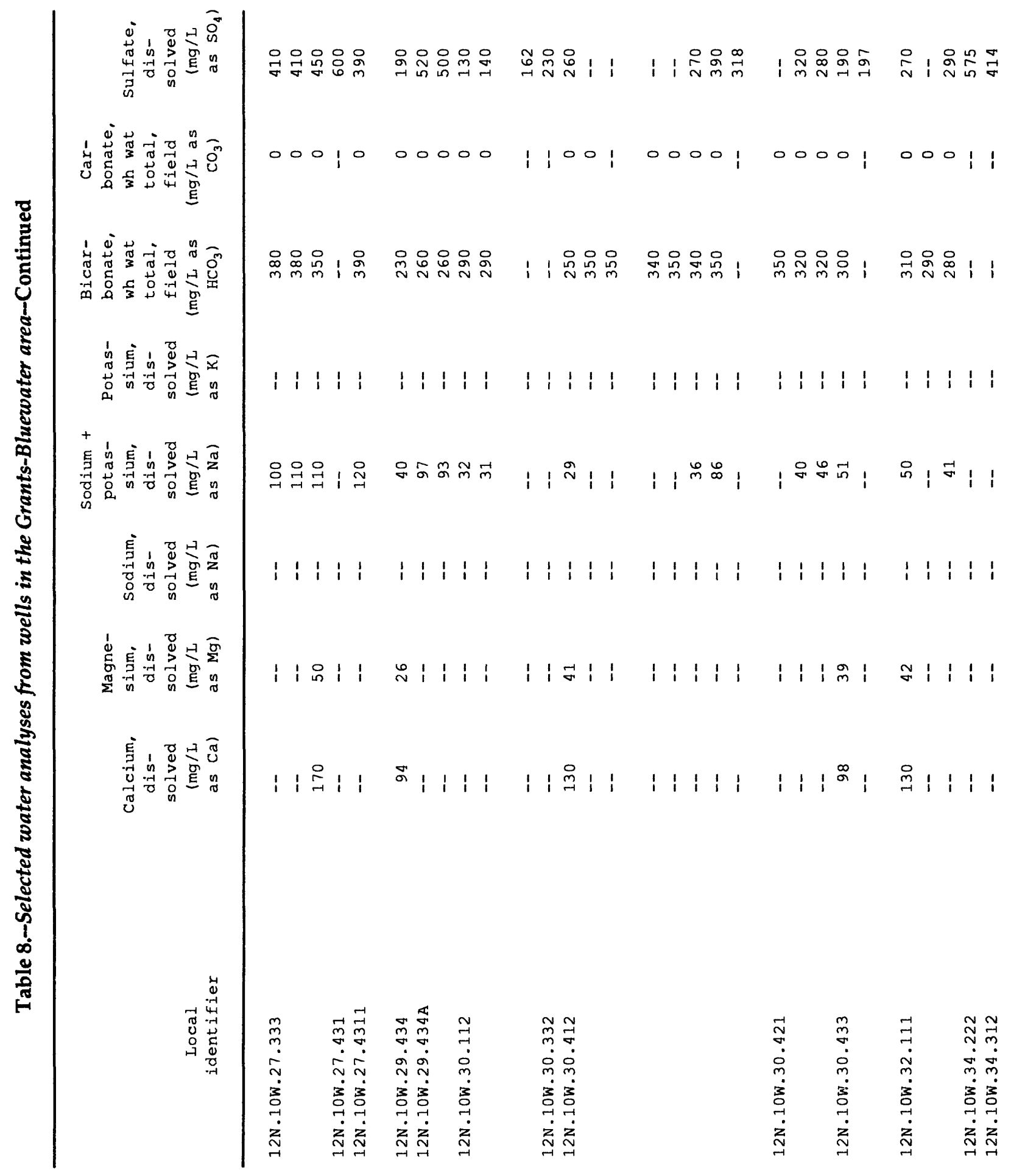




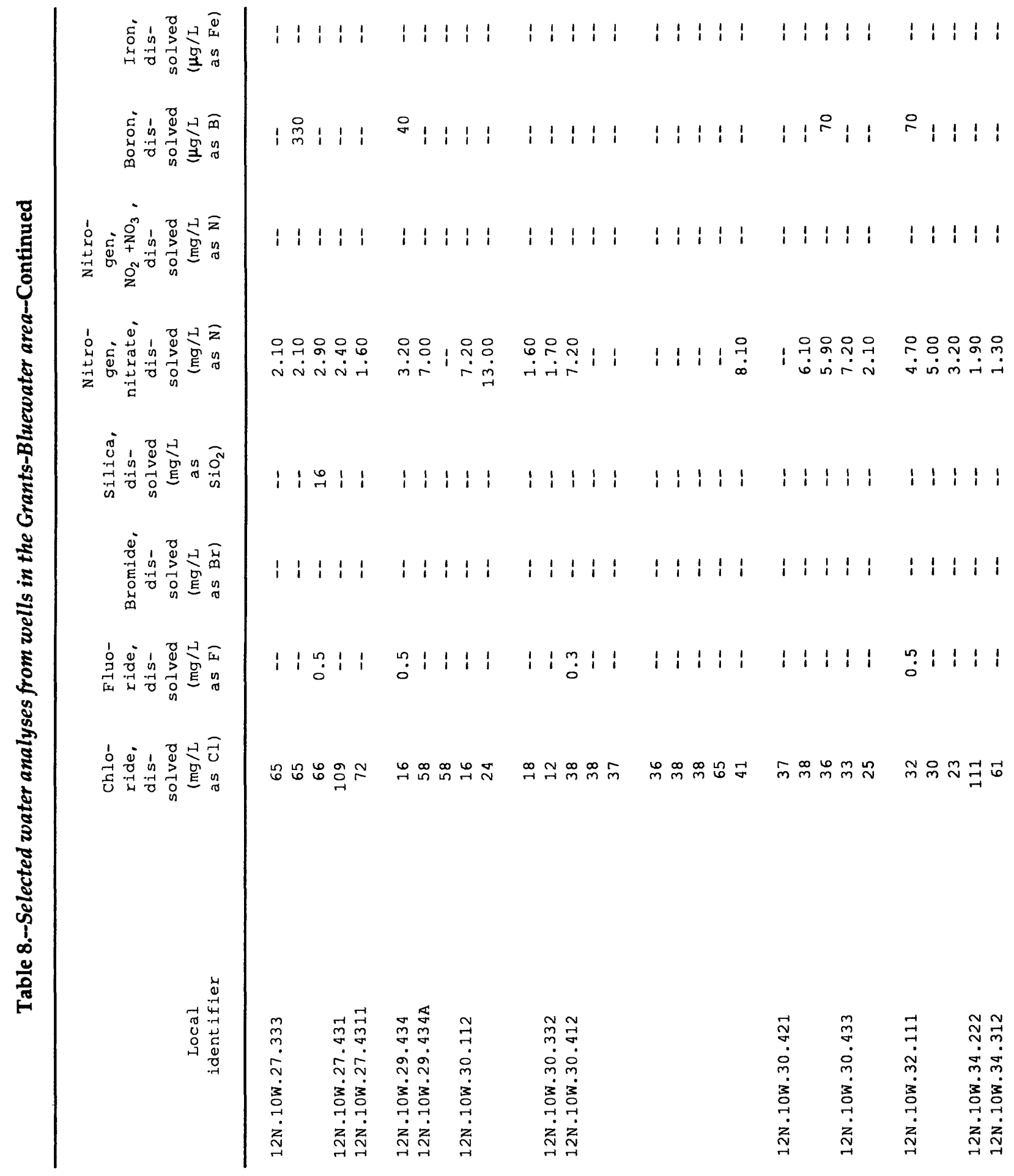




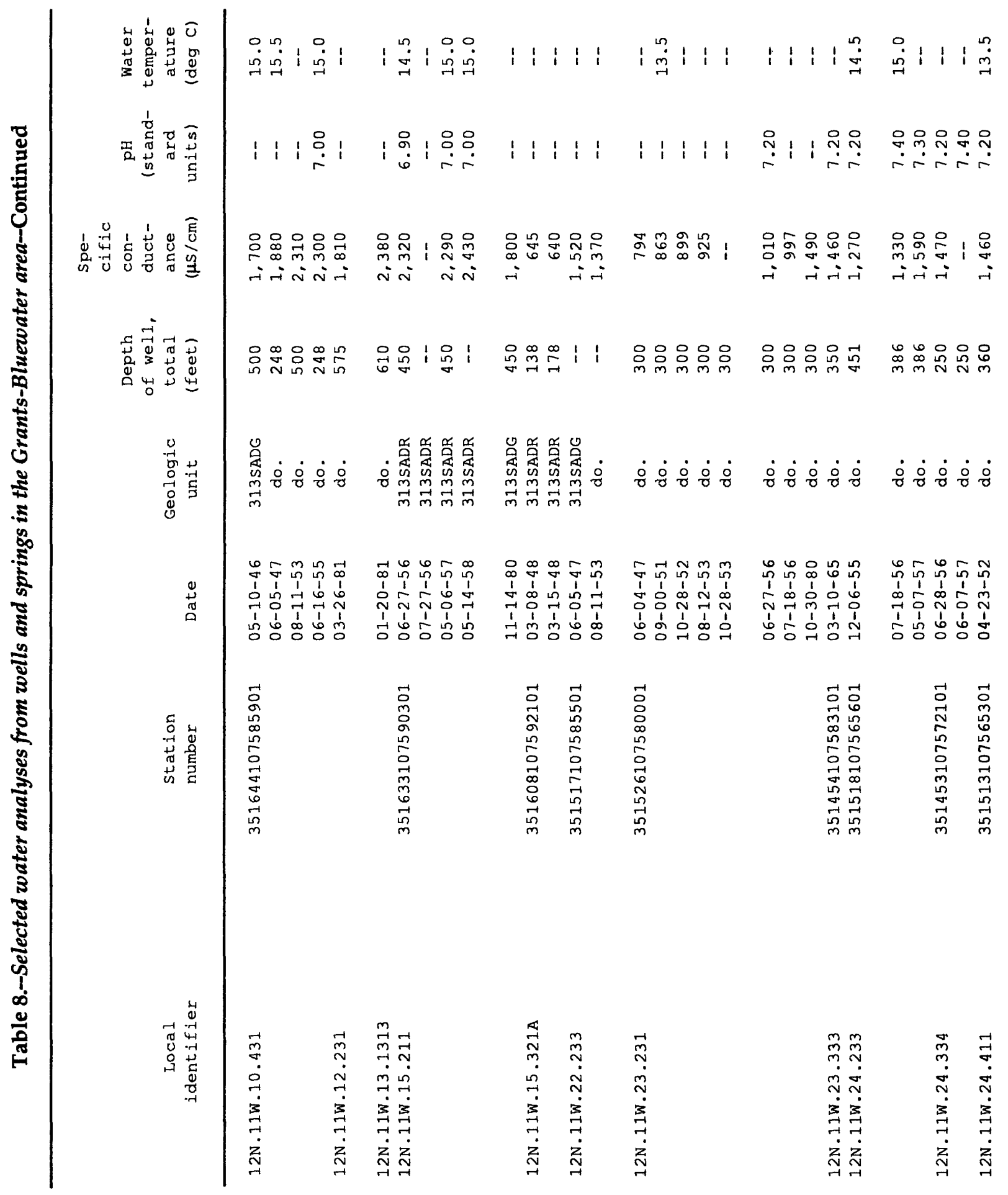




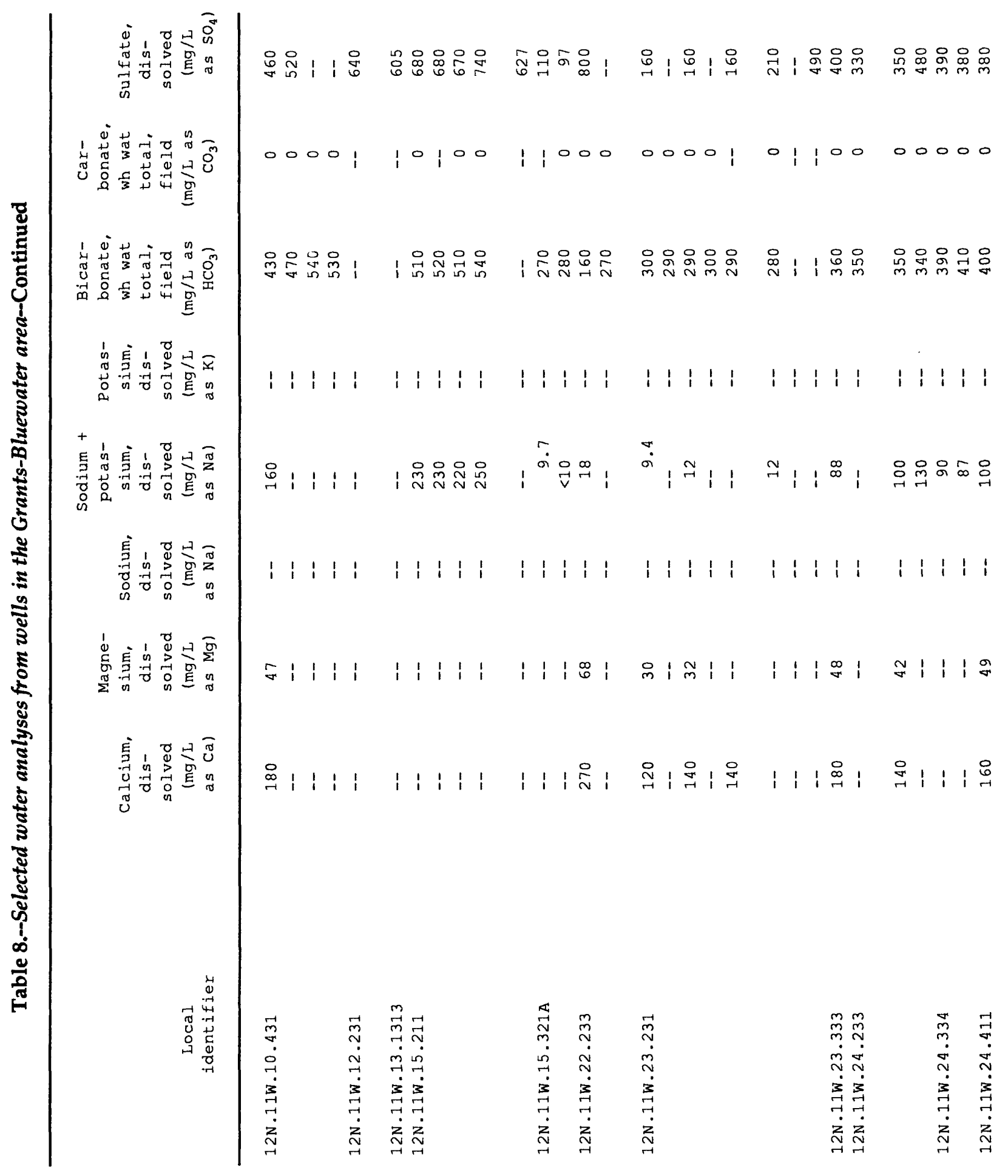




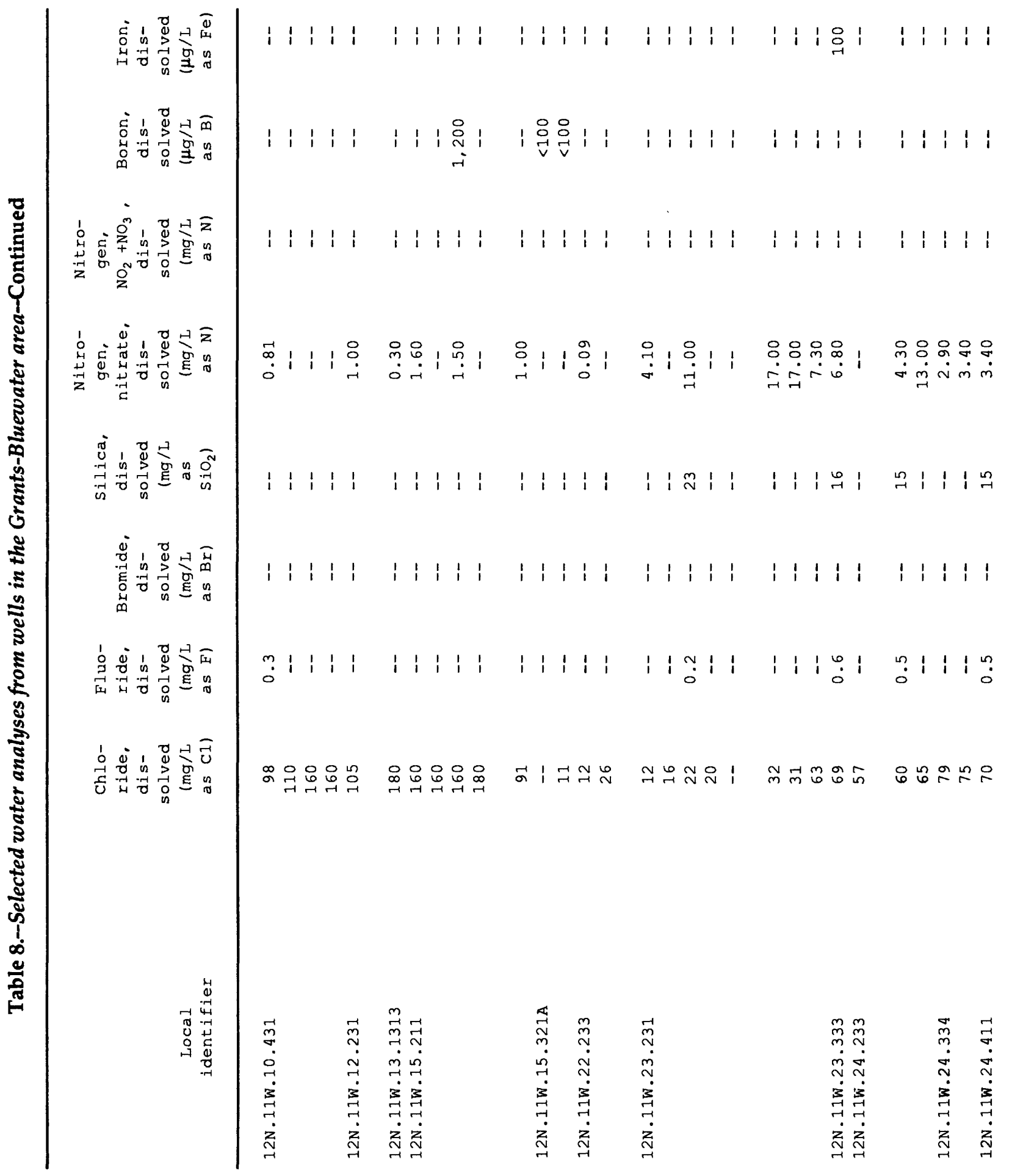




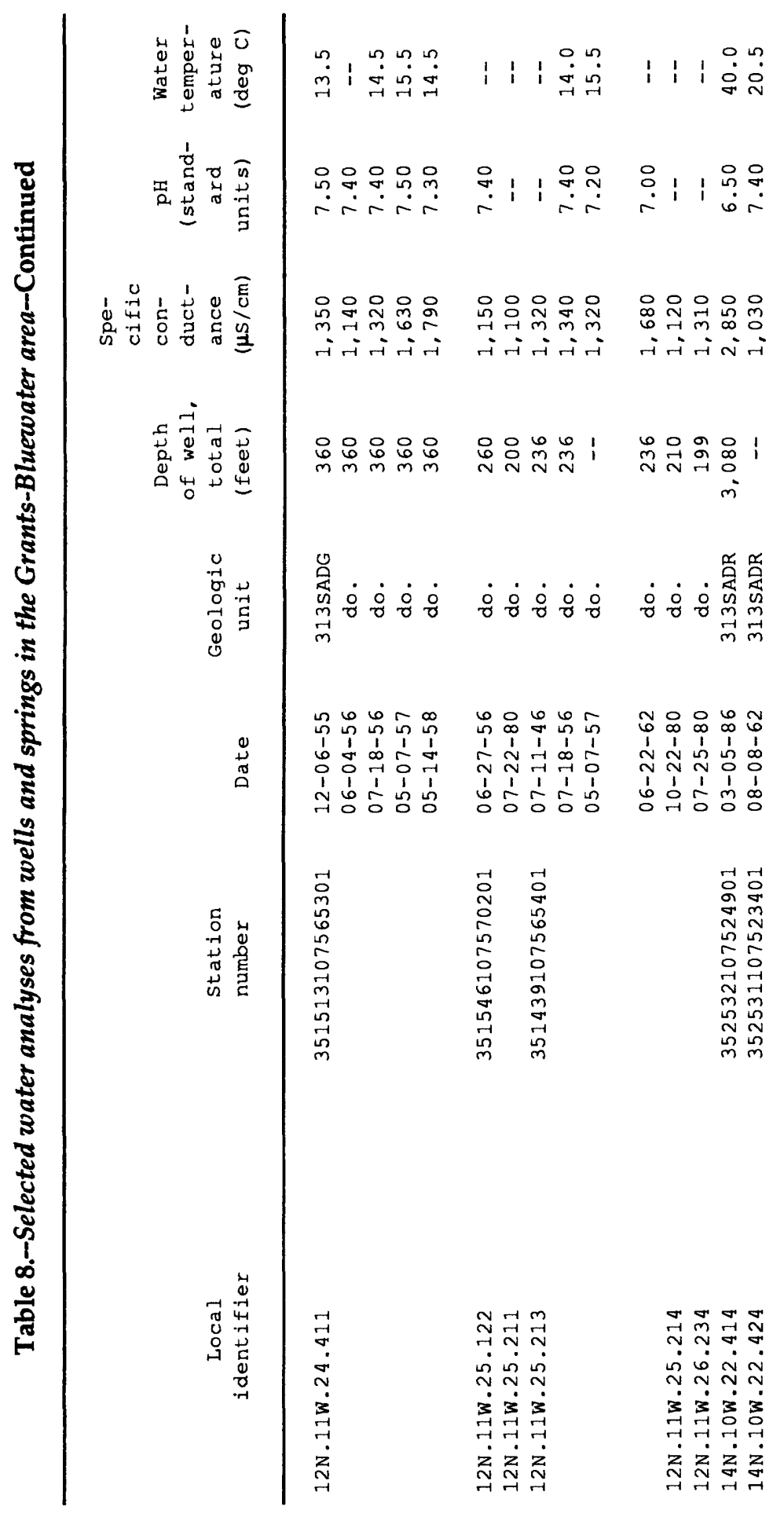




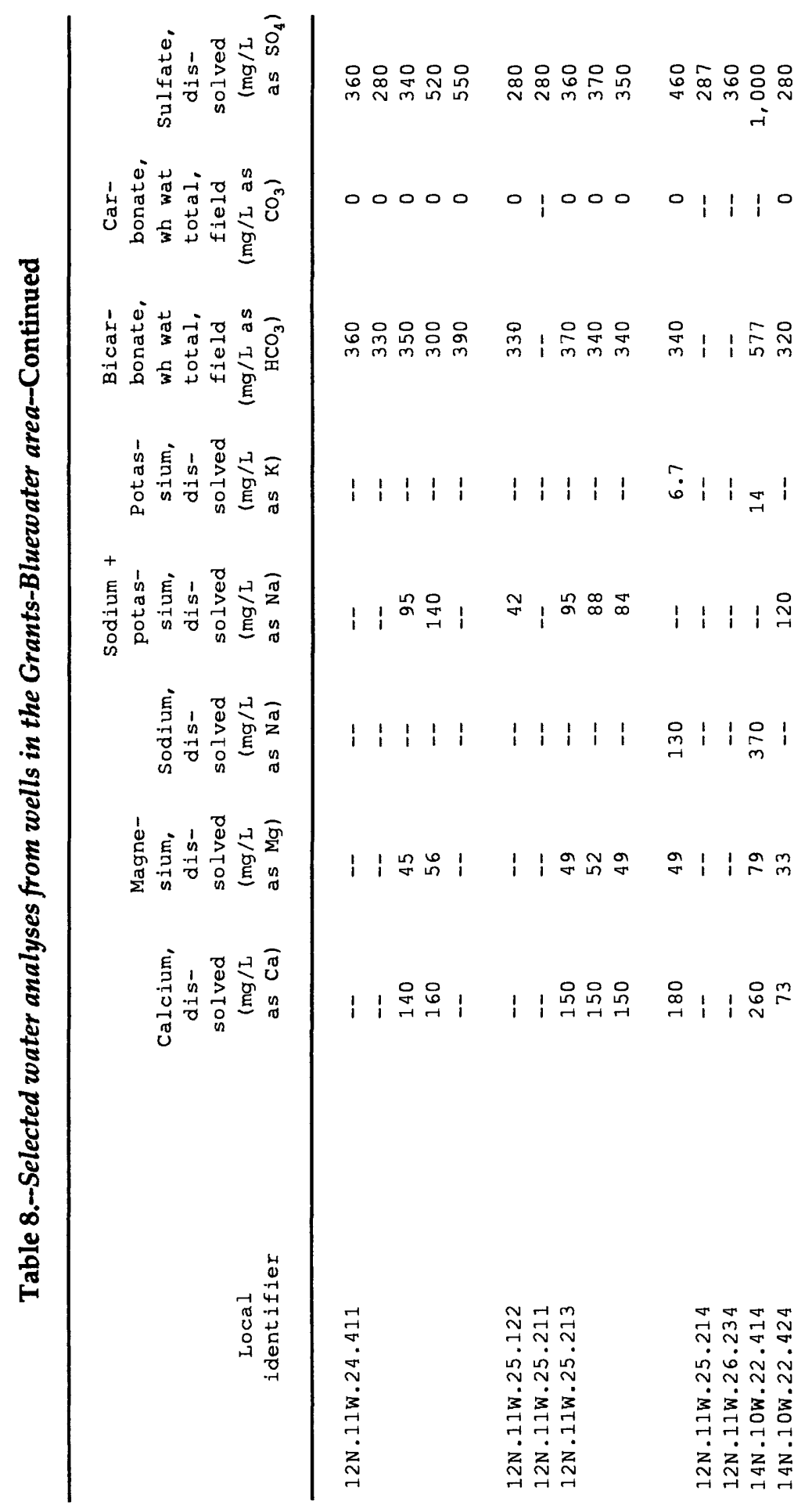




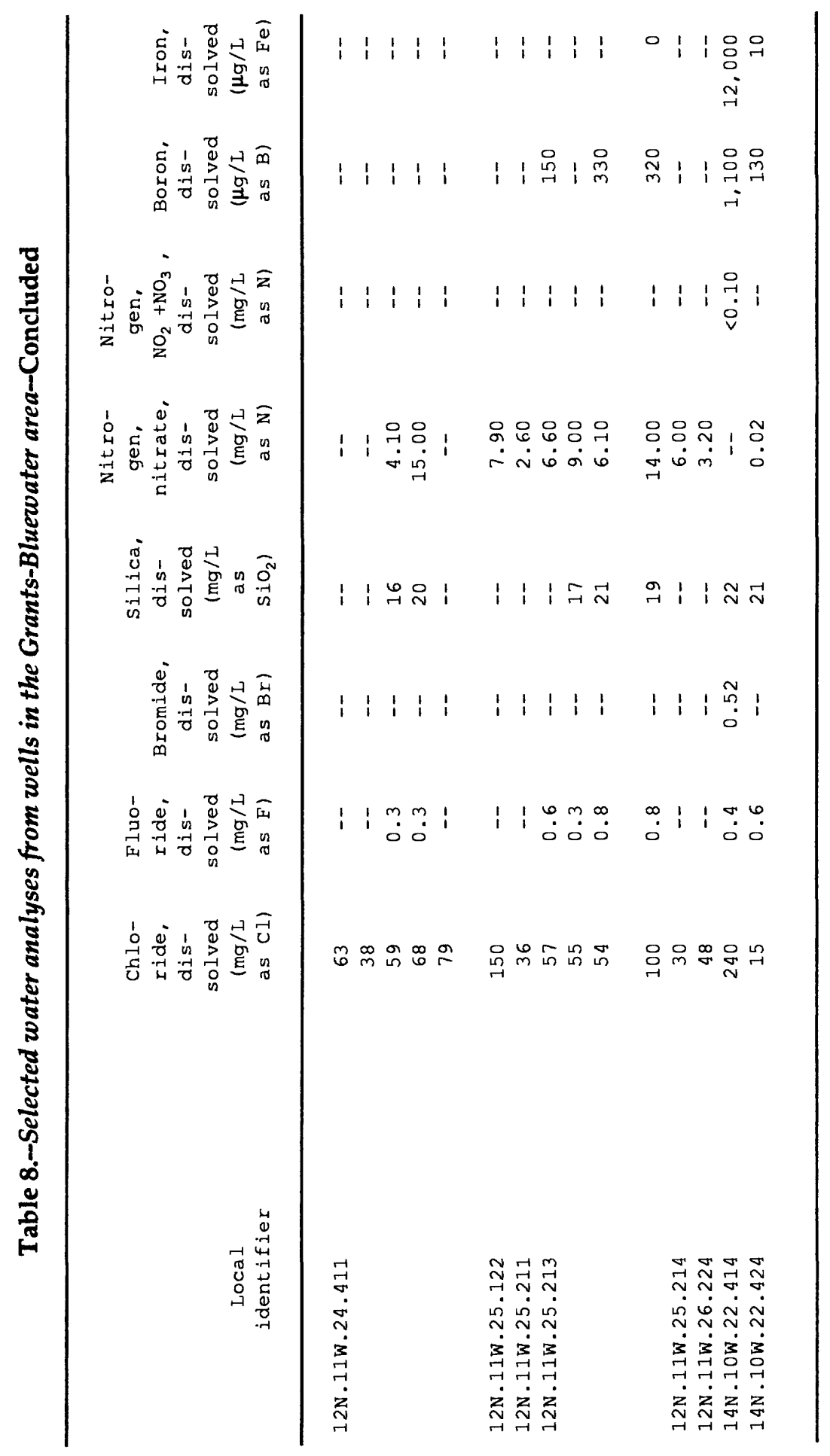




\section{EXPLANATION}

Local identifier: see text for explanation. Station number: the first six numbers are the latitude, the next seven numbers are the longitude, and the last two numbers are the sequence number. (B) after date indicates that analysis was done by the U.S. Bureau of Indian Affairs Laboratory-all other analyses done by U.S. Geological Survey. Geologic unit indicates source of water: blank, unknown; 000EXRV, extrusive rocks; 110AVMB, Quaternary and Tertiary alluvium; 112SNTF, Tertiary Santa Fe Group; 210MCDK, Cretaceous Mancos Shale and Dakota Sandstone, undivided; 210MNCS, Cretaceous Mancos Shale; 211DKOT,

Cretaceous Dakota Sandstone; 211GLLP, Cretaceous Gallup Sandstone; 211MVRD, Cretaceous Mesaverde Group; 221BLFF, Jurassic Bluff Sandstone (former usage; now Horse Mesa Member of Wanakah Formation); 221ENRD, Jurassic Entrada Sandstone; 221MRSN, Jurassic Morrison Formation; 221TDLT, Jurassic Todilto Limestone Member of Wanakah Formation; 231CHNL, Triassic Chinle Formation; 310YESO, Permian Yeso Formation; 313SADG, Permian San Andres Limestone and Glorieta Sandstone, undivided; 313SADR, Permian San Andres Limestone; 318ABOU, Permian Abo Sandstone, upper unit; 325MDER, Pennsylvanian Madera Limestone; 326MGDL, Pennsylvanian Magdalena Group. $\mathrm{SP}$, spring; GW, ground water; $\mathrm{SW}$, surface water; $\mathrm{uS} / \mathrm{cm}$, microsiemens per centimeter at 25 degrees Celsius; deg C, degrees Celsius measured onsite; $\mathrm{mg} / \mathrm{L}$, milligrams per liter; ug/L, micrograms per liter; bicarbonate or carbonate wh wat total field, bicarbonate or carbonate whole water sample, not filtered, done onsite;

* indicates bicarbonate concentration calculated from laboratory alkalinity concentration; E, estimated; <, less than; --, no data. 


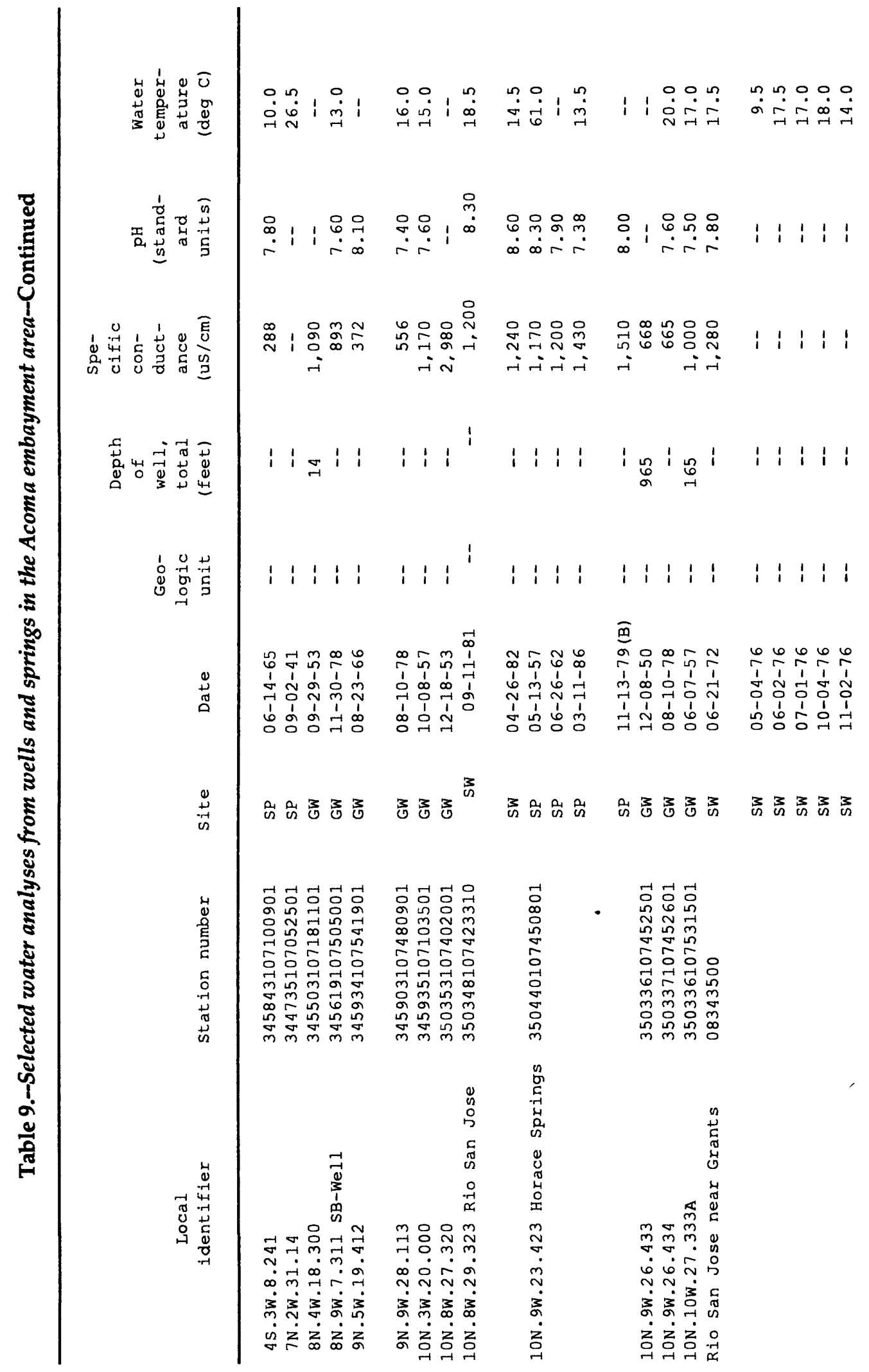




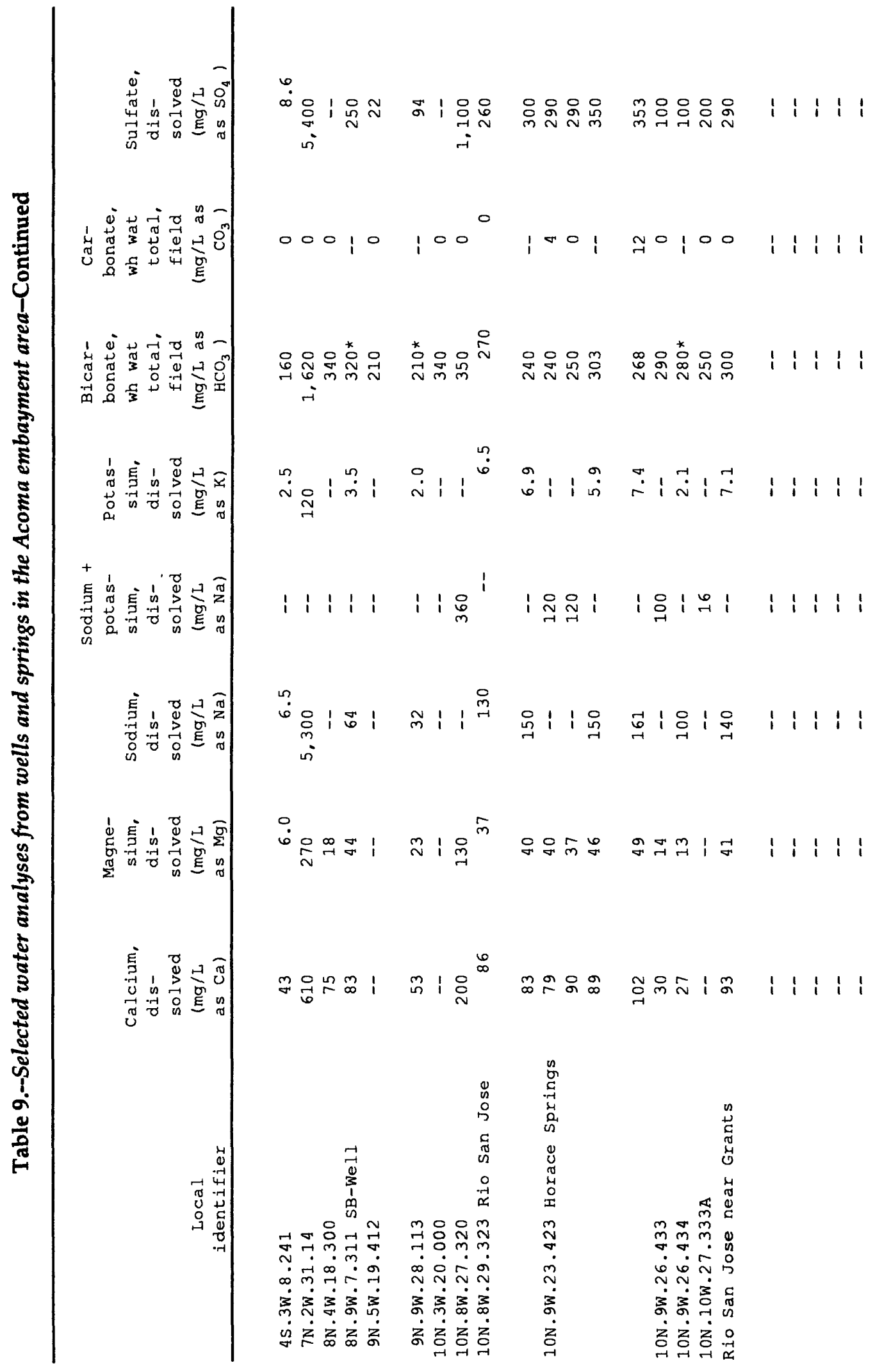




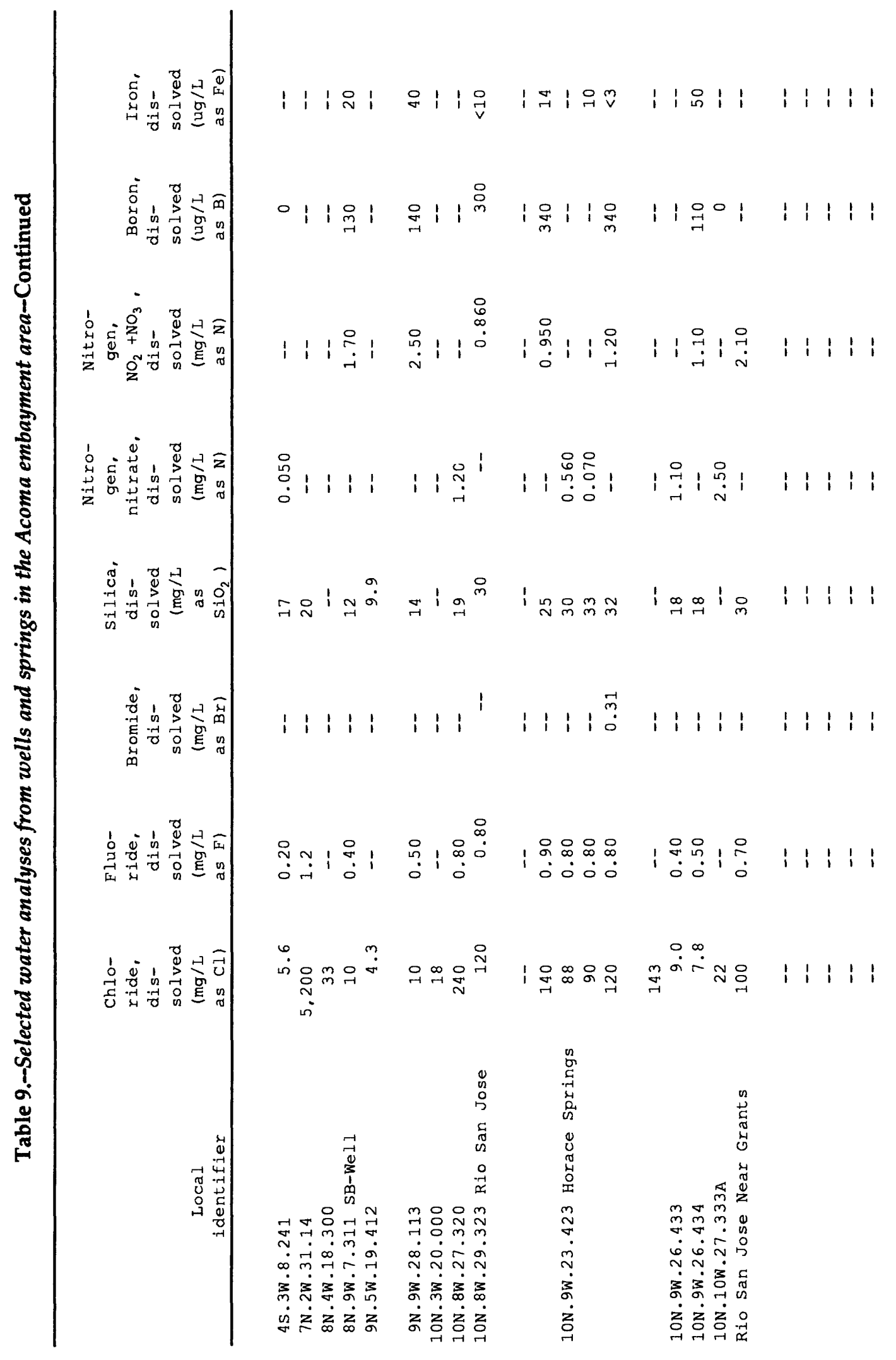




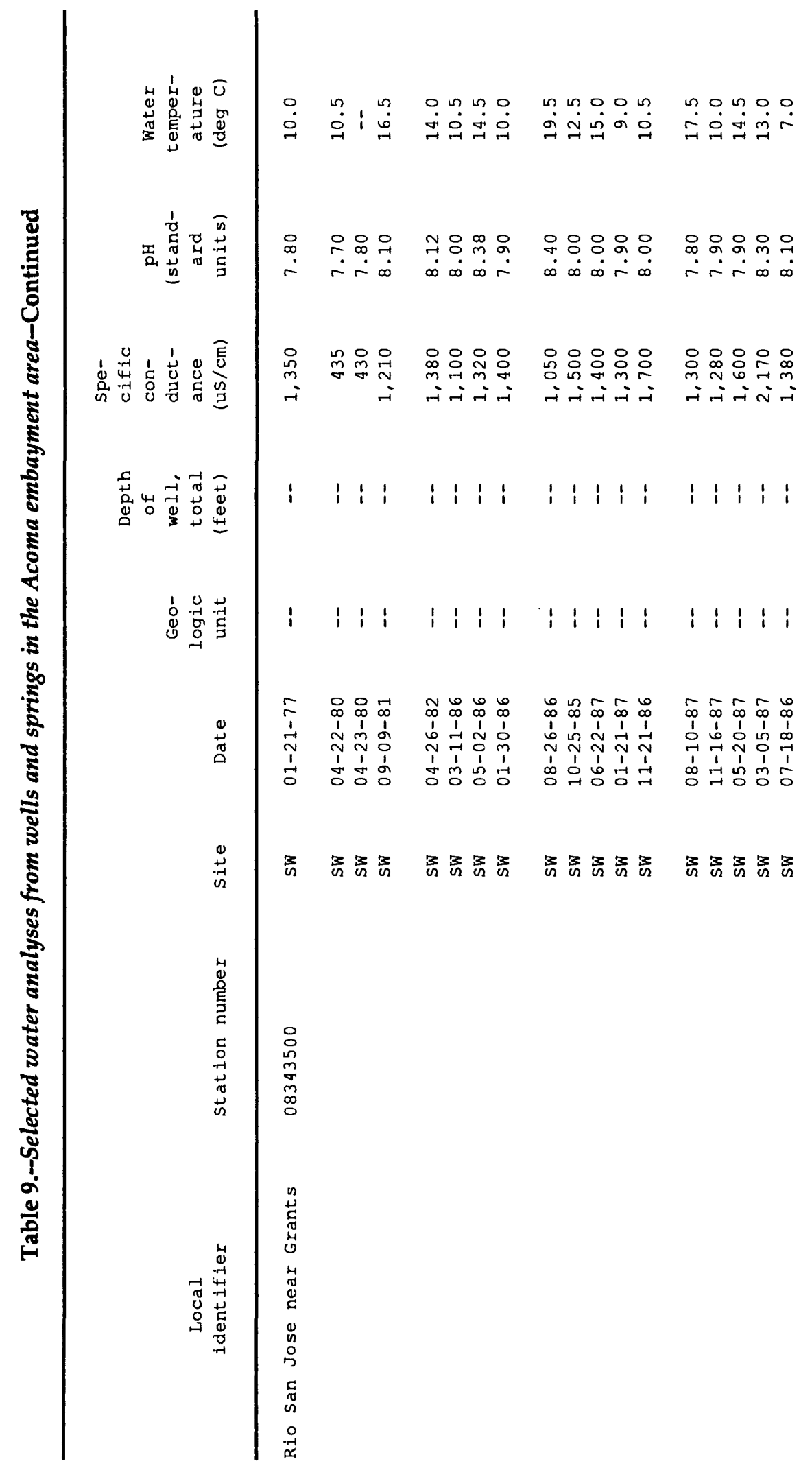




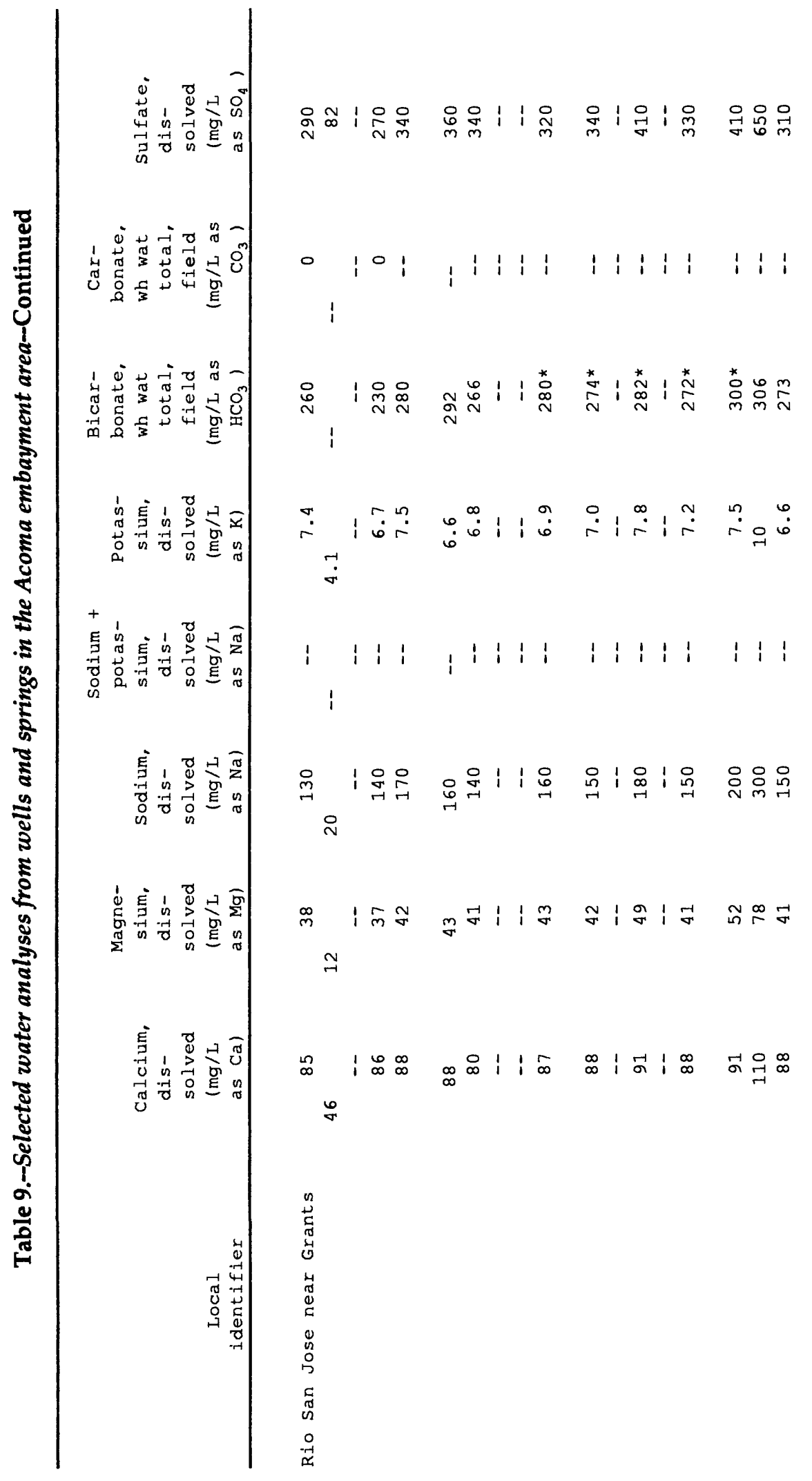




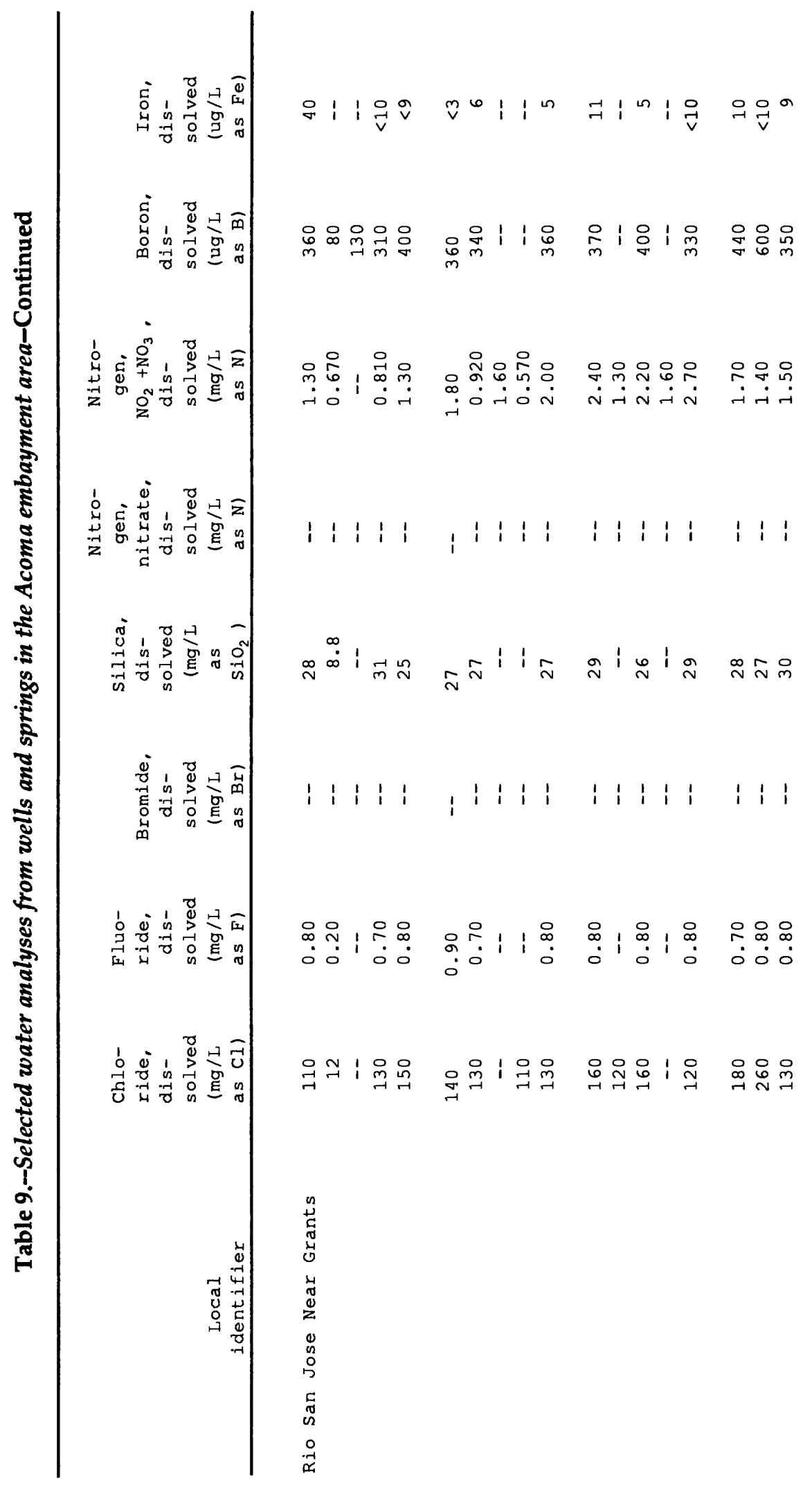




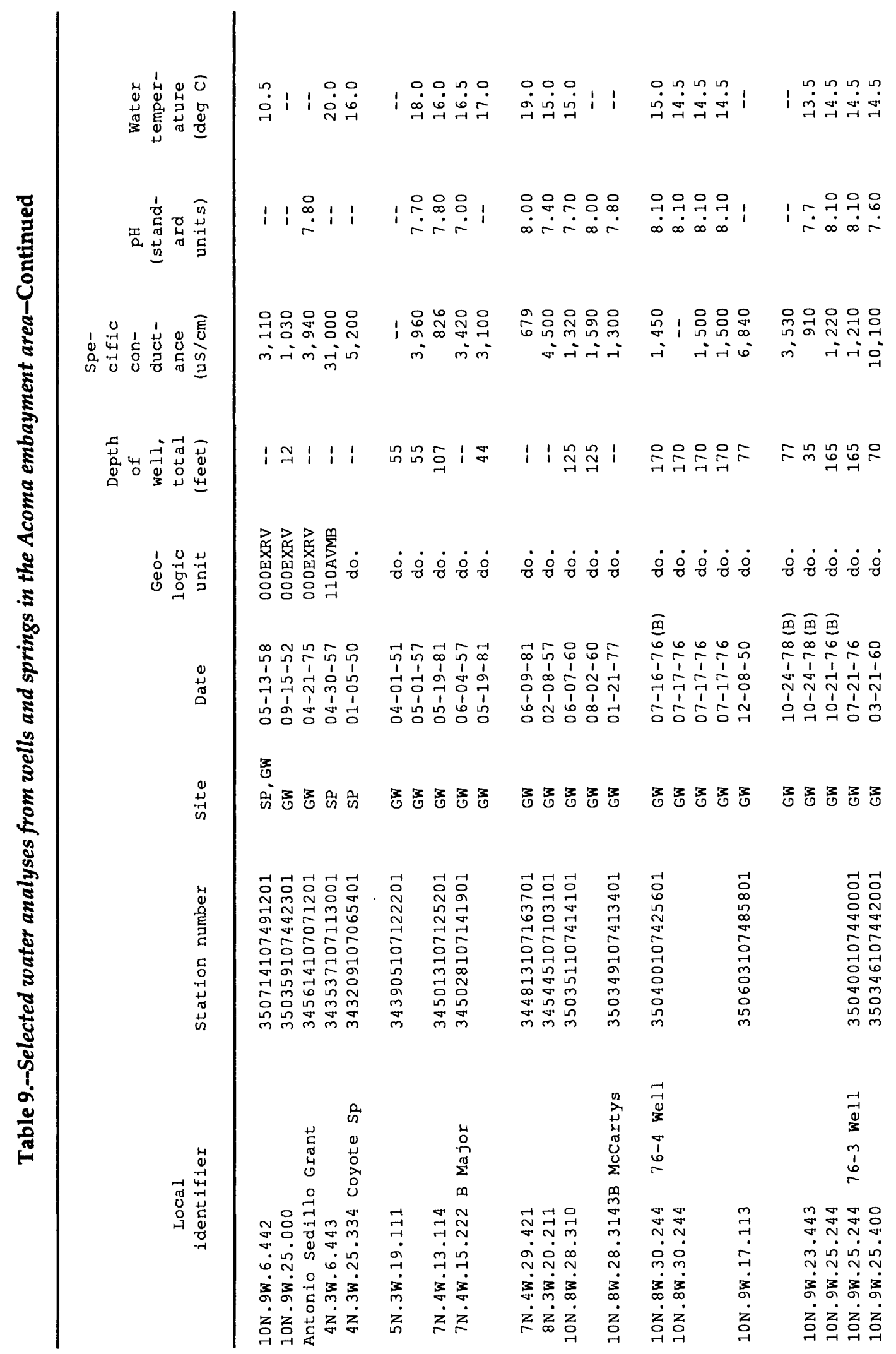




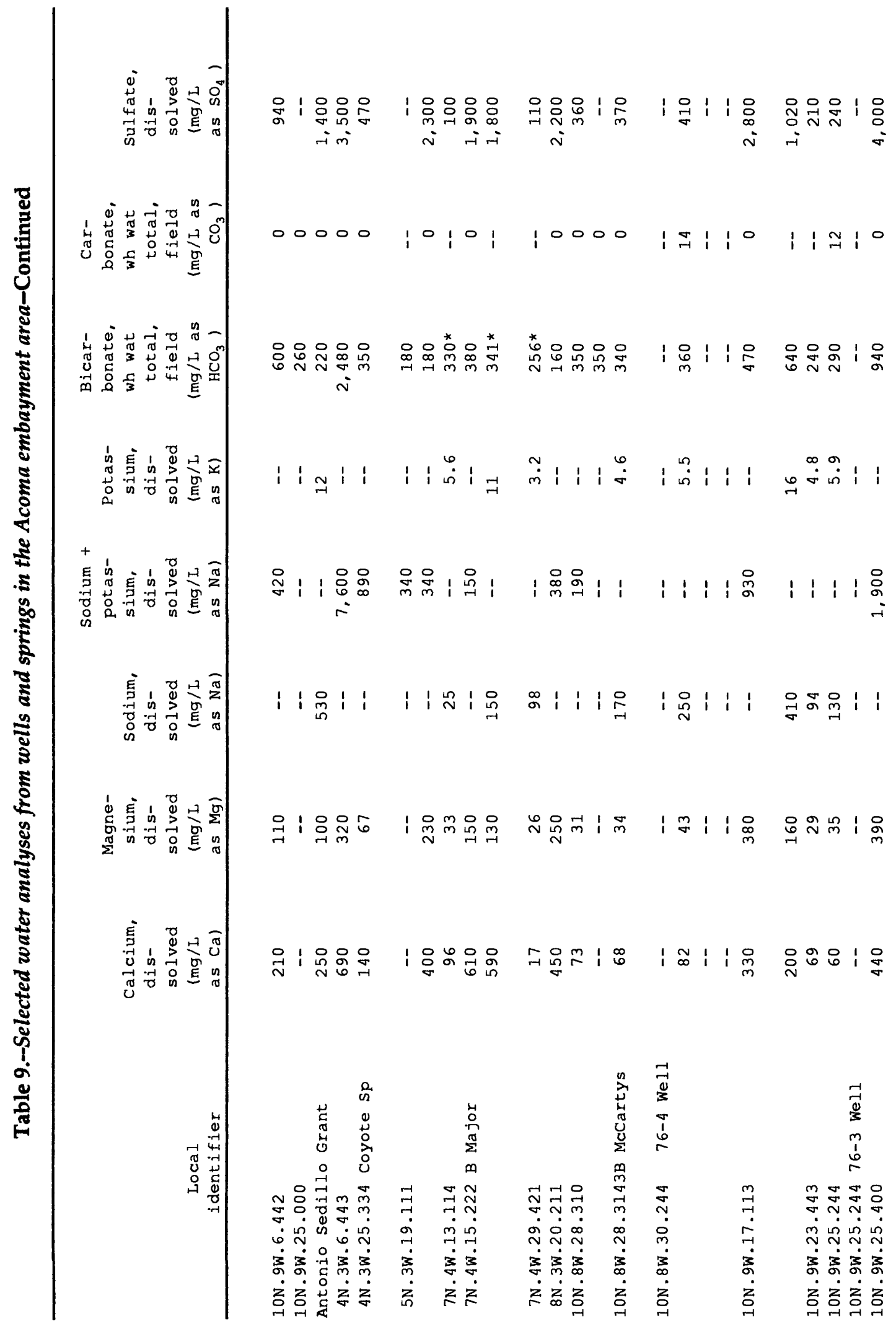




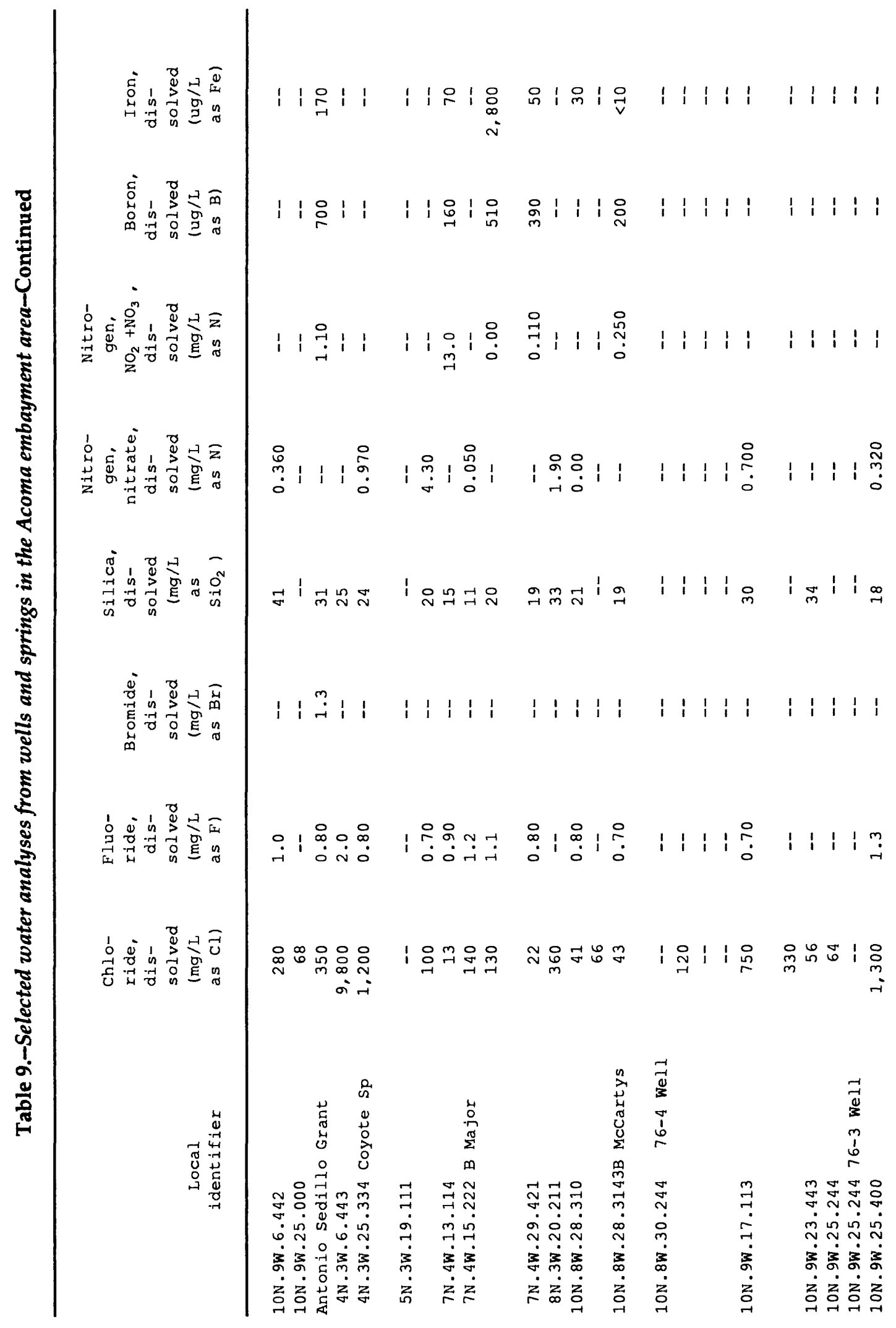




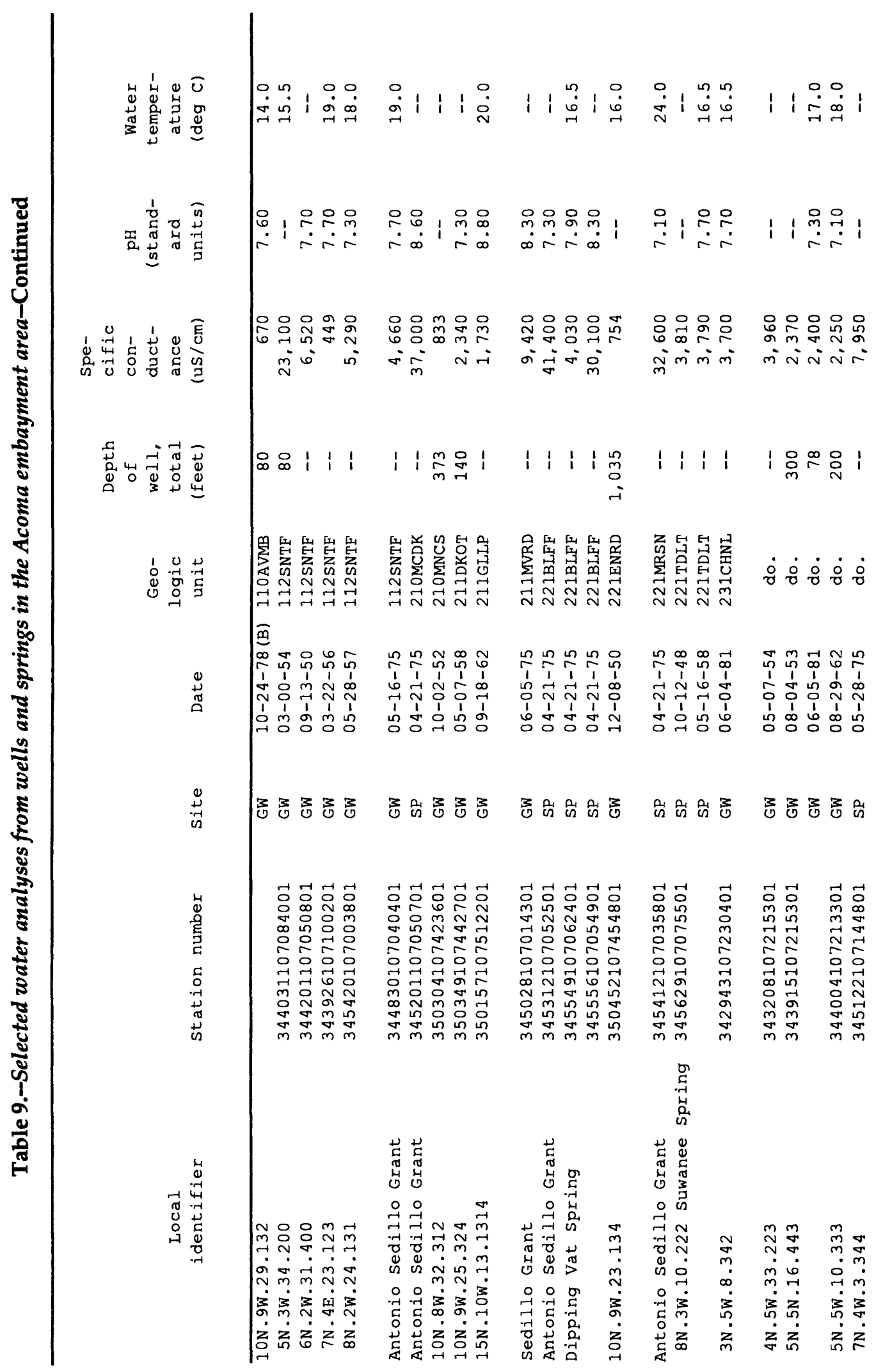




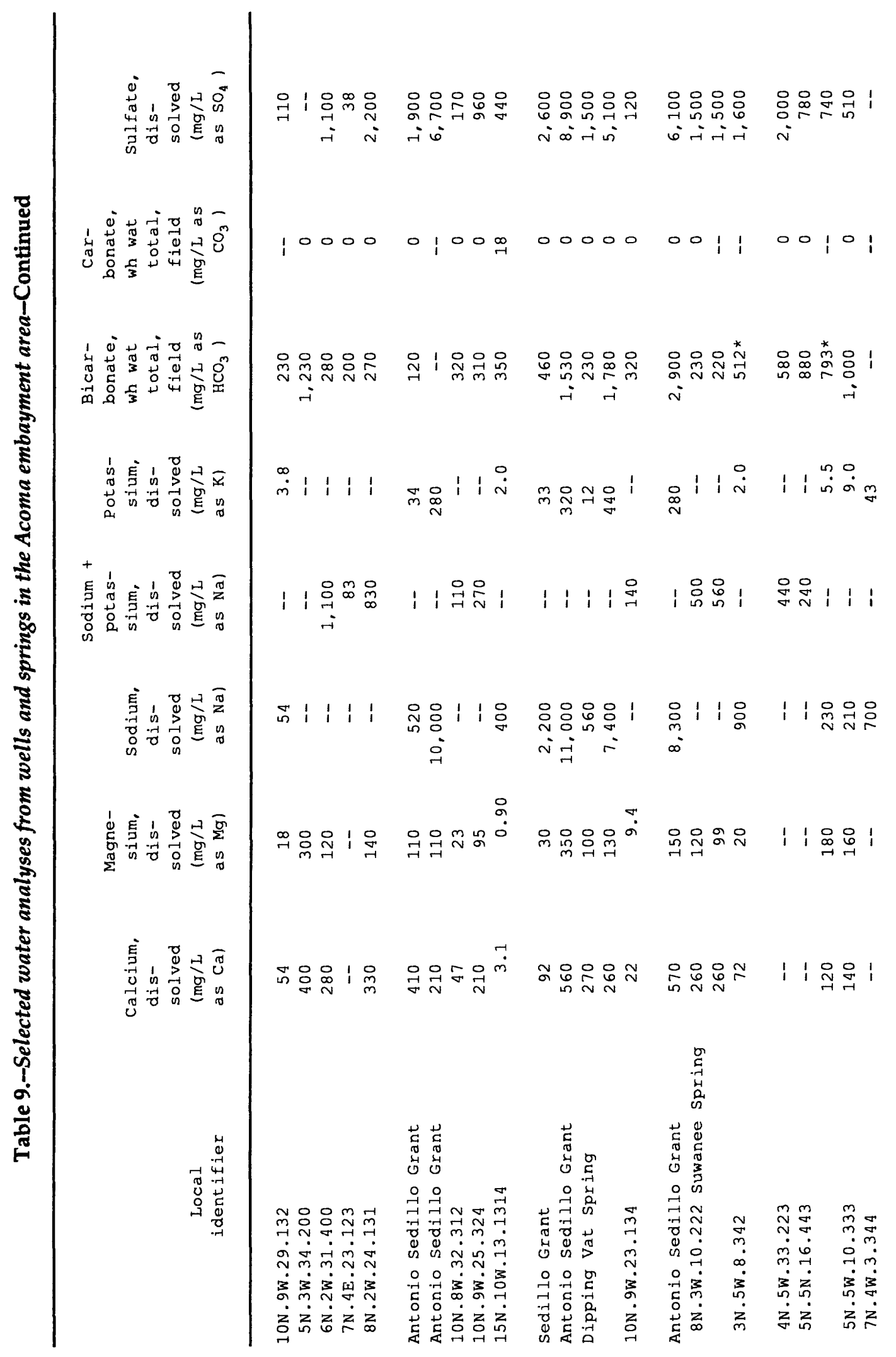




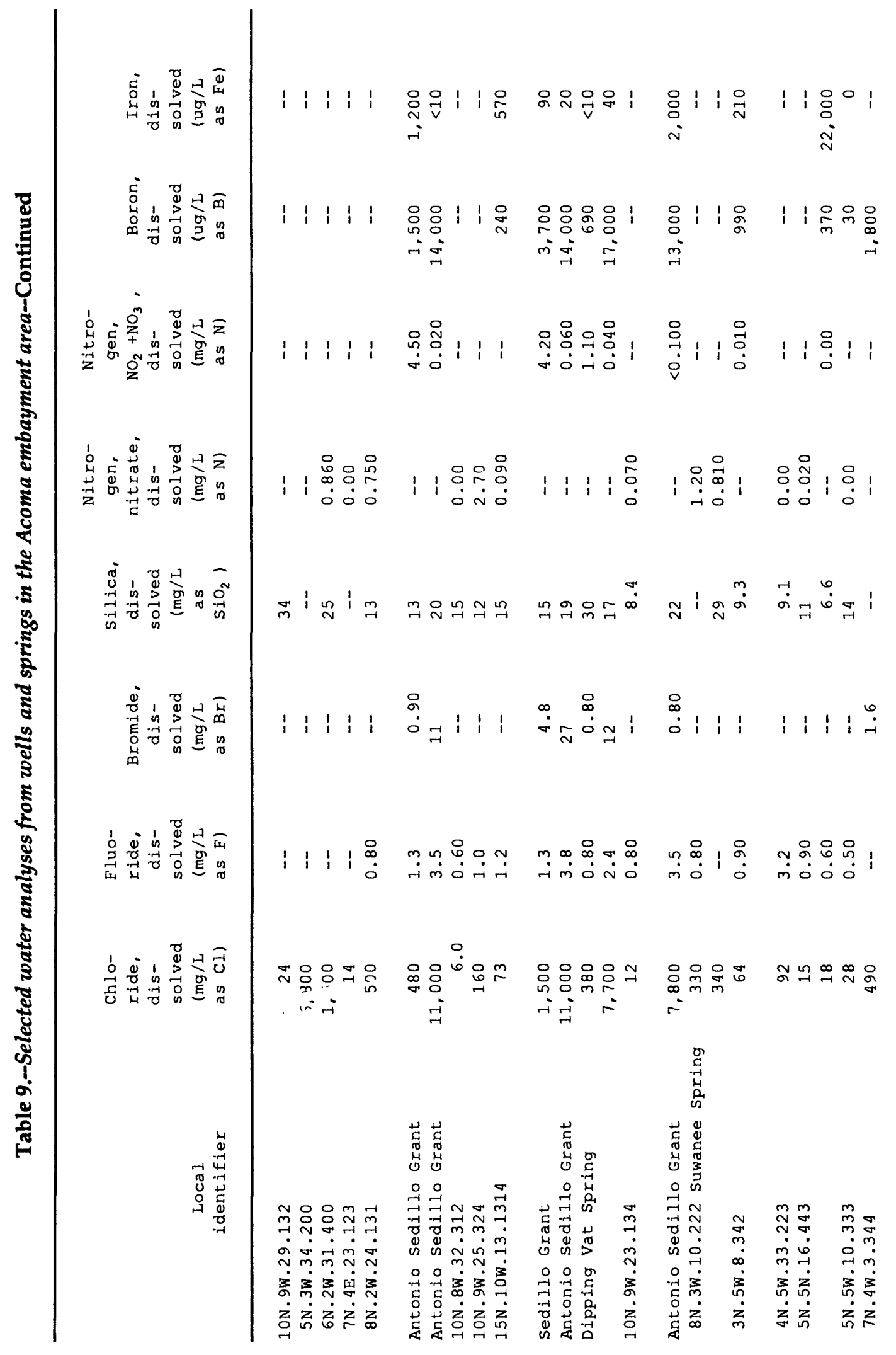




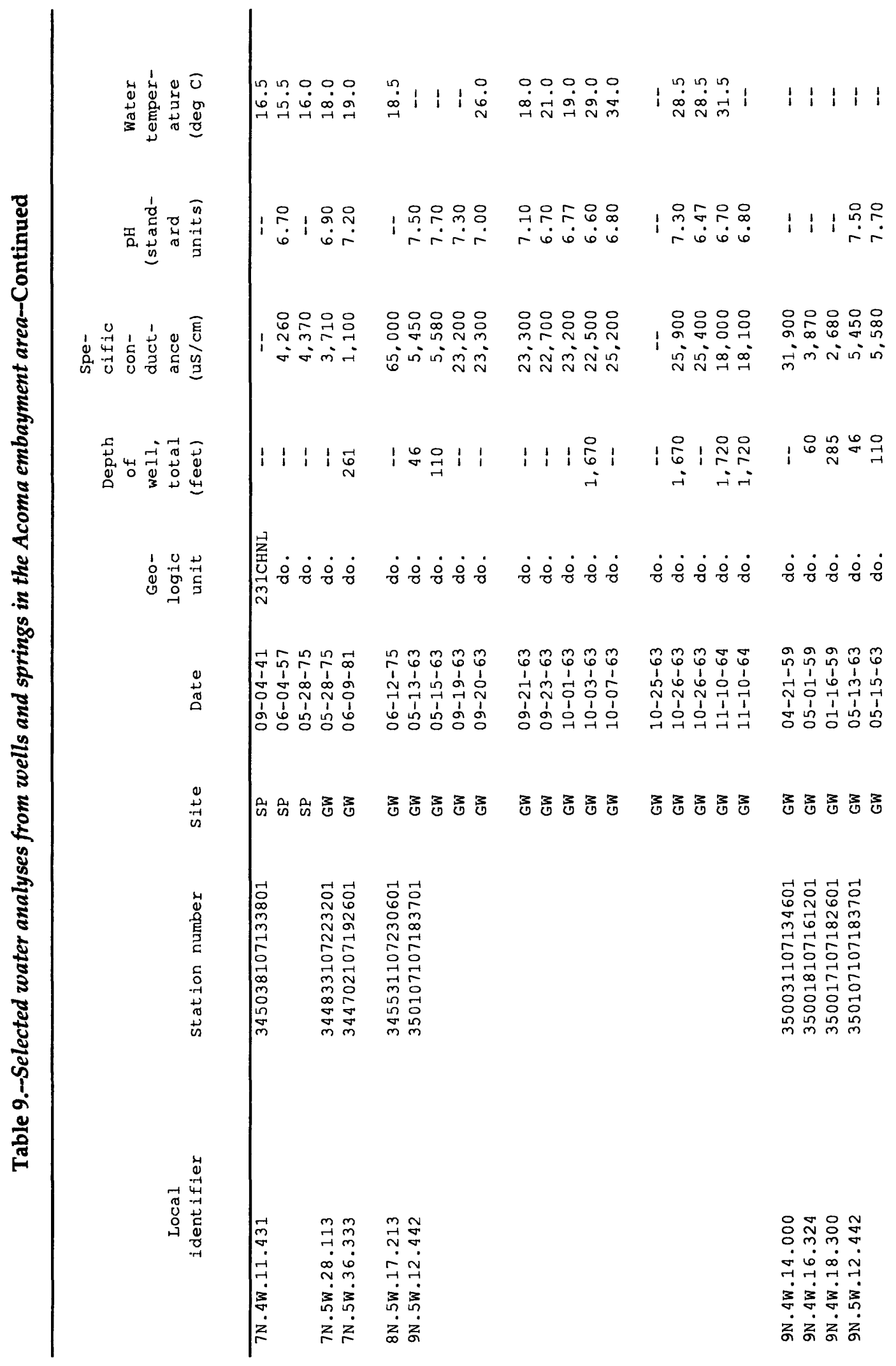




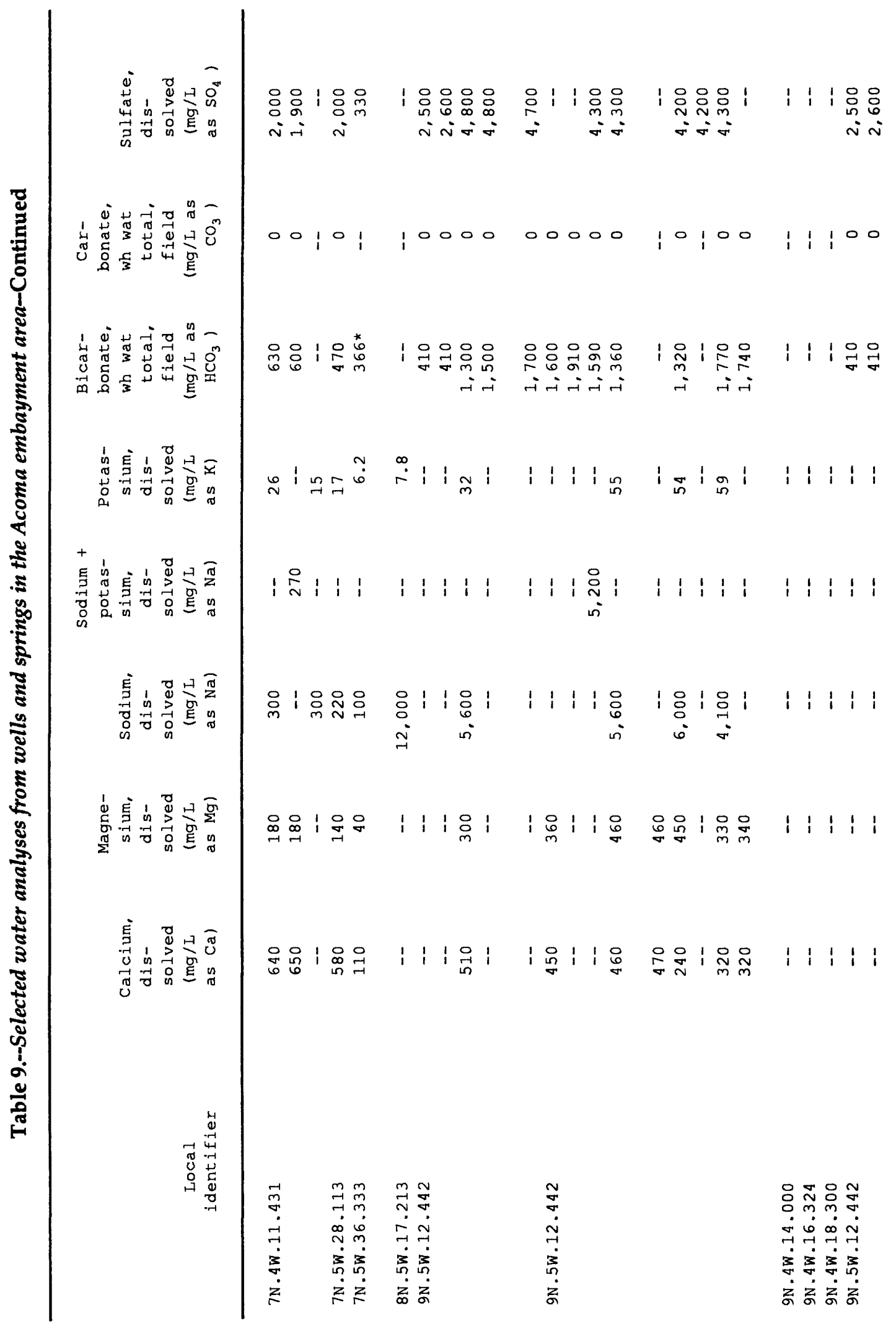




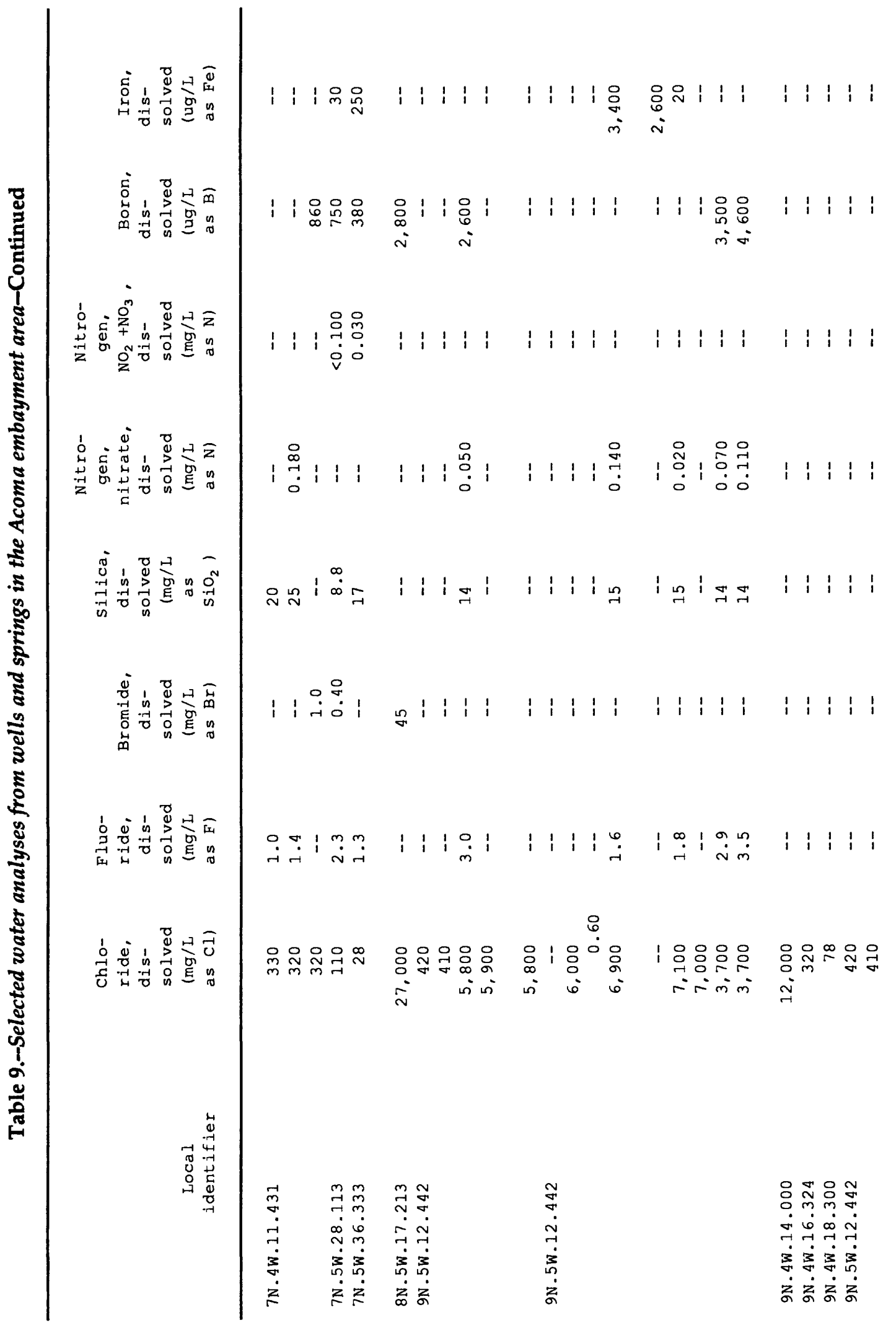




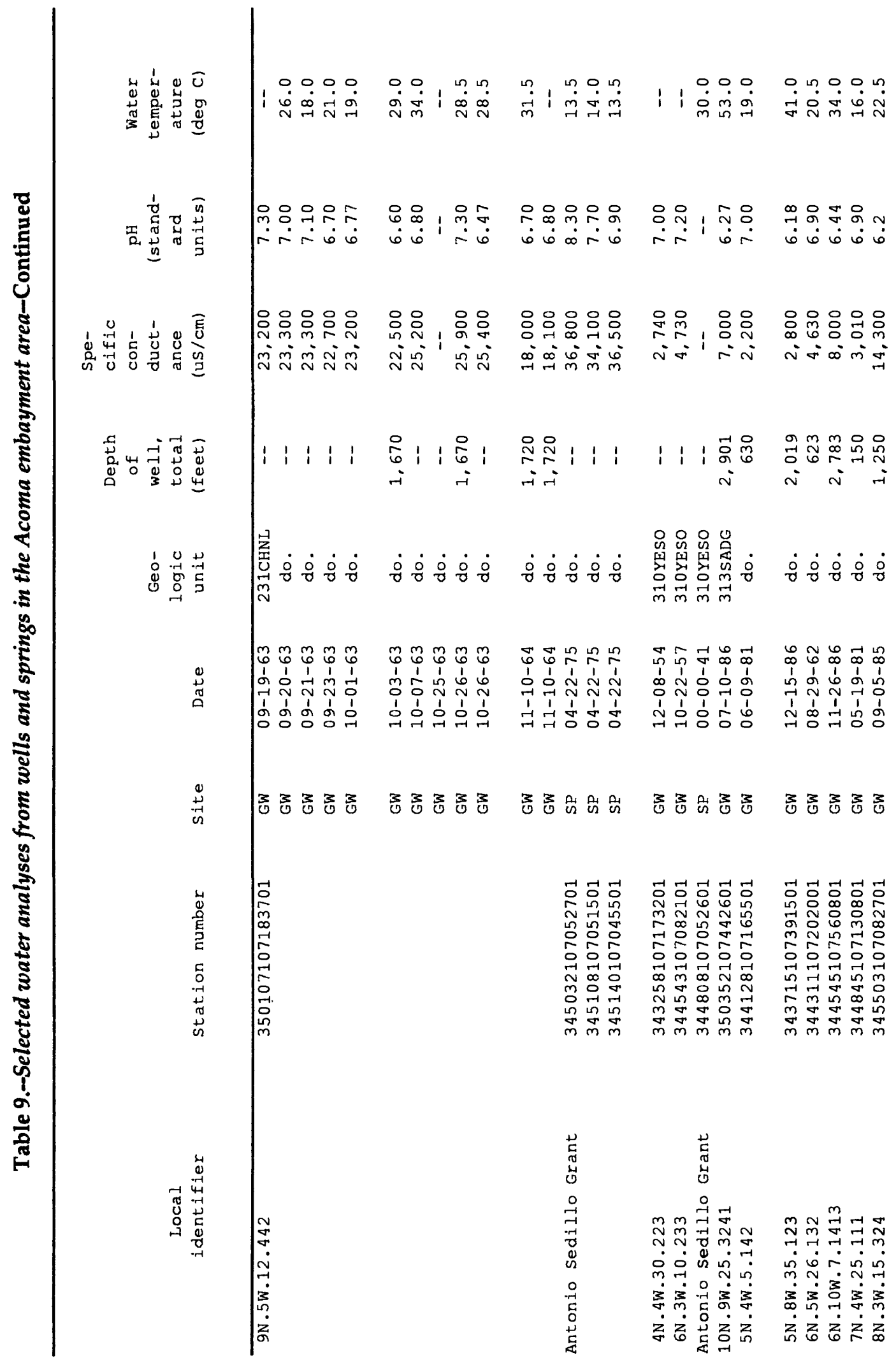




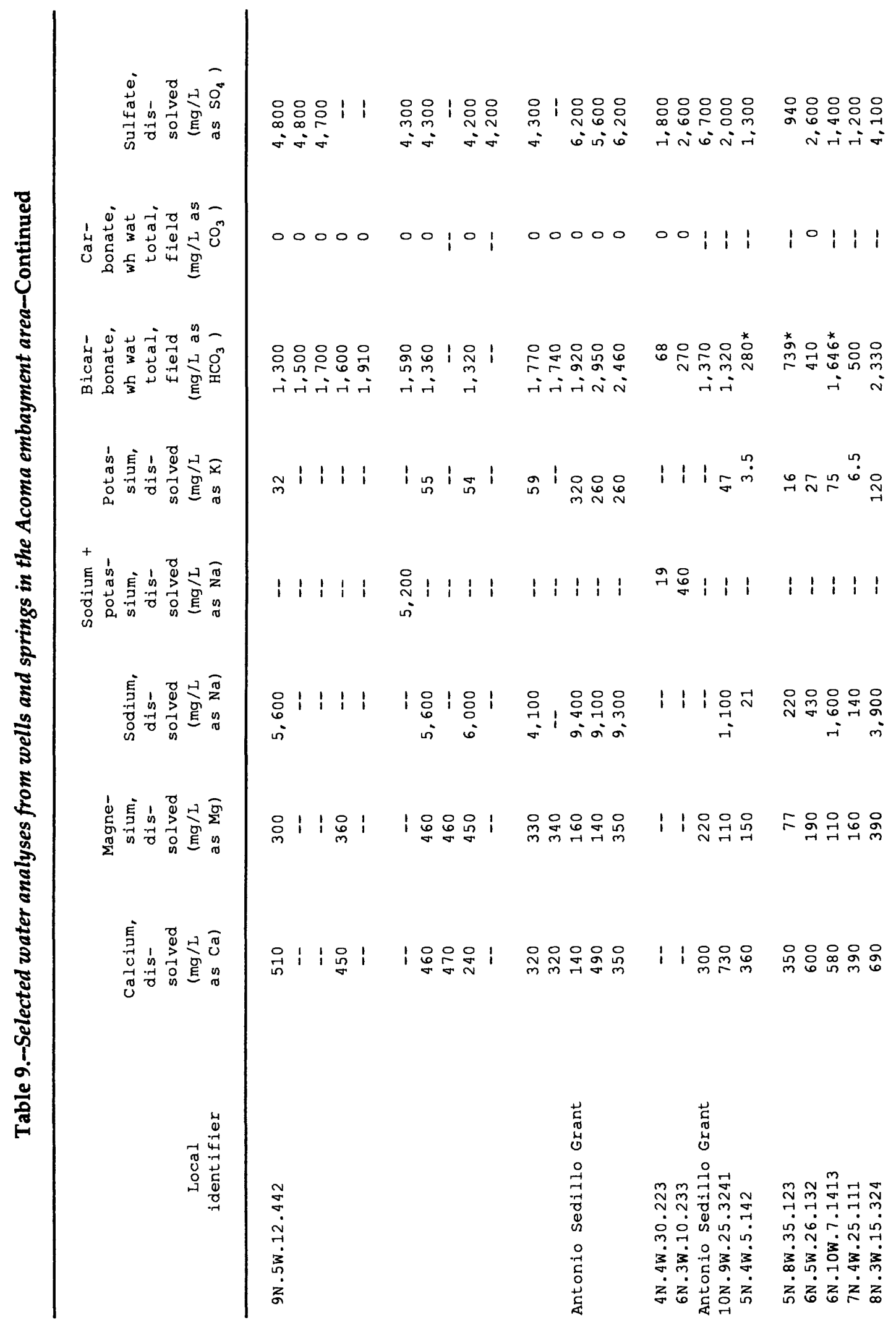




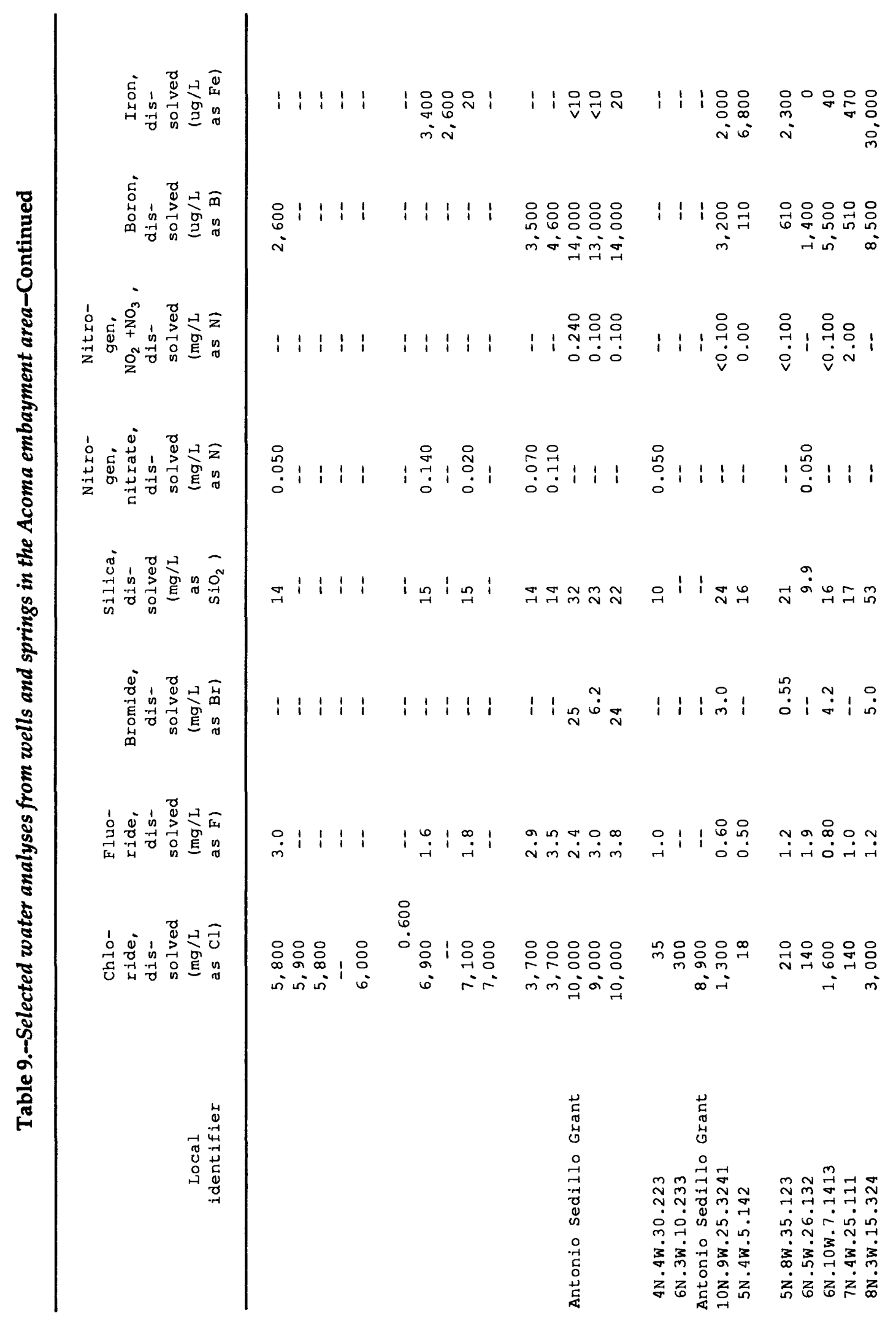




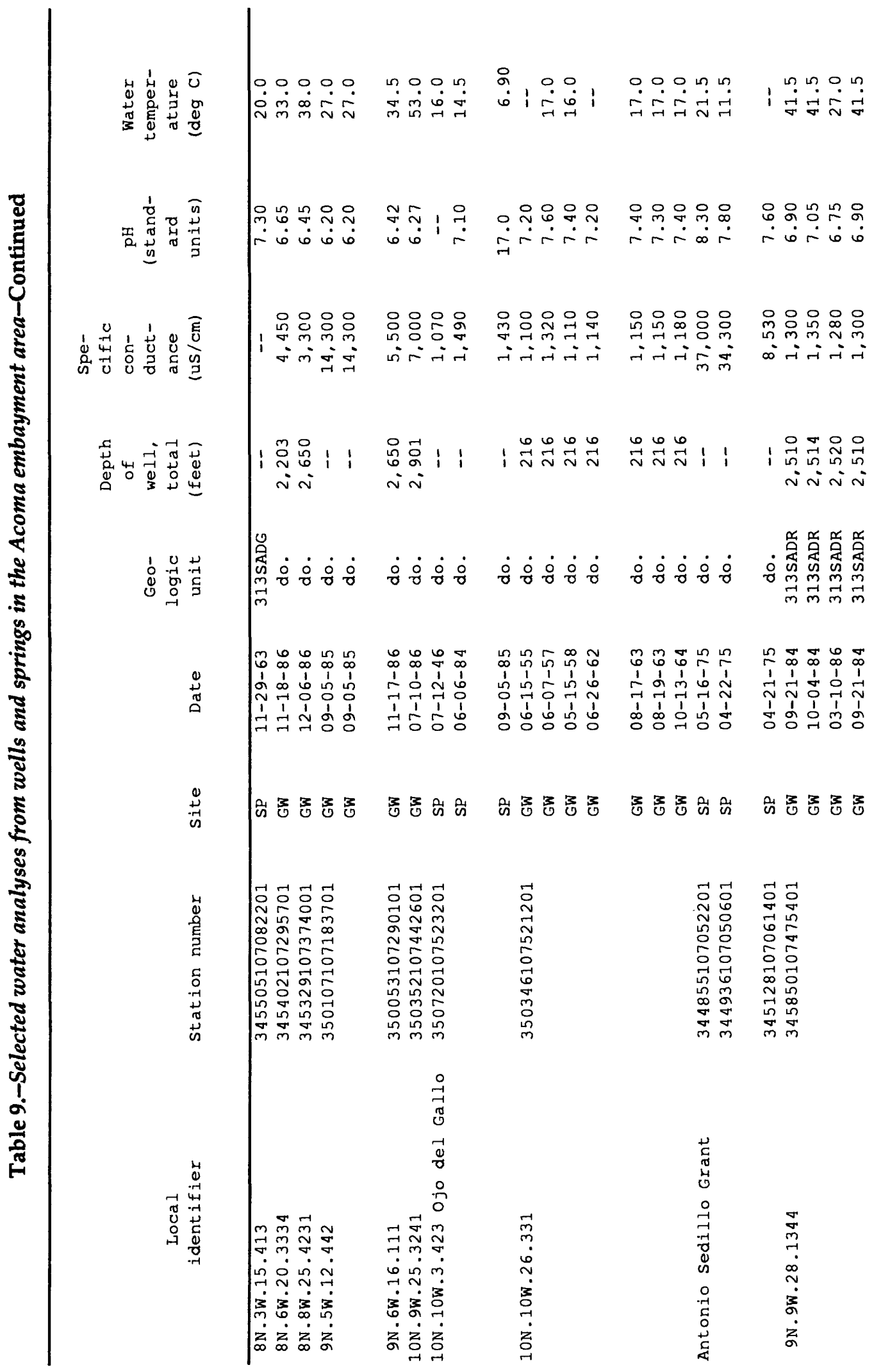




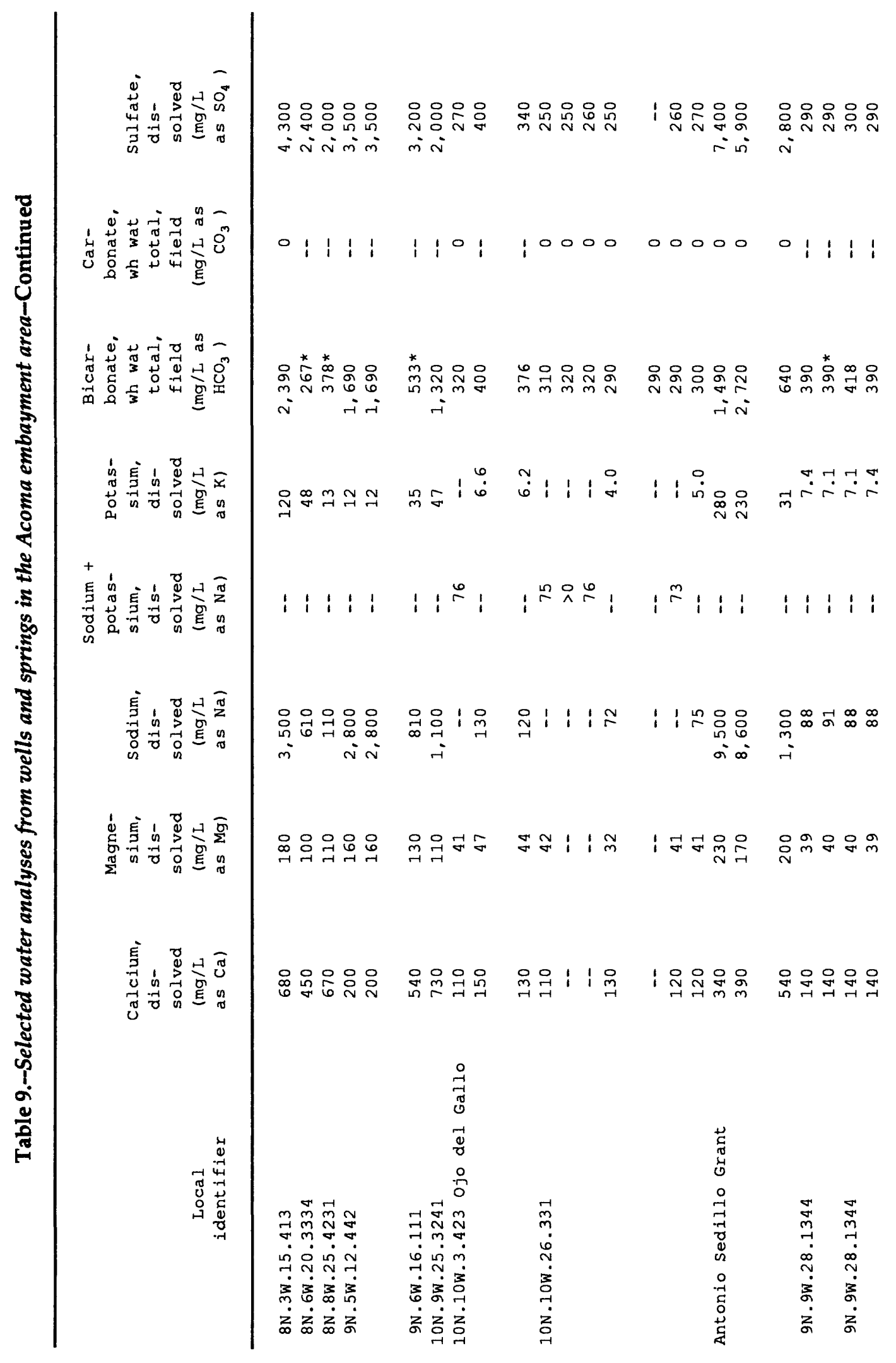




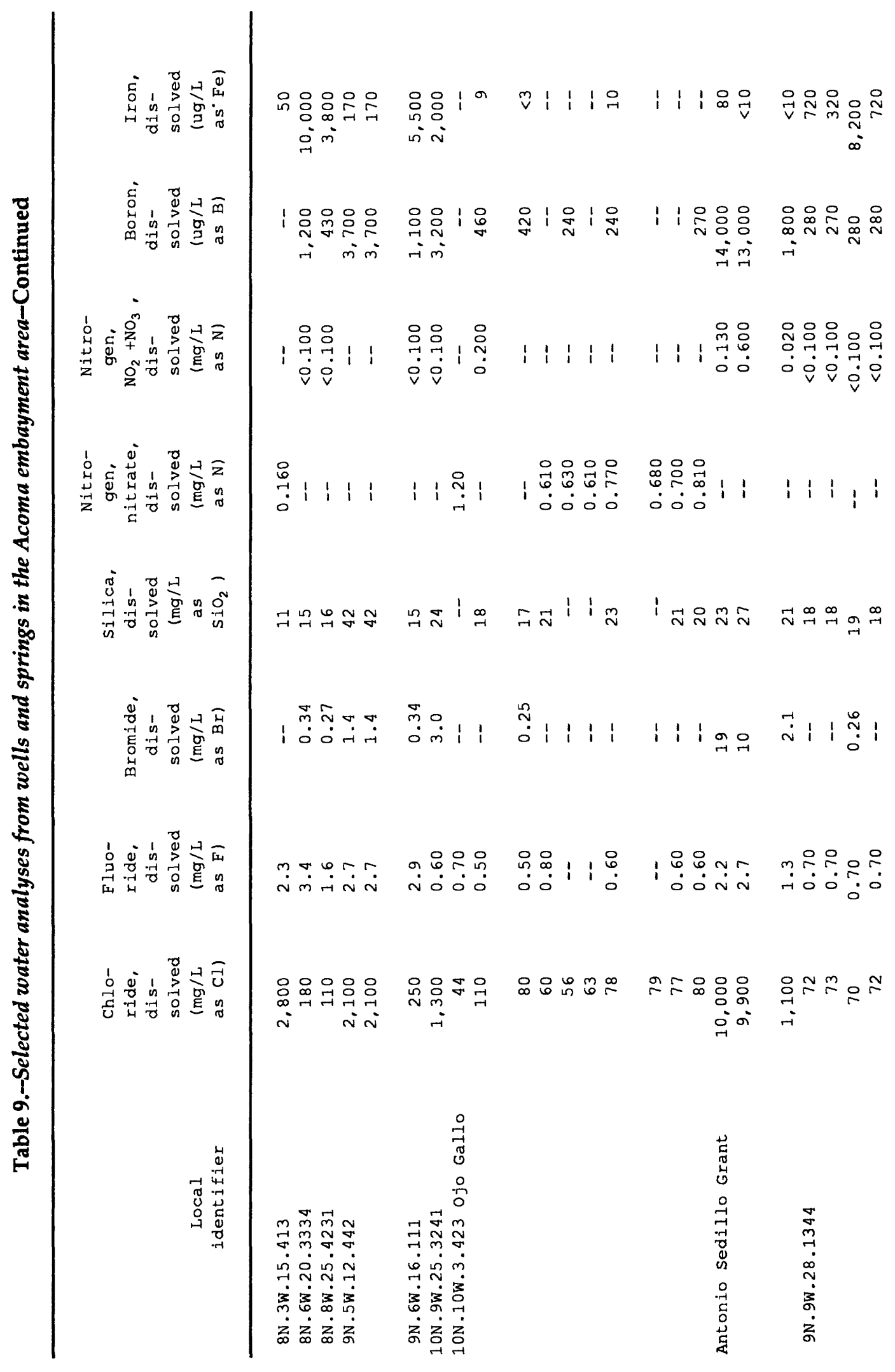




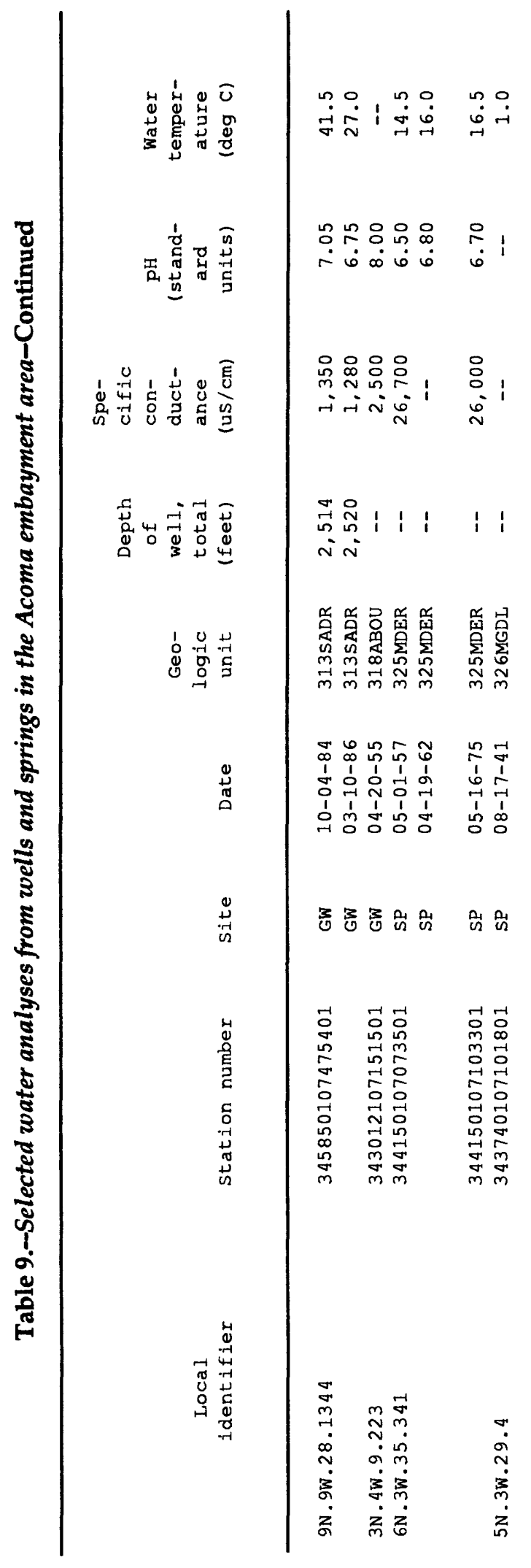




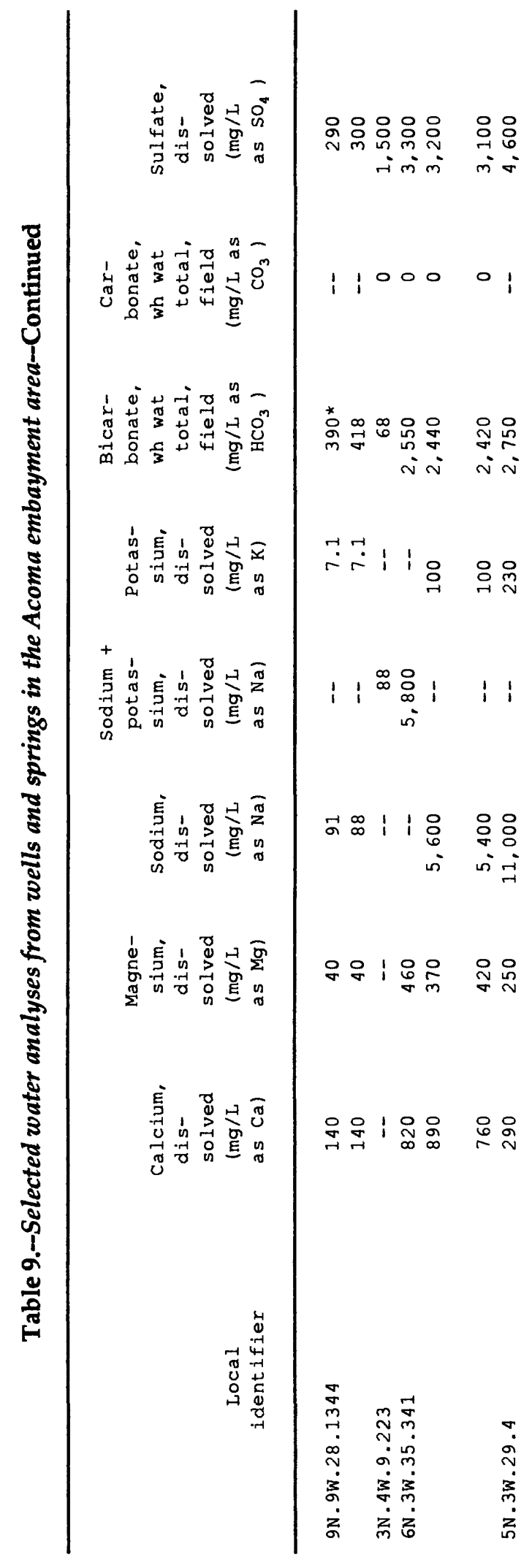




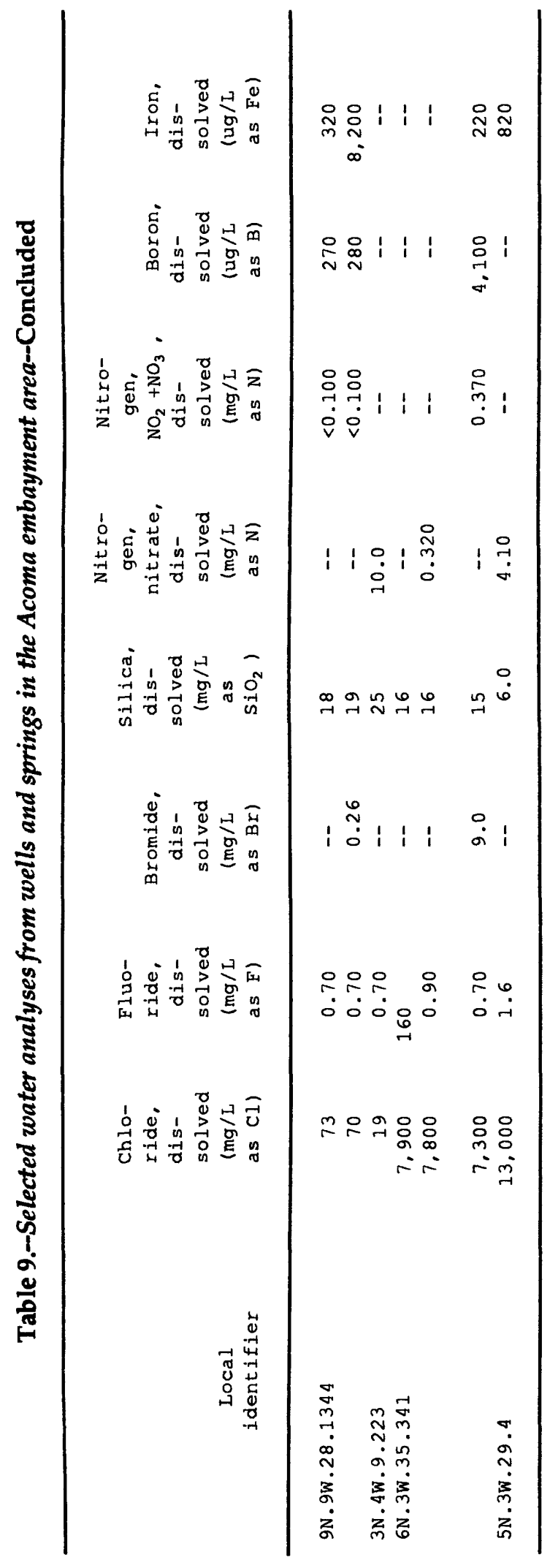

